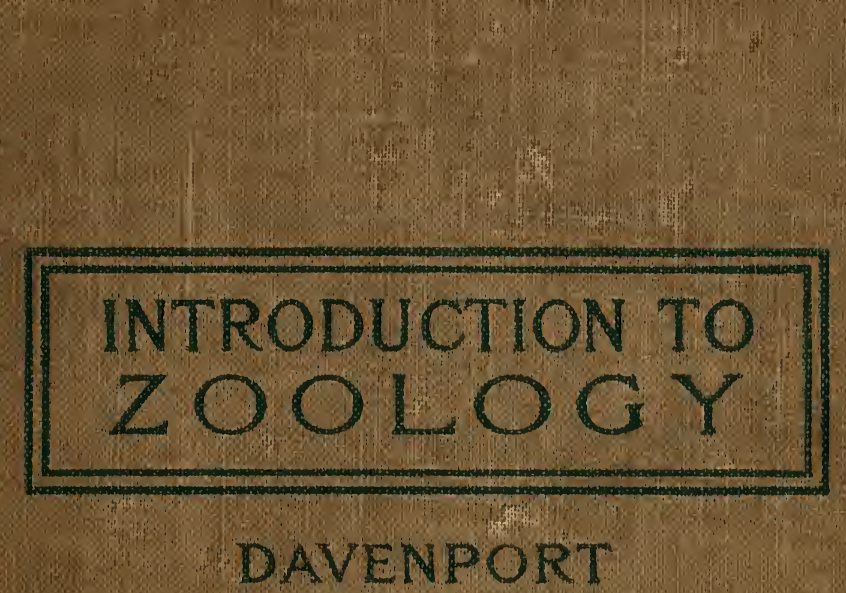




\section{MARINE BIOLOGICAL LABORATORY.}

Received

Accession No. 29.2\%

Given by

Place,

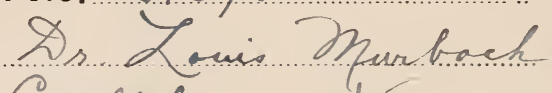

1928

** No book or pamphlet is to be removed from the Laboratory without the permission of the Trustees. 


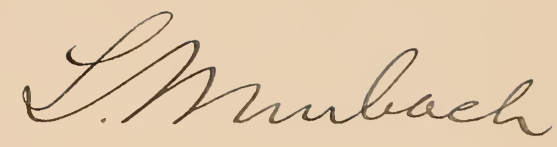





INTRODUCTION TO ZOOLOGY 


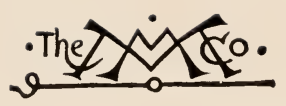




\title{
INTRODUCTION TO Z00LOGY
}

A GUIDE TO THE STUDY OF ANIMALS

\author{
FOR THE
}

USE OF SECONDARY SCHOOLS

BY

CHARLES BENEDICT DAVENPORT, PH.D. ASSISTANT PROFESSOR OF ZOOLOGY IN THE UNIVERSITY OF CHICAGO DIRECTOR OF THE BIOLOGICAL LABORATORY OF THE BROOKLYN INSTITUTE OF ARTS AND SCIENCES, LOCATED AT COLD SPRING HARBOR, LONG ISLAND

AND

GERTRUDE CROTTY DAVENPORT, B.S. FORMERLY INSTRUCTOR IN ZOOLOGY AT THE UNIVERSITY OF KANSAS

WITH THREE HUNDRED AND ELEVEN ILLUSTRATIONS

Xrew Mark THE MACMILLAN COMPANY, 5 , 5 . LONDON: MACMILLAN \& CO., LTD. 1900 
Copyright, 1900 ,

BY THE MACMILLAN COMPANY.

Norwood 秘星s

J. S. Cushing \& Co. - Berwick \& Smith

Norwood Mass. U.S.A. 


\section{PREFACE}

THE general plan of this text-book is at the same time both old and new. Old, because it attempts to restore the old-time instruction in Natural History; new, because "Natural History" is not to-day what it was a generation ago. The treatment will seem new also in contrast with modern text-books of zoology, since they are devoted primarily to comparative anatomy, a field upon which we lay little stress.

This departure is the outcome of a conviction that the needs of the secondary student are not best met by a course in comparative anatomy. That conviction is not altered by the circumstance that anatomy is fundamental for advanced work in zoology and physiology, for only a sixth of the secondary students go to college, and probably less than four per cent of them continue their zoological work there. The vast majority of secondary students, then, are not to be zoologists, but rather men of affairs. What the ordinary citizen needs is an acquaintance with the cońmon animals that may be the companions of his country walks, and that may even stray into Wall Street, Dearborn Street, or Commonwealth Avenue. He wants to know where else over the world the common animals of his State are to be found and, as a legislator or as a taxpayer, he wants to know how animals affect man. It is more important for him to know these matters than to know the location of the pedal ganglion of the snail, or 
to be able to recite the various ingenious hypotheses of the ancestry of echinoderms. Our conviction is, we feel sure, the common conviction of college teachers of zoology, who have often occasion to deplore the ignorance that their students show about common animals. It is the conviction of many other thoughtful men also who have recognized that an interest in nature is a powerful agent in making men more moral, more capable of appreciating the world they live in, and of finding satisfaction in living.

The aim of the book is indicated by its title. It is not a treatise on the modern science of zoology. It is a guide to the study of animals, which it is hoped may introduce many students to the sciences of comparative anatomy, comparative embryology, cytology, general physiology, variation and inheritance, and the others that are grouped under "zoology." This book is like a "Synoptic Room" in the vestibule of a vast museum, containing the most essential things for those who can go in but a little way, but also fundamental for those who can penetrate farther.

The illustrations of this book have received especial attention. An attempt has been made to give a lifelike figure of a representative of almost every family mentioned in the text. For courteous permission to reproduce the copied figures we are deeply indebted to many publishers and authors. We have to thank the authorities of the Field Columbian Museum for original photographs, Figs. 301, 302, and 305. Mr. H. W. Menke, of the same institution, kindly gave us permission to use his interesting photographs of live rattlesnakes, Figs. 261, 262. To Mr. V. H. Lowe, Entomologist of the New York State Agricultural Station at Geneva, N.Y., we are indebted for the photo- 
graphs marked V. H. L.; these are published by permission of the Director of the Station. The majority of the original photographs, designated by the initials W.H.C.P., were made by Mr. William H. C. Pynchon, Instructor in Biology at Trinity College, Hartford. All of these, excepting Figs. 183, 18t, 188, and 203, are photographs of animals occurring around the Biological Laboratory at Cold Spring Harbor, Long Island. They have thus a certain scientific value as indicating the fauna of that region. As many of these figures are from living animals, probably never before photographed in their natural attitudes, their publication may be considered as something of a contribution to science. Of the other photographs, Figs. $31 a, 122$, 276, 281, and 288, marked D. and S., were contributed by Professor N. F. Davis of Bucknell University, Lewisburg, Penn., and Mr. Ernest A. Sterling of the same institution; and Figs. 127, 251, and 259 were contributed by Mr. E. R. Downing, graduate student at the University of Chicago. The figures of birds by Louis Agassiz Fuertes have been reproduced from "Citizen Bird," by Mrs. Wright and Dr. Coues, published by the Macmillan Company. Figures of the types used in the outline of laboratory work have been purposely avoided.

Finally, the authors have to thank several secondary teachers who have kindly made suggestions and helpful criticisms on the outline of laboratory work and the main text. We solicit a continuance of these favors to the end that this book may become as perfectly adapted as possible to the needs of secondary instruction in zoology.

C. B. DAVENPORT.

GERTRUDE C. DAVENPOR'T.

Chicago, May 19, 1900. 



\section{CONTENTS}

\section{CHAPTER I}

PAGE

The Grasshopper and its Allies . . . . . . . . . 1

Key to the four principal families of Acrididie . . . . . 2

Appexdrx : Key to the principal families of the Orthoptera 14

\section{CHAP'TER II}

The Butterfly and its Allies . . . . . . . 15

Aprendices : Key to the principal families of Lepidoptera • 41

Key to the principal families of Hymenoptera . . . 42

\section{CHAPTER III}

The Beetle and its Allies . . . . . . . . . 44

Appexdix : Key to the principal families of the Coleoptera . 58

\section{CHAPTER IV}

The Fly and its Allies . . . . . . . . 62

Appendix : Key to the suborders of Diptera . . . . 62

\section{CHAPTER V}

Lithobius ANd its Allies . . . . . . . 74

Appexin : Key to the principal families of the Myriapoda . 78

Key to the commoner species of the genus Lithobius . $\quad 79$

\section{CHAP'TER VI}

The Splder and its Allies . . . . . . . .80

Appexpix : Key to the seven suborders of the Araneina . $\quad .95$ ix 


\section{CHAPTER VII}

The Crayfish and its Allies . . . . . . . $\quad .97$

Appendices : Key to the six chief orders of Malacostraca - 122

Key to the principal families of Podopthalmata . . . 122

\section{CHAPTER VIII}

The Daphin and its Allies . . . . . . . . 125

Appendices : Key to the five orders of Entomostraca . . 131

Key to the principal families of Cladocera . . . . 131

\section{CHAPTER IX}

The Earthworm and its Allies . . . . . . . 133

Appendices : Key to the principal species of Earthworms of the

United States . . . . . . . . . 143

Key to the principal families of aquatic Oligochæta . . 144

\section{CHAPTER $\mathrm{X}$}

Nereis and its Allies . . . . . . . . . . 145

Appendix : Key to the more important families of Polychæta . 159

\section{CHAPTER XI}

The Slug and its Allies . . . . . . . . . . 160

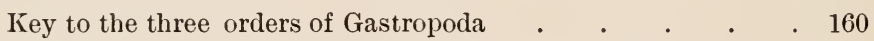

Key to the principal families of American Pulmonata . . 161 Appendix: Key to the principal families of marine shelled

Gastropods of the Atlantic coast of the United States . . 174

\section{CHAPTER XII}

The Fresh-water Ciam and its Allies . • • • 178

Appendix: Key to the principal families of marine Lamellibranchiata of the east coast of the United States . . . 188

\section{CHAP'TER XIII}

The Starfish and its Allies . . . . . . . 192 Appendix : Key to the principal classes of Echinodermata . 203 


\section{CIIAPTER XIV}

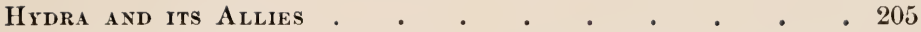

Appendices: Key to the principal subdivisions of the Cnidaria 220

Key to the families of the Hydromedusæ . . . . 220

\section{CHAPTER XV}

The Paranecium and its Allies . . . . . . . 222

Appendices : Key to the four classes of Protozoa $\quad$. $\quad$. 229

Key to the subclasses and orders of Infusoria . . $\quad$. 229

\section{CHAPTER XVI}

The Suelt and its Allies . • . • • • • . 230

Appendices: Key to the principal orders of fishes . . . 252

Key to the six suborders of Teleostei . . . . . 252

\section{CHAPTER XVII}

The Newt and its Allies . . . . . . . . 254

Appendices : Key to the orders of Amphibia . . . . 266

Key to the families of Urodela . . . . . . 266

\section{CHAPTER XVIII}

The Lizard and its Allies • • • . • • • . 268 Appendix : Key to the four orders of Reptiles . . . . 280

\section{CHAPTER XIX}

The English Sparrow and its Allies. • • • • . 281 Appendices : Key to the orders of Birds . . . . . . 314

Key to the families of Passeres of northern United States . 315

\section{CHAPTER XX}

The Mouse and its Allies . . . . . . . . 318 Appendix: Key to the orders of Mammalia . . . . 331

\section{CHAPTER XXI}

The Development of the Frog's Egg 


\section{APPENDIX I}

OUTLINE OF Laboratory WORK IN ZOOLOGY

\section{INTRODUCTION . . . . . .}

Exercises . . . . . . . . . . . . 342

I. Grasshopper . . . . . . . . 342

II. Butterfly . . . . . . . . $\quad$. 343

III. Beetle . . . . . . . . . 344

IV. Housefly or Bluebottle Fly . . . . . 345

V. Lithobius . . . . . . . . . 347

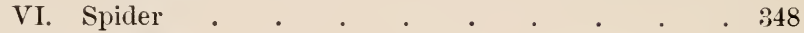

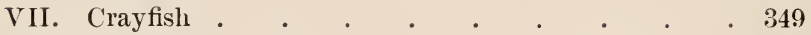

VIII. Daphnia . . . . . . . . . 351

IX. Earthworm . . . . . . . . . 352

X. Nereis . . . . . . . . . . 353

XI. Slug . . . . . . . . . . 354

XII. Fresh-water Clam . . . . . . . 356

XIII. Starfish . . . . . . . . . 357

XIV. Hydra . . . . . . . . . . 358

XV. Paramecium . . . . . . . . . 859

XVI. Smelt . . . . . . . . . . . 361

XVII. Newt . . . . . . . . . . . 362

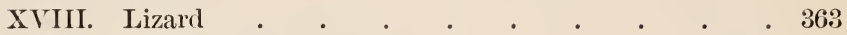

XIX. "English" Sparrow . . . . . . . 364

XX. Mouse . . . . . . . . . 365

XXI. Development of the frog's egg . . . . . . 366

Methods of Examisation . . . . . . . . . 367

\section{APPENDIX II}

A List of Books dealixg cmefly with the Ecological and Srstematic Zoologr of Anerican dximals . . . . . 369

\section{APPENDIX III}

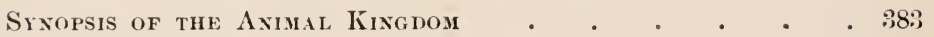




\section{INTRODUCTION TO ZOOLOGY}

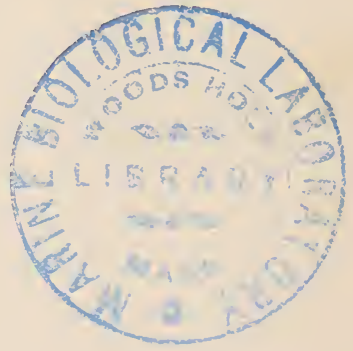





\section{INTRODUCTION TO ZOOLOGY}

\section{CHAP'TER I}

\section{THE GRASSHOPPER AND ITS ALLIES}

Relationships. - The grasshopper belongs to an order of insects called Orthoptera. ${ }^{1}$ In this group of insects ${ }^{2}$ there is an incomplete metamorphosis during development, so that the general form of the young resembles that of the adult. The anterior and posterior pairs of wings are unequal. The jaws are adapted for hiting.

The name "grasshopper" is applied to two families of insects; namely, the Acrididie ${ }^{3}$ and the Locustidie. Both of these families have long hind legs, used in jumping, an elongated body flattened from side to side, and a wedgeshaped head directed downward; they differ in the length of the antennie.

Habits. - The Acrididre, or short-horned grasshoppers, are found in both hemispheres. They live, for the most part, on the ground in very diverse conditions, such as in low, damp meadows or in dry uplands, arid deserts, and rocky mountain sides. 'They are all herbivorous, and may

1 ó $\rho \theta$ ó $\tau \epsilon \rho o s$, with straight (lying straight out) wings.

2 The principal families of Orthoptera may be distinguished by the key in the Appendix to this Chapter, p. 14.

${ }^{3} \dot{\alpha} \kappa \rho i \delta \iota \nu$, a smail grasshopper of Dioscorides. 
feed upon almost any green part of plants. Some of the species are gregarious (i.e. go in swarms) and may be very destructive. ${ }^{1}$

Melanoplus ${ }^{2}$ is the prevailing genus of North America and covers nearly all of the continent. While in the East certain species of the genus Melanoplus may become destructive to vegetation, the injury done is not so great as was formerly done by the Rocky Mountain locust. At various times for some cause, probably drought, this locust has migrated eastward from its mountain home in countless millions and devastated our Western States as far as the Mississippi River. In 1873 to 1877 the Rocky Mountain locust was so destructive to vegetation in the transMississippi region that Congress appointed a commission to investigate the species. In describing its effect the commission reports : -

"Falling upon a cornfield, the insects convert in a few hours the green and promising acres into a desolate stretch of bare, spindling

1 The following key will aid in determining the four principal American subfamilies of the Acrididæ : -

$a_{1}$. Feet without a claw-pad. Pronotum covering all the body. Fore wings lobe-like .

Tettigidee (Tettix shorthorns)

a. Feet with a claw-pad; antennæ longer than anterior femora.

$b_{1}$. Prosternum without a spine.

$c_{1}$. The plane of the vertex of the head meeting the plane of the front of head at an angle, the face looking down . . . Tryxalidce

(Angle-headed shorthorns)

$c_{2}$. The planes of the vertex and head round over into each other . . . . . E Edipodce

$b_{2}$. Prosternum with prominent spine . . . Melanoplidie

$2 \mu \dot{\epsilon} \lambda a s$, black ; ö $\pi \lambda a$, armor.

(Thorn-throated Shorthorns) 
stalks and stubs. ... Their flight may be likened to an immense snow-storm, extending from the ground to a height at which our visual organs perceive them only as minute, darting scintillations, leaving the imagination to picture them indefinite distances beyond. ... In alighting, they circle in myriads about you, beating against everything animate or inanimate; driving into open doors and windows; heaping about your feet and around your buildings, their jaws constantly at work, biting and testiug all things in seeking what they can devour."

The locusts of the Old World are likewise frequently very destructive. The species that lives in southern Europe, North Africa, Asia Minor, Syria, Java, and Japan is doubtless the locust of the Bible. The description given by the prophet Joel is very vivid and accurate:-

" $A$ day of darkness and of gloominess, a day of clouds and of thick darkness, as the morning spread upon the mountains; a great people and a strong; there hath not been ever the like, neither shall be any more after it, even to the years of many generations. A fire devoureth before them, and behind them a flame burneth: the land is as the garden of Eden before them, and behind them a desolate wilderness; yea, and nothing shall escape them. The appearance of them is as the appearance of horses; and as horsemen, so shall they run. Like the noise of chariots on the tops of mountains shall they leap, like the noise of a flame of fire that devoureth the stubble, as a strong people set in battle array. Before their face the people shall be much pained; all faces shall gather blackness. They shall run like mighty men; they shall climb the wall like men of war; and they shall march every one on his ways, and they shall not break their ranks.... They shall run to and fro in the city; they shall run upon the wall; they shall climb up upon the houses; they shall enter in at the windows like a thief."

General Development of the Grasshopper. - The common red-legged grasshopper lays its eggs during the fall in holes in the ground which the female drills by means of 
the horny plates at the tip of the aldomen. The eggs, thirty to one hundred in number, are laid in a mass and covered with a gelatinous secretion. In these holes, an inch or so below the surface of the ground, the eggs pass the winter and hatch out in early summer into young grasshoppers, looking like adults except for their small size and the absence of wings. As they grow larger they moult several times, i.e. cast off their cuticular coverings. After each moult the body is left soft and colorless, but being freed of its hard, tight casement, it is in a condition to grow rapidly. After each moult also the rudimentary wings (wing-pads) become larger, and the relative sizes of the parts of the body change. Just before the last moult the pupa crawls up some vertical ohject, clutches it firmly with the hind feet, and remains motionless in this position for several hours. Then the cuticula splits along the middle of the back, the head and body inside the cuticula swell, the head emerges from the case, and gradually the entire body works forward out of the old cuticula; not easily, indeed, but with violent contortions and pullings. The legs and antenne are especially difficult to free; they can pass out of the joints of the old skin only because they are soft and flabby; but as soon as they become exposed to the air their surface secretion hardens into a firm covering. The wings are at first rolled up; they now expand broadly, dry, and then fold up in the way we see them in the adult.

Allies of the Grasshopper. - The Gryllidæ, ${ }^{1}$ or crickets (Fig. 1), include cosmopolitan insects that have short, cyliudrical bodies and live chiefly in hidden places, such as beneath stones or in holes which they make in the

${ }^{1}$ Name derived from sound made by crickets. 
ground. Their eggs are laid loosely in these retreats. They feed on plants and, if numerous, may be decidedly injurious to vegetation. They make a familiar chirping noise, the blended somnds of which, as heard on a summer evening, rise and fall in a distinct rhythm. The rate of chirp seems to be entirely determined by temperature, so that one may compute the temperature by means of the formula

$$
T=50+\frac{N-40}{4}
$$

in which $T$ stands for temperature, and

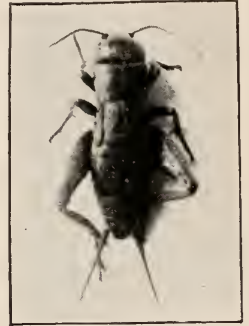

FIc. 1. - Gryllus, ericket. Nat. size. Photo. liy IV. H. C. P.

$N$ the number of chirps per minute. The mechanism by which the chirp is produced is as follows: Near the mid-

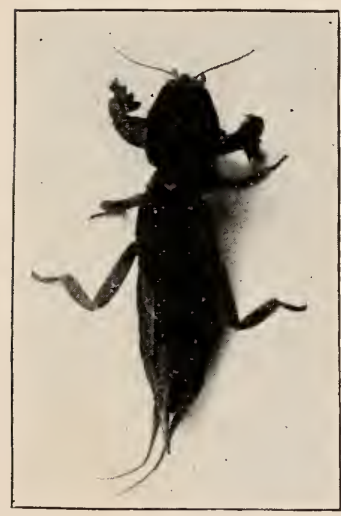

Fig. 2. - Gryllotalpa borealis, mole cricket. Nat. size. Photo. by W. H. C. P. dle of each of the upper wings of the male cricket is a vein so modified as to form a sort of file, and near the margin of the wing is a thickened scraper. When the upper wings are brought in contact above the body, and the scraper of one is rubbed across the file of the other, the wings are set in vibration, producing the call.

An aberrant form of Grylliclie is the mole cricket (Fig. 2), whose fore feet have become much modified for burrowing.

'The Locustidæ, ${ }^{1}$ or long-horned

1 From the Latin name for the locust and grasshopper, as well as the lobster. 
grasshoppers and katydids, are close allies of the shorthorned grasshoppers already defined. Next to the numer-

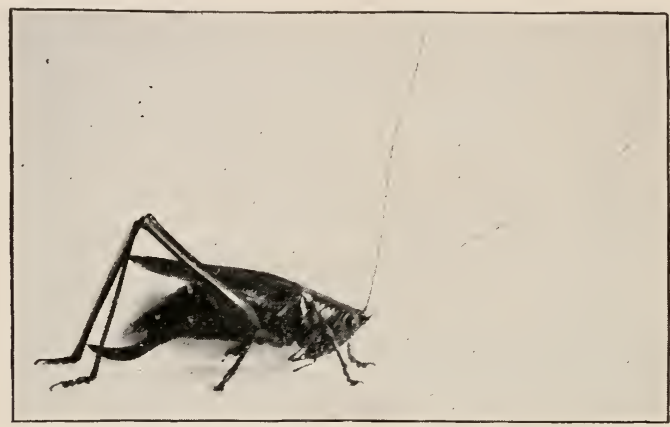

Fic. 3. - Orchelimum, meadow grasshopper. Nat. size. Photo. by W. H. C. P.

ous meadow grasshoppers (Fig. 3) belonging to this group, the katydids are the best known of its representatives. The katydids have their whole body green, like the foliage they

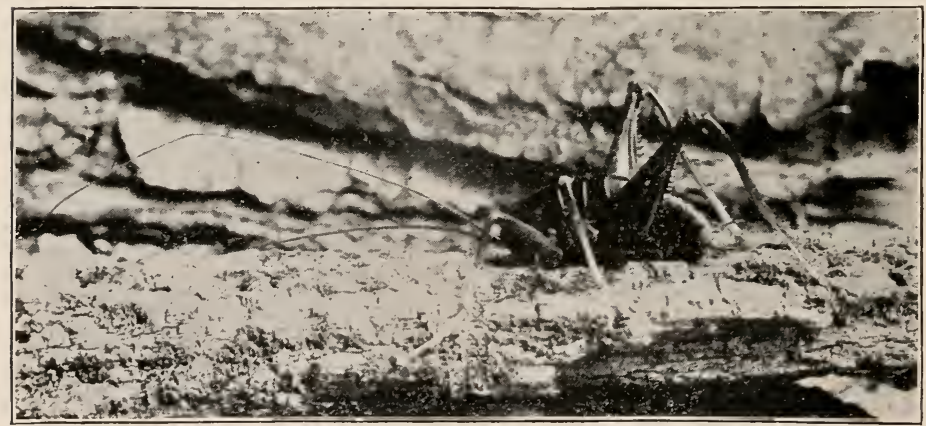

FIg. 4. - Ceuthophilus, ericket-grasshopper. Two-thirds nat. size. Photo. by W. H. C. P.

inhabit. The wings are large; and when the upper wings are rubbed together, they vibrate, and cause the familiar 
note. Other members of this group are the cricket-grasshoppers (Fig. 4), wingless forms, of a brown color and arched profile, which live under stones and rubbish, and also the cave "crickets," which are colorless and bliud.

'The Phasmidæ, ${ }^{1}$ or' walking-sticks and leaf-insects, display, to a marvellous degree, a protective resemblance to the twigs and leaves among which they live. 'The most remarkable forms live in the tropics. They have large wings, which strikingly resemble, in form, color, and venation, either living or dry leaves. Upon those species which resemble dried leaves, blotches looking like fungous patches are found. Even the legs may be thin and expanded, resembling foliage. In our country only the twig-like, wingless forms, or walking-sticks, occur. These insects are furthermore protected by clanges in color, corresponding with the seasonal color changes in twigs; for the young walking-sticks, which appear in the spring, are green like the twigs, but in the autumn they

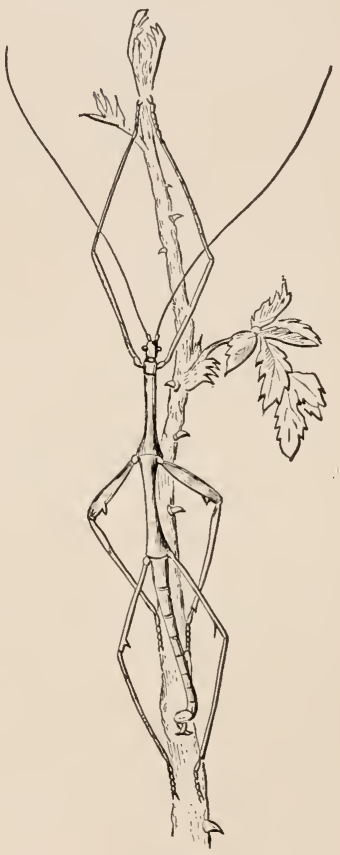

Fig. 5.-Diapheromera, walking-stick of northern U.S. Nat. size. Copied from Packard. become gray or brown. Figure 5 shows our only common northern species, Diapheromera femorata. It feeds on leaves, especially those of the oak, and occasionally does much damage to trees. 
The Mantidæ ${ }^{1}$ are popularly called praying-mantis, on account of the devotional attitude in which the greatly enlarged front legs are held. Unlike other Orthoptera, they

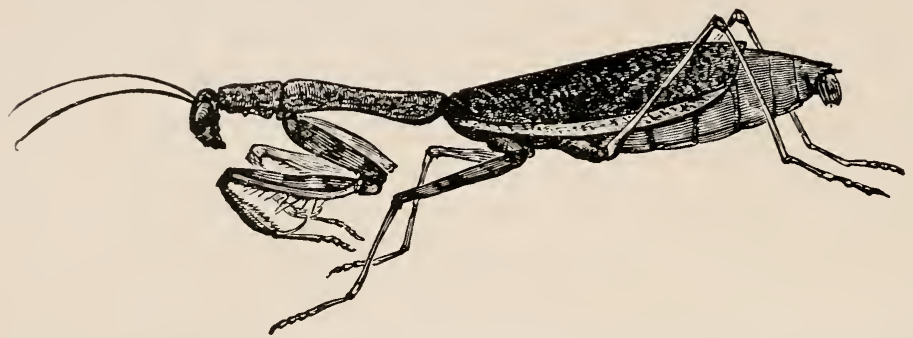

Fig. (5. - Phasmomantis cerolinu. Praying-mantis of southern U. S. Nat. size. Copied from Packard.

are carnivorous. 'They hunt and devour other insects sometimes larger than themselves, and even prey upon each other. While most of the species are tropical, one species, Phasmo-

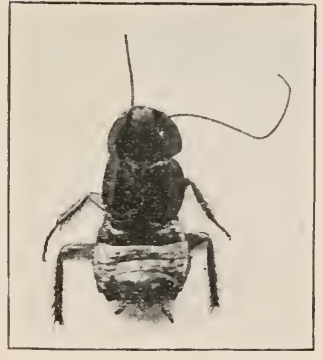

Fis. 7. - Wingless cockroach. Nat. size. Photo. by W. H. C.P. mantis curolinu (Fig. (i), is abundant in our Southern States, and another occurs in the Missouri valley.

'The Blattidæ, ${ }^{2}$ or cockroaches, are especially creatures of the tropics; and those which live in colder climites frequent warm as well as dark places. The two which are our household pests have been imported from Europe, - both the small brown "Croton bug," which is found among water-pipes in the kitchen, and the large black species commonest in sugar-refineries, slaughterhouses, and bakeshops. 'They are omnivorous, eating, 
among other things, breadstuffs, clothing, book-bindings, bedbugs, and other insects. We have also a number of native cockroaches, which live chiefly in fields and woods, under stones and logs. Some of these are wingless (Fig. 7).

The following groups are frequently excluded from the Orthoptera, but show a certain relationship with them:-

The Forficulidæ, ${ }^{1}$ or earwigs, are rare in the northern United States, but commoner in the Gulf and Pacific States. In general appearance they resemble rove-beetles, but differ from them in having a pair of forceps at the posterior end of the body. They hide, during the day, in the corollas of
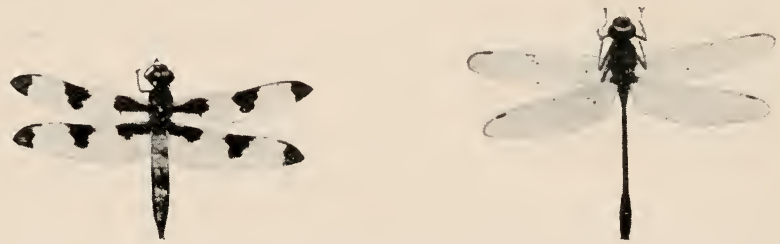

Fig. 8. - Two North American Odonata, belonging to the fanily Libellulicm. About one-half nat. size. Photo. by V. H. L.

flowers, upon which they feed, and fly about at night. The name earwig seems to have arisen from an unwarranted belief that these insects penetrate into the ears of persons when asleep. They were especially dreaded on account of a fear that they might thus penetrate into the brain.

The Odonata, ${ }^{2}$ or dragon-flies, have four membranous, netveined wings, of which the front pair are never larger than the hind ones. Their large heads carry relatively enormous eyes. Two groups of dragon-flies may be distinguished according as the wings, at rest, are extended (Fig.8) or

1 forficulu, a small forceps.

2 oboús, tooth, from the teeth of the mandibles. 
folded together over the back. Dragon-flies live on the wing, hovering over water and preying upon other insects, especially mosquitoes. The eggs develop

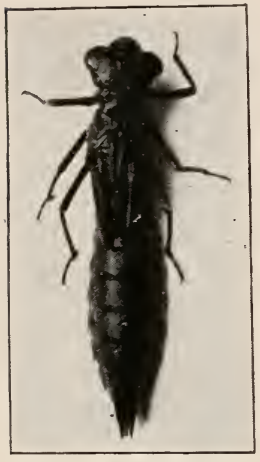

Fig. 9. - Eschna, old larva, or pupa. Nat. size. Photo. by IV. H. C. P. in the water into aquatic larvæ which are quite unlike the adult. Especially the jaws are peculiar, being jointed and capable of sudden protrusion, in order to catch the animals which serve as prey. These larva are easily reared over winter in an aquarium, where not only their ferocious habits, but also their peculiar method of breathing by means of water taken in at the anus, may be observed (Fig. 9).

The Ephemeridæ, ${ }^{1}$ or May-flies. The adult May-fly possesses finely veined fore wings, which are much larger than the hind wings. The mouth parts are rudimentary and the abdomen terminates in two or three filamentous appendages. As their systematic name implies, they have a very ephemeral existence in the imago state. The imago appears in swarms early in the summer and. lives but a few hours, eating nothing and depositing eggs upon or under stagnant water. The larve feed upon small aquatic plants and insects, breathe by means of gills placed on the back, and live for nearly a year, or even for two or three years, in the immature stages. After many moultings the apparent adult emerges, but, unlike other insects, undergoes an additional moult before laying its eggs. As the insect is subjected to many accidents in its long and defenceless life, each species is preserved only by an enormous fecundity.

${ }^{1} \dot{\epsilon} \phi \dot{\eta} \mu \epsilon \rho \nu \nu$, a day, i.e. lasting but a day, short-lived. 
White ants, or termites (Fig. 10), while not true ants, live a very similar social or communal life. They differ from ants in the venation of the net-veined wing (when present). White ants are most abundant in the tropics, where they build great conical nests of sand cemented by their saliva; but they are found also in temperate countries. The common eastern white ant (Termes flavipes) ranges from Massachusetts southward, and lives in wood or under stones. Three kinds or castes of white ants occur in any community: (1) workers, with small, round

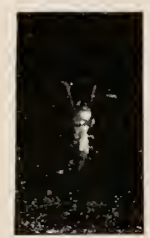

FIG. 10. - Termes faripes, white "ant." Nat. size. Photo. by IV. H. C. P.

heads and concealed mandibles; (2) soldiers, with large, square heads, and long, powerful mandibles; and ( 3 ) the royal class of kings and queens, which have wings until after the marriage flight. At a certain time in May the males and females from the various colonies fly forth to mate, and thus an interbreeding takes place between colonies. Only a few of the pairs, however, find workers to aid them in establishing a new colony. The queen, after she is established in a new hive, merely produces young, the abdomen becoming immensely swollen and elongated to fifteen centimetres with the eggs which are about to be laid. In tropical countries the termites are troublesome to man by injuring trees and derouring the woodwork of houses.

The order Neuroptera includes certain insects which differ from the Orthoptera in having larve very unlike the adult, and in having a resting pupal stage in which the metamorphosis into the adult is completed. There are four membranous, clear, net-reined wings, and the mouth 
parts are used for biting. The largest representative of this group is the Horned Corydalis (Fig. 11), whose larva lives in streams and is called the dobson. The adult is found among fallen leaves or on tree trunks.

The order Hemiptera includes certain insects which resemble the Orthoptera in

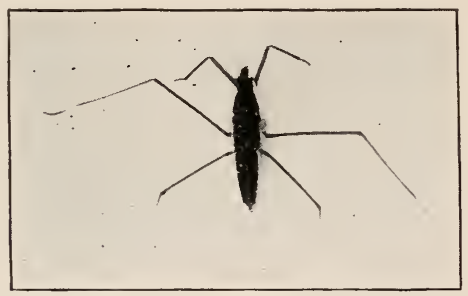

Fig. 12. - Hygrotrechus, water-stricler. Nat. size. Photo. by W. H. C. P.

undergoing an incomplete metamorphosis; i.e. in having larvie much like the adults in form, and in having no quiet pupal stage. 'They differ'

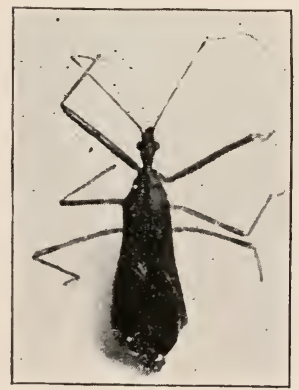

Fig. 13. - Reduvius, the assassin bug. Black. Nat. size. Photo. by W.H. C. P. from the (1) rhoptera in possessing moutlparts adapted to sucking.

The True Bugs (Ileteroptera) inclucle a vast number of generally small insects with very varied habits. Some of them swim through the water and are known as water boatmen ; others skip over the surface of the water and are known as waterstriclers (Fig. 12). Other's, like the 
Squash Bug, are destructive to plants; still others, like the Reduviidre, kill injurious insects (Fig. 13).

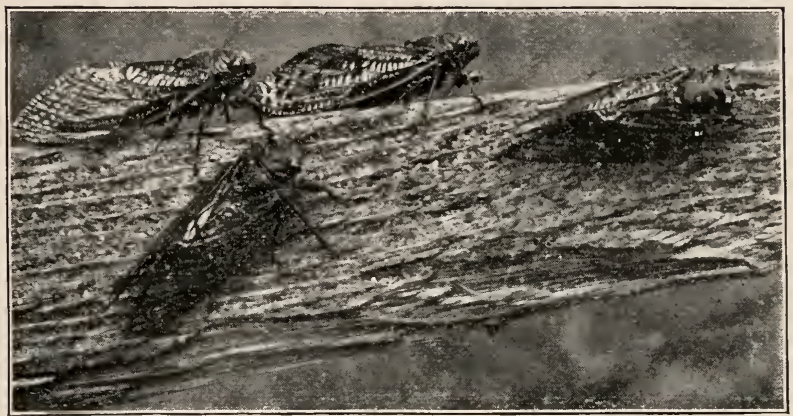

Frg. 14. - Cicarla sentematecem, the seventeen year loeust. Reduced. Photo. by V. H. L.

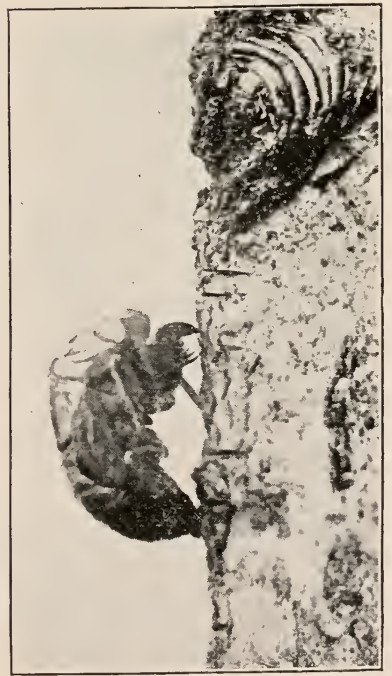

Fif. 15. - Pupal case of cicada. Twothirds uat. size. Photo. by W. H. C. P.

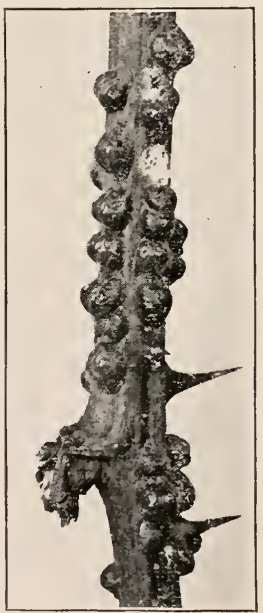

Fig, 16. - Ireanium, a scale insect. Remains of females after production of young ; seen as swellings on the bark. Nat. size. Photo. by V.H.L. 
The Homoptera include insects of very diverse size and form. The largest are the cicadas, or "locusts" (Fig. 14), some of which have the remarkable habit of requiring thirteen or seventeen years for their development. Con-

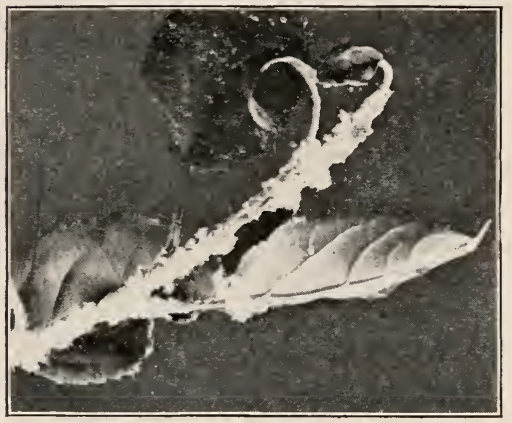

FIG. 17. - Schizoneura, a woolly aphis, on apple twig. Photo. by V.H. L. sequently these cicadas appear only at intervals of thirteen or seventeen years. The young bury themselves in the ground and live by sucking juices from the roots of trees. Eventually they come to the surface, leave their larval skin (Fig. 15), and fly away as full grown cicarlas. In the case of our common species of cicada there is a brood every year. Besides the cicadas the Homoptera include the little leaf-hoppers and tree-hoppers, the very destructive scalebugs (Fig. 16), and the mealy-bugs, most of which attack fruit trees and their fruits, and the plant-lice, or aphids (Fig. 17).

\section{APPENDIX TO CHAPTER I}

KEY TO THE PIINCIPAL FAMILIES OF THE ORTHOPTERA

$a_{1}$. Legs similar, fitted for rumning .

$a_{2}$. First pair of legs differentiated for grasping; prothorax elongated
Blattida

(Cockroaches)

Mantidae

(Praying-mantis) 
$a_{3}$. Legs similar, much elongated, and fitted for slow walking . . . . . . . Phasmidee

$a_{4}$. Hinder legs stouter or longer than middle pair.

(Walking-sticks)

$b_{1}$. Antennæe shorter than body . . . . Acridide

$b_{2}$. Antennæ longer than body.

(Locusts and Short-horned Grasshoppers)

$c_{1}$. Tarsi 4 -jointed

(Katydids and Long-horned Grasshoppers)

$c_{2}$. Tarsi 3-jointed . . . . . . Gryllida

(Crickets) 


\section{CHAP'TER II}

\section{THE BUTTERFLY AND ITS ALLIES}

Systematic Position. - Butterflies belong to the insect order Lepidoptera, ${ }^{1}$ characterized by the possession of a long, coiled, sucking proboscis; large, membranous wings, covered with colored scales; and a complete metamorphosis. They occur over the whole globe, but become more numerous in species in the tropics of South America and Africa. The number of known species is about twenty-five thousand. ${ }^{2}$

The Habits and Food of Butterflies. - The idea of a butterfly should not be limited to the winged adult called the imago, for strictly we may call a caterpillar a larval butterfly, and a pupa an adolescent butterfly. But in its different stages the habits and food of a butterfly change. Caterpillars feed, for the most part, upon plants. A fer such as the clothes-moth and certain enemies of scale insects - feed upon animal matter. Any single species of caterpillar feeds upon the foliage of a restricted number of kinds of plants. At one extreme we have forms which starve unless they can reach their own particular food plant; at the other extreme there are caterpillars which can live upon the foliage of many kinds of plants, and these are consequently called polyphagous. Certain fami-

$1 \lambda \epsilon \pi$ is, seale; $\pi \tau \epsilon \rho o ́ \nu$, wing.

2 The principal families of Lepidoptera may be distinguished by the key in the Appendix to this Chapter, p. 41. 
lies of plants especially serve caterpillars as foorl. Thus of the hundred species of New England butterflies, eight feed upon oaks, eleven upon willows, thirteen upon the Rosacea, and twenty-eight upon leguminous plants. It follows from the restricted food of many caterpillars, that the range of the species must often be determined by that of its foodplant.

The feeding of the butterfly is mostly done in the larval stage: the pupa can take no food. The imagos of many species touch no food, but in other cases they take small quantities of the nectar of flowers, the sap of plants, and the juice of fruits.

The imagos fly in the daytime, especially in the sunshine. Certain species are characteristic of the roadside, others of meadows, gardens, or woods, while still others are found flying everywhere. Owing to its ordinarily short life, the imago is usually found not far from the larval food-plant, upon which it lays its eggs.

The Broods of Butterflies and their Polymorphism.Butterflies winter over in various stages, some in the egg stage, some as larve, others as pupa or as imagos. Some kinds pass the winter in either of two stages. In whatever stage they tarry, the life current runs very slow, and during this season few changes take place. In the spring, development goes on rapidly: the winter generation becomes mature and a summer generation is started. Frequently there is more than one brood produced during the summer, even in the Northern States. Farther south two and even three summer broods are still commoner. Where two or three broods occur they may be and usually are quite dissimilar. 'This is very strikingly illustrated in the case of the Zebra Swallow-tail, Iplliclides (Papilio) ajur, 
of the southeastern United States, which is multiplebrooded. The early spring form (marcellus form) is the smallest, and has the tail tipped with white; the summer form (ajax) is the largest, and has the tail two-thirds longer than the marcellus form. Other illustrations of this seasonal difference are given by the imported Cabbage Butterfly, the Gray-veined White and the Spring Azure. This dissimilarity between the broods of different seasons is known as seasonal dimorphism or polymorphism. The cause of the difference between the different broods seems to be the dissimilar climatic, especially thermic, conditions under which they have developed. Mr. W. H. Edwards in this country, and Weismann and others in Europe, have shown that, when the summer form is kept during development in a refrigerator, the butterfly has the color of the winter form.

Protective Resemblance and Mimicry. - Every one who has visited a natural history museum must have noticed that the polar mammals are apt to be more or less white, while those which live in tropical forests are dark. It is easy to understand that these colors in their proper surroundings make the animals which wear them hard to see. This may be of advantage in enabling them to escape the observation of their enemies, which are seeking for them, or to avoid being seen by their prey as they approach. This general resemblance to their background is seen even in some caterpillars, e.g. the tomato-worm, which is colored so exactly like the leaf on which it feeds that it is hard to find. Other caterpillars, belonging to the geometrid moths, have the color of the twigs of the plant on which they feed, and the resemblance is heightened by the way they have of stiffening and standing out like a branch 
from the stem. The moths of the genus Catocala, ${ }^{1}$ which fly by night, rest by day on the bark of trees, which they so resemble as to be almost indistinguishable. Still more striking is the resemblance which we find between some adult butterflies and dry leaves as seen, for example, in Kallima, a butterfly of the East Indies. ${ }^{2}$ The resemblance of the butterfly to the leaf extends even to details, for the clear patches on the wing resemble holes, while little cir-

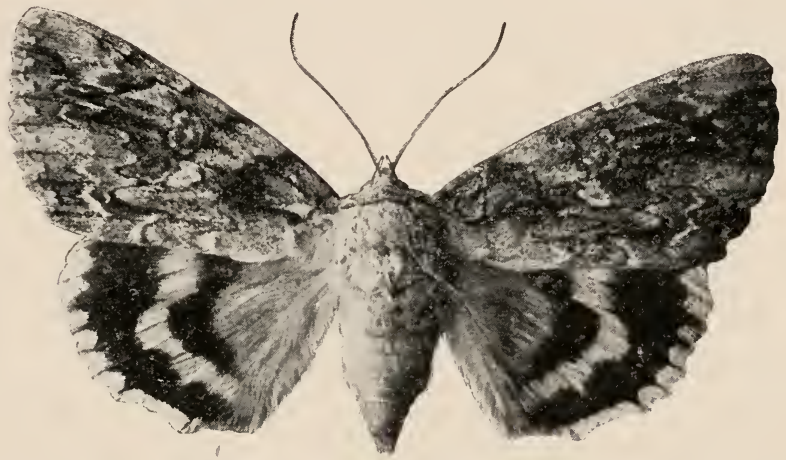

Fig. 18. - Catocala ilia, the underwing. Upper wings, bark color; lower wings, black with orange bands. Photo. by C. Bullard.

cular markings resemble the patches made by particular kinds of fungi. This resemblance of an organisin to inanimate objects in its environment is known as protective resemblance.

There are certain species of butterflies which appear to be let alone by birds, owing to their rlisagreeable odor or acrid taste. Examples of such are the Heliconidx, characteristic of tropical South America, and the Danaidæ, to which family our " Monarch" belongs. Closely resembling
${ }^{1}$ Fig. 18.
2 Fig. 19. 
the Monarch in this country is the "Viceroy," Limenitis archippus. This resemblance of the edible Viceroy to the inedible, acrid Monarch, it is believed, is sufficient to

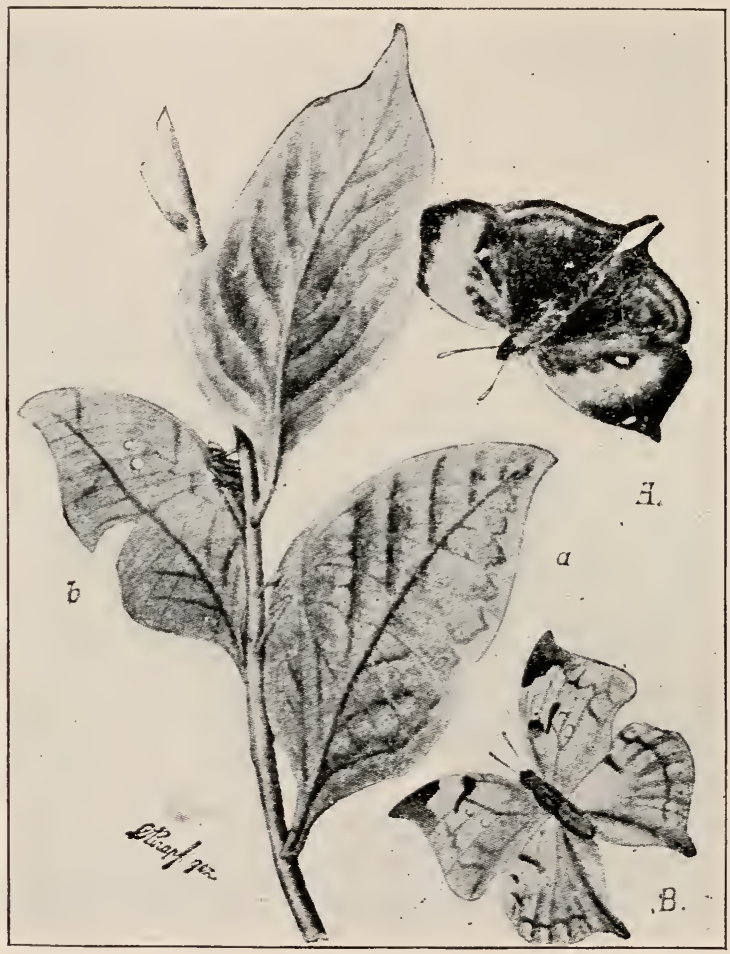

FI(x. 19. - A, Kallima, the leaf-butterfly of the East Indies, flying; " at rest. $B$, siderone, another leaf-buttertly, flying; $b$, at rest.

deceive even the birds, and thus the Viceroy gains considerable immunity from attack. This resemblance of an edible to an immune species is known as mimicry. The origin of protective resemblance and mimicry are both 
explained by the theory of Natural Selection or Darwinism. Since either of them is of great utility to the organism, their possession, even to a slight degree, however accidentally gained, will give their possessor an advantage over its neighbors in the Struggle for Existence. Consequently it will be more apt to survive and transmit its peculiarity to its offspring. By this means an adapted race will arise and crowd out the unadapted.

Types of the Butterflies. - The group Papilionidre includes the butterflies which fly by day. An account of the most important follows. The Papilios (Swallow-tails) are our largest butterflies. Here belong the yellow Tiger Swallow-tail (turnus), with black stripes, which is found over nearly the whole United States; and the black Swallowtail (asterias), whose wings are crossed by rows of yellow spots, and whose hind wing bears an orange, black-eyed spot. Its larvæ feed on wild or cultivated umbelliferous plants, especially parsnip leaves.

The Cabbage-butterflies (Pieris) have white or yellowish wings, tipped and spotted with black, or sometimes with orange. They hover over damp spots in roads or fly through garden patches. The larva are very destructive and feed on cabbage and other cruciferous plants.

To the Nymphs belong the Angle-ivings whose fore wings are notched on their outer edge. Here belongs the butterfly which we sometimes see on warm days in winter or early spring - the Mourning-cloak. This has purplish brown wings with a broad yellow border, and a row of pale blue spots. The Graptas belong here, too; they may be told by the silver spot on the hind wing. In the Admirals the wings are less deeply notched. The red Admiral is purplish black above, with an 
orange band and white spots ruming obliquely across the upper side of the fore wing. It occurs in England as well as in the United States. Here belongs also the Viceroy, which is not closely related, but is quite similar to the Monarch because the former mimics the latter. 'They are both of a tawny orange color, with a whitespotted black border on the outer wing margin. The Monarch is the larger, and like the birds has the habit of migrating southward in the fall and returning in the spring. The Fritillaries (Argynnis ${ }^{1}$ ) include some large butterflies, having numerous round and triangular silvery spots on the under side of the hind wing.

'To the Lycænas ${ }^{2}$ belong the Blues, or Spring Azures, including small satin or steel-blue species which exhibit marked seasonable polymorphism ; the Coppers, orangered, or brown species; and the Hairstreaks, or 'Theclas, ${ }^{3}$ which are small, biown butterflies, usually with two tails to the hind wing.

Types of the Moths. - These include all Lepidoptera, excepting the family of Papilionida. Seven families are of rather large size (Macrolepidoptera); the remaining four are of small size (Microlepicloptera).

The Sphingidæ, ${ }^{4}$ or Hawk-moths, fly swiftly and powerfully, and as they hover over flowers at duis can hardly be distinguished from humming-birds. 'The larva have a eaudal horn or tubercle. The commonest of these are the tomato or potato "worm," green in color and banded. There are about one hundred species of the Sphingidæ in

1 'A $\rho v \nu \nu$ is, the "silvery," a poetic name of Venus.

2 Aúkaıva, a poetic name of Venus.

${ }^{3}$ A Greek feminine name.

${ }^{4}$ From $\Sigma \phi i \gamma \xi$, or sphinx, a fabled monster. The larva of this moth assumes an attitude like the splrinx. 
the United States. 'The Twin-spotted Sphinx (Fig. 20), socalled from the black spots of the lind wing, is destructive

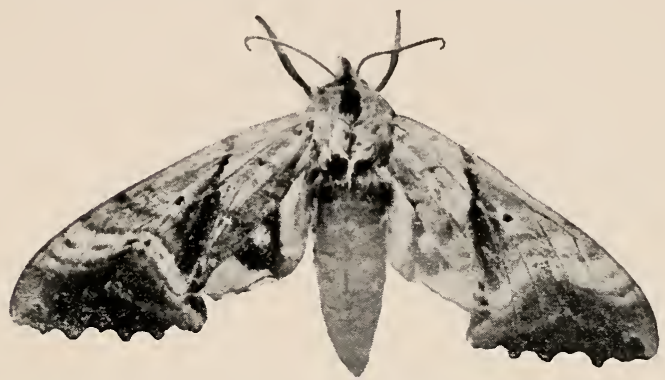

FIG. 20. - Smerinthus geminatus, the Twin-spotted Sphinx. Nat. size. Photo. by W. H. C. P.

to fruit and shade trees. The Pandorus Sphinx (Fig. 21) is of a beautiful olive color ; its larva feeds on vines.

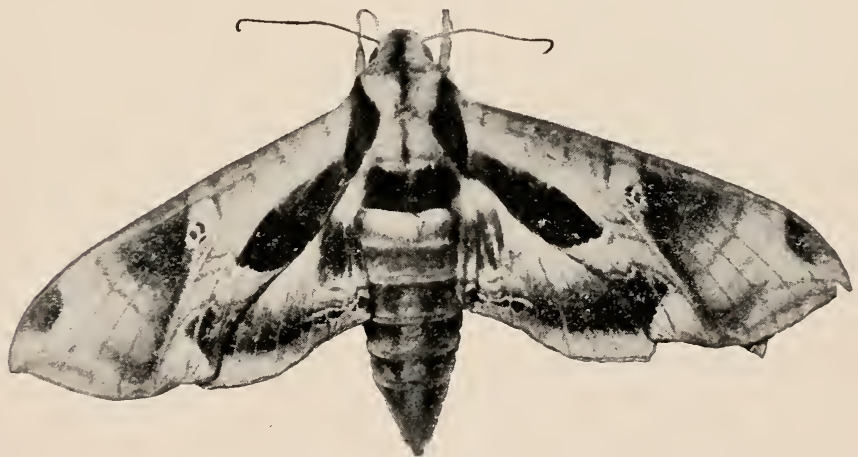

FIG. 21. - Philampelus pandorus, the Pandorus Sphinx. Nat. size. Photo. by W. H. C. P.

The Xylotropidæ ${ }^{1}$ are chiefly medium to small, clearwinged species which fly at dusk or in daylight. Their

$1 \xi \dot{v} \lambda o \nu$, wood; $\tau \rho \epsilon \dot{\phi} \phi \omega$, to feed; because the larvæ feed on wood. 
larva live in stems of squash, cucumber, etc., and bore into shrubs and trees (Fig. 22).

The Arctiidæ, ${ }^{1}$ or 'Tiger-moths, are for the most part conspicuonsly striped or spotted. The larva are very hairy. The best known is the furry, brick-red and black Isabella

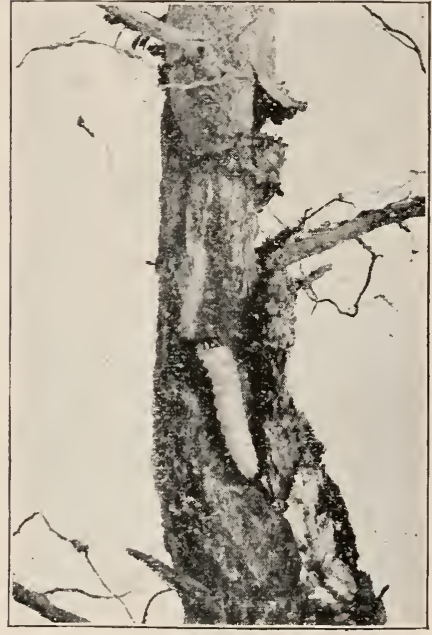

Fr. 2.2. - Larva of one of the Sesiida boring in stem. Nat. size. Photo. by V.11. L. caterpillar, which can be seen during October in New England, hurrying nervously in search of winter quarters.

The Bombycidæ2 include, as a rule, large and thickbodied moths. Here belong the silkworm moths - the only moths of use to man. Of these, Bombyx mori ${ }^{3}$ is the most generally employed in the manufacture of silk. It criginally came from China, feeds on the leaves of the white mulberry, and is reared chiefly in China, Japan, Italy, and France. The method of culture is as follows: The eggs ("grains") are laid in the autumn, kept over winter in a dry, airy, and cool place, and hatehed when the mulberry begins to send out its leaves. On these leaves the larvie are put to feed, and after a month they begin to spin. For commercial purposes the larva are induced

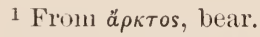

2 Bombyx-like. Aristotle called the rustling silk $\beta$ ó $\mu$ os; hence the name Bombyx for the silkworm.

3 morus, a mulberry tree. 
to spin the cocoons on prepared twigs or straw. A few days after the cocoon is completed its inhabitant is killed

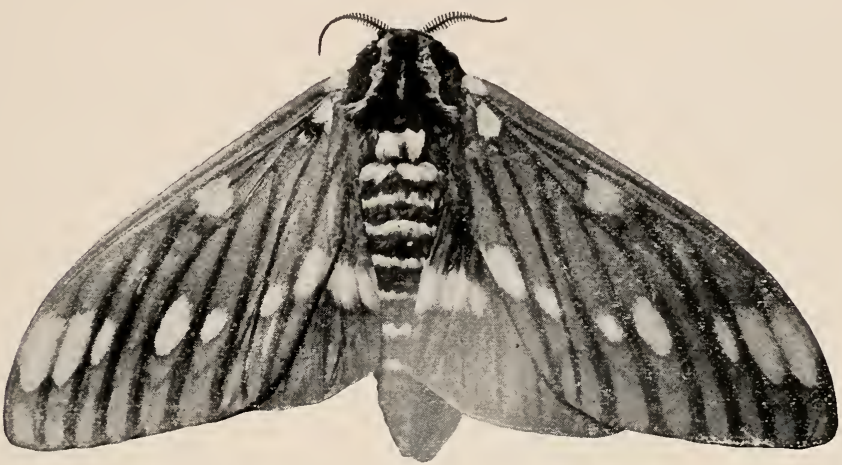

Fia. 23. - Citheronia regalis, the Regal moth. Olive and red wings, yellow spots. Nat. size. Photo. by W. H. C. P.

in.hot water. The cocoon is made of a continuous thread about three thousand metres long, of which, however, only

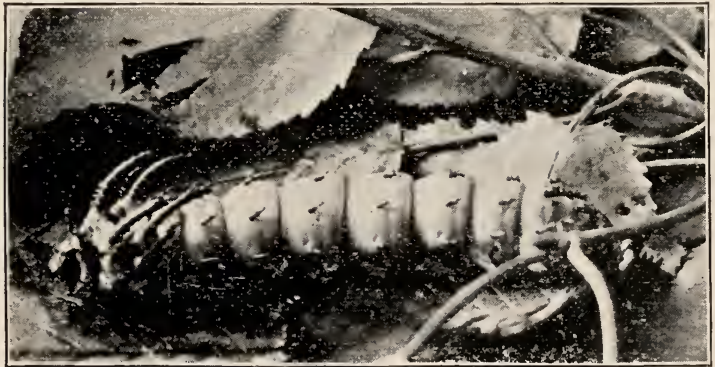

FIG. 24. - Larva of Citheronia regalis. Head to left. One-half nat. size. Photo, by IV. H. C. P.

about six hundred metres make good silk. 'This long thread has to be unravelled. The outer end is loosened 
by soaking the cocoon in hot water; then several of these ends are brought together and united to form a single fibre

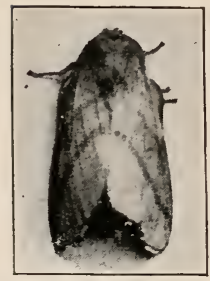

Fig. 25. - Adult female of Clisiocampa disstria. From life. Nat. size. Photo. by V. H. L.

of raw silk. Another imported silk-moth common in parts of the United States is the Cynthia ${ }^{1}$ moth, whose larva infests Ailanthus trees. True American forms are the brown Polyphemus ${ }^{2}$ moth, whose larva is colored light green, with oblique yellow stripes; the Promethea ${ }^{3}$ moth, whose cocoon is formed in a folded leaf which is securely fastened by silk threads to its twig; the Cecropia moth, expanding six inches, whose coarse tegumentary cocoon is bound along its whole length to a twig; and the nearly equally large Regal moth (Citheronic regalis, Fig. 2:3), whose larva is our largest caterpillar (Fig. 24). All of these species are easily reared from the larvæ or cocoons.

Closely allied to the Bombycidie are the

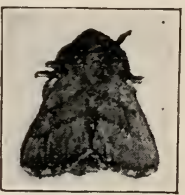

FI: 26. - Adult male of Clisiocampa. From life. Nat. size. Photo. by $\mathrm{V}$. H. L. Tent-coterpillars, which are never of great size. These are

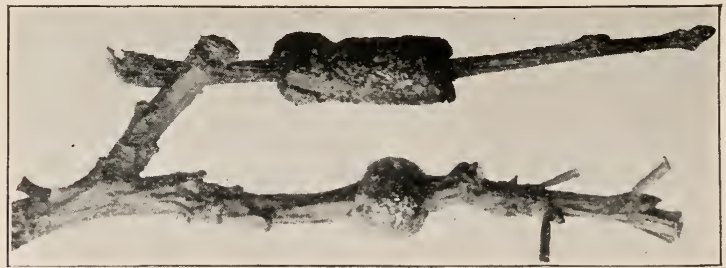

FIG. 27. - Egg masses of forest Tent-caterpillar, laid on branch. Photo. by V. H. L.

1 A poetic name of Diana, from the mountain Cynthus.

2 The name of the fabled one-eyed giant blinded by Ulysses.

3 A name in Greek mythology. 
destructive species, which infest apple trees and even forest trees (Figs. 25 and 26). Eggs are laid in a ring-like cluster around a twig (Fig. 27). Here they pass the winter and hatch out in the spring as young larve. 'The larve are gre-

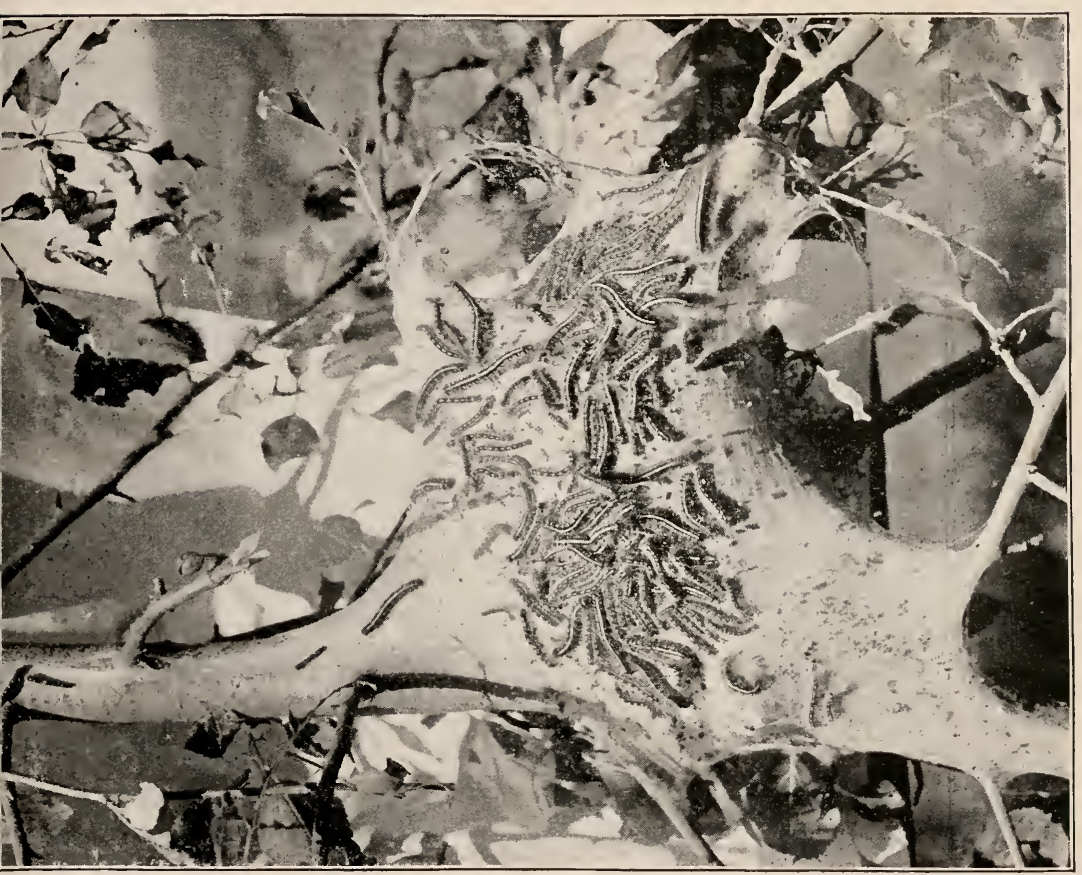

Fig. 28. - Nest of Clisiocampa disstria, the forest Tent-caterpillar, showing the web and the way the larvæ crowd together on it. Photo. by V. H. L.

garious and spin a tent-like weh, on which they live when not feeding (Fig. 28). When ready to transform, they spin a cocoon made of a yellow powder mixed with silk. The Noctuidæ ${ }^{1}$ (Owlet moths) are night fliers and are 1 From nox, night. 
attracted by our lamplights. They are the most numerous of all our moths, eighteen hundred species being known from our country. Among the largest members of this

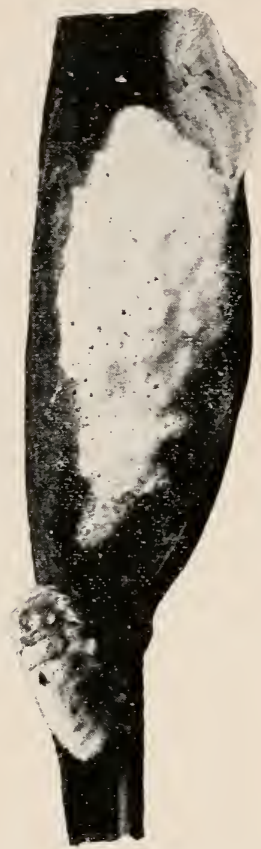

Fig. 29. - Notolophus, the Tussock moth. The wingless female is shown below a mass of eggs she has just laid. Nat. size. From life. Photo. by W. H. C. P. group are the Catocala ${ }^{1}$ moths already referred to. Here also are placed the boll-worm, which eats cotton-pods and grreen ear's of maize; the cotton-worm, which destroys the foliage of cotton; the army-worm, which devours grass and young grain; and the myriad cutworms, of which some gnaw off young garden shoots at the level of the ground, while other kinds ascend trees and destroy buds. 'To the Noctuida belong' also the Tussock moth (Fig. 29), whose variegated larva bear's dense brush-like tufts of whitish hairs on the first four abdominal segments, and is very destructive to shade trees in our cities; the Gypsy moth, lately imported in to Massachusetts, where the state has attempted its annihilation; and the Brown-tail moth, also lately imported to Boston.

'The Geometridæ, or measuring-worms, are, like the Noctuids, very numerous and very destructive. They are so called because the larve have a way of proceeding, as it were, by inches in their locomotion. One of the most important subdivisions is that of the canker-worms, which often strip fruit and shade trees of their foliage.

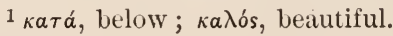


The Pyralidæ ${ }^{1}$ include among other pests the bee-moth. The larva of this species feeds upon the wax of the hive and constructs silken galleries in the comb.

The Tortricidæ ${ }^{2}$ contain numerous small, inconspicuous moths, whose larve are, however, very destructive. The colling-moth is a pest of the fruit-grower, for the larva bores into apples and pears, causing them to fall prematurely. Many species are called leaf-rollers, from the fact that the larva causes the leaf on which it feeds to curl.

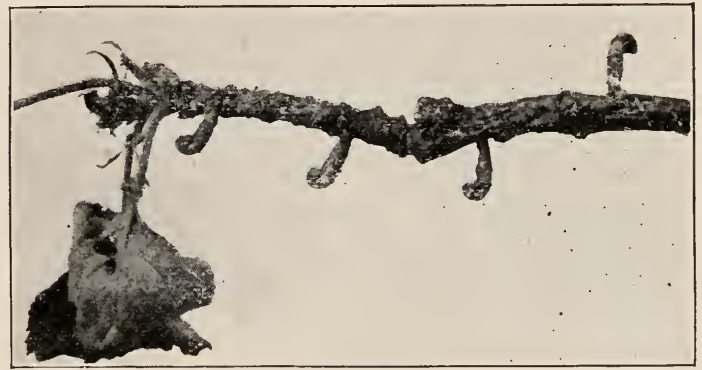

Fig. 30. - Case-bearing insects on a 1 wig. Phot:. from life hy Y. H. L.

The Tineidæ ${ }^{3}$ contain the smallest of the Lepidoptera. Their wings frequently bear long fringes. The larvæ are so small that they often live in the interior of leaves, and form winding or blotch-like "mines" in them. The larvie of some species make a case out of pieces of leaves united by silk, and carry this about with them. They are known as "Case-bearers" (Fig. 30). Here also belong the clothes-

${ }^{1}$ From $\pi \hat{v} \rho$, fire; because the ancients believed these insects to arise from and live in fire.

${ }^{2}$ tortor, tortivix, winder, from tormen, to roll or wind; with reference to the habit of twisting up leaves.

${ }^{3}$ tinea, moth. 
moths, of which we have three species. These moths fly early in May, and lay their eggs on woollen cloth, furs, or feathers, upon which the larva feed.

This review of the Lepidoptera shows us that, on the whole, despite their beauty, they are great enemies of agriculture, since most of them feed on vegetable products. Not only do we in this country have an abundance of native forms, but several exotic species have been imported; and being thus removed from their natural enemies, their natural fecundity has been unchecked, with the result that they have brought great devastation upon vast agricultural districts. The earnest attempts of a state to keep down for a while an introduced pest, even at great expense, is commendable.

The Hymenoptera ${ }^{1}$ include bees, wasps, ants, and certain less well-known insects. They all have four similar membraneous wings as the Lepidoptera do; but unlike the Lepidoptera, their wings are not covered with scales, but are transparent. The mouth parts are formed for biting or for sucking, but the proboscis is not so long that it rolls up as in Lepidoptera.

The Hymenoptera belong to one or the other of two groups, - the stinging Hymenoptera, in which the female is provided with a sting, and the boring Iymenoptera, which are provided with an ovipositor, or long tube, by which eggs can be placed at some distance below the surface. To the first division belong the bees, wasps, and hornets, certain digging or boring wasps, and the ants. To the second division belong certain species, - as, for example, the ichnemmon flies, - which are parasitic on

$1 \dot{v} \mu \dot{\eta} \nu$, skiı, membrane ; $\pi \tau \dot{\epsilon} \rho o \nu$, wing. 
other insects, the gall-flies, or gall-wasps, and the planteating Hymenoptera. ${ }^{1}$

The bees $\left(\right.$ Apidæ $\left.^{2}\right)$ include both social species and others which lead solitary lives. Of the latter, some dig their nests in the ground; others are masons, and build their nests of mud; others are carpenters, and make tumnels through pithy plants, or even solid wood; while still others are leaf-cutters. These léaf-cutting bees carve circular disks from rose leaves, out of which they make cells for their young.

Of the social bees, our native species belnng to the genus Bombus, - the "bumble" bees. The bumblebees build nests in the ground. The queens only survive the winter. In the spring each queen chooses some mouse nest or other ready-formed cavity in a meadow, and places within it a ball of pollen. Upon this food she lays eggs, which develop into

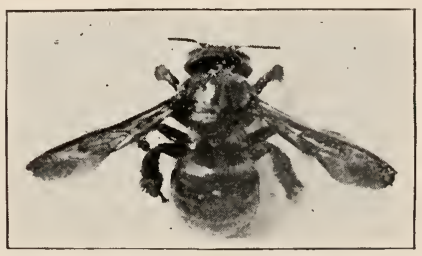

Fig. 31. - Bombus, the bumblebee. Nat. size. Photo. by W. H. C. I'. worker bees. As soon as the workers are full grown they begin the task of gathering food, and the queen then devotes all her energy to egg-laying. Later in the season males and young queens also appear in the nest. The old and young queens dwell together in harmony until autumn, when all the members of the colony perish excepting the young queens, which pass the winter in some sheltered spot and form new colonies in the spring.

${ }^{1} \mathrm{~A}$ key to the principal families of the Hymenoptera is given in the Appendix to this Chapter, p. 42.

2 From apis, bee. 
The introduced, semi-domesticated honey-bees have quite a different social economy. In the first place, the nest is perennial; consequently the young and old queens cannot remain in the same hive, else the nest would become overerowrled by the presence of too many families. As young queens mature, the old queen seeks to destroy

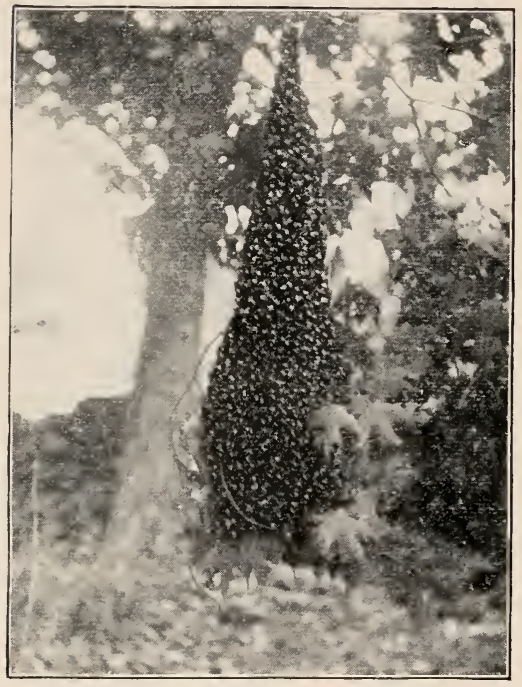

Fig. 31 $a$. Swarm of bees. Photo. by D. and $\mathrm{S}$. them; but she is usually forced out of the hive by the workers, a number of which accompany her. This migration is what we call "swarming." 1 When several young queens mature at the same time, duels or repeated swarmings ensue until only one queen remains. When a new colony is started in a hive or hollow tree, a comb is formed of wax secreted by the worker bees, and into this the queen deposits eggs destinerl to develop into workers. Still later, eggs destined to form drones are laid in cells larger than those in which workers develop. The developing young workers and drones are fed with honey and bee-brearl. Honey is derived from the nectar of flowers, which is lapperl up by the workers, is storer for a time in the crop, where it undergoes certain transformations, and is then 
regurgitated into the cells. The nature of the transformation of the nectar in the crop of the bee is not precisely known, but it is not great enough to prevent the characteristic flavor's of the flowers of the buckwheat, orange, and so on, from being retained in the honey. The bee-bread is made from the pollen of the flowers, which is brought into the hive on the hind legs of the workers. When a new queen is needed for the colony, and the queen cells are empty, one may be produced by the workers in the following manner: The partitions between three worker cells are destroyed and two of the embryos are killed. The enlarged cell is filled with a special nutritive compound manufactured by the workers and known as royal jelly. The remaining embryo, fed upon this especially nutritious jelly, develops, not into a worker, but into a queen.

(Of the true wasps ( $V^{\text {espidie }}{ }^{1}$ ), some are solitary; others, like certain of the bees, rear their families in the nests of other species (guest-wasps); while still others are social. The last group includes our best-known species. The colony of social wasps contains males, females, and workers. As in the case of bumblebees, only the females survive the winter, and in the spring they build small nests and lay worker eggs. The workers, when grown, enlarge the nest and care for the numerous progeny of the queen. Our social wasps

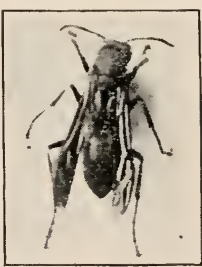

Fig. 32.-Polistes. Slightly reduced. Photo. by $\mathrm{IV}$. H. C. P. belong either to the genus Polistes, ${ }^{2}$ which includes the ordinary black, brown, or yellow bodied wasps, which build mushroom-shaped nests behind window blinds and under boards (Fig. 32), or to the genus Vespa,

${ }^{1}$ From respa, wasp. $2 \pi o \lambda \iota \sigma \tau \eta \dot{s}$, founder of a city. 
which includes the black and spotted hornets and yellowjackets, that build great masses of paper combs enclosed

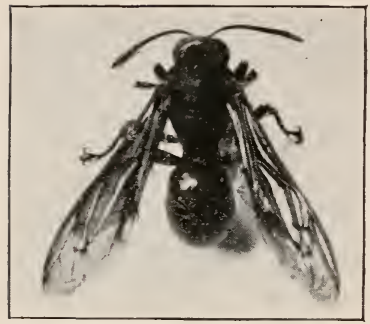

FIG. 33. - Vespa, a hornet. Nat. size. Photo. by W. H. C. P.

ing considerable pain. In all Hymenoptera the pain of the sting is due to the introduction of a poison into the body of the victim through the stinging organ. 'This poison is secreted by a special gland of the insect.

The digger and mud wasps (Fossoria ${ }^{1}$ ) have the most varied habits. One of the most familiar species is Pelopoeus, ${ }^{2}$ which somewhat resembles a true wasp, but may be easily distinguished from it by the long, slender attachment of the abdomen to the thorax and by the fact that the wings when closed lie flat and horizontal (Fig. 3t), while in the true wasps they are folded like a fan. Other species bore into the pith of plants or make burrows in the ground. Many are predaceous, feeding on spiders, cicadas, etc.

The ants (Formicidie ${ }^{3}$ ) constitute a well-known group having features so marked that other insects, excepting
1 From fossor, digger.
${ }^{2} \pi \eta \lambda o ́ s$, slime.
${ }^{3}$ From formica, ant. wasp, showing position of wings. Nat. size. Photo. by W. H. C. P. 
the termites, will hardly be confused with them. From the termites ants may be distinguished by the fact that the first segment of the abdomen forms a small knot or scale lying between the thorax and the remainder of the abdomen (Fig. 35).

The intelligence of ants is notorious. This intelligence has dereloped in connection with a highly organized social life. This social life is a communistic one. Homes are built, food is gathered, wars are made, and domains are defended bravely and loyally all for the sake of the entire community. The individual is little regarded, and each

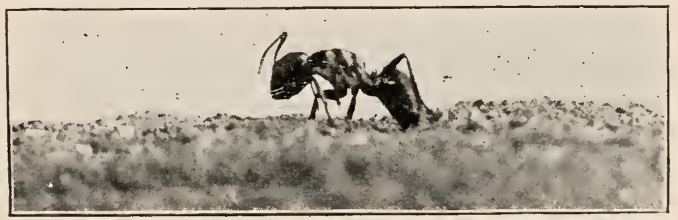

Fig. 35.-Camponotus, the carpenter ant. Uniformly black. Shows seale behind thorax. Nat. size. Photo. by W. H. C. P.

one is born to a caste from which escape is impossible. For, in addition to the distinction of sex characteristic of other species, we have here workers, and these workers may be of different kinds. Thus certain workers get food and care for the young; others, which serve as soldiers and defend the colony or conduct war, are in some cases provided with powerful jaws. In some species there are three or more classes of workers, each having its characteristic for'm of body.

Ant Colonies. - A colony is founded by a female. On warm days the young males and females may leave the nests and take flight in great numbers. This is the marriage flight of the queens. Within a few hours after 
nightfall of the day of this flight the males perish, while the queens settle down to the ground, tear off their wings, and each of them seeks an appropriate place to begin the formation of a new colony. If by chance a queen is discovered by some of her workers, she is cared for by them; otherwise she must get on alone. She makes a small nest and lays eggs, which quickly develop into workers, which then assume the task of constructing the nest of the new colony. The nests of our ordinary species consist simply of tunnel-like passageways dug in the ground and enlarged at intervals to form small chambers. Most species dig their nests preferably under protecting stones or the roots of trees; in other cases a hillock of earth and twigs, an "ant-hill," is constructed. These mounds may attain a diameter of from six to ten feet.

Ant Language. - In connection with their communal life ants have gained a power of communication. By the agency of their antennæ, with which two comrades are constantly stroking each other, they can tell each other of the whereabouts of food, of the approach of an invading army, or of the need of aid. They distinguish members of their own community from those of other communities, and recognize one of their number, even after a long absence, and receive it back to the colony with demonstrations as of joy.

Social Life of Ants. - To illustrate the complex social life of ants, a more detailed account is here given of certain interesting species. Certain ants, such for instance as our Formica ${ }^{1}$ difficilis, ${ }^{2}$ a rust-red species often found living beneath large, flat stones, make slaves of another species of ant which (a curious coincidence) is a dark-colored species. In at least one slave-making species the jaws have become 
so modified to aid it in capturing slaves that it is absolutely dependent upon its slaves for food, and it would die surrounded by foor were none of its slaves at hand to feed it.

The Agricultural Ant. - One of our most interesting ants is the Agricultural Ant of Texas (Myrmica ${ }^{1}$ molefaciens ${ }^{2}$ ). This ant makes a circular clearing about its mound, upon which it allows only one species of grass to grow. Indeed, some observers maintain that the seed of this grass is planted upon the clearing by the ants. Certain it is that the ripe seeds of the grass are carefully harvested by the ants and stored within the chambers of their mound. From time to time the seerls are brouglit out and dried to prevent sprouting. During rainy seasons, when the seeds germinate despite all precautions, the ants are said to nip off the sprout upon its first appearance.

The army ants, of which there are several species, occur in great numbers in tropical south America. Like many other species which live by hunting, they migrate from a locality after having exhausted it of their foot. While on the march, the young of the species are transported by some of the adults. IThen au army of these ants approaches a place, every living animal endeavors to escape. The breeding birds must be on the alert to pick off the advance ginard to prevent them from returuing to the army with news of the presence of nestlings. Insects of all sorts, young and old, fall a ready prey to these swarms. Some spiders escape by
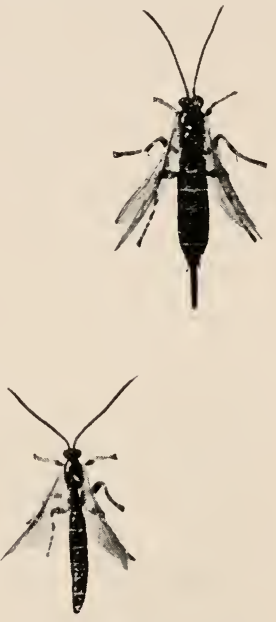

Fig. 36.-Pimpla pedalis, a parasite on the caterpillar of Clisiocampa. Upper figure female, lower male. Photo. by V. H. L. suspending themselves by their threads, and insects which resemble leaves often find safety in keeping rigidly still. When an army of these ants enters a house, the inhabitants find it wisest to leave the invaders in possession, for in a few hours the house is clearerl of every living thing - moths, cockroaches, rats, mice, all have fled or been devoured.

The leaf-cutting ants are another tropical American species. The $1 \mu \dot{\rho} \rho \mu \eta \xi$, ant. 2 Mole or mound builder. 
colony is very perfectly organized. The duties of the workers are divided among different gangs. Thus, when a tree has been selected, one gang ascends the trunk and cuts the leaves in pieces of a definite shape. The pieces flutter to the gromd, are picked up by another gang and carried to the entrance of the ant-hill, where they are deposited to be carried into the nest by a third relay. The bits of leaves are used to line certain of the passageways, and a fungus is grown upon them which serves the ants as food. The leaves are probably stored to provide this fungus food.

The parasitic Hymenoptera have the habit either of laying eggs in the body of another insect, - one of the plantlice, a caterpillar, or other species, - or else they lay their eggs in the nest of some species of insect so that the larva can make its own way into the host (Figs. 36-38). The long, tail-like ovipositors of the female ichneumon are, in

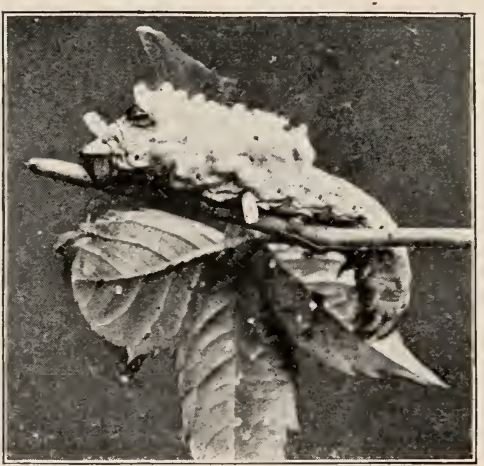

FIr. 37. -- Cocoons of Nicrogaster, a parasitic hymenopter, on a sphinx larva. Photo. from the living object by V.H. L. some cases, used to drill holes into trees occupied by insect burrows so that her eggs can be laid therein. These parasitic species are invaluable to agriculture in keeping down injurious insects.

The gall-wasps, popularly not distinguished from the strict gall-flies, are familiar to us from theif works. They lay eggs in various kinds of plants, especially in oaks and members of the rose family. An excessive growth of the plant tissue, called a gall, is cansed either by a poison dropped into the plant with the 
egg, or by the irritation of the developing embryo. ${ }^{1}$ The galls of gall-wasps are often more or less spherical masses

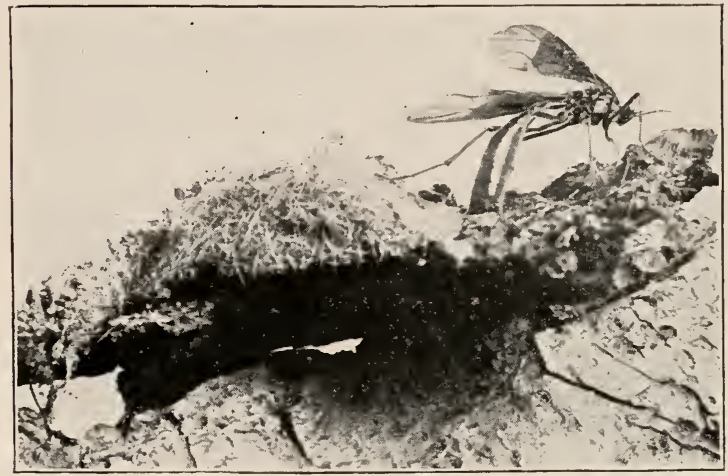

Fig. 38. - Ophion, an Ichneumon which infests caterpillars. Nat. size. Photo. by W. H. C. P.

which are closed, in consequence of which the confined insect must bore its way out. The galls made by the same

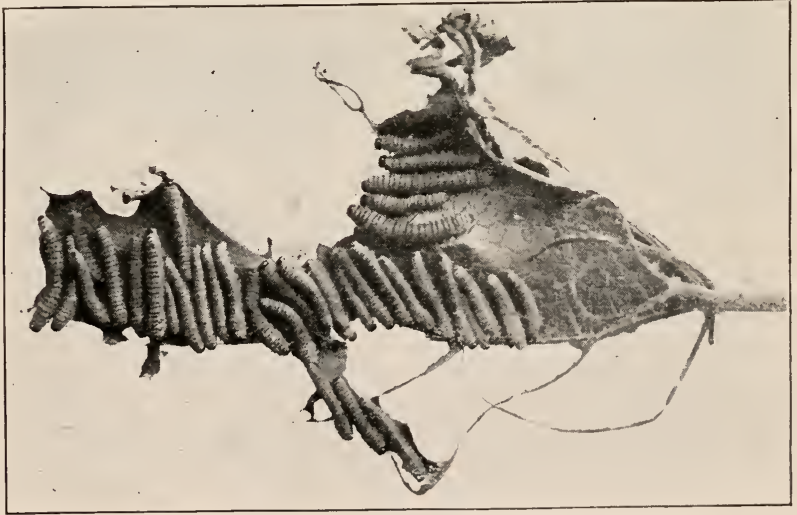

Fig. 39. - Larve of saw-tly on grape leaf. Photo. by V. H. L.

1 Cf. Fig. 69, p. 67. 
species of insect on one kind of tree are quite similar, but if the same insect stings another species of tree, a different kind of gall is produced. Also when different species of gall-wasps sting one and the same leaf, the galls will be unlike. Hence the characteristic form of the gall is determined both by the species of plant and by the

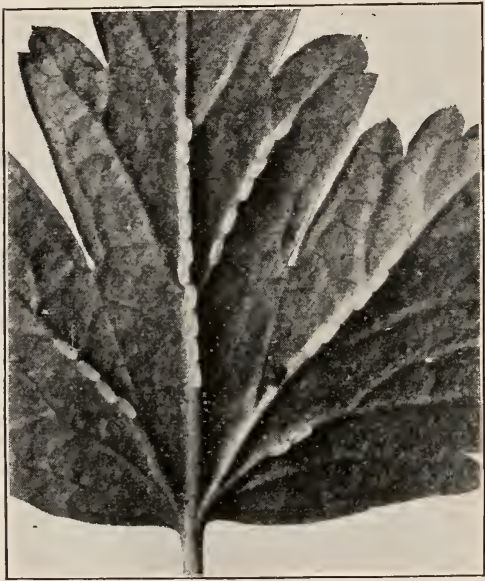

Fig. 40. - Eggs of Nematus, a saw-Hy on gooseberry leaf. Photo. by V. H. L. species of insect which lives in it. It is interesting to collect galls, wateh for the emerging wasps, determine their species, and thus get their entire life history. 'The gallwasps are, on the whole, injurious to agriculture.

\section{The plant-eating $\mathrm{Hy}$ -} menoptera are extremely destructive pests. The young are known as "slugs," from their resemblance to the true slugs, which are snail-like animals. 'They infest pear' trees and rose bushes, leaving scorched, dried leaves behind them. ${ }^{1}$ Here also belong the currant-worm and the sawflies (Figs. 39 and 40), which eat leaves like caterpillars, but differ from them in having twelve or sixteen prolegs instead of ten.

1 See "The Pear Slug," in Circular No. 26, 2d Series, U. S. Department of Agriculture, Division of Entomology. 


\section{APPENDIX 'TO CHAP'TER II}

KEY TO THE PRINCIPAL FAMILIES OF LEPIDOPTERA

$a_{1}$. Antennæe club-shaped at apex; wings when at rest held vertical (Fig. 19) . . . . . Papiliomidte

(Buttertlies)

a.2. Antennæe usually laving the form of a bristle, spindle, or thread, often with a comb; wings at rest held out flat (Fig. 23), or else folded over body like a gable roof (Fig. 25).

$b_{1}$. Hind wing usually with one or two dorsal veins [Macrolepidoptera, large-winged moths].

$c_{1}$. Antennxe spindle-shaped or keeled, rarely club-shaped; wings small; dusk fliers.

$c_{1}$. Antennæ prismatic . . .

$d_{2}$. Antennæe not prismatic, but

Sphingida

(IIawk-moths)

$e_{1}$. attenuated at end, occasionally pectinate

$f_{1}$. Clear winged (Sesiina).

$f_{2}$. Wings speckled, antennie much longer than head (Cossina).

$f_{3}$. Antennæ hardly longer than head (Itepialina).

$e_{2}$. club-shaped, occasionally pectinate. . . .

$c_{2}$. Antennæ bristle- or thread-like; wings Sylotropiale (Wood-borers) mostly broad, night fliers.

$d_{1}$. Wings when at rest placed like a gable roof over borly, or enveloping it; proboscis well developed.

$e_{1}$. Subcosta of hind wing united with radius for a considerable distance; body hairy . . .

$e_{2}$. Subcosta of hind wing nearly or quite distinct from radius; abdomen ending conically . .

Zyganiale (Zygenids)

Arctiide (Tiger-moths)

Noctuide (Owlet-moths) 
$d_{2}$. Wings as in $d_{1}$; proboscis usually weak; abdomen rounded at apex; antennæ pectinate . . .

Bombycidae (Silk-worms)

$d_{3}$. Wings rest horizontally; proboscis weak

Geometride

(Measuring-worms)

$b_{1}$. Hind wing with three dorsal veins [Microlepidoptera, small-winged moths].

$c_{1}$. Wings not divided or parted.

$d_{1}$. Wings rest in gable fashion, with short fringe or none at all.

$e_{1}$. Anterior wings elongate-triangular; palps extending beyond head . . . .

Pyralida

(Pyralids)

$e_{2}$. Anterior wings much elongated, cambered; antennæ with thick basal segment ; palps slightly protruding . . . .

Tortricide

(Leaf-rollers)

$d_{2}$. Wings at rest, flat or enveloping the body; the anterior wings with long fringe; strongly developed palps . . . . .

Tineide (Leaf-miners)

$c_{2}$. Wings divided or parted . . . . Pterophoride (Plume-moths)

\section{KEY TO THE PRINCIPAL FAMILIES OF HYMENOPTERA}

$a_{1}$. Trochanter simple; female with sting.

$b_{1}$. First segment of the hind leg more or less compressed, at least on inner side, and often thickly hirsute . . . . . A Apide

$b_{2}$. First segment of hind leg more or less cylin(Bees) drical, neither markedly broadened nor hairy. 
$c_{1}$. Anterior wings folded once lengthwise; antennæe usually clearly bent at an angle . . . . . . .

$c_{2}$. Anterior wings not folded lengthwise.

Vespida

(Wasps)

$d_{1}$. Abdomen appended or pedunculate, oval or broadest anteriorly, gradually tapering posteriorly .

Superfamily

Fossoria

(Digger and I ud Wasps)

d2. Abdominal stalk formed of one or two knots or scale-like rings ; antennæ flagellum-like . . . Formicide

(Ants)

$a_{2}$. 'Trochanter of two segments; female with ovipositor.

$b_{1}$. Abdomen not sessile, but appended or pedunculate; anterior rings without lancet-cells; hind wings with two root-cells .

Superfamily Entomophaga

(Parasitie and Gall-producing Hymenoptera)

$b_{2}$. Abdomen sessile (or continuous with thorax); anterior wing with lancet-cell ; hinder wing with three root-cells . . Superfamily

Phytophaga

(Plant-eating Hymenoptera) 


\section{CHAPTER III}

\section{THE BEETLE AND ITS ALLIES}

Beetles (Coleoptera ${ }^{1}$ ) can be distinguished from other insects by the fact that the anterior pair of wings (elytra) are modified to form two horny shields, covering the posterior part of the body, while the posterior pair of wings are membranous. The mouth parts are formed for biting. ${ }^{2}$

During development, the beetles, like the Lepidoptera and Hymenoptera, undergo great changes of form. These changes may be observed in the potato-beetle. In this species the orange-colored eggs are leposited often in a very regular manner on the under side of the potato leaf. Here they develop for several days. In about a week, however, the young, reddish, black-spotted larva, or "grub," emerges. Like the adult beetle, it has three pairs of thoracic legs. After feeding actively for two or three weeks, the larva descends into the ground, forms a naked yellow

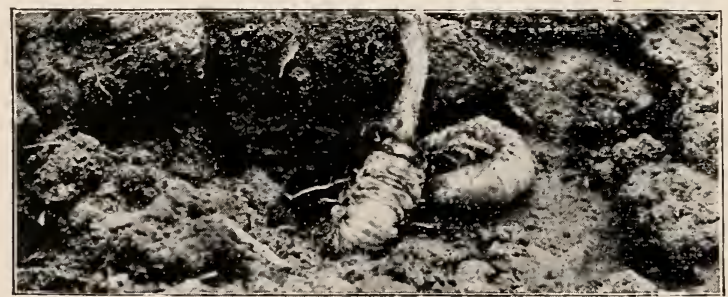

Fig. 41. - Larva of Lachnosterna, the June bug, at roots of aster. Photo. of living animals, nat. size, by V. H. L.

$1 \kappa o \lambda \epsilon o ́ s$, sheath ; $\pi \tau \epsilon \rho \delta \nu$, wing.

${ }^{2} \mathrm{~A}$ key to some of the chief families of Coleoptera is given in the Appendix to this Chapter, page 58. 
pupa, and emerges in about ten days as an imago. From two to four broods are produced during the year. The adult beetles hibernate in the ground, emerging and laying eggs the following spring.

The larval habits of the different kinds of beetles are extremely varied, quite as varied as the habits of the adult. The details of these differences may be best considered when we take up the different kinds of beetles.

The number of species of beetles which have been described is very great, probably over one hundred thousand. Of these, over ten thousand inhabit America, north of Mexico. Fortunately this vast number can be included within a relatively small number of families. Leaving the precise definition of these families to the table in the Appendix, we may here consider certain of the salient general characteristics.

\section{The running beetles} include two principal families. The first of these is the tiger-beetles
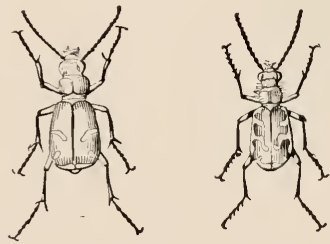

Fig. 42. - Three common species of Cicindela, the tiger-beetle. Left, red-copper bronze; middle, brown, witl yellow markings; right, bright green, cream-colored markings. From Packard.

\section{(Cicindelida ${ }^{1}$ ), which}

are colored bright brown or green. 'They frequent sunny places, especially paths or sandy shores, and are extremely agile. $^{2}$ The larve are hunch-backed creatures, have a huge head armed with long jaws, and live in burrows, at the entrances to which they lie in wait for their prey.

The second family of the rumning beetles includes the ground-beetles (Carabidae ${ }^{3}$ in narrow sense). 'This family

1 Derived from candela, candle. $\quad 2$ Fig. 42. $\quad{ }^{3}$ кá $\rho$ aßos, beetle. 
is composed of about ten thousand species, of extremely varied form, size, and coloration. Most of them are of a shiny black color, usually with longitudinal ridges or rows of punctations on the elytra. ${ }^{1}$ They live on the ground, and during the daytime they are concealed underneath boards and stones, but at night they fly and climb trees and shrubs in search of other insects. They are most abundant near watercourses, and are sometimes found on the seashore. Some species enit ill-smelling fluids, often

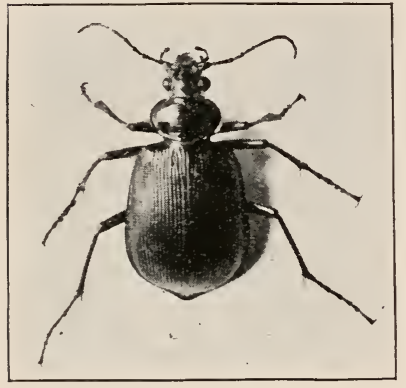

Fig. 43. - Calosoma serutator, the searcher, a ground-beetle. Nat. size. Photo. by W.H.C. P. with a popping sound. These fluids serve to defend them from their enemies. Some species are vegetable feeders, for instance one species whose larvie are destructive in the South to young Indian corn.

The next two families, Dytiscidæ ${ }^{2}$ and Gyrinidæ, ${ }^{3}$ include beetles which are quite as destructive to animal life of the water as the rumners are to those of the land. The Dytiscidre are often large species, which have long, thread-like antenne. The Gyrinidie have short antennæe and whirl around on the surface of the water, often in groups. Each eye is divided into an upper half, used for looking into the air, and a lower half, used for looking into the water. The larve of both of these families have a long and spindleshaped or flattened body and live in the water.

1 Fig. 43.

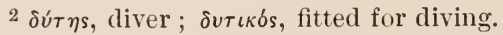

3 From $\gamma \hat{v} \rho o ́ s$, circle; because this beetle swims in a circle. 
Another family of aquatic beetles includes Hydrophilus ${ }^{1}$ and its allies, which are less strictly carnivorous than the last two families. Their antennæ are short and club-shaped, and their bodies are plumper than that of Dytiscus, which is of about the same size and lives in similar places.

The next family includes certain short-winged beetles (Staphylinidie ${ }^{2}$ ), so called because the elytra cover only a small part of the abdomen (Fig. 4t). These beetles ("rove-beetles") are usually black and of small size. They are very common under decaying organic matter, stones, and other objects

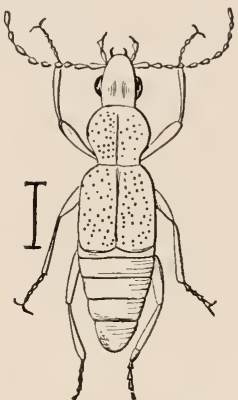

Fig. 44.- Anthophagus, a staphylinid. From Packard. lying on the ground. They run swiftly. Some species mimic ants and wasps. Not only do they resemble these

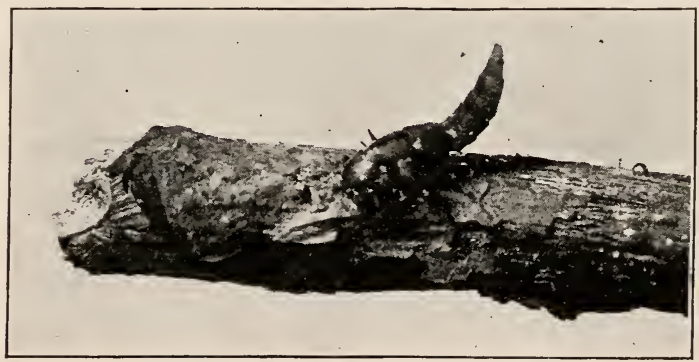

FIG. 45. - A staphylinid elevating the abdomen. Photo. by W. H. C. P.

Hymenoptera in the general form of the body, but also in the movements of the tip of the abdomen, which, when the

1 vi $\omega \rho$, water; $\phi i \lambda o s$, loving.

$2 \sigma \tau a \phi u \lambda \hat{\imath} \nu$ s, from $\sigma \tau a \phi v \lambda \dot{\eta}$, a cluster, is Aristotle's name for a certain insect. 
animal is irritated, is raised as though to sting (Fig. 45). 'These beetles feed upon decaying animal and plant matter; consequently they are useful scavengers. Some species in-

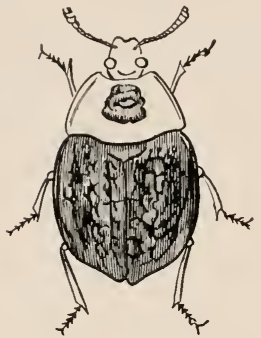

Fig. 46. - Silpha americana, a carrion beetle. From "Standard Natural History." labit the nests of ants and of termites, but their relations with their hosts are unknown. The larve are not unlike the adults, and inhabit similar situations.

The carrion or sexton beetles (Silphidis ${ }^{1}$ ) are usually of medium or large size, and are either stout-bodied, with red spots on each elytron (Necrophorus ${ }^{2}$ ), or very much flattened and with thin-edged elytra (Silpha, Fig. 46). The species of Necrophorus are powerful animals. When one or more pairs of these beetles discover a dead bird or small mammal on the ground, they dig out the earth from underneath and pile it upon the animal until eventually the carcass is entirely buried. Then the female deposits her eggs upon the body, so that a rich supply of food is provided for the young làve which hatch from the eggs. The members of the genus Silpha do not bury a carcass, but live and rear their young beneath it.
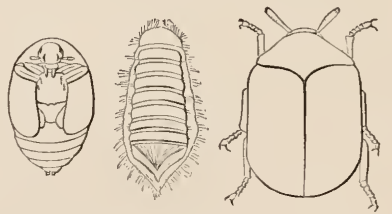

Fic. 47.-Anthrenus, the muse$11 \mathrm{~m}$ pest, a dermestid. Left, larva; middle, pupa; right, adult. From Packarel.

While the families of beetles hitherto considered are in general useful to man by acting as scavengers or by destroying insects injurious to vegetation, we have now

${ }^{1} \sigma i \lambda \phi \eta$, an ill-smelling insect.

2 $\nu \epsilon \kappa \rho \dot{s}$, a dead body ; $\phi \epsilon ́ \rho \omega$, to bear. 
to consider a family, that of the Dermestidæ, ${ }^{1}$ which is economically directly injurious in a variety of ways. The species of this family include small, oval, or elongated beetles with gray or brown markings, which are due to scales and can be rubbed off. The larve are fuzzy, and are more injurious than the imagos. They feed on wool, leather, fur of all sorts, as well as on dried and salted meats. Our most destructive species have been imported from Europe. One of them is the carpet-beetle or "buffalo-bug," which lives upon carpets and clothing. The museum pest is a closely related species which works sarl havoc with insect collections, unless these are subjected several times a year to the poisonous fumes of carbon disulphide (Fig. 47).

The stag beetles (Lucanidie ${ }^{2}$ ) have received their common name from the resemblance of their long, often branched mandibles to the antlers of a stag. The plates of the club-shaped antenna cannot be brought compactly together, as in the next family. The adult beetles live on the sap of trees, and the larve bore into the wood of the roots and trunk. The common large stag-beetle, which is often attracted into our houses by lamplight, is Lucums dama. In the South the giant stag-beetle (Lucams elephans) is found, with mandibles which, in the case of

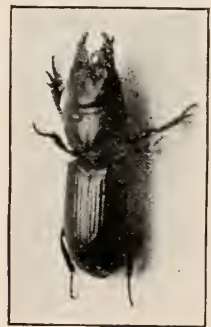

Fig. 48.-Doreus, a stag-beetle. Nat.size. Photo. by IV. H. C. P. the male, are more than three-fourths the length of the body.

Closely allied to the last is the great family of lamellicorn ${ }^{3}$ beetles, in which the ends of the antenne bear flat,

$1 \delta \epsilon \rho \mu \eta \sigma \tau \eta^{\prime} s$ ( $\delta \dot{\epsilon} \rho \mu a$, skin; $\dot{\epsilon} \sigma \theta \dot{\omega} \omega$, to gnaw), a worm which destroys pelts.

2 From lucus, grove.

${ }^{3}$ lamella, a small plate or leaf ; cornu, horn. 
closely applied plates. This family includes many very large insects. We can separate it into two groups, - the scavengers and the leaf-chafers.

The scavenger lamellicorns, commonly known as tumblebugs, live in the dung of horses and cows, which they form

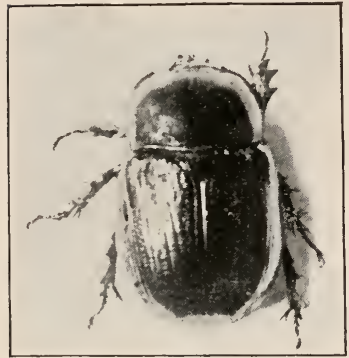

Fig. 49. - Copris, a tumblebug. Nat. size. Photo. by W. H. C. P. into balls and roll long distances (Fig. 49). The dung-rolling habit has long excited interest; indeed, among the Egyptians it was a source of superstition. So high was the veneration of this people for this their sacred beetle, that they reproduced it in their paintings and sculpture. The ball of dung is really intended for the deposition of an egg, and it is rolled by both males and females to a hole in the ground which has been dug in a safe place for its reception.

The leaf-eating lamellicorns include the May-beetles or "June-bugs" (Lachnosterna ${ }^{1}$ ) which are attracted by lamplight at night. They enter with a busy humming sound, soon come in violent contact with the wall or a piece of furniture, and fall heavily to the floor. They feed at night upon the foliage of trees and shrubs. Another common species is the rose-bug, ${ }^{2}$ which bears the name Macrodactylus ${ }^{3}$ subspinosus. It is destructive to the blossoms and young fruit of grapes,

$1 \lambda a ́ \chi \nu \eta$, sheep's wool; $\sigma \tau \dot{\epsilon} \rho \nu$, the chest.

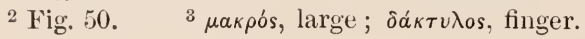

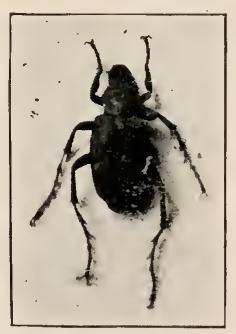

FIG. 50. - Macrodactylus, the rose-bug. Nat. size. Photo. by W. H. C. P. 
roses, and other members of the plant family Rosacer. The larva of the May-beetles are the fat, whitish, bowed grubs which are often found in the spring in the soil where they have passed the winter. They are very destructive, for they feed on roots of grass, herbs, and shrubs (Fig. 41).

Another family of beetles very destructive to trees is that of the metallic woodborers or Buprestidæ. ${ }^{1}$ The adults are found upon flowers and the bark of trees, where their metallic colors glitter in the sunshine (Fig. 51). The larvæ, which have relatively enormous heads, bore beneath the bark of trees or into the wood. This family reaches its highest development in the tropics.

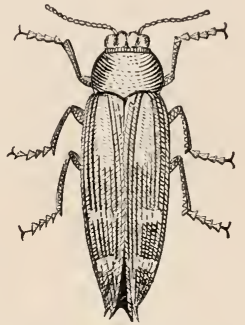

Fig. 51. - Buprestis rufipes, a metallic wood-borer. From "Standard Natural History.",

Closely allied to the foregoing is the family of click beetles or Elateridie. ${ }^{2}$ These have the power, when placed

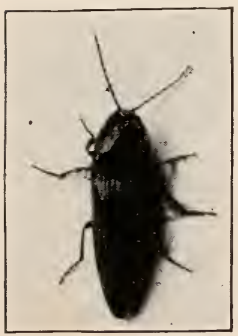

Fit. 52.-One of the click beetles. Nat. size. Photo. by W. H. C. P. on their backs, of leaping into the air by means of a special device on the under side of the animal (Fig. 52). The larve, called "wire-worms" because of their round, hard bodies, live under the bark of trees and in rotten wood or upon vegetation in the ground. They are most destructive to germinating grain, especially maize. It requires several years for them to mature.

The fireflies (Lampyrid ${ }^{3}$ ) make up

$1 \beta o v i \pi \rho \eta \tau \iota s$, among the ancients a poisonous beetle, living in grass by swallowing which oxen ( $\beta$ ovs s) swell out $(\pi \rho \dot{\eta} \theta \omega)$.

$2 \dot{\epsilon} \lambda a \tau \eta^{\prime} \rho$, driver.

${ }^{3} \lambda a ́ \mu \pi \omega$, to shine; oúpá, tail. 
another and a well-known family. They are distinguished by soft wing-like elytra and by the great expanse of the

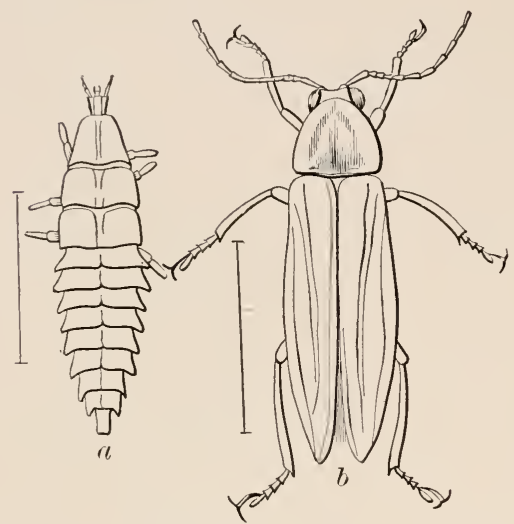

Fic. 53. - Photuris, a firefly. a, larva;

$b$, adult. The lines to the left of figures represent actual lengths of animals. From Packard. thoracic shield, which partly or wholly covers the head. Certain nonluminous species live on flowers, especially the golden-rod ; the luminous species are nocturnal. 'The light-giving organ lies in the abdomen. The larve also are luminous and are known as glow-worms (Fig. 53).

A family of considerable economic importance is that of the Tenebrionidæ, so called from

the principal genus Tenebrio, ${ }^{1}$ the larva of which, known as the mealworm, occurs in flour and cereals and looks much like a wire-iworm. ${ }^{2}$ The adult beetle is black and about one-half an inch long (Fig. 54). The family is not abundant in the northeastern part of the United States.

Several kinds of adult beetles (an be found under the bark of
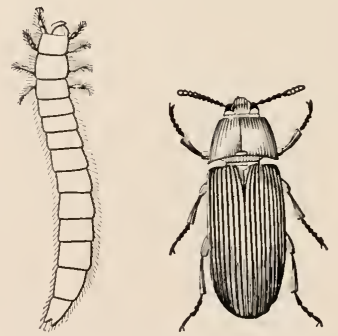

Fic. 54.-Tenebrio, the mealworm. Left, larva ; right, adult. From Leunis.

1 Miller, because it lives in flour.

2 These larvie are reared by bird-fanciers for bird food, and may be obtained in bird stores. 
trees, but these are mostly carnivorous and are seeking their prey there. 'The minute bark-borers or engraver beetles (Scolytidie ${ }^{1}$ ), however, feed on the innermost layer of bark. As they eat in lines, a pattern is formed which is characteristic for each species. Along these lines, niches are made in which eggs are laid and larve hatch. The borings are injurious to the trees, often causing their death. Herbaceous plants also are infested by certain spicies. An example is the destructive Pine Borer (Fig. 55 ), which is common throughout the United

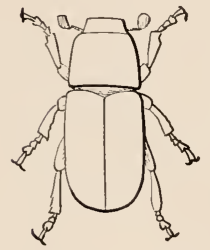

Fig. 5.5. - Dendroctonus, an engraver beetle. Magnified 2.5 times. From "Standard Natural History."
Sitates and C'anada.

One of the most injurious of all the families of beetles is that of the weevils (Curculionidic $^{2}$ ). 'These beetles are small, and their heads are drawn out into a long snout by which they bore holes in plant tissue to receive their eggs (Fig. 56 ). The dull colors of the beetles render them in-

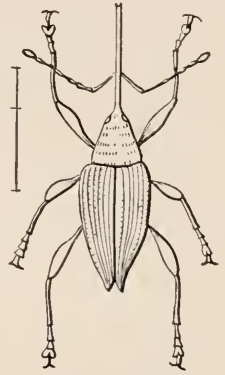

FIG. 56. - Balaninus, a weevil, of brown color. From Packard.

conspicuous to insect-feeding birds. 'The number of species is reckoned at over ten thousand, and the family is of worldwide distribution, its dispersion having been aided by commerce. Grain-weevils are great pests in stored wheat, rice, or maize. They also oviposit in the planted seeds. Buds are attacked, and nuts, stone fruit, and fleshy fruits are made "wor'my" by them.

Extremely destructive also is the great family of long-

1 From $\sigma \kappa o \lambda \dot{\pi} \pi \omega$, to mutilate.

2 curculio, a grain-weevil. 
horned beetles, "buck-beetles," (or Cerambycidie ${ }^{1}$ ), of which about six hundred species are known in North

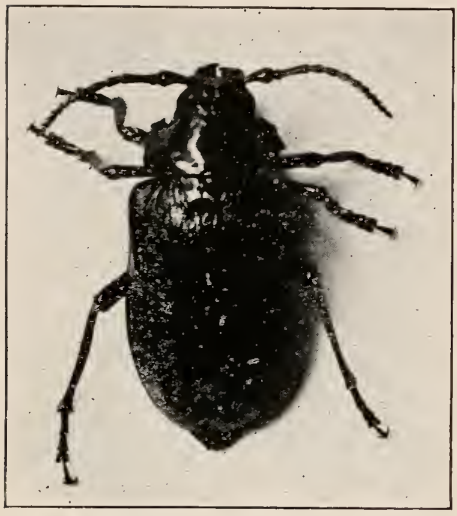

Fig. 5T.--Prionus laticollis, a longhorn. Black. Nat. size. Photo. by W. H. C. P.

America alone. The antenne and legs of these beetles are very long. ${ }^{2}$ 'The larva bore into even the hardest woods, and live in the wood for two or three year's. Timber and shade trees are thus greatly damaged. A favorite collecting ground for Cerambyciclie is the golden-rool, where the black, yellowbanded locust borer, C'yllene robince (Fig. 59), is pretty sure to be found.

Still another destructive family is that of the leaf-eating beetles, - the Chrysomelidre, ${ }^{3}$ to which the potato-beetle belongs. These beetles are thick and round in shape. They lay their eggs upon the leaves of plants. The larvie feed on the leaves or burrow in the stem. Usually the larva is conspicuously colored and exposed, and relies for protection upon its disagreeable odor and taste. The most destructive species to agriculture in the northern United

$1 \kappa \epsilon \rho a ́ \mu \beta v \xi$, a beetle with long horns.

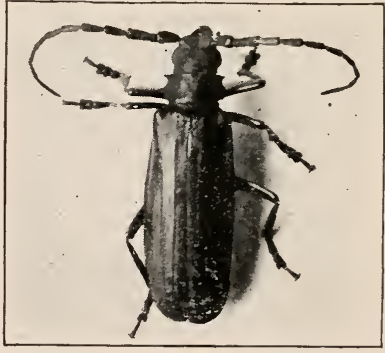

Fia. 58. - Orthosome brunneum, the straight-borlied Prionid. Brown color. Nat. size. Photo. by $\mathrm{W}$. H. C. P.

2 Figs. 57 and 58.

3 chrysomela, gold beetle, from $\chi \rho v \sigma o s$, gold, and $\mu \hat{\eta}$ ov, apple. 
States is the ten-lined Colorado potato-beetle, Doryphora ${ }^{1}$ decemlineata. Until about 1859 this species fed upon the sand-bur (Solanum rostratum), at the eastern base of the Rocky Mountains and south into Mexico. With the advent of settlers and the planting of the cultivated potato (Solanum tuberosum, a native of Mexico), this more thrifty, cultivated species was adopted as its food-plant, and the potato-beetle began its eastern migration. It spread slowly at first, but within fifteen years had reached the Atlantic coast. The little red, yellow, and black asparagus-beetle, the yellow, black-striped cucumber and melon beetle, the tortoise-beetle, whose broad, iridescent, translucent elytra are conspicuous on the leaves of the morning-glory, nettle, and other plants, all belong to this family.

So long has become our list of destructive beetles that it is with satisfaction that we turn at the end to a family which is almost wholly beneficial to the vegetable kingdom, as well as to most vegetable-feeders, including man. This is the ladybird family, Coccinellidie. These beetles are predaceous, both in the larval and adult stages, feeding upon small insects and insect eggs (Figs. 60 and 61). They are especially

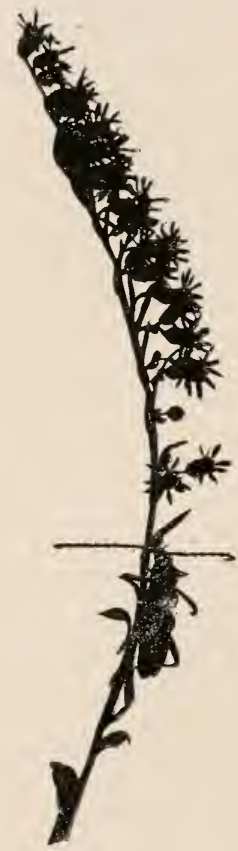

Fig. 59. - cyllene robinx, the locust borer, found on the golden - rod. Photo. by IV. H. C. P.

active in freeing plants from scale-insects and plant-lice. So rapidly do the latter multiply that were it not for the voracious larve of the ladybird most plants would be

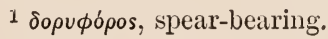


destroyed in a single season. The larva of the ladybirds are dark, spotted, and hirsute. One of the commonest of

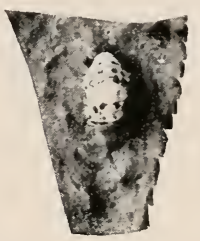

Fig. di0. - Pupa of Aratiscrellatuon a leaf. Nat. size. Photo. by V.H. I. our eastern ladybirds is a redbacked, two-spotted one (Adulia lipuncetuta).

The food of beetles is, as we have seen, extremely varied, more varied, indeed, than that of any other order of insects; woodfibre, bark of living or deat trees, leaf and stem tissue, nuts, fruits,

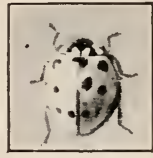

F I G. (i1. Anatisocellutu. Adult. Nat. size. Photo. by V.H. L.

grains, insects, adult and larval and dead animals of various sorts, are all utilized by them as food. Those beetles which destroy living plants, or which feed on fruits and grains utilized by man, those which burrow in tim-

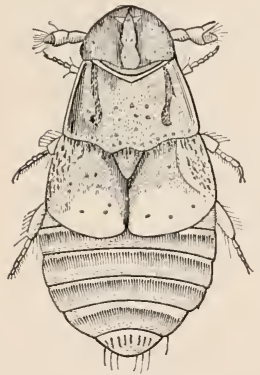

Fig. 62. - Platypsylla castoria, the beaver parasite. From Packard. ber, devour meat or articles of human industry and collections prized by man, may be ranked as economically injurious. One species, indeed, is injurious as a parasite of a useful animal; this is a curious beaver parasite, Platypsylla ${ }^{1}$ castoria. ${ }^{2}$ In so far as certain predaceous beetles feed upon other camivorous species of insects, as do certain tiger and carrion beetles, or upon small fish, as do some of the Dytiscidie, or upon domestic bees, like certain allies of the weevils, they may be indirectly injuring man. Of all the families of beetles, probably the leafeaters cause greatest destruction; next to them come the weevils, followed by the Cerambycidie and the others.

$$
{ }^{1} \pi \lambda a \tau u ́ s, \text { broad; } \psi \dot{v} \lambda \lambda a \text {, a flea. }
$$$$
2 \text { Fig. } 62 .
$$ 
Every part of the plant has its coleopterous enemy. As Le Conte and Horn have said: "As the function of the Cerambycidie is to hold the vegetable world in eheck by destroying woody fibre, the Bruchidie (weevils) effect a similar result by attacking the seeds, and the Chrysomelidie by destroying the leaves."

The list of beetles directly or indirectly useful to man is small. The carrion-beetles, tumble-bugs, and rovebeetles, which feed upon decaying animal and vegetable matter, are useful as scavengers. Of those which serve us by killing other insects injurious to vegetation, the ladybird beetle stands first. The economic importance to us of this one family can hardly be estimated. Different kinds of ladybirds feed on different species of insects. At one time it seemed that the orange industry, if not that of fruits in general, was doomed in California on account of the destruction wrought by the introduction of a scale-insect. As the insect had been imported, we had no native beetle which attacked it. Search was made abroad, and a ladybird beetle was found in Australia which feeds on this particular scale-insect. The Australian beetle was introduced into California, and now the scale-insect is subdued. The larve of some of the checkered beeties ${ }^{1}$ feed upon the larve of boring beetles, while the larva of tiger-beetles watch at the mouth of their burrows for other insects upon which they feed. Carabid beetles are said to ascend trees in search of canker-worms. Larvie of ground-beetles prey upon the pupating plum Curculios. Other beetles eat cutworms, and infest the common wasps.

One beetle, the blister-beetle, known in the markets as

${ }^{1} \mathrm{~A}$ family of rather small beetles, living in flowers and on trees, and often with contrasting colors. 
the Spanish fly, has been for ages used as a drug. When disturbed, there exudes from the joints of this insect a liquid serving as a protection, since it burns or blisters the disturber. This property is retained in the extracted or dried substance. The article sold in drug stores is obtained from crushing the dried beetle. The larva of various beetles have been prized as food by certain peoples from the Romans of Pliny's time down to the present, for they are eaten with relish by certain tribes of South American Indians. Fireflies sewn in lace are sometimes worn by the Spanish and Cuban women as adornments for evening clresses, while other beetles with particularly hard and beautifully colored and iridescent wing-cover's are used as settings in hat ornaments and buckles, as well as in jewels.

\section{APPENDIX TO CHAPTER III}

KFY TO THE PRINCIPAL FAMILIES OF THE COLEOPTERA

(The terminology of the key may be understood by reference to the figures on page 59.)

$a_{1}$. Hind tarsi with five segments, as likewise also usually the other tarsi, certain aquatic families excepted [Pentamera].

$b_{1}$. Elytra, short, exposing nearly whole of abdomen .

Staphylinide

(Iiove-beetles)

$b_{2}$. Elytra, nearly or quite covering abdomen.

$c_{1}$. Antennæe bent, first segment long, terminating in a club made of applied lamellie.

$d_{1}$. Lamellæe closely applied and flattened

Lamellicornia

$d_{2}$. Lamellie not closely applied ; mandibles very large . . . . Lucanide 


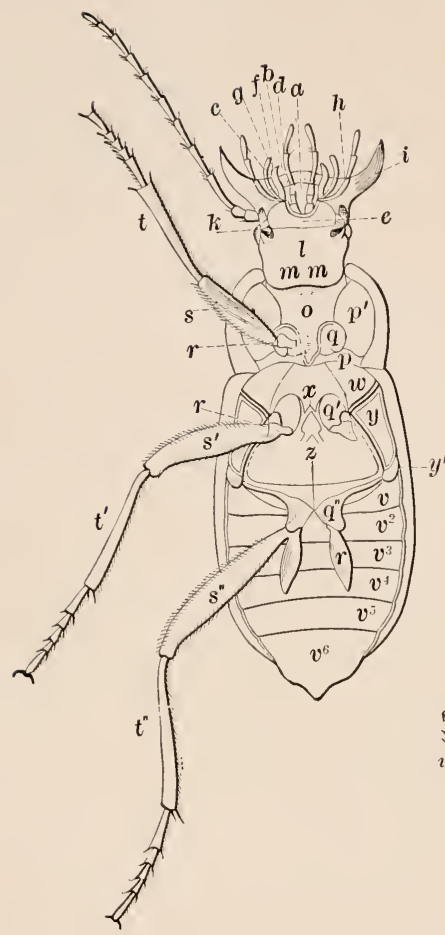

Fig. 62a.-Under surface of Harpalus, a ground-beetle. After Le Conte. $a$, ligula ; b, paraglossa ; $c$, supports of labial palp ${ }^{\mathrm{l}} ; \boldsymbol{d}$, labial palp ; $e$, mentum; $f$, inner lobe of maxilla; $g$, outer lobe of maxilla; $h$, maxillary palp; $i$, mandible; $k$, buccal opening; $l$, gula or throat; $m m$, buceal sutures; $o$, prosternum ; $p^{\prime}$, episternum of prothorax; $p$, epimeron of prothorax; $q, q^{\prime}, q^{\prime \prime}$, coxas $r, r^{\prime}, \imath^{\prime \prime}$, trochanters; $s,{ }^{\prime}, s^{\prime \prime}$, femora or thighs; $t, t^{\prime}, t^{\prime \prime}$, tibia ; $v, v^{2}, v^{3}$, ete., ventral abdominal segments; $w$, episterna of mesothorax (the epimeron just behind it); $x$, mesosternum; !, episternum of metathorax; $y^{\prime}$, epimeron of metathorax ; $z$, metasternum.

1 The leader should run to base of labial palp, $d$.

Fig. 62 $b,-$ Upper surface of Necrophorus, a carrion beetle. After Le Conte. ", mandible; $b$, maxillary palp; $c$, labrum ${ }^{1}$; $l$, epistome ; $e$, antenna: $g$. vertex of head; $h$, back of head; $i$ neck; $l$, prothorax; $m$, elytron ; $n$, wing or hind wing; $o$, seutellum (of mesothorax) ; $p$, dorsal surface of metathorax; $q$, femur or thigh ; $r, r^{2}, r^{3}$, etc., dorsal abdominal segments; $s, s^{2}, s^{3}$, etc., spiracle openings or stigmata; $t, t^{\prime}, t^{\prime}$, tibiæ; $v$, tibial spurs; $w$, tarsi.

1 The leader should run to the $V$-shaped piece in front of $d$. 
$c_{2}$. Antennæ straight, or, if bent, not terminating in lamellate club.

$d_{1}$. Maxillary palp as long as or longer than antennie . . . . Hydrophilide

(Water-seavengers)

$d_{2}$. Maxillary palp clearly shorter than antennie.

$e_{1}$. Six to seven ventral segments, or if only five, the first 3 or 4 are grown together.

$f_{1}$. Anterior coxie spherical or transverse, projecting little from the coxal cavity.

$g_{1}$. All legs used in running or walking . Carabide

(Runners)

$g_{2}$. At least the hinder legs used for swimming

$f_{2}$. Anterior coxæ conical or Dytiscide (Divers) Gyrinida J (Whirligigs) tooth-like, projecting prominently from coxal cavities.

$g_{1}$. Anterior coxæ conical ; abdomen composed of six rings .

Silphide (Carrion-beetles)

$y_{2}$. Anterior coxa approximately cylindrical ; cuticula soft, leathery

Lampyrila

(Fireflies)

$e_{2}$. Abdomen composed of five rings.

$f_{1}$. Anterior coxæ spherical; prothorax with a process resting in a depression of the mesothorax.

$g_{1}$. Not capable of leaping into the air . . Buprestida 
$g_{2}$. Capable of leaping into the air. . .

Elateride

$f_{2}$. Anterior coxæ conical, pro-

(Click-beetles)

truding from coxal cavities . . .

Dermestide

(Dermestids)

$a_{2}$. Hinder tarsi 4-jointed; anterior and posterior tarsi, 5-jointed [IIeteromera].

$b_{1}$. Fore coxæ separated, more or less enclosed in coxal cavity

Tenebrionide

(Meal-beetles)

$b_{2 .}$. Fore coxæ near together, protruding; neck evident; elytra broader than attachment to thorax

Meloida

(Blister-beetles)

$a_{3}$. Tarsi apparently 4-jointed, really 5-jointed, with very small, hidden, penultimate segment [Cryptopentaniera].

$b_{1}$. Head drawn out into proboscis . . . Curculionide

$b_{2}$. Head not drawn out into proboscis.

(snout-beetles)

$c_{1}$. Head prominent; antennæ usually as long as or longer than body . . Cerambycidee

(Long-horns)

$c_{2}$. Head short, sunk in thorax.

$d_{1}$. Antennæ short, bent, with thick terminal knob . . . . Scolytide

(Engravers)

$d_{2}$. Antennæ thread-like or beaded . Chrysomelide

(Leaf-beetles)

a4. Hind tarsi apparently 3-jointed, really 4-jointed, with inconspicuous penultimate joint [Cryptotetramera]. Short head, without clearly markedoff thoracic shield . . . . . 


\section{CHAPTER IV}

\section{THE FLY AND ITS ALLIES}

THE term "fly" is applied to many of the insects belonging to the Diptera ${ }^{1}$ or group of two-winged insects. ${ }^{2}$ It is strictly applied to the family Muscidæ. ${ }^{3}$ The most generally known representatives of this family are the house-fly with a sucking mouth, the stable-fly with a mouth fitted for piercing skin and sucking blood, and the blow-fly with a steel-blue abdomen. These flies love sunshine and dryness. On a bright day they fly actively in the open air. On damp days, on the other hand, they swarm into houses and

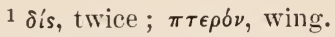

2 The following is a key to the principal suborders of the Diptera :-

$a_{1}$. All three thoracic segments fused, usually winged;

under lip unsegmented.

$b_{1}$. Adults not parasitic; maxillie covered by upper lip.

$c_{1}$. Antennæ long, many-jointed . . . Nematocera (Gnats and Midgets:

$c_{2}$. Antennæ short, usually 3 -jointed ; the third joint ringed . . . . . . Brachycera

(Flies)

$b_{2}$. Adults parasitic; upper lip enveloped by maxillæ as by a sheath

Pupipara

(Ex. sheel-tick)

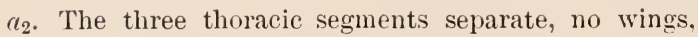

under lip segmented . . . . . Aphaniptera

(Fleas)

3 musca, fly. 
stables to avoid the wet, and otherwise show so great a sensitiveness to moisture that we predict rain by their stickiness and general increased ability to annoy. Both the house-fly and the stable-fly are abundant about stables, where their eggs are laid, and also about household provisions.

The different species of flies require different kinds of food, and the food of the larve is usually different from that of the adult. Thus the larva of the house-fly develops in horse manure and various other kinds of filth, while the adult feeds chiefly upon fluids or substances which can be dissolved by their saliva and then sucked up. The larva of the stable-fly lives in and feeds upon horse manure. The adult sucks blood. The larvæ of the blow-fly develop in meat, cheese, or nitrogenous vegetable material.

The development of flies is rapid. One or two hundred eggs may be laid by a single individual. These, in warm weather, hatch in a few hours into larvæ, commonly called "maggots." The larvæ are wholly footless, and even the head is only a slightly developed structure. 'The larvæ acquire full size in about a week; pupate and hatch about a week later. The process of pupation is a complicated one, for all the larval organs, excepting certain patches of tissue, are destroyed. By the growth of these patches the individual is formed anew. These changes are all deep lying, and nothing seems more passive than the brown pupal case. Finally the case breaks at one end, and the fully formed fly emerges. The metamorphosis which the fly has just undergone is a complete one.

The larvæ as well as the adult flies breathe, like other insects, by means of a system of air-tubes, which begin with slits in the body wall, stigmata, and pass inward to 
all parts of the body - the muscles and all other internal organs. These air-tubes are called trachea. They can be seen best in some aquatic larve with the aid of a strong magnifying-glass. Air is driven in and out of these tubes by means of expansions and contractions of the body wall. Although so very numerous, flies would be still greater pests if it were not for the fact that they are preyed upon by various parasitic animals and plants. The larva of the house-fly is sometimes infested by minute hymenopterous parasites. A still more important foe is a minute plant a fungus called Empusa ${ }^{1}$ muscce ${ }^{2}$ - which infests houseflies in the autumn. The dear flies may often be seen on window panes with fine white threads sticking out of the body, and surrounded by a halo made up of the spores discharged from the fungus upon the glass.

The order Diptera is a large one and a difficult one to study, for it contains many species and many of the species are composed of small individuals which are comparatively unknown. The members of the group can usually be distinguished by having only two wings, the posterior pair being rudimentary and transformed into knobbed "balancers." An account of the principal families follows.

The short-horned Diptera (Brachycera ${ }^{3}$ ), to which family the house-fly belongs, includes flies in which the third segment of the antenns is unsegmented, called true Brachycera, and flies in which the third segment of the antenna is segmented, called anomalous Brachycera. The true Brachycera include, besides the common flies, several other common or especially interesting flies.

$1 \stackrel{\epsilon}{\mu \pi} \pi \nu \sigma a$, a hobgoblin.

2 of a fly.

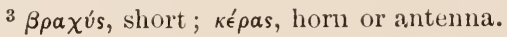


A member of the family Muscida, which is especially destructive in tropical Africa, is the tsetse-fly (Fig. 63). The bite of this fly is so dangerous that horses and dogs cannot penetrate the region infested by it. Eren herds of cattle may be killed by this fly. Consequently travellers have been hindered in penetrating into this country, and the opening up of tropical Africa to agriculture and commerce has been much interfered with. The injurious

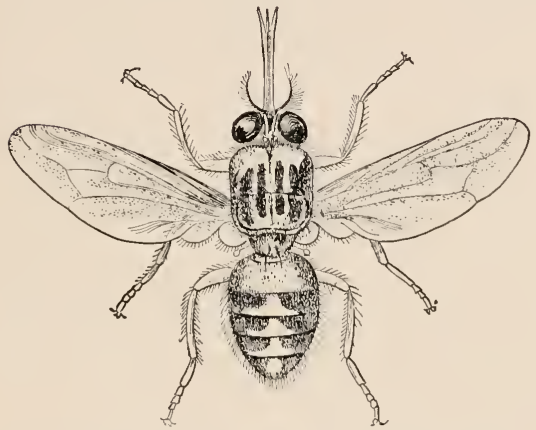

Fig. 63. - Glossina moristans, the tsetse-fly.

From the "Standard Natural History."

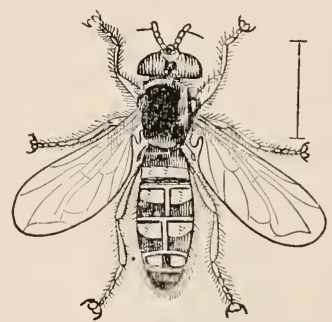

Fig. 6it. - Syrphus. From Patckard.

effect of the bite of this fly is clue to a parasite introduced by it into the body of the victim.

Another destructive family includes the bot-flies (CEstrid $\left.x^{1}\right)$, which have a general resemblance to honey-bees or bumblebees. Their larvæ are parasitic in mammals. Of this family the bot-fly of the horse, Gastrophilus ${ }^{2}$ equi, ${ }^{3}$ is the most generally known. These flies hover about the legs of horses and lay their eggs upon the horse's hair. The larva, irritating the horse's skin, are licked by the horse into its mouth and swallowed. In the stomach or

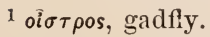


intestine of the horse they get abundant food, and there they develop. 'The larve of another species, "the oxwarble" or "grubs," are taken into the mouth of cattle, and live for a time in the osophagus. Then they bore their way through the walls of this tube, and travel on until they make their way out through the skin to the surface. Another injurious species is the sheep bot-fly, whose larve cause "staggers" in sheep.

The Syrphidæ, ${ }^{1}$ like the bot-flies, mimic honey-bees, bumblebees, and wasps. ${ }^{2}$ The adults feed on the pollen and nectar of flowers, and even imitate the humming of the bee. The larvie of some forms feed upon plant-lice; other's, upon decaying vegetable matter. They may occupy the nests of various stinging Hymenoptera. The larvæ of some species are known as rat-tailed maggots on account

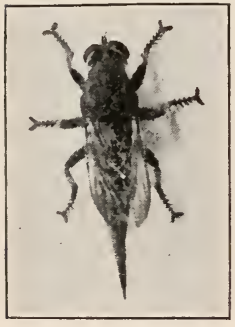

Fit: 65. - Robber-

1y. Nat. size. Photo. by IV. H. C. P. of their having a characteristic appendage. These are sometimes found floating in foul water or even in salt water.

The robber-flies (Asilidx ${ }^{3}$ ) are usually of large size, have a short head, prominent eyes, legs covered with stiff hairs, and abdomen either long and slender (Fig. 65), or stout. These flies attack and devour other flies and even insects much larger than themselves, such as bumblebees and dragon-flies.

The horse-flies ('Tabanidæ ${ }^{4}$ ) include the large mourning horse-fly, Tabanus astratus, which is of a uniform black color, the white-lined Tabanus, T. lineola (Fig. 66), and the smaller golden-headed horse and ox flies with banded

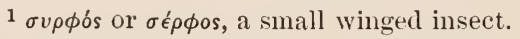

2 Fig. 64.

${ }^{3}$ From asilus, a gadfly. $\quad$ From tabanus, the gadfly of Pliny. 
wings (Fig. 67). Only the female sucks blood, while the male feeds in flowers. They are powerful and rapid fliers. The larve are carnivorous and live in the earth or water.

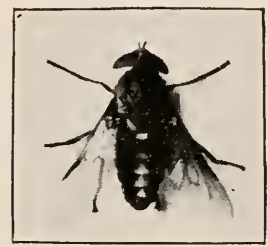

Fig. 66. - Tabanus lineola, whitelined horse - fly. $\times 1.2 . \quad$ Photo. by IV. H. C. P.

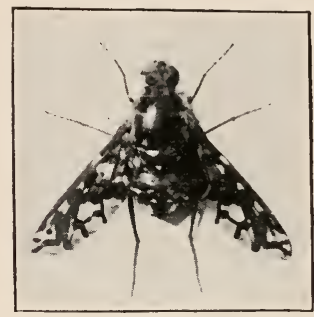

Fic. 67. - Chrysops, banded horsefly. $\times 1.5$. Photo. by W. H. C. P.

The black-flies (Simuliidae ${ }^{1}$ ) are representatives of the long-horned flies (Nematocera). They are familiar pests in the forests of our Northern country. 'The females, which alone suck blood, occur in such numbers and are so active that they render certain places almost uninhabitable to man. Their bite often produces widespreading and painful inflammation, accompanied by swelling (Fig. 68). The larve are aquatic. 'The Southern black-fly or "buffalo gnat" sometimes causes the death of domestic animals.

The gall-gnats (Cecidomyidæ ${ }^{2}$ ) are minute flies which lay eggs on plants. The larva make their way into the plant tissue, and cause the further development of the tissue to be abnormal, so that excrescences

${ }^{1}$ From simul, together; or simultas, a hostile encounter.

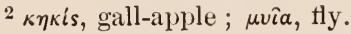


or galls are produced. The galls are formed only in growing tissue such as the tips of branches, buds of flowers or growing leaves, and are less striking on the whole than the galls of Hemiptera (Fig. 69). A certain kind of gall-fly, called Hessian-fly (Fig. 70), is extremely injurious to wheat

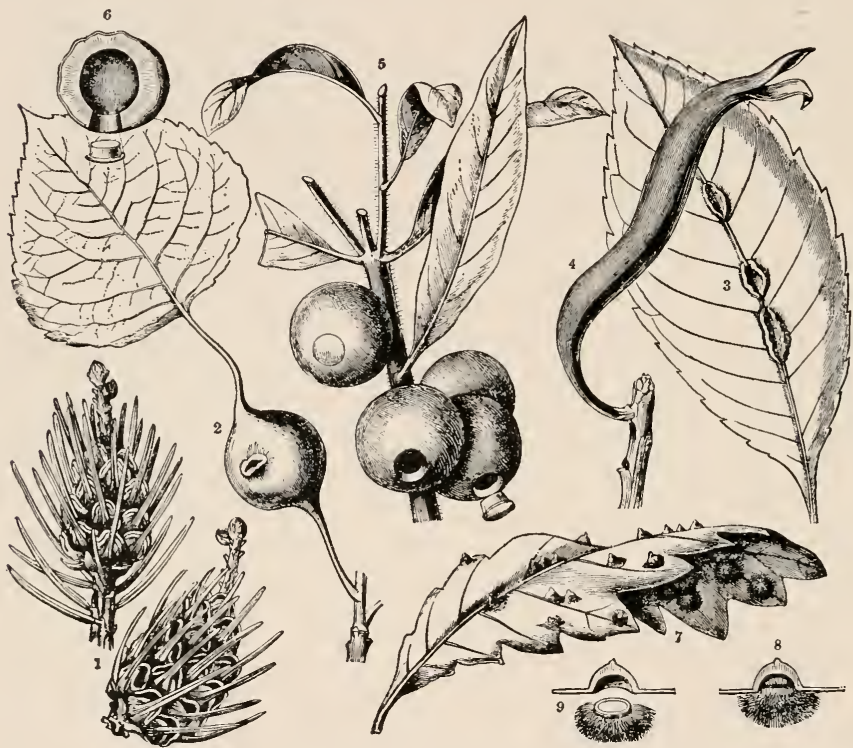

Fig. (6). - Plant galls produced by Hemiptera and Diptera. 1. Pine-apple gall on twigs of the spruce fir produced by the spruce-gall Aphis (Chermes abretis, one of the Hemiptera). 2. Covering gall on the petiole of the pyramidal poplar (Populus pyramidalis), produced by Pemphigus bursarius, one of the Hemiptera. 3. Covering galls on an ash leaf (Fraxinus excelsior), produced by Diplosis botularia (Diptera). 4. Covering gall on Pistacia (Pistacia lentiscus), produced by Pemphigus cormicularius. 5. Solid galls on the cortex of Duvana lomgifolia, produced by Cecidoses eremite (Hemiptera). (i. Longitudinal section of one of these galls. 7. Capsule galls on the leaf of the turkey oak (Quercus cerris, Hemiptera), produced by Cecidomyid cerris. 8. One of these aalls cut through, with the operculum still firmly attached. 9. The same, with the operculum falling away $: \times 3$. The remaining tigures natural size. From Kerner, "Pflanzen Leben." 
because it infests wheat seedlings and so weakens them that they produce no grain. Other minute gnats or midges are destructive to clover in the United States, either by binding the leaves together and sucking the sap of the plant or by destroying the young seed.

The mosquitoes, or Culicidæ, ${ }^{1}$ are so well known that it is hardly necessary to describe them. They can always be identified by the feathery antenne, by the presence of a
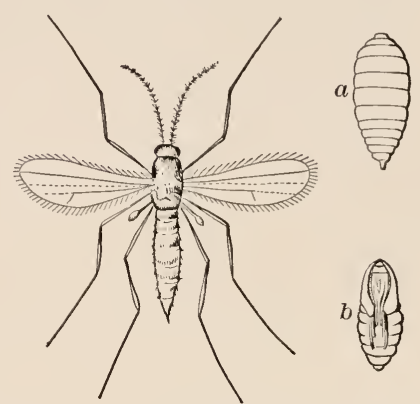

Fig. 70. - Cecidomyia, the HessianHy. ", larva; b, pupa. From the " Standard Natural History." fringe of hairs on the hind margin of the wing, and by the fact that the marginal vein runs all around the periphery of
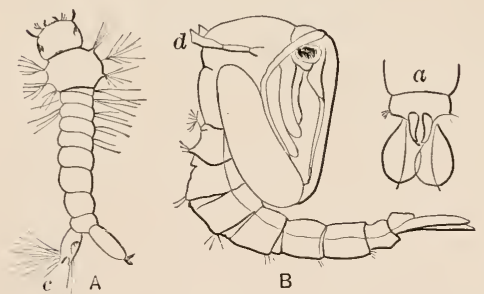

Fig. 71. - Culex, the mosquito. A, larva ; $c$, its respiratory tube. $B$, pupa; $d$, the respiratory tubes; $a$, the end of the abdomen with the two oar-like swimming appendages, dorsal view. After drawing of E. Burgess.

the wing. 'The larvæ are usually aquatic, but some species which are abundant on our Western arid plains must breed in the earth. The eggs of the aquatic species are laid in a boat-shaped mass, which floats on the surface of the water. The larve escape from the lower ends of the egg-cases, and are known as "wigglers." The larve rest vertically near the surface of the water, head downward, with the tail end of the body at the surface of the water, 1 Culex was Pliny's name for the fly. 
since respiration takes place at that end (Fig. 71, $A, c$ ). Upon emerging from the water, the mosquito floats in its pupal skin until its legs and wings harden. Since a disturbance in the water at this time would jeopardize the life of the mosquito, this insect always breeds in quiet waters. From the habits of the larve, it follows that they can be easily killed while in the pond by pouring kerosene oil on the water, for this forms a film on the surface and

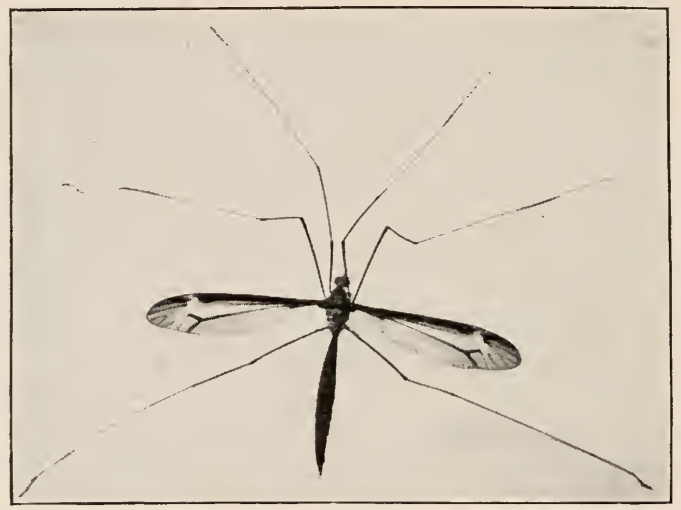

FI(: 72. - A crane-tly. Nat. size. Photo. by W. H. C. P.

prevents respiration. 'The objection to this treatment, however, is that most of the other aquatic organisms also are killed by it.

The crane-flies (Tipulidæ ${ }^{1}$ ) look like mosquitoes, but can easily be distinguished from them by the fact that they have a V-shaped suture on the back of the thorax. They are larger, and have relatively longer legs than the

${ }^{1}$ tipula, among the Latins an insect which courses rapidly on the water, - a water-spider. 
mosquito. Their legs are easily broken, and seem to be so much in the way that flight is clumsy. The adults are quite harmless, but some of the larve are destructive in that they feed upon tender plants and cause them to wither and die.

There remain to be considered a number of degenerate fies - degenerate because parasitic in the adult state. The first family we may consider is that of the louse-flies, ${ }^{1}$ or Hippoboscidæ. ${ }^{2}$ These small insects have a firm proboscis used for piercing, and stout legs. Only certain of the genera develop wings, and some of these lose them after they gain their hosts. 'They live, like lice, in the fur of mammals or the feathers of birds. They are viviparous, the larvæ being ready to pupate at the time of birth. The sheep-tick, Melophayus ${ }^{3}$ ovinus, ${ }^{4}$ is one of the best-known forms. Diptera allied to the foregoing live as parasites on the body of the honey-bee.

Fleas (Aphaniptera ${ }^{5}$ ) are likewise wingless, blood-sucking parasites. The body is laterally compressed so that it can move easily among the hairs of its host. The hindermost legs are strongest, and are used in springing. In Europe the human flea, Pule ${ }^{6}{ }^{\text {irrituns, }}{ }^{7}$ is a common pest, but in this country the $\log$ or cat flea is the one which causes most inconvenience to man. The dog flea differs from Pulex irritans in having a row of tooth-like spines on the lower margin of the head. The fleas develop in dust in the cracks of the floor and about the sleeping-places of domestic pets. They may be combated by means of cleanliness and Persian insect powder.

1 Suborder P'upipara.

2 i $\pi \pi$ os, horse ; $\beta$ ó $\sigma \omega \omega$, to feed.

${ }^{3} \mu \hat{\eta} \lambda o \nu$, sheep (wool); $\phi a ́ \gamma \omega$, to eat.
${ }^{4}$ Relating to sheep (oris).

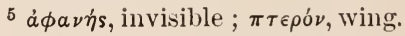

6 Flea.

${ }^{7}$ Irritating. 
Diptera affect man directly in very diverse ways. House-flies, black-flies, mosquitoes, and fleas are a positive source of discomfort, and often of disease. Thus there is a minute round worm, Filaria ${ }^{1}$ hominis, ${ }^{2}$ allied to the vinegar eel, which thrives as a parasite in the blood-ressels of men living in the tropics. The existence of this parasite, it is believed, depends upon the mosquito. The embryos are found in the surface circulation only at night, during which time man is most defenceless toward the mosquito. The embryos of the Filaria which have been sucked out of the blood by the mosquito develop in its alimentary tract, later they are deposited in stagnant water with the eggs of the mosquito, and reach man's body again if the water be drunk by him.

It is a current scientific belief that house-flies, whose larval stages are often spent in filth, which also the egglaying females visit, are an important agent in the distribution of disease. At least the suspicion is strong enough to justify all care taken to exclude flies from contact with food.

Indirectly Diptera are injurious to man by attacking domestic animals and cultivated plants. Thus the tsetsefly is a menace to the commerce of a large part of a continent. The horse-fly, the horn-fly, which worries cattle, the buffalo-gnat, which worries or even kills domestic animals, and the dangerous bot-fly, are all causes of great loss to industry. Also we liave seen that the larve of some flies infest vegetables, - such as cabbage, radish, cauliflower, onion, - as well as various fruits, and cause great damage. The gall-gnats destroy clover and its seed; and, worst of all, the Iessian-fly infests wheat and Indian corn. This last-named scourge, so called because of a tradition that it 
was imported in the straw bedding of the troop-ships which brought over the Hessian mercenaries in 1775 , has spread, within a century, over the eastern half of the United States, and has at virious times injured the wheat crop to the value of millions of dollars. The larvie of certain Muscidie, especially the genus Chlorops, ${ }^{1}$ attack, in Europe, the stems, leaves, and ears of wheat, rye, and barley, and cause in some year's great destruction, especially in Scandinavia.

Over against the injury wrought by the Diptera may be placed certain benefits bestowed by them. In the first rank come certain species which prey upon injurious insects, either in the larval or adult stage. The robber-flies prey on the Diptera, Hymenoptera, and certain beetles, but they are not careful to choose alone injurious species. The larvæ of the Syrphidie prey on the injurious plant-lice; those of horse-flies are carnivorous, and feed on insect larve. The larvæ of certain small flies are internal parasites of bugs, beetles, and other (mostly injurious) insects; while those of various other Diptera are useful in acting as scavengers, - mosquito larve, for example, serve in this way. The carrion-fly devours putrid animal substances, which might otherwise be a source of discomfort or disease. 'The insects which feed on decaying vegetable matter are also not to be despised. Finally, the larve of some crane-flies, robber-flies, and Syrphidae, by boring into rotten wood, help in the work of forming forest mould. The Diptera, like almost every other insect group, has its economically injurious and beneficial species, and it is impossible to say whether mankind would be better or worse off were the group to be exterminated.

${ }^{1} \chi \lambda \omega \rho \dot{s}$, green ; $\omega ّ \psi$, eye. 


\section{CHAPTER V}

\section{LITHOBIUS AND ITS ALLIES}

Lithoвius is a representative of the group Myriapoda. ${ }^{1}$ which are air-breathing, wingless Arthropods, closely allied to insects. ${ }^{2}$ In the body only two regions, head and trunk, can be distinguished; the head bears one pair of antennie, a pair of jaws, and one or two pairs of maxilla. Every segment bears legs. Myriapods differ from insects, then, in that they have no legless abdomen.

Myriapods fall into two principal groups, - Chilopoda ${ }^{3}$ and Diplopoda. ${ }^{4}$

The chilopods, or centipedes, to which group Lithobius belongs, are active and ferocious myriapods. They are especially abundant in tropical countries, but thrive also in elevated, cold situations, and at least one species inhabits the caves of North America. All are terrestrial, and live in damp and dark places, especially under stones and bark, within or under decaying wood, among barn-yard refuse, in loose soil, and under fallen leaves. Chilopods feed upon living insects, mollusks, and worms, and may be useful to agriculture through the destruction of injurious

1 uvpios, very many ; moús, foot.

2 Keys to the principal families of the Myriapoda, and to the commoner species of Lithobius, will be found at the end of the Chapter, page 78 .

3 More correctly Cheilopoda, from $\chi \epsilon \hat{\imath} \lambda o s$, lip, and mov́s, foot ; because the mouth parts (modified feet) are partially united to form a sort of lip.

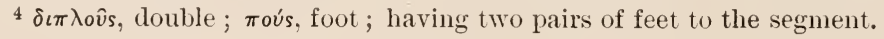


insects. Lithobius has been observed to spend hours in killing an earthworm, whose juices it sucked as food. Blue-bottle flies also serve it as food while in confinement.

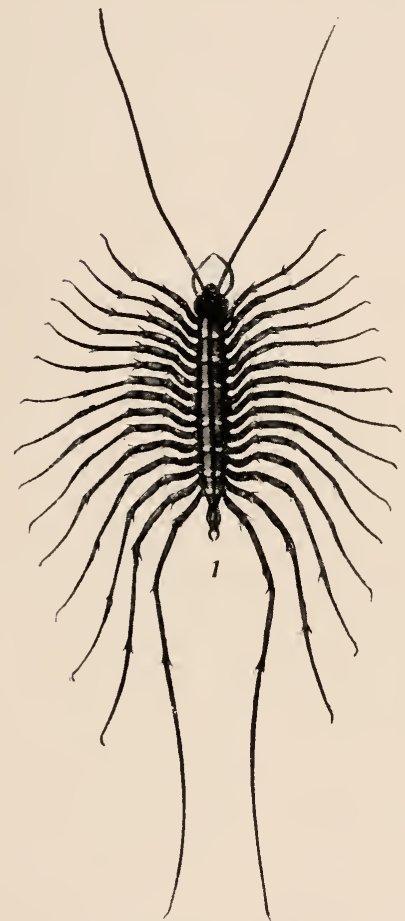

Fig. 73. - Scutigera. Nat, size. From Wood.

Lithobius $^{1}$ is of world-wide distribution, and over one hundred species are recognized. Our common strawcolored, eastern species, Lithobius forficatus, ${ }^{2}$ is found also in South America, as well as over most of Europe. It seems to be replaced south of Virginia by another species, spinipes.

Scutigera $^{3}$ is easily distinguished by its long legs; its hind legs, indeed, are longer

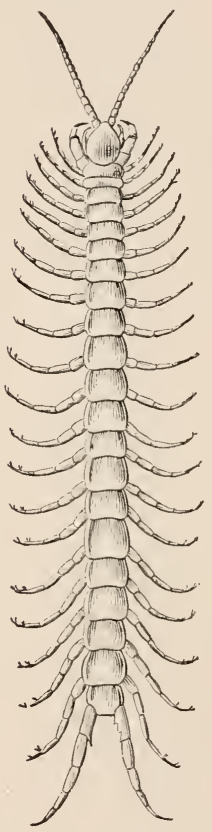

Fig. 74. - Scolopendra. Nat. size. From Leunis.

than its trunk.4 Our common Eastern species (rare north of New York City) is about 25 centimetres long, and is of a light brown color, with stripes on the back. It is

$1 \lambda i \theta o s$, stone ; $\beta \iota$ ó $\omega$, to live.

${ }^{3}$ scutum, shield; gerere, to bear.
2 Provided with shears, forfex.

4 Fig. 73. 
very active, and feeds especially on spiders. It looks something like a spider itself when in rapid movement. The Scutigeras are characteristic of the tropics, where they live especially in cellars, crawling up horizontal walls.

Scolopendra ${ }^{1}$ includes longer and stouter myriapods than Lithobius. ${ }^{2}$ To this genus belong the poisonous centipedes of tropical countries. Among these is the giant Scolopendra of our Southern States, South America, and the West Indies, which reaches a length of 25 centimetres or more. This animal has a poisonous bite, which is fatal to insects and other small animals, and causes painful and even dangerous wounds upon man. The biting apparatus is the first pair of feet, modified to form sharp

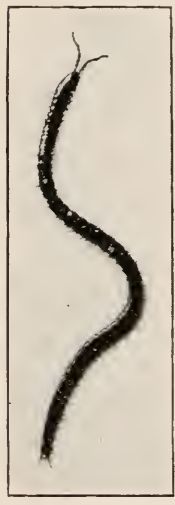

Fig. 75.-Geophilus mordax. Nat. size. Photo. by W.H.C.P. hooks, and provided with poison-glands, which open near the apex of the claw. According to Humboldt, the Indian children of South America tear off the heads of large centipedes and eat the remaining portions.

Geophilus ${ }^{3}$ includes relatively slow-moving species, often attaining great length, having up to two hundred segments to the trunk (Fig. 75). The species are common in Europe and America. They live mostly under' stones. There is a European species, Geophitus electricus, which is phosphorescent, shining in the dark like a glow-fly.

Julus $^{4}$ is very different in appearance from the preceding, for it has a cylindrical body and numerous small legs nearly concealed beneath it. It is commonly known as "galley-worm."

${ }^{1} \sigma \kappa о \lambda o ́ \pi \epsilon \nu \delta \rho a$, myriapod of Aristotle.

2 Fig. 74.
${ }^{3} \gamma \hat{\eta}$, the earth ; $\phi \iota \lambda \epsilon^{\prime} \omega$, to love.

4 iou ${ }^{\prime}$ os, centipede. 
The members of this genus crawl rather slowly, and when at rest coil the body. When disturbed they give out a strong odor through lateral openings of the body. They feed on dead snails and earthworms; some species, on ears of Indian corn or strawberries. Their eggs are laid in holes in the ground in the spring; consequently they may be easily dug up at this

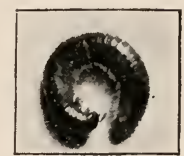

FIG. 76. - Julus cancdensis. Nat. size. Photo. by W.H.C.P. season. One of the common Eastern species of North America is Julus (Parajulus) canadensis, which is dark brown or black above, has sides spotted with yellow, and nearly colorless feet, and is about 20 to 25 millimetres

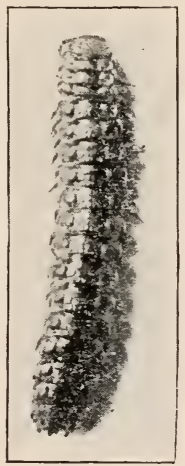

Fig. 77. - Polydesmus canadensis $(=P$. serratus). $\times 1.5$. Photo. by W. H. C. P.

long (Fig. 76). Spirobolus is a large species, 10 to 12 centimetres long.

Polydesmus ${ }^{1}$ includes much-flattened species, which, when disturbed, roll up spirally. P. canalensis, of the northern United States, is deep brown, with pubescent antennie. These myriapods are somewhat destructive to agriculture, especially to cabbage and strawberries.

Two genera of myriapods which stand somewhat isolated deserve a passing notice. Pauropus ${ }^{2}$ and allied genera include a few animals about 1 millimetre long, found on the moist loam of woods. They are intermediate between chilopods and diplopods, inasmuch as they have only one pair of legs

${ }^{1} \pi \circ \lambda u ́ \delta \epsilon \sigma \mu \rho s: \pi 0 \lambda u ́ s$, much; ; $\delta \epsilon \sigma \mu o ́ s$, band.

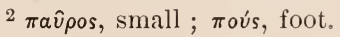


to a segment and only one pair of maxille. P. huxleyi occurs both in Europe and in the United States (vicinity of Boston and Philadelphia). Scolopendrella ${ }^{1}$ is a small, white species, having very large antennæ and a pair of backward-directed stylets. The mouth parts are very much like those of the lowest insects, so that Scolopendrella bridges the gap between myriapods and true insects.

\section{APPENDIX TO CHAPTER V}

\section{KEY TO THE PRINCIPAL FAMILIES OF THE MYRIAPODA}

$a_{1}$. Not more than 1 pair of feet to the segment; much segmented antennæ; 2 pairs of maxillæ [Chilopoda].

$b_{1}$. With facetted eyes; 8 dorsal plates; long legs . . . . . . .

b. $\quad$ No facetted eyes, but single or aggregated Scutigeride (Ex. scntigera) simple eyes; 15 or more dorsal plates. $c_{1}$. $\quad 15$ pairs of legs; antennæ at least $\frac{1}{3}$ as long as body; body usually with more than 20 segments . . .

$c_{1}$. More than 21 pairs of legs.

$l_{1} .21$ to 23 pairs of legs; antemnæ more than 14 -jointed

d. Never less than 30 pairs of legs; antennæ 14-jointed .

$a_{2}$. Most of the segments with 2 pairs of legs; antennæ with 5 to 8 segments ; 1 pair of maxillie [Diplopoda].

$\succ_{1}$. Anus in penultimate seginent ; body covered with bunches of hairs . . . . 
$b_{2}$. Anus in ultimate segment; body without bunches of hairs.

$c_{1}$. Mandibles not rudimentary; mouth parts not suctorial.

$d_{1}$. Segments 30 or more.

$e_{1}$. Anal segment produced into a spine . . . .

Julidae

(Ex. Julus)

e.. Anal segments produced into 2 slender papillæ, or unidentate . . . Craspedosomida $d_{2}$. Segments 19 or 20 . . . Polydesmidce (Ex. Polydesmus)

$c_{2}$. Mandibles rudimentary, mouth parts reduced

Polyzoniilla

KEY TO COMMONER SPECIES OF THE GENUS LITHOBIUS

$a_{1}$. Posterior angles of none of dorsal plates produced; pores on coxæ uniseriate.

$b_{1}$. Anal feet armed with 1 spine; posterior coxæ unarmed; spines of first pair of feet, 2,2 , 2-2, 3, 2 (Central States)

$b_{2}$. Anal feet armed with 3 spines; coxæ with indistinct spine; spines of first pair feet, $2,3,2$ (Central States) . . . .

$a_{2}$. Posterior angle of the $9,11,13$ dorsal plates produced ; antennæ, 33-4:3 joints (eastern U.S.)

$a_{3}$. Posterior angle of the 7, 9, 11, 13 dorsal plates produced ; 31-38 joints of antennæ (southern U.S.)

a. Posterior angle of the $6,7,9,11,13$ dorsal plates

produced ; joints of antennæ, 14-23 (eastern U.S.) • • • • • • . .

\author{
bilabiatus
}

cardinalis

forficatus

spinipes

multidentatus 


\section{CHAPTER VI}

\section{THE SPIDER AND ITS ALLIES}

SPIDERs constitute a well-defined group called Araneina, ${ }^{1}$ characterized by an unsegmented cephalothorax and abdomen, of which the latter is stalked, and bears spinning tubercles or spinnerets upon its hinder end. Antennæ are absent. 'The first pair of mouth appendages are called chelicere and end in claws, at whose apices the poisonglands open to the exterior. The second pair of mouth parts, called pedipalps, are long, and seem to take the place of antenne. Near the stalk of the abdomen on the ventral side is a pair of slits which open into two lung sacks (hence Dipneumones). In a few spiders there is a second pair of slits; these spiders have four lung sacs (hence Tetrapnemmones). ${ }^{2}$

The best known of our spiders are the orbweb-spinning garden spiders, belonging chiefly to the genera Epiera ${ }^{3}$ or Argiope ${ }^{4}$ and the house cobwebspinning spider Theridium. ${ }^{5}$

Argiope spins webs of very geometric form between stems of weeds, branches of shrubs, or along fences in our meadows. ${ }^{6}$ Its web belongs to the full-orb type in

1 aranea, spider.

2 A key to the seven subdivisions of the Araneina will be found at the end of this Chapter, page 9.).

${ }^{3}{ }^{\prime} \epsilon \pi \tau \epsilon \iota \rho$ s, skilful, experienced.

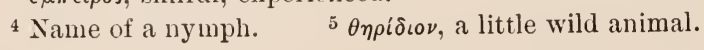

${ }^{6}$ Fig. 78. 
contrast to the condition in other orb-spinners, in which a sector of the circle is omitted or in which a sector only is formed. At the centre of the web of Argiope there is an oval, closely woven shield of silk. 'The spider, when at rest, is usually found upon or under this shield. Another frequent character of the web is a zigzag ribbon, extending

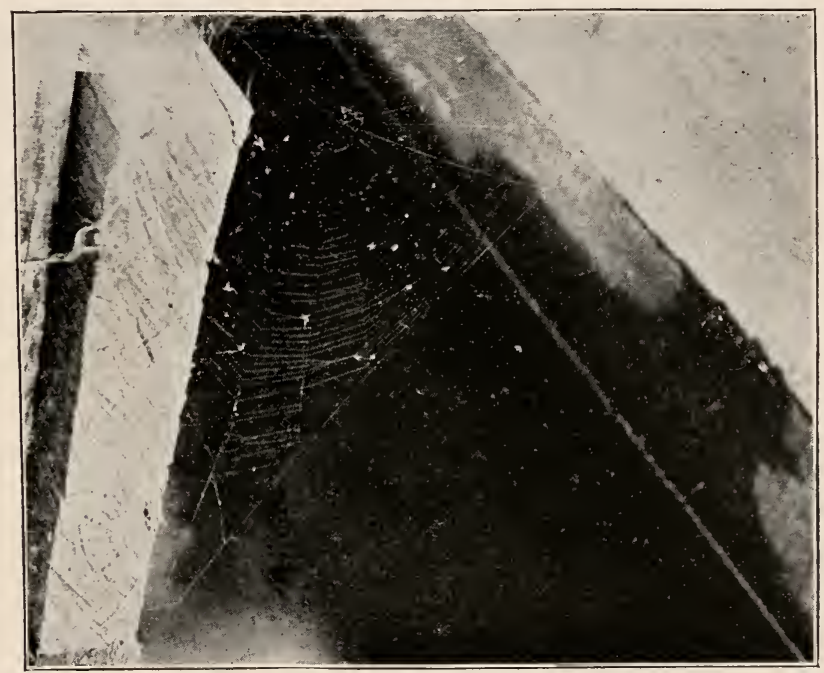

Fig. 78. - Web of Argiope, placed horizontally over a fish-way. Photo. by W. H. C. P.

downward from the central shield, and sometimes upward also, and attached to two or more radii. This zigzag, which is doubtless the "winding stair" referred to in the rhyme, "The Spider and the Fly," is formerl, as Fig. 79 shows, by preventing the fusion of the strands as they emerge from the spinnerets. 
The genus Theridium and its allied genera constitute the most extensive family found in the United States. The spiders belonging to the family are small, with relatively large, rounded abdomens. They have eight eyes, arranged in the manner shown in the diagram, Fig. 80. Their webs

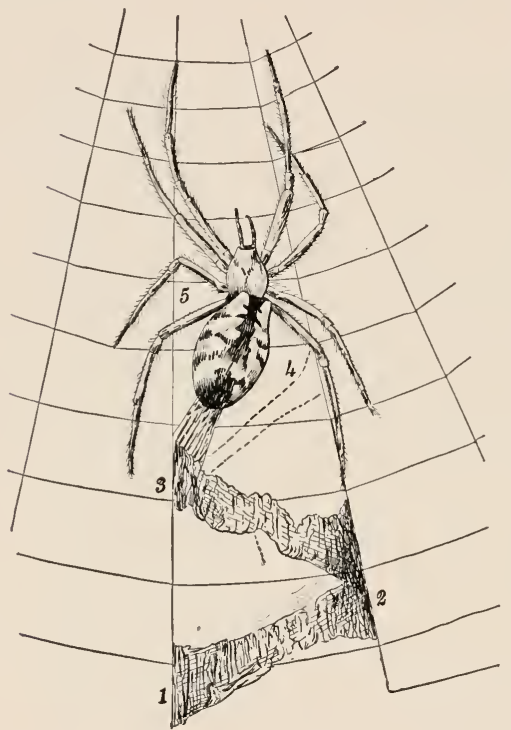

FI(s. 79. - Argiope spinning the "winding stair." The numbers $1,2,3,4$, indicate points successively formed in the order of these numerals. From McCook. show no attempt at geometric ar'rangement, such as is seen in the web of Argiope and other orb-weavers, but the threads cross in every direction, forming a sort of intricate trestlework. 'The species Theridium tepidariorum is the common little cobweb-spinner of our houses and barns ; it also spins about fences. Its color varies from a livid white to a livid brown or plumbeous color. In the south this species is much preyed upon by mud-daubing wasps (Sphex ${ }^{1}$ ), which put twenty to thirty of them in each cell of the nest as food for the young. Probably this enemy is one of the causes that has driven this species to the homes of man.

Food. - Both Argiope and 'Theridium feed upon insects. Flies, bees, grasshoppers, etc., are caught in the web and 
bound up, either for immediate or future consumption. A few authentic instances have been recorded of the capture of mice by ordinary spiders, and some tropical spiders are said to capture occasionally small birds within their webs. All spiders eat voraciously, and ordinarily drink a great deal of water; yet they may survive, in the absence of food and water, for many months.

FIG. 80.- Diagram of position of eyes in Theridium. The four central eyes are the largest.

Distribution. - Argiope occurs over all of North America. A. cophinaria, the basket Argiope, is the large black and yellow spider well known to all frequenters of fields. It occurs from Massachusetts to Texas, and west to the Pacific coast. A. argentata, distinguished by the serrated form of the abdomen, is found in the Southern States, the West Indies, and northern South America. 'Theridium occurs all over the world. T. tepidariorum is found, outside of the United States, in South America, Europe, and Australia. Twelve other species of this genus are found in New England alone. Some of these spin webs in trees or bushes, others in stone walls or among rocks.

Spinning Habits. - Spiders spin for a variety of purposes. Cocoons are made of silk, for the protection of eggs ; underground nests, like that of the trap-door spider, are lined with silk; and, especially, nets are made of it to ensnare insects. The silky threads may serve also to suspend the spider while it drops from a tree, or they may, by their friction with the air, serve to suspend certain spiders in aërial migrations. ${ }^{1}$ This latter use is especially noteworthy.

1 The ballooning habit of spiders has been noticed since early times, but it was formerly misinterpreted. Thus Pliny speaks of wool being rained. The poet Spenser wrote :- 
A small spider, when desirous of taking flight, climbs up some high object, such as a fence post, elevates the spinnerets, and spins loose silk into the air (Fig. 81). After enough of it has been thus formed, the spider lets go, and is supported by the currents in the air while it is wafted great distances. Thus Darwin, on his voyage in the Beagle, saw cobwebs bearing up spiders floating in the

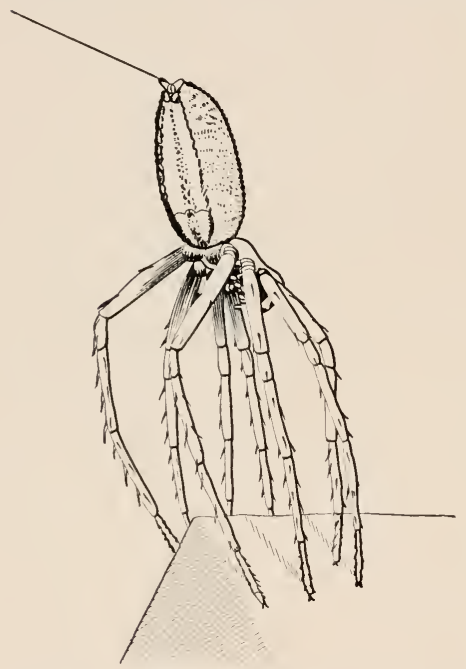

Fig. 81. - Young Lycosa about to fly. From Emerton. air over his vessel more than sixty miles from shore.

'The method of spinning deserves careful attention. The spinning-organs consist of a set of glands lying in the hinder part of the abdomen, and opening to the exterior through a number - often several hundred - of spinning "spools." These spools are the modified mouths of glands, and are grouped upon and between tubercles called s pin nerets. The secretions of the glands, as they are poured out into the air, fuse together and harden into a thread. The thickness of the thread is determined by the number of glands secreting together.

"More subtle web Arachne cannot spin;

Nor the fine nets, which oft we woven see,

Of scorched dew, do not in th' ayre more lightly Hee."

Thompson writes :--

"How still the breeze! save what the filmy threads

of dew evaporate brushes from the plain." 
Classification. - Spiders are separated, according as they spin webs or do not do so, into two main groups, sedentary and wandering spiders. The sedentary spider's are subdivided into four sub-orders, which we shall consider in turn :-

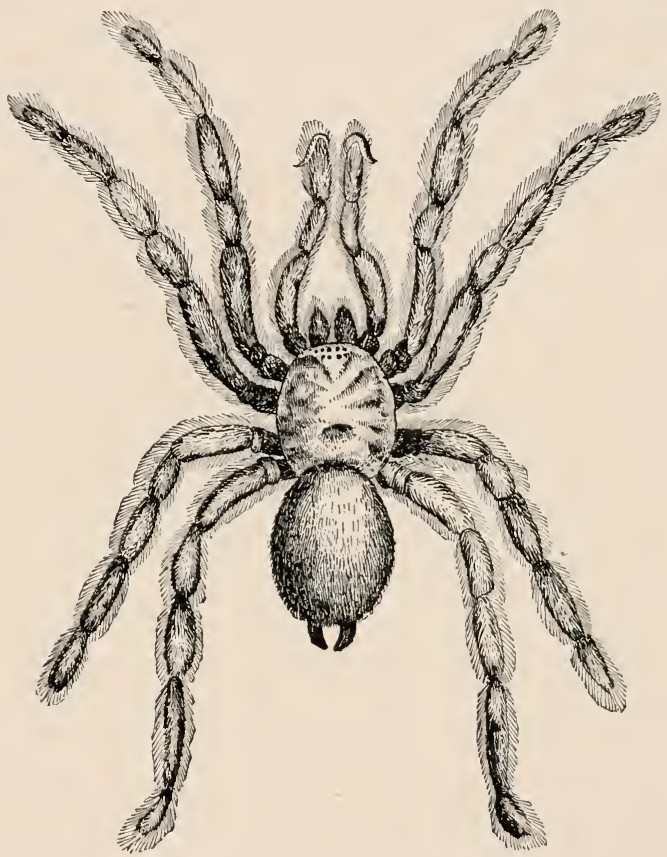

FiG. 82. - Mygale, a Tumnel-weaver, allied to the "trap-door spider." Nat. size. From Emerton.

1. Tunnel-weavers ('Territelariae ${ }^{1}$ ). These spiders make tubes in the earth, and line them with silk. The representatives of this group in the Southwestern States are

1 terra, earth ; tela, tissue or web. 
commonly known as trap-door spiders. The lid of the nest is covered with hardened dirt, and when closed, looks

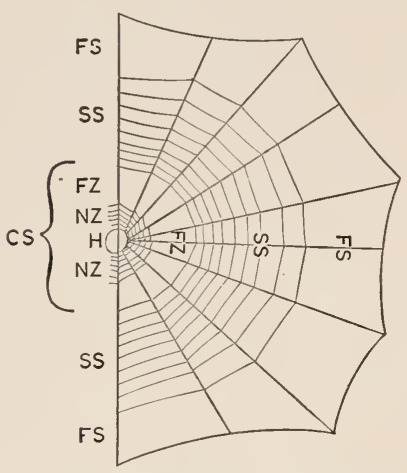

Fig. 83. - Diagram on nomenclature of parts of an orb-web. FS, foundation space; $S S$, spiral space; CS, central space; $F Z$, free zone; $N Z$, notched zone; $H$, centre. From McCook. exactly like the ground around it. Some of these spiders gain a great size and capture birds (Fig. 82).

2 . Orb-weavers (Orbitelarise ${ }^{\mathbf{1}}$ ). These, which are typically represented by Argiope, are well known; yet few persons have studied the almost mathematical precision with which the webs are built. Foundation lines (Fig. 8:3) of unusual strength are first laid down, to form the periphery or frame of the web. 'Then radii are spun from a central little ball of floss to the frame. The radii are, often at least, laid down alternately on opposite sides of the centre. The number of radii formed by a species of spider is not perfectly constant, but varies within limits. It would be an interesting occupation to sketch a number of webs of Argiope showing the variations in the number of radii and the other details of form. After the radii ale placed, the spiral lines are laid down. In the completed web four regions are distinguishable, as follows, passing from the centre outward: (1) the notched zone, consisting of four to eight turns of a spiral at the centre; (2) the free zone in which no spiral is laid down; (3) the spiral space, the main part of the spiral framework; (4) the 1 orbis, circle ; tela, web. 
foundation space, without the spiral lines, and at the outer margin of the web. No study is more interesting than that of the details of construction of these parts of the spider web, while they are being made out of doors or in large glass jars.

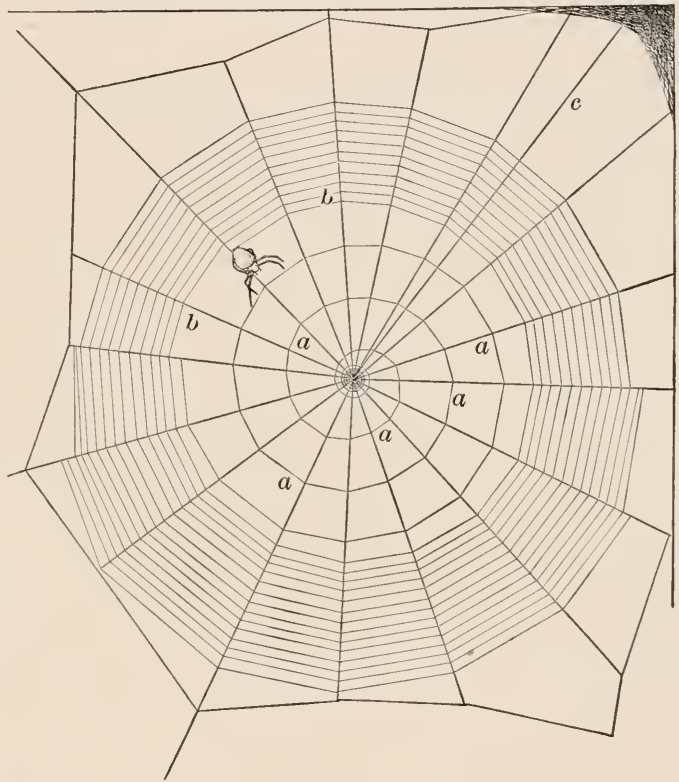

Fig. 84. - Orb-web of Epeira. $a$, first spiral line; $b$, second spiral line; $c$, line to nest. From Emerton.

3. Line-weavers (Retitelaria ${ }^{1}$ ). - Of this group Theridium is a type. The web consists of a fine irregular mesh with strands running above and below in various directions. $^{2}$ The spider stands below the main part of the net, back downward.

1 rete, net; tela, web.

2 Fig. 85. 
4. Tube-weavers ('Tubitelarie ${ }^{1}$ ). - Here belong the spiders that spin webs in the grass, which are so conspicuous in the morning when laden with dew (Fig. 86). At one side of the web a tube leads down among the grass stems. At the opening of this tube the spider stands ready to

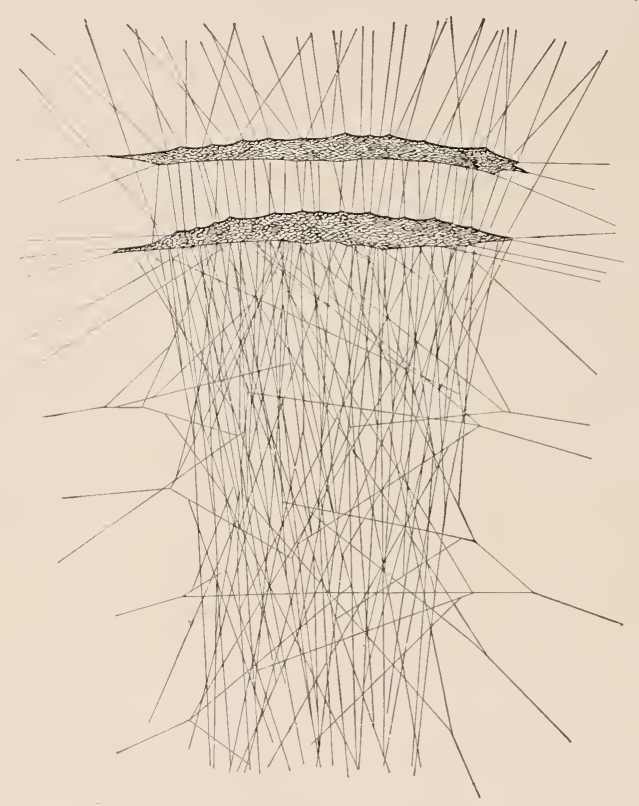

Fig. 85. - Web of Theridium, a " cobweb." From Emerton.

dart out after prey, or to retreat as occasion demands (Fig. 87).

The wandering spiders do not spin webs of any kind. They are classified into three groups as follows:-

1 tubus, tube ; tela, web. 
(1) Crab spiders (Laterigradia ${ }^{1}$ ) are so called because they run sideways. 'They make nests by fastening together leaves by threads of silk. 'Their young are reared in these nests, and watched over by the mother (Fig. 88).

(2) Running spiders (Citigradie ${ }^{2}$ ). - These are for the most part large and powerful species which wander over

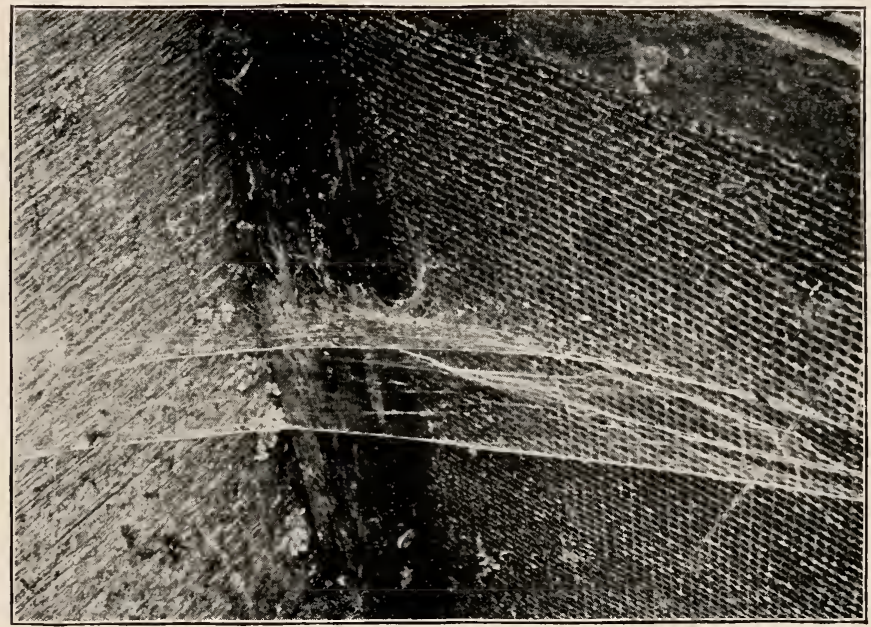

FIG. 86. - Web of a tube-weaver; looking down upon the web, which is in a corner between two vertical walls. The tube is in the angle. Photo. by W. H. C. P.

fields or along watercourses in search of prey. Our Northern species belong chiefly to the genus Lycosa ${ }^{3}$ (Fig. 89). They live in holes in the ground, making a ring of silk at the orifice. The female carries her eggs about in a special cocoon attached to the end of the abdomen. The
1 latus, side; gradus, locomotion.
2 citus, rapid, + gradus.

3 入úkos, wolf. 


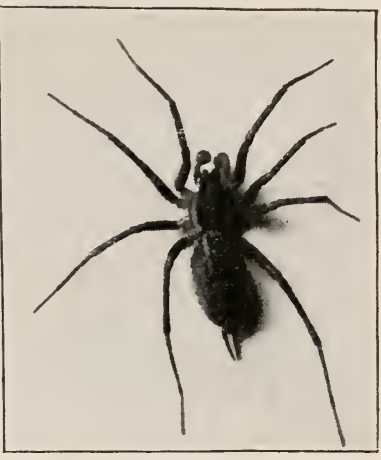

Fig. 87. - Agalena, the common grass spider. Nat.size. Photo. by W. H. C. P.

young are borne on the back of the mother. The great size, black color, and hairiness of some of these spiclers have given them an apparently unjustified reputation of being very poisonous. Naturalists who have allowed these spiders to bite the land report that the bite is rarely more poisonous than that of the mosquito.

(3) Jumping spiders (Saltigradie $\left.{ }^{1}\right)$. - This family includes many familiar, active species of high intelligence. Some of these of grayish color live in houses, and are recognized as members of this family by their half-running, halfjumping gait (Fig. 90). The cocoon is attached to some object and enclosed in a sort of tent, in which the mother also lives to guard the young.

The economic importance of spider webs is considerable. First of all, they are of the greatest importance in capturing many destructive insects, such as flies, mosquitoes, and moths. Another use

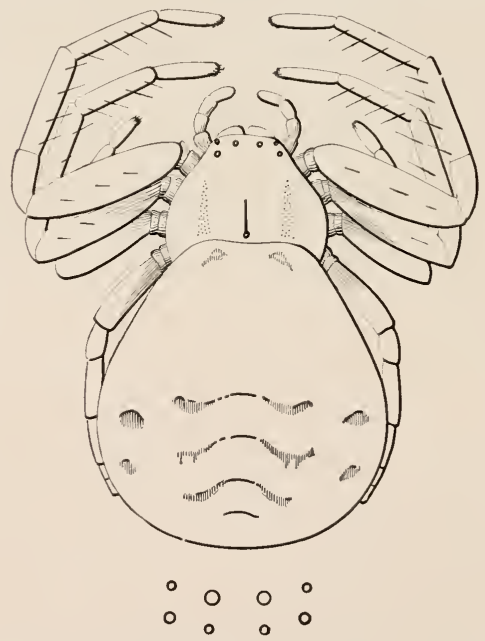

FIG. 88. - Thomisus, a crab spider. Diagram showing arrangement of eyes at bottom of figure. From Emerton. 
to which they have been put is in making silk cloth. The silk of the spider is smoother and glossier than that of the silk-worm, but it is much harder to collect in quantity. A spool is passed against the spinnerets of an individual spider and slowly revolved, winding the silk upon it. The difficulty comes in rearing the spiders, for they are extremely voracious and if the supply of flies is insufficient

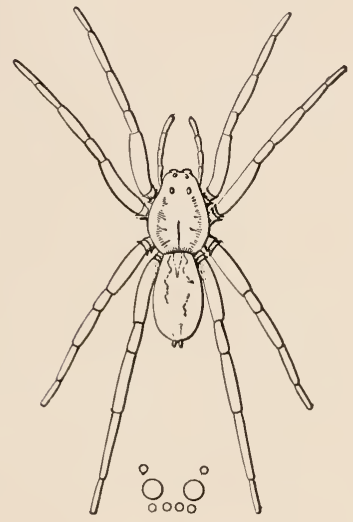

Fig. 89. - Lycosa, a running spider.

Ocelli formula below. From Emerton.

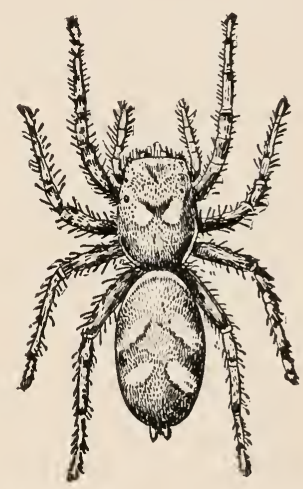

Fig. 90. - Attus, a jumping spider. From Emerton.

they attack and devour one another. Consequently they must be kept isolated and fed individually, and yet yield in the end only an ounce or so (about 30 grammes) of silk. Other uses of spider's' silk are : in the construction of cross-hairs in telescopes, and in medicine as a narcotic in case of fevers, - a temporary fad.

Poisonous Spiders. - Spiders are feared by many people from a belief that they are very poisonous, even fatally so. Spiders have, indeed, biting jaws provided with poison- 
glands, and their bite is often fatal to insects, and even to small birds and mammals. But most spider's cannot spread the chelicerse sufficiently to make a bite in the human skin, and even the largest forms seem to inflict but a slight wound, scarcely ever greater than that of a mosquito. The stories of the severe effects of the bite of the Tarantula, one of the Lycosilæ, are entirely fabulous.

Spiders show a marked sexual dimorphism. Particularly among the orb-weavers the males are much smaller than the females of the same species, but the legs of the male are relatively the longer and stronger. The male is usually shorter lived than the female, for the latter has often to watch the egg-cocoons, or carry them about with her until the young hatch out. The male also builds less perfect webs than the female. The relation existing between mated pairs is often peculiar. The male is frequently killed and eaten by the female; but if the male can overcome the female, she may fall his victim. Among wandering spiders there is often a selection by the female from among several rivals, which engage in severe battles with each other.

Allies of the spider must be briefly mentioned. The spider belongs to the class Arachnoidea, ${ }^{1}$ characterized as follows: Air-breathing, wingless arthropods, whose head and thorax are usually united to form a cephalothorax, which bears two pairs of jaws and four pairs of legs; the abdomen, which is not always separated from the cephalothorax, possesses no legs. The principal subdivisions of the Arachnoidea are as follows:-

The Arthrogastra, ${ }^{2}$ including the scorpions and their allies, are characterized by the fact that the abdomen is

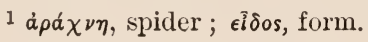

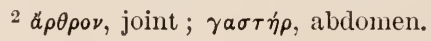


segmented and intimately joined with the cephalothorax. ${ }^{1}$ Here belong the true scorpions, in which the posterior six segments of the abdomen are much smaller in diameter than the seven anterior segments, and form a sort of tail (post-aibdomen). Nearly twenty species of scorpions occur in the warmer parts of North America. Centrurus infamatus ranges from the southern Atlantic States, through Texas, and north into southern Kansas. The tip of the tail bears a sting, which connects with a poison-sac. The largest scorpions of the tropical countries are the most dangerous, but the wounds even of these are rarely fatal.

The Phalangina, ${ }^{2}$ the extremely common "Daddy-long-legs," or harvest-men, in which

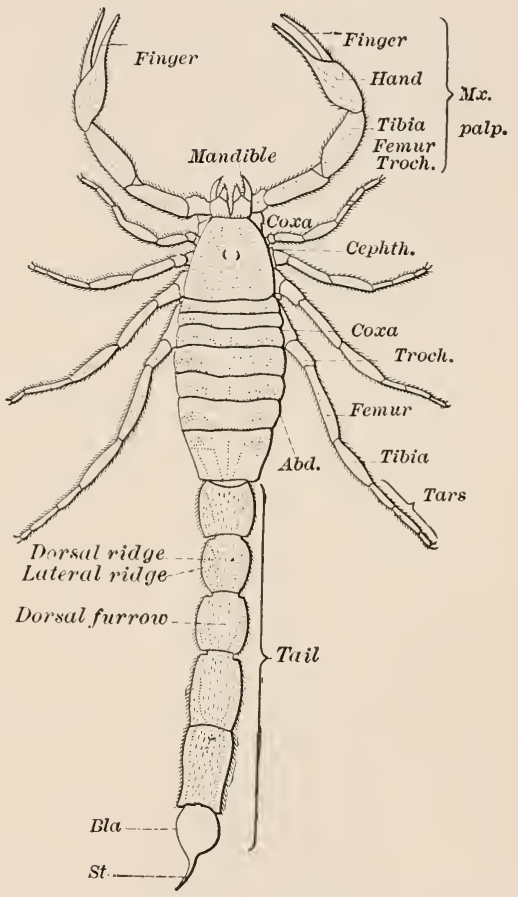
the legs are very long, Fig. 91.-Buthus, a European scorpion. and the abdomen short Dorsal view. Mrx., maxillary; Cephth., and thick. They occur cephalothorax; Troch., trochanter; Tars., and thick. 'They oceur tarsus; Abd., abdomen; Bla., poison bladabout houses, in woods, der; St., sting. From Kraepelin in "Das and in fields. They Tierreich."”

feed on small insects and are highly beneficial animals to

${ }^{1}$ Fig. 91.

${ }^{2} \phi a \lambda a ́ \gamma \gamma \iota \nu \nu$, a spider, especially a poisonous species. 


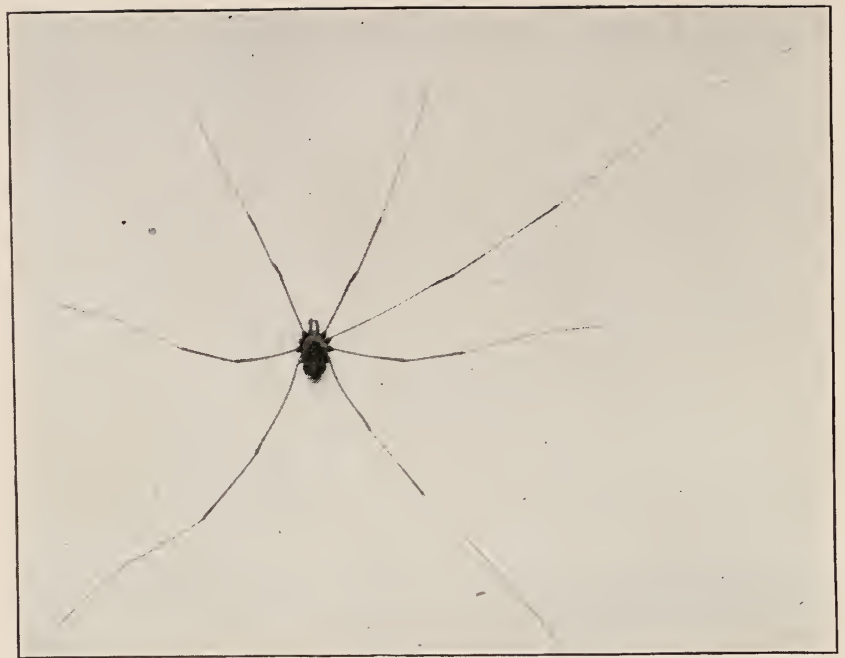

Fig. 92.-Liobunum dorsatum, one of the harvestmen. The long legs are apt to be thrown off in handling the living animal. The second left leg is accordingly absent in this specimen. Nat. size. Photo. by W. H. C. P.

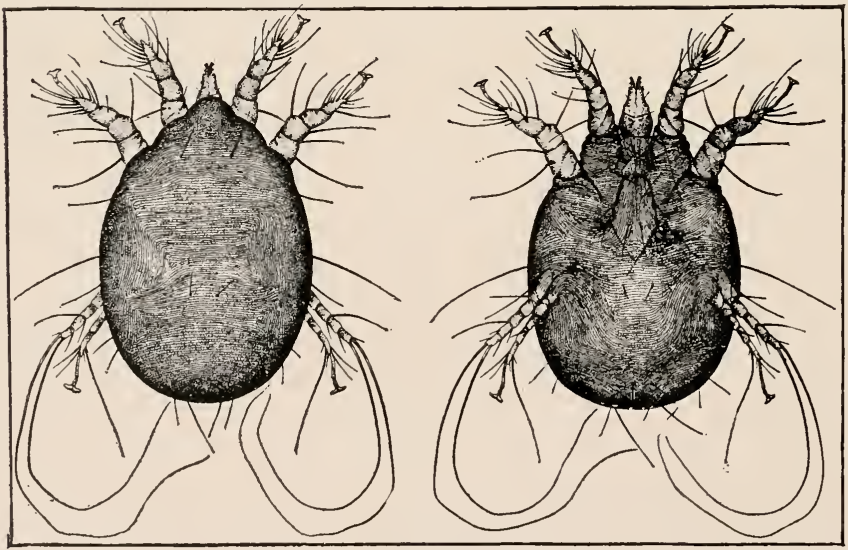

Fig. 93. - Psoroptes, the sheep scab, female. light figure, dorsal view ; left figure, ventral. Much enlarged. After Salmon, Bulletin 21, Bureau Animal Industry. 
man. Liobunum dorsatum is a common grayish species with a darker dorsal band, which emits a clear fluid when handled (Fig. 92).

The Areneina, or spiders, already considered.

'The Acarina, ${ }^{1}$ or mites and ticks, in which, as in spiders, the abdomen is unsegmented, but is fused with the cephalothorax. Mites have typically a round body. 'They exhibit great diversity of form and habits. All are terrestrial, excepting one group of aquatic mites, and are often of a bright red color (Atax). The free-living species prey on smaller animals, as well as dead organic substances. Others are parasitic in animals or plants, living in fur or feathers, ${ }^{2}$ and even penetrating into the skin, as the small red "jigger" or "chigger" of our Southern States does.

Finally, there lives in the sea an aberrant family of spiclers which crawl on the sea-bottom or over hydroids, and thus have forsaken a terrestrial life for a completely aquatic one (Fig. 94).

\section{APPENDIX TO CHAP'TER VI}

KEY TO THE SEVEX SUBORDERS OF THE ARANEINA

$a_{1}$. With 4 slits into lung sac [Tetrapneumones]. Chelifer claw directed downward ; 8 closely grouped eyes . . . . . . .

$a_{2} .2$ slits into lung sac [Dipneumones]. Chelifer claw directed inward.

$$
1 \stackrel{\alpha}{\kappa} \alpha \rho \iota, \text { mite. } \quad 2 \text { Fig. } 93 .
$$


$b_{1}$. Eyes in 2 transverse rows; most species spin webs [Sedentariæ].

$c_{1}$. Legs not spread flat out.

$d_{1}$. Spinnerets short and inclined together, and on under side of abdomen, which is usually round.

$e_{1}$. Anterior row of eyes near margin of head . . . . . Orbitelarice

(Orb-weavers)

$e_{2}$. Anterior row of eyes remote from margin of head . . . . Retitelarice

(Line-wearers)

$d_{1}$. Spinnerets at end of abdomen, which is elongated . . . . . Tubitelarice (Tube-wearers)

$c_{3}$. Legs spread flat out . . . . . Laterigrada

$b_{1}$. Eyes in 3 transverse rows; spin no webs, but (Crab spiders) hunt prey [Vagabundæ].

$c_{1}$. Anterior eyes smallest . . . . Citigradce (Rumning spidiers)

$c_{2}$. The anterior eyes largest . . . . Saltigradce (Jumping spiders) 


\section{CHAPTER VII}

\section{THE CRAYFISH AND ITS ALLIES}

THE crayfish belongs to the class of Crustacea, since it breathes by means of gills, possesses two pairs of antennx, a pair of mandibles bearing palps, and a pair of appendages on all body segments excepting the last. The Crustacea are divided into two subclasses, - Entomostraca, of which Daphnia is an example, and Malacostraca, to which the crayfish belongs. All the Malacostraca ${ }^{1}$ have 19 pairs of appendages. ${ }^{2}$

The crayfish, ${ }^{3}$ which is closely related to the marine lobster, ${ }^{4}$ is an inhabitant of fresh-water lakes, rivers, and pools. It thrives in diverse surroundings; for some species prefer cool mountain streams and others muddy pools, while certain species, both in Europe and America, are found in brackish as well as fresh water. Indeed, the European Astacus fluriatilus is said to be frequently

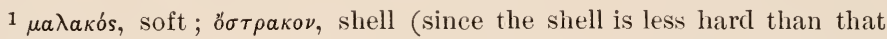
of mollusks).

2 Keys to the six chief orders of Malacostraca and to families of the stalk-eyed crustacea will be found in the Appendix to this Chapter, p. 122.

"The old English spelling of this word was "crevis" or "crevice." The cre came to be spelled phonetically croy, while vis became changed to fish in accordance with the popular nomenclature of all aquatic animals.

4'The English word "lobster" is from the old English lop?/stre, which is probably corrupted from the Latin locust, , by which term Pliny refers to the lobster. 
caught off the Livonian coast, even some distance out at sea. Individuals of an American species have been taken from a mineral spring impregnated with sulphur and magnesia at a temperature of $70^{\circ} \mathrm{Fahr}$. (21 ${ }^{\circ}$ Cent.), while several kinds of the American "burrowing" or "chimney"-forming species have been found in mearlows and clay bottoms, often at great distances from streams. Certain species that are blind inhabit caves only. In England, according to Huxley, "in granite districts, and others in which the soil yields little or no calcareous matters to the water which flows over it, crayfishes do not occur. 'They are intolerant of great heat or of much sunshine; hence they are most abundant in those parts of rivers which flow east and west, and thus yield the most shade from the midday sun.'

The food of the crayfish is very varied; it may be living or dead, animal or plant. On account of the need of calcareous matters in the food, crayfishes are especially fond of the stoneworts (Chara) and various succulent roots, like the carrot. It is said that crayfishes sometimes make excursions inland in search of plant food. They likewise devour shells of snails, their own cast-off skins, and occasionally each other, shell and all.

There are two great groups or subfamilies of crayfishes. One, restricted to the Norther'n Hemisphere, is found in Europe, Asia, and North America. The other is found in the Southern Hemisphere, in Australia, Tasmania, New Zealand, Fiji Islands, Madagascar, and South America. No crayfishes have been found on the continent of Africa, or in the rivers of northern Asia that flow into the Arctic Ocean, or in those of southern Asia. These Asiatic rivers are populated by fluviatile crabs, to which the cray- 
fishes of the region have probably succumbed. All the islands now inhabited by crayfishes, such as England. Japan, and Cuba, ${ }^{1}$ were probably once connected with the mainland.

The northern subfamily of crayfishes contains, according to Faxon, two genera-Astacus and Cambarus - of which the latter can be subdivided into the subgenera Cambarus and Cambaroides. These groups occupy distinct geographical areas. The genus Astacus is found, in the Old World, in Europe and western Asia as far south as the Aral and Caspian seas, and in America in the region west of the Rocky Mountains, draining into the Great Salt Lake and the Pacific Ocean. It is thus seen to occupy the western sides of the two northern continents. Likewise Cambarus and Cambaroides occupy the two eastern coasts of the northern continents; for Cambarus is found in North America east of the Rocky Mountains in the region bounded on the north by Lake Winnipeg and New Brunswick and on the south by Guatemala and Cuba, while Cambaroides is limited to the Amoor River basin in Asia, and to Japan.

We thus find among the crayfishes what is known as discontinuous genera; that is, genera which now occupy widely separated areas, such as Astacus in Europe and Pacific North America, but which once ranged over the intervening regions as well. From some cause, the struggle for existence became too severe in the intervening regions, so that Astacus and Cambarus were annihilated on the eastern and western sides of the continents respectively. In southern Asia we find that the struggle was doubtless with the successful river-crab. It is interesting to note

${ }^{1}$ It is doubtful whether Cuba has been connected with the mainland. 
that, probably on account of the preserving influence of climate, the other animals and the plants of the eastern sides of the two continents and those of the western sides are more alike than those from opposite sides of the same continent. One of the best pieces of evidence for the conclusion of a former hemispherical distribution of the two genera of crayfishes is that there occur in the caves of Carniola in southern Austria crayfishes ${ }^{1}$ belonging to the genus Cambarus - the only known living representatives of this type in Europe. 'The mere fact that it lives in a cave is not sufficient to make the Carniola crayfish a Cambarus, for in North America the genus has certainly not originated under the influence of subterranean life; it is more likely that the caves of Carniola have protected these crayfish from the widespread destruction which has overwhelmed their fellows outside.

Only one crayfish, Cambarus Bartonii, is found in New England, and here, with two or three local exceptions, only in the rivers of Maine. This C. Bartonii has the widest geographical distribution of all the northern species. C. Blandingii is the most widely distributed of the southern species. C.pellucides is the blind species found in Nammoth and Wyandotte caves.

The lobster (Homarus) is, as we have already seen, the nearest living salt-water relative of the crayfish. There are only two species of the genus Homarus. One, Homarus americanus, occurs on our Atlantic coast, the other, $H$. vulgaris, is the lobster of Europe. On our Pacific coast there is the "spiny lobster," but this is not closely related to the eastern lobster (Fig. 95). The national gov-

1 These crayfishes are blind, like the cave-inhabiting Cambarus of America. 
ernment has transplanted the Atlantic lobster to several localities on the Pacific coast, but it is not yet known whether it will thrive there. The American lobster ranges from Labrador to Delaware Bay, and from near shore to a

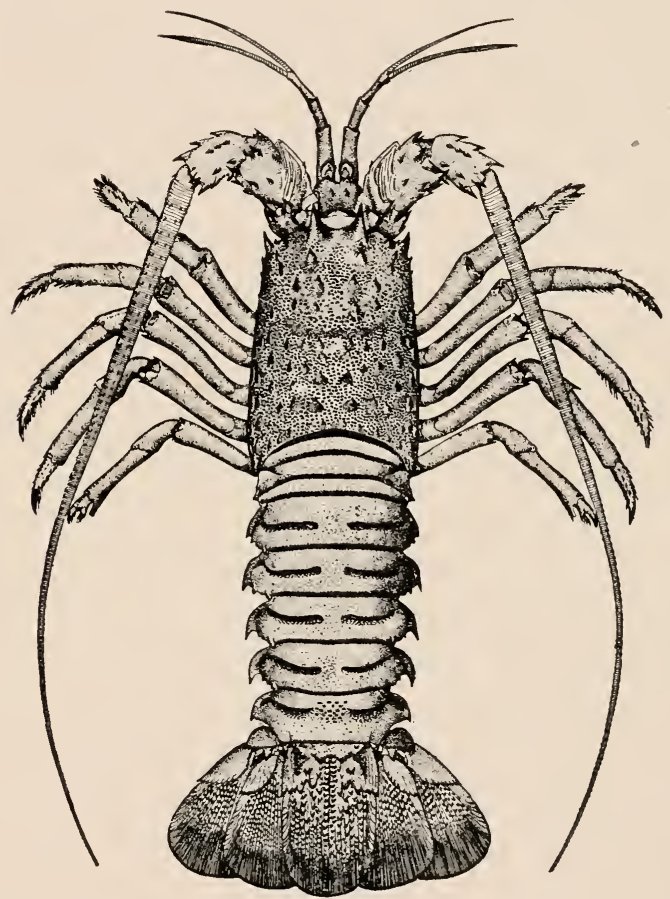

Fig. 95. - Palinurus, the spiny lobster. One-fourth nat. size. From Rathbun ; drawn by H. L. Todd.

depth of 100 fathoms. It attains its greatest size on the rocky shores in the cooler waters from Maine to Labrador. It migrates but little along the coast; in the fall, however, it moves out into deep water, and in the spring back again 
into the shallower bays; the time of migration depending upon the length of the season. It is said to be a nocturnal animal, searching most actively for its food at night. The sense which probably aids it most in this search is that of smell, as the attraction of the bait in the traps - the socalled lobster-pots - testifies. In respect to food it is, like the crayfish, omnivorous.

Protection of the Lobster. - There has been much difference of opinion in regard to the size at which a lobster becomes mature and before which, therefore, it cannot be caught without danger of extermination. The legislation on the matter has accordingly been very varied. In Connecticut the law makes the limit six inches, while in Massachusetts and New York it is placed at ten and onehalf inches. Herrick has carefully investigated the relation of length to maturity, and concludes that, on the Massachusetts coast at least, the lobster becomes mature between the limits of eight and twelve inches, and hence that all present legislative protection is insufficient. The increasing rarity of large lobsters in our markets testifies to the correctness of this conclusion.

Enemies of the Lobster. - Besides its worst enemy, man, both the adult (particularly the egg-bearing female, called by fishermen the "berry lobster," or "berry hen") and young lobsters are attacked by many kinds of fish. Two or three internal parasites are known to infest the lobster, while sometimes it is greatly hampered in its movements by the number of messmates it carries about attached to its shell. Barnacles, mussels, tube-forming worms, and various seaweeds are all found at times attached to the shell of the lobster. Upon moulting, however, the animal is enabled to rid itself of all these hangers-on; but this very process of 
moulting, or casting off the entire shell at intervals, is attended with great dangers to the lobster, since the animal is so soft bodied as to be able to offer little resistance to its enemies.

The moulting process in the lobster, crayfish, and other Crustacea is made necessary from the fact that these animals are enclosed in a chitinous covering which is impregnated with salts of lime. It is evident that an animal cannot increase in size while so encased; hence special provision for growth has to be made by the moulting or casting off of the hard shell. This process is accomplished in the following manner: previous to the throwing off of the old skin a new soft one is formed inside, the lime is absorbed from the old shell in a dorsal line along the carapace, reaching from the rostrum to its posterior margin. Absorption also takes place at the joints of the limbs. When the lobster has attained this stage it is dark in color, and known by fishermen as the "black lobster." The carapace now splits along this dorsal median line of absorption, the blood leaves the limbs, which are thus matle flabbier, and by involuntary muscular movements they are drawn, large claw and all, through the joints of the old shell. The anterior portion of the body is first drawn out through the dorsal rent, and lastly the tail. Not only is the entire outer covering cast off, but the lining of the cesophagus, stomach, and intestine as well, since these organs are formed by an infolding of the skin. By means of the return of the blood to the limbs and rapid absorption of water, the body of the lobster soon swells to a size far beyond that of the old shell. There remains in the stomach, after moulting, a calcareous nodule which has long been known by the name of "crab'seyes." These "crab's-eyes" were formerly much sought 
after and prized on account of their supposed medicinal qualities. The function of these gastroliths or "crabseyes" was for a long time rather obscure. It is now believed that during the time of absorption of lime from the shell, previous to moulting, the blood becomes strongly impregnated with lime. If all the lime that must be removed were to remain in the blood, it would probably be fatal to the animal; hence it is taken up by secreting cells located in the wall of the stomach, and there deposited. After the old skin is cast, the gastrolith is soon absorberl,

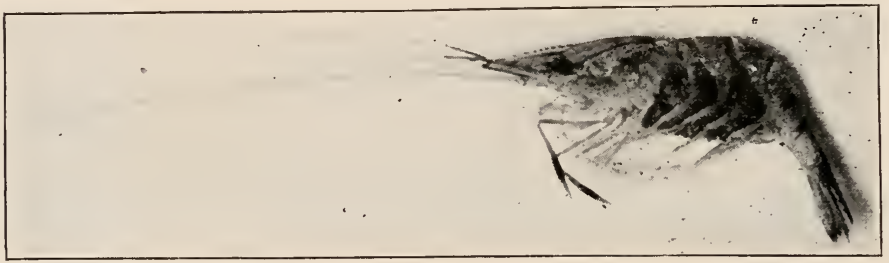

Fig. 96. - Palamonetes vulgaris, a common shrimp. Nat. siz?. Photo. by W. H. C. P.

probably to aid in strengthening the new shell. Bits of water-worn shells, entire gastropod shells, parts of lobster coverings, spines of sea-urchins, etc., have been found in the stomachs of lobsters and crayfish, which likewise would probably have been dissolved and used in hardening the shell.

Shrimps and prawns ${ }^{1}$ belong to a thin-skinned, long-tailed family of Crustacea. ${ }^{2}$ They are extremely common in bays

1 These are common names of small Crustacea applied chiefly to the decapod family Caridide,* although also applied to certain Schizopods. The term shrimp is applied to the smaller species, and prawns to the larger.

2 Fig. 96.

* kapis, a small marine crustacean. 
along our coast, and even penetrate into rivers. Two river' shrimps ${ }^{1}$ are found in the United States east of the Mississippi River. These Crustacea are able to maintain their enormous numbers only by virtue of their great reproductive capacity, necessitated by the circumstance that they furnish almost the entire food supply for many kinds of fishes and other foes. Even in the principal shrimping grounds of the Uniterl States - such as San Francisco and

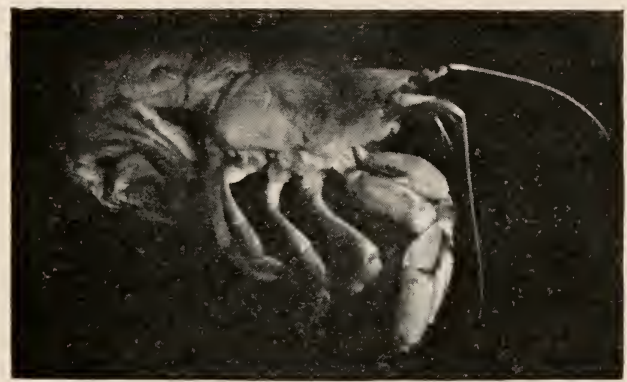

Fig. 97. - Gebia affinis, right side. Two-thirds natural size. Photo. by W. H. C. P.

New Orleans - there is said to be no diminution in the numbers of shrimps.

The Thalassinidæ ${ }^{2}$ include certain crayfish-like species which live on our coast, burrowing in mud-flats, where they live concealed dluring the day. On account of their being of only medium size and difficult to obtain, they are commonly little known. Our Eastern species are Gebia affinis (Fig. 97) and Callianassa stimpsoni.

The hermit crabs (Paguridie ${ }^{3}$ ) occupy a position intermediate between the long and short tailed Decapods in

1 Palamon Ohionis and Paleomonetes exilipes.

$2 \theta a \lambda a ́ \sigma \sigma \iota \nu o s$, color of the sea. $\quad{ }^{3} \pi a$ rovoos, a kind of crab. 
respect to the length of their abdomen. The abdomen is soft, and the animal protects it by inserting it within the coiled shell of some gastropod. Moreover, the abdomen is asymmetrical, being coiled to one side to correspond with the shape of the borrowed house (Fig. 99). The abdominal feet become degenerate, with the exception of the posterior pair, which are modified into a hook-like process, by means of which the crab maintains itself securely in the shell.

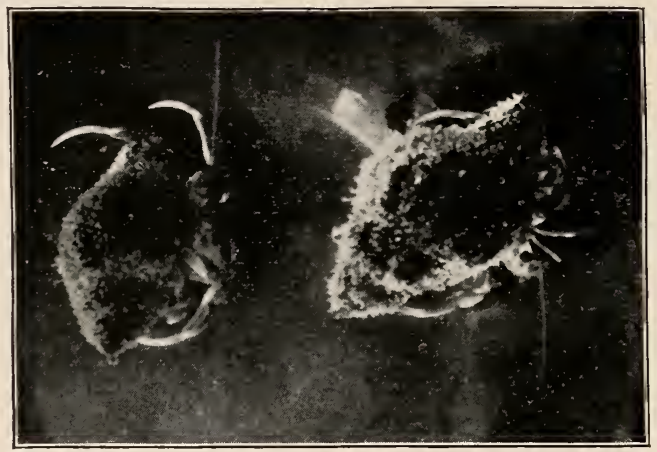

FIG. 98. - Eupagurus longicarpus. Two individuals in shells. Photo. while alive by $\mathrm{W}$. H. C. P.

When one shell becomes too small, it is abandoned for a larger one. Numerous species of hermit-crabs occur on our coast, ranging from the shore line to a depth of several hundred fathoms. Eupayurus longicurpus is the little active hermit found in almost any tide-pool from Massachusetts Bay to the Gulf of Mexico. Hydroids, polyps, sponges, often attach themselves to these borrowed shells (Fig. 98); indeed, a Chinese hermit-crab always bears an anemone on its large claw, with which it plugs up the aperture when obliged to retreat within its shell. One of 
the East Indian hermit-crabs, the so-called palm-crab, feeds upon cocoanuts, which it opens by inserting its claws into the eyes and then breaking the shell upon the rocks.

The Hippidæ include certain oval animals, which burrow, like a mole, head first, in sandy beaches. The name of our common eastern species, Hippa ${ }^{1}$ talpoides, ${ }^{2}$ indicates this resemblance (Fig. 100).

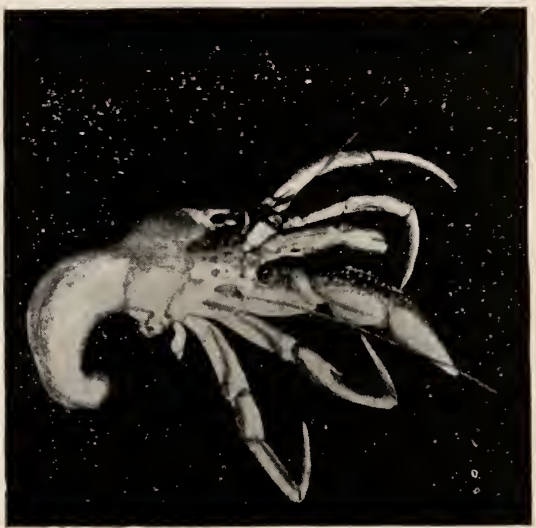

Fig. 99. - Eupagurus longicarpus removed from shell. $\times 1 \frac{1}{2}$. Photo. by W. H. C.P.

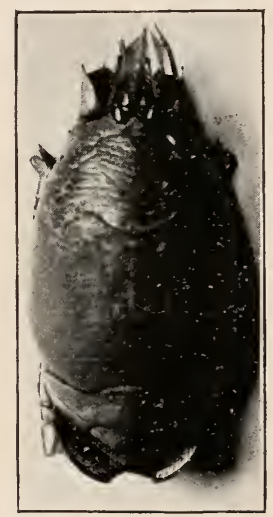

Fig. 100.-Hippatalpoides. Nat. size. Photo. by W. H. C. P.

The Brachyura are represented on our shores by three principal families, which may be designated as triangular crabs, áched crabs, and square crabs.

The spider-crabs, or sea-spiders, as they are sometimes called, belong to the triangular crabs. As their name implies, their legs are very long and slender. ${ }^{3}$ 'These crabs frequent oyster-beds and sea-bottoms in general. When

${ }^{1}$ From $i \pi \pi$ s, horse; used by Aristotle as the name of a kind of crab.

2 Like talpa, the mole. 3 Fig. 101. 
seen stalking over such uneven surfaces, the advantage of these stilt-like legs is at once evident. 'The surface of the body of some species of spider-crabs is hairy, entangling inorganic matter, while hydroids, barnacles, and alga attach themselves to the shell. Libinia emarginata and dubia, the former ranging from Maine south, and the latter from Cape Cod to the Gulf of Mexico, are our two species which

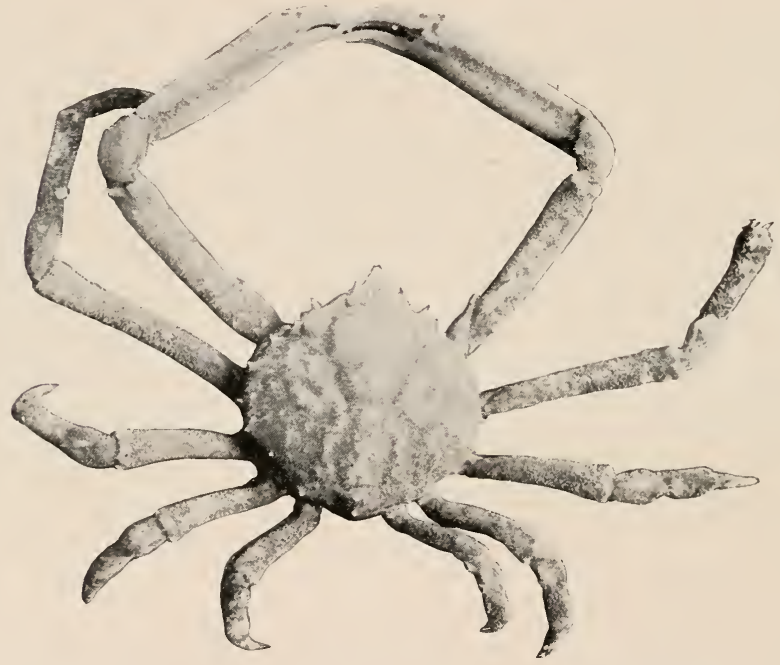

FIG. 101.-Libinia dubia. One-third nat. size. Photo. by W. H. C. P.

undergo such concealment. The great Japanese spiclercrab is sair to be the largest of all the Crustacea, some individuals measuring, from tip to tip of the first pair of legs, 18 to 20 feet.

'The edible crab is a typical archer crab. It is so called because the carapace is arched in front. The carapace is also broader than long, and narrower behind than in front. 
The legs of this family are short and broad, and in some species the posterior pair is especially broad - an adaptation for swimming. 'These crabs may be divided into two groups - the burrowing crabs and swimming crabs. T'o the burrowing crabs belongs the genus Cancer (Fig. 102), which includes the edible crab of Europe, especially prized in England, together with several American species; while our common edible, soft-shelled or blue crab, Callinectes hastatus

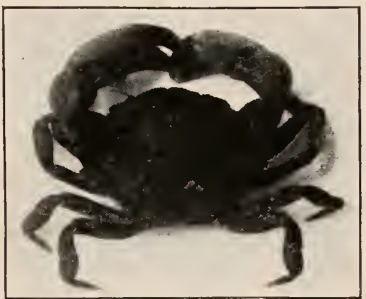

Fig. 102. - Pamopeus sagi, allied to Cancer. The mudcrab. One-half nat. size. Photo. by IV. H. C. P. (Fig. 103), and the beautiful "lady crab" (Fig. 10t) belong to the swimming group. Representatives of other families of crabs are, however, eaten in various localities and by various peoples. For example, our little Pinnotheres

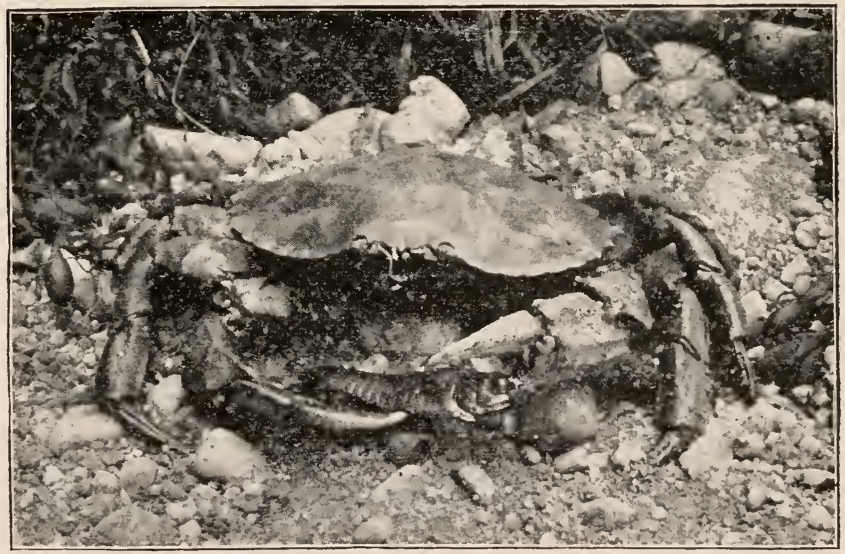

Fig. 103. - Callinectes hastatus, blue erab. Reduced to one-third. Photo. by IV. H. C. P. 
ostreum (Fig. 105), found in the mantle chamber of the oyster, is eaten by us together with the oyster or separately.

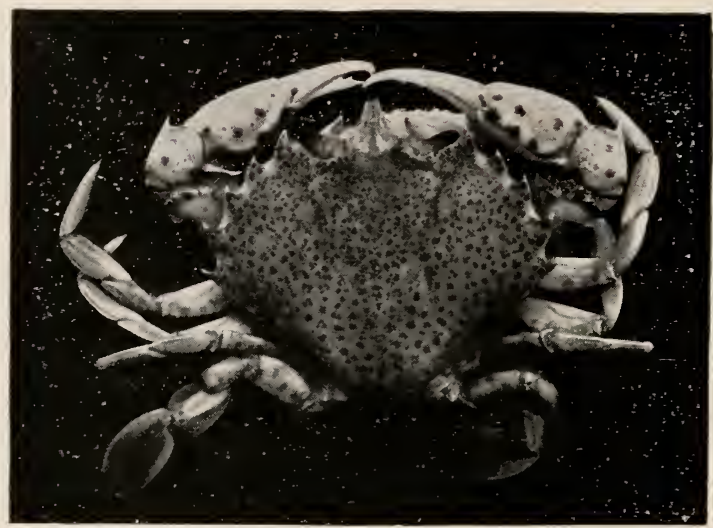

Fig. 104. - Platyonichus ocellatus, lady crab. Reduced to one-third. Photo. by W. H. C. P.

The fiddler crabs are representative of the square crabs. These are the familiar animals which crowd salt marshes and run sideways to and from their burrows. One claw is

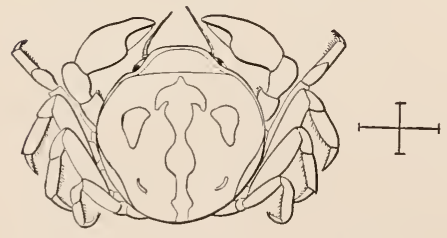

FIG. 105. - Pimotheres ostreum. $\times 4$. From Rathbun. much larger than the other. When the crab is disturbed, the large claw is brandished in a manner which has been likened to the movements of a fiddle as one plays upon it. Gelasimus pugnax is the most abundant species, and ranges from Cape Cod to the Gulf of Mexico. Together with Cambarus it does much damage by burrowing in the levees of the Mississippi River (Fig. 106). 


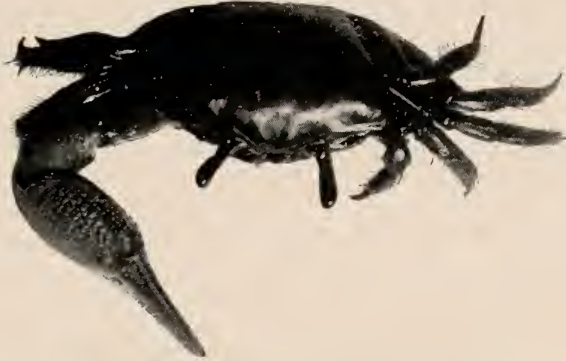

Fig. 106. - Gelasimus pugnax. Nat. size. Fronto-dorsal view. Photo. by W. H. C. P.

The economic importance of the Decapoda may be inferred from the fact that the receipts for the lobster alone, taken and sold by Uniter States fishermen, is estimated for 1892

at one million dollars. The yield to Canadian fishermen was in addition worth half a million dollars. From the United States Fish Commission Bulletin for 1890-91 we find that the blue-crab fisheries on the Atlantic and Gulf coasts returned almost half a million dollars, while the shrimp catch in the same waters brought nearly a quarter of a million dollars more. The latter industry on the California coast is much greater, for the shrimp trade of San Francisco Bay alone is valued at a quarter of a million dollars yearly.

The remaining orders of Malacostraca may be briefly mentioned. The Stomatopoda ${ }^{1}$ include only Squilla, ${ }^{2}$ the mantis shrimp, so

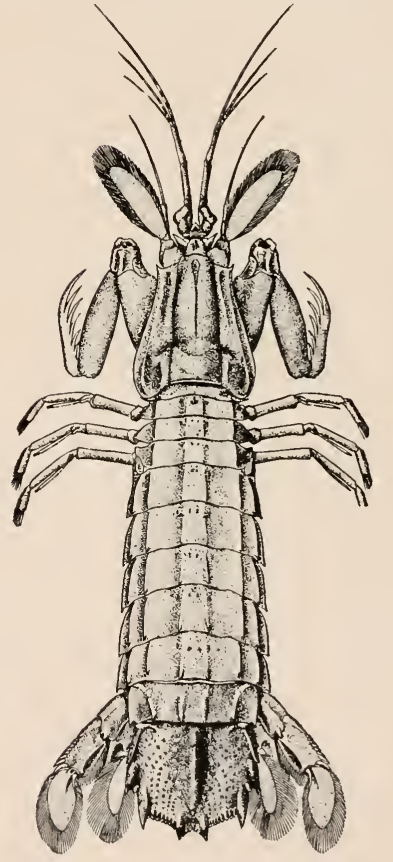

Fig. 107. - Squilla empusa, the mant is shrimp. Dorsal aspect. From Bigelow.

${ }^{1} \sigma \tau o ́ \mu a$, mouth ; $\pi$ oús, foot.

${ }^{2} \sigma \kappa i \lambda \lambda a$, classic name for a marine crustacean. 
called because of a certain resemblance to the mantis insect (Fig. 107). 'This animal is found on our east coast, where it burrows in the sand. It is a little longer than a crayfish. Being hard to catch, it is not much used as food. 'The Cumacea include a few small marine Crustacea, not ordinarily seen. They are of interest because of the reduced carapace which is transitional to the condition found in the lower ('rustacea. The Isopoda ${ }^{1}$ include

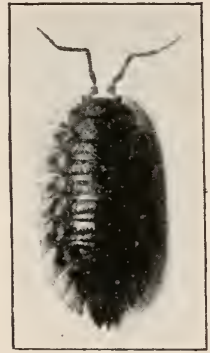

Fig. 10s. - Onis:'us, the sow-bug. Dorsal view. Nat. size. Photo. by W. H. C. P.

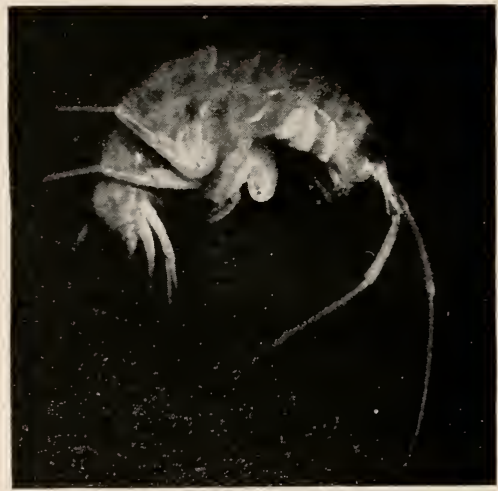

Fig. 109. - Talorchestiu lomgicormis, the beach Hea. Nat. size. Photo. by W.H. C. P.

the sow-bugs or wood-lice (Fig. 108), noteworthy for forming the largest group of land Crustacea, and certain marine and fresh-water groups. The Amphipoda ${ }^{2}$ are exclusively aquatic creatures, found under decaying vegetation on beaches of lakes or the sea (Fig. 109), and crawling amidst marine hydroids. Being laterally compressed, the Amphipods tend to lie on one side when at rest.

1 loos, equal ; roús, foot.

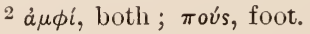


Edible Lobsters. - The American lobster, Homarus Americanus, differs little in appearance from the European lobster, $H$. vulgaris. Formerly the American lobster attained the greater size, but the excessive catches of our species in the last few years are rapidly doing away with this difference. The so-called Norwegian lobster finds its way into European markets, while on our Californian coast the socalled spiny lobster or sea-crayfish takes the place of our true Atlantic lobster, and, like the latter, is said to be in danger of extermination on account of overfishing.

Edible Crayfish. - The nearest fresh-water ally to the lobster - the crayfish - has not yet attained the popularity in our markets which it possesses in Europe, particularly in France. So much is the crayfish esteemerl in Paris that the enormous crayfish farms throughout France are unable to supply that city, consequently crayfishes are imported in considerable quantities from Germany. In America, it is our French population mainly that makes a market for the crayfish. Astacus nigrescens is the crayfish sold in San Francisco markets. (On the Atlantic coast, New York and New Orleans are the main centres of consumption. Cambarus affinis, taken from the Potomac River, is the crayfish found in the spring in the New York markets. Later in the season this market is supplied by $C$. virilis and immunis, which are shipped from Montreal, Milwaukee, and other Western cities.

Edible Crabs. - Of the crabs which reach our market the most important is the blue crab. These crabs are kept moored in floating boxes until they have moulted, and then they are sent to market as soft-shelled crabs. 
The shore crabs, Cancer, are little eaten in the United States. ${ }^{1}$

Edible Carididæ. - The shrimps and prawns have within recent years begun to appear in large numbers in the Eastern markets. For many years the Pacific species

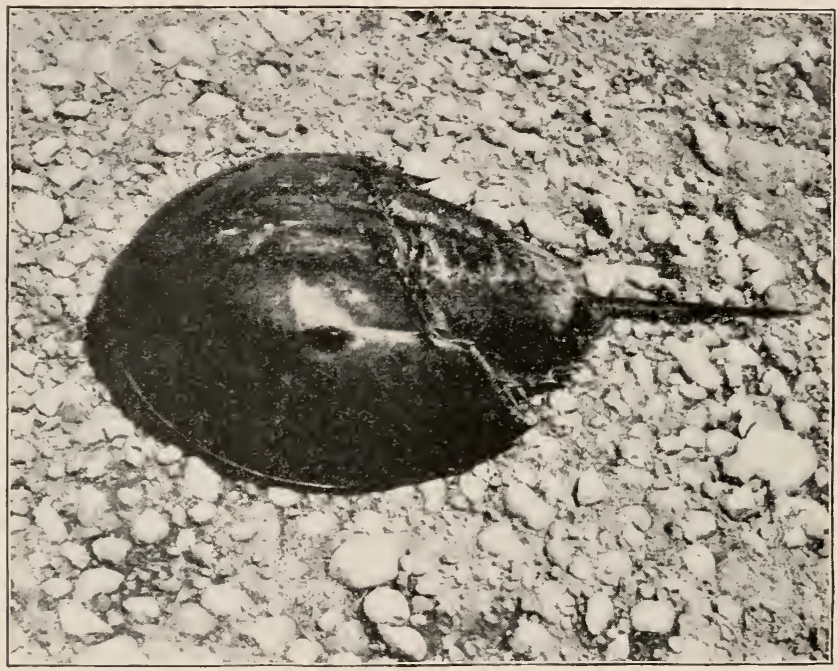

FIG. 110. - Limulus polyphemus, the king-crab or horseshoe-crab.

have heen dried and shipped by the Chinese in large quantities to China.

1 Very unfortunate is the destruction of the "king-crab," Limulus, which is only distantly related to the Decapoda. In Delaware Bay they are canght in great numbers and ground up as fertilizer. As they are taken only during the breeding season, they are being rapidly exterminated. The American Limulus belongs to an order entirely unrepresented on the European coast (Fig. 110). 
Development of Lobsters. - Lobsters lay eggs in July and August. In the fall they migrate to deep water, and pass the winter there. In the spring they migrate back to the shore - the females tarrying behind the males until the eggs of last summer, which she still carries attached to her swimmerets, shall be further advanced. In .June the young hatch out, moult, and swim to the surface. The

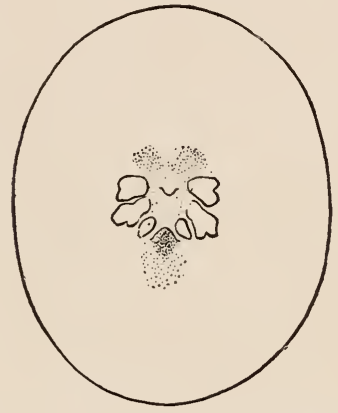

Fig. 111. - An early stage of development of egg. Appendages becoming bifid. Paired dotted areas above indicate eyes; these are followed by the first three paired appendages: antennules, antemna, and mandibles. Below in the mirldle line is the forming tail; above is the mouth. After Herrick.

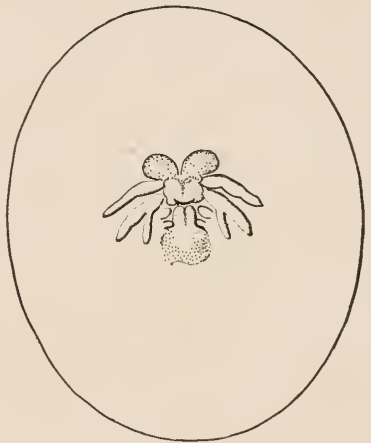

Fig. 112. - Surface view of egg nauphius. Antennse show beginning of segmentation; mandibles and maxille seen on each side of the abrlomen. Embryo 16-18 days old. $\times 25$. From Herrick.

female now moults, but does not spawn again for a whole year ; that is, she spawns in alternate years. The number of eggs carried varies with the age of the female; middleaged lobsters may carry up to one hundred thousand eggs. but the old or young ones as few as three thousand. The egg as freshly laid is about 1.5 millimetres in diameter and is stored with food material, called yolk, much as in the case of the hen's egg. As in the chick, the development 
takes place, as it were, on top of the egg (Figs. 111, 112). Eyes and mouth appendages early make their appearance; then the other appendages, and the tail (Fig. 113). For a long time the back of the thorax is greatly distended by the yolk stored there, and the eyes are huge (Fig. 114).

Immediately after hatching, the young lobster is about one-third of an inch long. The eyes are still abnormally large, the telson is spatulate, and the abdomen is without

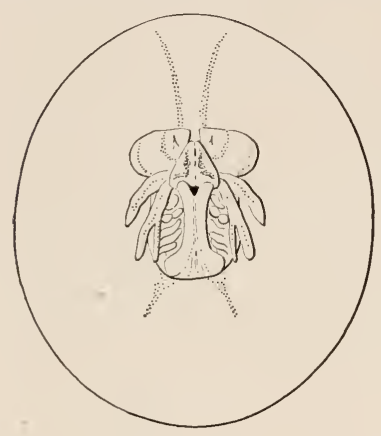

Fig. 113. - Surface view of embryo with all of thoracic appendages formed. The forked telson partly overlies the brain. Note the large eyes, which are yet without pigment. Embryo about 21 days old. $\times 25$. From Herrick.

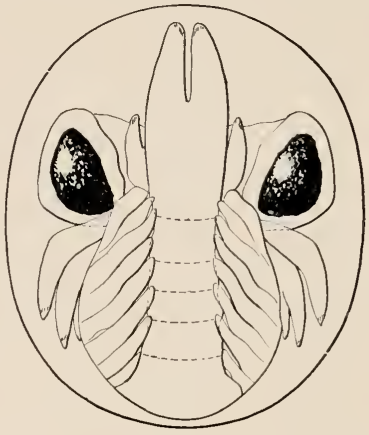

Fig. 114. - Loloster embryo. 61 days old; eyes have developed pigment. $\times 15$. From Herrick.

swimmerets. On account of its resemblance to the Schizopoda, the larva at this stage is known as the "Schizopod larva" (Fig. 115). In moulting for the fourth time, the exopods are lost from the future walking appendages, and the animal resembles a lobster except for its small size (Fig. 115a). During these early moultings the young lobsters undergo a terrible mortality, so that out of ten thousand embryos hardly two, on the average, survive. After the 
fifth or sixth moult the little lobsters sink to the bottom, and then begin their journey shoreward. From this time until they are about four inches long, only very few individuals have ever been seen. This is due, it is said, to the fact that they hide deep down among the rocks, where they cannot be dredged. When they are four inches long or so, they become bolder, leave the rocks, and, like the

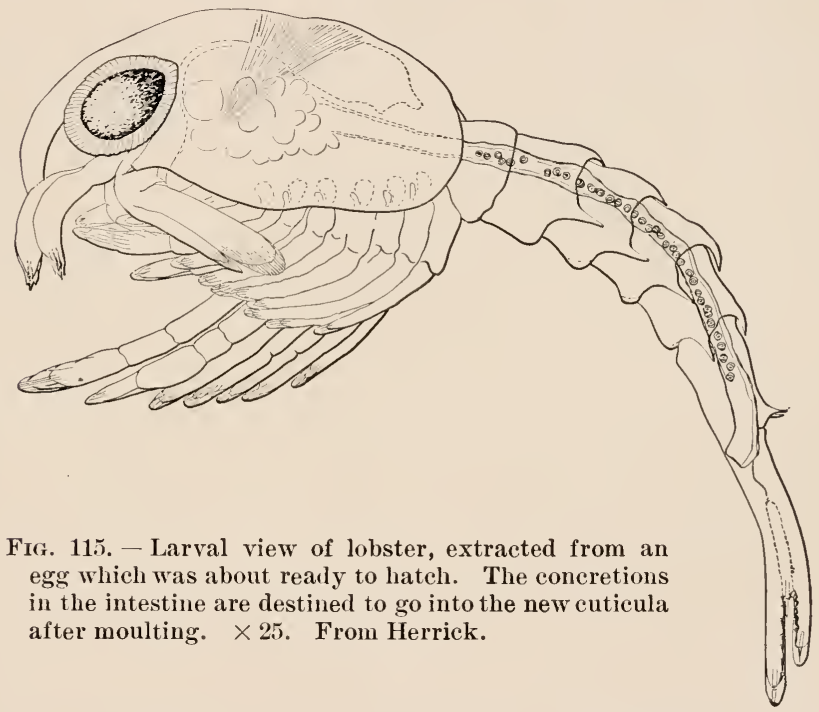

adults, make burrows for themselves in the sand or under stones.

Development of Crayfish. - The crayfish develops similarly to the lobster, - from a large egg filled with yolk. The early stages are much like those of the lobster; but those changes which in the lobster take place during the furst three stages of free life are in the crayfish passed in the egg. Consequently at the time the crayfish hatches it 
is almost, but not exactly, like an adult crayfish except in size. The telson of the just-hatched crayfish has, to be precise, a somewhat more oval form, and the first pair of swimmerets are undeveloped; but these differences soon disappear.

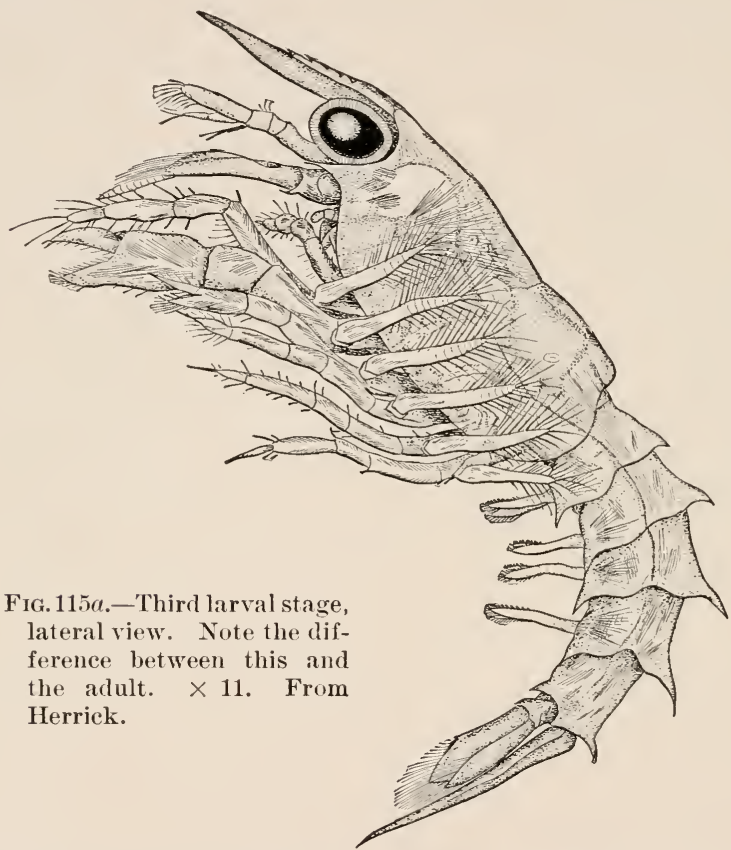

Regeneration of Lost Parts. - If you attempt to pick up a crab by one of its claws, you frequently find yourself in possession of a portion of the leg only, while the crustacean has marle good its escape. Noreover, it will be seen that the leg always separates at a certain place; namely, between the second and third segments. This is the place where a fusion occurs between two segments which are free 
in the first larval stage. This power of defensive mutilation occurs in those appendages which are most apt to be seized, - namely, the five thoracic legs, - and is wholly under the control of the reflex nervous system, for it may occur when the entire voluntary nervous system has been removed. The leg of a dead crustacean shows no such capacity. If the leg of a lobster is cut off at some point distal to that of normal rupture, the limb will later be found cast off up to this point. Here a sort of double membrane or diaphragm exists, with a central opening only large enough to admit the passage of nerves and blood-vessels. Upon rupture this passage is soon plugged up by coagulated blood-clearly a device to prevent excessive hemorrhages. Soon after a leg is cut off a papillalike body grows out from the stump of the limb, develops into the shape of a small limb, and grows larger, with each successive moult, until the normal size is reached. The antennæ, too, are much exposed to injury, but with them autotomy is not practised. They begin to grow out at the place of injury, and at least one moult is necessary for their complete restoration.

Abnormalities in the claws of the lobster are not uncommon. The thumb-like protuberances of the next to the last of the joints of the great claw is sometimes bifid, or carries a large wart. The finger which opposes the thumb is also sometimes forked (Fig. 116). Many of these abnormalities are probably due to injury of the claw; but others cannot be explained in this way. For instance, cases have been observed of lobsters having crushing claws of equal size on the two sides of the body. An antenna has been seen replacing an eye, and this result may be obtained by cutting off an eyestalk near its base 
when an antemna will regenerate (Fig. 117), one or two extra oviducts may occur, or double monsters-sort of
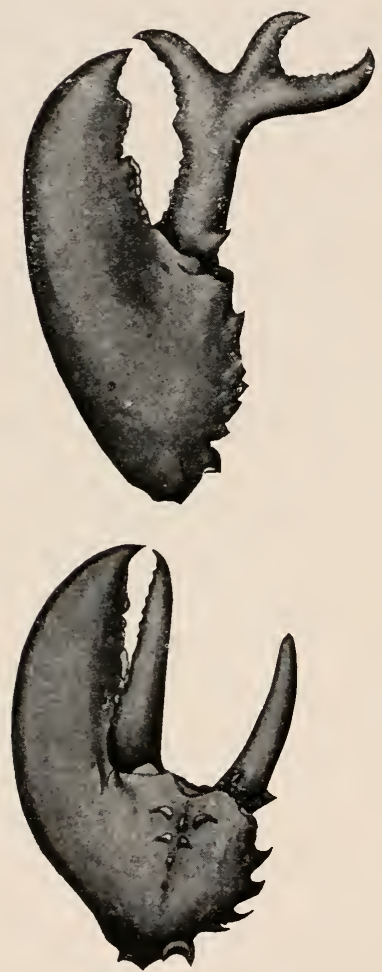

Fic. 116.-Two abnormal claws.

Upper figure shows a double outgrowth to the finger. In lower figure there is an extra finger. From Herrick.

Siamese twins - may be hatched out. Similar monstrosities are found in other arthropods.

\section{Physiological Division of Labor.}

- 'The difference between a "highly developed" animal and a lowly organized one is not first of all a difference of size nor a difference in the number of parts, - just as a large population or numerous cities are not the primary characteristics of a highly civilized state. But just as a complex civilization is one in which each of the different citizens has his own special task to perfor'm for the commonwealth, so a highly developed organism is one in which each different organ has its special rôle to play. The worm Nereis has more segments to the body than the crayfish, but these segments are very nearly alike - the parapodia especially are quite similar. In the cray fish, on the other hand, the appendages are dissimilar. Each pair has a special function to perform and is specially adipted, often complexly fashioned, to meet this need. What is true of the appendages is like- 
wise true, to an equal degree, of the internal organs. The internal organs of Nereis are repeated in each segment; but in the crayfish the egg-ducts lie in one segment, the heart in another part of the body, and so on. Some of the segments have given up one or more functions to perfect a

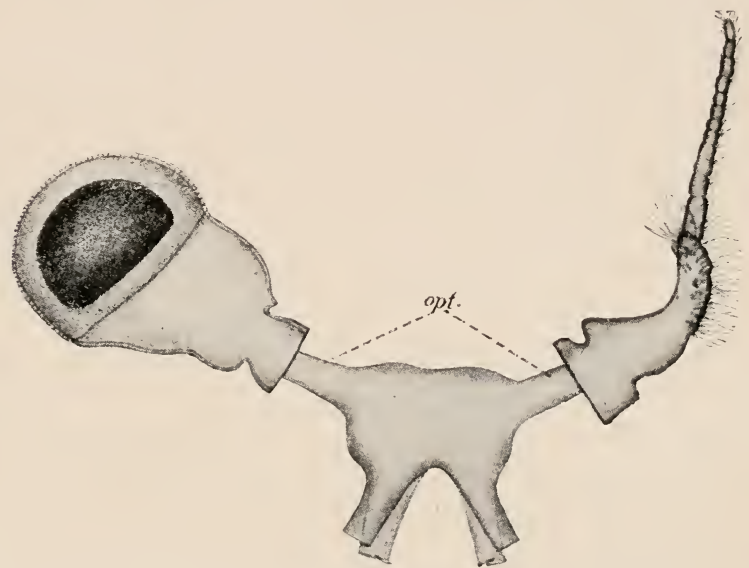

FIG. 117. - Eyestalks of a Decapod dissected out. On the right an antenna has regenerated in place of the amputated eye. opt., optic nerve. After Herbst.

single one in which it has specialized. There has been a division of labor between the different parts of the body, and in consequence a greater perfection in the performance of each function. More perfect fulfilment of function is the result of physiological division of labor, just as a higher civilization is the result of individual division of labor. 


\section{APPENDIX TO CHAPTER VII}

KEY TO THE SIX CHIEF ORDERS OF MALACOSTRACA

$a_{1}$. Body segments, 20 ; abdomen with 7 segments; at least 1 pair of maxillipeds.

$b_{1}$. Cephalothorax with carapace, at least 2 pairs of maxillipeds ['Thoracostraca].

$c_{1}$. Eyes stalked.

$d_{1}$. No uncovered thoracic segments; 3 or 2 pairs of maxillipeds, and 5 or 6 pairs of leg.

$d_{2} .3$ free thoracic segments; 5 pairs of maxillipeds ; 3 pairs of legs

Podopthalmata

(Ex. Crayfish)

Stomatopoda

$c_{2}$. Eyes not stalked; 4 to 5 thoracic seg-

ments not covered by carapace ; 2 pairs of maxillipeds ; 6 pairs of thoracic legs

Cumacea

$b_{2}$. Cephalothorax without marked carapace; usually 7 free thoracic segments; only 1 pair of maxillipeds; eyes not stalked [Arthrostraca].

$c_{1}$. Body usually broad; abdomen with short, often-fused segments, and with gills on legs . . . . .

$c_{2}$. Body laterally compressed; abdomen mostly elongated, with 3 pairs of swimming legs, and behind them 3 pairs of springing legs . . . . .

$a_{2}$. Body segments, 21, enclosed in bilobed shell; abdomen with 8 segments; the last 2 without appendages; no maxillipeds [Leptostraca] .

Isopoda

Amphipoda

The crayfish belongs to the order Podopthalmata. The following is a key to the most important families of this order :-

$a_{1} .3$ pairs of maxillipeds which differ in form from the following 5 pairs of thoracic legs ; the latter are locomotor, and often end in pincers [suborder Decapoda]. 
$b_{1}$. Body mostly depressed; antennæ short; abdomen short and folded under the cephalothorax, with 1 to 4 pairs of appendages, and usually without tail-fin [superfamily Brachyura].

$c_{1}$. Male duct opens on thoracic plate; cephalothorax usually quadrangular, at times transversely oval; anterior lateral area (liver area) of carapace small; usually fewer than 9 pairs of gills; orbits look forward or obliquely downward .

Catometope

(siluare Crabs; Fiddler-crabs)

$c_{2}$. Female opening on broad thoracic plate;

male opening on coxa of 5th pair of thoracic legs; 9 pairs of gills.

$d_{1}$. Cephalothorax broad, diminished behind, bowed in front; liver area large ; orbits directed obliquely upward and forward.

Cyclometopa (Arched (rabs)

$d_{2}$. Cephalothorax triangular, anteriorly pointed, with longer or shorter rostrum ; liver area small; orbits directed outward . . . .

Oxyrhyncha (Triangular Crabs; spider-crabs)

$b_{2}$. Body mostly elongated; antennæe long; abdomen long, not bent under, or only partly so, typically with 5 pairs of legs and a large tail-fin [superfamily Macrura].

$c_{1}$. Last pair of thoracic legs shoved backward and rudimentary.

$d_{1}$. Last thoracic segment not free; abdomen with hard shell, hinder half turned under; first pair of legs typically non-chelate . . .

Hippide

(Mole-crabs)

$d_{2 .}$. Last thoracic segment free ; abdomen typically with thin cuticula, unsymmetrical and with rudimentary legs ; first pair of legs very large, clielæ unsymmetrical . . .
Paguridae (Hermit-crabs) 
$c_{2}$. Lasi pair of thoracic legs not shoved backward.

$d_{1}$. Antenne without squame; first pair of thoracic legs chelate; cephalothorax with 2 longitudinal lines . $d_{2}$. Antemie with squame.

$e_{1}$. Squame small; antemnules and antemine near each other ; first pair of thoracic legs very heavy with great chelæ; cephalothorax with cross-suture; gills brush-like . . . .

Astacuda

(Ex. Craylish)

$e_{2}$. Squame large; antennæe usually under antennules; first pair of thoracic legs with small chele ; cephalothorax without cross-suture, gills laminate .

$a_{2} .2$ pairs of maxillipeds resembling the 6 following pairs in being bifid [suborder Schizopoda]. 


\section{CIIAP'TER VIII \\ THE DAPHNIA AND ITS ALLIES}

Relationships. - I aphnia ${ }^{1}$ belongs to the division of Crustacea called Entomostraca. ${ }^{2}$ The Entomostraca ${ }^{3}$ are distinguished from the higher Crustacea - the Malacostraca - by the negative character that the number of segments and appendages in the body is variable, instead of there being constantly 19 pairs of appendages.

The group of Entomostraca to which Daphnia belongs comprises the more primitive of living Crustacea. They occur in both fresh and salt water and, excepting Protozoa, are the most abundant aquatic animals. They are of great economic importance, since they constitute the main food supply of fish. On the coast of Norway and Scotland the fishermen prepare for a catch of herring or mackerel when the sea becomes red with Entomostraca. Whalers likewise seek their booty where these Crustacea are abundant on the open seas, for even the whalebone whales devour the small animals in great quantity, straining them out of the sea-water by means of their whalebone strainers. Despite all their enemies, the numbers of Entomostraea are maintained by virtue of an enormois fertility. The

${ }^{1}$ From $\Delta x \phi \nu \eta$, daughter of the river-god Peneus ; she was transformed into a laurel tree.

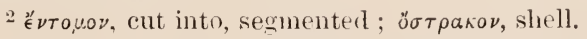

3 The five orders of intomostraca may be distinguished by means of the key given at the end of this Chapter, page 131. 
Entomostraca are rich in species also, partly because they occur in such diverse enviromments. Thus they live in fresh water, in the sea, and even in the Great Salt Lake and in vats where salt is crystallized out. They live in little pools, such as dry up in summer. They are found also as parasites on the gills or in the skin of fishes.

Habitat and Food. - Dathnia ${ }^{1}$ lives in ponds, lakes, and slow-rumning streams over all the globe. During the fall in northern latitudes the Daphnias, of at least certain species, lay fertilized eggs, called winter eggs, which may lie dormant, however, not merely for the winter but throughout an entire year. During most of the year females alone occur and unfertilized "summer eggs" are alone produced.

The abundance of Daphnia in any pond is determined by a number of causes. One of the most important of these is food. The food of Daphnia consists chiefly of fresh-water alge, such as nostoes and diatoms; and it has been shown that the abundance of Daphnia in a pond is closely determined by the abundance of the kind of alga

${ }^{1}$ Key to the principal genera of the family Daphnidæ : -

$a_{1}$. Head rounded, not beaked.

$b_{1}$. Antennules long; abdomen not wholly covered by shell

Moina

$b_{2}$. Antennules short; whole body enclosed in shell

$a_{2}$. Head beakerl below.

$b_{1}$. Beak slight; shell angled below or extending in long spines from lower angle; pigment spot roundish

Scapholeberis

$b_{2}$. Shell rounded below, with a blunt spine above ; pigment spot elongate Simocephalus

$b_{3}$. Shell extending in sharp spine at upper posterior angle; pigment spot small 
which forms its principal food. Another factcr upon which the number of Daphnia in a pond depends is temperature. A high temperature seems to be mufavorable to Daphnia, so that not the summer, but the spring and autumn are its periods of maximum reproductive activ ity. 'This activity is likewise checked in winter even though there is plenty of food.

The family Branchiopoda ${ }^{1}$ is closely allied to the Cladocera. The common representative of this family, Branchipus, has an elongated, distinctly segmented body which carries eleven pairs of lobed, leaf-like feet, functioning both as respiratory and locomotor organs. Like Daphnia, Branchipus produces winter eggs which can withstand desiccation even for years; incleed, in some cases, a certain amount of desiccation is a prerequisite of hatching. Apus differs

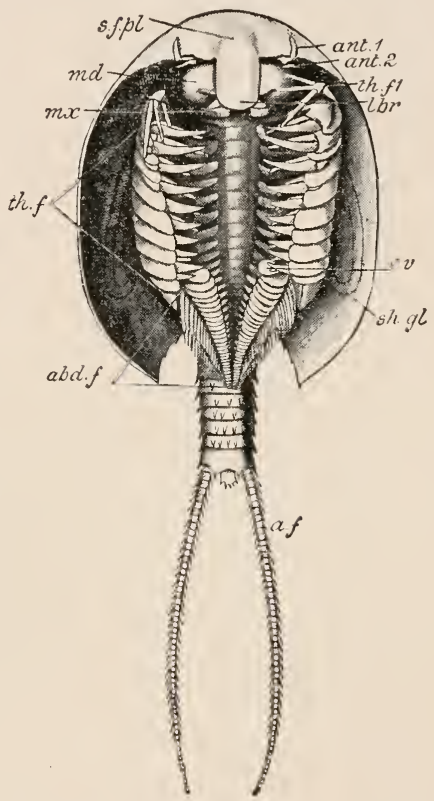

Fig. 118. - Apus glacialis, ventral aspect. $a b d . f$., abdominal feet; ant. 1, antennule; ant. 2, antenna; lbr., labrum; md., mandible; m.x. first maxilla; ov., aperture of oviduct; s. $f$. pl., sub-frontal plate; sh. gl., shell-gland; th. $f$., thoracic feet; th. $f$. 1, first thoracic foot. After Bernard. from Branchipus in having a broad shield (Fig. 118). The family Ostracoda ${ }^{2}$ comprises some very abundant,

${ }^{1} \beta \rho a ́ \gamma \chi \iota a$, gills ; $\pi$ oús, foot.

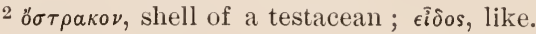


minute, bean-shaped little crustaceans, which have to move their appendages very vigorously to support their heavy bodies in the water. The Ostrucods are found in almost all pools and streams, especially in the early spring. Many of them seem to be exclusively parthenogenetic.

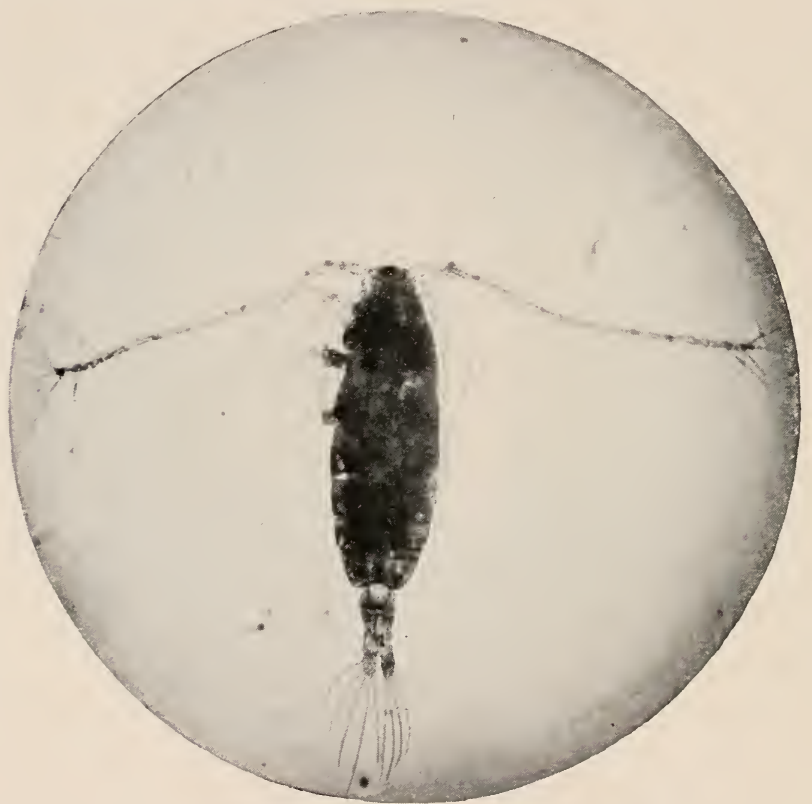

Fig. 119. - Acartia, a marine Copepod. Greatly magnified. Photo. by IV. H. C. P.

Of the Copepoda ${ }^{1}$ the commonest fresh-water genus is Cyclops, which occurs in a similar habitat with Daphnia and is sometimes found even in pure drinking water. The female carries a conspicuous egg-sac on each sirle of the abdomen, and reproduction occurs with such rapidity that

$$
{ }_{1} \kappa \omega ́ \pi \eta \text {, var; } \pi \text { oús, foot. }
$$


one ('yclops might, moler the most favorable conditions, lave 5,000,000,000 descendants in one year. It is consequently easy to understand low Cyclops often becomes the most abundant entomostracan in our waters, and how in some lakes it has been found that there are over one million of them to each square metre of water surface. Large numbers of the Copepola are marine. One of the most common is Acartia (Fig. 119), which swarms to such

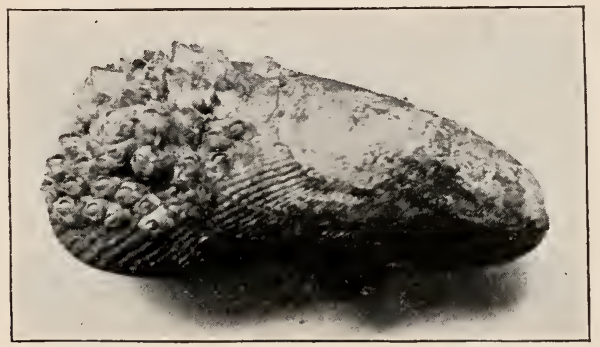

Fig. 120. - Mussel-shell bearing harnacles (Balanus). Photo. by W. H. C. P.

an extent on the surface of the water as to make great phosphorescent areas.

Barnacles are the only attached non-parasitic Crustacea. Certain species of them are found fastened to rocks on the seashore at low-ticle mark. If you watch barnacles in rock pools, you can see them open the valves of their shells, protrude their elongated appendages, which together form a sort of rake, and pull in particles which happen to be floating about them. Other species of barnacles attach themselves to floating seaweed, ship bottoms, and whales ; under. these circumstances, despite their sessile habit, they enjoy a constant change of locality. Barnacles doubtless gain great protection from the circumstance that they are 
sessile and enclosed in shells; but their peculiar habits have given rise to certain peculiarities in reproduction. They are hermaphroditic; i.e. both male and female germcells occur in the same individual. Despite this fact, dwarf male individuals are occasionally found inside the shell of the barnacle; these are known as "complemental males." The general form of the barnacles has also be-

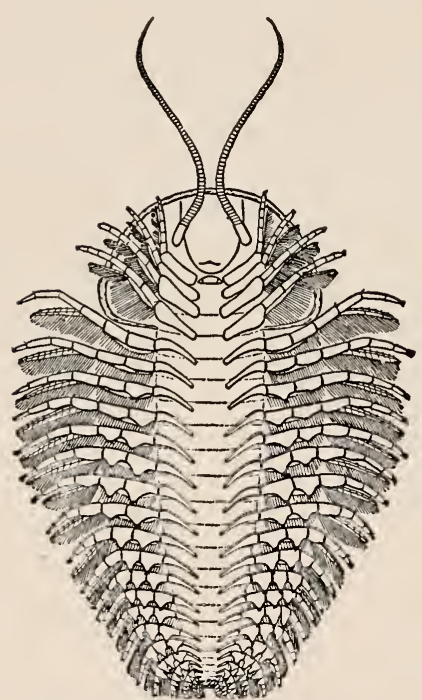

Fig. 121. - A restoration of the ventral aspect of a Trilobite. Note in particular the character of the appendages. After Beecher. come greatly modified by their sessile habit, so that they were long regarded as mollusks, until it was shown that the larva are almost exactly like those of other Entomostraca.

Trilobites ${ }^{1}$ are extinct giant Entomostraca, closely allied to Branchipus. They were inmensely abundant in early geologic times, and their remains form a large part of certain rocks. They had a segmented body, with bifid appendages and long antennie, and their compound eyes were borne on the great frontal shield. Some of them were nearly half a metre long.

1 Having three lobes. 


\section{APPENDIX TO CHAPTER VIII}

\section{KEY TO THE FIVE ORDERS OF ENTOMOSTRACA}

$a_{1}$. Free-living or parasitic inhabitants of the sea or of fresh water.

$b_{1}$. 2 pairs of maxillæ.

$c_{1} \quad$ Mandible without palp; 4 or more pairs of foliate swimming legs behind maxillæ [Phyllopoda].

d. With 10 to 40 pairs of legs . . Branchiopoda (Ex. Branchipus)

$d_{2}$. With 4 to 6 pairs of legs . . . Cladocerc (Ex. Daphnia)

$c_{2}$. Mandible with leg-like palp; only 2 pairs of appendages behind maxillæe . . Ostracota

$b_{2}$. Only 1 pair of maxillæ, followed by $4-5$ pairs of bifid, oar-like feet; often deformed as a result of parasitism . . . . .

$a_{2}$. Sessile marine animals, whose body is surrounded by a usually calcified mantle; 6 pairs of tendrillike feet

Key to the principal families of Cladocera, to which group Daphnia belongs :-

$a_{1}$. Body enclosed in a bivalve shell ; mandibles truncate below ; maxillæe distinct, spiny.

$b_{1}$. 6 pairs of similar, foliaceous, distinctly branchiate feet; swimming antemnæ with 2 unequal rami; intestine straight . .

b. 5 (or 6 ) pairs of feet, the anterior pair more Sidida or less prehensile and destitute of branchiæ. $c_{1}$. Rami of antennæ $3-$ and 4 -jointed; 5 pairs of feet, the last with a curved appendage guarding the branchial sac ; antennules of the female sort, 1 -jointed 
$c_{2}$. 6 pairs of feet; antennules elongated, many-jointed . . . . . Bosminida

$c_{3}$. Antennæ with both rani :3-jointed; intestine convolute. . . . . Lynceidce

$a_{2}$. Body wholly or nearly destitute of a bivalve shell ; feet not branchiate, spiny; abdomen curved, ending in two long stylets . . . . . Polyphemide 


\section{CHAP'TER IX}

\section{THE EARTHWORM AND ITS ALLIES}

Relationships. - Earthworms ${ }^{1}$ belong to an orcler of Annelids known as Oligocheta. ${ }^{2}$ This group is distinguished by a prevailingly non-marine life, by the absence of parapodia, by few bristles, and by the absence of tentacles, palps, cirri, and gills. ${ }^{3}$

Habits. - Earthworms, as the name implies, are inhabitants of the ground, through which they burrow and in

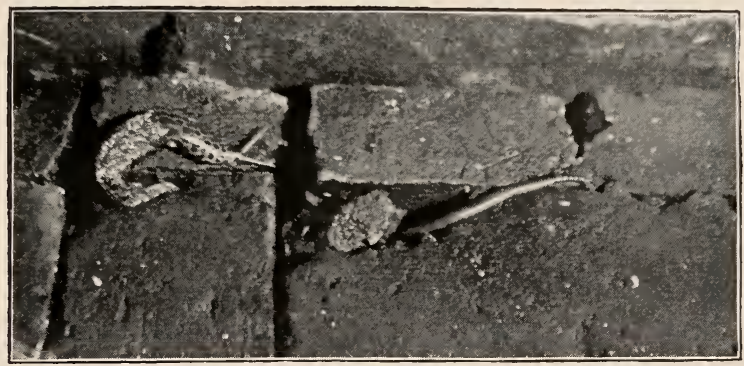

Fig. 122. - Flash-light photograph of earthworm and slug crawling on a pavement at night. Photo. by D. and S.

1 There are not very many kinds of terrestrial Oligochreta. 'The principal American species may be distinguished with the aid of the key given in the Appendix to this Chapter.

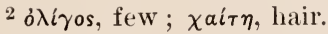

3 The Oligochrta exhibit two principal subdivisions; the first of which includes terrestrial species of the single family Lumbricidie, and the second various aquatic families, - a key to which is given on page 144 . 
which they gain their food. They sometimes come to the surface at night in search of companions and food (Fig. 122). Even during the day in rainy weather they extend the anterior end of the body out of their burrows. Earthworms, found on the surface at other times, have, for the most part, been parasitized by a fly, and are in consequence weak or dying. During the daytime, if the surface moisture permits, they lie near the mouth of their burrows, probably for the sake of the sun's warmth. In this position they can be seen by looking down into the holes. At such times they are often canght by birds. In dry weather, or when the ground is freezing, earthworms burrow deep to a moist stratum, or to below the frost line, and hibernate there.

Food. - Earthworms are omnivorous. As they burrow through the ground, the earth is taken into the alimentary tract, and the digestible particles are dissolved out and absorbed as food. Earthworms can, however, be fed upon green and dead leaves, decaying wood, seedlings, bits of flesh, and even filter paper. Earthworms have the habit of dragging into their burrows leaves which they intend to devour. 'There the leaves are moistened with a fluid excreted by the worm. This fluid partially digests the food. After being taken into the alimentary tract, the food reaches an organ of the canal known as the gizzard. This part has thick muscular walls, and contains in its cavity small stones; by the action of both the muscular gizzard and the small stones, the food is ground up in much the same way as are the grains of corn by the aid of stones in the gizzard of a hen.

Resistance and Regeneration. - The capacity which earthworms possess of resisting certain untoward conditions is 
very great. Thus they may be kept for months in a moist vessel without food, or with only filter paper, without starving. On the other hand, they die in a dry atmosphere in a few hours, whereas they may be submerged in water for several days without injury. Very remarkable is their power of healing after injury. If an earthworm be cut in two near the middle, and the halves be kept under favorable conditions, each half may develop its missing organs so that two complete worms will result. The anterior half of one worm may be attached to the hinder end of a second worm by the cut edges, owing to the fact that the cut edges grow together. This operation is called grafting.

Economics. - Earthworms are, to a certain extent, injurious to vegetation, since they eat tender seedlings and roots, but, on the other hand, they are almost indispensable to agriculture. Their burrows permit rain to percolate leep into the ground, instead of running off on the surface. They keep the soil loose, facilitating the penetration of the roots of plants. The earth that passes through their bodies is ejected on the surface of the ground near the openings of their burrows, and is called a "casting." By means of castings the deeper-lying earth is brought to the surface, and the surface layer of rich earth, called "vegetable mould," is in this way increased in thickness by additions to its upper surface. The thickness of the layer of mould which the castings of one year, if uniformly spread out, would make has been estimated by Darwin to be in England about two-tenths of an inch. Most of these castings are merely taken from the deeper-lying mould, but they are enriched by the intestinal secretions in passing through the body of the worm. These intestinal secre- 
tions are said to have the power of slowly dissolving sand and thus of turning it into soil. Darwin says, "It is a marvellous reflection that the whole of the superficial mould over any smooth expanse has passed, and will again pass, every few years, through the borlies of worms. 'The plough is one of the most ancient and most valuable of man's inventions, but long before he existed the land was, in fact, regularly ploughed, and still continues to be thus ploughed, by earthworms."

The group to which earthworms belong is closely related to that which includes Nereis of the seashore. They are both ringed worms or Annelids. ${ }^{1} \quad$ But whereas Nereis and its allies have parapodia provided with numerous bristles, the earthworm has no parapodia, and only a few bristles on each segment. The group to which Nereis and its allies belong is called (see Chapter $\mathrm{X}$ ) Polycheta, and the group to which the earthworm belongs is appropriately named Oliygchcetr.

The aquatic Oligochæta ${ }^{2}$ are among the commonest inhabitants of ponds and ditches, living sometimes in the mud and sometimes at the surface of the water.

Tubifex ${ }^{3}$ is common in slow-rumning brooks, and lives in the mud of the bottom, forming tubes in it. The thread-like bodies of the worm are stretched up beyond the surface of the mud and wave in the water in graceful undulations. Often the worms are so numerous that their reddish color gives a decided tinge to the bottom. They thrive well in fresh-water aquaria.

1 Anmulus, a little ring.

$2 \mathrm{~A}$ key for the determination of the principal families of aquatic Oligochreta is given in the Appendix to this Chapter, page 144.

s tubus, tube; facere, to make. 
Dero ${ }^{1}$ is very common on the surface of ponds, particularly in the midst of duck-weed (Lemna), the leaves of which it cements together to form a floating tube in which it lives, and by which it is accompanied in all its migra-

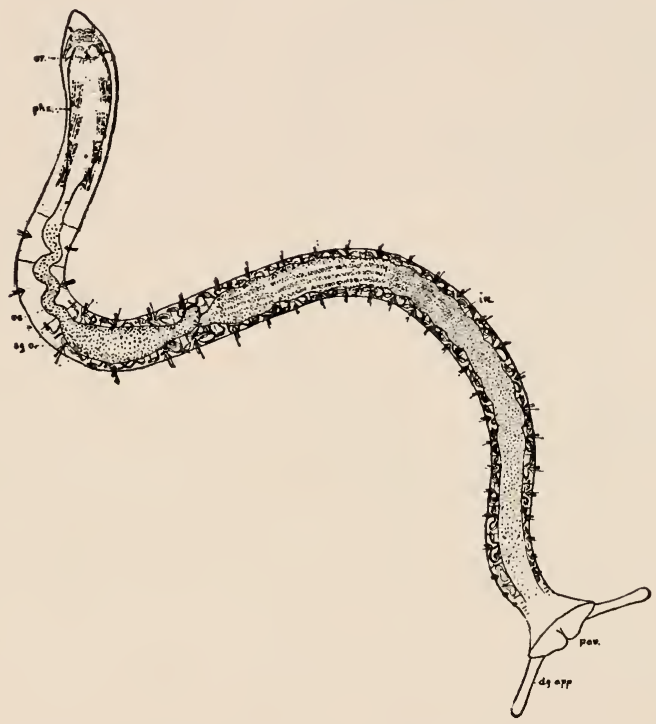

FIts. 123. - Dero, the duck-weed worm. Enlarged. After Reighard. The lettering is as follows: or., mouth; phx., pharynx; oe., oesophagus; $s g . o$, segmental organ ; in., intestine; pav., pavilion or tumel; $d g$. app., fingerlike appendages. From Reighard.

tions. Dero can also be told by the sort of fumnel at the hinder end of the transparent body, from the margins of which finger-like filaments arise which aid in respiration (Fig. 123).

Nais ${ }^{2}$ does not construct tubes, and it has no respiratory

$1 \delta \dot{\epsilon} \rho \omega$, to $\operatorname{skin}(=$ flay $)$.

2 vais, a water-nympl. 
filament at the hinder end of the body (Fig. 124). It also has eyes; while Dero has none. Both Dero and Nais have

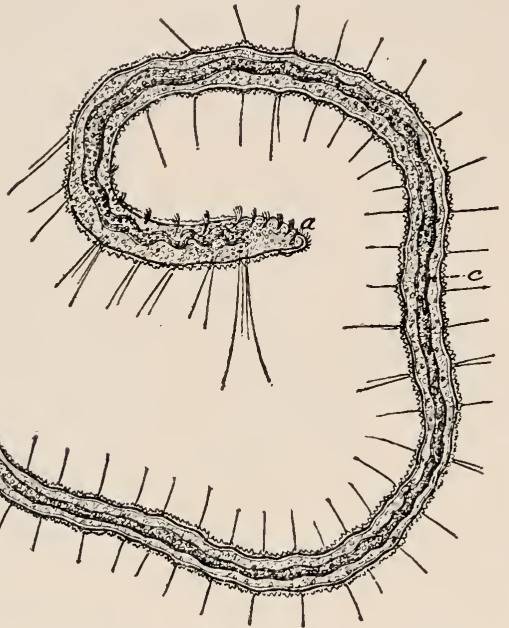

Fig. 124.-Nais: $a$, mouth; $b$, anus; $c$, intestine. From Leunis. the interesting habit of reproducing by dividing the borly transversely. In the middle of the body tentacles begin to arise, a new mouth is formed, and the worm constricts into two. I n d e e d, sometimes several new heads may be forming in the midst of a single worm. This habit is of arlvantage not only in multiplying the number of individuals of the species, but also as a means of protection. For if, by chance, the larva of the water-beetle Dytiscus seizes a Nais and bites it in two, the part which escapes can go on developing new individuals.

The slow-moving, burrowing habit of the earthworm has led to a nearly complete alsence of such appendages as Nereis possesses. There are other ringed worms in which the burrowing habits have led to a loss even of the segments in the adult. This is the case in the group Gephyrea. ${ }^{1}$

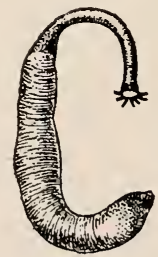

Fig. 1:5. - Phaseslosoma, a Gephyrean. One-fourth nat. size. From Leunis.

${ }^{1} \gamma \epsilon \phi \nu \rho$, bridge ; because they were once considered to bridge the gap between holothurians and worms. 
'This group contains several rather rare animals. One of the commonest is Phascolosoma, ${ }^{1}$ which is a tough but smooth-skinned, cigar-shaped worm, which one can dig up on our sandy beaches (Fig. 12.5). One end is pointerl; from the other a great proboscis terminating in tentacles surrounding a mouth can be extruded. Another species found on our beaches after a storm, something like a small cucumber in shape and size, has a row of bristles at each end, indicating its relationship with the bristle-bearing worms. This species, Echiurus, ${ }^{2}$ is segmented when young like Nereis, but eventually it loses its segmentation (Fig. 126i). Several species of Sipunculus are erlible, and are held in esteem by the Chinese.

To the account of the Oligocheta above given may be added some statements concerning a group of ammelirls of very different appearance. The leeches, or "blood-suckers," are flattened worms, which, like the earthworm,

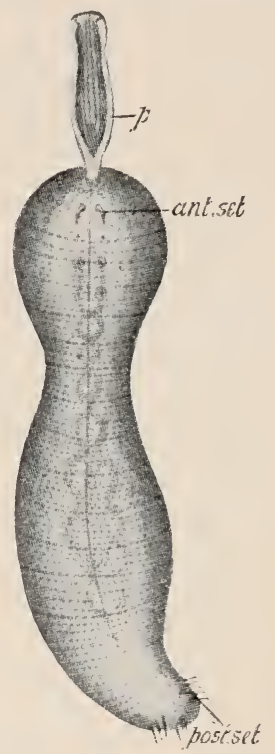

FIG. 126. - Echiurus. About one-half nat. size. prob., proboscis; ant. set., anterior setre; post. set., posterior setae. After Greef, from Parker and Haswell's "Textbook."

show metamerism; that is, there is a repetition of the intermal organs. They are also segmented; that is, the body has external rings, although they may be obscure. One segment does not, however, as in the earthworm,

1 фá $\sigma \kappa \hat{\omega} \lambda$ os, sac; $\sigma \hat{\omega} \mu a$, body.

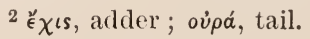


correspond with one metamere, but there are three, four, or five segments to a metamere. Leeches have no parapodia and no bristles; but they have a sucking disk at the posterior end of the body for the purpose of adhesion (Fig. 127). 'They usually have a smaller, anterior sucking' disk around the mouth, which may or may not be provided with teeth, for the purpose of cutting through the skin. When there are no teeth, the pharynx is protrusible, forming a proboscis. With a few exceptions, all leeches

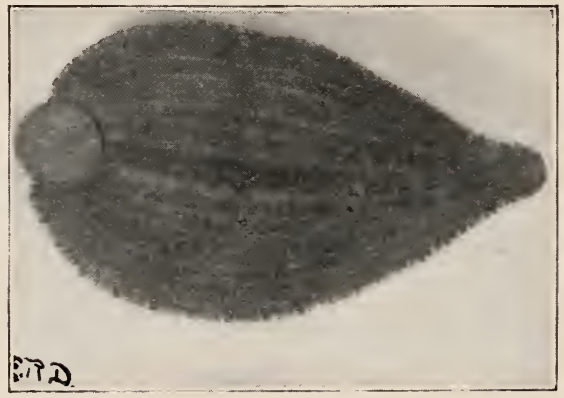

FIG. 12-i- - Clepsine, the flat blood-sucker. Ventral view. Posterior sucker at left. Nat. size. From life. Photo. by E. R. D.

live in water; but in ('eylon there is a land leech which lives in foliage and attacks man and other animals. Other leeches may live in damp places at a considerable distance from water. Leeches suck the blood of fishes and other aquatic animals. C'ertain kinds devour worms, insects, and other small creatures.

The commonest of the larger blood-suckers of our waters is Nephelis. ${ }^{1}$ which is not distinctly segmented. It varies from black to slate color, and is sometimes striped or spotted. It lives in running water, in ditches, and ponds.

${ }^{1} \mathrm{~N} \epsilon \phi \epsilon \hat{\epsilon} \eta$, wife of Athamas. 
Clepsine ${ }^{1}$ is a very flat and broad leech, which is common under floating wood. It feeds on snails and creeps like the inch-worm. The female carries its young attached to its under surface (Fig. 127).

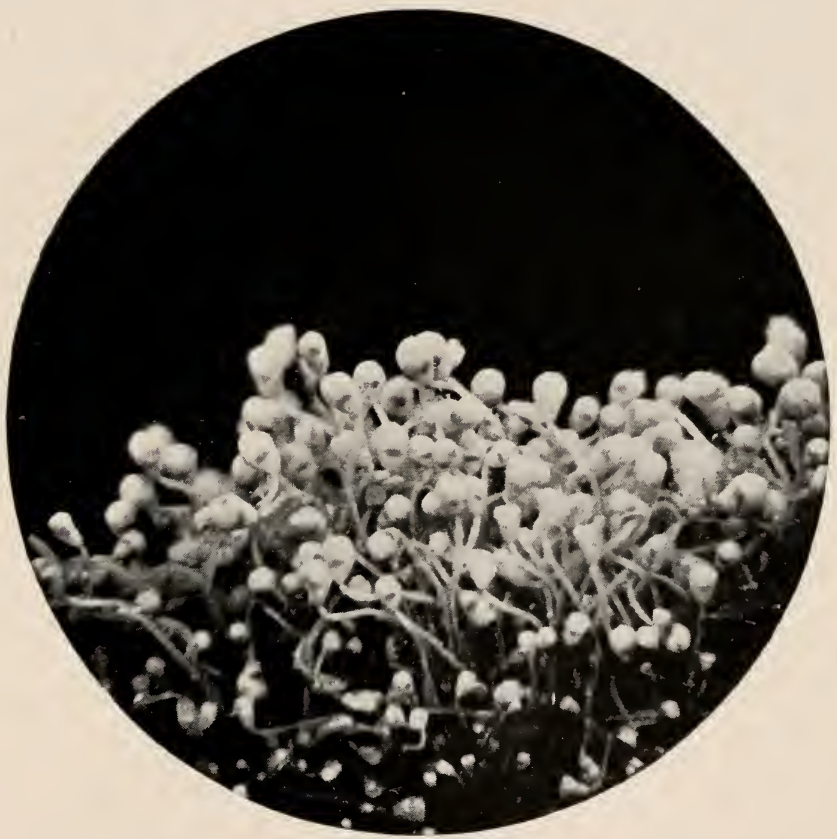

Fig. 128. - Pedicellina americana, an endoproctous bryozoan. A colony, magnified 15 diams. Photo, of living animals by W. H. C. P.

Possibly allied to the Gephyrea is the group of Bryozoa. ${ }^{2}$ or moss-animals. These are noteworthy from the fact that they are compound, many individuals budding off from one another, as in plants. 'They are found abundantly both in the sea and in fresh water. Two main groups are dis-

${ }^{1}$ From $\kappa \lambda \epsilon \dot{\epsilon} \tau \omega$, to steal.

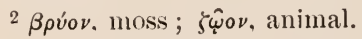




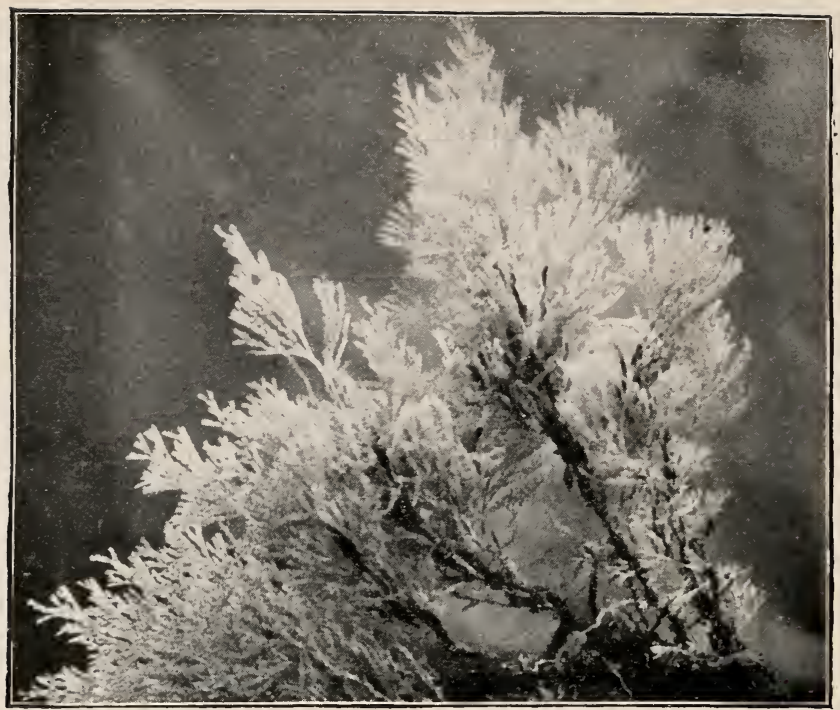

Fig. 129. - Bugula turita, a marine ectoproct. A colony, magnified 1.5 diams. Photo. of living animals by W. H. C. P.

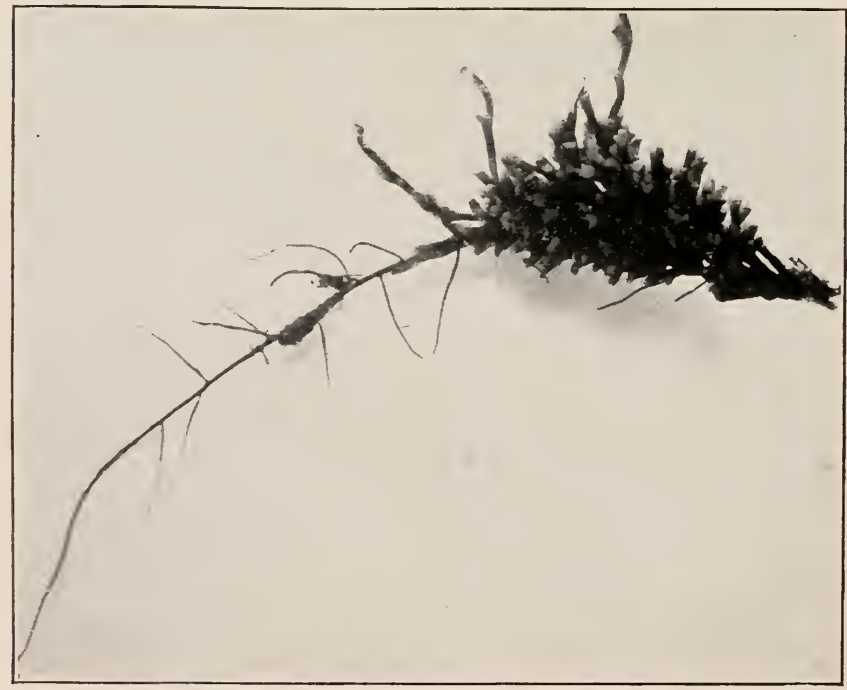

Fí. 130.- Plumatella pol!morpha, a fresh-water ectoproct, magnified 1.5 diams. Photo. of living animal by IV. H. C. P. 


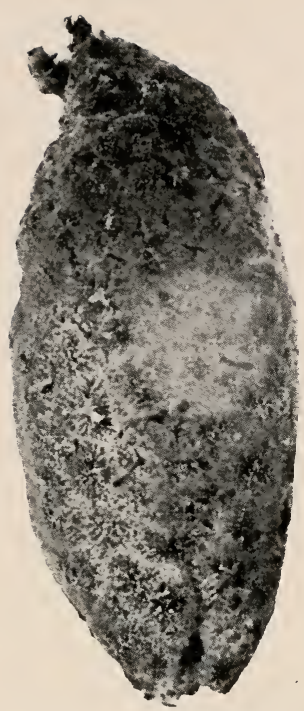

tinguished, the Endoprocta (Fig. 128 ), in which the individual consists of a long stalk and a "head" or body proper; and the Ectoprocta (Figs. 129-131), usually without such a stalk. The Ectoprocta are the prevailing type. The marine species form lace-like mats on seaweed or stand up as branching, bushy colonies (Fig. 129). Some of the fresh-water forms make loose, antlerlike colonies (Fig. 130), while others lie on the surface of a more or less spherical mass of jelly which they have themselves secreted (Fig. 131).

Fig.-131, - Pectinatella marnifica, a dense complex of colonies, growing upon a stick. Each star-shaped group represents a single colony. One-half nat. size. Photo. of living mass by W. H. C. P.

\section{APPENDIX TO CHAPTER IX}

KEY TO THE PRINCIPAL SPECIES OF EARTHWORMS OF THE

\section{UNITED STATES}

$a_{1}$. Clitellum begins on segment xiii or xiv; $\hat{\delta}$ pore on segment xviii or xix ; 2 gizzards in segments $\mathrm{v}$ and vi.

$b_{1}$. 2 dorsal vessels; lives in soil of prairies $\{$ Diplocardia

$b_{2}$. 1 dorsal vessel; lives in river-bottom land . D. riparia

$a_{2}$. Clitellum does not begin in front of segment xviii ; $\delta$ pore on segments xii and xiii, or (usually) xv. $b_{1}$. Prostomium incompletely divides buccal lobe [genus Allolobophora]. 
$c_{1}$. Tubercles on segments xxviii-xxxi; illsmelling; purple-banded . . .

A. foetida

$c_{2}$. Tubercles on segments, xxxi and xxxiii .

A. caligosa

$c_{3}$. Tubercles on segments xxvii, xxviii; color reddish brown. . . .

A. tumida

$c_{4}$. Tubercles on segments xxiv-xxx; about 100 segments . . . . .

$c_{5}$. Tubercles on segments xxviii-xxx . A. subrubicunda

$c_{6}$. Tubercles on segments $x x i x-x x x i$ (occasionally $\mathrm{xxix}, \mathrm{xxx})$; number of segments, 150 . . . . . . . A. rosea

b. Prostomium completely divides buccal lobe [genus Lumbricus].

$c_{1}$. Tubercles on segments xxviii-xxxi; redbrown or purple; about 120 segments.

$c_{2}$. Tubercles on segments xxxiii-xxxvi;

number of segments, 180 . . . L. herculeus

KEY TO THE PRIXCIPAL FAMILIE OF AQUATIC OLIGOCHETA

$u_{1}$. Dorsal blood-vessels visible only in the anterior part of the body; farther back, as intestinal sinus, disappearing underneath the intestinal

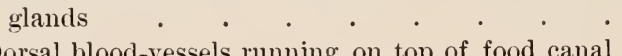

$a_{2}$. Dorsal blood-vessels ruming on top of food canal and visible throughout its entire length.

$b_{1}$. In each segment, except the first, contractile lateral blood-vessels . . . . . Lumbriculida

$b_{2}$. Lateral vessels contractile only in anterior segments.

$c_{1}$. Dorsal and ventral vessels united in each segment, except in the first 5 , by 2 lateral vessels . . . .

Enchytreidce

L. rubetlus 


\section{CHAPTER X}

\section{NEREIS AND ITS ALLIES}

Nerers ${ }^{1}$ is one of the commonest worms found on our seacoast. It occurs in sandy or muddy beaches, at or below low-water mark, especially where tidal currents flow swiftly. It inhabits burrows, which it makes in the sand and lines with a mucilaginous secretion to bind together the walls of sand or mud. At certain seasons of the year, during the breeding season, these worms may be found swimming near the surface of the sea.

Nereis lives on both plant and animal food. To capture its prey it thrusts out a long proboscis, provided with two powerful jaws. The thrusting out consists essentially of a rolling inside out, - just as the finger of a glove may be rolled inside out. When the proboscis is rolled in again, the jaws, retaining their grip on the food, carry it into the food canal. While many kinds of small animals serve Nereis as food, it is itself devoured by various fishes which dig it out of the sand or capture it when it swims free at night or during the breeding season. Such a favorite with fishes naturally makes excellent bait, and is well known to fishermen under the name "clam-worm " or "sand-ivorm."

Nereis is distinguished by the fact that its segments are numerous and nearly all alike, and bear appendages of similar form. The single pair of jaws on the proboscis is

1 Nipeis, daughter of Nereus, one of the Nereids, or sea-nymphs. 
characteristic; and the four eyes on top of the head, combined with two antennæ and two palps, serve to determine its family with precision. The parapodia have a dorsal and a ventral cirrus. The commonest species on the coast of New England and in Long Island Sound is Nereis virens, ${ }^{1}$ which grows to a length of thirty centimetres. Its color is dull green to bluish green, and iridescent. The gills on the parapodia are green at the head end, but farther back they become bright red, owing to the blood which flows through them. This species lives in northern seas, and is found on the coasts of Great Britain, Norway, Labrador, and south

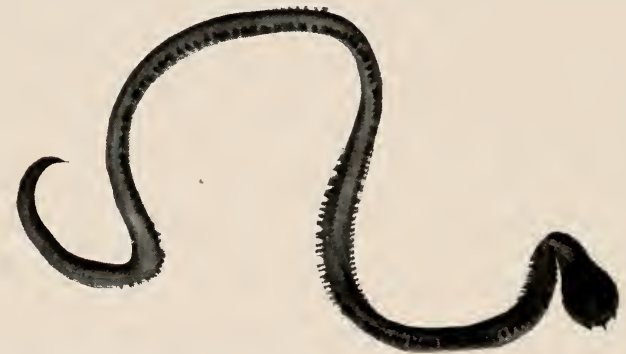

Fı, 132. - Euglycera. One-half natural size. Photo. by IV. H. C. P.

to Long Island Sound. South of Long Island Sound the commonest species is Nereis limbata, ${ }^{2}$ which grows to a length of, at most, only fifteen centimetres, and is of a dull brown or bronze color. This species is found as far south as South Carolina.

Often associated with Nereis in sandy beaches is a large, strong, flesh-colored worm, pointed at both ends, so that the head is not nearly as evident as in Nereis, and having small appendages, so that it looks smooth like an earthworm. This

1 Green.

${ }^{2}$ Bordered or edged. 
is Euglycera. ${ }^{1}$ Its proboscis has four jaws, situated at the corners of a square, instead of two as in Nereis. The pointed head and powerful writhing muscles enable the animal to burrow with great rapidity (Fig. 132).

A second kind, Autolytus, ${ }^{2}$ is a small animal which lives in little tubes attached to algæ or hydroids (Fig. 133). The parapodia at the anterior half of the animal are different from those at the posterior half, for the latter are large and fitted for swimming. Eventually one of the middle segments of the body becomes transformed into a head, with eyes and tentacles, then the whole of the hinder half breaks off spontaneously. The newly formed head is now the head end of the new individual. This individual leads a different kind of life from the half which remains in the tube, for it swims freely in the water. The separated individuals are either male or female, whereas the part which lives in the tube never produces eggs, but merely forms a new tail every time the old tail is cut off to form a sexual individual.

A third kind, Lepidonotus ${ }^{3}$ is characterized by the possession of

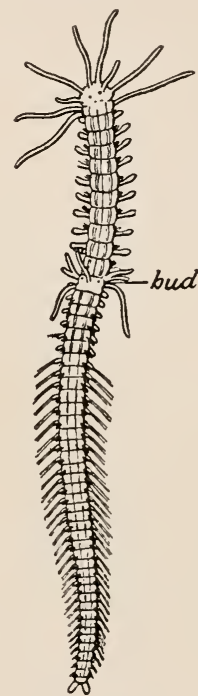

Fig. 133. - Autolytus, a representative of a family of Polychata in which the animal buds off male or female individuals from its hinder encl. bud, head of the buddedindividual. After A. Agassiz.

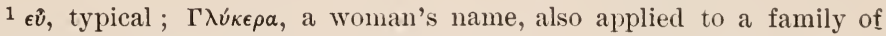
Polychæta. Euglycera means typical of the family Glyceridæ.

2 aúrós, self ; $\lambda u ́ \omega$, to separate; hence, self-separating.

${ }^{3} \lambda \epsilon \pi i s$, scale ; $\nu \hat{\omega} \tau o s$, back. 
a double row of scales covering over the back (Fig. 13t). These scales are outgrowths of the dorsal part of the parapodia, and serve for respiration. In allied genera the scales are covered with bristles, which may be so very long and abundant as to hide the scales. They produce a brilliant iridescence. One of these worms with the great bristles may be several inches long and relatively broad, and is commonly known as the "sea-mouse" (Fig. 135). Both Lepidonotus and the sea-mouse occur in out-of-theway places, - crevices of rocks at low tide

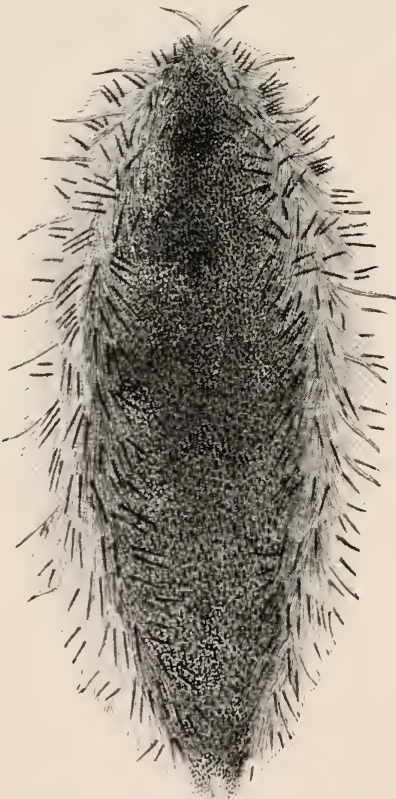

FIG. 135.- Aphrodite, a sea-mouse.

Nat. size. From Johnston. or fairly deep water, - so that they are not commonly seen at the seashore.

The sedentary Polychæta are mostly smaller and less familiar :mimals than the free-living Polychæta, but they have an interest for us in showing how greatly modified an organism becomes when it takes on a sedentary life. Its swimming appendages become rudimentary; its eyes are usually lacking: there is no protrusible proboscis armed with powerful jaws; the gills become grouped almost exclusively about the upper end of the body, where 
they can be thrust out of the tube: the mouth comes to lie at the bottom of a fumnel, which receives as food small particles floating in the water; even the segmentation of the body becomes lost at the hinder end of the animal; in a word, all those organs which are useful for active carnivo-

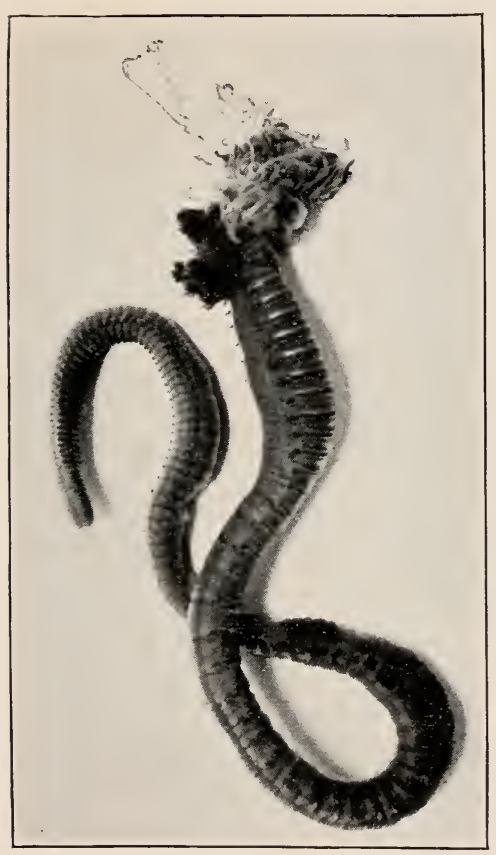

FI(i. 1:36. - Amphitrite, removed from its tube. Nat. size. Photo. by W. H. C. P. rous life have become reduced to the bare needs of a quiet herbivorous life.

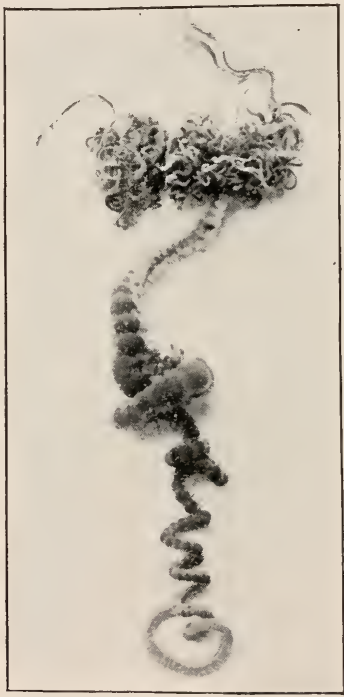

Fir. 137.- Polycirrus, the bloor spot. Nat. size. Photo. by IV. H. C.P.

The first of these sedentary worms that we have to consider is not completely modified from the type found in free-living species.

Cirratulus ${ }^{1}$ lives in tubes in mud or sand. It is yellow

1 From cirrus, curl, ringlet. 
or orange in color, and has long cirri, which, arising from nearly every segment, reach out in all directions. These function as gills, and when broken off may remain alive for days.

Clymenella, ${ }^{1}$ which looks like a reddish, jointed straw, builds tubes of agglutinated sand, and has a serrated, funnelshaped tail end. Its parapodia are very small (Fig. 139).

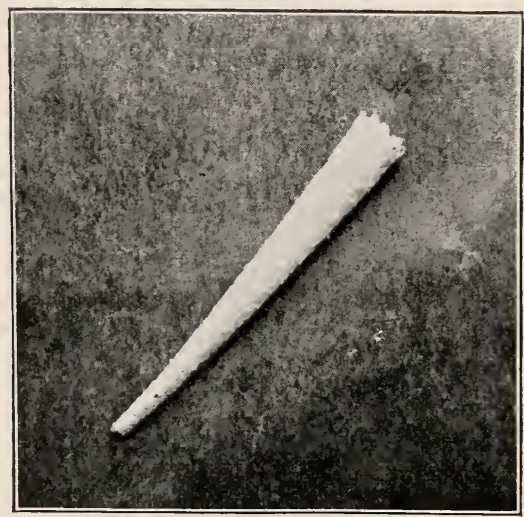

Fig. 138. - Tube of Cistenides. Nat. size. Photo. by W. H. C. P.

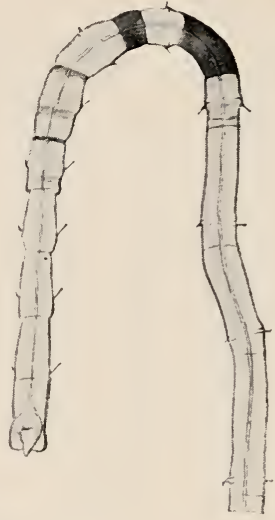

FIG.139.-Clymenella,strawworm. The anterior segments only are shown. After M. Lewis.

Amphitrite $^{2}$ (Fig. 136) builds firm tubes of sand. From the head spring numerous tentacles and three pairs of bloodred gill-tufts. The body is large anteriorly but becomes slender behind, where there are no bristles. Allied to Amphitrite are a large number of common worms found on our coast. Polycirrus, or the blood-spot (Fig. 137), is somewhat smaller than Amphitrite and characterized by a

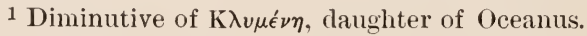

$2^{\prime}$ 'A $\mu ф \imath \rho i \tau \eta$, wife of Neptune, goddess of the sea. 
uniform crimson color and a large number of cirri massed at the head. The tubes made by some of the Terebelliclie are very beautiful. The tube of Cistenides (Fig. 138) is found in the sand under stones and is composed of grains of sand cemented together and regularly arranged so as to form a firm wall.

Finally, Serpula ${ }^{1}$ secretes crooked, round calcareous tubes, which may be found adhering to stones near low water (Fig. 140). From the mouth of the tube the hearl, with its tentacles, may be protruded, but it quickly retracts from danger and closes the opening of the tube as a marine snail does its shell, by means of an operculum or lid.

Some worms have gained a parasitic habit, and in con-

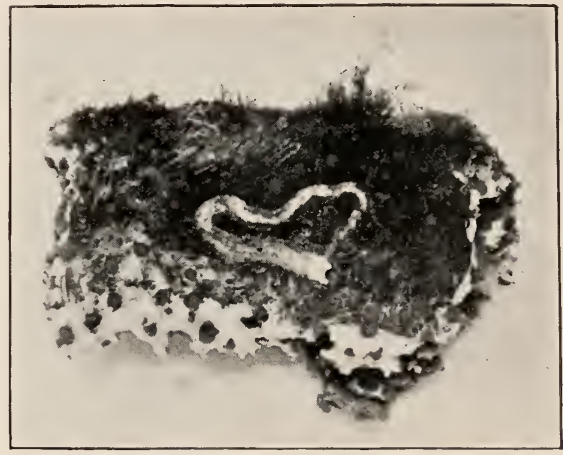

Fig. 140. - Serpula tube on a bit of oyster shell that is perforated by the boring sponge. The tube lies in the centre of the figure. Nat. size. Photo. by W. H. C. P.

sequence have become much modified in form and structure. Such is the case with some of the roundworms. Some of these are thread-like. live in springs or pools, and are regarded by the uninitiated as animated horse-hairs. Others are spindle-shaped, as for example the "vinegar eel" and the round-worms that are common in stagnant water. Others live in the food canal, as for example the stomach worm (Ascaris) of the horse and the

1 Diminutive of serpens, serpent. 


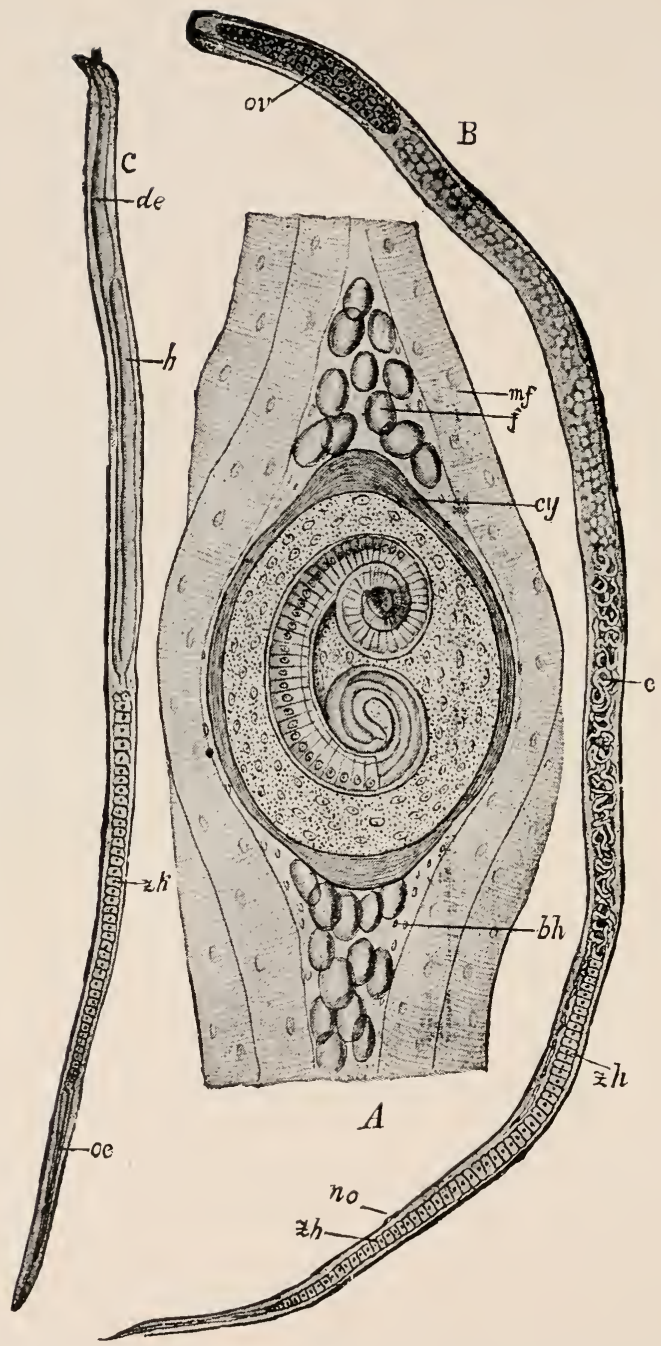

Fig. 141. - Trichina. $A$, encysted form in muscle of pork; $B$, female; $C$, male ; bh, envelope of cyst; $c y$, eyst; de, male duct; $e$, embryos ; $f$, fat globules; $h$, testis; $m f$, muscle fibre; oe, pharynx; $\omega v$, ovary ; no, opening to egg duct; $z h$, cell masses in intestines. After Claus. 
pin-worm of man. (Others still penetrate into the muscles, and cause great pain and often death. Such is the pork-worm, Trichina, ${ }^{1}$ which gets into man through uncooked pork, multiplies in the food canal, migrates in great numbers into the muscles and encysts itself there (Fig. 141).

Another groul, which is largely parasitic is that of the flatworms. Some flatworms live free in ponds. They will be found abundantly among plants taken from small ponds in the summer and autumn, and are commonly known as Planaria ${ }^{2}$ (Fig. 142). They may be recognized not only by their flattened form, but also by a curious proboseis which protrudes from the middle of the under side of the borly and bears a mouth at its tip. 'These creatures have a marvellous power of regeneration, so that every piece into which a worm is cut will reproduce an entire one (Fig. 143). If the worm

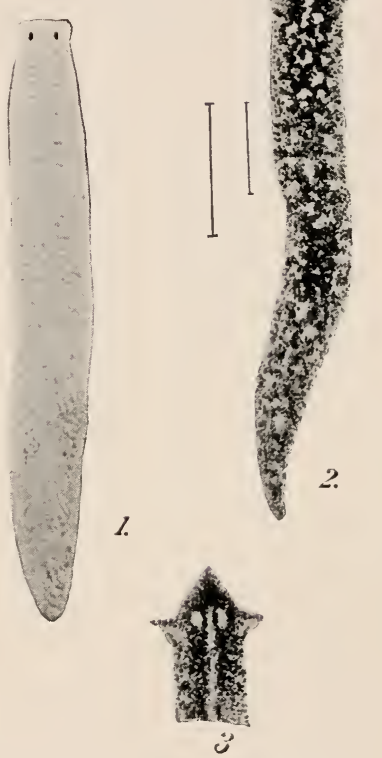

FIG. 142. - Species of fresh-water Planaria. 1, Dendrocoelum lacteum, cream color; 2, Planaria maculata; 3 , head end of same to show light streak. After Woodworth. is mutilated but not wholly eut in two, bizarre forms may result by a modified tendency to regenerate (Fig. 144).

Other flatworms are parasitic, such as the liver-fluke of the sheep (Fig. 145). This destructive parasite has a 
complicated series of stages to go through before it becomes adult. Thus the flukes in the liver of the sheep produce eggs which develop into embryos. These embryos get out of the liver into the food canal, and thence
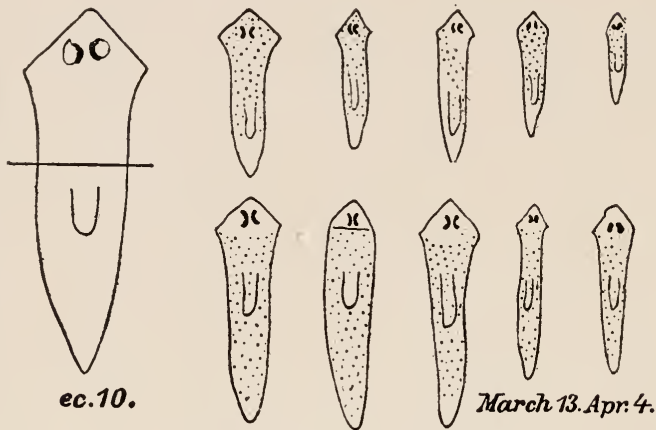

Jan.25. Feb.5. Feb.17

Dec.10.
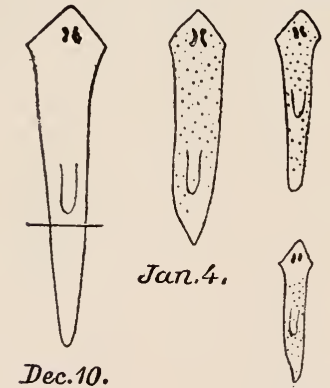

Jan.2.5.
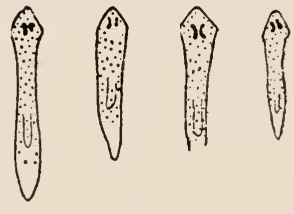

FIG. 143. - Showing results of cutting Planarians into two pieces; the pieces develop into entire animals. After Morgan.

to the exterior. If they are depositer near a pool of water, they may develop further, otherwise they must die. In the water a ciliated larva ${ }^{1}$ hatches from each egg, swims about for a time until it finds a fresh-water snail, bores into it, and encysts itself there. In this 
encysted stage the worm is known as a "sporocyst," because it is full of germs (spores) of a new generation. ${ }^{1}$ The spores develop in the snail into curious organisms, a sort of secondary larva known as redia. ${ }^{2}$ The redise may produce, by a kind of internal budding, new redix, and so on re. peatedly, until at last, on the death of the snail, or from some other cause, the last generation of relia produces liver-flukes. ${ }^{3}$ 'The
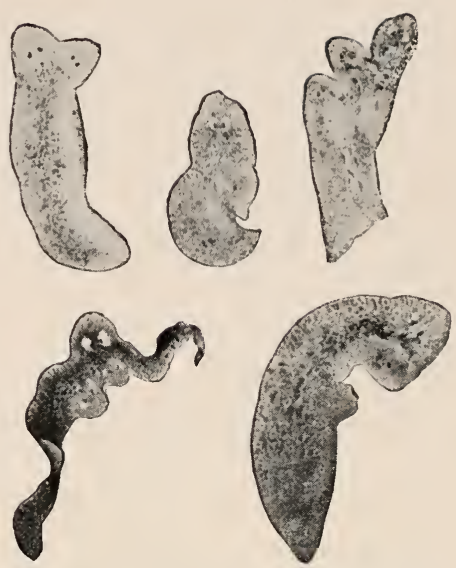

Fig. 14t. - Showing abiomal forms resulting from mutilation of Planarians. After Van Iluyne. young liver-flukes wriggle out of the snail, attach themselves to damp grass, lose their tails, and encyst them-

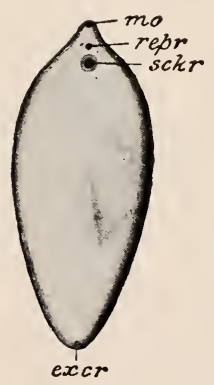

FIG. 145. - Distomum, the liver-fluke. Nat. size. Excr., excretory pore; mo., mouth; repr., reproductive aperture; sckr., posterior sucker. From Parker and Haswell. selves. If these cysts be eaten by a sheep, they develop in the sheep's body into an adult liver-fluke (Fig. 145). Thus the stages which we can recognize in the liver-fluke are:-

First generation: egg from liver-fluke, larva, and adult sporocyst.

Second generation: redia (this may be several times repeated).

Third generation: "cercaria" larva, encysted larva, and adult liver-fluke.

1 Fig. 146, B.

2 Fig. 146, $C$.

3 These, while young, have tails, and are called "cercaria." 
Another flat worm is such an abject parasite that it has lost most of the organs usually possessed by worms. This is the tapeworm (Fig. 147). When the eggs of the tapewor'm are taken into the body of an herbivorous animal, the embryos develop there for a way and then stop. When flesh containing these embryos is eaten by a carnivorous
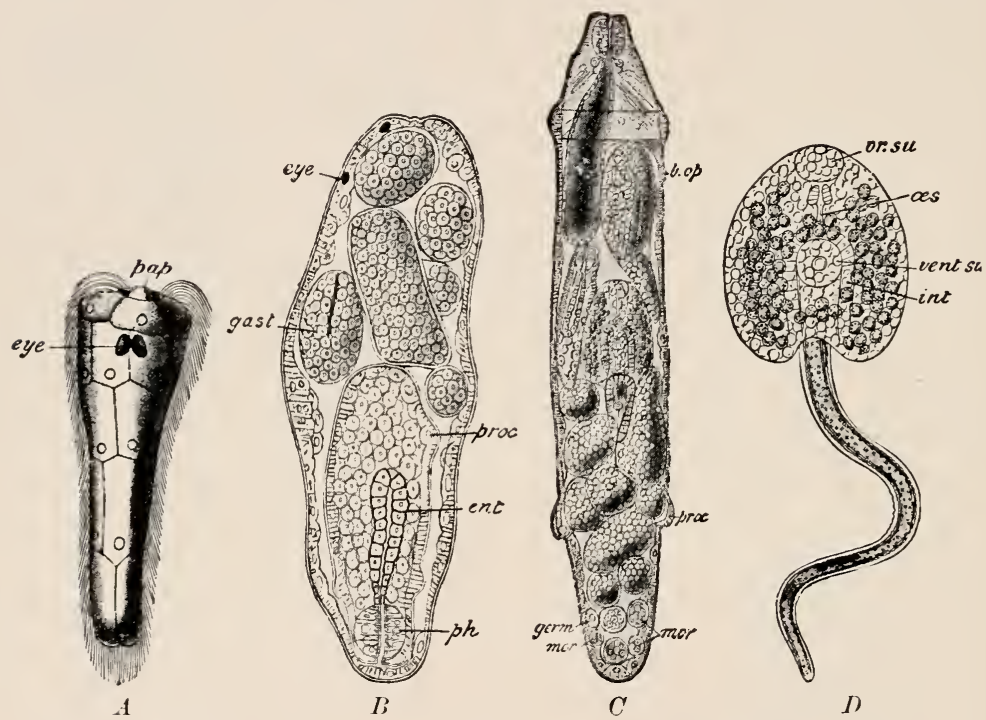

FIG. 146. - Development of Distomum. A, ciliated larva : $B$. sporocyst eontaining developing redix; $C$, redia, containing a daughter redia and embryo liver-flukes; $D$, free-swimming, tailed larva of liver-fluke;- $b$. op, birth opening; ent, food canal of redia; eye, eyespots; gast, young redia; germ, mor, early stages in formation of the embryo liver-fluke; int, intestine of larval liver-fluke; $\iota s$, osophagus; or. su, oral sucker; pap, head papilla of ciliated larva, $1 ; p h$, pharynx; proc, processes of redia; vent. su, ventral sucker. After Thomas.

animai, the embryos attach themselves to the food canal of their host and form, by rapid growth, a long chain of segments, each of which is full of germs. The chain, or 


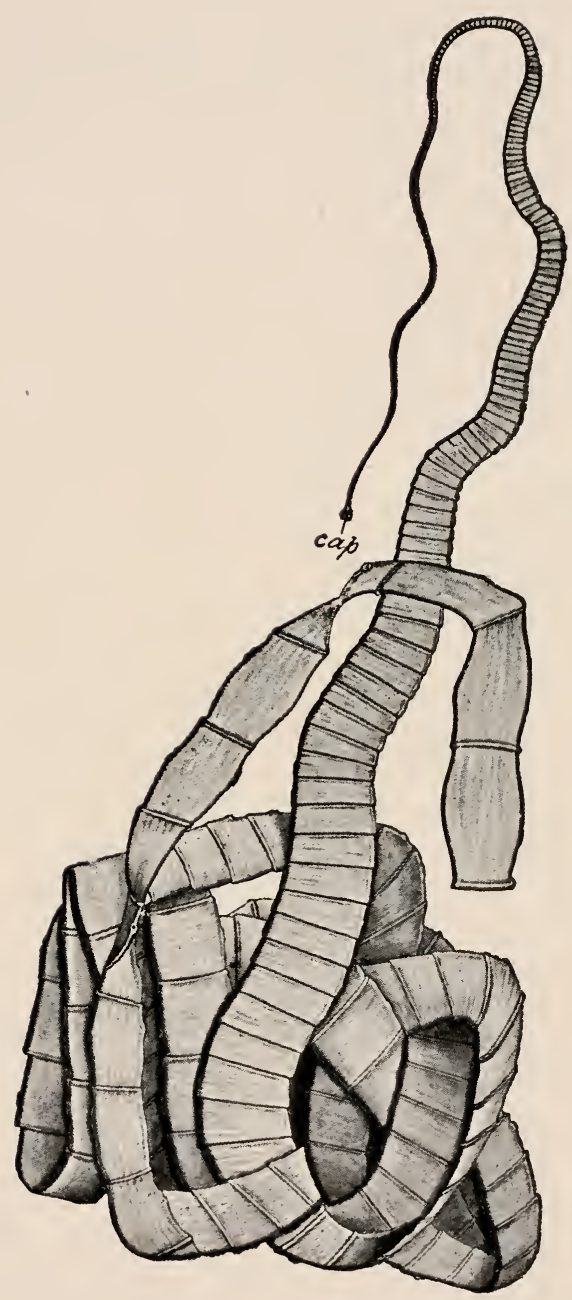

FIG. 147.-Tænia solium, the human tapeworm. Entire specimen, about natural size. Cap, head. After Leuckart. 
"tape," absorbs fluid food, which soaks through its body wall. As the segments at the older end of the animal mature, they are set free and pass out of the alimentary tract, to be picked up, perchance, in the food of an herbivorous animal or else to perish.

The economic importance of parasitic worms is very great. Thus, although no great epidemics of the flukes

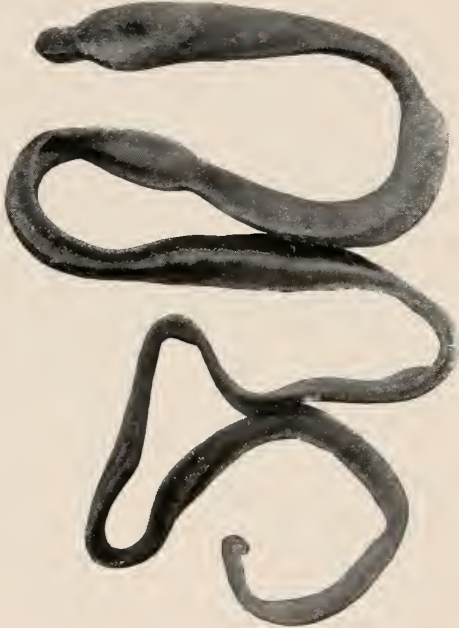

FIG. 148.-Cerebratulus, a cream-colored nemertean. Head end at upper part of figure; mouth turned toward observer, proboscis retracted. Instantaneous photograph of living worm by W.H.C.P.

have occurred in this comntry, a million sheep are annually lost by this parasite in Great Britain ; and in 1879 and 1880 it was estimated that three million sheep died annually in England alone of this parasite. In Buenos Ayres, during 1882, a million sheep died of fluke disease. By great care in preventing infection, especially during damp seasons, we may be able to prevent any such disaster in this country.

The group of Nemertini is allied to the flatworms. It includes chiefly marine animals, of somewhat flattened form and great length, even as great as thirty metres. They protrude a long, slender proboscis. These worms are especially abundant in the sand of the seashore, although land nemerteans occur. Cerebratulus (Fig. 148) is a common form from the east coast. 


\section{APPENDIX TO CHAPTER $\mathrm{X}$}

\section{KEY TO THE MORE IMPORTANT FAMILIES OF POLYCHATA}

$a_{1}$. Head distinct from trunk; proboscis protrusible [wandering Polychreta].

$\mathrm{b}_{1}$. With broad dorsal scales . . . . Aphroditide

$b_{2}$. No scales; only one mouth-segment.

(Ex. Lepidonotus)

$c_{1}$. Cirri not leaf-like; body long and not flattened.

$d_{1}$. Head not segmented.

$e_{1}$. Jaws composed of many pieces .

Eunicidte

$e_{2}$. Two powerful jaws. . .

Vereiclue

(Ex. Nereis)

$d_{2}$. Head with its lobes segmented . .

Gilycerida

(Ex. Euglycer:a)

$c_{2}$. Small worms, body flattened, cirri evident

Sigllidice

(Ex. Autolytus)

$a_{2}$. Head not distinctly separated from trunk; pro-

boscis short, not protrusible; no jaws [sedentary Polychæta].

$b_{1}$. Gills, when present, arise either from almost all, or else the middle segments.

$c_{1}$. Body not separated into various regions; distinct head; no antennæ; gills in form of elongated, thread-like cirri

Cirratulide

(Ex. Cirratulus)

$c_{2}$. Body divided into 2 or 3 different regions; no antennal cirri; proboscis present; no gills . . . . . . .

$b_{2}$. Gills almost always present and limited to the Maldanide (Ex. Clywenella) anterior end of the body; no cirri ; body divided into an anterior and a posterior part. $c_{1}$. Gills confined to the anterior segments; head lobe small; numerous antennæ in 2 bunches; no antemal cirri . .

$c_{2}$. Gills confined to head; 2 inrolled leaves Terebellidae (Ex. Amphitrite) standing at the sides of the mouth . Serpulicla 


\section{CHAP'TER XI}

\section{THE SLUG AND ITS ALLIES}

THE slug belongs to the group of Mollusca. ${ }^{1}$ This group contains animals which possess two distinctive organs - the foot, by means of which locomotion is effected, and the mantle, a fold of skin covering over or enclosing a greater or less part of the body. The mantle usually secretes on its outer surface a calcareous shell. Exceptionally, both shell and mantle may be entirely absent in the adult.

Among the Mollusca, the slug occupies the class Gastropoda ${ }^{2}$ characterized by the possession of a hearl, which bears feelers and eyes, and an umpaired font, situated on the ventral surface of the body and used to crawl upon. ${ }^{3}$ Gastroporls are either with or without an external shell. When the shell is present, it is made of one piece, that is, it is univalve. ${ }^{4}$

1 mollis, soft.

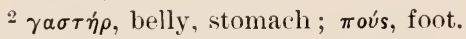

${ }^{3} \mathrm{~A}$ key to the principal families of gastropod shells of the Atlantic coast of the United States is given in the Appendix, p. 174.

${ }^{4}$ The three orders of Gastropoda may be distinguished by aid of the following key :-

$a_{1}$. Breathing by means of lungs; no operculum ;

living on land and in fresh water. . .

Putmonata

$a_{2}$. Breathing by gills; chiefly marine. 
Slugs belong to the group of air-breathing, land-inhabiting gastropods, or Pulmonata. ${ }^{1}$ They may be found in the spring, summer, and autumn, under wet, decaying pieces of wood, under stones or fruit, in the grass, on the shady side of fences; in a word, in moist, dark situations. They especially shun sand, ashes, and sawdust, because these substances tend to dry up the mucus which they secrete over their body to retain its internal fluids. Slugs are nocturnal (Fig. 122), hence they have the reputation of being rather rare. During the winter they live in the ground encased in their own slime, but some species frequent greenhouses in cold weather, and in consequence of this habit may remain active all the year round.

The food of slugs consists chiefly of the green leaves of succulent plants, and also of ripe fruit, such as apples. ()ur largest slug, Limu, maximus, ${ }^{3}$ is easily maintained

$b_{1}$. Gills in front of heart; mantle-complex on anterior side of intestinal sac; operculum constantly present . . . . .

Prosobranchiatu

$b_{2 .}$. Gills behind heart; if shelled, without operculum

Opisthohranchiate

Key to the principal families of the American Pulmonata :-

$a_{1}$. Eyes at apex of (usually retractile) tentacles.

$b_{1}$. With external shell; 4 tentacles .

Helicidce (Ex. IIelix)

$b_{2}$. Without external shell.

Limacida

(Ex, Limax)

$a_{2}$. Eyes on inner side or at base of the (nonretractile) tentacles.

$b_{1}$. Thick shell, with thick, often-toothed outer edge

Auriculide

$b_{2}$. Thin shell, with sharp margin . .

(Ex. Melampus)

Limnceidae

(Ex. Physa)

1 Provided with lungs; from pulmo, lung.

${ }^{2} \lambda \epsilon i \mu a \xi$, naked snail.

${ }^{3}$ Largest. 
in captivity by keeping in a lark box and feeding on the blanched leaves of cabbage. In captivity one individual will sometimes devour another.

Of our three principal species of slugs there may be first mentioned Limax maximus, which gains a length of about 10 centimetres and has a light brown color, marked with longitudinal rows of black spots along the back and sides.

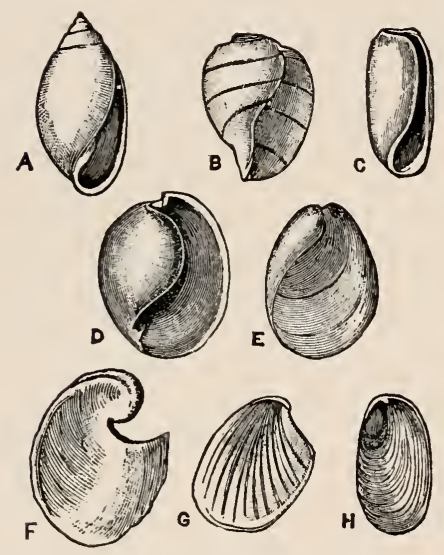

FIG. 149. - Illustrating the transition of form in the shell of certain Opisthobranchs, from the pointed spiral to the almost flat plate. The genera figured are: $A$, Actreon; $B$, Aplustrum; C', Cylichna ; D, Atys; $E$, Philine; $F$, Dolabella ; $G$, Aplysia ; II, Pleurobranchus. Drawn to various scales. From Cooke, "Mollusea." This species was almost unknown in this country until the middle of the sixties, but it is now widespread throughout the East. It has doubtless been introduced from the continent of Europe, where it is very abundant. Second, Limax agrestis ${ }^{1}$ is usually about 2.5 centimetres long; it varies in color from whitish through gray to black. It is now common in the eastern United States, but is believed to have been introduced from Europe. Third, Limax campestris, ${ }^{2}$ a native species, is smaller than agrestis, and its tuberosities are not so much flattened or plate-like. It occurs widely distributed east of the Rocky Mountains.

Economically, slugs are of importance because at times in some localities they cause much destruction in gardens

${ }^{1}$ Living in the field. 2 Living in open fields. 
and greenhouses. Particularly in Europe, Limax agrestis has often devastated fields of young shoots; this species is especially fond of bulbous plants.

In the apparent absence of a shell the slug seems to be an aberrant gastropod. Other land gastropods-the snails - have an evident shell. In Limax the shell is reduced to a thin, horny plate, embedded in the mantle. Between the condition seen in the snail and that in Limax there are intermediate conditions, in which the large shell is partly covered by the mantle, and others in which the shell has become reduced in size. In allies of Limax - in a genus called Arionthe shell is reduced to a few calcareous grains. An exactly similar series

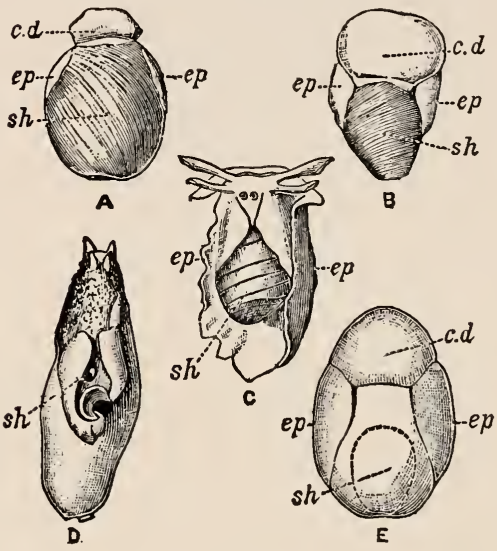

Fig. $149 a$. - Illustrating the gradual covering of the shell $(s h)$ in certain Opisthobranchs by the epipodia (ep) and mantle; $c . d$, ceplalie dise. Drawn to various seales. $A$, Haminea; $B$, seaphander ; $C$, Aplustrum ; D, Aphysia ; E, Philine. From Cooke, "Mollusca." in the degeneration of the shell is found in certain Opisthobranchs, illustrated in Fig. 149. The beginnings of this process of covering the shell are seen in many gastropods in which the mantle edges may protrude beyond the lips of the aperture, and are folded back over the outer surface of the shell. A more developed condition is seen in species like Aplysia, in which the mantle is permanently reflected. ${ }^{1}$ In Limax the reflected edges of the mantle

1 Fig. $149 a$. 
have permanently grown together. The reflection of the mantle seems to be of arlvantage by affording additional

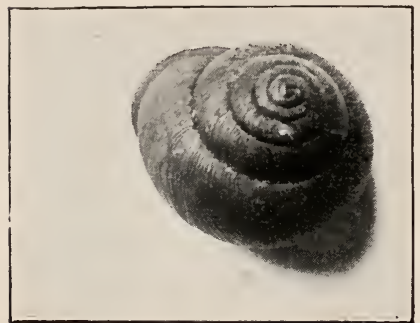

Fia. 150. - Shell of Helix albolabris, a common forest snail. Nat. size. Photo. by W. H. C. P. protection to the visceral mass. But after the complete overgrowth of the mantle the shell seems to be useless, and consequently degenerates.

The Pulmonata are either terrestrial, like the slug, or aquatic. Of the terrestrial pulmonates other than the slug the most important are the snails of the genus Helix. ${ }^{1}$ Helix ${ }^{2}$ is noteworthy, because it is richer in species than any other molluscan genus, since it contains over three thousand species. The distribution of the genus is worldwide. In North America the snails are most abundant in limestone regions, consequently they are more numerous in individuals in the South and West than in granitic New England. One of the most interesting species is Helix nemoralis, a European form, which has been introduced into our country at Burlington, New Jersey, and Lexington, Virginia. At these places it has multiplied so rapidly, and varied to such a degree, that three hundred and eighty-five varieties have been enumerated from an area, at Lexington, not over one thousand feet in extent in its greatest diameter ${ }^{3}$ (Fig. 151). Any species of Helix collected in large numbers is apt to show abnormalities in the number of tentacles and of eyes upon the

$1 \stackrel{\xi}{\epsilon} \lambda \xi \xi$, a turning round, as in spire of snail shell. 2 Fig. 150.

3 See paper by Professor J. L. Howe, in American Naturalist, December, 1898. 
tentacles. Besides Helix, a very abundant cosmopolitan land pulmonate is Pupa." Being of small size, it is, how-

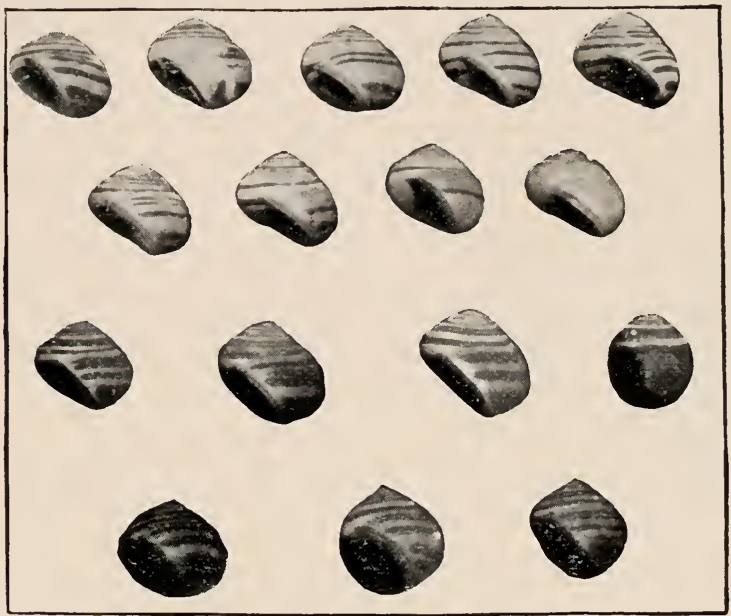

FIt. 151. - Melix umoralis, from Lexington, Va., collected by Professor J. I. Howe, showing variation in stripes. Upper line, first figure, normal form, 5 stripes; other figures of first and second lines show reduction of stripes ; third line shows broader (and fewer) stripes (the last figure is very dark and is poorly reproduced). The shells in the lowest line show more than five stripes. From a photograph; reduced one-half.

ever, less commonly known. It is found in woods under leaves or in old stumps and decaying logs, where it feeds. The shell is many times whorled, and has a blunt apex.

Intermediate between the terrestrial and aquatic pulmonates is the family Auriculiclie, the members of which live on the seashore, in salt marshes or on rocks where they may even be immersed in brackish water

1 A little girl or doll.

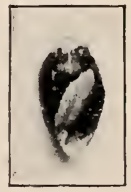

FIG. 152. - Nelampus, the saltmarsh suail. Nat. size. Photo. by W.H.C.P. 
at high tides. One of the commonest forms is Melampus (Fig. 152), found among the roots of marsh grass.

Of the aquatic pulmonates three genera are common and easily distinguishable. Limnæa, ${ }^{1}$ the "pond snail," is common in ditches and muddy or stagnant ponds. Its shell runs up into a sharp spire, and is right-handed, i.e. hold-

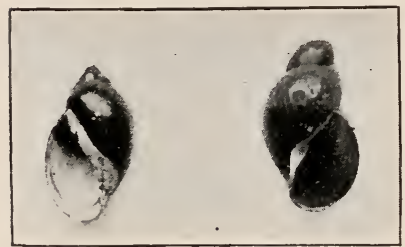

FIG. 153. - Left, Physa heterostropha, the left-handed pond snail. Right, Limnsea, the righthanded pond snail, with the apex eroded off as is usually the case in adult shells. Nat. size. Photo. by W. H.C.P. ing the shell so that its aperture is next the olsserver and below, the aperture is at the right (Fig. 153). Limnaa crawls over the bottom, up the stalks of aquatic plants, and on the surface film of water. During drought it burrows into the mud, and closes the aperture of the shell.

Physa $^{2}$ has a smaller, relatively stouter shell than I imnxea, and one whose coil is left-handed (Fig. 15.3). It lives in even the smaller ponds and brooks, and may be easily reared in aquaria. It feeds freely upon any kind of vegetable matter. Physa heterostropha is the common species of the United States (Fig. 153, left).

Planorbis ${ }^{3}$ is coiled in one plane like a watch spring. 4 It lives in a similar habitat with Physa. A great many species are distinguished which vary considerably in size. Snails of this genus

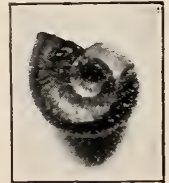

Fig. 154.- Planorbis, the tlat-coiled pond snail. Nat. size. Photo. by W.H.C.P. likewise are easily kept in the aquarium, and lay numerous

1 From $\lambda i \mu \nu \eta$, a marsh.

$2 \phi \hat{v} \sigma a$, bellows.
${ }^{3}$ plamus, flat; orbis, circle.

4 Fig. 154. 
eggs encased in gelatinous envelopes adhering to the glass.

Of the shells of marine gastropods, which are favorite objects in collections because of their beauty and permanence, only a few types can be mentioned.

Littorina ${ }^{1}$ is an example of the entire-mouthed prosobranchs. The commonest form at most parts of the shoreline north of New York at the present time is Littorina ${ }^{2}$ littorea. ${ }^{2}$ This is known in England as the periwinkle, and is there used as food. As its systematic name implies, it occurs on the seashore, which it often crowds so as to force all other species from it. It occurs north to Greenland, and on the northwestern European coast. It has not always Fic. 155.-Littorinu litoccupied our shores, but has been migrating southward. In 185.5 Lit-

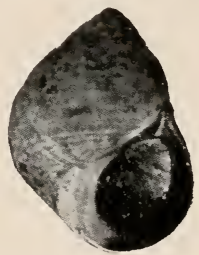
tored, the shore snail. Nat. size. Photo. by W. H. C. P. torina was found in the Gulf of St. Lawrence; in 1869 it was stated to occur in Halifax; in 1870 a few individuals were found on the Maine coast; during 1871 the species occurred on the New Hampshire coast; in 1872 one specimen was found at Salem, Massachusetts; in 1875 the first two specimens were taken at IVoods Hole, Massachusetts, south of Cape Cod; in 1880 the first specimen was taken at New Haven; in 1891 it occurred as far south as Delaware Bay. Yet at the present time it is not very abundant at Cold Spring Harbor, near the western end of Long Island Sound. Persons who live on the coast south of Cape Cod would do well to note carefully the abundance of the species on their part of the

1 Fig. 155.

2 From littus, the seashore, 
shore-line. Besides littorea there are two species of Littorina which were on our coast when records first began to be made. The species may be distinguished by the circumstances that $L$. littorea has a black head and a heavy shell of brown or olive color. $L$. rudis ${ }^{1}$ is smaller, has an angle at the apex of $60^{\circ}$ to $70^{\circ}$, and its shell varies in color from white to red. L. palliata ${ }^{2}$ has an apical angle of $95^{\circ}$, and a shell varying from white to orange, slate, or brown.

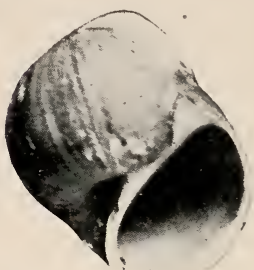

F16. 156. - Natica (Lunatia) heros. Two-thirds 11at. size. Photo. by IV. H. C. P.

Natica is another common species with an entire mouth. It can be at once distinguisherl from Littorina by the

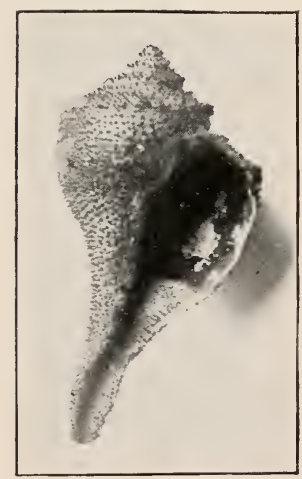

FIt. 157. - Shell of Fulgur (Sycotypus) caniculatus, one of the Fas i o la ridæ. Onefourth nat, size. Photo. by W. H. C. P.

1 Rough, rude. "umbilicus," or depression situated at the left of the mouth and in the axis of the shell (Fig. 156). In the living animal the shell is often quite enveloped by the large fleshy foot. The members of this genus lay their eggs in spiral "collars" made of agglutinated sand. These are common objects of the seashore.

Fulgur ${ }^{3}$ is a good example of a prosobranch having a canaliculated shell. The canal exists for the purpose of containing the siphon by which water is brought to the animal as it lies buried in the sand. Fulgur is our largest common gastroporl. Its ${ }^{2} \mathrm{~A}$ cloak.

${ }^{3}$ Lightning. 
shell is about 150 millimetres long, and pear-shaped. In one species the margins of the whorls are grooved (Fig. $157)$; in the other they are carried out into thorns. The egg-cases are tough and membranaceous and resemble rows of coin strung on a string, the whole being slightly coiled.

In Urosalpin $x^{1}$ the canal is short (Fig. 158). This typical representative of the Muricidie is everywhere abundant on our Eastern coast. It is much hated by oystermen, by whom it is known as the "oyster drill." It bores through the shell of this and other bivalves by means of its radula and sucks out the contents through the hole.

Crepidula, ${ }^{2}$ the boat shell or "decker," represents a type in which the spire has become almost obsolete. It is

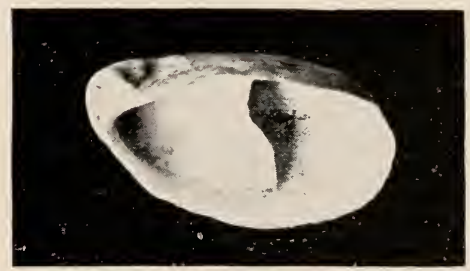

Fig. 159. - Crepidula, the boat shell. Two-thirds nat. size. Photo. ly IV. H. C. P.

still represented, however, in a rudimentary way at the left of the aperture (Fig. 159). The modified shape is associated with the habit the mollusk has of lying, aperture down-
1 oủpá, tail ; $\sigma a ́ \lambda \pi \iota \gamma \xi \xi$, a trumpet.
2 A small sandal (rrepid $\iota)$. 
ward, close to the rock or another shell. By this means the animal is better protected. "The "deck" is a plate

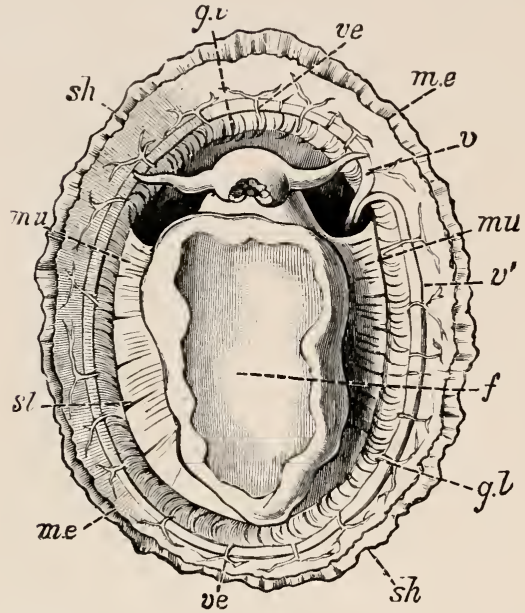

Fig. 160. - Patella vulgata, seen from the ventral side. $f$, foot; $g . l$, circlet of gill lamellæ; m.e, edge of the mantle; mu, attachment muscle; $s l$, slits in the attachment muscle; sh, shell; $v$, efferent branchial ressel ; $v^{\prime}$, aorta; ve, smaller vessels. From the "Cambridge Natural History." which has been developed internally to help hold the animal in the shell.

The limpets are modified prosobranchs. They are bilaterally symmetrical, and are covered by a flat, conical shell, which is applied closely to the rock all around the base in such a way as to protect the animal within. In some species (genus Fissurella ${ }^{1}$ ) there is an opening at the apex of the shell through which the water is expelled which has passed over the gills. Our common Eastern rock limpet is not perforated; it is known as Acmcea. ${ }^{2}$ In Europe, limpets (Patella, Fig. 160) are used as food; but on our Eastern coast they are too rare for this.

The opisthobranch mollusks include a large proportion of symmetrical shell-less species. The most familiar of these are the nudibranchs. 'They may be found among hydroids hanging from rocks, or in tide-pools. Our species are usually less than 20 millimetres long. They are often

1 A little slit or fissure. $2 \dot{a} \kappa \mu a \hat{\imath}$ s, in full bloom, maturity. 
covered with numerous gills, which give them a velvety aspect. When placed in an aquarium, they lay eggs in gelatinous coils on the hydroid stems. Eolis ${ }^{1}$ is a common genus (Fig. 161).

Besides the gastropods, two groups of mollusks may be briefly mentioned here. In one group the body is very

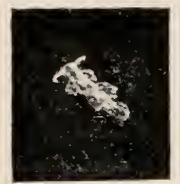

FIG. 161. - Eolis (Cratina), a nudibranch. Nat. size. Photo. of living animal by $\mathrm{W}$. $\mathrm{H}$. C. P.

symmetrical, not only extermally, but also internally, which is not true of most symmetrical gastropods. A common representative is $\mathrm{Chi}$ $\operatorname{ton}^{2}$ (Fig. 162). This animal has a sort of

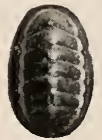

FIG. 162. - Chiton (Trachydermon) apiculatus, the armadillo snail. Nat. size. Photo. by W. H. C. P.

coat of mail, since its shell is made up of eight pieces, lying one behind the other, along its back. When removed from the rock or shell on which it rests, it coils up like a pill-bug or armadillo.

Coörlinate with the Gastropoda is the group of Cephalopoda. ${ }^{3}$ In this group belong the squids and cuttlefishes. They have a large, distinct head, a circle of arms about the mouth, a funnel-shaped foot, and huge eyes on each side of the head (Fig. 163). The squids are the best-known cephalopods, since they travel in schools in our harbors and are often cast upon the shore after a storm. 'They can also be obtained in the markets of our coastwise cities, since their flesh is used to a certain extent as food. Cuttlefishes,

1 Eolis, daughter of Eolus, the god of the winds.

${ }^{2} \chi \iota \tau \dot{\omega} \nu$, coat, case, covering.

${ }_{\kappa} \kappa \phi a \lambda \dot{\eta}$, head ; $\pi$ oús, foot; because the arms or foot are placed around the mouth. 
best known from their "bones" or rudimentary shells embedcled in the mantle, are inhabitants of deeper

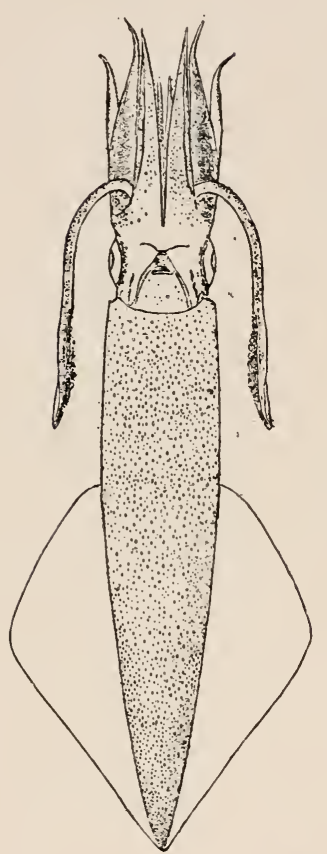

FIG. 163. - Loligo Pealii, eastern squirl. One-third nat. size. From Rathbun. waters. 'They have shorter bodies than the squids, and their arms are eight in number instead of ten as in the case of the squids. In both groups locomotion is effected by the reaction to a stream of water which is taken into the mantle chamber at the edges of the mantle and is forced out through the "fumnel," which lies between the eyes in Fig. 163.

'The shell is rudimentary in both the squids and the cuttlefishes, and like that of the slug is emberded in the mantle. Even in Spirula the shell, though coiled and containing a siphon, is completely covered by the skin of the animal. 'There are two living genera of Cephalopoda which have an external shell. One is an ally of the cuttlefishes - the paper nautilus or Argonauta, ${ }^{1}$ which is found in all tropical seas. 'The other is the sole survivor of a once abundant group. 'This is the Pearly Nautilus of the Indian and Pacific oceans. Its shell is divided into water-tight compartments, in the last formed of which the animal lies. It keeps its attachment to the shell by means of a central strand of tissue - the siphon (Fig. 16t, s). Allierl to the Nautilus is the huge 
family of Ammonites, of which two thousand species are known, ranging from the Silurian up to the Cretaceous formations.

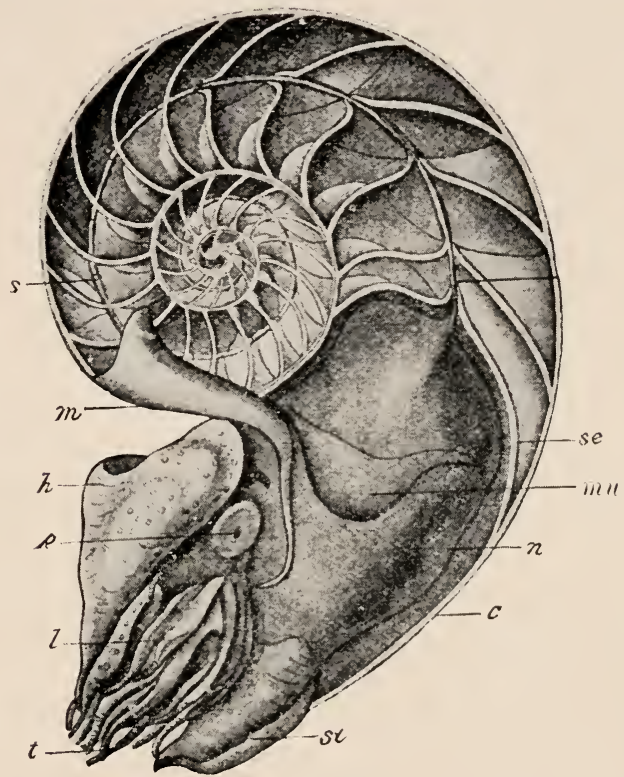

Fig. 164. - Nautilus pompilius, the Pearly Nautilus. Median section. $c$, outermost chamber whose bottom is formed by the septum, se; $s$, siphon traversing all compartments; $\rho$, eye: $h$, hood; $m$, part of mantle, reflected over the shell; $l$, lobes enclosing tentacles $(t) ; s i$, incomplete funnel; $m u$, shell muscle; $n$, gland secreting the capsules for eggs. After Owen. 


\section{APPENDIX TO CHAPTER XI}

KEY TO THE PRINCIPAL FAMILIES OF MARINE-SHELLED GASTROPODS OF THE ATLANTIC COAST OF THE UNITED STATES, ADAPTED FROM A. C. APGAR

$a_{1}$. Shell spiral, of one to many whorls.

$b_{1}$. Spire in a single plane, and whorls not in contact. [A cephalopod shell; liable to be mistaken for a gastropod-shell, page 172]

$b_{2}$. Spire dextral.

$c_{1}$. Operculated; aperture not over $\frac{1}{2}$ area of sliell.

$d_{1}$. Anterior margin of aperture entire.

$e_{1}$. Shell tubular; spiral at apex, irregularly twisted near aperture

$e_{2}$. Shell regularly spiral, elongated; width less than $\frac{1}{2}$ length; whorls 5 or more; angle of spire less than $45^{\circ}$; aperture less than $\frac{1}{2}$ length of shell.

$f_{1}$. Whorls rounded, almost separated, crossed by elevated longitudinal ribs ; aperture oval; lip continuous; our species over $10 \mathrm{~mm}$. long . Spiruliale

Vermetide

Scalariate

$f_{2}$. Whorls about 5 ; minute shell, less than $5 \mathrm{~mm}$. long; width about $\frac{1}{2}$ length; aperture about $\frac{1}{3}$ length ; apex blunt $f_{3}$. Whorls 5-10; shells elongated, conical, turreted ; aperture $\frac{1}{4}-\frac{1}{3}$; length of shell of our species 4-10 mm. long .

Pyramidellide

$e_{3}$. Shell regularly spiral, shortened; width nearly as great as or greater than length; whorls 
usually few ; angle of spire always over $50^{\circ}$, usually over $90^{\circ}$; aperture over $\frac{1}{2}$ length of shell.

$f_{1}$. Shell conical, pearly under epidermis and within aperture, usually brilliantly so ; umbilicus deep and large .

$f_{2}$. Shell globular or oval; spire

Trochile short, body whorl large ; umbilicus rounded, distinct, either free or covered by a callus; angle of spire $90^{\circ}$ or more

Naticide

(Ex. Natica)

$f_{3}$. Shell top-shaped to globular ; interior pearly, 8-30 $\mathrm{mm}$. long; umbilicus when present not rounded nor covered with a callus . .

Littorinide

$f_{4}$. Shell minute, nearly diskshaped, widely umbilicated (Ex. Littorina)

Acterbida

d. Anterior margin of aperture notched or produced into a canal.

$e_{1}$. Shell with canal formed by a decided prolongation of anterior end.

$f_{1}$. Large, heavy shells, over 100 $\mathrm{mm}$. long, pear-shaped ; whorls angulated or nodulous.

Fasciolariide

(Ex. Fulgur)

$f_{2}$. Rather thin shells, 20-80 mm. long, ovate to pear-shaped ; whorls rounded and covered with $40-60$ small revolving ridges . . .

$f_{3}$. Shells over $20 \mathrm{~mm}$. long, with longitudinal, rib-like undulations crossed by revolving lines. . . .

Buccinilue

\author{
Muricide \\ (Ex. Urosalpinx)
}


$f_{4}$. Shells less than $20 \mathrm{~mm}$. long; aperture with a notch near posterior end, formed by outer lip not squarely meeting body wall . . .

$f_{5}$. Shells less than $15 \mathrm{~mm}$. long; aperture entire at posterior end ; narrow, and a little less than $\frac{1}{2}$ the length of the shell; canal rather short

$e_{2}$. Canal short or absent; aperture notehed.

$f_{1}$. Shells large, $40 \mathrm{~mm}$. or more long; whorls rounded .

$f_{2}$. Shells 20-40 mm. long; whorls rounded . .

$f_{3}$. Whorls flattened, surface usually beaded; aperture over $\frac{1}{3}$ length of shell .

$c_{2}$. Non-operculated, or operculum very minute; aperture with neither a canal nor a notch at anterior end.

$d_{1}$. Aperture over $\frac{3}{4}$ area and $\frac{3}{4}$ length of shell ; spire distinct, pointed ; shell ear-shaped . . . .

d. A perture $\frac{1}{2}$ the area or more, and the full length of the shell.

$e_{1}$. Shell with 1 whorl, less than 2 mm. long . . . .

$e_{2}$. Shell with several whorls, under $4 \mathrm{~mm}$. long; spire flat . .

$e_{3}$. Several whorls, a pit in place of spire, over $6 \mathrm{~mm}$. long . .

Pleurotomida

Columbellicte

Buccinitle

Muricitie

Nassirla

Naticinte

Philinida

Scaphandridte

Bullide

d.3. Aperture less than $\frac{1}{2}$ the area of the shell.

$e_{1}$. Aperture $\frac{3}{4}$ to whole length of shell; spire distinct, usually flattened; under lip with single fold or smooth . . 
$\rho_{2}$. Aperture $\frac{1}{2}-\frac{3}{4}$ length of shell; under lip with 2 or more teeth

$c_{3}$. Non-operculated; aperture with canal at Auriculide (Ex. Melamplus) anterior end; our species $20 \mathrm{~mm}$. or less long . . . .

Plenotomidere

$b_{3}$. Sinistral; whorls in contact.

$c_{1}$. Shell ovate-globose, small, not over $5 \mathrm{~mm}$. long, transparent. . . . .

$c_{2}$. Shell elongated, turreted, slender, less than $30 \mathrm{~mm}$. long. . . . .

$c_{3}$. Shell large, over $100 \mathrm{~mm}$. long, with produced anterior canal

Limarinide

Triforidce

Fasciolariatle

$a_{2}$. Shell flat, boat or cup shaped, if somewhat spiral, not forming a complete whorl.

$b_{1}$. Shell with apex somewhat spiral and an internal, usually horizontal, partition or diaphragm . . . . . . .

$b_{2}$. Shell conical or cup-shaped, with apex turned (Ex. Crepidula)

forward ; no shelf or partition.

$c_{1}$. No perforation at apex or notch in margin . . . . . .

Acmaida

(Limpets)

$c_{2}$. Apex recurved; margin or apex perfoFissurellitle 


\section{CHAP'TER XII}

\section{THE FRESH-WATER CLAM AND ITS ALLIES}

THE fresh-water clams belong to the group of lamellibranch mollusks, characterized by the absence of a distinct head, by the possession of leaf-like gills on the sides of the body, and by the presence of a calcareous shell composed of a right and a left valve. Economically this group is the most important to man of all Mollusca. It includes both marine and fresh-water species. About six thousand species of living lamellibranchs and over ten thousand fossil species are recognized. They all fall into two principal subdivisions. The first (Siphonata) includes species which possess a siphon and have the mantle edges grown together, while the second (Asiphonata) has no siphon and has the mantle lobes for the most part wholly separated. ${ }^{1}$

Anodonta and Unio are extremely common in the ponds. lakes, and rivers of North America. Anodonta is more apt to be found in still waters and Unio in running water's. They lie partly buried in the mud of the bottom, with the valves of the shell gaping open and the partly united edges of the mantle protruding. They do not lead wholly sedentary lives, but may burrow or plough along the bottom.

Their food is gained from organic particles borne along

${ }^{1} \mathrm{~A}$ key to the principal families of bivalve shells will be found in the Appendix, p. 188. 
in the current of the water. A part of this current is carried through the mantle chamber and forced out again, deprived of usable food and of the oxygen used in respiration. By devouring organic matter these clams act as useful scavengers of the water.

The family of Unionidæ, to which Unio and Anodontia belong, is of world-wide distribution, but nowhere else are Unionidre so numerous as in the United States. They show in our country a most marvellous variability also, so that hundreds of kinds have been described from our waters. The extraordinary abundance of Unios in North America is due to the fact that nowhere else is there such a large area of soluble limestone as in our Mississippi valley. The clams take from the water the lime which they use in the construction of their shells, change it into an insoluble form, and thereby advantageously reduce the amount of the inorganic matter in solution, for this change in the quality of the water renders it more fit to drink and to sustain other animal and plant life.

Although numerous and of large size, the Unionidre do not seem to be much used as human food. The aborigines, however, made use of them, as the great shell-heaps on the banks of rivers of the Ohio valley testify. 'They yield also pearls, which occasionally, especially in the Ohio valley, are of precious quality. Even the small, imperfect pearls are of value, since they are ground up to make the powder used in polishing the more valuable pearls.

The spawning season of our Unionidie is short. The eggs pass, during the latter part of October, into the gills of the parent, where they undergo their early development, protected by the parent shell and supplied richly with oxygen. The cleavage is mequal because of the larger 
amount of yolk in some of the cells than in the other's. Eventually a shell is formed, which divides into two valves united by a straight hinge. A spine is formed on the free edge of each valve, and a thread (byssus thread) is secreted from the body. The young at this stage is known as Glochidium (Fig. 165). In the spring Glochidia become free from the mother, and attach themselves to the gills or fins of a fish by means of the spines on the shells. Here they become transformed. The single adductor muscle disappears, and becomes replaced by the two characteristic of
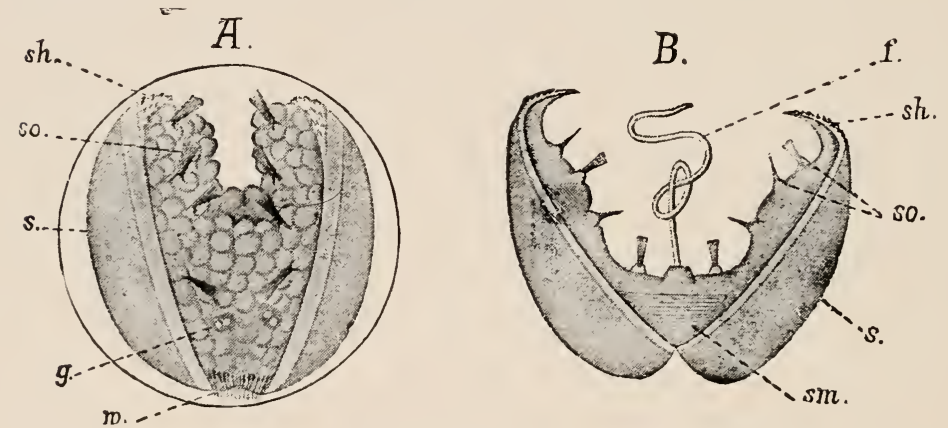

Fig. 16i. - $A$, advanced embryo of Anodonta: $B$, free glochidium. $f$, provisional byssus ; $s$, shell ; sh, hooks : $s m$, adluctor muscle; so, sense organs; $w$, cilia. From Korschelt and Heider's " Embryology."

the adult: the gills arise, the shell gains its adult character, and becomes free from the fish on which it has lived temporarily as a parasite.

There are other species of fresh-water lamellibranchs besides the Unionidie. These belong to the Cycladidæ, allies of the marine Cardidre or Veneridre. They have much the shape of our common hard-shell clam of the sea, but are much smaller in size, rarely exceeding 15 millimetres. Cyclas (or Sphærium) is of world-wide distribu- 
tion, but it is especially abundant in North America. It occurs in ditches, ponds, and river's of New England, as well as in the South and West Some species of it inhabit brackish water. Pisidium has both valves unsymmetrical. Its species are still smaller than those of Cyclas, rarely exceeding 10 millimetres. It likewise is found in ditches, ponds, and streams all over our country.

The remaining families which we shall consider come from the sea, and all occur on our Eastern coast.

The Pholadidæ ${ }^{1}$ and Teredidæ ${ }^{2}$ include certain wood and rockboring species, which do great damage by boring into wooden vessels and pilings (Fig. 166). In such locations they are commonly called ship-worms. The boring is done by the movements of the shell, combined with the action of the muscles and foot. The only thing which seems effectively to stop these mollusks from boring into wood is iron rust, so that piles driven full of nails are apt not to be attacked.

$1 \phi \omega \lambda a ́ s$, Greek name for a boringr mussel.

$2 \tau \in \rho \epsilon ́ \omega$, to bore.

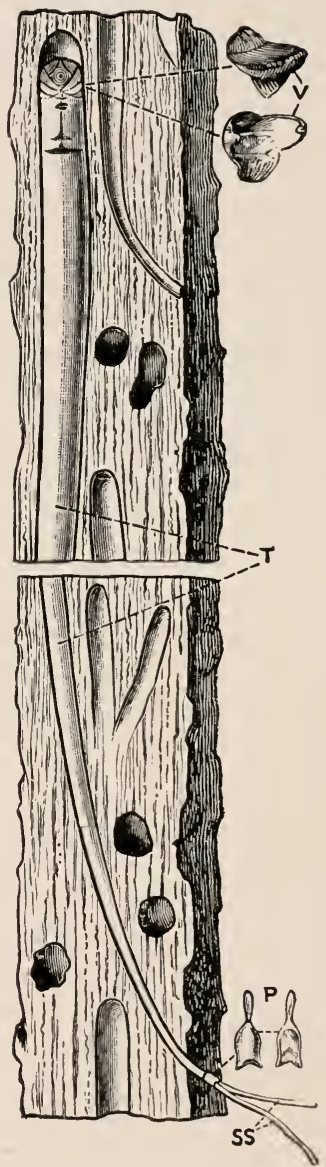

Fus. 16i6. - Teredo navalis, in a piece of timber. I'. pallets: $S S$, siphoms: $T$. tube; $V$, valves of shell. From the "Cambridge Natural History." 
The Solenidæ 1 include the "razor-shell" (Fig. 167). This animal, like the shell, is elongated and subcylindrical. By means of its foot, which can be protruded between the

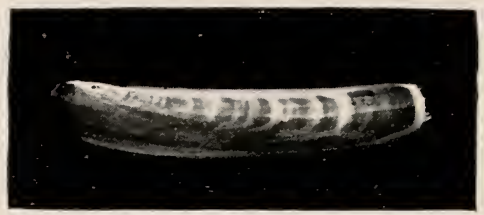

Fig. 167.-Ensis directus. Young. Nat. size. Photo. by IV. H. C. P.

ralves, it excavates, with great rapidity, a hole in the sand or mud, into which it draws itself. These mollusks are sometimes used for food, but it is not easy to get them in quantity.

The Mactridæ ${ }^{2}$ include species commonly known in the North as hen-clams and surf-clams. They are more eiliptical and larger than the common hard-shelled clam or "quohog," and have a proportionately lighter shell (Fig. 168). They are not often used as food because they become very tough when cooked.

The Myidæ ${ }^{3}$ include the common clam of New England. Mya arenaria, abundant along our whole Eastern coast and used as food chiefly in New England. These clams occur in great numbers in every mud-flat. Their great siphon is extended at high tide to the surface of the ground, so as to take in and throw out water (Fig. 169); but at low tide it is retracted, and the clam lies invisible in its burrow. This clam was much prized by the Indians, as the great, ancient shell-heaps along the coast testify. In 1892 the clam com-

$1 \sigma \omega \lambda \eta \dot{\nu}$, a channel or tube. ${ }^{2} \mu a ́ \kappa \tau \rho a$, a baking-trough.

${ }^{3} \mu \dot{a} a$, Greek name for a kind of mussel. 
merce for New England was estimated to be worth nearly half a million dollars.

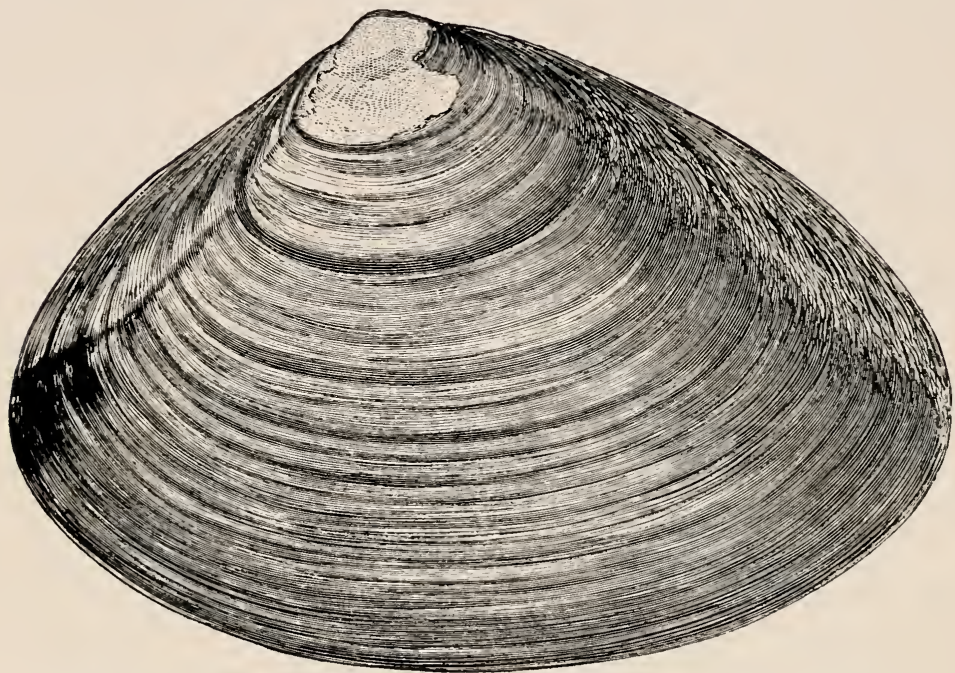

Fig. 168. - Mactra solinlissima, the Eastern hen clam. Nat. size. From Gould-Bimney.

The Veneridæ ${ }^{1}$ include the hard-shelled clam or "quohog" of the Indians. Tenus mercenaria is the commonest species, and is most abundant south of Cape Cod. It owes

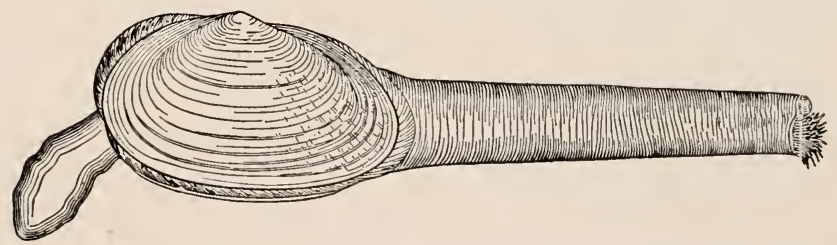

Fig. 169. - Mya arenaria, the New England " clam." At the left the foot is seen ; at the right, the siphon. One-half nat. size. From Verrill, "Invertebrates of Vineyard Sound."

1 Tenus, the goddess of love. 
its name "mercenaria" to the fact that the purple-colored patch seen on the margin of the shell was used as money

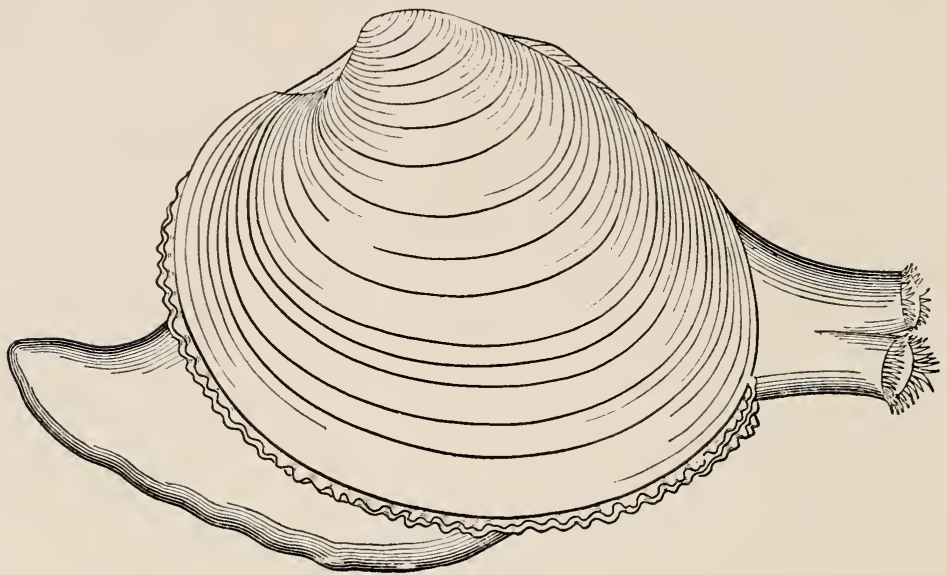

Fis. 170. - lenus merconuic, the hard-shelled clan. At the left the foot protrudes from the shell; at the right the siphons. Nat. size. From Verrill, "Invertebrates of Vineyard Sound."

("wampum") by the Indians. The shell is extremely heavy, and usually nearly circular in outline (Fig. 170).

The $\operatorname{Arcidæ}^{1}$ and their allies include several species hav-

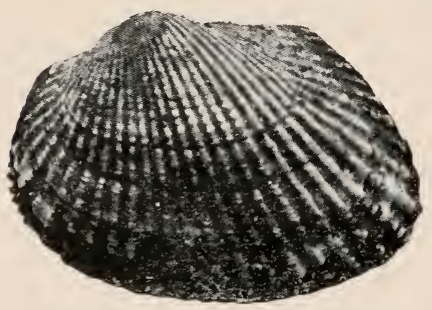

Fix. 171. - Arca pexatu, the bloody clam. Nat. size. Photo. by W. H. C. P. ing a more or less elongated hinge-joint crowded with many smali teeth. Our common Eastern species (Aica pexutu, Fig. 171) has bright red blood and is commonly known as the "bloody clam.'

The Mytilidæ ${ }^{2}$ include the mussels, which are the 1 arce, all ark. $2 \mu v \tau i$ Aos, an edible mussel of the Greeks. 
familiar blue-black, wedge-shaped shells attached in elusters or beds to rocks near low tide (Fig. 17:2). They are edible. In France they are reared for the market on woven nets, which are submerged at each tide.

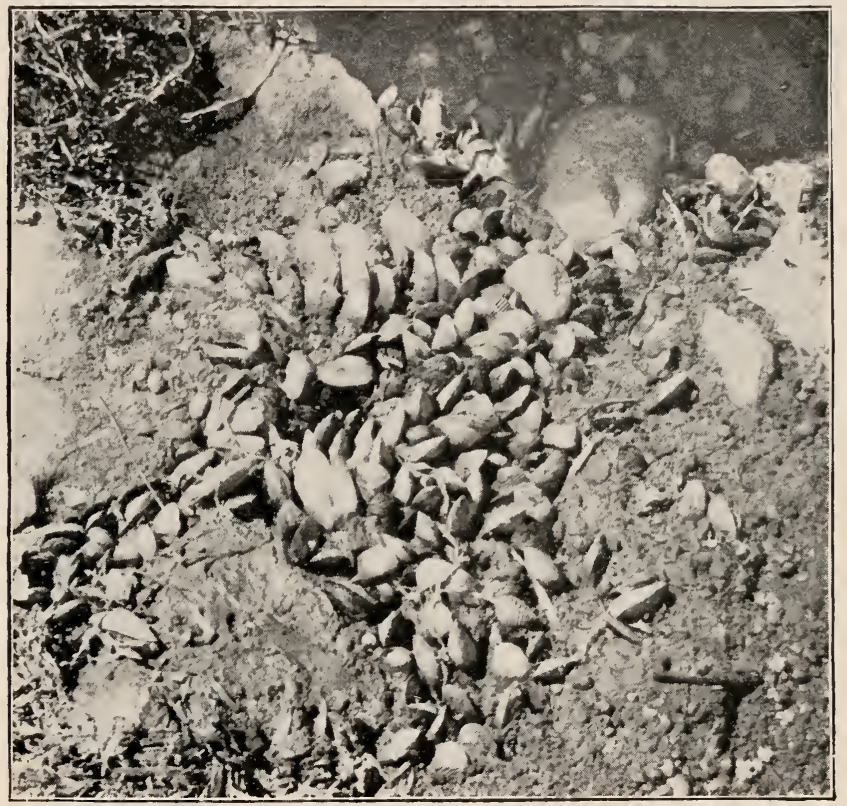

Fik. 172. - A bed of Modiola, the horse-mussel, on a mud-bank. Photo. by II. H. C. P.

The Aviculidæ ${ }^{1}$ are a group closely allied to the last, but not represented on our shores. It is important because mollusks of this family produce the best pearls. Pearlfishing has been carried on since the earliest preserved historic records. The pearl banks of C'eylon are known $1 \mathrm{~A}$ small bird (ucis). 
to have been fished for two thousand years. The finest pearls come from the Persian (iulf. They are gathered there by native divers, who, after taking several deep inspirations, either dive down unaided or descend upon weighted ropes. When they can no longer remain under water, they either ascend again unaided or are rapidly drawn up to the boats above. The pearl oysters brought up to the surface are then examined for pearls. The pearl is the secretion of the oyster about a small foreign body,

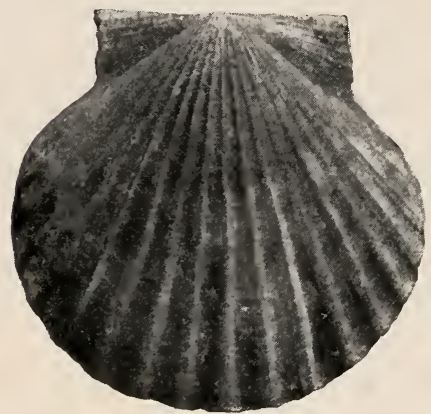

Fif. 17:3. - Pecten irradians, scallop, left or upper valve. Nat. size. Photo. by W. H. C. P. such as a grain of sand. This secretion prevents the irritant from injuring the tissues. It is of the same nature as the substance lining the shell. The latter' is the mother of pearl of commerce, and is used for knife handles, buttons, and the like. 'The iridescence is not due to the chemical composition of the secreted substance, but to the fact that it is deposited so as to leave fine lines on the surface which diffract the light.

The Pectinidæ ${ }^{1}$ include the scallop-shells. These occur along our whole coast. They live in shallow water, and are capable of rapid movement in the water by clapping. the valves. The adductor muscle of the valves alone is eaten by man. The common species is Pecten irradians. It varies greatly in color, from bluish to reddish and orange (Fig. 173). 
The Ledidæ include certain elongated shells with a shiny epidermis, and a large number of teeth on the hinge, which are found chiefly in mud in rather deep water. The animal has a large foot (Fig. 17t) with which it burrows rapidly. It can also move rapidly through the water as the scallops do.

The Ostreidæ ${ }^{1}$ include the oyster's, which are the most important invertebrate food fishery, being valued at

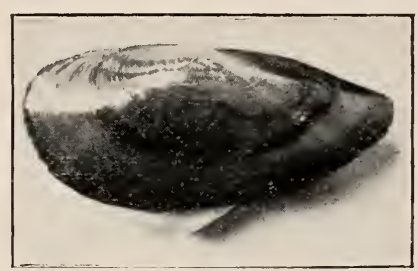

Fit. 174. - Yoldia, one of the Ledidae. Foot protruding below. Nat. size. Photo. by W. H. C.P. twenty to thirty million dollars per year for our Atlantic seaboard. Oysters are found on all coasts. Our Ostrea virginiana ${ }^{2}$ extends from the Giulf of St. Lawrence to the Gulf of Mexico. The oysters of our Western coast are not so important as the Atlantic species. O. edulis is the prin-

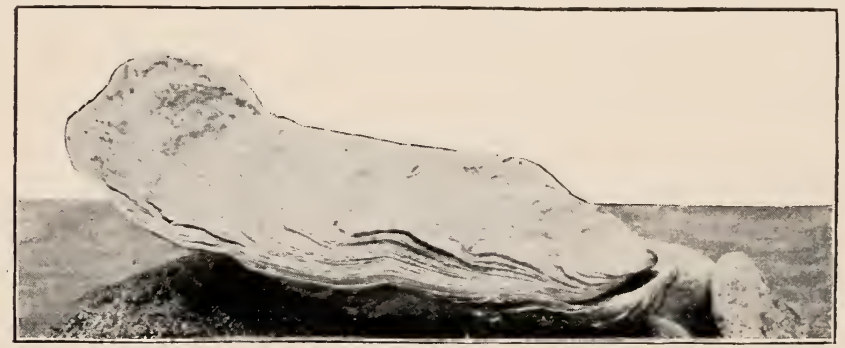

Fig. 175. - Ostrea virginiana, the Eastern oyster. One-third nat. size. Photo. by IV. H. C. P.

cipal European species. In Japan there is a species occasionally gaining a length of three feet. The oyster was formerly commoner and larger north of Cape Cod than

${ }^{1}$ From Greek name for oyster.

2 Fig. 175. 
it is now, for the great aboriginal shell-heaps ("Kitchenmiddens") of the New England coast contain shells of enormous size. 'The cause of this gradual extinction of the oyster is uncertain, but is believed to be due partly to general climatic and geographic changes and partly to orer-fishing.

\section{API'ENIIX TO ('HAP'TER XII}

KEY TO THE PRINCIPAL FAMHLEN OF MARIXE LAMELLIBRAXCHIATA OF THE EAST ('OAST OF THE UXITED STATES

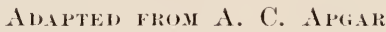

$a_{1}$. Shell when closed at ventral side, gaping nore or less at the ends.

$b_{1}$. Without toothed hinge or proper ligament, often with accessory valves ; no distinct epidermis.

$c_{1}$. Length decidedly greater than height .

c. Length and height nearly equal; shell small . . . . . . .

Pholadide

Teredicle

b. With proper hinge, often distinetly toothed (shipworms)

and with hinge ligament or pad.

$c_{1}$. Ilinge with many small cardinal teeth in eac!l valve . . . .

Ledide

c.. Hinge of not over 4 cardinal teeth in (Ex. Yoldia) each valve. $d_{1}$. Shells equivalve.

$e_{1}$. Two or nore times as long as high, gaping nore or less at ends.

$f_{1}$. Length :; to 6 times height; epidermis polished ; mmbones not over one-yuarter from anterior end .

Sulenide (lazor Clams) 
$f_{2}$. Length about 3 times height; umbones central, Psammoliide

$f_{3}$. Length less than 3 times height; surface covered with radial ridges, chalky white, umbones near anterior end . . .

Petricolidte

$f_{4}$. Length about 2 times h eight; epiderm is polished, with notched border extending beyond the edge of the thin shell, Solemyidte

$f_{4}$. Shell with thick black epirlermis ; external ligament prominent and on shorter end of the shell,

$e_{2}$. Length less than twice height.

$f_{1}$. Shell somewhat triangular, with internal cartilage between deep triangular pits, similar in each valve . . .

f:. Shell thin, rounded in front, Martivide (IIen ('lams) narrowed and gaping behind, cartilage pit shallow; external ligament short . . . Saxicaride (Hen (latms)

$d_{2}$. Shells inequivalve.

$e_{1}$. Length and height about equal, Semelitie

$e_{2}$. Length decidedly greater than height.

$f_{1}$. Over $25 \mathrm{~mm}$. long; right valve nearly flat; whole shell compressed to onesixth length . Pandoriclie

$f_{2}$. Over $50 \mathrm{~mm}$. long ; slightly inequivalve ; no external ligament; internal cartilage on spoon-shaped process of left valve Myidae. 
$f_{3}$. Shell under $18 \mathrm{~mm}$; ; prominent external ligament,

$a_{2}$. Shell not at all gaping.

Tellinidae

$b_{1}$. With not over 3 cardinal teeth in each valve.

$c_{1}$. Valves equal in size, curvature, and markings.

$d_{1}$. Anterior muscular impression very small, hinder large; shell elongated, mussel-shaped; umbo at or near posterior end

Mytilida

(Mussels)

$l_{2}$. Hinge line straight, formed by ears at sides of umbo, radiating ribs, scalloped edge . . . .

Pectinida

(Seallops)

d. Height and length nearly equal; a decided pallial sinus . . .

I'eneride (Hard-shelled Clams)

$d_{4}$. Height and length nearly equal; no distinct pallial sinus, at most a mere undulation of pallial line at posterior end.

$e_{1}$. With a plain lunule in front of umbones; without radial ribs.

$f_{1}$. Over $20 \mathrm{~mm}$. long, compressed, ligament external Astertide

$f_{2}$. Shell somewhat quadrant shaped; less than $8 \mathrm{~mm}$. long; surface with concentric ridges.

Crassatellidie

$f_{3}$. Shell less than $5 \mathrm{~mm}$. long, very much compressed; ends rounded.

Erycinide

$e_{2}$. With no lunule and with distinct radial ribs . . . Cardiide

$c_{2}$. Valves unsymmetrical.

$d_{1}$. 2 muscular impressions, a distinct pallial sinus. (See $d_{2}$ under $a_{1}$.)

d. 1 muscular impression; height never much less thain length 
$e_{1}$. Fixed mollusks with large rough shells attached by large valves,

Ostreide

(Oysters)

$e_{2}$. Fixed mollusks, with their pearly shells attached by smaller valve which is flat or concave and perforated or notched .

Anomiidae

(Jingle shells)

$e_{3}$. Free mollusks; hinge line straight, formed by ears at sides of umbo; with radial ribs

Pectinide

$b_{2}$. With many small cardinal teeth in each valve.

$c_{1}$. With distinct radiating ribs; shell over $30 \mathrm{~mm}$. long . . . . .

Arcida (Ark-shells)

$c_{2}$. Smooth, length and height equal ; under $12 \mathrm{~mm}$. long . . . . . Nuculidee

$c_{3}$. Elongated shells, length nearly or twice height; a pallial sinus. . . . . Ledide

KEY TO THE PRINCIPAL GENERA OF FRESH-WATER LAMELLIBRANCHIATA

$a_{1}$. Siphonate; without marked muscular impression,

$b_{1}$. Valves sub-symmetrical .

Fam. Cycladida

$b_{2}$. Valves unsymmetrical; siphons united .

- Genus Cyclas

$a_{2}$. Asiphonate; with two muscular impressions . Fam. Unionide

Pisidium $b_{1}$. Hinge with teeth.

$c_{1}$. With short cardinal teeth and long lateral teeth. . . . . .

Unio

$c_{2}$. With short cardinal teeth and no lateral teeth. . . . . Margaritana

Hinge without teeth, or with only a small ridge, Anolonta 


\section{CHAPTER XII}

\section{THE STARFISH AND ITS ALLIES}

Systematic Position. - The starfishes belong to the group of Echinodermata, ${ }^{1}$ characterized by a radial, usually five-rayed, structure, a more or less well-developed system of calcareous plates in the skin; a system of water-tubes, which is used by the movable forms for locomotion; and the separation of the intestine from the body cavity.

Distribution and Habitat. - The common pink starfish of the eastern United States (Asterias ${ }^{2}$ vulgaris ${ }^{3}$ ) ranges from Labrador to northern Florida. A dark brown form, sometimes called Asterias Forbesii, ${ }^{4}$ is recognized by some authors as a separate species inhabiting the coast from Massachusetts Bay southward. Our shore starfish extends out into fairly deep water, but is not abundant at greater depths than 60 fathoms. In Long Island Sound it is found especially on the oyster beds, where it is very destructive. On rocky coasts starfishes will be found in crevices of the rock or in tide-pools. They love cool waters, and are often found hanging on vertical walls or ledges. Upon reaching the surface of quiet water, they may extend one or more of their arms out upon the under side of the surface film.

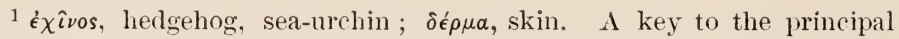
classes of Echinodermata will be found in the Appendix to this Chapter.

$2 \dot{a} \sigma \tau \dot{\eta} \rho$, star; $\dot{a} \sigma \tau \epsilon \rho i a s$, starred.

${ }^{3}$ Common.

4 ()f Forbes, an English zoologist. 
Food. - The favorite food of the starfish is some kind of mollusk, especially bivalves, such as mussels and oysters. Their method of feeding is as follows: They crawl over the bivalve, arch the body over it, apparently pull open the valves, then turn the stomach inside out over the soft body within the shell, and gradually digest it. The starfish probably finds its food by means of a keen chemical sense.

Starfishes are of economic importance on account of their destructiveness to oysters, but since the oystermen have learned to keep the beds clear of starfishes and that tearing starfishes into pieces only aids in their increase, as each piece produces a whole starfish, the damage wrought by starfishes must be less than it was formerly.

Development. - Starfishes have the sexes distinct; and the sex can usually be told by the color. The female has a more bluish tint, while the males are of a reddish brown color. Both the eggs and sperm are extruded into the water through small openings on the aboral surface at the interspace between two adjacent arms. The egg is hardly visible to the naked eye, and is enclosed in a delicate membrane. 'The egg undergoes cleavage; that is to say, the single sphere breaks up into two, four, eight, sixteen spheres, and so on. Finally a hollow ball, made up of these spheres or cells, is formed, called the "blastula." Next the wall of this hollow sphere is pushed in at one side, forming a sort of cup with two walls. This is the so-called "gastrula." The cavity of this cup is the digestive cavity. At first it is a sac with only one opening, but later a second opening, the true mouth, breaks through, and the former opening persists as the anus. Pairs of arms, edged with cilia, now bud out on 
each side of the body, and the larva becomes bilaterally symmetrical. ${ }^{1}$ Meanwhile, inside the borly, the system of water tubes of the adult starfish has begun to form, and finally, over the stomach on the left side, five main water tubes, radially arranged, make their appearance; these are the five radial tubes, one of which runs down each future arm. ${ }^{2}$ On the right sicle of the stomach, calcareous plates are laid down to form the aboral wall of the starfish. ${ }^{3}$ The young star is now found as a parasite at the hinder end of the larva. Soon all the front end of the larva, together with the long arms, becomes absorbed. Up to this stage the larva has been free-swimming, but it now settles to the bottom. There the process of resorption is completed, the upper and lower surfaces of the star approach each other, the calcareous skeleton and suckingfeet rapidly develop. At this stage the disk is so large, and the arms so short, that the young starfish looks more like a sea-urchin than an adult starfish. 'The elongaterl arms and the pedicellarice of the adult are not gained until three years have passed.

1 Figs. 176 and 177.

2 Fig. 178.

Fig. $179, a b^{\prime}$.

FIx. 176-179. - Larval stages and metamorphosis of starfish. After drawings of E. B. Wilson, from Brooks, "Invertebrate Zoology."

FIs. 176. - Dorsal view of starfish larva with begimnings of ciliated arms.

IIt: 177. - Ventral view of same larva.

Fig. 178. - Side view of an older larva in which young star is beginning to arise.

Fig. 179. - Ventral view of same larva. $a$, anterior end; $b$, posterior end; $1-4$, ciliated projections; $a^{\prime}$, preoral arms; $a m$, oral surface of young star with beginning water tubes, $a m-a m^{5} ; a b, a b^{\prime}, a b^{5}$, aboral surface of star;

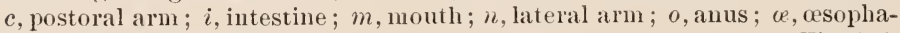
gus; $q, q^{\prime}$, dorsal lateral arms; $s$, stomach; wu', water tubes; am, Fig. 177 . region from which water tubes arise. 


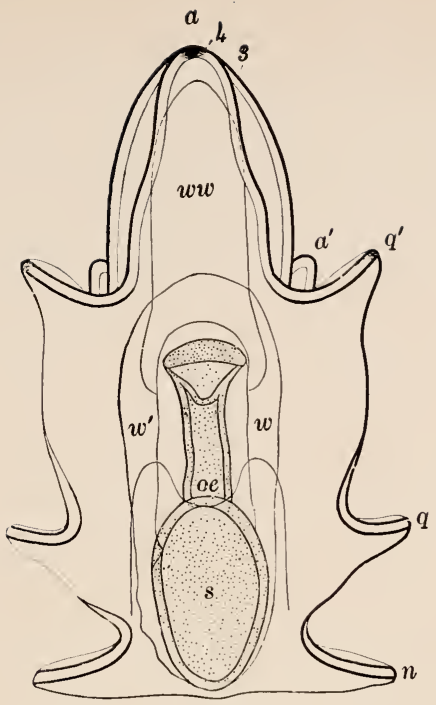

FIg. 176.

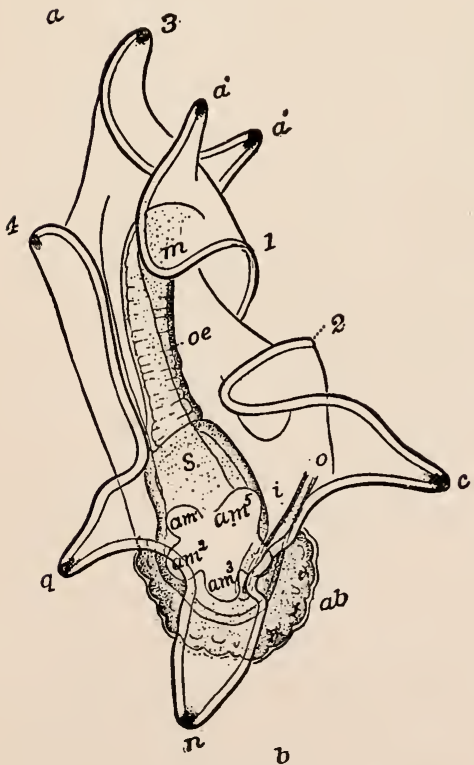

Fig. 178.

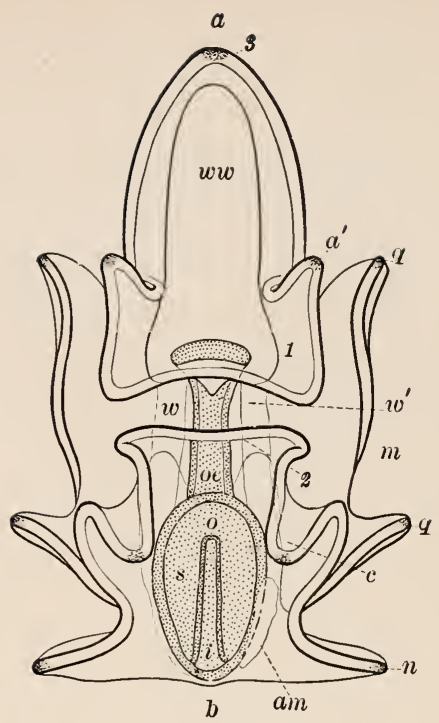

FIG. 177.

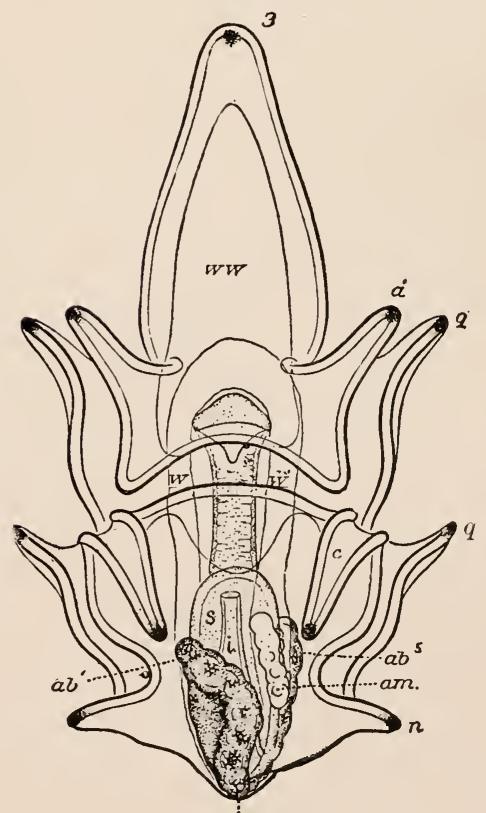

FIเ. 179. 
Abnormalities are frequently found among starfishes, -

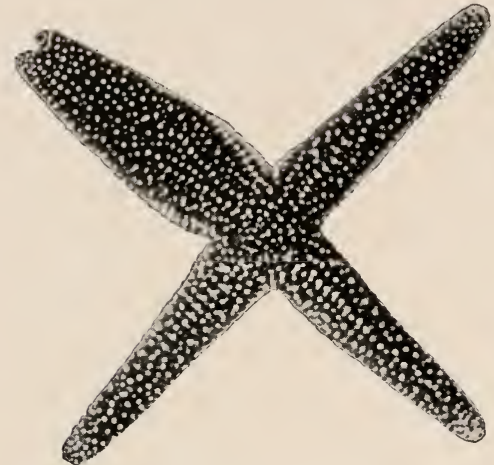

FIg. 180. - Abnormal starfish (Asterias), apparently produced by fusion of two rays. One-half nat. size. Photo. by W. H. C. P. partly on account of their capacity for regeneration, even from the disk and a single arm. Thus one may find a starfish with three or four rays, or with a small ray interpellated in between normal-sized ones. Not all abnormalities seem to be the result of mutilation, however; for example, sometimes two arms seem to be fused (Fig. 180). Other Starfishes. - Aste-

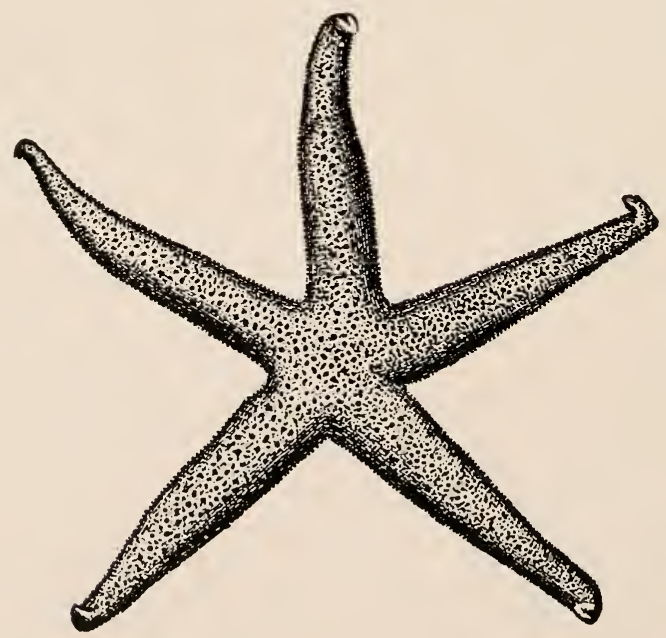

Fıg. 181. - C'ribrella sanguinolenta. Nat. size. From Leunis. 
rias vulgaris belongs to the group Asteroidea. ${ }^{1}$ But there are over five hundred other species of starfishes. In some of these - as in Asterias - the skeletal plates of the skin make a network; in others they form a solid calcareous covering. To the first class belong, besides Asterias vulgaris, Asterias ochracea, ${ }^{2}$ which occurs commonly on the Pacific coast from Sitka, Alaska, to San Diego, California. This has a much thicker, more solid skin than the Atlantic species. A. $g^{i-}$

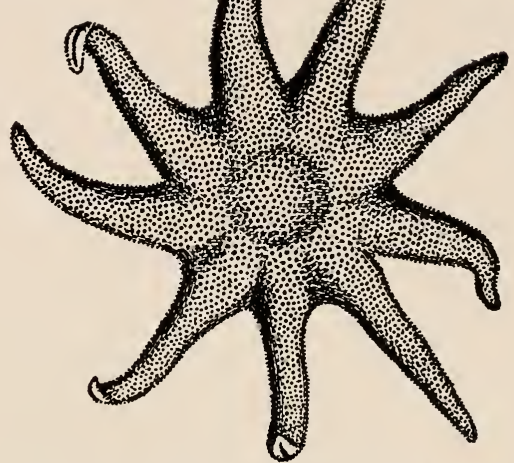

Fig. 182. - Solaster, a multirayed starfish. Reduced. From Leunis.

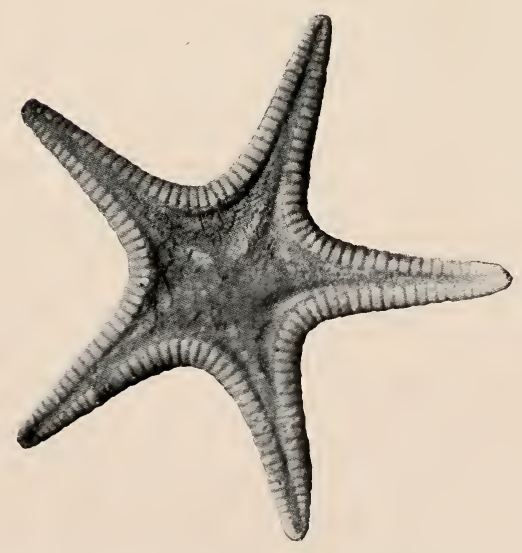

FIG. 183. - Archiaster, a webbed starfish. Slightly reduced. Photo. by W.H.C.P. gantea ${ }^{3}$ attains a diameter of over two feet. Next to A. vulgaris, our commonest Eastern species is a smooth, leathery, blood-red starfish, about 10 centimetres in diameter, called Cribrella ${ }^{4}$ san-

$1 \dot{\alpha} \sigma \tau \eta \dot{\eta} \rho$, star ; $\epsilon \hat{i} \delta o s$, form.

$2 \dot{\omega} x \rho \delta s$, pale yellow.

${ }^{3}$ giganteus, gigantic. This species occurs on our Pacific coast.

${ }^{4}$ cribrum, sieve. 
guinolenta $^{1}$ (Fig. 181). Certain starfishes have many arms instead of only five, as in the case of Solaster ${ }^{2}$ endeca ${ }^{3}$ of the northern Atlantic (Fig. 182). In still other starfishes the rays are partially connected by a membrane like the web of a duck's foot, so that the whole outline is nearly pentagonal (Fig. 183).

The Ophiuroidea. - In the Ophiuroidea ${ }^{4}$ the organs are not prolonged from the disk into the arms, consequently

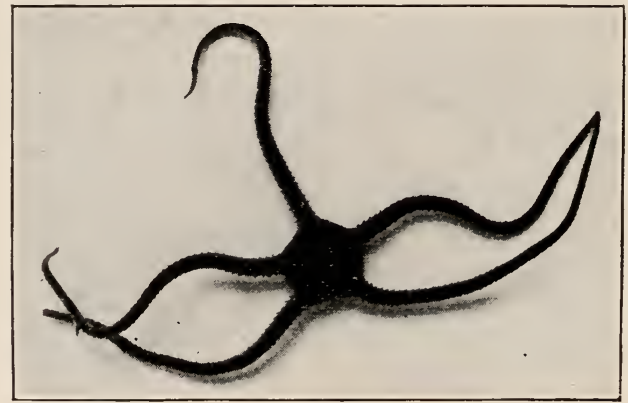

Fig. 184. - Amphiurc squamata. One of the Ophiuridæ. Nat. size. Photo. by W. H. C. P.

the arms may be thrown off without injury to the animal; hence the name "brittle-star." The brittle-stars fall into two groups, in one of which, the serpent-stars, the arms are unbranched, while in the other, the "basketfish," the arms are branched.

Of the serpent-stars there are two common forms on the New England coast, — a white species, with long, slender arms, Ainphiura ${ }^{5}$ squamata $^{6}$ (Fig. 184), and the spotted Ophiopholis, 'i which has shorter, stouter arms. The

1 Blood-red.

2 sol, sun ; aster, star.

$8 \ddot{\epsilon} \nu \delta \epsilon \kappa a$, eleven.

${ }^{4}$ b申ıs, serpent; ovjó, tail.
$5 \dot{a} \mu \phi \ell$, round about; oúpá, tail.

${ }^{6}$ Scaled (squama, a scale).

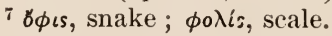


animals live in crevices of the rock, and being of rather small size, are not commonly seen. At the base of the arms, on the right and left, are a pair of slits, which form the exits from pouches into which the reproductive glands open. In certain species the pouches are used for hrooding the young. 'The basket-fish occur in Northeastern

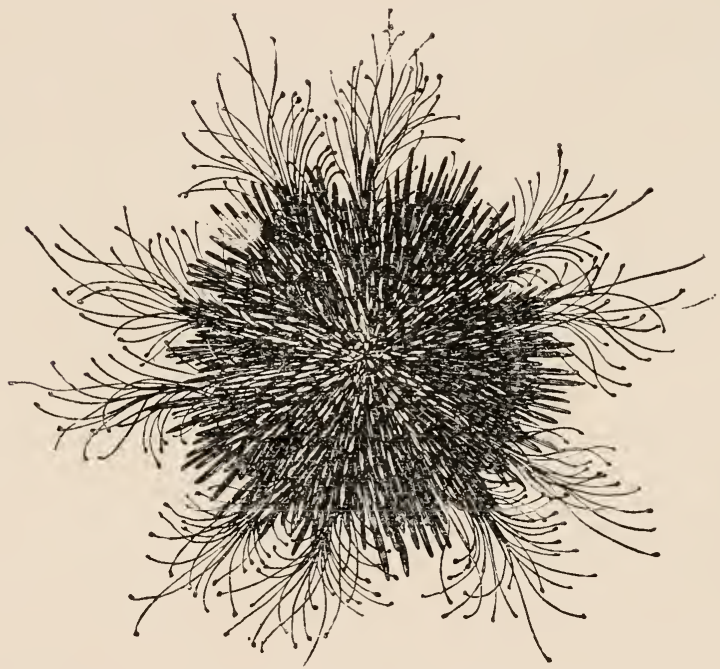

FIx. 185. - Strongylocentrotus, the Eastern green sea-urchin, with tube feet extenderl. From "Standard Natural History."

waters, from low tide to one honclerl fathoms, and are often brought up by fishermen, to whose lines they have a habit of clinging. The branching of the arms enables the animal to hold its prey, which consists of shrimp and fish.

The Echinoids, or sea-urchins, may be regarded as starfishes in which the arms have shortened and the rlisk enlarged so as to fill up the interspaces, and make a solid, 
nearly spherical form. The sea-urchins eat various small animals, and get food also from small bits of organic matter in the mud which they swallow. 'They live more concealed than the starfish, for some burrow in the mud and others - such as our green sea-urchin of the Maine coast (Fig. 185) - grind out pockets in the rocks by means of their spines. Others cover themselves with seaveed, and thus become inconspicuous. Besides the green sea-urchin,

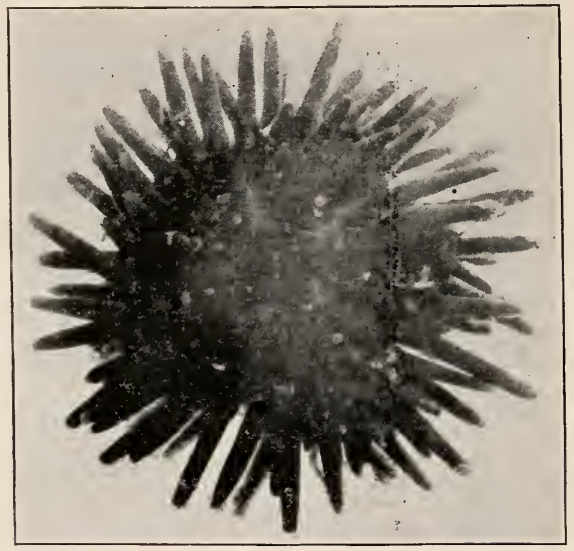

FIG. 186. - Arbacia, the Eastern black sea-urehin. Tube feet retracted. Nat. size. Photo. by W. H. C. P.

which is found north of Cape Cod, we have a black seaurchin (Arbacia, Fig. 186), which extends south as far as North Carolina. We have on the east coast also two kinds of flat sea-urchins (sand-dollars), which live in the sand from low water to one hundred fathoms. 'Their spines are small and silky (Fig. 187). Some sea-urchins lose their strictly radial form and become bilateral, having a pointed anterior end (Fig. 188). 
The Holothurians ${ }^{1}$ may be likened to soft-skinned seaurchins, with the body drawn out to the form of a cucum-

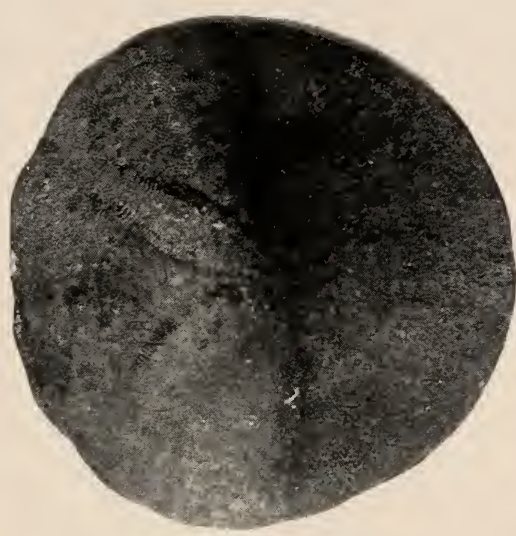

Fig. 187.-Echinarachnius parma, the sand dollar. Spines removed from left side. Nat. size. Photo. by W. H. C. P.

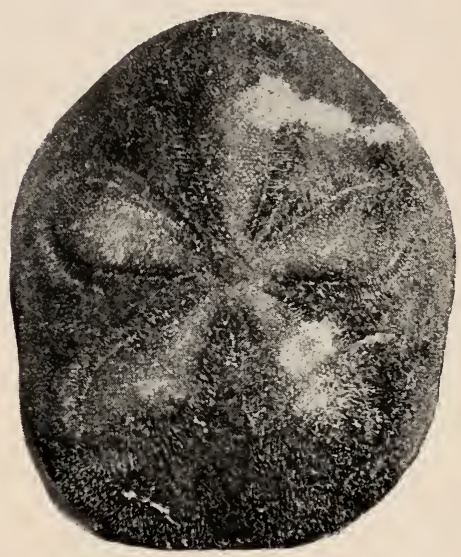

FIG. 188. - Clypeaster, a bilateral sea-urchin from the West Indies. Spines partially removed and surface rubbed in patches. Reduced photo.

ber, or even of a worm. 'The calcareous skeleton is reduced to small plates embedled in the skin. 'The mouth is surrounded by a circle of tentacles. The ambulacral feet are sometimes absent. The Holothurians live in sand and mud, often deeply buried, and feed on small marine animals or the decaying particles mingled with the mud which they devour. They are of considerable economic

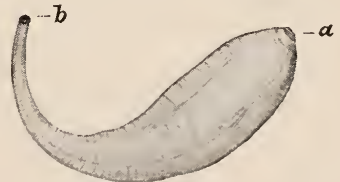

FIG. 189. - Caudina, the tailed Holothurian. $a$, mouth; $b$, anus. After Selenka. importance. The members of one genus (Holothuria) is taken in great numbers on the coral reefs of the Pacific

\footnotetext{
$1 \dot{\rho} \lambda \circ \theta 0 u \dot{\rho} \iota \circ \nu$, a sort of water-polyp.
} 


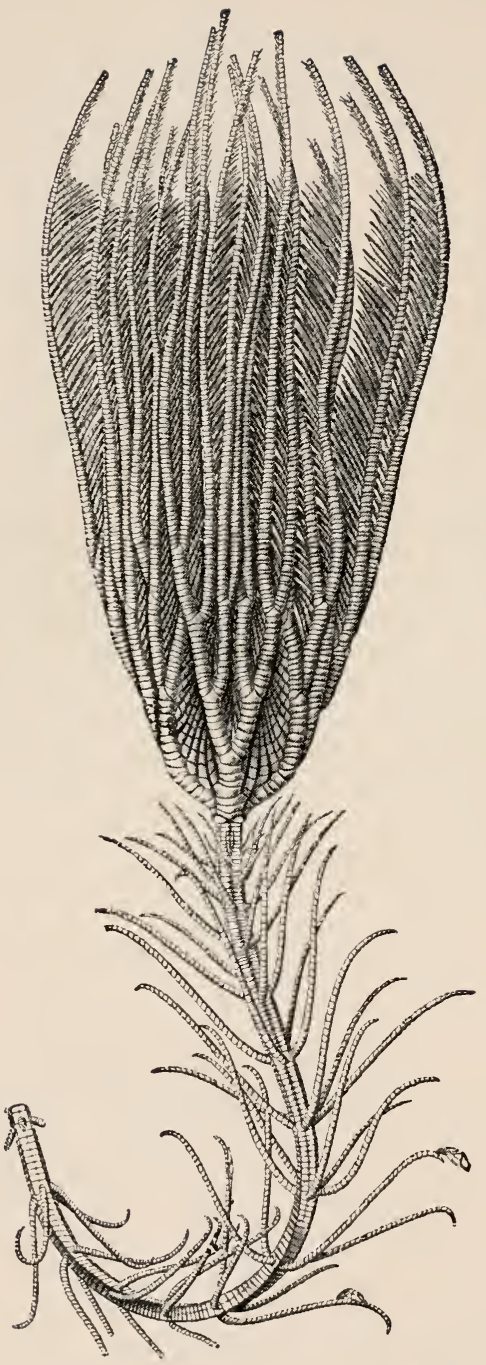

FIG. 191. - Metacrinus interruptus. After P. H. Carpenter.

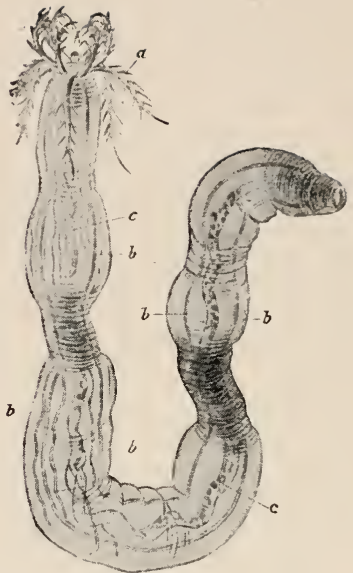

Fic. 190. - Symapta inherens. a, tentacles; $b$, longitudinal muscles; $c$, alimentary tract. After Quatrefages.

Ocean and the China Sea, where they are commonly known as "trepangs." 'They are cut open, washed, boiled, dried, and sometimes smoked. 'They are sold in Chinese ports, and some splecies are considered by Chinese epicureans as great delicacies. Several species of Holothurians oceur on the Naine coast. A barrel-shaped form with a 
sort of tail (Caudina, ${ }^{1}$ Fig. 189) occurs on the Massachusetts coast. A worm-like form, but with a beautifully transparent skin (Synapta, ${ }^{2}$ Fig. 190), is found in sandy beaches from Massachusetts to New Jersey.

The Crinoids, ${ }^{3}$ or sea-lilies, are familiar as fossils to residents of New York State and the Ohio and Mississippi valleys. The living animals are less often seen, for they are inhabitants of the deep sea. They have a cup-like body, with the mouth at its centre directed upward, and surrounded by tentacles (Fig. 191). 'The cup is either borne on the end of a long stalk or is mustalked. The former condition is more usual among the fossil species.

\section{APPENIDX TO CHAPTER XII}

\section{KEY TO THE PRINCIPAL CLASEE OF ECHINOIERMATA}

$a_{1}$. Sessile ; mouth turned upward ; body calyx-shaped

Crimoider (Sea-lilies)

$a_{2}$. Not sessile.

$b_{1}$. Body short; skin hard, containing calcareous plates; mouth directed downward ; madreporic plate present.

$c_{1}$. Body with arms which carry a longitudinal series of plates.

$a_{1}$. Arms with ventral furrow . . Asteroiden (startish)

d. Arms without ventral furrow . . Ophiuroidea (Serpent stars)

1 cauda, tail.

$2 \sigma v \nu a \pi \tau o ́ s$, fastened together ; from $\sigma \dot{v} \nu$, with, and $\ddot{\pi} \pi \omega \omega$, to fasten. ${ }^{3} \kappa \rho i \nu o \nu$, lily ; $\epsilon \hat{l} \delta o s$, form. 
$c_{2}$. Body without arms; more or less spherical or cake-shaped . . . . Echinoidea (Sea-urchins)

$b_{2}$. Body elongated; skin soft, leathery, containing microscopic calcareous bodies; madreporic plate absent; mouth surrounded by tentacles $. \quad \cdot \quad \cdot \quad \cdot \quad . \quad \begin{array}{r}H o l o t h u r o i d e a \\ \text { (Sea-cucumbers) }\end{array}$ 


\section{CHAPTER XIV}

\section{THE HYDRA AND ITS ALLIES}

Hror A belongs to the group of Cœlenterata, ${ }^{1}$ which includes sponges, and certain organisms with nettling capsules - Cnidaria. ${ }^{2}$ 'The Colenterata have a more or less radial form, and a system of internal cavities serving for digestion as well as for body cavity.

The sponges are all sessile, have no nettling capsules, have the body wall perforated by many fine incurrent openings, and a larger exhalant opening (Fig. 192).

The Cnidaria ${ }^{3}$ have nettling organs of some sort. Hyclra belongs to this group.

There are two common species of Hydra; the one is of a green color (Hydra ${ }^{4}$ viridis ${ }^{5}$ ), and the other is fleshcolored (H. fusca ${ }^{6}$ ). They are found in standing or slowrunning water, attached to submerged plants, sticks, and stones. 'Throughout the winter they live at the bottom of ponds, below the ice. The body of Hydra is soft and lighly contractile, so that, when first drawn from the water, it appears like a speck of jelly. Left undisturbed, the animal expands, and its five to eight tentacles wave

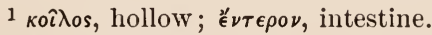

${ }^{2} \kappa \nu \delta \delta \eta$, nettle.

${ }^{3} \mathrm{~A}$ key to the principal subdivisions of the Cnidaria and especially of the Hydromedusæ will be found in the Appendix to this Chapter.

4 " $\delta \rho a$, a mythological monster, capable of regenerating its head.

5 Green.

6 Brown. 
slowly about in search of food. The tentacles are richly supplied with nettling cells, each of which contains a fluid-filled capsule, in which is coiled a thread-like tube.

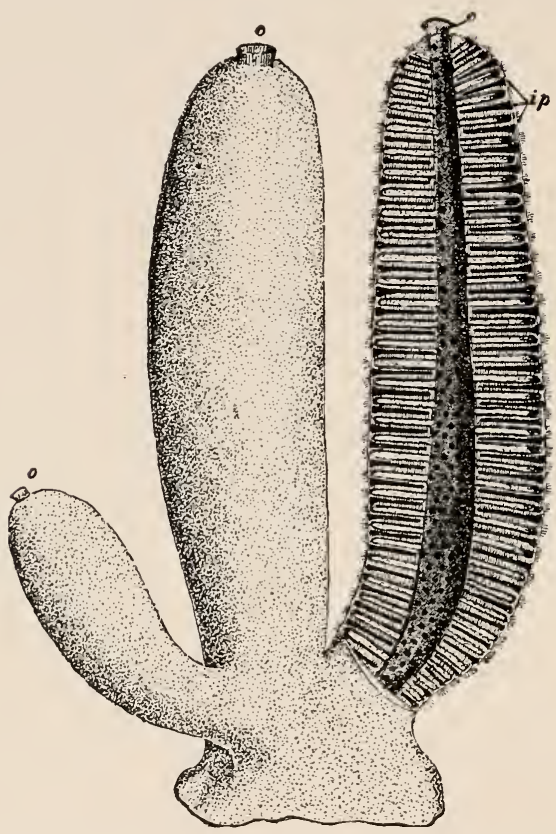

Fig. 192. - Sycon gelatinosum. A portion slightly magnified: one cylinder (that to the right) bisected longitudinally to show the central stomach cavity opening on the exterior by the osculum, and the position of the incurrent and radial canals; the former indicated by the black bands, the latter dotted. ip marks the position of three of the groups of inhalant pores at the outer ends of the incurrent canals; o, osculum.

When stimulated by contact with some foreign body the tentacle closes around it, while from each capsule the lasso-thread rolls out as the finger of a glove is rolled inside out, and discharges the irritating poison.through 
the lumen of the thread. If a small animal has been the irritant, it is instantly caught in the thread, paralyzed by the poison, and soon conveyed to the Hydra's moutl. The principal food of Hydra is small worms and the smaller Crustacea, such as Daphnia and Cyclops.

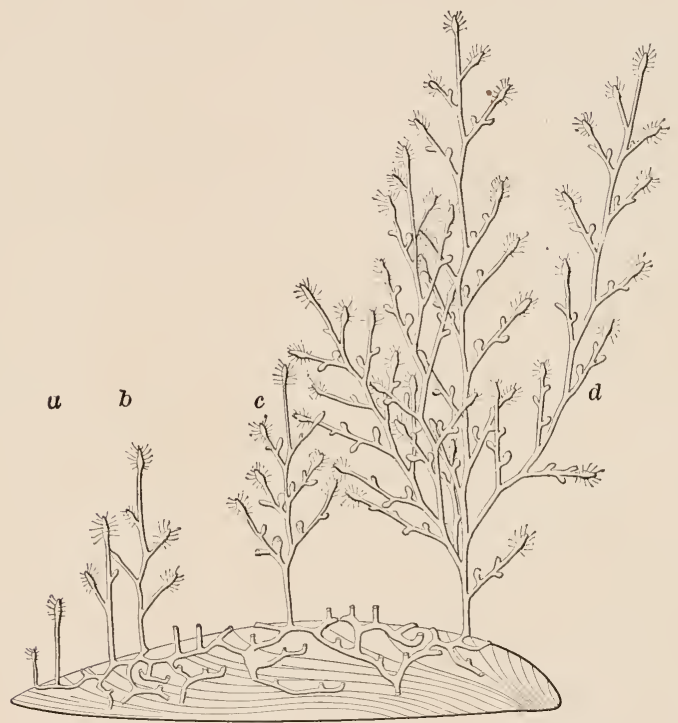

Fig. 193. - A colony of Cordylophora lacustris, on a shell of Mytilus. For clearness, a number of the erect branches are cut off at the stolon. $a$, very young shoot without lateral branches; $b$, young stock with lateral branches but no gonophores; $c$, a stock with gonophores on lateral branches; $d$, fully grown stock with lateral stems. After Schulze.

Fresh-water Cnidaria are of extremely few kinds. Hydra was once regarded as the only instance, but others are now known. One of these, called Cordylophora, is found chiefly in brackish water or in fresh water, near the coast. Like many of the marine hydroids, Cordy- 
lophora produces its young in special capsules, called gonophores, which are rudimentary jelly-fishes (Fig. 193). The young become free when they have gained an elongated, cylindrical form. There are other fresh-water species which have free jelly-fishes. In this country we have a species, Microhydra ${ }^{1}$ Ryderi, hitherto known only about Philadelphia, whose hydroid stage is extremely small and bears no tentacles. The jelly-fishes are set free during July. Fresh-water jelly-fishes have also been described from Lake Tanganyka, Africa, and from a tank at Regent's Park, London, to which they had doubtless been imported on plants. It is very probable that all fresh-water hydroids which produce jelly-fish have, geologically speaking, recently come from the sea. Hydra, however, is probably a long-established fresh-water species.

The marine hydroids are, in contrast to the fresh-water ones, very numerous. The Hydrocorallidæ ${ }^{2}$ are peculiar in that they secrete a great amount of calcareous substance, so that they were formerly regarded as belonging to the typical corals (Scyphozoa). They may be easily distinguished by the absence of raclial septie in the cups occupied by the hydroid. Here belong the millepore corals of Floricla.

The Tubularidæ ${ }^{3}$ include some hyclroids of large size, single individuals of Tubularia becoming six inches long. Other species grow on gastropod shells which are oceupied by hermit-crabs (Figs. 194 and 195). So thickly do they grow that they make a plush-like covering on the upper part of the shell, and they have the curious halit

1 Small Hydra.

2 Combining the qualities of Hydra and the corals.

${ }^{3}$ From tubulus, a little tube. 
of building out the lip of the shell so as to enlarge the aperture. They do this in order that the hermit-cral), as it grows larger, shall not be forcerl to exchange the shell for a larger one, leaving the hydroids on the cast-off shell to roll about on the beach and perish.

Of the Campanularidæ, ${ }^{1} \mathrm{or}^{\circ}$ bell-hydroids, one of the common representatives is Obelia, ${ }^{2}$ which may be found at low tirle langing from rocks beneath seaweed, and looking like delicate white threads (Fig. 196). Observed

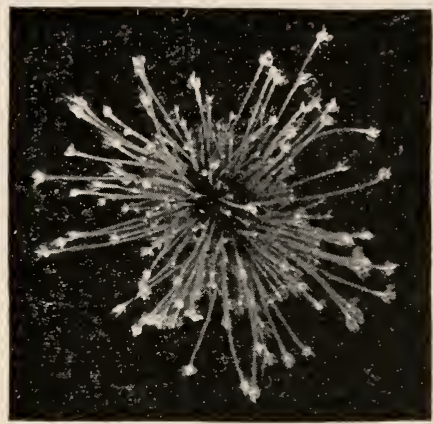

FIG. 194. - Stylactis, a tubularian hydroid, growing on a snail. Nat. size. Photo. of living animal by W. H. C. P.

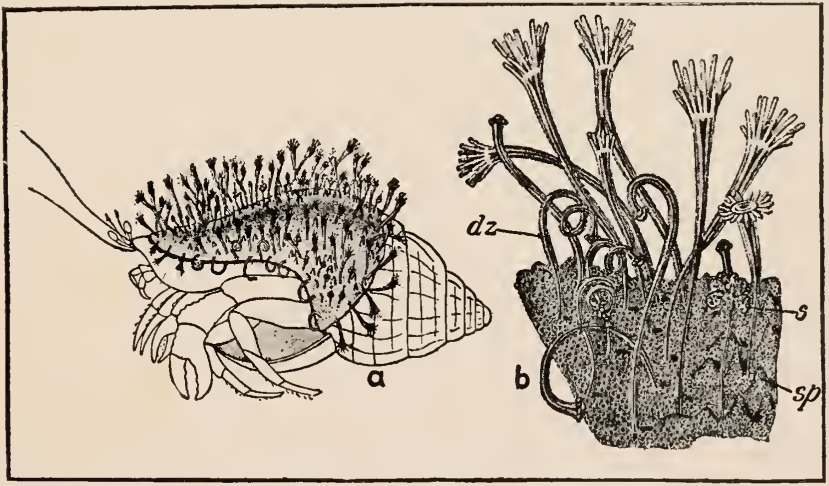

FIG. 195. - Hydractinia, a tubularian hydroid. a, colony growing on gastropod shell inhabited by a hermit-crab ; $b$, bit of colony enlarged ; $d z$, modified, tactile, individuals; $s$, reproductive individuals; $s p$, spines. From Parker and Haswell. 
uncler the microscope each stem appears as a series of hychanths placed in zigzag fashion, one beyond the other.

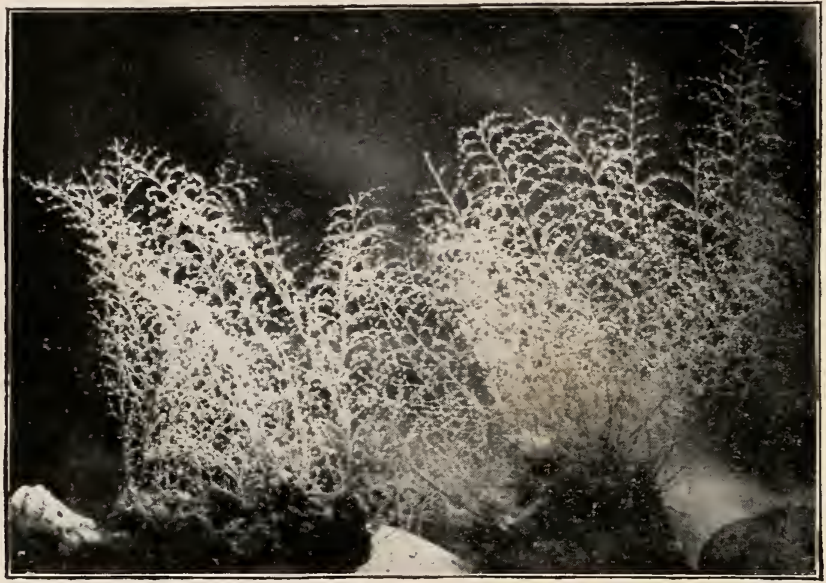

Fig. 196. - Obelia (?), a group of campanularian hydroid colonies. Nat. size. Photo. by W. H. C. P.

Another common kind is Sertularia, ${ }^{1}$ which forms rusty brown threads (Fig. 197). All the hychanths of one stem

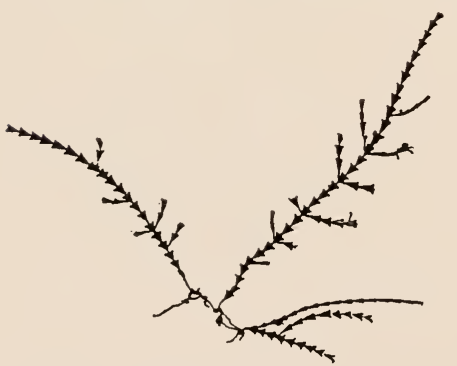

Fir. 197. - Sertularia, a small colony. 1.5) nat. size. occur in one plane and opjositely.

Both tubularian and campanularian hychoids may give rise to jelly-fishes. These jelly-fishes are formed as buds on the hydranth, and after they become able to move of themselves they are cut off from the parent and

${ }^{1}$ Derived from serta, garland. 
swim away. The jelly-fishes then give rise to the sexual products and discharge them into the water (Fig. 198). In other cases the jelly-fish is formed hut never separated

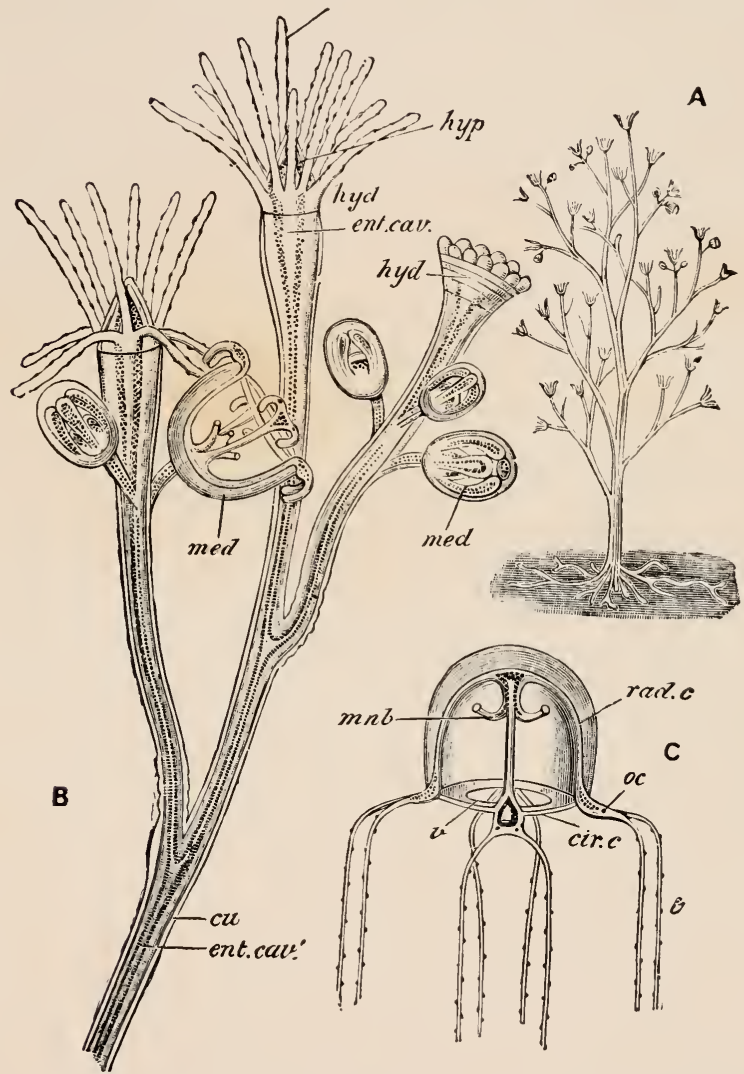

Fig. 198. - Bougainvillea ramosa. A, entire colony, natural size; $B$, portion of the same magnified; $C$, immature medusa; cir. $c$, circular canal; $c u$, cuticle or perisare; ent. cav, enteric cavity; hyd, polyp or hydranth; hyp, hypostome or manubrium ; med, medusa ; mnb, manubrium ; rad. $c$, radial canal; $t$, tentacle; $v$, velum. From Parker's "Biology," after Allman. This is closely allied to the New England B. supercilians. 
from the parent, and the eggs develop in the bud. In still other cases a mere burl, called gonophore, is formed, which becomes full of sexual products without ever acquiring resemblance to a jelly-fish. The jelly-fish is the primitive type which has undergone a reduction in some cases to a gonophore. It is an interesting fact that in certain species sometimes jelly-fishes and sometimes gonophores will be produced. In the Campanularidre the

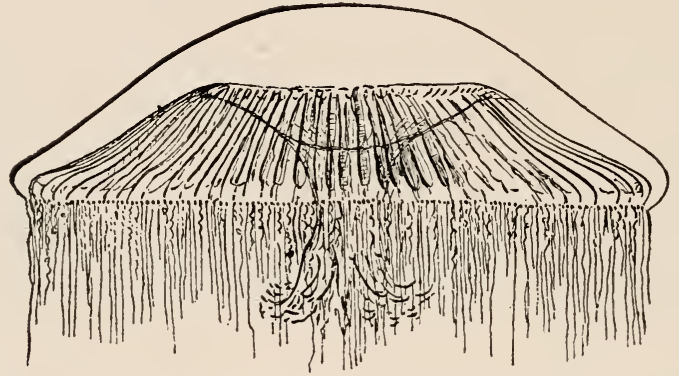

FIG. 199. - Zygodactyla. Reduced. From a drawing by A. Agassiz.

gonophores are encased in a cuticular capsule, but in the Tubularidie they are quite naked.

There are certain hydromedusæ in which the hydroid stage is unknown or known to be lacking. Here belong some jelly-fishes of large size, like Zygodactyla, one of the Trachomedusæ of our coast, which may become eight to ten inches in diameter (Fig. 199). Besides these the sea contains many small species, which are easily captured in the net, and which are of extreme beauty and delicacy.

Besides the Hydromeduse, the group of Hydrozoa includes the Siphonophora. ${ }^{1}$ These animals are always colonial and free-swimming, and are among the most

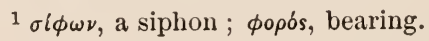


beautiful inhabitants of the sea. Those who have crossed the Atlantic are acquainted with the "Portuguese man-of-

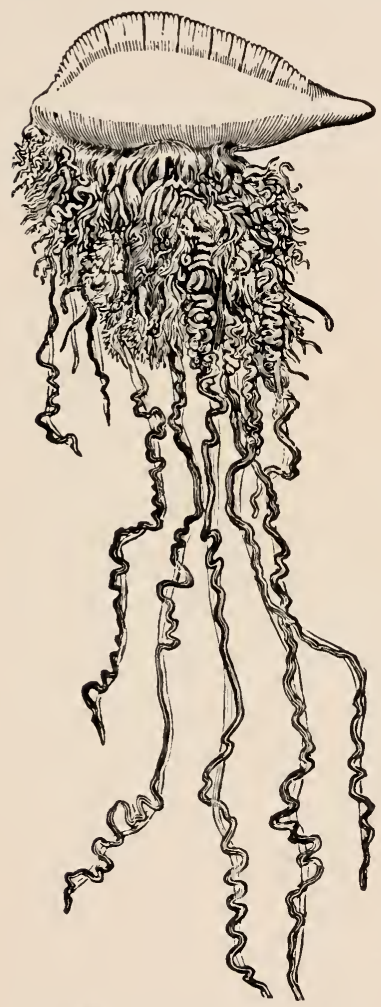

Fig. 200. - Physalia arethusa. Nat. size. After Agassiz.

Fig. 201. -- Halistemma tergestinum. The entire colony. $c \varkappa$, cœnosare; $d z$, dactylozooid ; hph, hydrophyllium or bract; nct, nectocalyx or swimming-bell; ntc, battery of nematocysts; $p$, polyp; $p n$, pneumatophore or float; $t$, tentacle. After Claus.

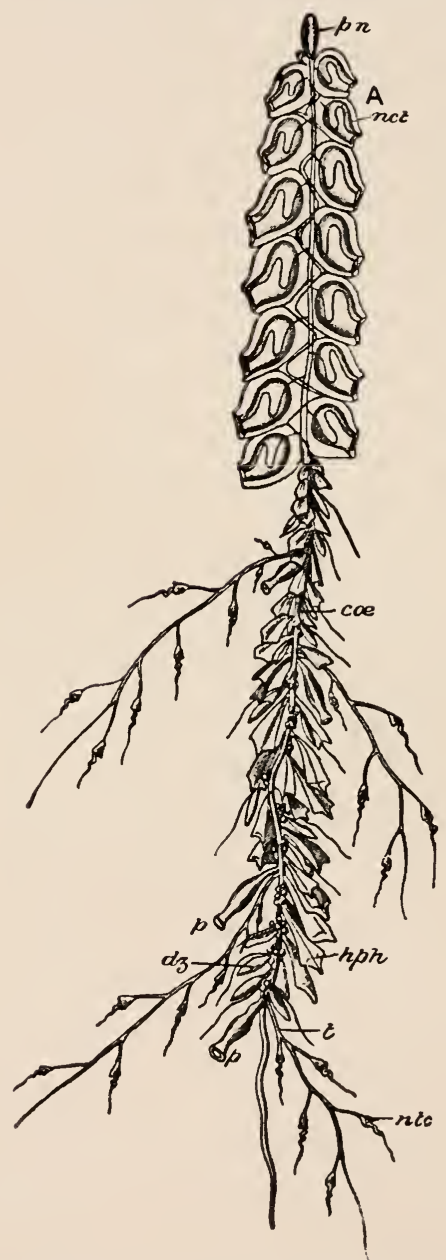


war" (Physalia, ${ }^{1}$ Fig. 192), which often swarms in the Gulf Stream. The huge float which lies on the surface of the water serves also as a sail by which the animal is transported by the wind. There are other smaller, more graceful species of more typical form (Fig. 201). The structure of a siphonophore is very complex. From the float hangs a central stem. Cpon this stem are budded feeding zooids-hydranth-like forms provided with mouth and tentacles - and reproductive zooids - gonophore-like forms which produce the germ cells. There are leaf-like expansions also, which are rudimentary medusæ. All the many forms budded on the stem are modifications of the hydroid type.

Contrasted with the Hydrozoa are the Scyphozoa, ${ }^{2}$ which are, on the whole, larger animals. These, too, occur both in the sessile, polyp form and in the jelly-fish form. The sea-anemones are common examples of the polyp. These are, for the most part, solitary, fleshy creatures, often brilliantly colored, and therefore appropriately called by the Germans "sea-roses," and in this country and in England "sea-anemones." They are of cylindrical form, bear a circle of tentacles around the mouth at the upper end, and have a muscular base by which they attach themselves. They vary in diameter from one-sixth of an inch to two feet. Some species live in the sand, out of which they get some organic food, and at least one species (Minyas ${ }^{3}$ ) is free-swimming.

Our commonest Northern sea-anemone is Metridium marginatum (Fig. 202), which occurs on rocky shores south

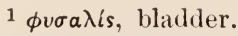

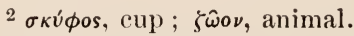

${ }^{3}$ For a figure of Minyas, see Harker and Haswell, "Text-book of 'Zoology," p. 189, Fig. 139. 
to New .Jersey, but reaches its maximum development along the coast of Maine. It varies greatly in color, some individuals being white, others salmon-colored or olive. The flat upper surface bears the slit-like opening to the internal sac. Either one or both angles of this slit have thickened edges, and corresponding to this difference is a

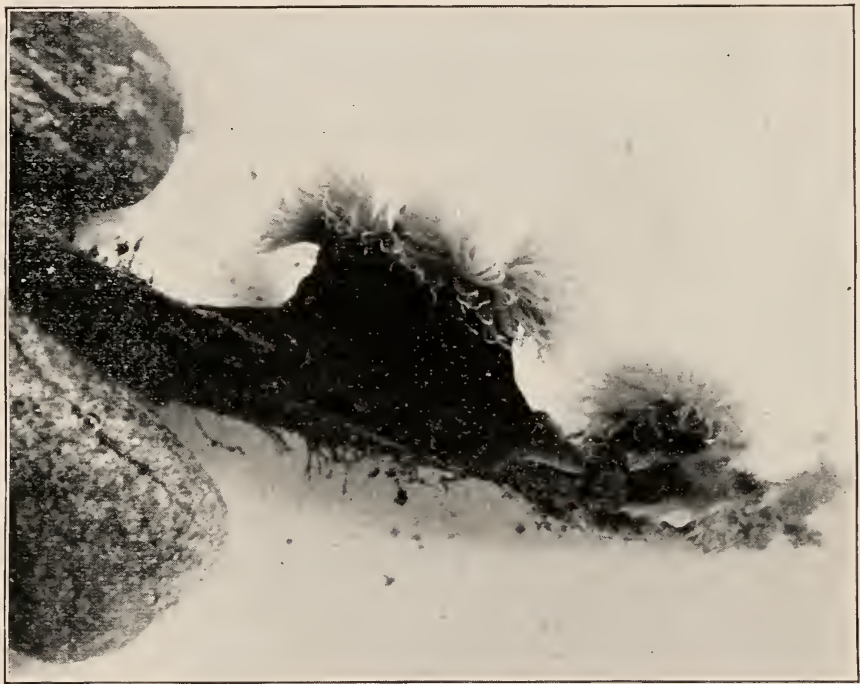

Fig. 2(1). - Metridium, one of our sea-anemones. Two individuals shown expanded. Photo. of the living animals in the water, by W. H. C. P.

difference in the internal structure. Insicle, the central cavity is separated into compartments by radial partitions.

The coral polyp does not differ essentially from Metridium. But it has the habit of secreting lime at its base, so that, in course of time, a high cup is built up. The top of the cup bears radial septa, ${ }^{1}$ which are laid down 
in the interspaces between the fleshy partitions mentioned in speaking of Metridium. Since most corals, like

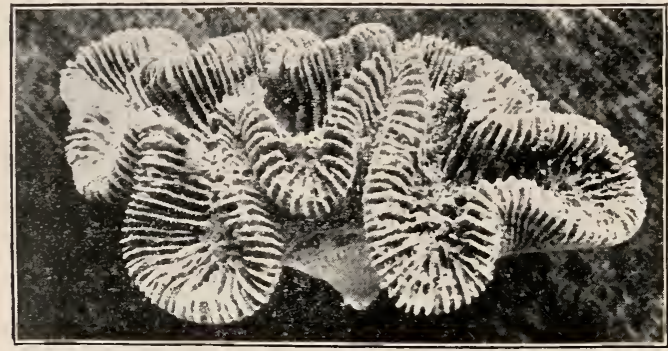

FIt. 203. - Coral cup of manicina. Nat. size. Photo. by W. H. C. P.

liydroids, bud freely, and since every bud secretes coral at its base, an extensive and complicated limy mass may be produced. 'This is the way in which the brain corals and

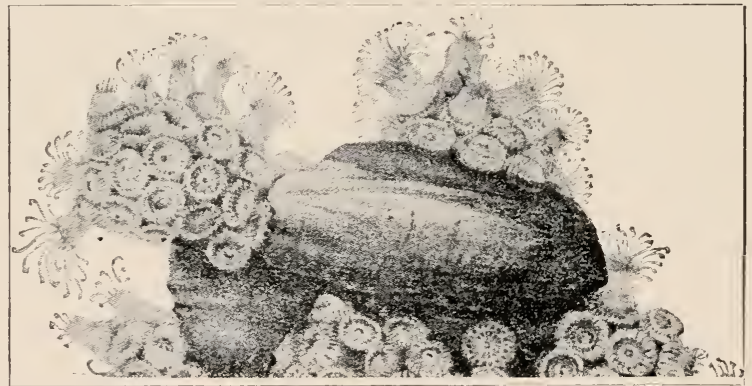

FIc. 204. - Astrungia dunx, a cluster of our Northern coral-polyps, resting on limy hases of their own secretion. The animals are extremely delicate and transparent. From a lithograph by Lonis Agassiz's artist Sonrel.

branching corals are formed. The only coral of the northeastern United States is Astrangia dance, which occurs north to Cape Cod. It is a beautifully transparent species, and forms thin encrustations of limy matter (Fig. 20t). 
Coral reefs are almost exclusively the product of coral polyps modified by the envirommental conditions. The reef-building corals live in shallow water from low-water mark to a depth of one hundred feet only. Their distribution along the coast line depends upon the winter temperature of the sea, since they cannot live at a temperature below $20^{\circ} \mathrm{C}$.; consequently reef-building corals are confined to warm latitudes. However, tropical shores which are washed by arctic currents, such as the west coasts of Africa and South America, are destitute of coral formations. On the other hand, shores in the temperate zone that are washed by tropical currents, such as our Florida coast which is washed by the Gulf Stream, may be rich in coral reefs. Corals demand undiluted sea-water, hence they do not thrive in harbor's which receive the waters of great rivers - a circumstance of great importance for the commerce of tropical countries. Moreover, corals require a rock bottom on which to build, and they cannot gain a foothold on shores where the cliffs descend precipitously to great depths. Coral reefs receive different names according to their varying relations to the shore. Fringing reefs are found close to the shore line. Barrier reefs lie at some distance from land, with a body of quiet water between them and the shore. An Atoll is a further step, in which a small island, formerly surrounded by a barrier reef, has disappeared, leaving a circular reef surrounding a body of water (Fig. 205). Exactly how the central land disappears, whether by sul)sidence of the sea floor as the reef grows up or by being washerl away, is still a matter of dispute.

Budding and the Formation of Colonies. - The Cnidaria are one of three groups of animals which have the habit of 
forming colonies by budding, somewhat after the fashion of plants. The other groups are the Bryozoa, or " seamats," and the Tunicata, or "sea-squirts." In all cases the buds arise from a definite part of the parent body and develop into a definite form, often exactly like that produced from the egg. When the buds remain attached to the parent, a compound individual or colony is produced. These colonies differ greatly in form. Thus among hydroids we have colonies which produce runners, from which alone, and not from other hydranths, new hydrantlis arise.

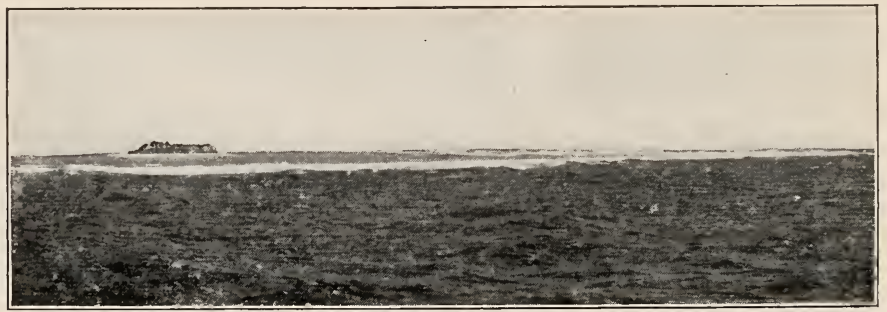

Fig. 205. - Atoll in Fiji Islands (Nanuku Levu). The large circle of white made by breakers indicates the position of the coral reef. A small bit of land still remains in the interior lagoon. Photo. by Dr. Wr. McM. Woodworth. From A. Agassiz, "Coral Reefs of Fiji.",

In another case (()helia), one hydroid buds from the side of another and rises beyond it, continuing the main stem of the colony. Since its descendants do the same, the stalk is made up of successive generations of hydranths. Sometimes the hydranths are placed close together and olposite, like the leaves of Arbor vitre (Sertularia, Fig. 197). Again, there may be a main stalk composed of one hydranth and a series of lateral branches in one plane, making a fan-like arrangement of the colony. Or the lateral branches may arise in any plane, producing a bushy colony. 
The variety in the form of the colony possessed even by a single species adds to the diversity of hydroids.

The Ctenophora, or sea-walnuts, are a small group of exclusively marine organisms which float on the surface of the sea, and like most animals having this habit have become clear as glass. Many of them are highly phosphorescent (Fig. 206).

In any colony a division of labor may occur among the constituent individuals, or zooids. Thus in the simplest cases we have crawling zooids, or stolons, and feeding zooids. In Hydractinia ${ }^{1}$ we have, in addition, reproductive zooids, nettling zooids, and passive, thorn-like zooids. Here we see how completely subservient the individual is to the good of the community. This subserviency has ruled in all successful colonies of animals.

Regeneration. - C losely allied to the power of budding is that of reproducing a lost organ. Supposing the "head" (mouth and tentacles) of a Hychra to be cut off, the base will reproduce the lost head. Suppose the base to be removed, the head will reproduce a new base. When a Hydra is cut in two transversely, two Hydras result where formerly there was only one. Even three or more Hydras may arise when a Hydra has been cut into so many pieees. Where other conditions are favorable to life, you can hardly kill a Hydra by mutilation. A trace of this 1 Fig. 195. 
capacity for regeneration, as it is called, is seen also in man when a wound heals, and a diseased organ, even when partly destroyed, is made whole again.

\section{APPENDIX TO CHAPTER XIV}

\section{KEY TO THE PRINCIPAL SUBDIVISIONS OF THE CNIDARIA}

$a_{1}$. Body composed of 4,6 , or many rays ; nettling organs well developed.

$b_{1}$. Mouth at apex of an oval cone; cavity simple . . . . . . Class

$c_{1}$. Existing for the most part in 2 forms ;

a sessile one, hydroid; and a freeswimming one, medusa. The hydroid form is sessile; the medusa are mostly small, or may remain attached to the hydroid . Order

$c_{2}$. Free-swimming colonies composed of hydroid and medusoid individuals budded on a floating stem . Order

$b_{2}$. Mouth at bottom of an oral crater ; cavity dividerl by radial partitions. The more common forms are large jelly-fishes . Class

$a_{2}$. Body composed of 2 radii, with 8 meridional

rows of plates of cilia ; nettling capsules modified to form adhesive organs . . Class

Hydrozoa

Hydromedusce

Siphonophora (Portuguese manof-war, etc.)

Scyphozon fied to form adhesive organs

Ctenophora (Sea-walnuts)

KEY TO THE FAMILIES OF THE HYDROMEDUSA

$a_{1}$. Hydroid individuals, without cuticula or stolons; fresh water . . . . . . Hydroida

$a_{2}$. Hydroid individuals, if present, with cuticula or (Ex. Hydra) stolons; marine. 
$b_{1}$. Hydroids present; medusæ without free auditory clubs.

$c_{1}$. Hydroid stocks, with calcareous external skeleton ; no free medusæ . Hydrocorallida

$c_{2}$. Hydroid heads never enclosed in cuticular cup; medusæ, if free, without marginal vesicles; gonads on manubrium . . · $\cdot$

$c_{3}$. Hydroid heads enclosed in calyx ; medusæ, if free, with gonads on radial canals . . . . . . Campanularide

$b_{2}$. Hydroids absent; medusæ with free-standing auditory clubs.

$c_{1}$. Gonads on radial canals . . . Trachomeduse

$c_{2}$. Gonads on manubrium . . . Narcomeduse 


\section{CHAPTER XV}

\section{THE PARAMECIUM AND ITS ALLIES}

Paramecium ${ }^{1}$ belongs to the Protozoa, ${ }^{2}$ the lowest group of animals, characterized by the fact that the body contains no specialized tissues and organs, but is made up of a single cell, and is usually microscopic. Protozoa live in water or in moist situations. ${ }^{3}$

The Infusoria were unknown to man until the latter half of the seventeenth century, when a Dutch naturalist named Leeuwenhoek, by means of the newly invented compound microscope, studied and described several kinds which he had found in standing water and called animalculie or water insects. As the microscope became perfected, progress was made in the study of these organisms, but even in the early half of our century several eminent zoologists maintained that the Infusoria possessed digestive, neural, hæmal, and reproductive organs. The proper structure of the Infusoria has been generally recognized only within the last fifty years.

The conceptions formerly entertained concerning the origin of Infusoria were as erroneous as those relating to their internal structure. These erroneous conceptions were an inheritance from a time when even scientific men

$1 \pi$ a $а \mu \eta \dot{\eta} \kappa s$, somewhat long.

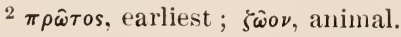

${ }^{3}$ Keys to the four classes of Protozoa and to the orders of Infusoria will be found in the Appendix to this Chapter, page 229. 
held that many of the larger animals, such as eels, bees, and flies, were generated without parents. 'This was the theory of "spontaneous generation." In time this theory became much more restricted. It was found that the maggots in putrid meat are not generated "spontaneously" out of the meat, hut are derived from flies' eggs, and, in their turn, develop into fertile flies. But the irlea that Infusoria are formed out of inorganic material continued to be held until much more recently, until Pasteur, Tyndall, and others demonstrated that fluids heated to a sufficiently high temperature for a sufficient time, and then, while hot, sealed from contact with air, do not develop Infusoria, no matter how long they may be kept. This method of excluding Infusoria and other minute organisms, especially bacteria, is employed to-day in canning meat, vegetables, and fruit. 'The experiments referred to gave a death-blow to the theory of spontaneous generation, and led to the conclusion that all Infusoria are derived from living germs.

Whence the living germs come which enter the water it is not difficult to determine. Many Infusoria can pass into a quiescent "spore" stage in which they may be dried and blown about without loss of life. Dry grass, straw, and other substances contain some of the germs, and others float in the air and fall as dust into the water. Even drinking water may contain here and there an infusorian or its germ. When, therefore, one fills a clean vessel with pure water, and puts hay or dry leaves in it, and lets it stand open to the air in a warm place, the result is pretty sure to be that germs develop in the mixture. The heat and the organic infusion merely facilitate this development. 
Of all the Infusoria, none is more abundant than Paramecium. It occurs everywhere, principally in stagnant fresh water, but also in salt water. It lives entirely on vegetable fool, and is sure to abound wherever plant matter is undergoing decay. When a culture is once

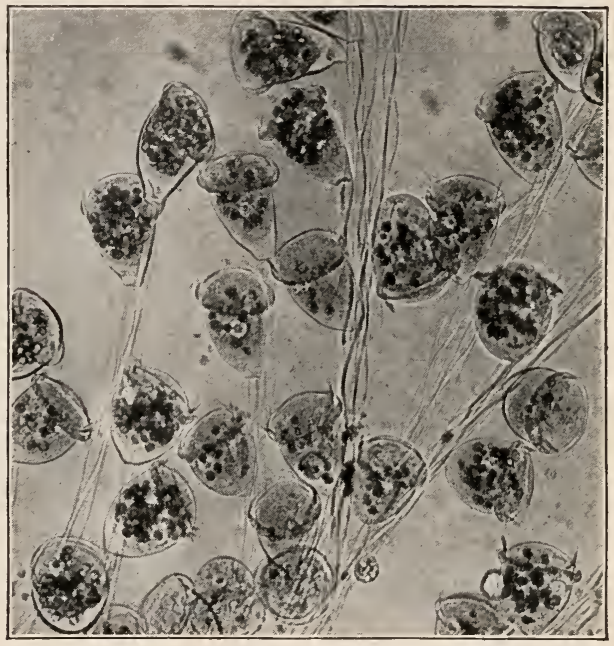

FIG. 207. - Carchesium, a stalked Vorticella. Greatly magnified. From a photograph of the living animals.

started from a hay infusion, - which takes one or two weeks, - it will be found to thrive especially on corn-meal.

As an example of the Heterotricha, Stentor, ${ }^{1}$ the trumpetanimalcule, may be mentioned. Stentor is found attacherl to vegetable débris - sticks, stones, water-weeds, and other objects-occurring in pools, ponds, lakes, and sluggish streams. These things should be gathered and placed in

$1 \Sigma \tau \epsilon \nu \tau \omega \rho$, a Greek at Troy, known for his loud voice. 
an aquarium, when the Stentors, if present, will attach themselves to the glass sides of the vessel. The attachment of Stentor to objects is not permanent, for it may loose its hold and swim free. When the animal is stained in hrmatoxylin, the characteristic nucleus, looking like a chain of beads, becomes evident.

Vorticella, ${ }^{1}$ the bell-animalcule, is found in pools or infusions, permanently attached by a long stalk. When the animal is irritated, it contracts its stalk, which twists into a close spiral. Carchesium 2 differs from Vorticella, in forming colonies, so that a number of heads are attached to a central stalk. A colony, when fully expanded, appears like a fine, white mould attached to a submerged object. In both of these types the food consists of small organic particles, which are swept into the gullet by the circlet of cilia placed around the upper end of the body.

The Suctoria ${ }^{3}$ are sessile Infusoria, from whose upper surface numerous remarkable sucking-tentacles arise. By means of these tentacles the animal can hold on to Paramecia and other free-swimming Infusoria, from which it extracts the body fluids. Some Suctoria are stalked (e.g. Podophora ${ }^{4}$ ), while others are unstalked (e.g. Acineta ${ }^{5}$ ). They are found most abundantly in standing water, either fresh or salt, and are often attached to other animals, Bryozoa, entomostracans, and pulmonate mollusks.

Of the group Flagellata, ${ }^{6}$ or lash-animalcules, Euglena ${ }^{7}$ is a common representative. It is of microscopic size, but occurs in such numbers as often to give a decided green
1 Dim. from vortex, whirlpool.

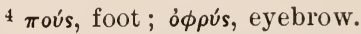
$2 \kappa a \rho \chi \eta \dot{~} \sigma \nu \nu$, goblet, Fig. 207.

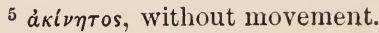
${ }^{3}$ From sugere, suctum, to suck.
${ }^{6}$ flagellum, a lash.

${ }^{7} \epsilon \ddot{\gamma} \gamma \lambda \eta \nu$ s, with a beautiful eye. 
color to the pools of water it inhabits. It is spindleshaped, and bears a flagellum at its anterior end. At the base of the flagellum is a red "eyespot."

Allied to Euglena is Volvox, ${ }^{1}$ a spherical, multicellular

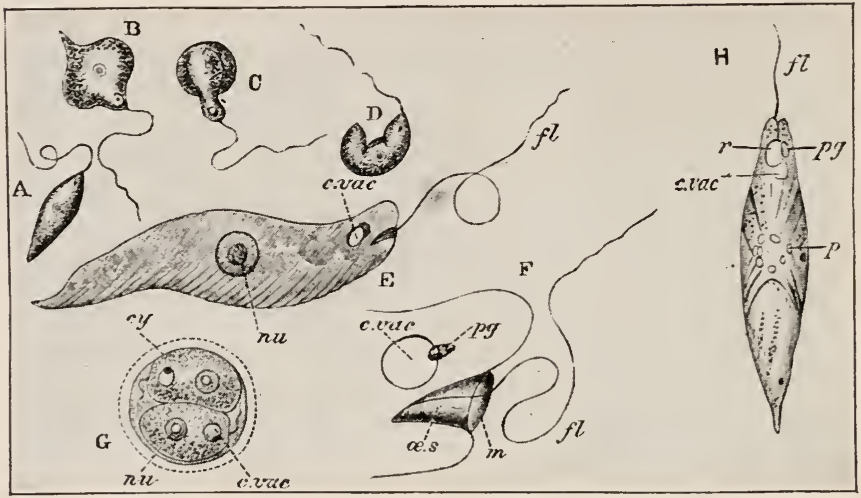

Fig. 208. - Euglenc viridis, a lash-animaleule. $A-D$, four views illustrating the characteristic movements; $E$ and $I$, enlarged views of adult; $F$, outline of anterior end further enlarged ; $G$, resting stage; $c y$, cyst ; $H$, Hagellum; $m$, mouth; $n u$, nucleus; $r$, gullet; $p g$, pigment spot; $r$, reservoir. After Kent and Klebs.

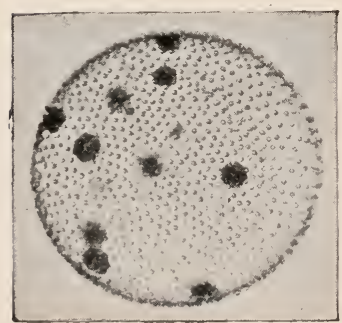

FiG. 209. - Volvox globator. Much magnified. Photo. of the living animal. organism, half animal and half planit, and forming a sort of connecting link between the Protozoa (or one-celled animals) and the multicellular higher organisms. Volvox occurs abundantly in our ponds and gets its name from its manner of revolving in the water (Fig. 209).

Very different in habitat from 
the foregoing are the Sporozoa, ${ }^{1}$ which are minute rodlike organisms, occurring as parasites in the body of various kinds of higher animals, especially in the foodtract. They increase by transverse division of their rodlike bodies; but periodically they encyst, and divide into numerous "spores," which, under favorable conditions, are set free in great numbers.

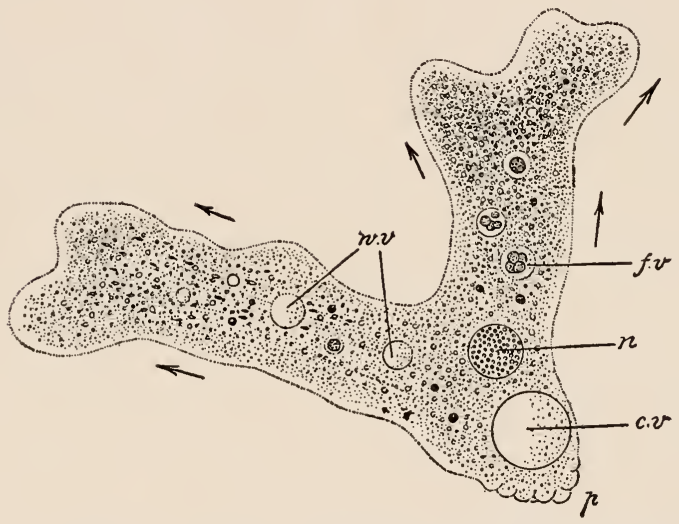

Fra. 210. - Amoba, the proteus animalcule. Greatly magnified. $u$, the muleus; $w . v$, water vacuoles; $c . v$, contractile vacuoles; $f$. $v$, food vacuoles. E. B. Wilson, "The Cell."

Of all Protozoa, probably the simplest is Amœba. ${ }^{2}$ 'This . type varies greatly in size, from $0.02 \mathrm{~mm}$. to about $0.3 \mathrm{~mm}$. It appears as a clear, highly refractive body of changing outline. The body does not look homogeneous when viewed with a high power, but contains various granules derived from ingested food, vacuoles of water, and a transparent, slightly more dense, spherical or ellipsoidal body,

$1 \sigma \pi$ ópos, spore ; $\zeta \hat{\omega} o \nu$, animal.

$2 \alpha \mu \circ \beta \eta$, alteration. 
the nucleus, which it is often difficult to make out on the living animal. The whole substance of the Amoba is mobile, so that the internal organs have no fixed relation to one another. Quantities of Amoba can usually be obtained for study by gathering the mud from the edges of stagnant pools, or by scraping the green growth from flower-pots, and letting these gatherings, covered with a little water, stand in a fairly warm place for two or three weeks.

Even the Protozoa bear important relations to man. One species, Amceba coli, has long been known occasionally to inhabit the food canal of man, and it is now known that an amobiform organism (probably one of the Sporozoa) is the cause of malarial diseases. Since in one common species 48 hours are required to complete a developmental cycle, the recurrence of the fever every alternate day is explained. It is now demonstrated that at least one of the common agents in infection with malaria is the mosquito, which carries the germs of the malaria parasite from one host to another. Other Sporozoa, of at least one species, are parasitic in the human liver, others attack fish and cause them to die in large numbers; still others cause sickness and death among domesticated animals. The Texas fever among cattle is believed to be caused by an organism ${ }^{1}$ belonging to this group, the inoculation of the cattle being effected by the cattle-tick.

The reproductive capacity of Protozoa is so great that their importance in the world, despite their small size, is not astonishing. One of the early students of Protozoa, Ehrenberg, computed that from one individual of Puramecium aurelia 268,000,000 might be developed in one

1 Called Piroplasma bigeminum. 
month by the process of division. Apparently the division cannot go on indefinitely, but from time to time the Paramecia unite temporarily in pairs and undergo an exchange of some of their nuclear matter. This is doubtless the beginning of what is known in the higher animals as sexual reproduction.

\section{APPENDIX TO CHAPTER XV}

KEY TO THE FOUR CLASSES OF PROTOZOA

$a_{1}$. Without non-retractile appendages.

$b_{1}$. With retractile pseudopodia . . . . Rhizopoda

$b_{2}$. Without pseudopodia; covered with an imperforate cuticula ; parasites . . . Sporozoa

$a_{2}$. With non-retractile appendages.

$b_{1}$. No cilia, but with one or more flagella . . Flagellata

$b_{2}$. With cilia, or sucking tentacles . . . Infusoria

(Ex. Parameeium)

KEY TO THE SUBCLASSES AND ORDERS OF INFUSORIA

$a_{1}$. With vibratile cilia and no sucking tentacles . Ciliata $b_{1}$. Body everywhere closely beset with cilia.

$c_{1}$. No adoral zone . . . . . Holotricha

$c_{2}$. Adoral zone present . . . . Heterotricha

$b_{2}$. Body only partly ciliated.

$c_{1}$. Cilia limited to ventral side . . . Hypotrich

$c_{2}$. Cilia form a circlet around or at upper edge of animal . . . . . Peritricha

(Ex. Vorticella)

$a_{2}$. With sucking tentacles . . . . . . Suctoris 


\section{C'HAP'TER XVI}

\section{THE SMELT AND ITS ALLIES}

THE smelt is one of the class of fishes. ${ }^{1}$ 'This class connprises vertebrates that breathe by means of gills and do not use their appendages for walking.

The smelts, which belong to the salmon family, are preeminently inhabitants of the northern temperate zone, since all but one of the ten genera occur only there. 'They are small marine fishes, and although a few are inhabitants of the deep sea, most live near the shore, and in the spring ascend rivers to spawn. Some of them lave become cut off from descending to the sea and live permanently, as "land-locked" forms, in fresh water. Such "land-locked" individuals are of smaller size than the marine ones. 'The food of smelts, like that of other Salmonidie, is chiefly animal, consisting of smaller fishes or insects, small crustaceans, and mollusks.

Smelt are of considerable economic importance, since they share with other members of the salmon family a delicately flavored flesh. Our Atlantic form, Osmerus ${ }^{2}$ mordar, ${ }^{3}$ which ranges from Delaware Bay northward, is caught most abundantly in Maine. The total Atlantic

1 Keys to the principal orders of fishes and the six suborders of the 'Teleostei will be found at the end of this Chapter, page 252.

$2 \delta \sigma \mu \eta \rho \delta s$, odorous; the Greek name is the equivalent of the English "smelt."

${ }^{3}$ Biting. 
smelt fishery is valued at $\$ 125,000$. Smelt eggs are artificially hatched and planted in rivers previously uninhabited by them. Smelt are said to return to these rivers after spending the winter in the sea. The early settlers on our Eastern coast, like the Indians before them, used smelt to fertilize the land. At present this wasteful proceeding is illegal; but the bones and scraps from the canning factories are used to make commercial fertilizers, since they are rich in phosphorus - an important plant fool.

The family Salmonidæ includes some of our most important food fishes. It is distinguished from other families of Physostomi by the circumstances that both ventral and adipose fins are present, that both premaxilla and maxilla bear teeth ${ }^{1}$ and form the margin of the upper jaw, and that the head is naked, body scaly, belly rounded, and pseudobranchix present. Besides the smelt there are numerous important species. The salmon proper ${ }^{2}$ are restricted to the north temperate and aretic regions, and live either in the sea, migrating to fresh water to spawn, or exclusively in brooks and lakes. The migrations of salmon from the sea up the rivers are remarkable. Hundreds of miles are sometimes journeyed, rapids swum, and falls leaped, for the purpose of laying eggs in some remote lake. The females, with their burden of eggs, have become so exhausted at the end of the migration that most, or all of them, die immediately after laying the eggs. On the Atlantic coast the Penobscot River has the most important run of salmon. The Pacific salmon passes up the Sacramento and Columbia rivers, and up many rivers of British Columbia and Alaska. In these rivers the fish 
are caught as they ascend to breed. Such is the greediness and lack of foresight of the canning fisheries on the

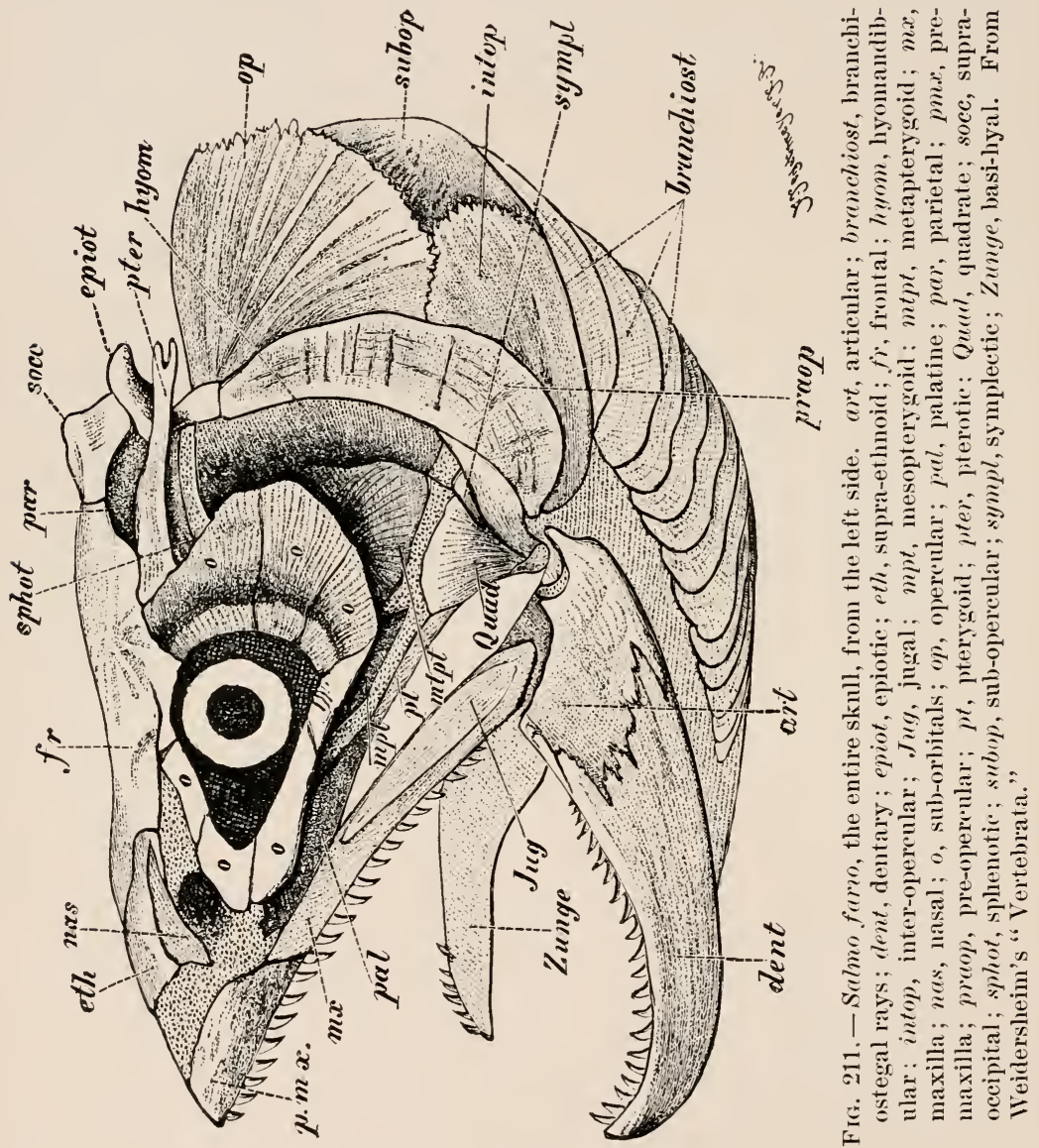

Columbia River that very few salmon are permitted to pass the nets of the canning factories, and consequently 
the apparently inexhaustible supply of this fish has been immensely reduced, and the fishery will soon become destroyed.

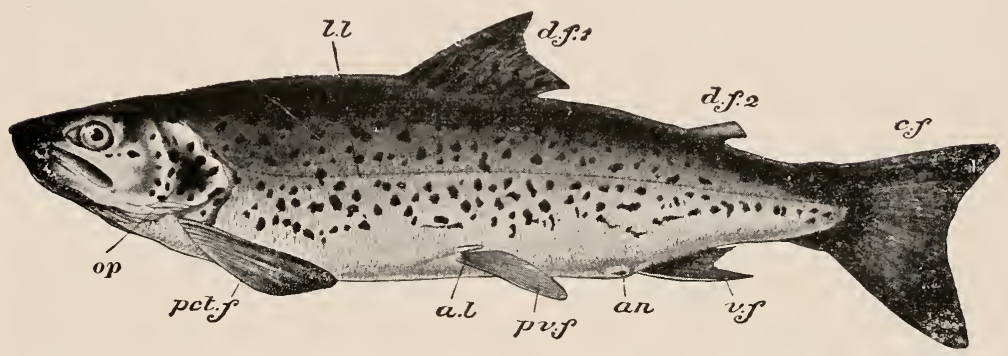

FIG. 212. - Sulmo furio. a. $l$, adipuse lobe of pelvic fin ; an, anus ; $c . f$, caulal fin ; $d . f$. 1 , first dorsal ; $l . f .2$, second dorsal or adipose fin : $l . l$, lateral line ; op, operculum; pet. $f$, pectoral tin; $p v \cdot f$, pelvic fin; $v \cdot f$, ventral fin. After Jardine.

The trout, of which there are a number of kinds on both continents, is commercially much less important than the

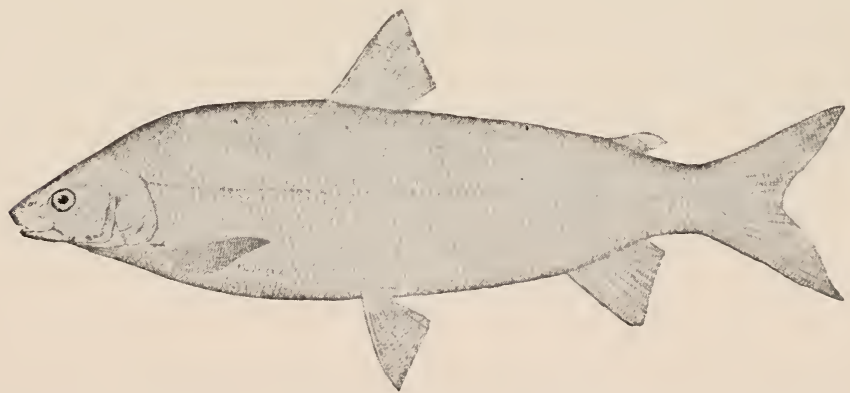

FIG. 213. - Coregonus, the lake whitefish. Much reduced. From Goode.

salmon proper. As a result of overfishing, and the pollution of streams by factories and sewage, this fish is disappearing from Eastern waters. 
The whitefish (Coregonus ${ }^{1}$ ), of which we possess many species, is exclusively an inhabitant of fresh water. ${ }^{2}$ Its teeth are almost completely absent, or very small; it feeds almost exclusively upon small arthropods and mollusks. It is of very great commercial importance, its fisheries being valued at nearly three million dollars a year.

Leaving now the Salmonidre, we may briefly consider some of the other more important families of bony fishes.

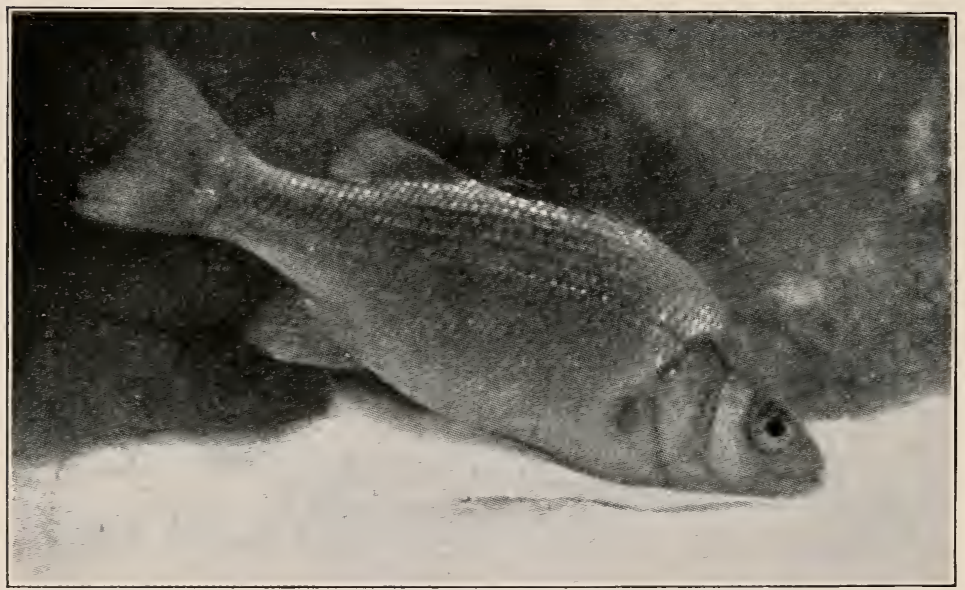

Fic. 214. - Morone americana, the white perch. The fish is searching for food along the bottom of the aquarium, an instinct which it shows in nature also. About one-third nat. size. Photo. of living animal by Dr. R. W. Shufeldt, from "Bull. U. S. Fish Com.," 1899.

The darters are spiny-rayed fishes of small size, from four to seventeen centimetres long, brightly colored, and with well-rleveloped pectoral fins. They live in clear streams, half concealed under stones, and are most abundant in the Mississippi drainage basin.

${ }^{1} \kappa \delta \rho \eta$, the pupil of the eye; $\gamma \omega v i a$, angle.

${ }^{2}$ Fig. 213. 
The perches are a widlespread family, represented in this country chiefly by the common yellow perch of the East, the "wall-eyed pike" of the Creat Lake region, and the white perch of the Atlantic coast (Fig. 21t). 'These fish have an oblong, compressed body covered with small scales; they are highly rapacious, and are believerl to be

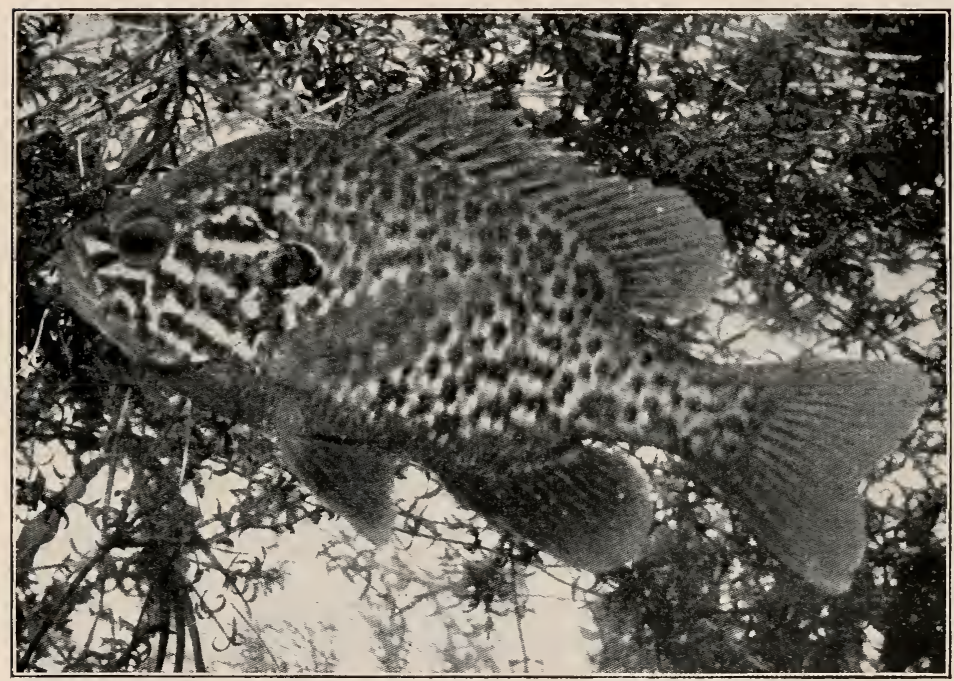

Fig. 215. - Eupomatis gibbosus, the common sunfish. Two-thirds nat. size. Photo. of living animal by Dr. R. W. Shufeldt, "Bull. U. S. Fish Com.," 1899.

destructive to the young of other speeies of fish. They are esteemed as food, although fortunately not to the extent of annihilation.

The sunfishes ${ }^{1}$ have a percoid form, but have only one dorsal fin instead of two. They live in fresh water, have 1 Fig. 215. 
rapacious habits, are brilliantly colored, and build nests in the sand, which both male and female watch over and

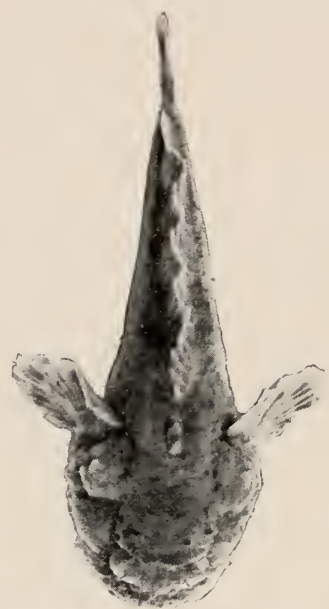

Fig. 216. - Batruchus tau, the toadfish. Dorsal view. Two-thirds nat. size. Photo. by W. H. C. P. defend with courage. Some species living in the Great Lakes are known as black bass or rock bass. 'The small New England species, with the brilliant red edge to the operculum, is called pumpkin-seed.

The toadfishes (Fig. 216) are represented in our faunas by a common species which lives under stones in harbors and attaches its eggs to the under side of stones. It is a vigorous fighter.

The sculpin (Fig. 217) is closely related to the toadfish. Like the latter it has a lroad head and nearly scaleless body. The pectorals are large, and the two dorsals extend along the greater part of the back. Allied to the foregoing is the rock eel (Fig. 218), which is sometimes brought up in the seine from a depth of 8 to 10 fathoms.

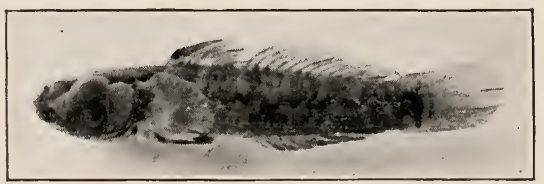

FIG. 217. - Acanthocottus, the little sculpin. Two-thirds nat. size. Photo. by W. H. C. P.

The silversides are especially abundant along our Atlantic coast. 'They have an elongated, somewhat com- 
pressed body, and a broad, bright silvery band on the sides, against a greenish general body color. 'The dorsal

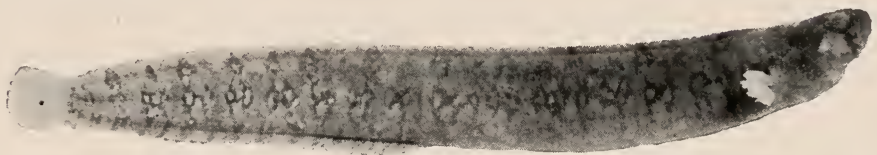

FI'. 218. - Pholis, the rock eel. Right side. Nat.size. Photo. by W. H. C. P.

spines are slender. The fish swim near shore, in dense schools. One species on the Californian coast is known as a "smelt," and is a good food fish.

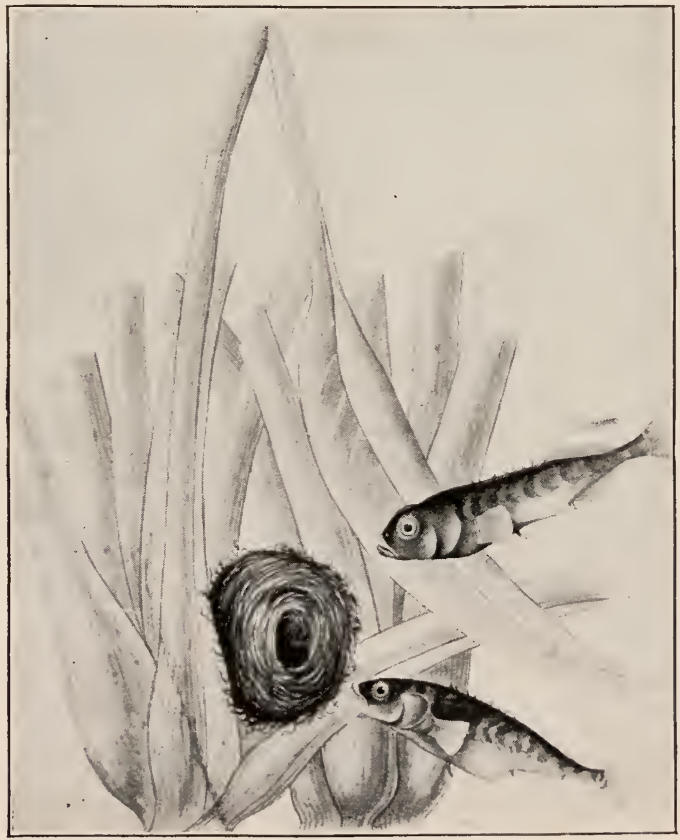

Fig. 219. - Gasterosteus pungitius, the nine-spined stickleback; male (above) and female near the nest in rushes. The female is about to deposit its eggs in the nest. 
The sticklebacks are small, elongated fishes, having an extremely slender tail and a large mouth. The dorsal fin is preceded by two or more large isolated spines. The fishes live in either fresh or brackish water. In some of

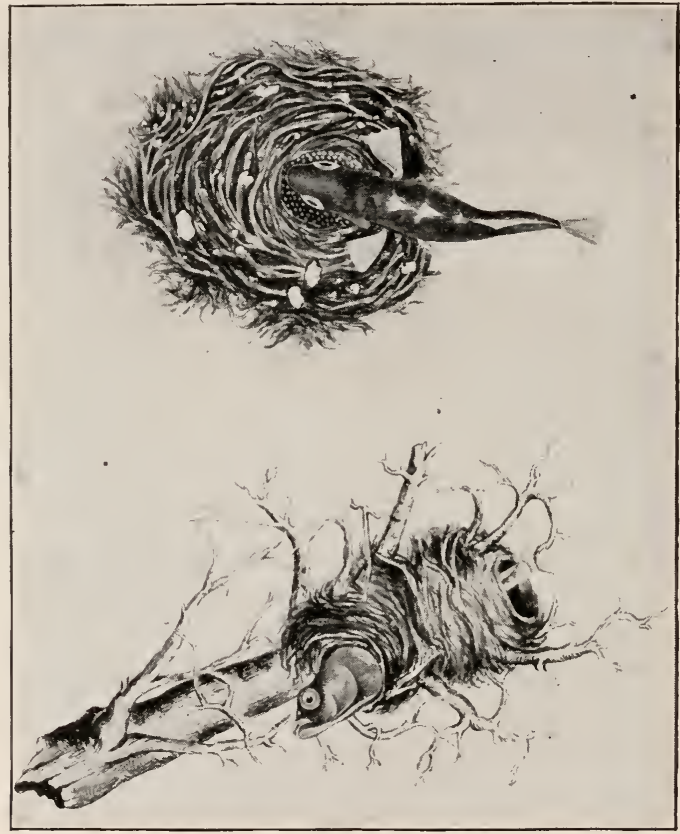

Fig. 220. - Gasterosteus bispinosus, the two-spined stickleback. Above, nest with eggs, and male entering. Below, male depositing its mil on the eggs.

Figs. 219 and 220 are reproductions of water-color paintings in the Museum of Comparative Zoology at Harvard College.

the species the male builds an elaborate nest from bits of aquatic plants, firmly united by a special mucilaginous secretion. The nest, which is built among the plants of the stream, consists of a short cylinder, through the hori- 
zontal cavity of which the fish can lie while it deposits its eggs. The male is polygamous, and guards the single nest, which receives the eggs from various females (Figs. $219,220)$.

The codfishes, among the most important of food fishes, are characterized by having ventral fins without spines, and articulated fin-rays, well-developed caudal fin, isocercal tail, and barbel on chin. Our common codfish (Fig. 221)

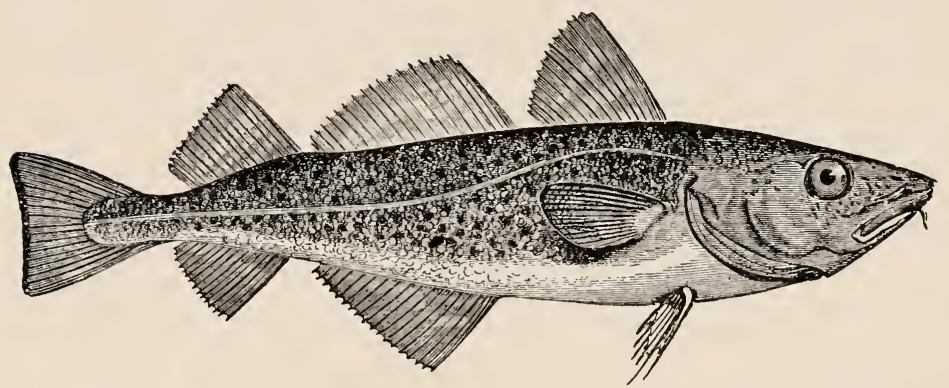

FTr. 221. - Gadus morrhua, the codfish. About one-seventh nat. size. After Storer.

occurs over the whole of the North Atlantic; but the most important fishing localities are the banks near Newfoundland, especially Grand Bank.

'The flatfishes are peculiar among fishes in that they have the habit in the adult stage of lying on one side. In consequence the under eye migrates to the upper side, so that both eyes come to lie on the same side of the body. The mouth also tends to become unsymmetrical. The flatfish, consequently, illustrates well the principles of selfadaptation to a peculiar environment.

The catfishes are distinguished by the possession of four to eight long barbels around the mouth, and by the 
absence of scales on the borly. They are characteristic of South America, but there are a large number of species in the United States, mostly found in the Mississippi valley

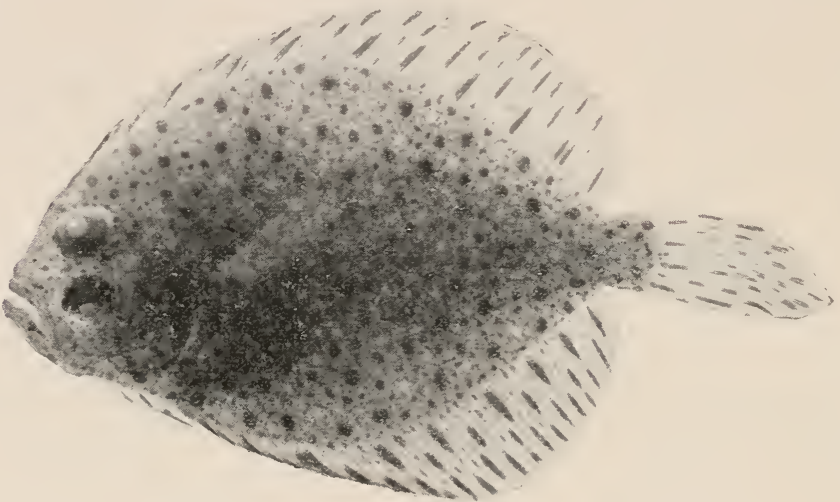

Fig. 229. - One of the flatfishes, seen from the upper side. Two-thirds nat. size. Photo. by W. H. C. P.

and the Great Lakes, inhabiting deep or sluggish waters. and living in the mul. The common New England

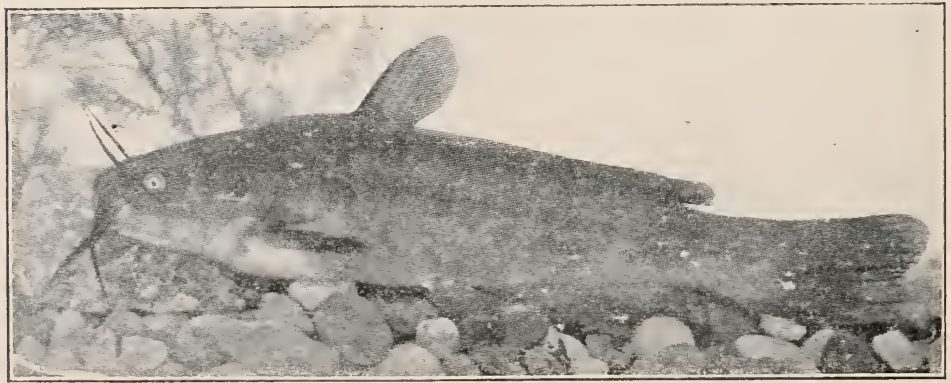

Fig. 223. - Ameiurus nehulosus, the eatfish. About one-half nat. size. Photo. of living animal by Dr. K. W. Shufeldt, "Bull. U. S. Fish Com.," 1899. 
pecies is Ameiurus ${ }^{1}$ catus, ${ }^{2}$ the bull-head or horn-pout. ${ }^{3}$ $t$ was with reference to this species that Thoreau wrote hat they are "a bloodthirsty and bullying race of rangers, nhabiting the river-bottoms, with ever a lance at rest and early to do battle with their nearest neighbor." The tiff, jagged rays of the pectoral fins can make severe vounds. The great catfish of the Mississippi River, which may weigh up to 90 kilogrammes, is known as Ameiurus lacustris. ${ }^{4}$ This, as well as most other species f catfish, is much prized as food.

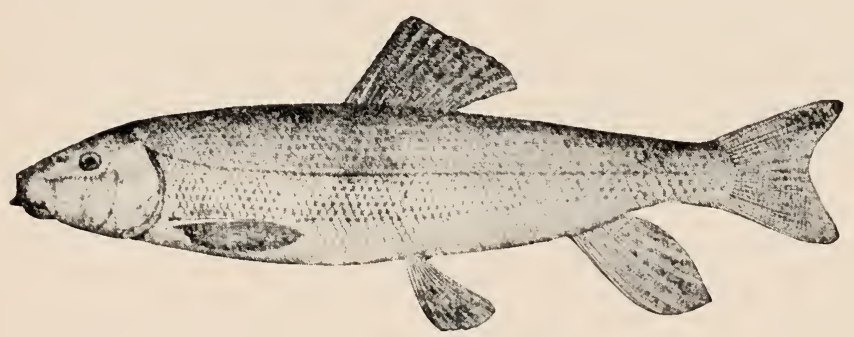

Fig. 224. - The brook sucker. After Goode.

The suckers are characteristic North American fish, bundant in every creek, and consequently known to every over of woods and brooks. Characteristic is the form of ips, which are thick and drawn down at the corners. ${ }^{5}$ They ire rather sluggish fishes, and feed on small aquatic insects and suck up mud. They are not generally esteemed as ood, inasmuch as their flesh is coarse and very full of ones. In the Mississippi valley, however, they are so ibundant and large that they are of some commercial mportance.

1 áuciovpos, not curtailed.

${ }^{4}$ Living in lakes.
2 Cat.

${ }^{3}$ Fig. 223. 
The term "minnow" is applied to two distinct families of small fish. One of these is also known as "killifish." The killifish have a broarl head covered with scales, and have well-developed teeth in the mouth. They occur in schools in shallow water on the shore, and ascend streams to their source. They are carnivorous, and feed at the surface. In one species from the Southern coast, Heterandria ${ }^{1}$ formosa, ${ }^{2}$ the male is only about two centimetres long, and is the smallest known rertebrate. Our commonest species on

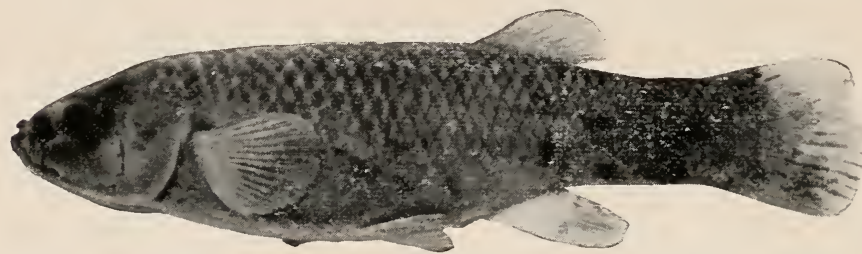

Fig. 225. - Fundulus heteroclitus, a killifish or shore minnow. Nat, size. Photo. by W. H. C. P.

the shore, or in brackish water, is Fundulus ${ }^{3}$ heteroclitus ${ }^{4}$ (Fig. 225). The minnows of the other family have a narrow head without scales, and with no teeth in the mouth. They occur exclusively in fresh water, and are known as "shiners." The "goldfish" is related to this group.

The pike and pickerel (Esox ${ }^{5}$ ) are roughly cylindrical fishes, with large mouth, elongated, depressed jaws, and strong, hooked teeth. ${ }^{6}$ They are large, voracious, freshwater fishes, confined, with the exception of a single species, to the United States. 'The "muskallunge" of the Great

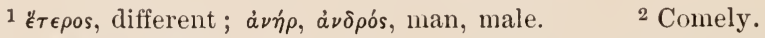

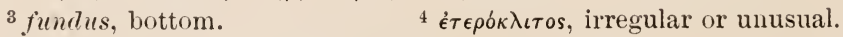

$5 \ell \sigma o \xi$, a fish living in the Rhine, mentioned by Pliny.

${ }^{6}$ Fig. 226. 
Lakes reaches a length of two metres. It is, fortunately, somewhat rare, otherwise there would be few other inhabitants of otir large streams.

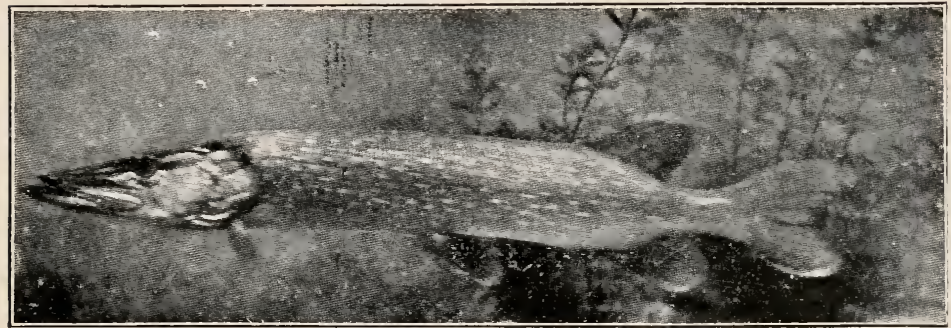

Fig. 226. - Lucius lucius, the pike. About one-fifth nat. size. Ploto. of living animal by Dr. R. W. Shufeldt, "Bull. I. S. Fish Com.," 1899.

The shad is a representative of a family - the herring family - which has played an important part in the civilization of Europe. There is an old adage in Holland to the

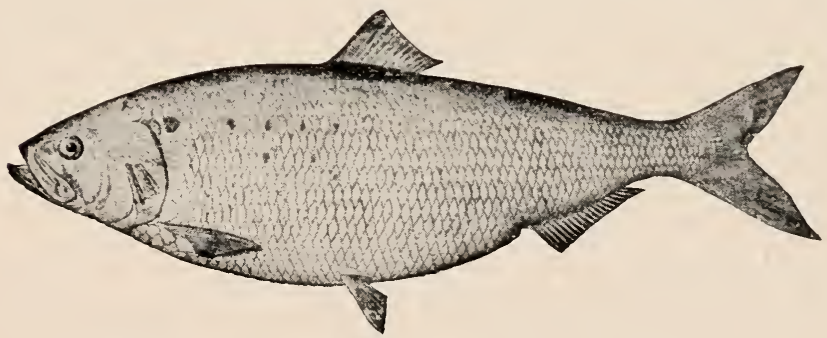

FIG. 227. - Alosa sapidissima, the shad. After Goode.

effect that Amsterdam is built on herring-bones; and the Emperor Charles V. said that the herring brought greater wealth to the Netherlands than did America to Spain. Our common shad, Alosa ${ }^{1}$ sapidissima, ${ }^{2}$ langes from New-

1 From Saxon allis, old name of the European shad.

2 Most delicious. 
foundland to Florida. ${ }^{1}$ Next to the Pacific salmon and cod, it is commercially our most important fish, for the catch of Atlantic shad for 1896 exceeded one and a half million dollars. The Pacific coast has been successfully stocked with shad from the Atlantic. The Atlantic shad, like the salmon, migrate up streams to deposit their eggs. The alewives have the same habit. The herring, on the contrary, spawn in the sea. As the common name, allied to the German Heer, an army, implies, they travel in great schools. The menhaden, which also occur in great schools, have of late years been destroyed in vast numbers to make fertilizers.

The eels are easily distinguished by their serpentine form, the absence of ventral fins, the long dorsal fin, and the rudimentary or absent scales. 'These fish occur' all along our coast and ascend streams. During the day they lie hidden in mud and at night they feed, their principal prey being small aquatic animals, the young of other fish, and shrimps and crayfishes during the moulting period. On account of the narrowness of the gill-opening, they may live for some time out of water in a moist place. 'The reproduction of the eel was long a mystery. All sorts of creatures have in past times been supposed to produce them, ranging from the gods to water-beetles. They have even been thought to be generated from slime. We now know, however, that there are both male and female individuals; that the males live chiefly, but not exclusively, in the sea; that reproduction occurs chiefly in the sea; and that the young females come from the sea and pass up the rivers during the spring.

The pipe-fishes and their allies (Lophobranchii) include ${ }^{1}$ Fig. 227. 
a number of aberrant forms. Some of these are greatly elongated, like the pipe-fish proper (Fig. 228) ; others are shorter and stouter, like the "sea-horse." All have an

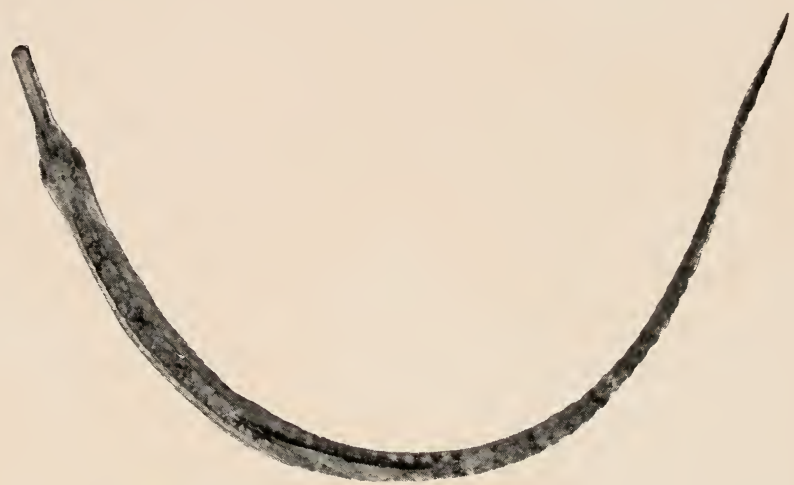

Fig, 228. - Siphostoma fuscum, the pipe-fish. Nat. size. Photo. by IV. H. C. P.

elongated snout, and usually a long, slender tail. The body is encased in bony plates, and the male is often provided with a brood-pouch, in which the developing young are carried.

Besides the bony fishes, which we have just considered in detail, there are various other classes of fish.

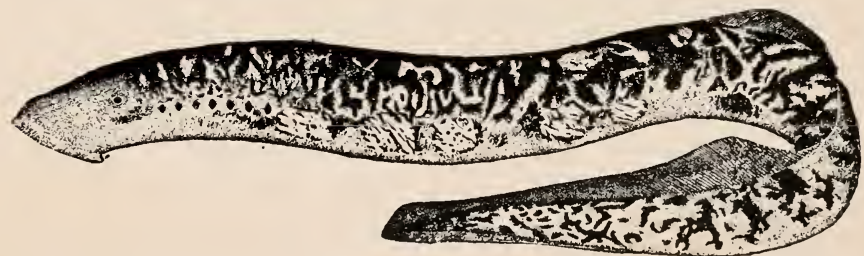

Fig. 229. - Petromyzon, the lamprey. One-fourth nat. size. After Goode.

The Cyclostomi, or lamprey eels, are the only parasitic vertebrates. In the adult stage they either live attached 
to the outside of other fishes, sucking their blood, or else

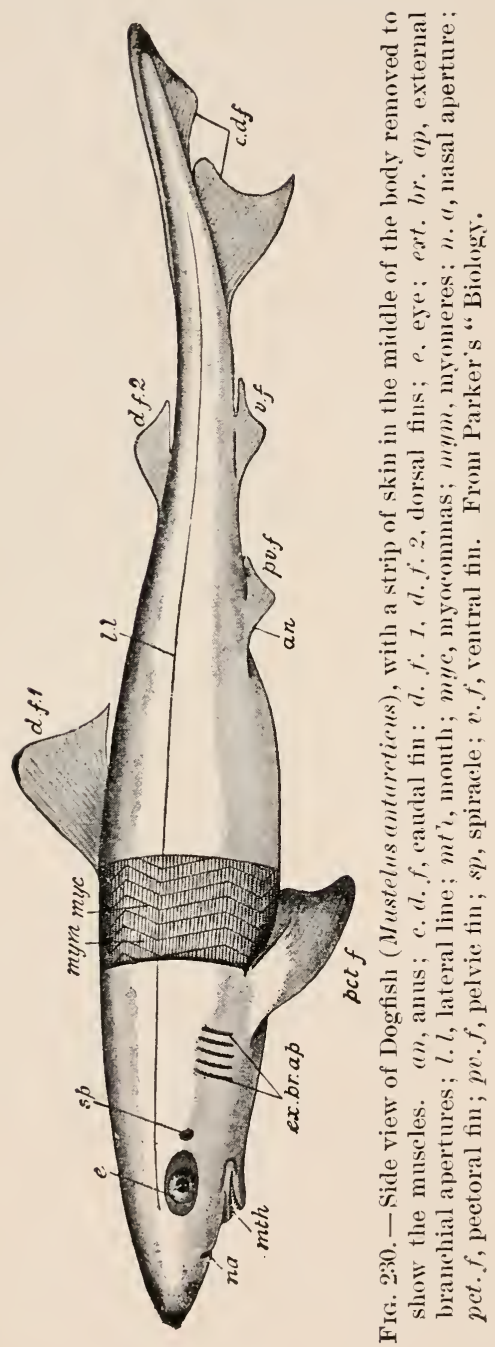
they may penetrate into the body cavity. They do not bite, because they have no lower jaw, and are known as "roundmouthed" eels. ${ }^{1}$ Lampreysare found in the seas and in the rivers of the temperate zones. They occur on our Eastern coast and ascend rivers; others live in the lakes of New York, in the Great Lakes, and in the Mississippi valley. In Europe they are much esteemed as food.

The Selachians include the sharks and rays, all inhabitants of the sea. They may be distinguished from the bony fishes by the rough skin, beset with spines, and by the cartilaginous skeleton. We have a number of sharks on our Northeastern coast, of which the dogfishes and the sand-shark are the

1 Fig. 229. 
commonest (Fig. 230). They are all carnivorous animals and powerful swimmers. They feed on the larger Crustacea and fish.

The living Ganoidei are a remnant of a very extensive group which existed in geological times. North America is especially rich in existing representatives of this group, as of several other old groups, such as the turtles, tailed amphibians, and the king-crab. Of the five families of ganoids, four are represented in this country. In the following four paragraphs we shall consider a type of each of the native families.

The sturgeons have five rows of bony scales on the trunk and four barbels on the head. ${ }^{1}$ They occur both

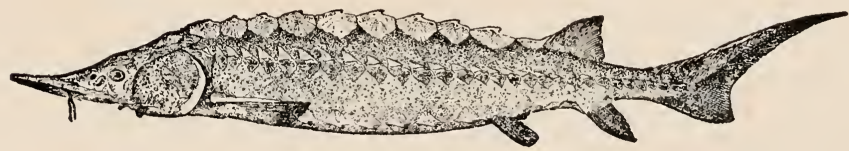

FIG. 231. - Acipenser, the sturgeon. One-sixteenth nat. size. After Goode.

in the sea and in the Great Lakes and the rivers of the Central States. Although of large size, they feed for the most part on small aquatic animals, such as worms, insect larve, and small fish. The flesh of some species is much used as food; the eggs taken from the ovaries (roe) constitute a delicacy known as "caviare."

The spoonbill, which has an elongated, flattened snout and is almost without scales, is a large fish found in the Mississippi River. It is also called "paddle-fish" or "duck-bill catfish." It becomes two metres long and seeks small animals in the mud, which it stirs up with its snout.

1 Fig. 2:31. 
The garpikes are known by their long snout (Fig 232). They are completely clad in an enamel coat of mail. They are of sluggish habits, but voracious, and their flesh is

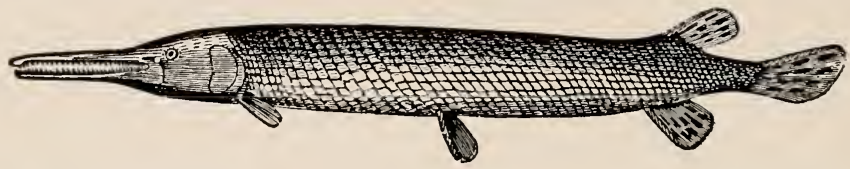

Fig. 232. - Lepidosteus, the garpike. One-eighth nat. size. After Tenney.

valueless as food. One species is found in China, the others in the rivers of North America.

The bowfin (Amia ${ }^{1}$ ) occurs in the rivers and lakes of the United States. It has a short body, a blunt head, and

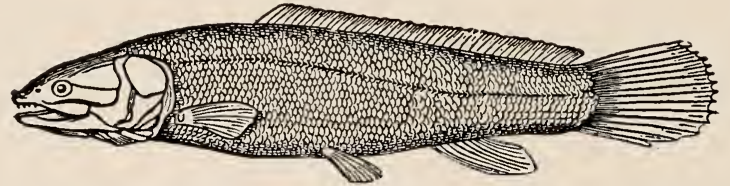

Fig. 233. - Amia calva, the bowfin. One-sixth nat. size. From Leunis.

a long, dorsal fin (Fig. 233). It is the sole survivor of a formerly large family.

The Dipnoi ${ }^{2}$ include only three rare foreign forms, which seem to form a transition between fishes and the higher groups, for some of them have lungs in addition to gills. From some such lunged fishes must the amphibia have arisen (Fig. 234).

Ancestry of Vertebrates. - The fishes, amphibia, reptiles, birds, and mammals, which are considered in this and the following chapters, constitute together the group of vertebrata, or backboned animals. All the animals treated of

$1 \dot{\alpha} \mu i a$, ancient name of a fish.

2 sis, twice ; $\pi \nu 0 \eta$, breath. 
TIIE SMELT AND ITS ALLIES

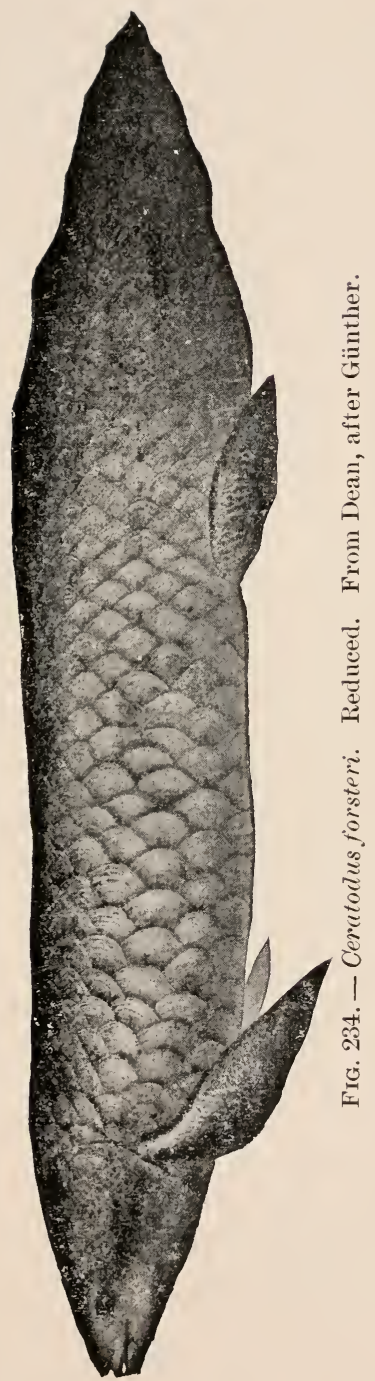

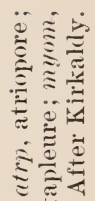
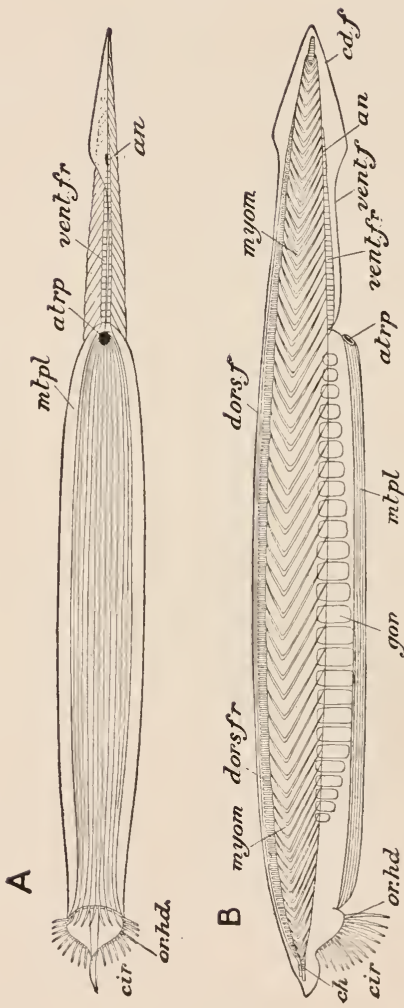

$\ddot{\Xi}$

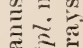

¿

$\dot{\ddot{c}}$

ङ

छ

05

Q

$\cong \stackrel{1}{I}$.

I I

४

है

亩 $\div$

ह

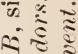

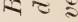

与 $\ddot{\Xi} \Xi$

Ð $\cong$

$\therefore \equiv$

$\overline{4} 0$

$\therefore \dot{2}$

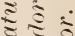

응

ำ

事 $\div$

¿

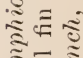

ฐิ

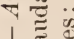

!

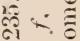

एवं 


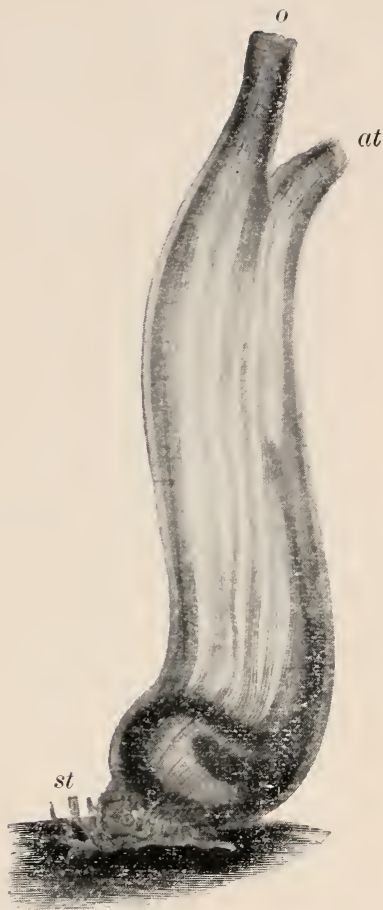

Fig. 236. - Ciona, a simple tunicate. $o$, mouth ; $a t$, opening of atrinm, or exhalant opening; st, stolon. After Lenckart and Nitche's diagrams.

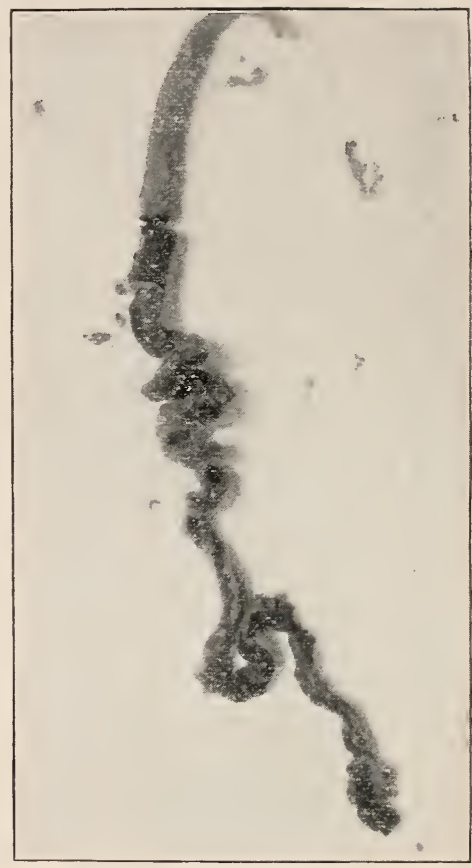

Fig. 2:S. - Balanoglossus, the acorntongued worm. The proboscis at the anterior end is at the top of the figure (partly outside); behind it is an orange-colored collar; then follows the long, brown-red trunk. Nat. size. Photo. of living animal by W. H. C.P.

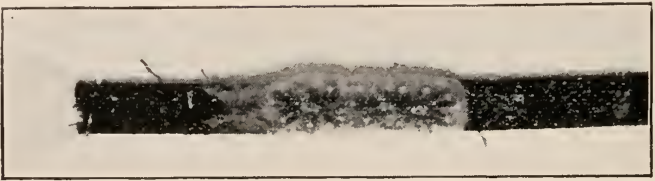

FIG. 237. - Botryllus, a compound tunicate. Nat. size. Photo. by W. H. C.P. 
in earlier chapters are invertebrates. Between vertebrates and invertebrates and connecting the fishes with more worm-like ancestors, is the lancelet or Amphioxus. ${ }^{1}$ This slender, rod-like animal is only 50 to 70 millimetres long. Its internal structure shows its relationship with vertebrates; it has the forerunner of a vertebral column and a spiral nerve and it has also gill slits like a fish, but it has no skeleton. ${ }^{2}$ It lives in sandy seashores in temperate and tropical zones. On our Eastern coast it is found from Chesapeake Bay south. It stands embedded in the sand, the tentacle-fringed mouth projecting above the surface. It feeds on minute organisms of all sorts.

Of the invertebrate groups, that of Tunicata lies nearest to the stem from which the vertebrates arose. The adult animals, however, are very different from vertebrates, for they are attached (Fig. 236), and sometimes even form colonies (Fig. 237). But the young animals are much like tadpoles of frogs; not merely superficially, but in their structure. Going further back it seems clear that vertebrates have developed out of the worms. A very worm-like animal, which seems to foreshadow the vertebrates in having gill slits and the forerumner of a backbone, is common in our sandy beaches. This is Balanoglossus ${ }^{3}$ - the acorn-tongued worm, so called from the shape of its proboscis (Fig. 2:38).

$1 \dot{a} \mu \phi i$, both [ends]; $\delta \xi v^{\prime}$, sharp pointed.

${ }^{2}$ Fig. 235. $\quad{ }^{3} \beta a ́ \lambda a \nu o s$, acorn ; $\gamma \lambda \hat{\omega} \sigma \sigma \alpha$, tongue. 


\section{APPENDIX TO CHAP'TER XVI}

\section{KEY TO THE PRINCIPAL ORDERS OF FISHES}

$a_{1}$. Without skull, paired fins, or heart ; blood colorless . . . . . . . . .

$a_{2}$. With skull, heart, and red blood [Craniota].

$b_{1}$. Without lower jaw or paired fins . .

$b_{2}$. With lower jaw and paired fins [Gnathostomi].

$c_{1}$. Intestine with spiral valve.

$d_{1}$. Without an operculum covering the gill openings; scales toothed

$d_{2}$. Operculate; skin with enamelled scales.

$e_{1}$. Breathing by means of gills only . . . . .

Ganoidei

$e_{2}$. Breathing by both gills and a lung

$c_{2}$. Intestine without spiral valve; skeleton bony . . . . . .

Acrania

(Ex. Amphioxus)

Cyclostomi

(Lamprey eels)

(Sharks and rays)

(Ganoid fishes)

Dipnoi

(Mud tishes)

Teleostei

(Bony Fishes)

KEY TO THE SIX SUBORIERS OF TELEUSTEI

$a_{1}$. Gills comb-like.

$\vdots_{1}$. Intermaxillaries and maxillaries movable on each other.

$c_{1}$. Dorsal fin, anal fin, and ventral fin spinous anteriorly.

$d_{1}$. Pharyngeal bones distinct . . Acanthopteri (Perches, dariers, sunfishes, toadfishes, sculpins, silversides, sticklebacks)

d. Pharyngeal bones united . . Pharyngognathi $c_{2}$. Dorsal, anal, and ventral fins without spines. 
$d_{1}$. Ventral fin, when present, placed on throat or breast; air-bladder without air tube . . . Anacanthini (Codfishes, flatfishes)

$d_{2}$. Ventral fin, when present, placed ventrally; air-bladder with airtube . . . . . . Physostomi (Smelt, trouts, whitefishes, catfishes, suckers, minnows, shads, eets)

$b_{2}$. Intermaxillaries and maxillaries united with each other and with skull . . . Plectognathi $\alpha_{2}$. Gills small, tuft-like; body covered with bony plates . . . . . . . . Lophobranchii (Pipe-fishes) 


\section{CHAPTER XIII}

\section{THE NEWT AND ITS ALLIES}

The newts belong to the class Amphibia, ${ }^{1}$ or, as it is also called, Batrachia, characterized by the fact that, while they have no rayed fins like fishes, but legs instead, they have functional gills during at least a part of their free life. The eggs, which are laid in water, are without a hard shell.

The little newt Diemyctylus viridescens ${ }^{2}$ is found in New England and westward to the Mississippi valley. During different stages of development it assumes widely different habits. The eggs are laid during the spring in water, where they hatch after three to five weeks and appear as olive-colored tadpoles with external gills. At this time they have an exclusively animal diet, feeding on minute Crustacea, larval insects, snails, and aquatic worms. In August the gills and tail-fin become absorbed, and the transformed animal takes to land and lives under stones at some distance, it may be, from water. At this time it has a vermilion color, ${ }^{3}$ and feeds on spiders, insects, and earthworms. After two or three years the newt assumes a

1 Keys to the Orders of Amphibia and to the families of Urodela will be found in the Appendix to this Chapter, page 266.

2 The newt of the Pacific coast is D. torosus.

3 The color and habitat of the terrestrial young Diemyctylus are so different from the fully matured aquatic form that the two were formerly regarded as distinct species. 
brown color, and eventually the olive-green or viridescent color of the adult. It then takes to the water and is found especially in springs, and in ponds and brooks fed by springs. It now subsists on various aquatic worms, crustaceans, insects, and mollusks. The newt gains oxygen for respiration by swallowing air mixed with water. ${ }^{1}$

Distribution. - The Amphibia live chiefly in tropical and subtropical countries, although a number of them belong to the colder parts of the temperate zone. There are no strictly polar species, although one species of frog extends from Massachusetts north to Mlaska. The Gymmophiona ${ }^{2}$ are confined to tropical countries and are most abundant in South America. They live, like earthworms, in the ground and have more or less rudimentary eyes. The Urodela are confined in their distribution to the Northern Hemisphere (excepting that two or three species extend along the Andes south of the equator). North America is especially rich, both in species and individuals, of Urodela. The Anura, or toads and frogs, are found in all parts of the world, especially in South America and Australia.

Families of Urodela. - Of the American Urodela, ${ }^{3}$ the Sirenidæ include the Siren, ${ }^{4}$ or mud-eel, of the Southern States. This species becomes 60 centimetres long, and is of a dark lead color (Fig. 239). It is needlessly feared by the negro rice cultivators, who slaughter it in great numbers.

${ }^{1}$ Newts may be captured by sweeping with a net the muddy bottoms of small, spring-fed pools. They can be kept for months in an aquarium, where they should be fed thrice a week with earthworms or freshly chopped beef.

${ }^{2}$ From $\gamma v \mu \nu o ́ s$, naked ; ó $\phi i \omega \nu$, a fabulous, snake-like animal.

3 oủpá, tail ; $\delta \hat{\eta} \lambda o s$, conspicuous.

${ }^{4}$ A mythological creature. 


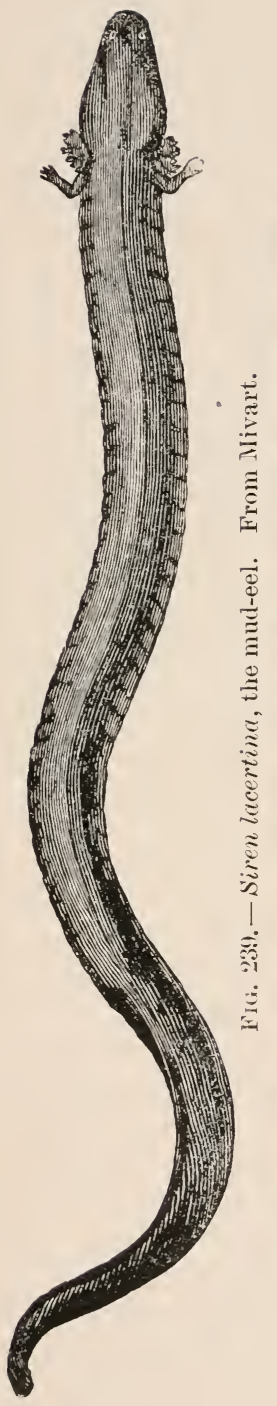

$\frac{5}{4}$

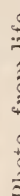
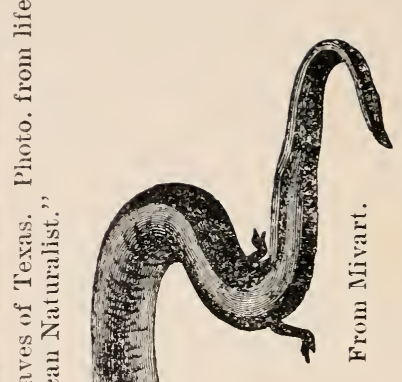

ธั

$\cong$

ह

$\sum_{i=1}$

돈

芩

范

菏

恶

$\stackrel{\Xi}{\Xi}$

$\Xi$

ats

inte

xe

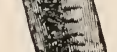

we

Was

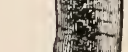

.

葛

$\Xi$

泀

$:$

3

3

$\stackrel{2}{\ddagger}$

స్స

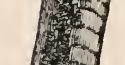

竎
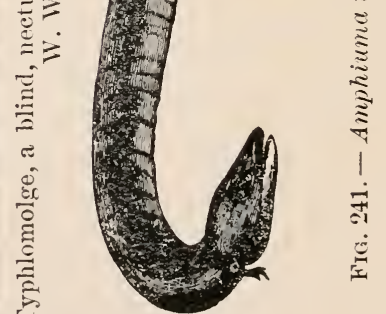

㳯 
The Proteidæ ${ }^{1}$ inchude our Necturus, commonly known as mud-puppy or water-dog, which is found from the Hudson River to the Mississippi valley, and is very abundant in the Great Lakes. Its external gills are very large, and red with the blood flowing in them. It feeds on small water-animals. In April or May it lays eggs about the size of a pea. A curionsly modified form of Necturus occurs in caves (Fig. 240). Another member of this family is the cave "olm" of western Austria.

The Amphiumidæ ${ }^{2}$ include only the Congo snake of the Carolinas and Gulf States. This black, snake-like Urodelian is about a metre long, and lives in bayous and muddy ditches (Fig. 241). It has the entirely undeserved reputation of heing injurious.

The Cryptobranchidæ ${ }^{3}$ include the so-called "liellbender" of the Ohio valley and south. ${ }^{4}$ It is a very voracious scavenger of the water, and bites the hook fiercely. It is noted for its great tenacity of life uncler unfavorable conditions. The only other living representative of this family is the Japanese giant salamander, which becomes three metres long.

The Amblystomidæ ${ }^{5}$ include some twenty-five species belonging to five genera, four of which occur in northern and eastern Asia, and the fifth, Amblystoma, is confined to the United States and Mexico, excepting one species, occurring in Siam. 'The common species of New England and the Central States is known as the Spotted Sala-

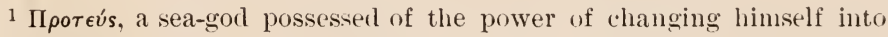
different shapes.

2 Probably a modification of a native name.

${ }^{3}$ крvтrós, hidden; $\beta \rho \alpha ́ \gamma \chi \iota \nu$, gill.

4 Fig. 242.

5 From $\alpha \mu \beta \lambda$ ús, blunt ; $\sigma \tau \delta \dot{\mu} \alpha$, mouth. 
mander. It is about 15 centimetres long, and black, with a series of yellow spots on each side of the back. It lays

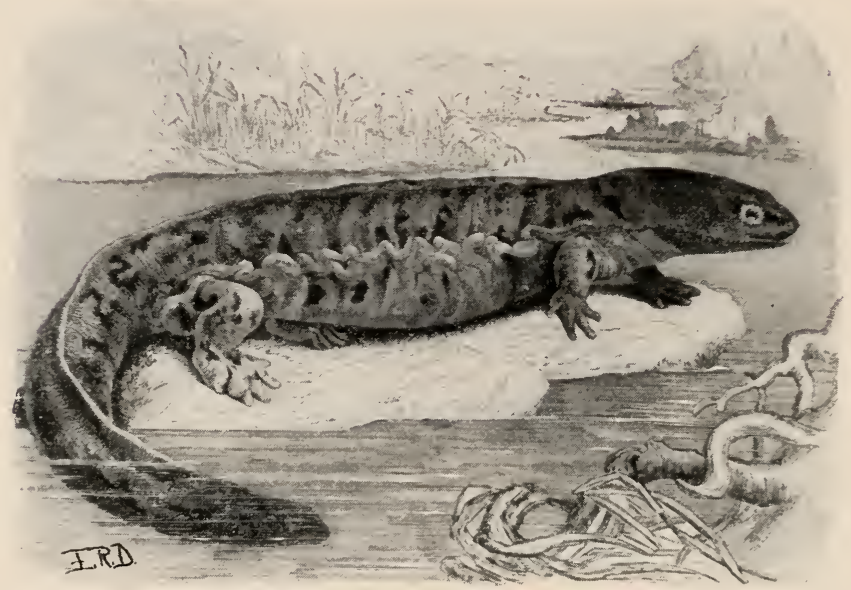

Fig. "2t2.-Cryptobranchus, the "hellbender." Reduced. From "standard Natural History."

eggs in springs or ponds during April: the dark gray eggs are contained in great masses of jelly which are

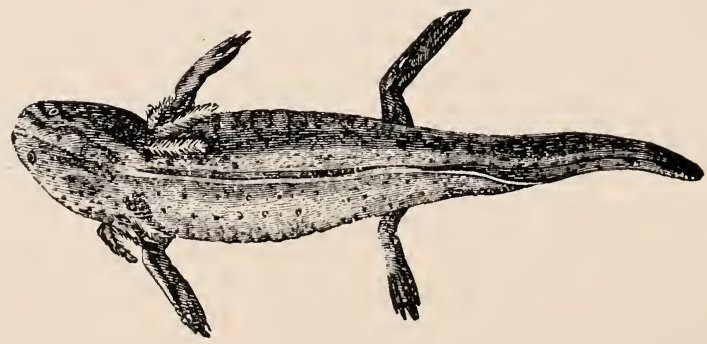

Fig. 243. - The larva of Amblystoma tigrimm, the Axolotl stage of the tiger salamander. From Mivart. 
attacherl to sticks at or near the surface of the water. The larvie of the more southern species often reach a size considerably larger than the adult, and breed before the gills are absorbed. In a Mexican species the larval state is never transcended. The larva of Amblystoma (Fig. 243) was formerly described, indeerl, as a distinct species.

The Plethodontidæ ${ }^{1}$ and Desmognathidæ ${ }^{2}$ include a number of small Lrodeles, having a close general resemblance

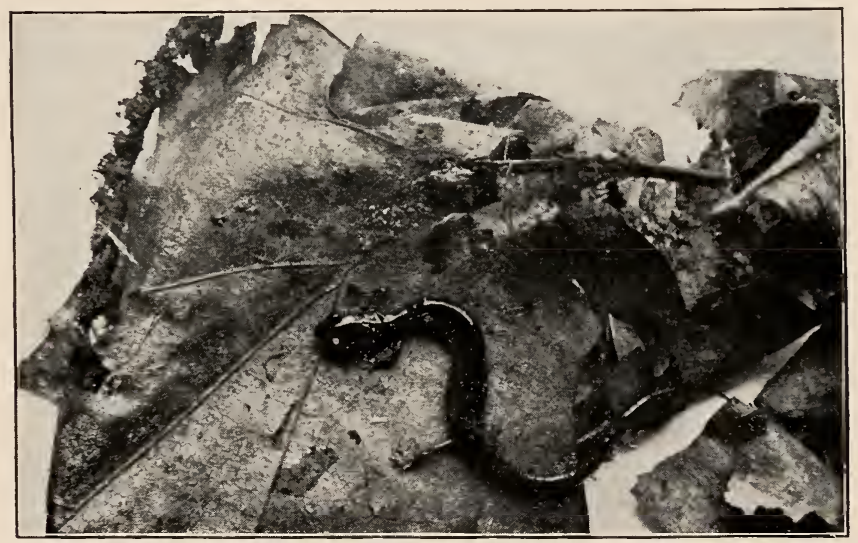

Fic. 244. - Plethodon, the red-backed salamander. Slightly reduced. Photo. of living animal resting on a leaf.

and similar habits. Plethodon, of the eastern United states, is lead-colored above, very often with a broad, red dorsal band (Fig. 24t). It is found under logs, and is very active. Spelerpes ${ }^{3}$ is lemon-yellow and white below, and Desmognathus is brown above, with gray or

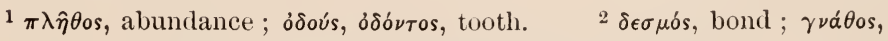
jaw. ${ }^{3} \sigma \pi \eta \dot{\eta} \lambda a \iota \nu$, cavern ; $\ddot{\epsilon} \rho \pi \eta$, a crawler. 
purplish spots on the sides. Both Spelerpes and Desmognathus live in and about rumning brooks, under stones and fallen logs. Their eggs are attached to the under surface of submerged stones. 'The adults are easy to keep' in confinement in a moist fernery. They may be obtained out of doors all the year round, excepting during the time of deep snow. There are four species of spelerpes and three species of Desmognathus in the northern United States.

Metamorphosis. - As we have seen, all Amphibia have gills while young, but some lose them before maturity while others retain them permanently. Those species which retain the gills pass their whole life in water' the others may live on the land. The loss of gills is assoriated with the assumption of a land life. In the Amblystoma we have species which are curionsly intermediate between the two classes in that they may retain their gills, tail-fins, and other structures adapted to aquatic life, ${ }^{1}$ even to the time of reproduction; or they may lose their gills and tail-fins. The first result follows if they are prevented from coning on land; the second, if they are forced to leave the water. The capacity of the Mexican Axolotl for eitier becoming an adult or remaining a larva was first shown by some experiments of the German naturalist Weismann and a pupil of his. It will be seen that when forcerl to live in the water Axolotl retains permanently a larval condition; and one wonld never know that in this larval condition the animal is not adult were it not for the accident of its sometimes becoming adult. It is quite possible that all of the Irodela which retain their gills throughout life may formerly have had a gill-less adult stage which is now lost.

1 Compare Fig. 243. 
Early Development of Urodela. - The eggs of Crodela are deposited in a gelatinous mass in water, and are attached to submerged plants, or to other objects in the

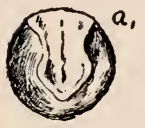

FIG. 5.

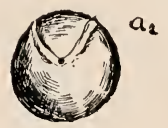

Fig.6.

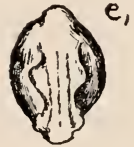

FIG. 14.

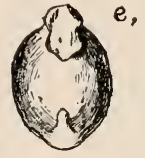

FIG. 15 .

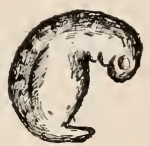

FIG. 16.

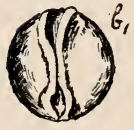

Fig. 7.

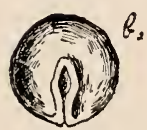

Fig. 8.

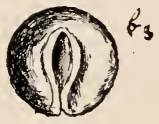

FIG. 9.

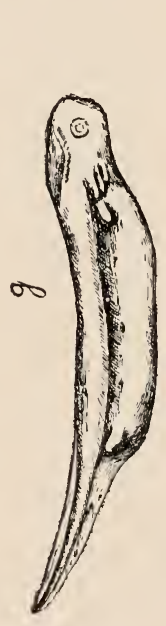

FIG. 18.

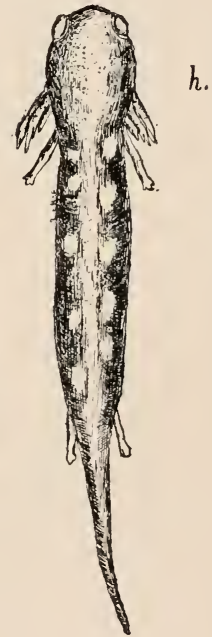

FIG. 19.

h.
FIG. 12.

FIG. 13.

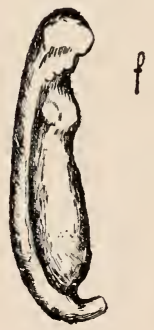

FIG. 17.
Fic. 245. - Developmental stages of Spelerpes bilineatus. Figs. 5-9, nemal groove beginning to form; Figs. 10, 11, neural groove closed ; Figs. 1:, 1:3, head beginning to form; Figs. 11-1f, tail formed, yolk absorbing: Fig. 17, embryo capable of moving in egg membrane; Fig. 18 , embryo just able to swim: Fig. 19, three days after hatching. The letters indicate the successive stages. After H. H. Wilder, from "The American Naturalist."

water, either singly or in masses, accorling to the species. The eggs contain much yolk; consequently the cleavage is partial, and the embryo seems to develop on a small part 
only of the yolk and for some time after hatching the yolk mass hangs as a lump on the under sicle of the embryo. Very early a deep groove, bounderl by a pair of folds, arises on the elge. This groove is large in front (Fig. $245, b)$. It forms the beginning of the brain and spinal cord. The feathery gills and the beginnings of the appendages

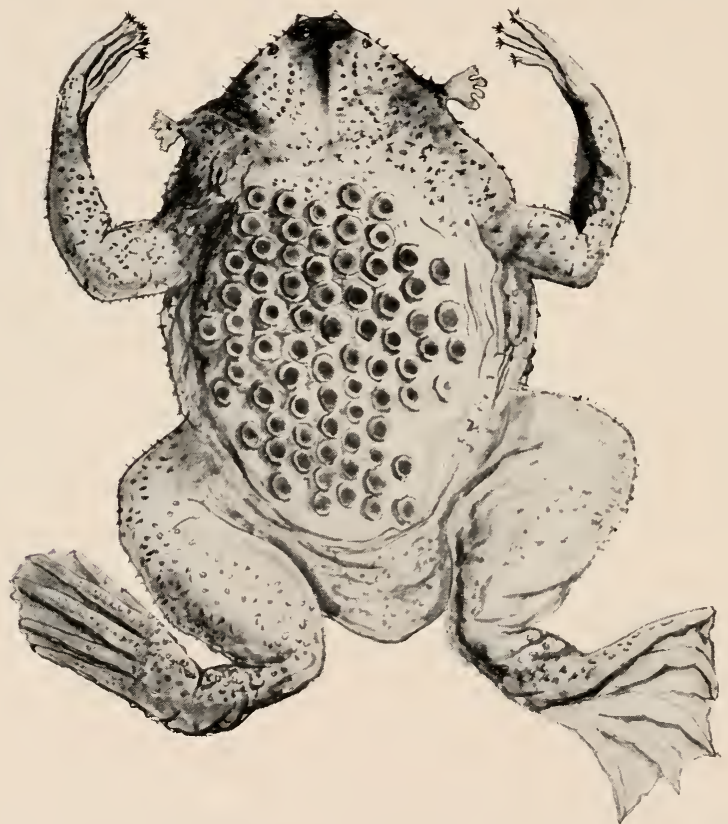

Fin. 246. - Pipa americanu. Female with young in pits on its back.

next sprout ont, while the trunk continnes to elongate and assume the form of a young salamander (Fig. 245).

Families of Anura. - Of the Anura there are eight or ten times as many species as there are of the Trodela. They are distributed into nearly a score of families. Of 
these a few of the more interesting leserve to be mentioned.

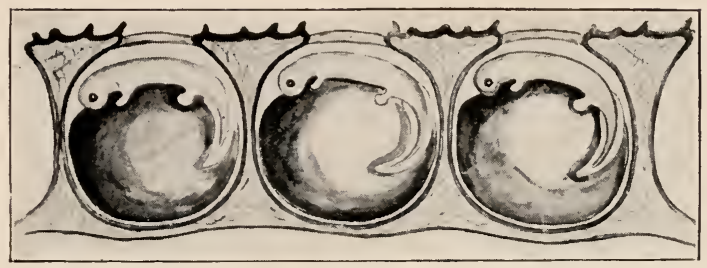

FIG. 247. - Section through skin of back of Pipa americana, showing developing embryos. Much enlargerl.

The Pipidæ include the South American Pipa, noteworthy because of the habit which the female has of brooding its young in pits of the skin on her back (Figs. 246, 247).

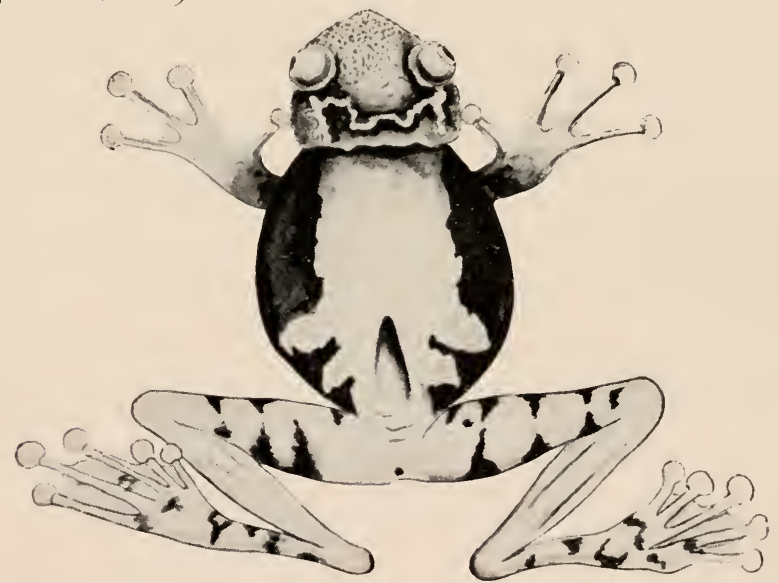

FIG. 248. - Nodelphys, brooding tree-frog, female, from Venezuela. In the hinder part of the trunk the opening to the brood-pouch is seen. From a watercolor painting at the Museum of Comparative Zoology at Harvard College.

The Hylidæ, or tree-toads, include various arboreal species in which the ends of the fingers are modified for 
holding on to objects by suction. Of these there are over one hundred and seventy species, especially abundant in tropical America. In one member of this family the female has a pouch on the back, opening in the hinder third of the trunk (Fig. 2t8). In this the young are

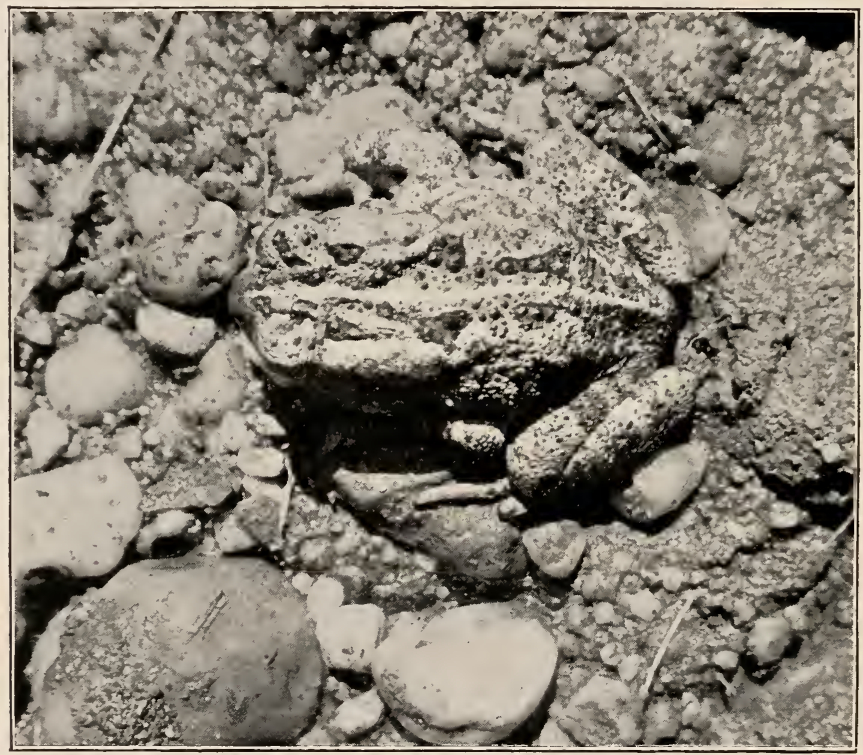

FI(: 249. - Bufo lentiginosus, the American toad. Photo. of living animal, resting on the ground, by W. H. C. P.

brooded. The most common tree-toad of the northern United States extends from Canada to Florida, and west to Kansas. It is variable in color, being green or brown, according to the color of the background, leaf, or bark, on which it is resting. It has a loud, coarse trill, often 
erroneously regarded as a weather sign. The eggs are laid in small bunches in shallow water.

The Bufonidæ include the common toads which occur all over the world. Our Eastern toad ${ }^{1}$ inhabits nearly all the United States east of the Rocky Mountains. ${ }^{2}$ It is crepuscular in its habits, and feeds chiefly on insects and worms. The eggs are deposited in two long, parallel strings of albumen, which lie coiled at the bottoms of

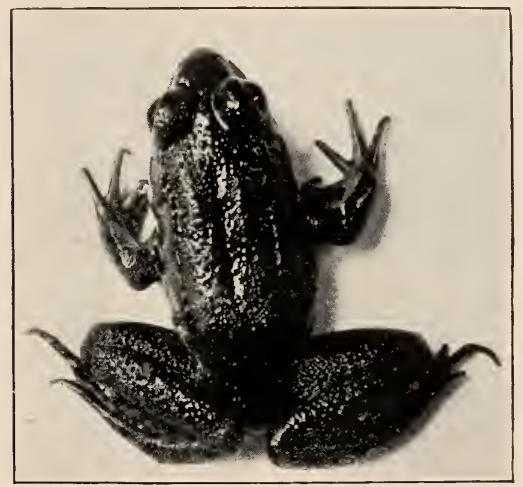

FIG. 250.-Rana clanutano, green frog. Nat. size. Photo. of living animal by W. H. C. P.

ponds, hatch out in May, and metamorphose about a month later.

The Ranidæ are alnost confined to the Northern Hemisphere and the East Indies. In the northern United States there are some eight species, of which the commonest are: the leopard-frog, of green color, with irregular black blotches edged with whitish; the pickerel-frog, light brown, with two rows of oblong square brown blotches

1 Bufo lentiginosus. 2 Fig. 249. 
on the back: the wood-frog, living in damp woods, pale reddish brown, with a brown band on the side of the head; the green frog, of uniform bright green to brown color. with numerous small dark spots, and with glandular folds (Fig. 2.50); and the bull-frog, of great size, green, with small faint spots on the back.

\section{APPENDIX TO CHAPTER XVII}

\section{KEY TO THE ORDERS OF AMPHIBIA}

$a_{1}$. Appendages and tail lacking; body worm-like; skin furrowed transversely . . . .

Gymnophiona

$a_{2}$. Appendages present.

$b_{1}$. Body elongated; tail present; generally 4, but rarely only the 2 anterior appendages present . . . . . .

$b_{2}$. Body short; in adult condition tailless .

Trodela Anura

$a_{1}$. External gills persistent throughout life ; maxillary bone small or wanting.

$b_{1}$. Body eel-like; hind legs absent; jaws with horny sheath. . . . . .

b. Body salamander-like; hind limbs present; teeth on jaws . . . . . .

$a_{2}$. External gills normally disappearing in adult;

limbs 4 ; maxillaries present.

$b_{1}$. Side of neck with spiracular opening; 110 eyelids.

$c_{1}$. Limbs rudimentary . . . . Amphiumide

$c_{2}$. Limbs well developed . . . . Cryptohranchida

$b_{2}$. Side of neck withont spiracular opening in adult ; eyelids present. 
$c_{1}$. Palatine teeth in transverse (or nearly transverse) series.

$d_{1}$. Vertebræ doubly concave.

$e_{1}$. Parasphenoid without teeth ; tongue large ; toes 4-5. Amblystomida $e_{2}$. Parasphenoid with teeth; tongue small . . . Plethodontide

$d_{2}$. Vertebræ convex behind only; tongue moderate; toes 5 . Desmognuthicle

$c_{2}$. Palatine teeth in 2 longitudinal series, diverging behind . . . . Pleurodelide. (Ex. Diemyetylus)

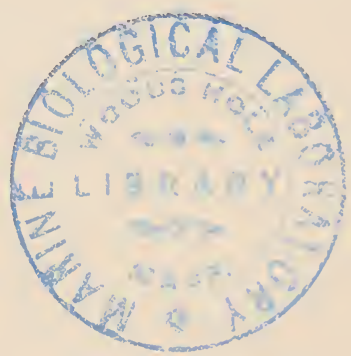




\section{('HAP'TER XVIII}

\section{THE LIZARD AND ITS ALLIES}

THe lizards belong to the class of Reptiles, ${ }^{1}$ which are vertebrates in whose skin horny or bony scales or plates are formed. 'They constantly breathe by means of lungs, and lay large eggs provided with a tough leathery or calcareous shell.

'The Sauria, or lizards, constitute a large order characteristic of the tropical and subtropical comtries and reaching the maximum of its development in South America, while in the northern continents it is relatively poorly represented. Lizards are, as a rule, carnivorous, and since they destroy insects injurious to vegetation, they may be counted as beneficial to man.

Anolis ${ }^{2}$ is one of the family Iguanidæ. ${ }^{3}$ a large group of lizards characteristic of the Western Hemisphere. The family is known by the thick tongue, by a large scale in the middle of the head in front of the eyes, and by the fact that all four legs are well developed. The genus Anolis contains eighty tropical species. Our species lives in pine woods from the latitude of Tennessee south to the Gulf and the island of Cuba. Its graceful form and bright colors make it one of the most beautiful of lizards. It

$1 \Lambda$ key to the four orders of Reptiles will be found in the Appendix to this Chapter, page 280 .

2 dnoli, native name.

3 Native name. 
lives on trees, eats insects, is not timid, can live well in confinement, and, like the chameleon of Europe, has the power of changing its colors from bright green to dirty brown. Besicles Anolis we have various other lizarls of the family Iguanidie. The horned toad of the Southwest, which has a hroal, flattened body and long spines on the head, and lives in dry, sandy places, is a familiar object. ${ }^{1}$ In the South Central and Southern Sitates lives the elongate "swift" of varying color, often with black, irregular"

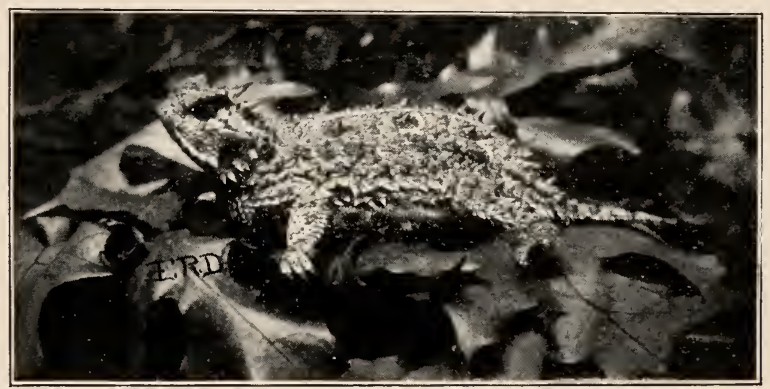

Fig. 251. - Phrynosoma, the horned toarl. Photo. by E. R. D.

cross bands above, with iridescent colors on the throat of the male, and with large, strongly keeled scales and a slender tail. The largest of the Iguanidae is the "leguan" of the IV est Indies and South America, which gains a length of 1.75 metres, or over five feet.

The family Varanidæ, ${ }^{2}$ or water-lizards, contains the largest known lizards. The Nile varanus attains a length of nearly two metres. It lives on the rivers of Africa, feeds on small Crustacea, birds, birds' eggs, frogs, fish, and occasionally also on young crocodiles and crocodile eggs.

${ }^{1}$ Fig. 251.

2 Latinized from the Arabic word waran, lizard. 
The ancient Egyptians regarded these crocodile-like lizards as the greatest enemies of the crocodile.

The Lacertidæ, ${ }^{1}$ which are common in middle and southern Europe, are agile, harmless creatures, often of bright colors, and are commonly and favorably known. The more

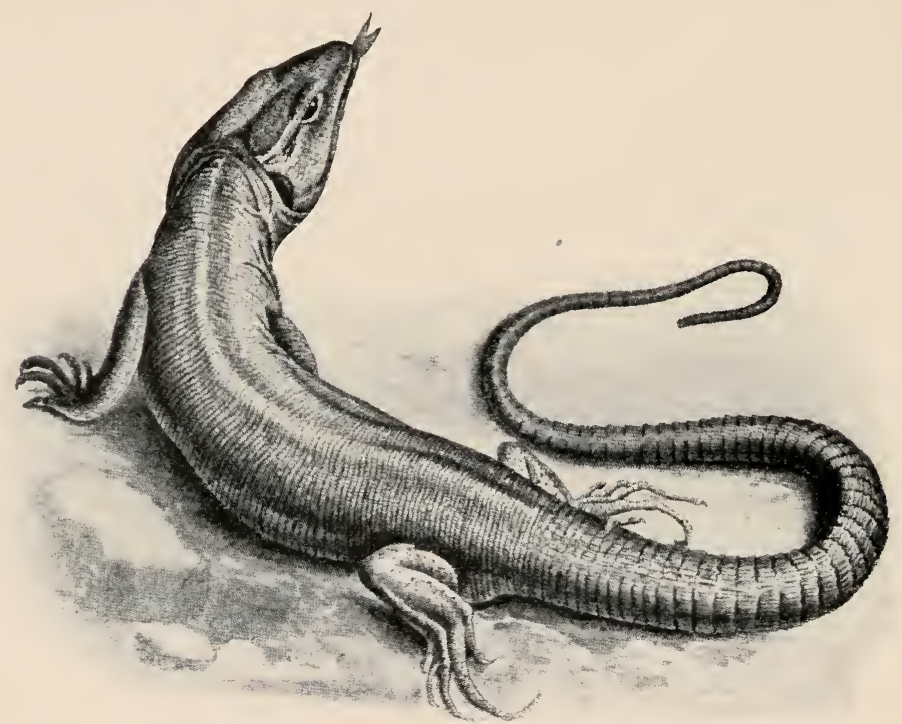

Fis. 252. - Lacerta viridis, the green lizard of Europe. After Brehm.

abundant are the "green lizard" (Fig. 252), the "sandlizard," and the "wall-lizard" of the Latin countries.

The Helodermidæ include the largest lizard of the United States, the so-called "Gila monster," which inhabits New Mexico, Arizona, and the country southward. The lizard is colored brown, with reddish spots and numer-

1 From lacerta, lizard. 
ous yellowish punctations (Fig. 253). It is nocturnal in its habits and its bite is very poisonous, although not often fatal to man.

The family Anguidæ, or slow-worms, includes the famous glass-snake or joint-snake of the South. This snake-like lizard has no legs, or only rudiments of the hinder pair. It is noted for the ease with which it breaks in two when

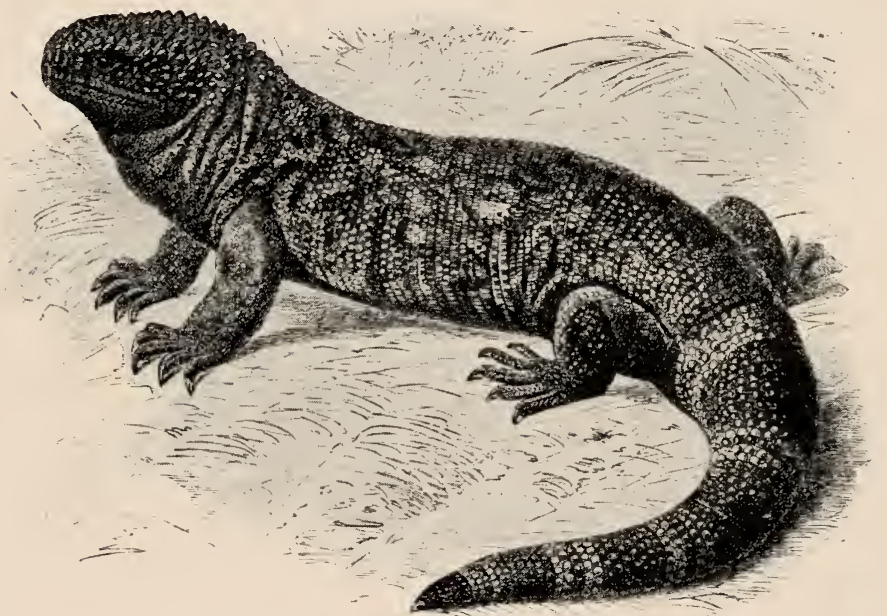

Fig. 253.-Heloderma, the Gila monster. About two-fifths nat. size. From Brehm.

struck or lifted by the tail. This result is due to the fact that, as in certain other lizards, the vertelore of the tail are unossified along the middle plane, so that they separate at this point upon the slightest blow. The muscles of this species seem also to be arranged so as to facilitate separation. In Europe there is a lizard of this family, the so-called "blind-worm" (having, however, well-developed 
eyes), which is found in retired localities, from which it comes out, especially in the evening, to capture earthworms and slugs.

The Chameleon famed in literature comes from $\mathrm{Africa}$. Its change of color depends upon the possession of several layers of different color in the skin, which layers can be separately expanded or contracted as required, as a result of which some one color comes to predominate. It captures insects, a habit which is facilitated by its power of

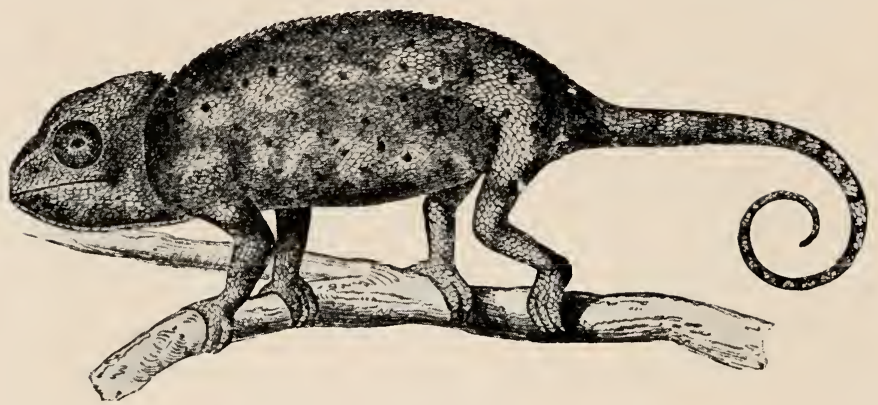

Fic. 254. - Chameleo, the chameleon. From Leunis.

protruding the tongue to over half the length of its body and bringing the sticky end in contact with its prey. The protrusions and retractions of the tongue are effected with marvellous rapidity (Fig. 254).

While in point of size the lizards of geologically recent times are inconsiderable, those of former epochs were huge. These former or fossil lizards were most characteristic of the midlle life erat or the Mesozoic age. They belong to three main groups; namely, swimming, walking or wading, ${ }^{1}$ and flying lizards. The swimming lizards were

${ }^{1}$ Fig. 2:4. 
sometimes over 10 metres long, and had feet modified as paddles. The land lizards were elongated, three-toed, carnivorous reptiles, with hollow leg bones like birds. In the flying lizards, a strong compact body was provided with hollow, air-filled bones, and locomotion was effected by a huge membranous expanse stretched between the

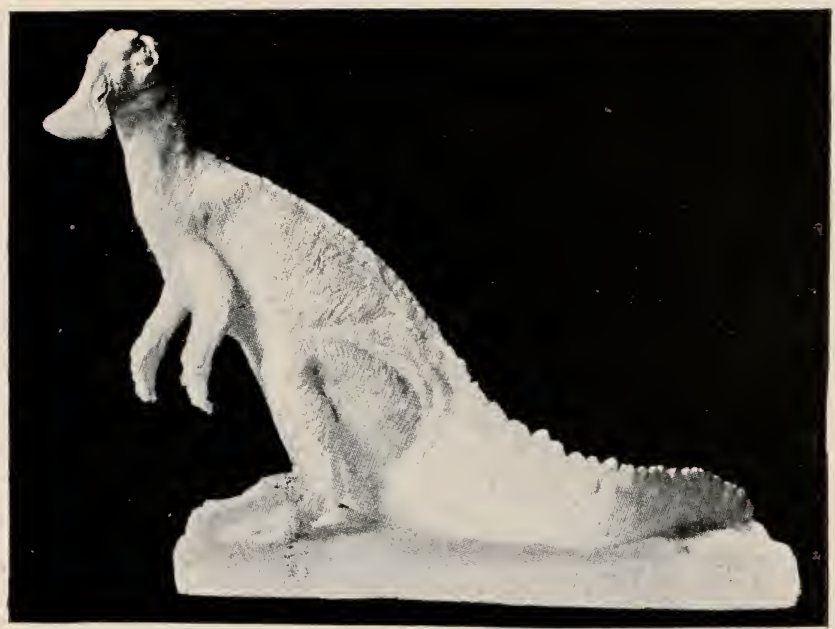

FIG. 255. - Hadrosaurus. From reconstruction model. Osborn, "Rept. Amer. Mus. Nat. Hist."

elongated posterior finger, the trunk, and the hind legs. 'The spread of the wing' was about three feet.

The Chelonia, ${ }^{1}$ or turtles, form an order distinct from the lizards. They are characterized by a depressed form, a bony case, and toothless jaws. Like other reptiles, they are most abundant in tropical countries. since the high ${ }_{1} \chi \epsilon \lambda \omega \dot{\nu} \eta$, turtJe. 
external temperature compensates in a way for the insufficiency of the mechanism for maintaining from the inside a high blood temperature. Turtles are abundant in Africa, and are much commoner in North America than in Europe. Three families of Chelonia may be distinguished. A short account of each follows.

The family Chelonidæ includes certain marine turtles. 'Turtles live in all oceans and may acquire a weight of as

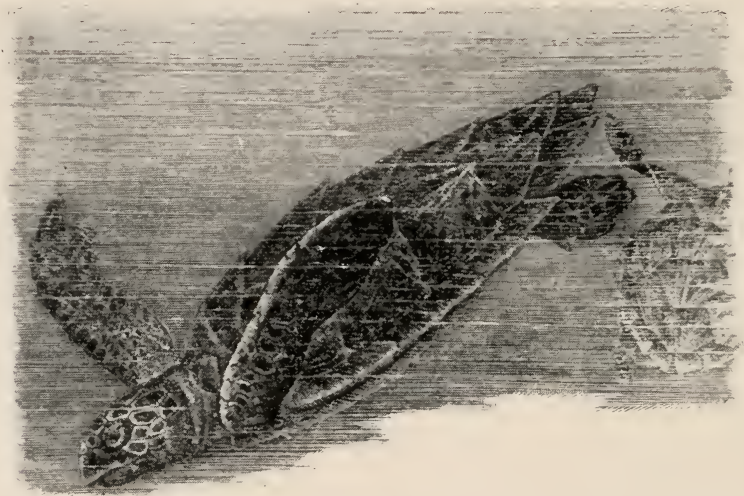

Fin. 22,. - Hawkbill-turtle. Much reduced. From Brehm.

much as one thousand pounds. The green-turtle, used in making soup, occurs on the Atlantic coast as far north as Long Island. From the hawkbill-turtle (Fig. 256) comes the tortoise shell used in certain ornaments. In the leather-back the shields are incompletely ossified.

The family Trionychidæ ${ }^{1}$ includes our soft-shelled turtles, which live in rivers or ponds of the Mississippi valley and the Gulf drainage basin (Fig. 25i).

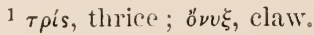


The family Testudinidæ ${ }^{1}$ inclucies the hard-shelled, fresh-water and land tortoises. ()ur snapping-turtle is distributed from Canarla to equatorial South America. It feeds on fish and lays from forty to fifty eggs, which it buries at a rlepth of about a metre. The alligator snapper of the Gulf States attains the length of a metre, and is regarded as the "most ferocious and, for its size, the strongest of all reptiles." The box-tortoises occupy the northeastern and central parts of North America. They are well known by the fact that the body is short and high, the plastron is provided with a movable hinge, and the carapace is

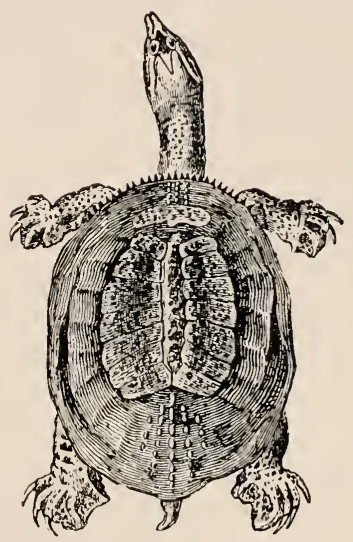

FIG. 25. - Trionyx, threeclawed turtle of the Mississippi valley. Reduced. From Lemis. colored black and yellow. ${ }^{2}$ other

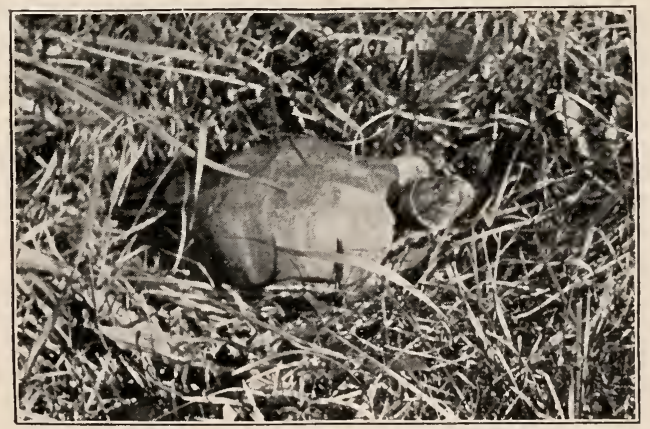

Fig. 258. - Terrapene carolina, the box-tortoise. Photo. of living animal by W. H. C. P.

${ }^{1}$ From testa, a shell.

2 Fig. 258. 
common tortoises of the eastern United States are the muskturtle, told by a strong odor of musk ; the painted turtle, of greenish black color and with marginal plates marked with bright red; the speckled tortoise, black with round orange spots; and the wood tortoise, with keeled shell, and plates marked with concentric strice.

The order Ophidia ${ }^{1}$ comprises the snakes, characterized by the elongated borly withont appendages, and by the

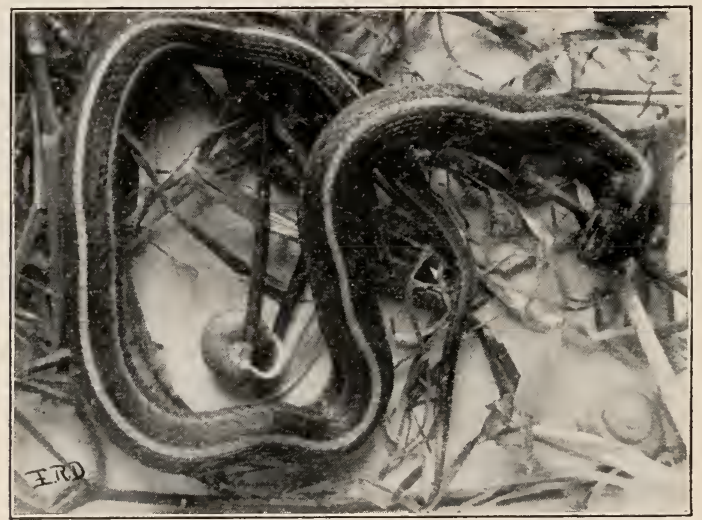

Fir. 259. - Eutania, garter-snake, dorsal view. Photo. by E. R. D.

absence of eyelids. Like other reptiles, the snakes are chiefly tropical, but inhabit also the temperate zones. They feed on living animals.

The family Colubridæ ${ }^{2}$ includes the great majority of our common non-venomous suakes, such as the gartersnake. ${ }^{3}$ water-snake, black-snake, milk-snake, and spreading adder. Allied are the boas of South America and the pythons of Inclia. which attain the length of six metres or

$1 \not ̈ \phi ı s$, serpent.

2 coluhra, serpent.

3 Fig. 259. 
more. Not being poisonous their bite is not clangerous. but they attack large birds and even medium-sized manmals and crush them to death in the folds of their body.

The family Elapidæ ${ }^{1}$ includes the large venomous serpents of the East, the cobra of the East Indies, and the as'p of the Egyptians. The bite of these serpents is quickly

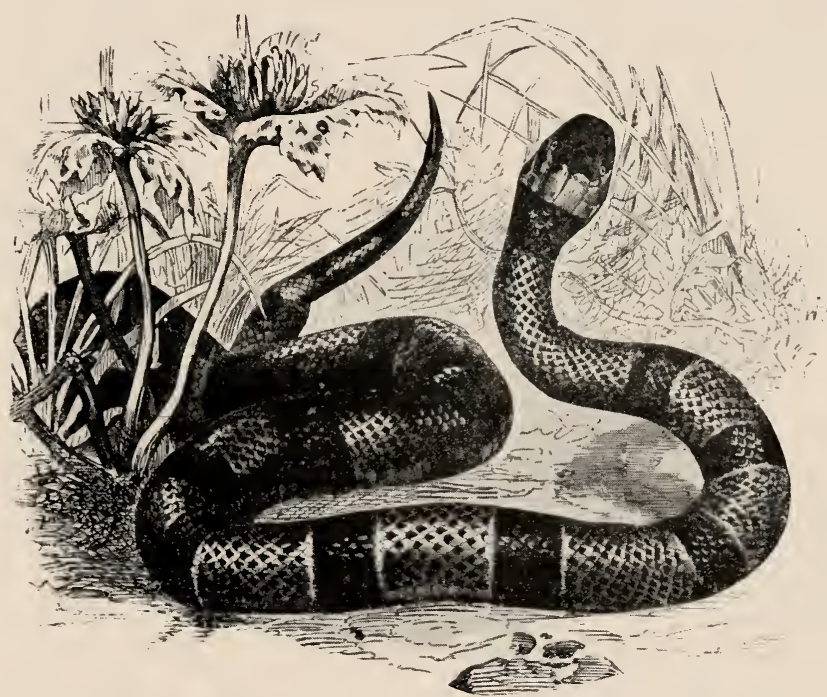

Fici, 260. - Elaps corcllinu, a harlequin snake of South America allied to the bead-snake of the Sonth. From "Standard Natural History," after Brehm.

fatal to man. To this family belongs also the bead-smake of our Southern States, which is however ham less (Fig. $260)$.

The Crotalidæ ${ }^{2}$ include the rattlesnakes, characteristic of Anerica. ${ }^{3}$ Of this family the most langerous is the water-

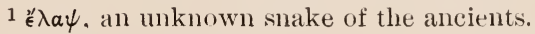

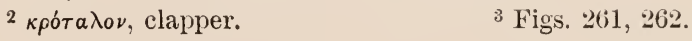




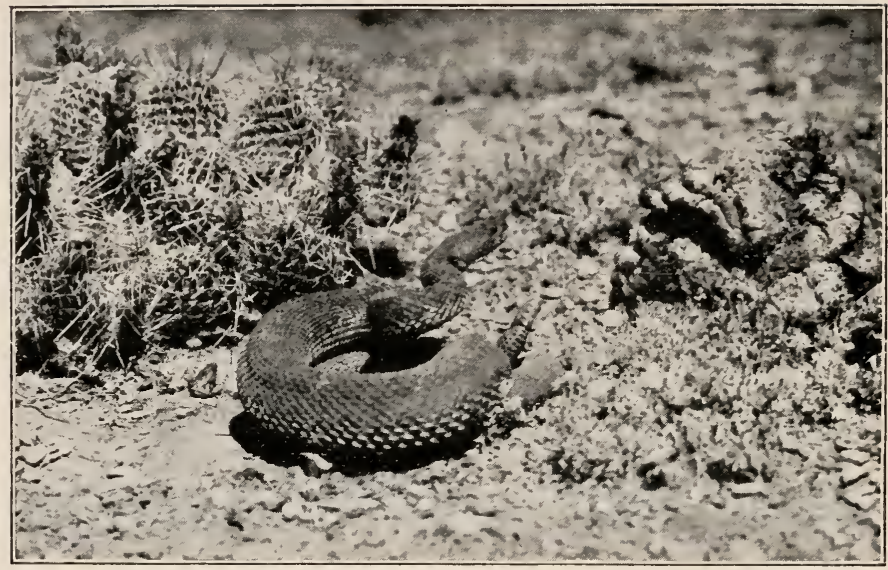

Fic. 261. - Crotalus, the rattlesuake. Photograpled as the snake was about to strike. Taken in Arizona and kinlly lent by H. W. Menke, Chicago, In

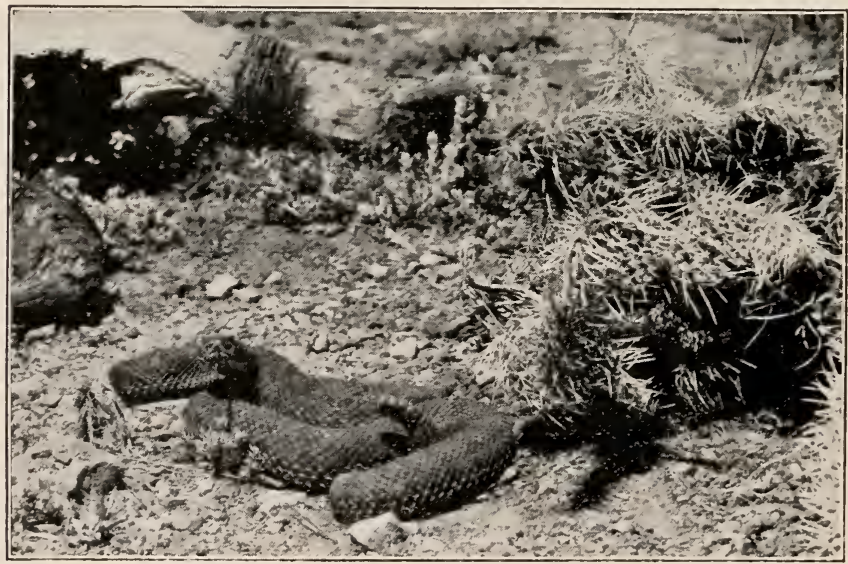

Fra. 262. - The rattlesnake. The recoil after striking. Photographed in Arizona and kindly lent by $H$. Wr. Menke.

Note in both figures the elevated rattle, toward the right. 
moceasin or black moceasin, which inhabits the Southern States, and given no warning noise as does the rattlesnake. The copperhead of the eastern half of the Enited States is also dangerous, but is mostly contined to wooded, mountainous regions. The rattlesnake was once common over' the whole of the Northern States as far west as the Rocky Momntains, but it is now nearly exterminated in wellsettled districts. Related to these are the venomous vipers of Europe.

'The order Crocodilina contains only some twenty species. distributed in three genera. The gavial is the erocodile

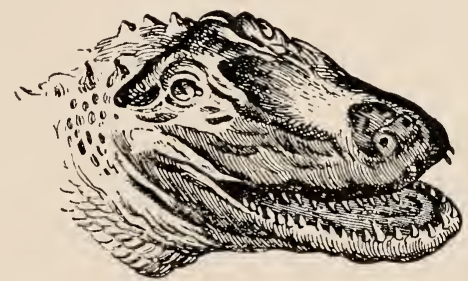

FIt. 263.- Head of Alligutor mississippiensis, the Nississippi alligator. From Leunis.

of the (ianges Rivel. It captures even large mammals and man. The crocodile in the strict sense is found in the Nile and other African rivers, in certain countries on the western border of the Pacific, and in northern Sonth America, Central America, and the Antilles. 'The American alligator, which has a different arrangenent of the dentition from the crocoliles, occurs in seven slightly differing species, all of which are South American excepting the alligator of our Southern States. It feeds on fish, and attacks horses and even man (Fig. 263). 


\section{APPENDIX TO CHAPTER XVIII}

KEY TO THE FOUR ORDERS OF REPTILES

$a_{1}$. Trunk enclosed in a case composed of a dorsal and

a ventral shield (carapace and plastron); jaws without teeth

$\epsilon_{2 .}$ Without encasing shields; teeth on jaws.

$7_{1}$. 'Teeth in special cups or alveoli; 4 legs;

cloacal opening a longitudinal slit . .

Chelonia

b... Teeth not in special alveoli ; cloacal opening a transverse slit.

$c_{1}$. Shoulder girdle and sternum present; eyelids usually present . . .

$c_{2}$. Shoulder girdle and sternum absent; eyelids absent; no feet . . . . Ophidia 


\section{CHAP'TER XIX}

\section{THE ENGLISH SPARROW AND ITS ALLIES}

THE term "English" sparrow is somewhat of a misnomer, for at the time it was introduced into our country this bird ranged over all Europe, where it is known as the house sparrow. The history of the spread of this bird shows us in a vivid way what are the successful qualities among birds. Originally this sparrow was confined to middle Europe, and probably made its way into Germany at the time of the Romans. It has since swept all over Europe, including the British Isles. and has penetrated even into Siberia. It has crossed the Mediterranean and is found along the Senegal River, and, probably through human agency, has penetrated to the Cape. It has been transplanted voluntarily by man to North America, Australia, and Java. It seems to occupy among birds the place taken among mammals by the rats. Crafty, pugnacious, obtrusive, thieving, dirty, it has become a nuisance wherever it has penetrated. But just these pushing qualities, combined with small size, great hardiness, a universal diet, and immense fecundity, have enabled it to make its way against all competitors. Its introduction into America can only be regarded as a deplorable blunder.

Spread of English Sparrow in America. - The first importations of the house-sparrow (Passer domesticus) to North America were made at Brooklyn, New York, in 1850 
and 1852. The second importation survived and multiplied. Subsequent importations were made to Maine, Rhode Island, and Pennsylvania, so that by 1870 the sparrow was firmly established in the eastern United States. From this time on the sparrow spiead at a rate unparalleled by any native bircl. By 1886 it had spread as far west as Kansas, and had established colonies at Salt Lake City, San Francisco, and other outlying regions; and throughout this territory it occurred in great abundance. Since then it has penetrated west to the Rocky Mountains, and south to 'Texas. This extraordinary spread has been due to several causes. As already suggested, the bird can adapt itself to various climatic conditions, and its fecundity is very great. Thus in our Southern cities there are from five to six broods a year, and from four to six young in each brood. Assuming that twenty-four young, half of them females, are produced by a pair each year, and that all the females breed when one year old, and sucessively for ten years, and that there are no deaths, then in the tenth year $138,000,000,000$ individuals will have been produced from the original pair. To the realization of the possible maximum of reproduction there are, however. many checks, especially the destruction of birds by accidents, disease, and beasts and birds of prey.

Food of English Sparrow. - The house-sparrow was introduced for the purpose of destroying or holding in check the "canker-worm" and the various other caterpillar's which destroy our fruit, forest, and shade trees. There is much doubt, however, whether the house-sparrow is at all efficient in the way of destroying insect pests, while it is quite certain that it fights with and drives away our native insect-eating birds. More important still, it de- 
stroys large quantities of grain in the field, as well as many kinds of garden produce, so that, on the whole, the English sparrow must he reckoned destructive to agriculture. Of late years it has come into our Southern markets as a substitute for the rice-bird.

Increase of Exotic Species. - The extraordinary spread of the English sparrow after importation to this country is not wholly explained by its large fecundity; for although equally reproductive in Europe, it increases less rapidly there than here. Also it is not due to any peculiarity of our country, for the bird is a similar pest in Australia. Similar facts concerning the spread of other animals lead us to conclude that it is the new country which permits the rapid spread and consequent destructiveness. Thus when the cabbage-butterfly (Pieris rapee) was brought to this country it spread with such rapiclity that, starting in 1860 at Quelec, it has now spread all over the Inited States as far as the Rocky Mountains. Again, the grapevine insect pest, Phylloxera, a native of this country, but not particularly destructive here, has been accidentally transported to France, and there it has wrought great havoc in the vineyards. Another instance, this time of an aquatic animal, shows the same result: the periwinkle, Littorina littoria, now the commonest snail on the seashore north of New York, has migrated down the shore from Ialifax since 1868 . This old species in the new country has almost driven out the other shore mollusks, to such an extraordinary degree has it multiplied. Now why should animals in a new country develop with such unusual rapiclity? It is because coming into a new country they have left behind them their natural enemies, and there has not yet been time for them to acquire new ones. Eventually 
the new enemies are gainerl or their old ones overtake them. and then the numbers of the exotic form become reduced; a new equilibrium becomes established.

The English sparrow belongs to the family Fringillidæ, which inclucles sparrows and finches. This is a large

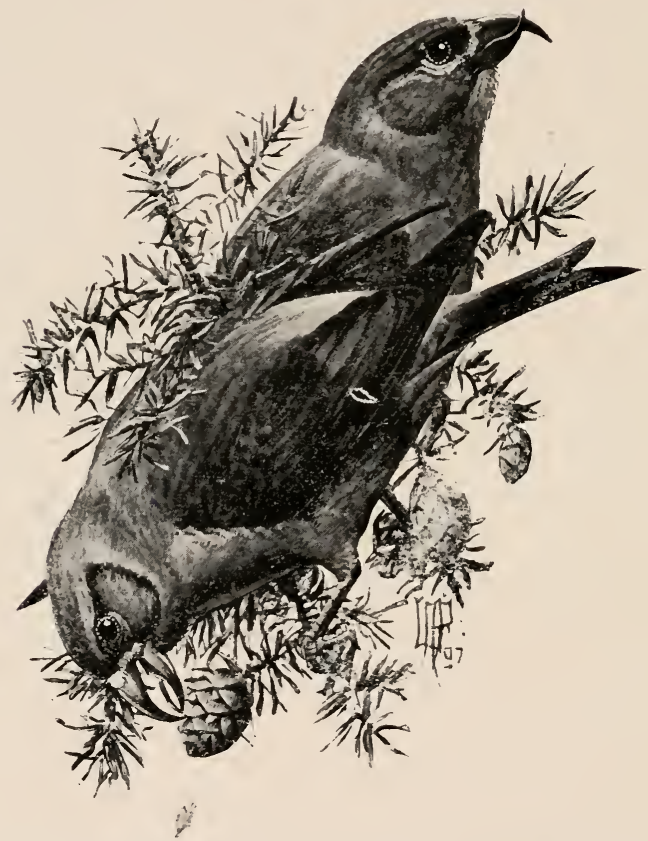

FIt, 2(it. - The American crossbill (Loxiu curvirostra).

family, comprising over five hundred species, found in all parts of the world, excepting, originally, Australia. In the United States this is the largest family of birds, comprising in most places about one-seventh of the species. Among common or striking native Fringillida may be 
mentioned the crossbills, ${ }^{1}$ yellow-birl, vesper-sparrow, white-throated sparrow, tree-sparrow, chipping-sparrow, ${ }^{2}$ snow-bird, song-sparrow, fox-sparrow, chewink, cardinal grosbeak, rose-breasted grosbeak, and indigo-bird. Most of these birks are known to every country boy.

The family of Turdidæ, or thrushes, includes several common American birks, - the robin, abundant about

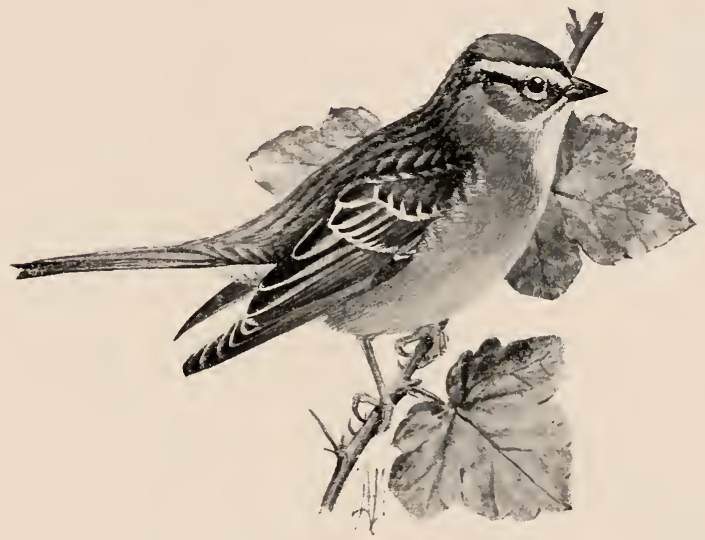

Fig. 26is. - chipping-sparrow (spizelle socialis).

houses during the summer but for the most part migrating south from New England during the winter; the wood or song thrush. ${ }^{3}$ one of our finest songsters; the bluebird, one of the earliest of our migrants, with " the sky on its back and the earth on its breast."

The family of Sylviidæ comprises the " warbler's" of the Old World. Here belongs the European nightingale. Its common representative in this country is the ruby-crowned kinglet (Fig. 267).
1 Fig. 264.
2 Fig. 265.
${ }^{3}$ Fig. :26t. 
The family of Paridæ inclurles the titmice, or tits and nuthatches. The tits are chiefly Old World birks, but we have a common representative in the black-capped chickadee, well known from its cheerful whistle. In this family

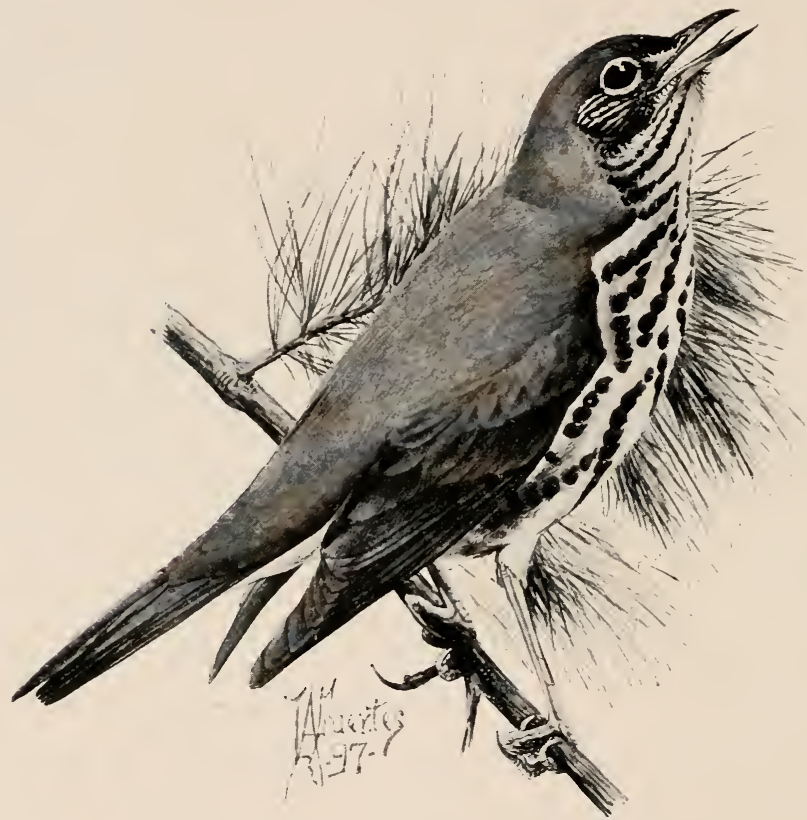

Fra. 26i. - Wood-thrush (Turdus mustelimus).

belong the nuthatches which run over tree-trunks, head up or down, indiscriminately (Fig. 268).

The family of Certhiidæ includes the little brown creeper which runs over tree-trunks much as the nuthatches do and uses its tail-feathers as props against the tree-trunk (Fig. 269). 
The Troglodytidæ, or wrens, are characteristic of sonth America, but some have sprearl into North America and northern Europe. Our house-wren, which is a near relative of the European house-wren, is an active little brown bird, with a sharply bent-rp tail. ${ }^{1}$ In this same family belong the mocking-birds, the centre of whose distribution is Central America, the Wrest Indies, and the south-

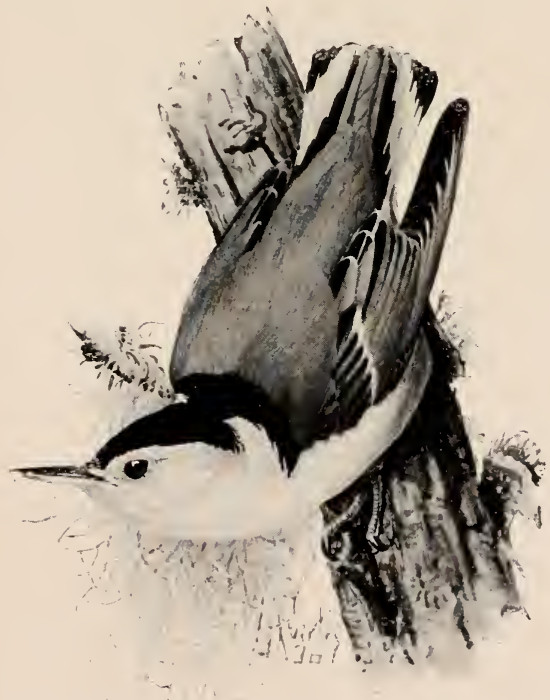

FIG. 2his. - White-breasted muthateh (Sitta curolinensis).

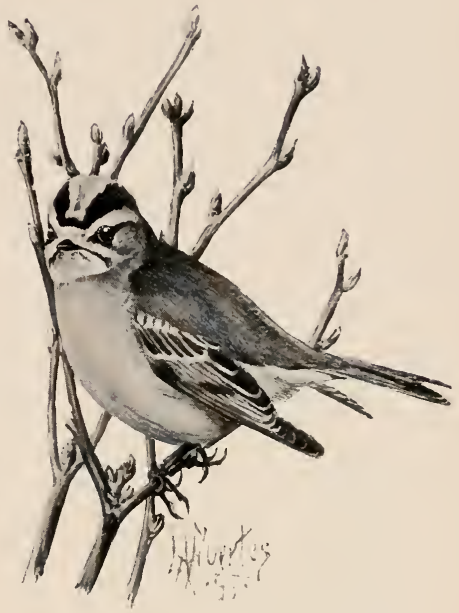

Fic. 2067. - Golden-crowned kinglet (Regulus satrupa).

ern Lnited States. The large brown thrasher and the cat-bird are familiar over the comitry. The mocking-bird does not get far north into New England. It is regarded by many as superior to the nightingale as a singer.

The family of Mniotilidæ, or "wood - warbler's," is the peculiar glory of America. It

${ }^{1}$ Fig. 270. 
contains numerous small, mostly brilliantly colored birds, which migrate. Although a few of them - like the redstart, the Maryland yellow-throat (Fig. 27i), the redpoll warbler, the chestnut-sided warbler, and the yellow warbler - are abundant, few of the thirty-five or forty Eastern

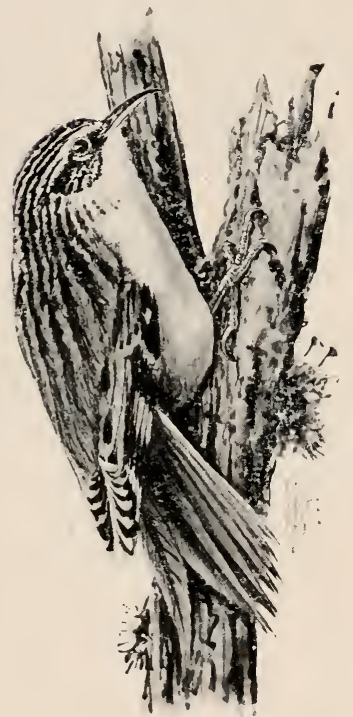

Fici. 26i9. - Brown creeper (C'erithiu familiaris).

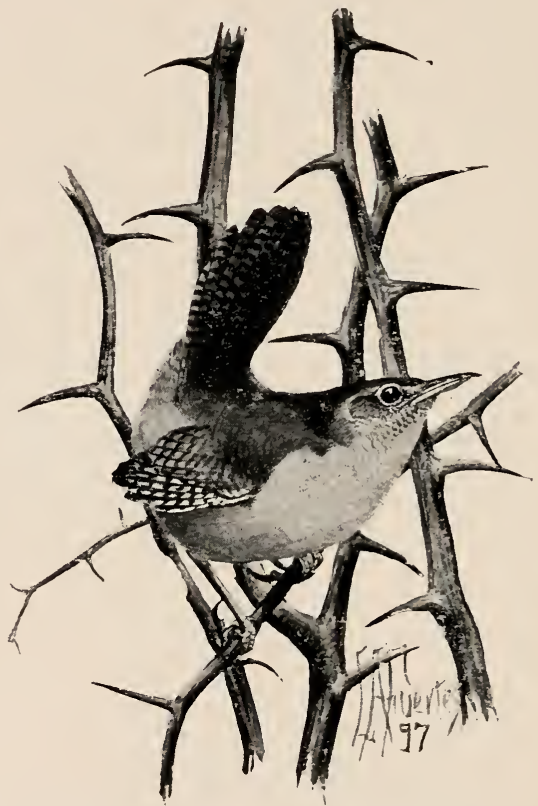

Fic. 270. - House-wren (Troglodytescüdon).

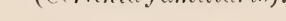

species can be said to be commonly known except to careful observers of birls ; for during the migrations they hide in thickets, and are extremely shy.

The Vireonidæ include the vireos, or greenlets, bright, handsome, and exclusively American birds. The com- 
monest species are the red-eyed viren (Fig. 272) and the yellow-throated vireo.

The Laniidæ, or shrikes, are of world-wide distribution. They are vigorous, pugnacious birds, which have the habit

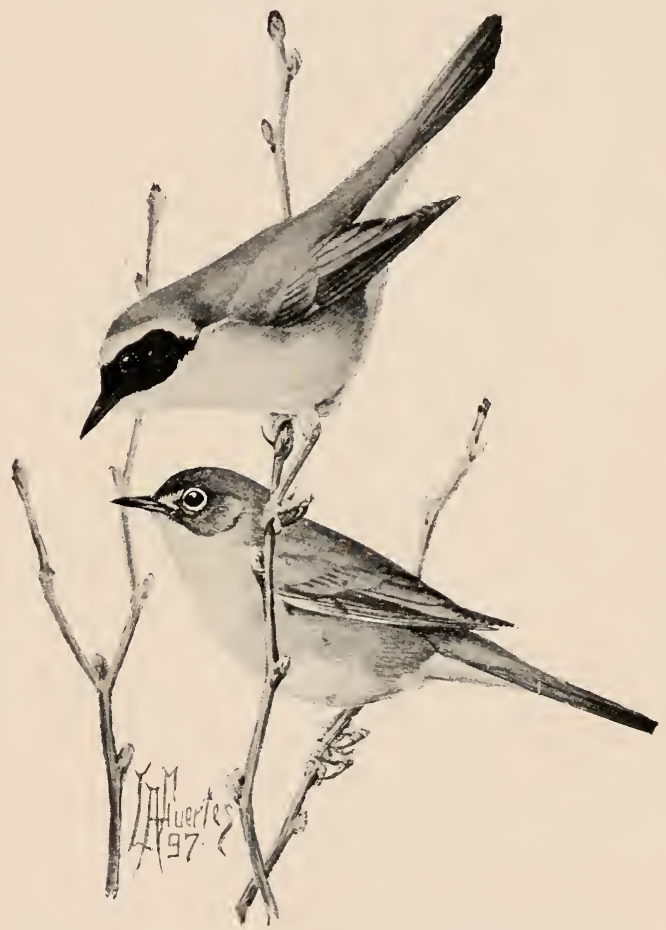

Fir. 271. - Maryland yellow-throat (Geothlypis triches).

of impaling grasshopper's and other small animals upon thorns, and leaving them there. In Germany there is a tradition that the shrike daily impales nine victims, and it is hence commonly called Neuntodter, or "ninekiller." The 


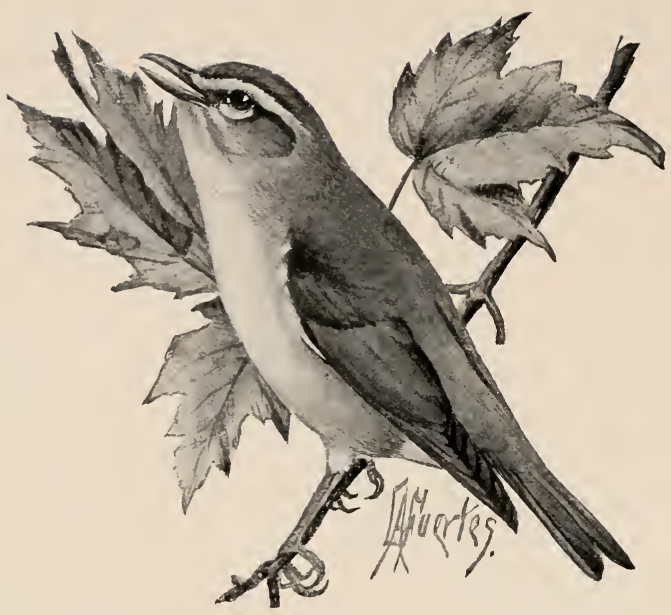

Fis. 272.- Red-eyed vireo (Vireo olinaceus).

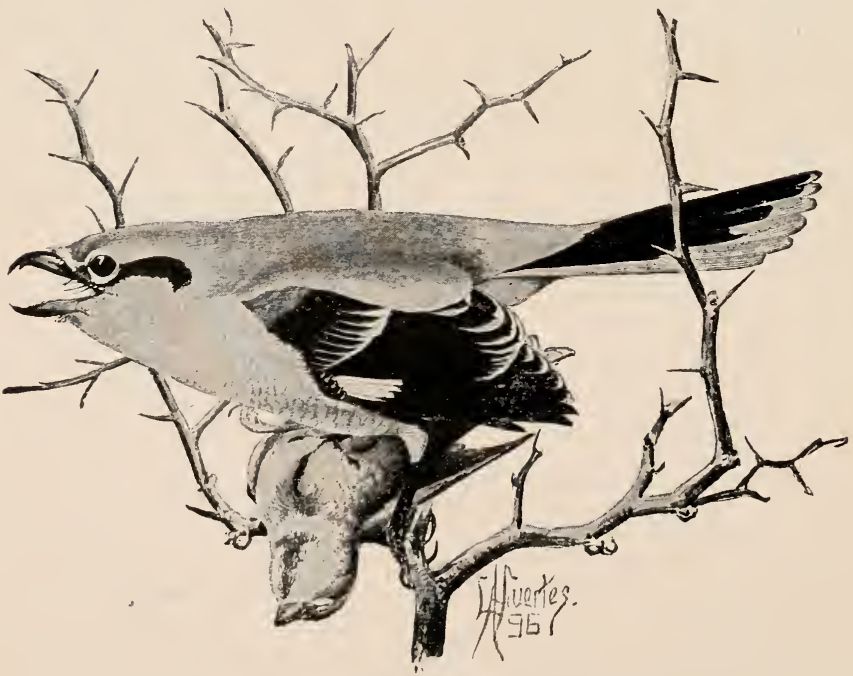

Fic. 273.- Great northern shrike (Lanius borealis). 
impaling seems to be done chiefly in the winter time, and apparently has for its purpose the storing of food against possible famine. Among birds frequently destroyed by them is the English sparrow, and it has been suggested that the shrikes should be encouraged to live in parks of cities

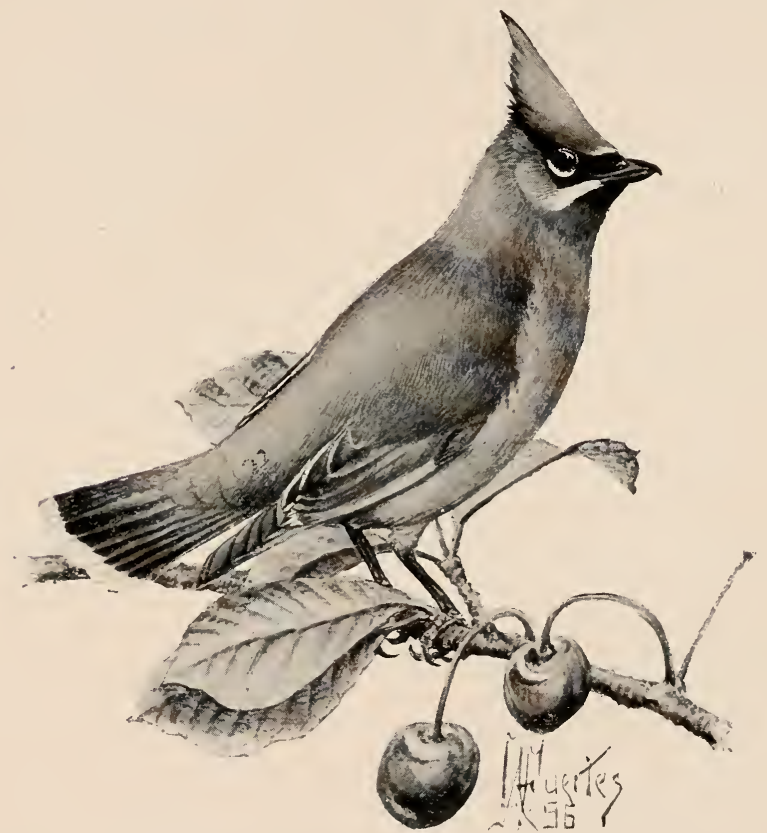

Fic. 274. - Cedar waxwing (Ampelis cedromum).

infested by sparrow pests; but unfortumately the shrikes do not confine themselves to this intruder. We have two species of shrikes, a northern (Fig.273) and a southern.

The Ampelidæ, or wax wings, are found over the Northern Hemisphere. They are migratory, go in flocks, feed on 
insects and fruits, and chatter rather than sing. Our commonest species is called " celar-hird" (Fig. 27t).

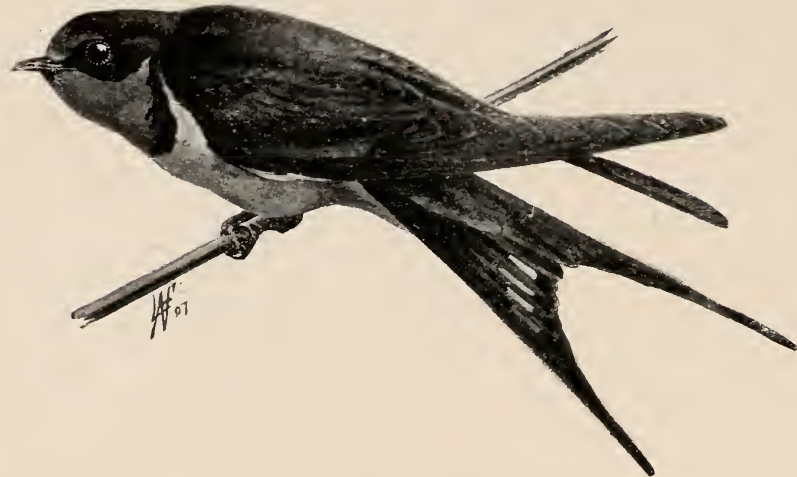

Fici, 275. - Barn-swallow (Chelirton erythroggaster).

The Hirudinidæ, or swallows, are fomd over the world. They are powerful fliers, and are insectivorous. Formerly all of them bred in boughs, cliffs, and hollow trees, and

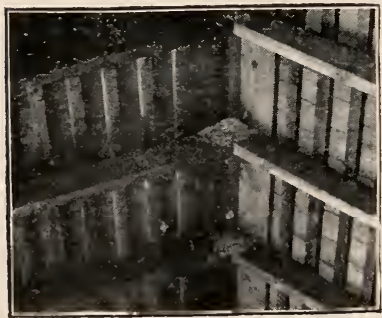

F11. 276. - Nests of barn-swallow. Photo. by D. and s. some species still retain these habits. The best-known species are the bank-swallows, which, living in rolonies, form numerous holes in railroad cuts and sandbanks in general; the white-bellied swallow, abundant about water : and the barn-swallow (Fig. 275), with a chestnut belly, which builds its nest in the rafters of our harns (Fig. 276).

The Tanagridæ, or tanagers, are exclusively American, and belong especially to the tropics. 'They live in the 
woods, and feed on berries and fruits. The northernmost member of the family is the scarlet tanager of the eastern Uniterl States (Fig. 27T).

The Icteridæ include numerous species with different habits. These are also confined to America, and are especially abundant in the tropies. They feed, for the

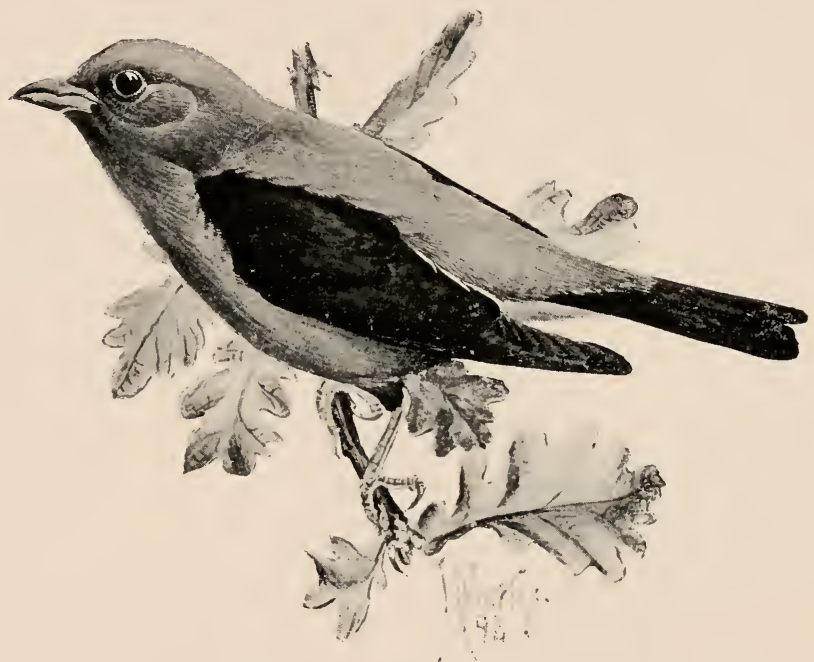

FIt: 277. - Scarlet tanager (Pirungu erythomelus).

most part, on seeds. The commonest representatives are the crow blackbird, ${ }^{1}$ of large size and iridescent plumage; the Baltimore oriole, which weaves a hanging nest; the orchard oriole, with less orange than the precerling; the large mearlow-lark, brownish above and yellow below; the red-winged blackbird: the cow-bird, which builds no nest but lays its eggs in the nests of various small birds; 
and the "bobolink," as it is called in the North, whose song is the merriest of all birds. In the South, whither the bobolink migrates in the winter, it is a great pest in

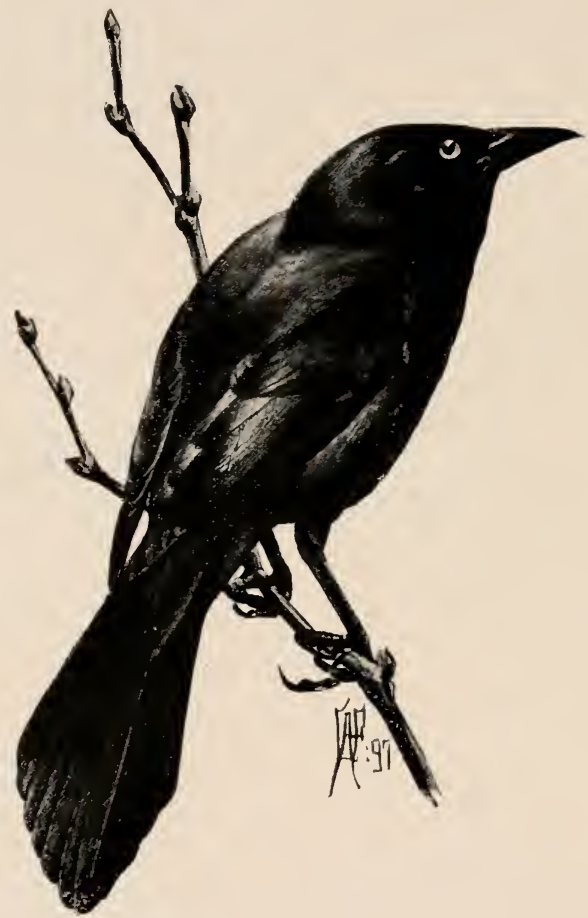

FI(. 278. - Purple grackle (Quiscalus quiscula).

the rice-fields, and is known as the "rice-bird." It is slaughtered there as a game-bird.

The Corvidæ include the crows and their allies, all of them birds of large size. The crow, the raven of the W' est and of Europe, and the blue jay (Fig. 279) are the commonest North American species of this family. 
The Alaudidæ, or larks, are a family chiefly of Old Wrorld birds of dull color, building a rough nest on the ground, and feeding on seeds and insects. The skylark of Europe is renowned as a songster. In this country we have one

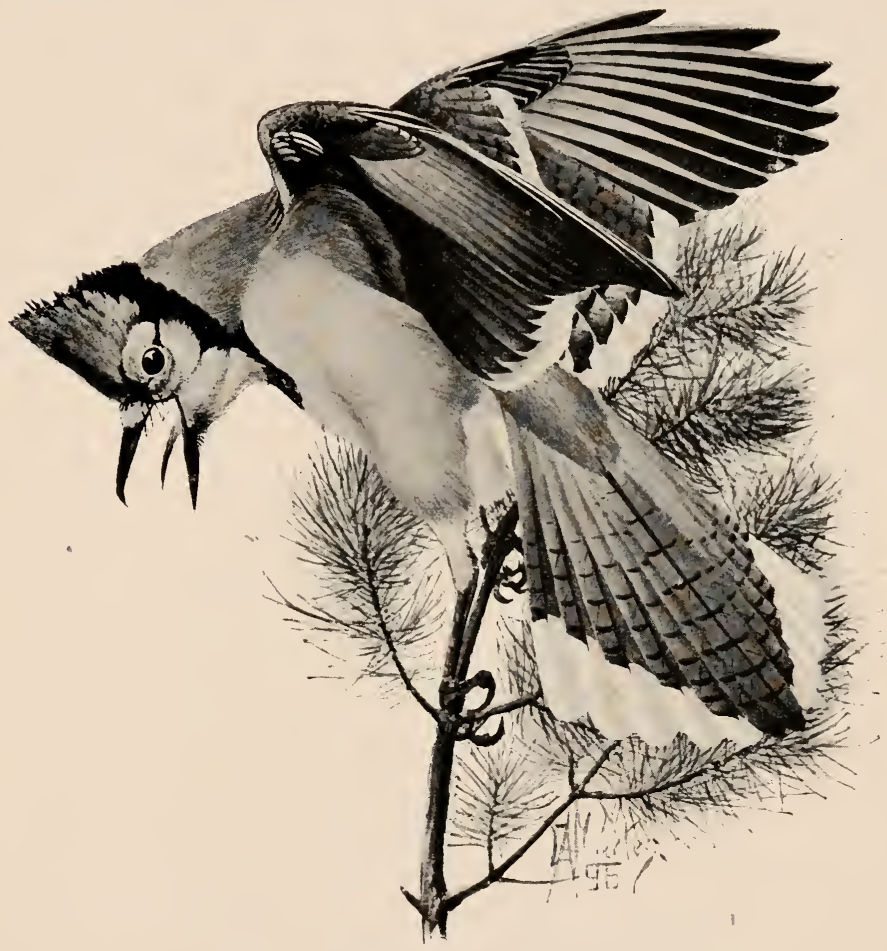

FIG. 279. - Blue jay (Cyanocitta cristata).

representative of the family, the horned lark, found also in Europe.

The Tyrannidæ, or flycatchers, are an exclusively American family, feeding on insects. The best-known represen- 
tatives are the courageous king-bird (Fig. 280), the wood pewee (Fig. 281), and the water-loving phobe.

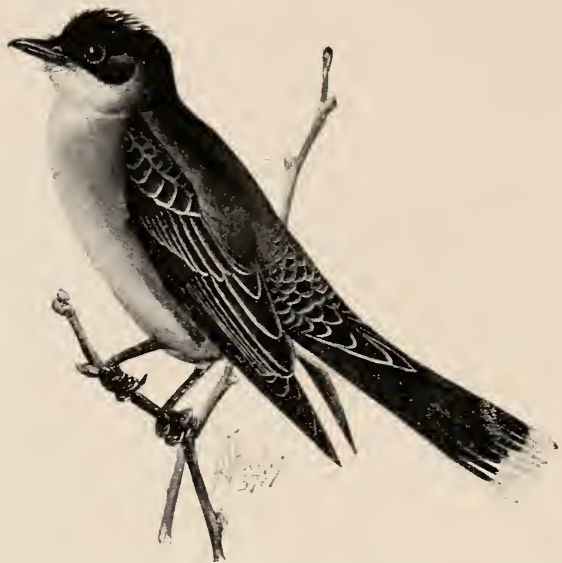

Fur, 2so. - Kingbird (Tyrammus turammus).

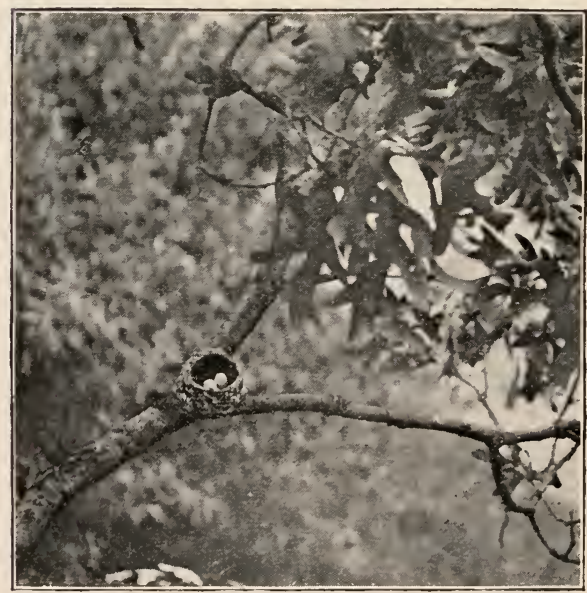

Fia. 281. - Nest of pewee. Photo. hy D. and s. 
We will now pass in brief review the principal Orders of Birds other than Passeres. The Psittaci inclucle the parrots and cockatoos. In the cockatoos the feathers of the head are elevated to form a crest. In the parrots there is no such erest; in one subdivision the tail is long; in a second, very short. The representatives of this

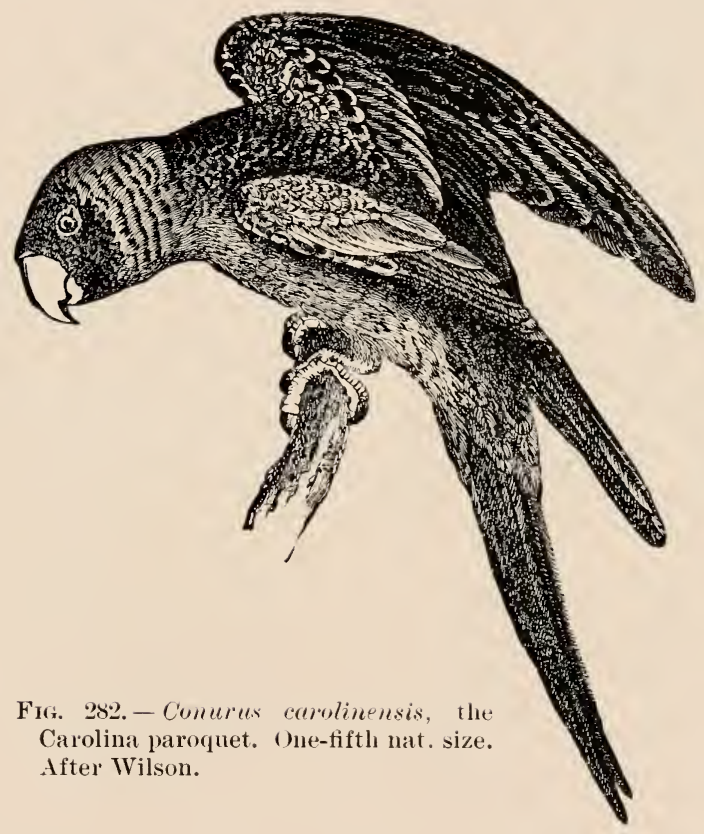

family are found almost exchusively in the tropics, in Brazil, the Moluceas, and in Australia. In general, these birds have a loud voice, and certain species may be trained to articulate words and combine them into sentences. There is only one parrot native to the United Statesthe Carolina paroquet (Fig. 282). 'This formerly occurred. 
north to the Ohio River, but it has been within recent years practically exterminated by plumage hunters.

The Raptores include eagles, hawks, and falcons; the vultures: condors; and owls. These birds feed chiefly on

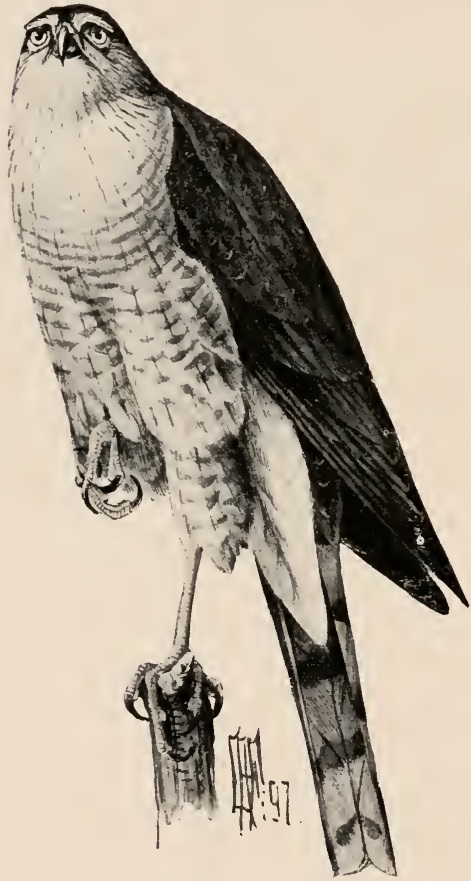

Fıc. 28:3. - Sharp-shinned hawk (Accipiter velox).

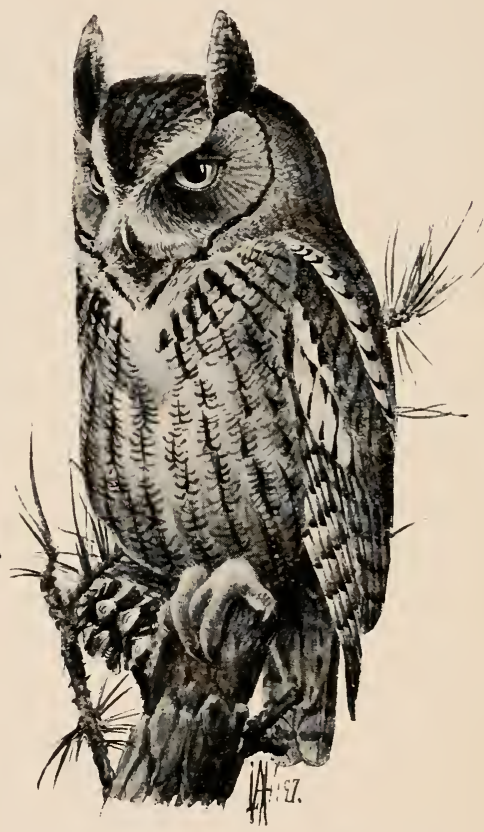

FIG. 28t. - screech owl (Megascops (asio).

bircls and mammals, which they capture alive in their claws or beaks; a few live on carrion. They occur in all parts of the globe. The bald eagle, userl as a symbol of the Republic, is the commonest of om eagles. Imong 
our hawks, the sparrow-hawk, which is only about the size of the robin, is one of our commonest; others are the sharp-shinned hawk, which kills bircls almost exclusively, and is especially destructive to poultry, ${ }^{1}$ and Cooper's hawk, which is also destructive to birds. These two hawks have practically no redeeming qualities, except the fact that they prey upon the English sparrow. 'The vultures are represented in our fauna by the turkey-buzzard, which, like other members of the family, feeds on carrion. 'The European and African vultures even exceed the turkey-buzzard in size. 'The condor' is the largest of the American Raptores. It preys even upon live sheep' and calves. 'The owls, which live in dark holes and feed upon small mammals at night, are found over the globe. Our commonest species is the reddish gray screech-owl. ${ }^{2}$ 'The great horned owl is an inhabitant of wooded tracts, and is destructive to poultry and small mammals. The snowy owl is one of the handsomest of all owls, and is frequently seen stuffed in houses in Europe as well as in North America.

The Scansores include the toucans and cuckoos on the one hand and the woodpeckers on the other. 'The toucans are characterized by an enormous bill, which in extreme cases is as long as the rest of the bird. It would be extremely heavy were it not filled with air spaces of great extent. These birds inhabit Brazil. The great bills are of use in feeding on fruits. Filling the place in the Old World of the toucans of the New are the hornbills of Africa and Asia, which are likewise frugivorous. The cuckoos are typically represented by the old World cuckoos. Like our own cow-bird, they have the peculiar 
habit of laying their eggs in the nests of other birds, especially insectivorous birds, where they are brooder and the young are fed by the foster-mother. Our native cuckoo, however, broods its own eggs, and is a useful insectivorous bird. The kingtishers are also placed in this group.

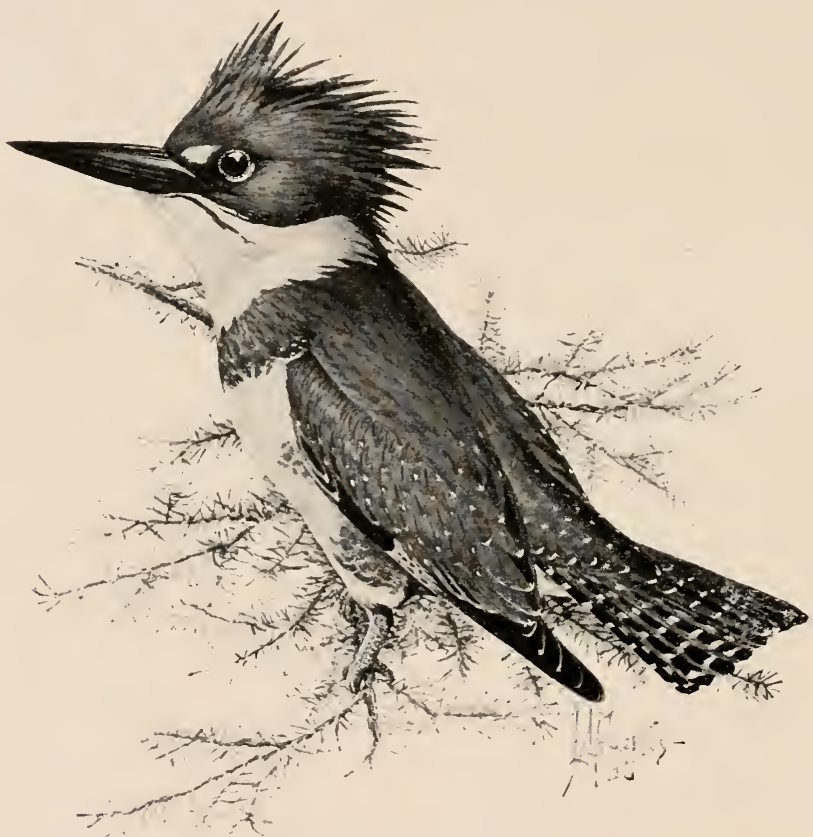

Furi. 20.T. - Belted kingfisher (Ceryle alryon).

They are especially an (Old World family, but one genus, Ceryle, has found its way into North America and even into South America. These birds feed chiefly on fish, and they have gained a compact oily plumage to prevent them from getting wet when they plunge for their prey. Our species is known as the helted kingfisher (Fig. 285). 
The woodpeckers include for the most part arboreal birds which feed chiefly on insects and have loud, harsh cries. The common idea that they are sap-suckers and destructive to trees seems to be true only of one of our species - the yellowbellied woodpecker. The heavy, long bill enables woodpeckers to peck holes in trees for wool-eating insects, and the long, barbed, protrusible tongue aids in removing the prey. Our commonest woodpeckers are the gollenwinged woodpecker, or flicker, ${ }^{1}$ the red-headed woolpecker, the hairy woodpecker, and the downy woodpecker. An interesting question concerning the golden-winged woorpecker's of the East and Southwest is whether they hybridize where

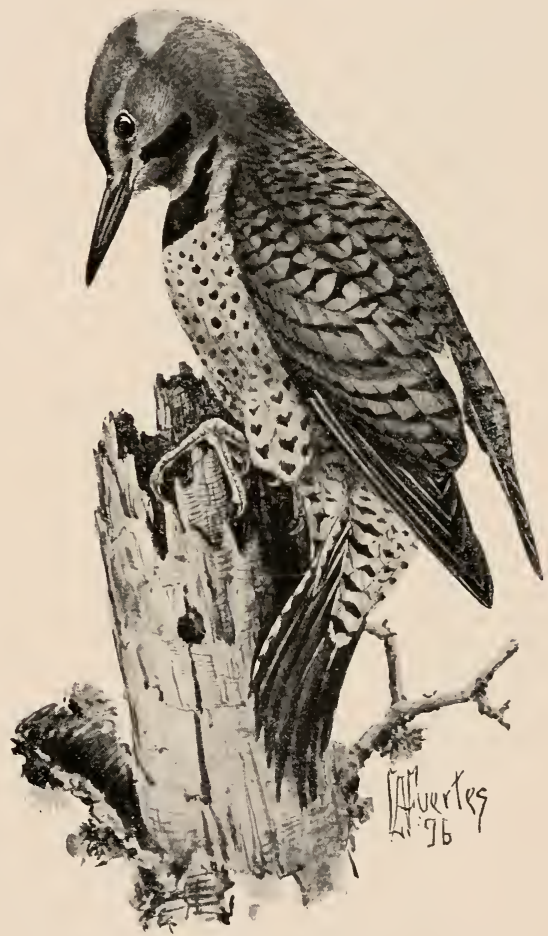

FIrs. 286. - Flicker (coluptes aurutus). their areas of distribution overlap.

The Cypselomorphæ include the humming-birds, swifts, and goat-suckers. The humming-birds are mostly small species, limited to onr hemisphere, and characteristic of

${ }^{1}$ Fig. 286. 
the tropies. One species, the ruby-throated hummingbird, reaches New England and ('anada. These usually

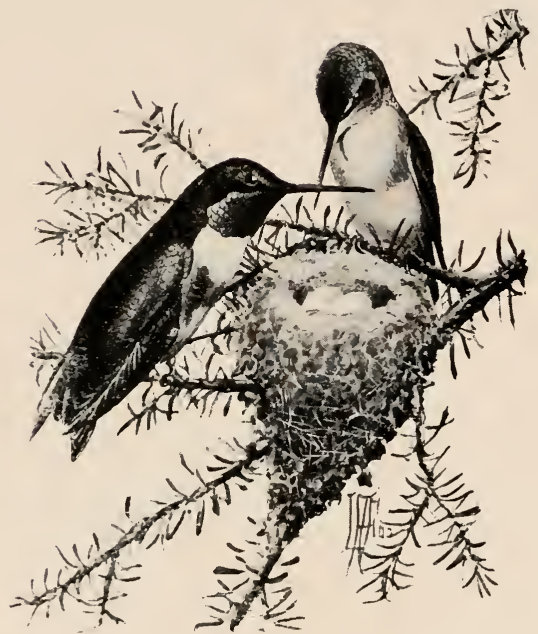

Fis. $2 x-$ - Ruby-throated humming-bird (Tirochilus colubris). brilliantly colored birds feed on insects and nectar, which they gather from flowers. They fly with great swiftness, nest in trees, and lay only two white eggs (Fig. 28T).

The Swifts have a broad gape, and no bristles at the base of the bill. They have habits much like swallows, and are found especially in the warm parts of the world. Most species of this family have salivary

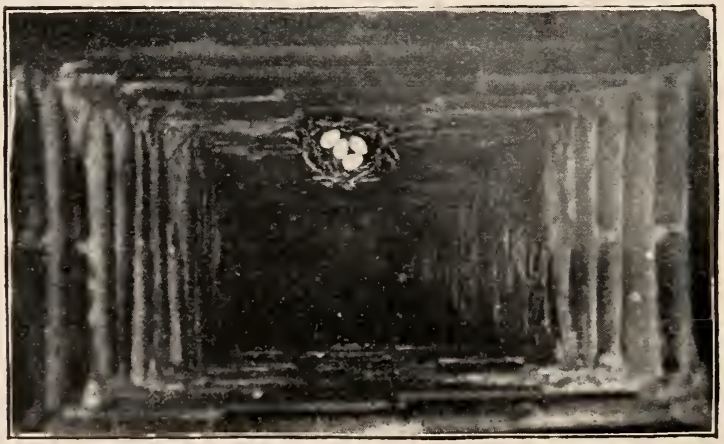

FIG. 288. - Nest of chimney-swift. Photo. looking down chimney, by D. and S. 
glands, whose secretions aid in cementing the nest. Our common representative of this group is the chimney-swift, or chimney-swallow. ${ }^{1}$ Certain Chinese species make nests entirely of the mucilaginous secretion of the salivary glands ; these constitute the edible birds-nests of the Chinese. The goat - suckers inclurle night-flying birds, with exceedingly broarl gape and insectivorous habits. The night-hawk of North America, and the whippoorwill, noted for it; characteristic night rry, are familiar examples.

The order Columbinæ includes the pigeons and allies, characteristic of the Lastern Hemisphere. The most interesting species of the group the dodo and the solitaire, formerly inhabitants of the islands of Mauritius and Rodriguez, respectively-

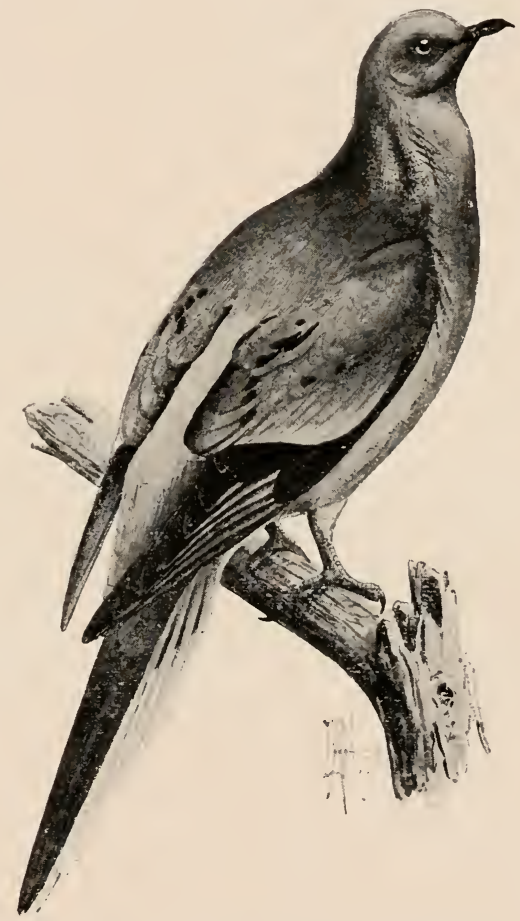

Fic. 289. - Passenger pigeon (Ectopistes migrotorius).

have become extinct within historic times through the settlement of these islands by white men. These birds had rudimentary wings and tail. 'Their nearest living 
ally seems to be the " manu-mea ${ }^{1}$ " of the Samoan Islands. The pigeons proper are represented in North America by three wild species (Fig. 289). The domesticated pigeon, Columba livia, is a native of southern Europe or western Asia.

'The order Gallinacei includes a number of terrestrial hirds of large size, especially the grouse or partridges, the pheasants and common fowl, the guinea fowl, and the tur-

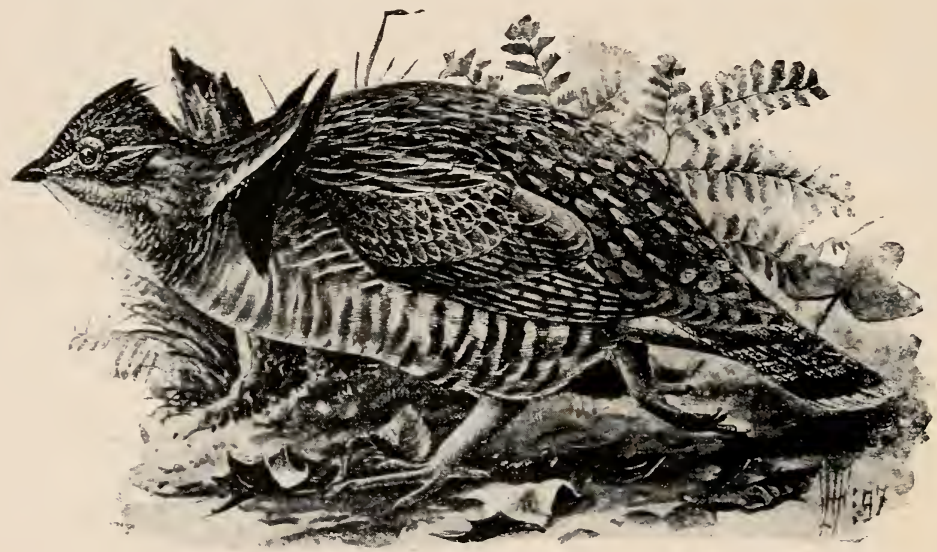

Fir. 2990. - Ruffed grouse (Bomusa nmbellus).

keys. On account of their large size and well-flavored Hesh, they are much used as human food. 'The grouse of America include the familiar "bob-white" or quail, which is undergoing a rapid extermination in populous regions; the C'anada grouse. which does not oceur south of New York; the ruffed grouse of the Eastern States ; ${ }^{2}$ and the prairie chicken of the (rieat Plains, which has also become almost exterminated. In Europe the large
1 Red-bird.
2 Fig. 290. 
"capercallie" and the blackeock are favorite game-birds. The pheasants are characteristic of southern Asia and ('hina; they comprise some of the most brilliantly colored and greatly ormamented of birds, such as the peacock and the golden pheasant. Here also belong our barnyard fowl, derived from a wild species. Gallus bonkiva, inhabiting northern India, the East Indies, and the Philippines. The guinea-fowl is a native of Africa, where it goes in large flocks and is difficult of approach. The turkeys are North American birds. The wild turkey formerly occurred over all the United States and Mexico. It was first taken to Europe in 1502, was domesticated there, and now occupies much of its former habitat as a domesticated fowl. From this brief view we see that the family of (rallinacei is, for man at least. one of the most important families of birds.

The Grallatores, or waders, include a great number of shore birds known as plovers, sandpiper's, snipes, rails. cranes, herons, and storks. The plover's walk and $\mathrm{Hy}$ along shore, picking up worms, mollusks, and amphibians; the golden plover and the killdeer are well-known gamebirds. The snipes are found in meadows or, less commonly, in woods. (One of the most common is the spotted sandpiper. also called "tip-up" from its rocking movements (Fig. 291). It is seen walking around small pools of water by the roadside or in fields. Along the coast are found woodcock and large snipes. Among the herons, our great blue heron attains a length of four feet and is a notable resident of swampy regions; the egrets have been practically exterminated to meet the demands of milliners ; the bitter'n is still common on ticle-flats.

The Natatores, or swimmers, comprise the ducks and 
geese, the pelicans, the petrels, the gulls and terns, and the divers. Of the geese, the wild goose, or C'anada goose, is most commonly seen in its migrations. Of the native ducks we have many kinds, almost all rapidly disappearing before the "sportsman." The pelicans are large fisheating lirds, with a huge lag-like lower bill. In this comntry the white pelican is not uncommon. The large-

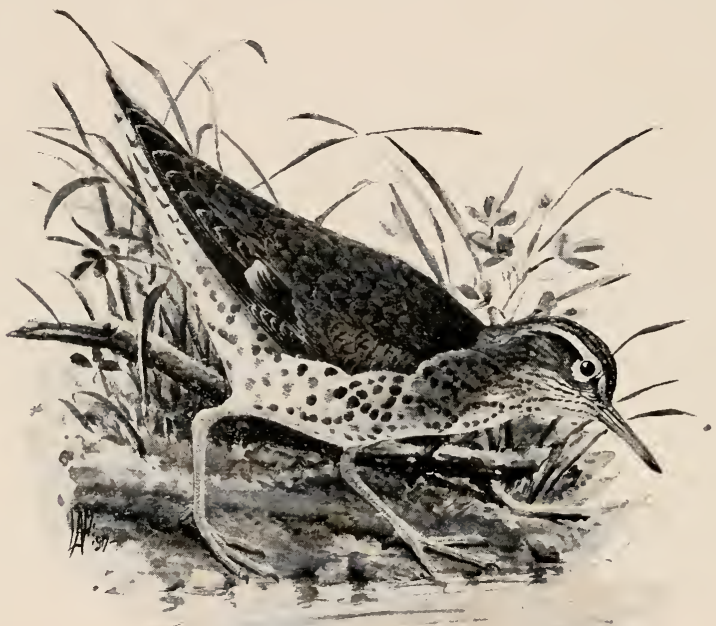

Firi, 2:1. - Spotted sandpiper (Actitis mucularia).

winged petrels follow in the wake of coastal vessels. The terns, which are slender birds with a straight bill, ${ }^{1}$ were once abundant along our coast, but have been decimated to " ornament" bonnets. 'The gulls, which are heavier than the terns and have hooked bills, are still abundant over all bodies of water. Finally, the loons are large birds, 
powerful fliers and swimmers, which are found in the lakes of the Northern Iemisphere. They are quick divers, and can swim under water for a considerable distance.

The order of Cursores inclurles the $A$ frican ostrich, the American ostriches or rheas, the cassowaries of the East Indies, and certain wingless birds of New Zealand $\left(A_{p}\right.$ -

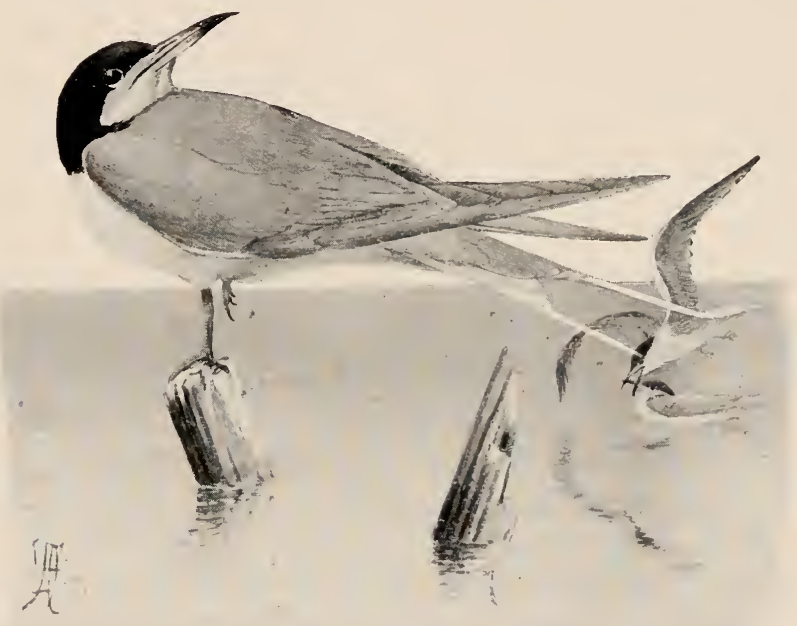

Fin. 29:2. - Common tern (Sterna hirumdo).

teryx ${ }^{1}$ ). These are regarded as the most lowly developed of the birds; the vanes of their feather's are not mited, but separate to form a sort of hair-like covering to the borly. The African ostrich is the largest living bird. It wanders in families or flocks in the deserts of Africa, and feeds on grass, grain, and small animals. It also swallows undigestible matters, such as stones, which probably aid

${ }^{1}$ Fig. 293. 
it in triturating its food. The nest consists of a hollow scooped out of the earth, into which about thirty eggs are lairl. Ostrich feathers are used for ornament, and so important is the commerce in these articles that ostriches

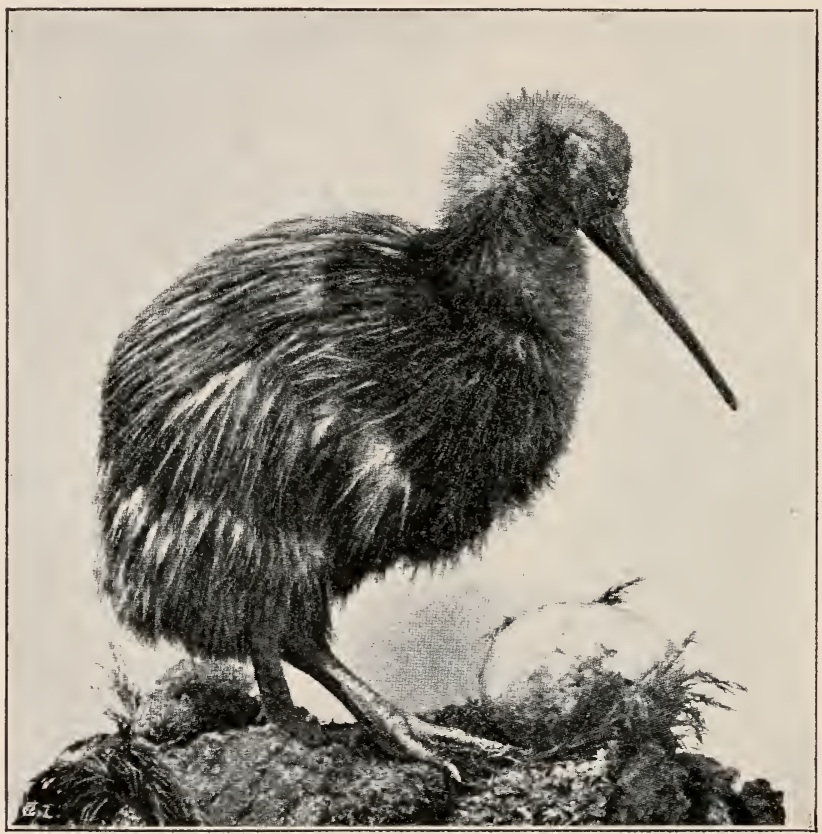

FIG. 293.-Apteryx australis with egg. From a specimen in the Royal College of Surgeons, London. From Parker and Haswell, "Text-book of Zoology."

are extensively farmed in South Africa. When reared in captivity the eggs are hatched in an incubator, and the young carefully fed. The feathers are cut off and not julled out, so that the operation of gathering the feathers is a painless one. 
Bird Migration. - The birds of any territory may be elassified on the basis of their residence into four groups: permanent residents, winter residents. summer residents, and transient visitants. In New York the permanent residents are represented hy the screech-owl, the crow, and the gold-finch. W'inter visitants are represented by the snow-bird and white-throated sparrow; summer residents by the wood-thrush, aat-bird, yellow warbler, bobolink, and barn-sivallow; transient visitants by most of the warblers, the fox-sparrow, and white-bellied swallow. As this classification indicates, the bird fauna of any place is, to a great extent, shifting from season to season. In the spring at any latitude many species are seen passing far north. and in the autumn passing south again. Temperate as well as souther'n latitudes receive in the winter time the southern erge of a more northern fama. Thus geese and ducks are forced by the universal ice of the Aretic winter to go to regions of open water, at least. Many kinds of birds which spend the winter in the South come North to breerl. For example, the bobolink is found nesting in the New England fields in summer, and is then altogether absent in the South. In the fall this bird is not found in New England, but oceurs in the Gulf States as the rice-bird. The cause of this migration on the part of birds breerling in the North is the need of food. Insectivorous birds, especially, could not obtain food enough in the North in winter.

Migration Routes. - It is known that many speeies which migrate even great distances travel along welllefinerl paths. In Europe the paths of the shore migrants have been carefully mapped out. It appear's that these birds follow the shore line very exactly, except in some 
cases in which it can be demonstrated that their paths are along ancient shore lines. As Wallace says: " It is easy to see how the migrations that had once taken place over continuous land would be kept up first over lagoons and marshes, then over a narrow channel, and subsequently over a considerable sea, no one generation of birds ever perceiving any difference in the route." The migration routes of North America have not been well studied. The Atlantic coast is one line; the Mississippi valley, formerly, no doubt, an arm of the sea, is another route along which even sea-birds now migrate. The question how birds recognize and are able to follow their migration routes, is a difficult one; they seem to have a marvellous sense of direction. There is great need of a more perfect knowledge of migration phenomena in North America. Every one who has learned to distinguish accurately the species of birds can contribute to this knowledge by keeping records of the time of appearance of migrants in the spring and the fall. 'The American Ornithologists' Union has for many year's solicited observations on this subject from voluntary collaborators.

Bird Flight. - The difficulties which must be overcome in order to fit birds for flight are, first, that of sustaining the heavy body in a medium of such low specific gravity as the air and, secondly, that of progression in this medium. To diminish the difficulty of sustaining the body, the specific gravity is reduced to a minimum by great airspaces in the body, which exist even in the hollow bones. The body is kept from being overturned in the air by the position of the wings, which are placed high up on the trunk while the digestive organs, breastbone, and breast muscles are placed low. To aid locomotion, the general 
form of the body is made conical. so as to offer little resistance to the air, while, hy varying the position of the head, wings, and tail, the centre of gravity is quickly shifted. In starting to fly, the bird gains an initial velocity, if on the ground, by springing into the air, or if on a tree, by combining the velocity due to gravity with a pushing from the limb; but aquatic birds strike the surface of the water with their wings. The best fliers have relatively large, pointed wings. Three methods of flight are employed by birds when once in the air : (a) stroking the air with the wing; (b) gliding or skimming; and (c) sailing or soaring. Some birds can use all three methods, and all good fliers use the first two. In the stroke the wing moves downward and forward, backward and upward, so that the tip of the wing describes a $\infty$; and the plane of the wing constantly changes so as to push downward against the air, and thus keep the bird up, and to push backward against the air, and thus drive the bird forward. At the same time, the wing must be brought back to its upper and anterior position without offering great resistance to the air. In gliding, the wings are spread, but are not flapped, - progression depends upon an acquired velocity or upon the wind. In soaring, the wings remain motionless, and the bird does not lose its velocity nor tend to fall. 'The way in which the bird is supported and carried along is uncertain. It seems to depend upon certain favorable currents in the air.

Birds, like insects, have the closest economic relations with man. A few of them, chiefly belonging to the orders of Natatores and Gallinacei, are very important as human food; but most of them concern man on account of their feeding habits, which are either favorable to man, as when 
noxious insects are lestroyed ; or injurious, as when grainfiels are ravaged or other birds are destroyed. Lnquestionably the vast majority of birds are commercially advantageous to man. The Raptores are only partially so, for they feed entirely upon animal food, chiefly birds and small (usually destructive) mammals. 'The bobolink and the Imerican crow, to he sure, together annually destroy millions of dollars' worth of grain, yet during the breeding season they both feed much upon insects. Outside of the group Raptores, there are few, if any, completely noxious birds, and even many of the hawks are efficient destroyers of insects. Legislation directed towarl the destruction of any kind of birds, excepting the English sparrow and the Cooper's and sharp-shimned hawk, is quite as apt to do hal'm as goorl.

Bird Protection. - 'Travellers in certain parts of Europe, where the poverty and ignorance of the people have led them to prey upon birds, have remarked on the desolation of a birdless country. The natural enemies of insects being destroyed, there is no adequate check to the destruction of vegetation by them and the beauty of a forest landscape is missing. North America has been richly provided with a native hild fauna: but within the last few years it has become plain that most of our species are undergoing reduction, and many are near extermination. Careful inquiries recently marle indicate that during the past fifteen years the number of our common song-birds has been reduced one-half, and the number of certain birds prized as food or ormament has been reduced to one-fourth. At the present rate, extermination of many species will oceur during the iives of most of us. The eauses of this destruction of birds are numerous. The most efficient 
cause is the shotgun in the hands of boys and thoughtless men, and of those who gather birdskins to meet the demand for bonnet "ormaments." Very great destruction is also caused by egg-collectors, who annually gather scores of

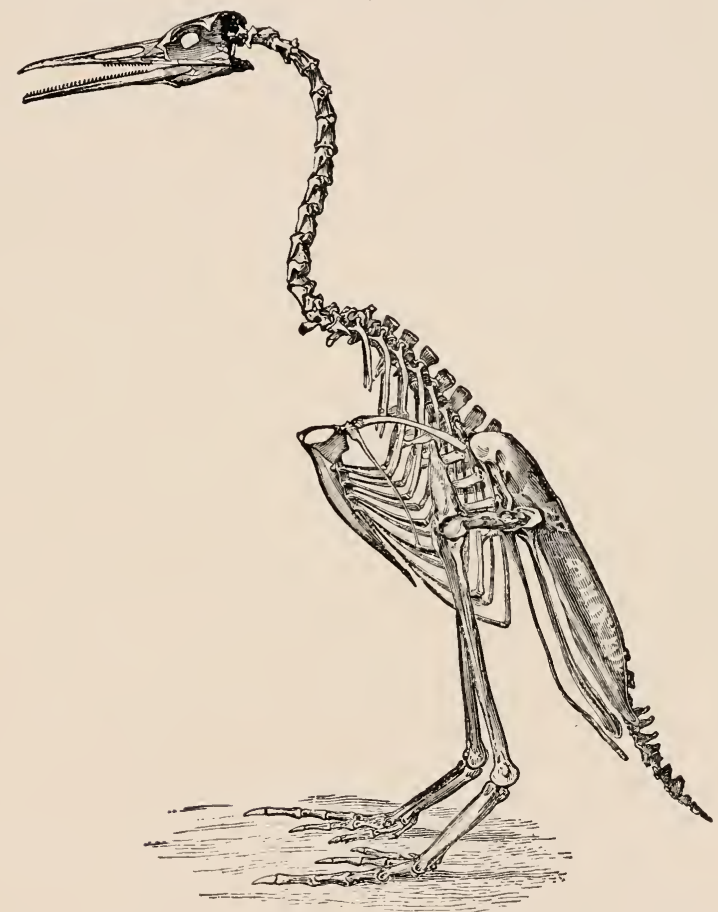

Fic. 294. - Hesperornis regalis. The restored skeleton. After Marsh.

thousands of eggs, often of rare birds. The disastrous results of killing birds need only to be appreciated in order to put a stop to this destructiveness.

Extinct Birds. - The destruction of species of birds goes on fast enough without the more efficient aid of man. 
We know of species which have become extinct within recent times through the introduction of new enemies among them. Such was the fate of the dodo. Then remains have been preserved to us in the rocks of species which lived in very remote periods. The oldest known fossil bird, Archwopteryx, of the Jurassic age, had a long tail like a lizard; but feathers, which are only modified scales, were present even in this oldest known bird. In the Cretaceons rock deposits of the Great Plains there have been found fossil birds with teeth set in sockets or grooves, precisely as they are to-day in reptiles (Fig. 294). These remains show us in the clearest manner that birds have been derived from reptiles. Indeed, the two groups are closely related anatomically, and are often united under the name Sauropsida or lizard-like animals.

\section{APPENDIX TO CHAPTER XIX}

KEY TO THE ORIERS OF BIRDS

$a_{1}$. Sternum with keel for insertion of flying muscles [Carinatie].

$b_{1}$. Toes more or less webbed or fringed, legs used for swimming or wading.

$c_{1}$. Short legs, broadly webbed [Swimmers]

$c_{2}$. Long legs, long, thin neck, and long beak

[Waders] . . . . . .

Natatores

Grallatures

$b_{2}$. Feet not webbed, fitted for walking.

$c_{1}$. With cere.

$d_{1}$. Beak strong, and bent downward at point; perching feet; flat nail .

Gallinacei

$d_{2}$. Beak not bent downward at point; short, cloven feet; nail compressed . . . . 
$d_{3}$. Beak hooked ; strong, sharp, hooked claws. . . .

$d_{4}$. Beak shorter than high ; thick, Heshy tongue

$c_{2}$. Without cere.

Psittaci

$d_{1}$. Beak long, of ten lieavy ; tongue thin; stiff plumage with little down; metatarsus with half rings on scutes; feet scansorial . .

$d_{2}$. Metatarsus with no scales or rudimentary ones; feathered in upper part

Cypselomorihte

tl $_{3}$. Metatarsus covered with laminæe or scales, rarely feathered, usually with singing apparatus; feet not scansorial, mostly migratory .

$a_{2}$. Sternum without keel [Ratitæ] . . . .

Sconsores

Passeres

Cursores

KEY TO THE FAMILIES OF PASSERES OF NORTHER UNITED STATES, BASED ON D. S. JORDAN

$a_{1}$. First of the 10 primaries more than $\frac{2}{3}$ lengtl of longest of the others [Clamatores] . . .

$a_{2}$. First of 10 primaries short, rudimentary or abTyrannida sent; musical apparatus highly developed [Oscines].

$b_{1}$. First primary short or spurious [primaries 10]. $c_{1}$. Tarsus booted; rictus with bristles.

$a_{1}$. Middle toe quite free from inner; birds of moderate size; length more than 15 centimetres.

$e_{1}$. Wings when folded not reaching beyond middle of tail; no blue Turdida

$e_{2}$. Wings reaching beyond middle of tail ; ours chiefly blue .

Saxicolide

$d_{2}$. Middle and inner toe comnected at base; length less than 13 centimetres . . . .

Sylviidee

$c_{2}$. 'Tarsus scutellate in front.

$d_{1}$. Nostrils concealed by bristly feathers. 
$e_{1}$. First primary not more than $\frac{1}{2}$ length of second; length less than 20 centimetres.

$f_{1}$. Bill as long as head; wings longer than tail

Sittide

$f_{2}$. Bill much shorter than head; wings about as long as tail

$\rho_{2}$. First primary more than $\frac{1}{2}$ length of second; length more than 20 centimetres

Corride

d. Nostrils exposed or merely overhung by feathers.

$e_{1}$. Bill notched near tip.

$f_{1}$. 'Tail longer than wings; general color gray or ashy brown.

!/1. Bill very stout and deeply notched and hooked; bird over 17 centinetres

Laniida

92. Bill neither stout, notched, nor liooked; bird over 17 centimetres

//3. Bill very slender; bird under 17 centimetres .

Pariclae

Corperitro

Tinedirte

sylviila

$f_{2}$. Tail shorter than wings; general color olivaceous. .

r. Bill not notched.

$f_{1}$. Rictus with bristles.

1/1. Quills not barred ; length

over 20 centimetres.

y:. Wing and tail barred;

length nuder 18 centimetres . .

Tireonida

$f_{2}$. Rictus without bristles .

1.2. First primary about as long as second; the real first rudinentary, leaving apparently 9. $c_{1}$ Bill triangular, depressed, as wide at base as long; gape twice as long as culmen $c_{2}$. Bill stout, conic, with convex outlines, 
adge of upper bill with lobes or nicks near middle . . . . .

$c_{3}$. Bill conical, corners of month drawn down.

17. Bill much shorter than hearl. usually notehed at tip or with bristles at rictus . . . . .

d.2. Bill usually about as long as head; no notch at tip nor bristles at rictus

Fringillider

Irteride

$r_{+}$. Bill not as above; edge of upper bill straight or very gently curved.

$d_{1}$. ('onspicuously crested ; bill triangular, depressed, notched, and hooked; tail tipped with yellow; wings red-tipped . . .

d.2. Nostrils concealed by bristly feathers; tarsus scutillate belind. .

d. No erest; nostrils exposed; tarsus with sharp ridge behind formed of union of two lateral plates.

$e_{1}$. Hind claw twice as long as misldle claw . . . .

$e_{2}$. Hind claw not twice as long as Moturillidie middle claw.

$f_{1}$. Billstout, compressed, hooked at tip; tail not blotehed with red or yellow . .

$f_{2}$. Bill various; little, if at all, hooked; colors often brilliant. . . .

rireonide

Sylriontidae 


\section{CHAPTER XX}

\section{THE MOUSE AND ITS ALLIES}

The mouse belongs to the class Mammalia, ${ }^{1}$ characterized by having milk glands whose secretion is used to nourish the young, and hair, which may be nearly or quite absent as in the case of porpoises or whales. ${ }^{2}$

The distribution of the house mouse, from which the different kinds of fancy mice have been derived, is now coincident with that of civilized man; but in early times it was limited to Asia. From Asia it made its way to Europe, and thence by vessels to other continents. It was imported to America (which has no indigenous members of the genus Mus) by the early explorers. There have also been imported to this country three other species of this genus, of such size that they are commonly called rats. Of these, the roof rat seems to have been imported by the early Spanish discoverers to the Southern States, where it still persists. It originated in Egypt. The second was the black rat, believed to have been imported to America about 1544. It has existed from time immemorial in Europe; it has a mild disposition, and from it the white rats we keep as pets have been derived. The brown, or Norway rat, has been the latest importation. The history of its migrations has been written. Probably originating in central

1 mammalis, belonging to the breast.

$2 \mathrm{~A}$ key to the orders of Manmalia will be found in the Appendix to this Chapter, page 331. 
Asia, it crossed the Volga in great troops in 1727, occupied Russia in 1730, France in 1750, and Denmark about 1810. Before the advance of this powerful and aggressive foe, the black rat of Europe gave way, and became well-nigh exterminated, although of late it is said to be reasserting itself in Germany. The brown rat was introduced into America in 1775, has spread over the whole country, reaching the Pacific coast about 1855, and, as in Europe, has nearly exterminated the black rat.

The habits of rats and mice are well known. They inhabit our buildings, gnaw our doors and furniture, destroy our provisions, kill poultry, and aid in spreading disease. They shun the light, living in holes during the day, rum with great agility, and are capable of making long leaps. Owing to their instinct to go into holes, they are easily trapped by a fumnel-shaped opening leading into a closed box. Despite the ease of trapping and their destruction by cats, they maintain themselves by virtue of a great fecundity, for, if no deaths occur, several hundred young may, in one year, descend from a single pair.

The food of mice is very varied. They naturally thrive best on a vegetable diet; oats especially are recommenderl for tame mice, and hard-shelled nuts are useful because the mice keep their teeth sharp by gnawing the shells. If the teeth are not kept worn off they soon become inconveniently long owing to the fact that they grow continuously throughout life, and are not formed, once for all, like our teeth. In addition to plant materials, rats and mice eat a certain amount of animal food.

The different races of tame mice illustrate the results obtained by preserving sports and selecting the best for breeding purposes. 'The white mouse, for instance, is an 
albino; that is, an animal without pigment. Albinos occur among almost all kinds of mammals, but the cause of them is unknown. So, likewise, the black race of tame mice is due to an excess of pigment, a sport found now and then among other mammals. The pure reddish brown races have probably been proluced by selecting the house mice with little black in the fur. By preserving occasional sports and by selecting for breeding the purest-colored individuals, all the different races of our domestic animals and plants have been establisherl and improverl.

Other Rodents. - The mouse belongs to the group Rodentia, ${ }^{1}$ distinguished from other mammals by the fact that

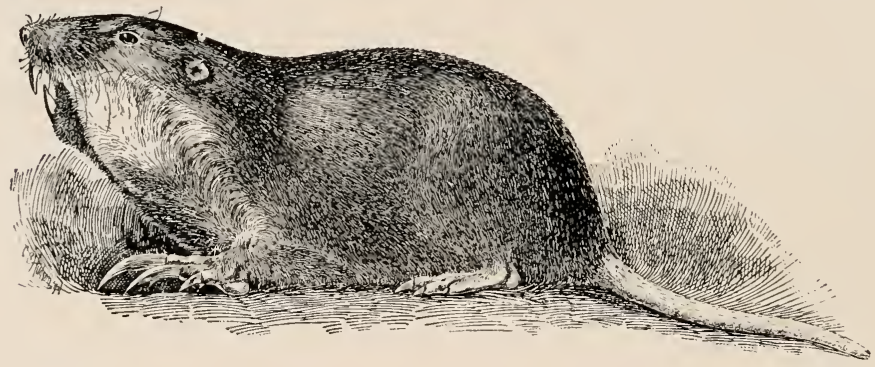

Frx. 295. - Geom!ls tuza, the Georgia gopher. One-half nat. size. After V. Bailey.

the cutting teeth grow continuously throughout life, a condition associated with the habit of gnawing. This group is very abundantly represented in North America, more so, indeed, than in other continents. All our rodents fall into seven families: (1) the squirrels, gopher's (Fig. 29.5), prairie dogs, and woodchuck, with long and hairy tail; (2) the beaver, with broad and scaly tail : (3) the pouched gophers, with peculiar cheek pouches opening outside the

\footnotetext{
${ }^{1}$ From rolere, to gnaw.
} 
mouth; (4) the jumping mice, with greatly elongated hind legs; (5) the muskrat and the various wood and field mice, closely related to the genus Mus; (6) the porcupines, with bristles replacing hairs; (7) the hares, with long ears and short tails. All of these familiar rodents are, on the whole, destructive to agriculture. As there are, however, other interests in life than agriculture, it is to be hoped that the warfare against our native rodents will not be too relentlessly pursued. At least one interesting species has been rendered well-nigh extinct by the

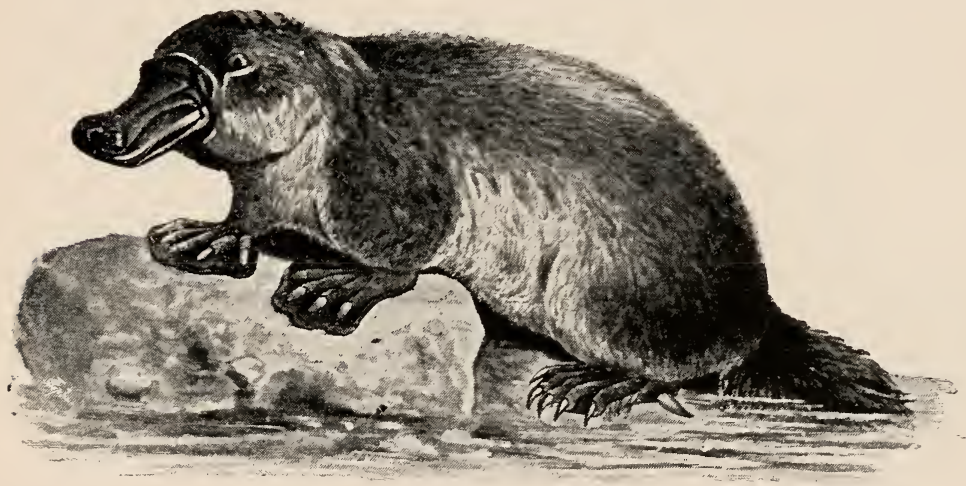

FIG. 296. - Ornithorhynchus anutınus, the duckbill. After Vogt and Specht.

avarice of fur hunters - this is the American beaver, an animal which has developed extraordinary instincts for the construction of dams and subaquatic passages.

Other Mammals. - The Monotremata ${ }^{1}$ are the lowest mammals, and in many ways seem to connect the class with reptiles or amphibians. The milk glands are in a

${ }^{1} \mu \delta \nu$ s, single, $\tau \rho \hat{\eta} \mu a$, hole or opening ; so called because urinary, genital, and alimentary canals have a common external opening. 
low state of development and eggs are laid, as in reptiles and birds. There are two principal types, - the "Duckbill" (Fig. 296), with aquatic habits, and the "Spiny Ant-eaters" (Echidna, Fig. 2:77), inhabiting rocky places. Both types are confined to Australia and neighboring islands.

The Marsupialia ${ }^{1}$ have a remarkable distribution over the earth to-day. All are confined to Australia and adja-

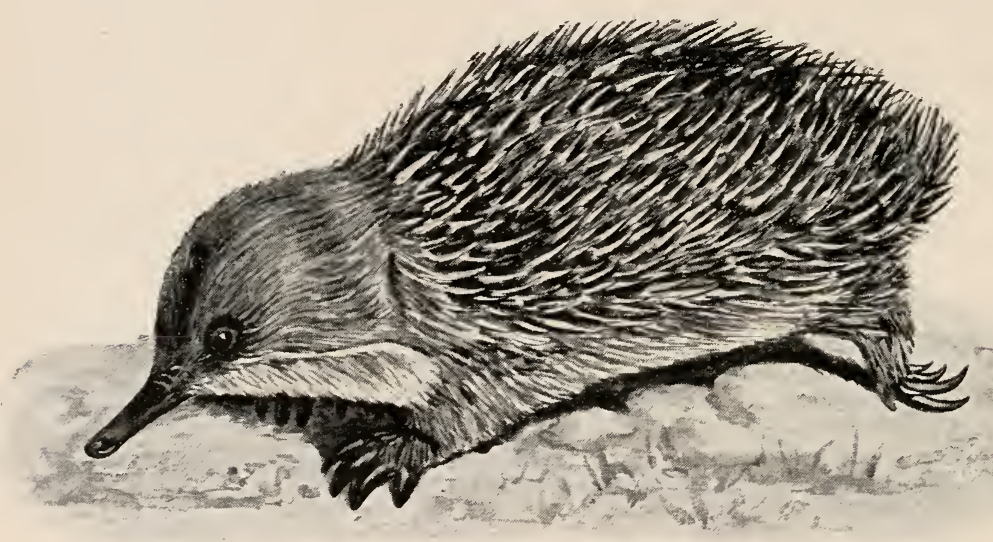

F1G. 2!7. - Echidna aculeatu, the spiny ant-eater. After Vogt and Specht.

cent islands, excepting the family of opossums (Fig. 298), found only in the Americas. There is thus a great discontinuity in the distribution of marsupials. This is accounted for by the evidence that formerly the whole world contained marsupials, so that those living to-day are the separated remnants of that once miversal race. The opossums are most numerous in the tropies, but the Virginian opossum ranges north to New York.

1 marsupium, a pouch. 
The Edentata, ${ }^{1}$ few of which are entirely without teeth, include the sloths, hairy ant-eater's, armadillos, scaly anteaters, and aardvarks, or African ant-eaters. The three first-named families inhabit South America; the two latter, Asia and Africa. Here, again, the discontinuity of the group indicates what fossils prove, that the Edentates

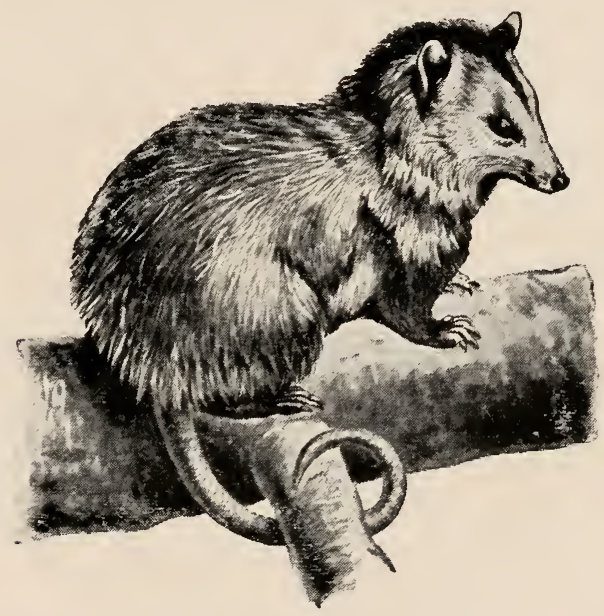

Fig. 298. - Diclelphys virginiun, the North American opossum. After Vogt and specht.

have been killed off from the connecting continents. The sloths have incisor teeth, live in trees, and eat leaves (Fig. 299). The armadillos are protected by strong plates developed in the skin; they are chiefly nocturnal and omnivorous animals, and burrow rapidly. The other three families feed on ants and termites, lack complete teeth (excepting the aardvarks), and are either arboreal or burrowing.

$1 e$, out ; dens, dentis, tooth. 
The Cetacea ${ }^{1}$ have taken to an aquatic life, for it is certain that their ancestors were land animals. The seacows (manatees ${ }^{2}$ ), found in rivers in various parts of the world, seem ${ }^{3}$ to show a transition to the marine forms,

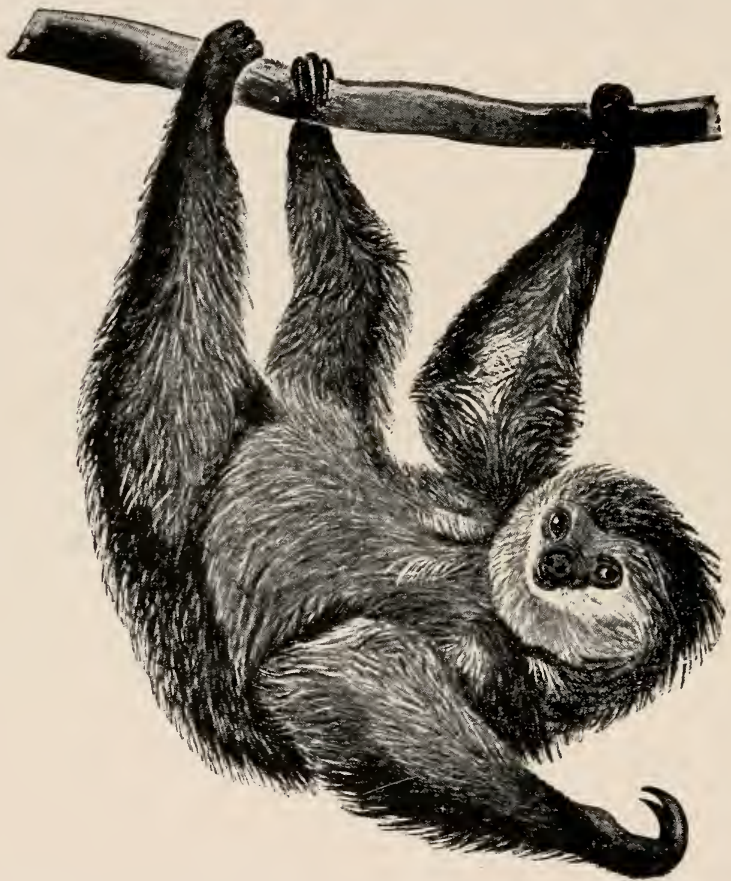

Fig. 299. - Cholœpus, the unau or two-toed sloth. After Vogt and Specht.

such as the dolphins, the toothed whales (Fig. 300), and the toothless or whalebone whales. The largest of these whales - the Greenland whale - reaches an extreme length of twenty-two to twenty-four metres, and a

1 cetus, whale.

2 From a native name.

3 The relation to Cetacea is not close. 
weight of over 100,000 kilogrammes. It is, indeed, the largest living animal. Although whales in general are partly adapted to an aquatic life, they still retain the essential mammalian qualities. They breathe air which passes to the lungs and is expelled again through the nostrils, which are placed high up on the head. The "blowing" of the whale is the forcible expiration of moisture-laden air, which becomes visible by condensation,

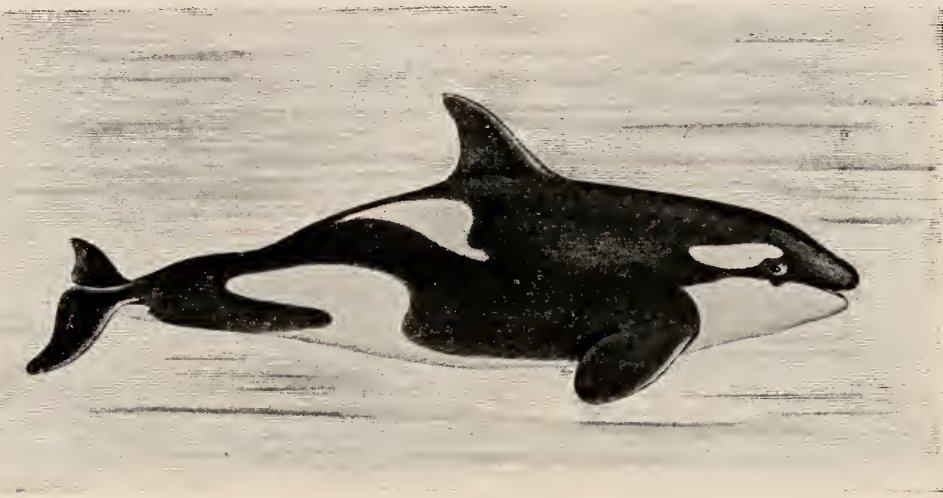

FIg. 300. - Orca, the killer whale. After True.

just as our own breath does on a cold day. The young are doubtless born in the water, but the breeding habits are poorly known. The various Cetacea have diverse feeding habits. All are predaceous. The toothed whales feed on larger animals, the whalebone whales on floating fish, Crustacea, meduse, and squids; their whalebone is, indeed, merely a strainer to let the water pass out of the mouth while the solid masses are retained.

The order Ungulata ${ }^{1}$ includes a large number of animals,

1 ungula, hoof. 
almost all of which are closely related. In the true ungulates there are never more than four functional toes; but in the subgroup of Subungulata, containing the elephants and certain small animals allied to the "coney" of Scripture, there are typically five. Of the true ungulates, we distinguish the even-toed and the odd-toed, which we may consider further.

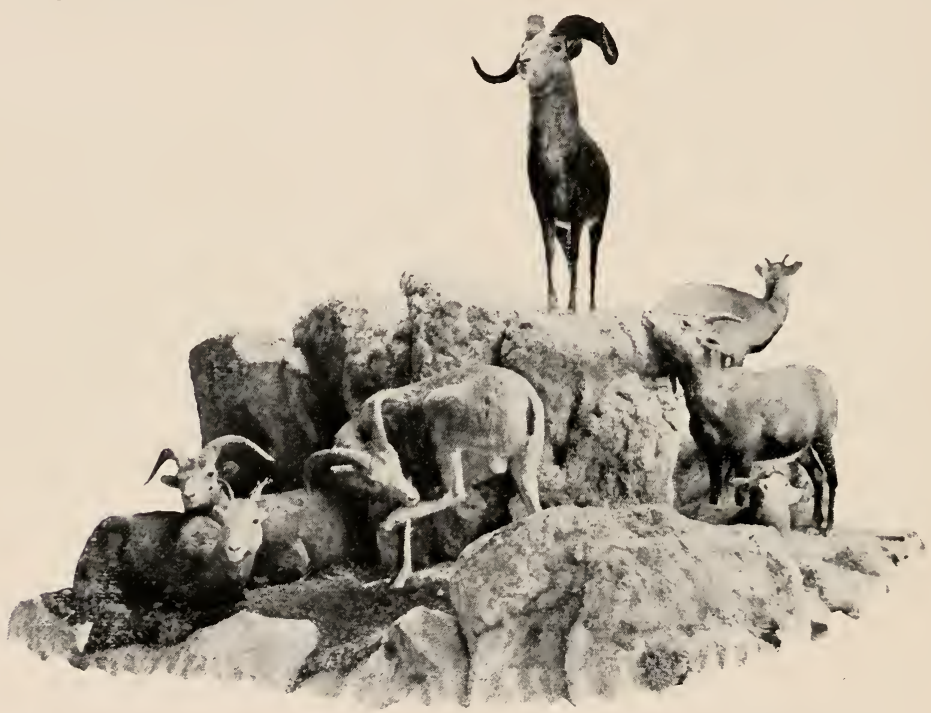

Fig. 301. - Stone's Alaskan black sheep. Photo. of a group in the Field Columbian Museum.

The Even-toed Ungulates include the hippopotamus and other pigs and the peccaries, the camels and llamas, the deer, the giraffes, and the antelopes, sheep (Fig. 301), and oxen. Excepting the pigs, most of these feed exclusively on plants. The giraffes and antelopes are characteristic of Africa; but the "mountain goat" of our highest ranges is 
a true antelope, as is also the chamois of Europe. The prong-horn of our Southwestern plains is remarkable in having hollow horns like the antelopes, which are, however, shed like those of the deer.

The Odd-toed Ungulates include the horses, tapirs, and rhinoceroses. The horses are remarkable in that they stand upon the toe-nail of the middle digit - all the other digits being rudimentary or absent. While fossil remains of horses are found in all continents, the living species have come from Asia and Africa. The African species are stiiped (zebras). The tapirs are found living to-day only in South America and southeastern Asia. They frequent the depths of forests near watercourses and feed on leaves and shoots of shrubbery. The rhinoceroses of Africa, of India, of Java, and of the Malay Arehipelago are quite distinct. All are large, stupid, and ferocious when attacked, feed on herbage, and wallow in pools.

The elephants are distinguished by their long trunks, great incisors (tusks), and huge, complex grinding teeth. The Indian and African types are quite distinct. Elephants are intelligent, tractable, and capable of doing much work for man. Their diet is vegetable, consisting especially of the leaves and young branches of forest trees, which they gather with their proboscis.

The Insectivora ${ }^{1}$ are small mammals and chiefly terrestrial. One of our common families includes species of moles which burrow in the ground, have small eyes and broad, shovel-shaped fore feet, used for digging their burrows. They feed chiefly on earthworms. The other common family is that of the shrews, which are mouse-like, live chiefly on the surface and in the woods, and feed on insects and small crustaceans.

1 insectum, an insect; vorare, to devour. 
The Carnivora ${ }^{1}$ include both land and marine forms. To the first group (Fig. 302) belong the cats (including tigers, lions, leopards, lynx, etc.) ; the civet-cats, mongoose,

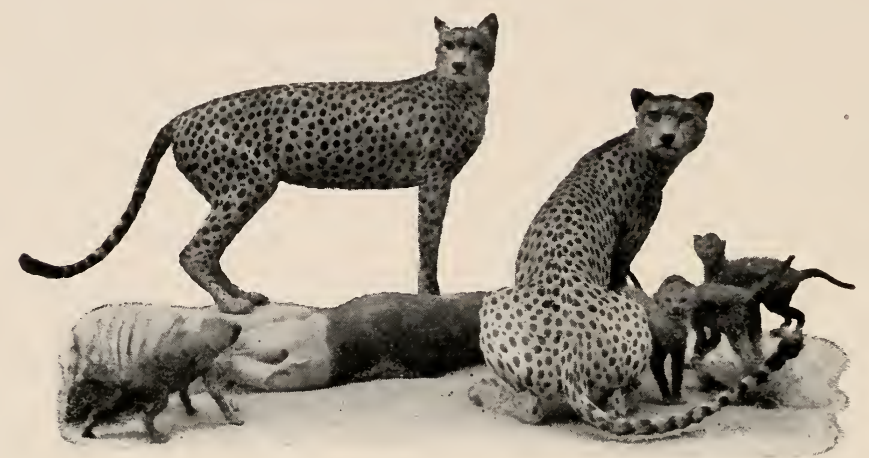

FIG. 302. - Felis jubata, the Cheetah or hunting leopard. Photo. of a group, in the Field Columbian Museum.

etc.; the hyenas; the dogs (including jackals, wolves, and foxes); the bears; the raccoons; and the great fur-bearers, martens, minks, weasels, badgers and otters, and skunks.

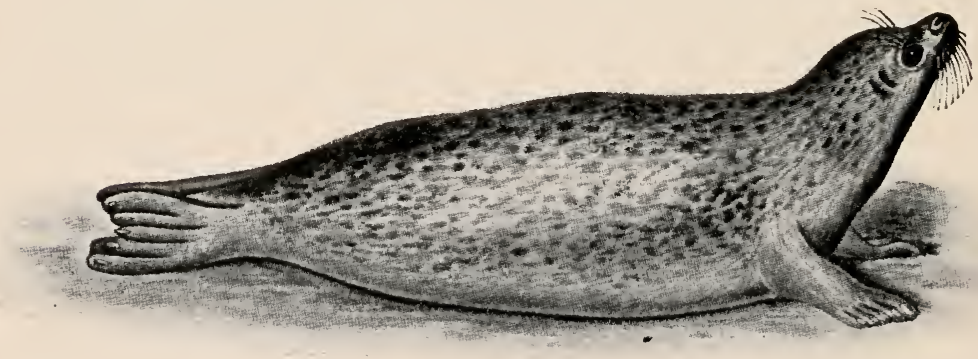

Fig. 303.- Phoca vitulina, the harbor seal. From Parker and Haswell, "Manual of Zoology."

${ }^{1}$ caro, carnis, flesh ; vorare, to devour. 
Marine Carnivora comprise the seals (Fig. 303), walruses, and sea-lions; the more valuable of which are disappearing as a result of man's lack of foresight. Altogether, the Carnivora comprise the most agile, the most intelligent, the most dreadful, and some of the commercially most important of fellow-animals.

The Cheiroptera, ${ }^{1}$ or bats (Fig. 30t), are extraordinarily modified mammals, which, like the birds, seem to have

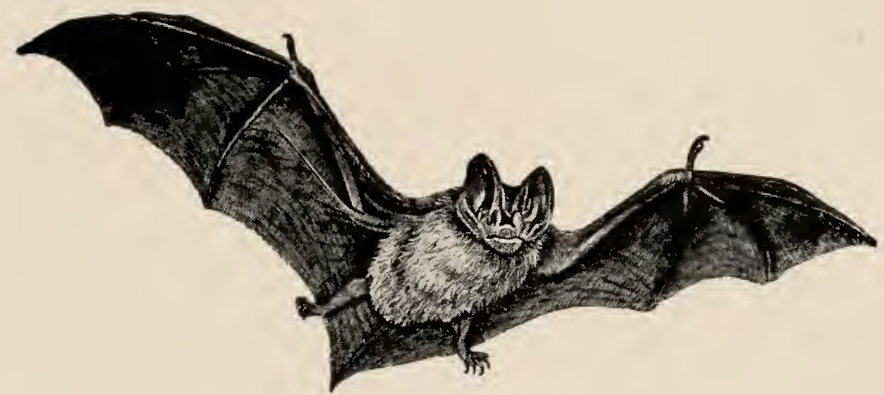

Fig. 304. - Synotus, an insectirorous bat. After Vogt and Specht.

penetrated into the air to prey on the flying insects. Not all bats are insectivorous, however, for certain Old World bats feed on fruits. Our commonest species are the little brown bats (with a nearly furless wing), and the red bat (with patches of fur on the wing membrane).

The Primates ${ }^{2}$ are of interest because we ourselves are placed in this category together with certain other animals that have attained a less lofty station. The lowest Primates are the lemurs, found chiefly in Madagascar. These have an arboreal habit, and feed on fruits, leaves, and

${ }^{1} \chi \epsilon i \rho$, hand; $\pi \tau \epsilon \rho o ́ \nu$, wing.

2 primus, the first. 
small birds and insects. Next higher come the American marmosets, the howling monkeys, and the flat-nosed, prehensile-tailed American apes; still higher are the smallnosed, nonprehensile-tailed apes, including the baboons,

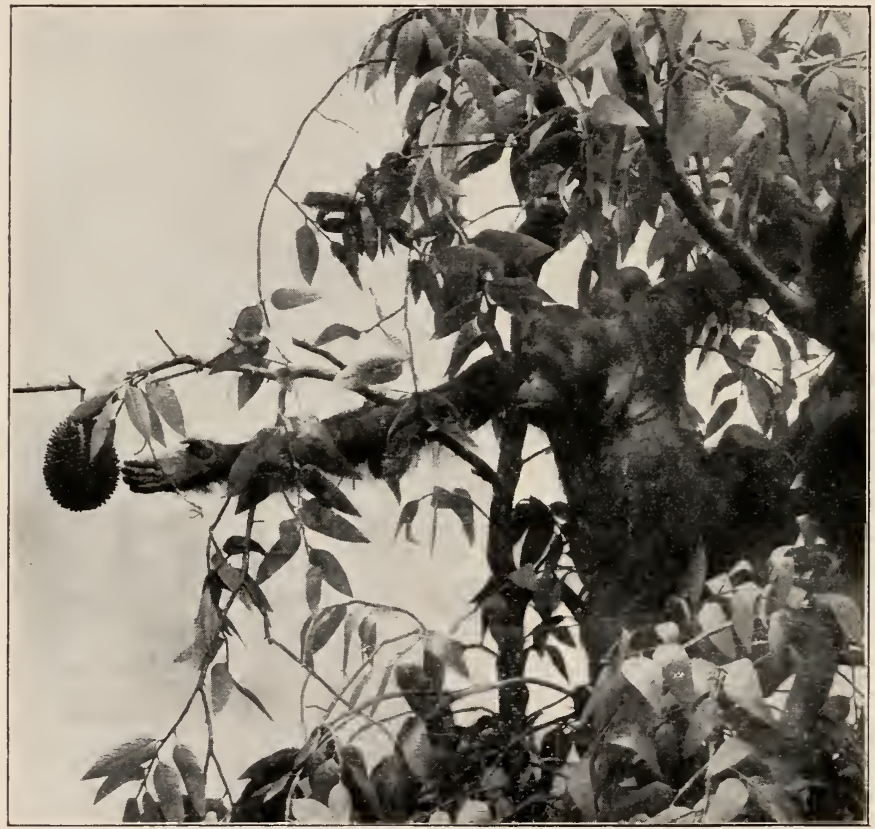

FIs. 305. - Simia satyrus, the orang-utan, in breadfruit tree. From a photograph of a group, in the Field Columbian Museum.

mandrills, and macaques. Finally, come the tailless, manlike apes, found exclusively in the Old World - the gilbons, orangs (Fig. 305), chimpanzee, and the gorilla. The two latter are nearest to man, but one cannot say one is the nearer. For, while the chimpanzee approaches 
man more closely in facial appearance and in intelligence, the gorilla is more man-like in the size and complexity of the brain and in its habit of walking on the ground. There is no reason to doubt that man's species came off from the anthropoid apes; the recent discovery, in Java, of a fossil form (Pithecanthropus erectus) intermediate between man and the man-like apes, is a strong additional piece of evidence. This differentiation of man's species probably began in late tertiary times.

\section{APPENTIX TO CHAP'TER IX}

KEY TO THE ORDERS OF MAMMALIA

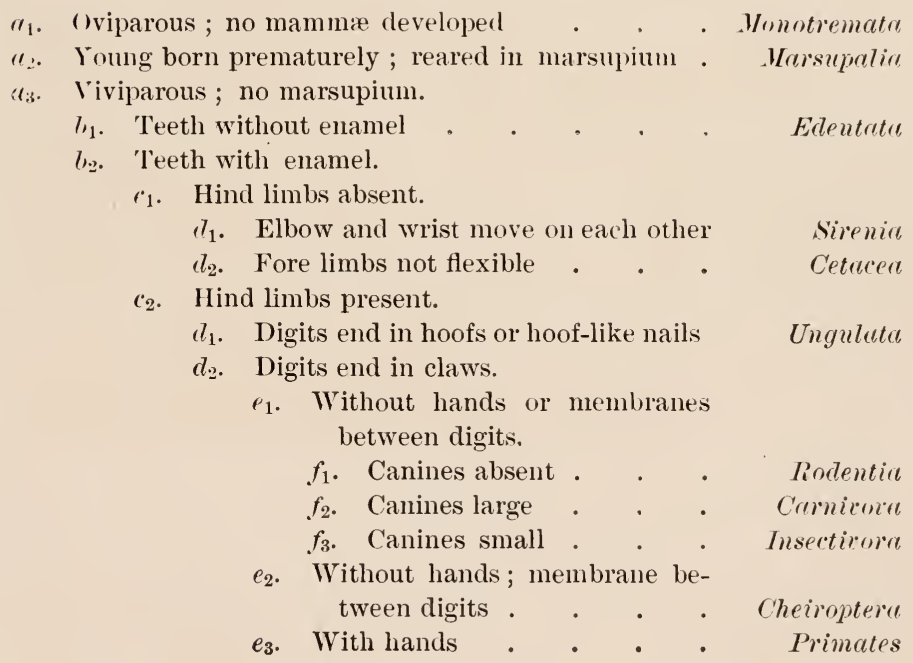




\section{CHAPTER XXI}

\section{THE DEVELOPMENT OF THE FROG'S EGG}

ALL living matter has the capacity of increasing itself under proper conditions to an almost unlimited extent, the food which animals devour being the material out of which the new living substance is made. This living substance exists in isolated particles, or masses, which we call individual animals or plants. The animal or plant has also at any stage a definite form which is not exactly alike in any two individuals, but is roughly alike inside the "species." Now the number of individuals of any species tends constantly to diminish through death. It is actually maintained by reproduction. Reproduction always takes place in one way; namely, by a piece of the parent individual being cut off to form a new individual. This piece may be at first almost shapeless or approximately spherical. But as it grows larger it assumes more and more the form and complex structure of the adult. This process of growing into the adult form is development. In most of the more familiar cases development begins with an approximately spherical egg.

In the case of the frog, the egg is between one and two millimetres in diameter. The eggs, which are numerous, are laid in a common jelly and during development float near the surface of the water in which they are laid. 
Effect of Heat and Light on Development. - Eggs developing in normal environments in nature arrive at nearly the same end-result even when the environments are not

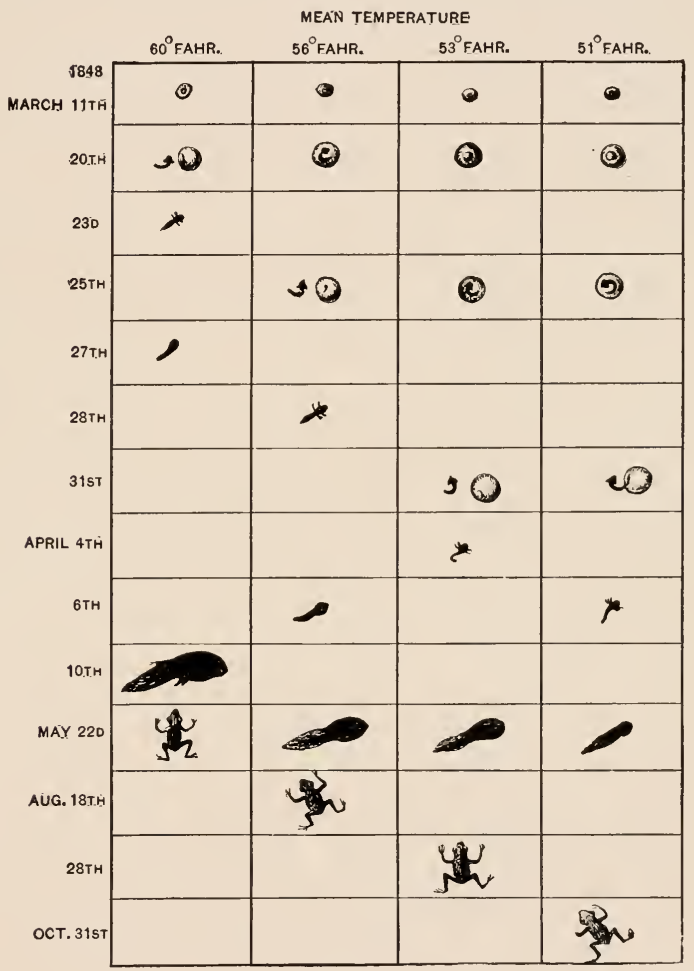

Fig. 306. - A chart showing the correlation between the stage of development of the frog on successive days and the temperature at which it has developed. From Higgenbottom.

identical. We gain, in consequence, an impression that development proceeds unaffected by any changes in the outside world. But this is not true. For one thing, the 
rate at which the development of frogs" eggs proceeds depends closely upon the temperature of the water. They develop most rapidly at about $30-32^{\circ} \mathrm{C}$. If the temperature is elevated above this point, the rate of development is retarded, and finally ceases at about $40^{\circ} \mathrm{C}$. So, likewise, as the temperature is lowered, the development is retarded, until at the temperature of freezing water it ceases (Fig. 306). If the temperature is too high, development may be abnormal, so that a monstrosity is produced.

Light has a less striking effect on the development of the frog. If light is excluded from the developing eggs, they will develop more slowly. The acceleration of development by rather high temperature and by daylight is probably due to a chemical effect of these agents. It indicates that development is a complex chemical process.

Healing and Regeneration. - If the egg of a frog be pricked slightly, there will be a loss of substance and the resulting embryo will be at first abnormal. Later, however, this abnormality will become smoothed over by appropriate development. So, also, if the tail of the developing larva is mutilated, the wound will heal and the missing parts will be re-formed. This capacity of the living organism to restore the normal form after mutilation is seen also in man. For if some of the skin be cut away, or even if parts of internal organs are removed, the wounds will not merely heal, but the lost part will regenerate. The remarkable thing is that in regeneration almost exactly that is produced which was lost. Both regeneration and healing in the adult are a survival of the same capacity for development which we see in the egg.

Postembryonic Development of the Frog. - After reaching a certain stage of development the embryo frog, called 
tadpole, begins to develop legs. The hind legs first appear, afterward the fore legs sprout out, and finally the tail begins to wither away, until the form of the fourlegged tailless frog (anuran) is fully developed. In the leopard frog, as in the toad, this change of form (metamorphosis) is completed during the first summer, but in case of the bullfrog and green frog the tadpole passes through the winter in the immature state, and does not complete its metamorphosis until the second summer. Consequently, it is not uncommon to find quantities of large tadpoles in ponds at the time the ice breaks up in the spring.

Since Amblystoma and Necturus do not lose their tails, the metamorphosis which they undergo is less profound than that of the frog. In Amblystoma, as stated in Chapter XVII., the gills and the fin on the tail of the tadpole are lost in the metamorphosis. Necturus, on the contrary, retains gills and tail-fin, so that its acquisition of legs is almost the sole indication of metamorphosis.

General Laws of Development. - Development consists of an unfolding of potentialities wrapped up in the germ ; an awakening in orderly succession of processes lying dormant there. But the causes which control development, the causes which determine when this process and that shall awaken, are still too obscure for us to attempt to picture them in detail. This much is certain, that the causes of development from the egg are the same as those of budding of leaves on a tree, the regeneration of the parts of a Hydra, or the healing of a cut in the skin. In the case of most of the higher plants and animals, the ripe egg will not develop until it is "fertilized," that is, until a germ from another individual has fused with the ripe egg. 
But the ripe egg of many of the lower plants and animals requires no fertilization for development, and the meaning of the fertilization process is quite obscure.

The developing eggs of all the higher animals pass through much the same sort of early stages. The egg "cleaves" into a number of cleavage spheres, each of which is destined to give rise to a particular part of the organism. By repeater division, a mass of small cells, constituting the morula stage, is formed. Usually a cavity arises in the middle of the morula, and into this some of the surface cells are pushed to form an internal sac - the food canal. This is necessarily an early step, as all food is taken into the interior of the body. The process by which external cells are pushed in is known as gastrulation. Very early the body is seen to be composed mostly of layers, or membranes and cavities. It is by the folding and union and breaking through of these membranes that most of the organs of the adult arise. Development of the individual is, on the whole, accompanied by increase in complexity. The evolution of animals in the animal kingdom is likewise, on the whole, accompanied by increase in complexity of organization. Thus both the embryonic development of the individual and the evolution of the species proceed from simple to complex, and since they start from about the same point and reach the same goal, we are not surprised to find that the individual development of any species often goes through stages markedly like the stages in the evolution of the species. The parallelism of development and evolution was early noticed, and is often called "von Baer's law," after a naturalist who lived in the middle of the nineteenth century and very clearly formulated this parallelism. 


\section{APPENDIX I}

NoтE. - This outline is reprinted, with some changes suggested by putting it in practice, and with the addition of Exercise XX., from an "Outline of" Requirements in Zoology intended for use in preparingstudents for the Lowrence Scientific School," Harvard University, published in 1 s: 98 by the University. The outline was the product of the Zoological Department of the University, was planned in detail by one of the present writers, and is repmblished by permission of the University. The outline agrees also with the requirements for admission in Zoology to the University of Chicago, and with the recommendations of the sub-committee of ten on Zoology oppointed by the National Educational Association. Its general plan has been followed in various schools over the country. The favorable reception of the outline justifies its reproduction here.

\section{OUTLINE OF LABORATORY WORK IN ZOOLOGY}

\section{INTRODUCTION ${ }^{1}$}

Time. - This outline of work in Zoology is designed for use in schools that can give to the subject five periods per week for half a year, including time spent in laboratory work, written exercises, and oral instruction by the teacher. It is likewise available for schools that follow the recommendation of the Committee of Ten of the National Educational Association and give to the subject three periods per week throughout the year.

Amount of work. - The outline includes much more work than any school ought to attempt in the time indicated above. It is believed that if about ten of the twenty-one exercises are thoroughly done, the time will be well filled. The number of exercises is made large to admit of a selection to suit the diverse conditions of schools. Thus, those schools which are not equipped with compound micro-

${ }^{1}$ Certain verbal changes have been made in reprinting the Introduction, a few sentences have been omitted, and there are certain additions, which are enclosed in brackets. 
scopes will, nevertheless, be able to select from nineteen exercises, while those which in addition are mable to make use of living marine animals will still have a choice from seventeen exercises. A thorough study of a few types, rather than a inore superficial study of many, should be aimed at.

General aim. - It is the general aim of these exercises to interest as well as to train the pupil; indeer, it is believed that the awakening of interest is the best preliminary and accompaniment to a useful mental training. Since young persons are especially interested in living animals, observations and non-injurions experiments upon the normal reactions and the methods of locomotion of animals are required in nearly every exercise. While the study of active animals will entail much additional labor on the part of the teacher, and some additioual expense, it is believed that the results will justify the cost. In order to carry out the aim of these exercises, it is desirable that the student find answers to his questions, as far as practicable, from the object before lim, rather than from the teacher or from books. Questions involving comparisons between the types have been onitted, not because they are regarded as unimportant, but because they would necessarily vary according to the particular types selected and the order in which these types are studied. However, the necessity which compels their omission is the less to be regretted, since it leaves the teacher free to exercise his own judgment and experience in this matter, but he should not fail to supply such questions.

Sequence of exercises. - The sequence of exercises must depend largely upon availability of material; but it is desirable that closely related types should be studied in immediate sucession to facilitate comparisons. The following are suggested for courses occupying different periods in the year :- 


\begin{tabular}{|c|c|c|}
\hline Whole Year. & First IIalf. & Second Half. \\
\hline $\begin{array}{l}\text { I. Grasshopper } \\
\text { II. Buttertiy } \\
\text { III. Beetle } \\
\text { IV. Fly } \\
\text { XII. Starfish } \\
\text { X. Nereis } \\
\text { IX. Earthworm } \\
\text { VI. Spider } \\
\text { V. Lithobius } \\
\text { VII. Crayfish } \\
\text { VIII. Daphnia } \\
\text { XI. Slug } \\
\text { XII. Anodonta or Unio } \\
\text { XIV. Hydra } \\
\text { XV. Paramecium } \\
\text { XXI. Frog's Egg } \\
\text { XVI. Sunelt } \\
\text { XVII. Newt } \\
\text { XVII. Lizard } \\
\text { XIX. Sparrow } \\
\text { XX. Mouse }\end{array}$ & $\begin{array}{l}\text { I. Grasshopper } \\
\text { II. Butterfly } \\
\text { III. Beetle } \\
\text { IV. Fly } \\
\text { XII. Starfish } \\
\text { X. Nereis } \\
\text { IX. Earthworm } \\
\text { VI. Spider } \\
\text { V. Lithobius } \\
\text { XVII. Newt } \\
\text { XVII. Lizard } \\
\text { XVI. Smelt } \\
\text { XIX. Sparrow } \\
\text { XX. Mouse } \\
\text { XI. Slug } \\
\text { XII. Anodonta or } \\
\text { VII. Crayfish } \\
\text { VIII. Daphnia } \\
\text { XIV. Hydra } \\
\text { XV. Paramecium }\end{array}$ & $\begin{array}{l}\text { VII. Crayfish } \\
\text { VIII. Daphnia } \\
\text { XIV. Hydra } \\
\text { XV. Paramecium } \\
\text { XI. Slug } \\
\text { XII. Anodonta or } \\
\text { Unio } \\
\text { IX. Earthworn } \\
\text { X. Nereis } \\
\text { VI. Spider } \\
\text { V. Lithobius } \\
\text { IV. Fly } \\
\text { III. Beetle } \\
\text { XVI. Newt } \\
\text { XXI. Frog's Egg } \\
\text { XVI. Smelt } \\
\text { XVII. Lizard } \\
\text { XIX. Sparrow } \\
\text { XX. Mouse } \\
\text { XIII. Starfish } \\
\text { II. Butterfly }\end{array}$ \\
\hline
\end{tabular}

Equipment. - A well-lighted laboratory provided with tables is almost necessary, but the teacher may find it possible, with much additional work and less satisfactory results, to conduct the exercises at the students' ordinary desks. The apparatus required will depend upon the exercises selected. In any case there will be needed at least one large aquarium. For this purpose battery jars twelve inches in diameter will be found serviceable. For keeping living insects, cages made of wire netting, placed over food plants growing in broad "seed-pans," are recommended. An ingenious teacher will be able to make many cheap substitntions for some of the apparatus specified. Thus in place of "Stender dishes" tumblers may be used.

Laboratory books. - The drawings should be made on a good 
quality of drawing paper. Tablets made of unglazed drawing paper, about eight inches by ten inches, are recommended. ${ }^{1}$ Where loose sheets are employed they must be bonnd at the end of the course. The drawings should be made with pencil of a hardness (HHI or HHHH) appropriate to the paper, and kept well sharpened. The use of colored crayons or water colors is to be discouraged. Few pupils can employ shading to advantage. Students are to be instructed that pencil lines should represent boundaries of structures. The names of the parts represented must be designated and should be the simplest applicable.

Records of experiments, answers to "Questions on External Anatomy," comparisons drawn, and other written exercises should be brief. They should not be made upon the same sheets with the drawings, but either in a separate note-book or on sheets of the same size as the drawing sheets and eventually bound up with them. ${ }^{2}$

Observations on the living animal. - The experiments upon living animals, especially such as involve reactions to stimuli, should be repeated two or three times, since the first response of the animal may be abnormal or irregular.

Topics for further study. - Under this heading there are given in each exercise suggestions for oral instruction by the teacher, or for reading and recitation on the part of the pupil, in connection with the laboratory work on the type. The teacher will find aid from the larger text-books, encyclopædias, systematic works, and compendia of Natural History. [The accompanying text-book is fitted especially to these Topics.]

Excursions. - The teacher is urged to undertake, so far as practicable, excursions with his pupils to localities where the organisms studied in the laboratory and their allies can be seen in their natural environment. The student should be encouraged to collect and study insects, mollusks, and other invertebrates, and to make observations on their habits. Directions for collecting various kinds of animals

1 [Boyer's Science Tablets, made by the Central School Supply Company, Chicago, are convenient.]

2 The Harvard requirement says: The laboratory work should be done under the immediate supervision of the teacher, so that he can certify that the drawings and written work are the pupil's own. 
are given in the Bulletin of the U. S. National Museum, No. 39. Parts A to MI, 1891-1899 are already published.

Material. - The teacher should know before beginning the course which of the types he can obtain alive in his locality, and where and in what months they can most readily be found. He should know these things not only about the ten types selected but also about others, as certain types may prove to be unobtainable when wanted. He must give due attention to the difficulty of procuring living material during cold weather. Pupils should be encouraged, where practicable, to aid in procuring material for class work; the excursions recommended may be utilized to some extent for this purpose.

Correspondence from teachers who, as a result of their experiences in using this outline, have any suggestions to offer which may be incorporated in a future revision of it, is solicited.

[Dealers in animals for class work-MIr. George K. Cherrie, Brooklyn Institute Museum, Eastern Parkway and Washington A venue, Brooklyn, N. Y., will undertake, after September 1, 1900, to supply schools with the animal material illustrative of most of the families referred to in the text, and will supply schools and colleges with preserved animals in quantity for class use.

Dealers in live animals are:-

Mr. C. J. Maynard, 447 Crafts Street, West Newton, Mass.

Mr. F. G. Hillman, New Bedford, Mass.

Aquarium Supply Co., Delair, N. J.

Messrs. C. E. Blake, 1486 E. 69 th Street, Chicago, Ill. (can furnish some of the material alive).

In addition to the foregoing, preserved material will be supplied by:-

The Marine Biological Laboratory, Woods Holl, Mass.

Messrs. H. H. \& C. S. Brimley, Raleigh, N. C. (also some living material).

Mr. F. W. Wamsley, Acad. Nat. Sci., Philadelphia.

Most of these dealers will furnish catalogues of material on application.] 


\section{EXERCISES}

\section{GRASSHOPPER (Caloptenus femur-rubrum)}

Caloptenus (which may be replaced by any other member of the Acrididæ or by a cricket) can be obtained abundantly in the autumn.

\section{Drawings}

1. Entire animal, left side, wings in place. $\times 2$.

2. Front view of head. $\times 4$.

3. Posterior view of antemna and first and third legs of right side drawn, for comparison, one below the other. $\times 3$.

4. Upper surface of right wings. Draw a rertical line representing the axis of the body, mark the anterior $(A)$ and posterior $(P)$ ends of the line, and draw the wings one behind the other to the right of this line. $\times 3$.

5. Lateral view of trunk (left side), with legs and wings removed. $\times 3$.

6. Nouth-parts, arrange in a column as in No. $4 . \times 5$.

7. Compound eye (hand lens). $\times 10$.

\section{Questions ox External Axatomy}

1. Is the number of trunk segments constant? (Count segments of three or more individuals.)

2. Is the number of segments in the leg constant in the corresponding legs of three individuals; in all the legs of the same individual?

3. Describe in not over one hundred words the difference between the oldest and the youngest individual you have, in respect to $(a)$ size of trunk; (b) size of wings; and (c) other characters.

\section{Observations on the Living Aximal}

1. Note the respiratory movements of the abdomen. Count the number per minute. Does the number vary with the individual? Does it vary with external conditions such as temperature and stimulation?

2. Iolding the grasshopper in the right hand, with the left put the tip of a blade of green grass to the mouth. Note the movements. 
How does the grasshopper react to different substances on the end of the grass blade?

3. Place the grasshopper under a bell-glass and note and record the position of the legs in successive phases of walking.

\section{'TOPICS FOR FURTIER STUDY}

1. Habitat and food of the grasshopper. 2. Distribution of the species studied. 3. Development (general and external). 4. Allies of the grasshopper: cricket, green locusts, walkingsticks, Mantis, cockroaches, earwigs, dragon-flies, ephemerids, termites, the Neuroptera, Hemiptera, and Homoptera.

\section{BUT'TERFLY}

Any one of various species whose larva can be obtained alive near the end of September may be employed. The cabbage butterfly (Pieris), the milkweed butterfly (Danais), or the swallow-tail butterfly (Papilio) will meet these conditions.

\section{Drawings}

1. Imago: Dorsal view, wings expanded. $\times 1$ or 2 .

2. Innago: Left side, wings closed. (The bodies in 1 and 2 are to be drawn parallel to each other.) $\times 1$ or 2 .

3. Imago: Front of head. $\times 10$.

4. Pupa : Left side.

5. Full-grown larva : Dorsal view.

6. Full-grown larva: Left side.

\section{Questions on External Anatomy}

1. How many segments behind the head in (a) the imago? $(b)$ the larva? (c) the pupa?

2. What external organs of the imago can be identified in the pupa?

3. Which feet of the larva correspond to those of the imago?

\section{Observations on tile Living Larva}

Each student (or group of students) should be provided with a glass vessel covered with netting and containing food leaves for keeping the larva during pupation. 
1. How is locomotion effected? Hllustrate by diagrams.

2. How does the larva feed? Observe and record the movements of the mouth-parts and of the head during feeding. Draw the outline of a partly eaten leaf.

3. (This obsertation must extend through several days.) Make and record observations upon the act of pupation.

\section{TOPICS FOR FURTHER STUDY}

1. The habits and food of butterflies. 2. The number of broods of butterflies during a single season and seasonal dimorphism. 3. Protective resemblance and mimicry. 4. The larger divisions and commoner native forms of Lepidoptera. (Examples of Lepidoptera illustrating the commoner native types shonld be shown and students encouraged to collect and classify them.) 5. The Hymenoptera: their structure, classification, and habits.

\section{BEETLE}

The May-beetle and the potato-beetle are recommended for studies from alcoholic specimens. If these are not available for the "Observations on the Living Animal," any other slow-creeping species may be employed.

\section{DrawiNgs}

\section{(From alcoholic specimens)}

1. Dorsal view, naming parts. $\times 8$.

2. Remove the antenna, mandible, maxillæ, and legs of right side. Draw posterior view of each part. Use lens. $\times 15$.

3. Remove the wing case and membranous wing from left side. Draw wing (a) folded, (b) unfolded, indicating position of creases. Draw imaginary cross-section of the folded wing.

4. Draw beetle from left side, indicating position of removed wings. $\times \mathrm{S}$.

5. (Optional.) Draw larva from left side. $\times 8$.

\section{Questions on Exterial Axatomy}

1. How many segments has the beetle behind the head?

2. (Optional.) How many segments has the larva? 
3. From which segments do the wings arise? The legs?

4. Of how many segments is each foot composed?

\section{Observations on the Living ANimal}

1. Place a beetle upon a piece of white paper; observe the order of movement of the legs in locomotion, and record by some graphic method. ${ }^{1}$ Analyze the movement of a leg of each pair; how does it help the animal to move? Compare with grasshopper.

2. Placing a bit of potato leaf (or other green leaf) at the mouth of the beetle, notice the movements of the mouth-parts in feeding.

3. Observe and record the movements of the feet of the larva in locomotion.

\section{TOPICS FOR FURTher STUdY}

1. Stages in the development of a beetle. 2. The principal classes of beetles: illustrate, e.g., rumners, divers, short-wings or rove-beetles, carrion-beetles, wool-beetles, stag-beetles, tumble-bugs, May-beetles, boring beetles, snappers, fireflies, bark-beetles, weevils, buck-beetles, leaf eaters, ladybirds. (Examples of these should be shown and students encouraged to collect and classify them.) 3. The food of beetles. 4. Economic importance: ( $a$ ) injurious beetles-destructive to regetation, to wood, to grain, to meat, to fur and cloth, to useful animals; (b) useful beetles - advantageous by acting as scavengers, by killing injurious insects.

\section{HOUSE-FLY or BLLEBOTTLE FLY (Musca domestica and $M$. vomitoria)}

To get larvæ of the bluebottle fly it is only necessary to expose flesh, even on a warm winter day, a week or so before the larvæ are needed for class work. The larva may be fed upon bran, and when well grown may be prevented from pupating by being kept at a temperature slightly above the freezing-point.

1 An excellent method, proposed by Professor F. E. Lloyd of Teachers' College, New York, is to have the beetle walk from an anilin ink pad (ordinary stamping pad) to the paper. The ink on the feet will leave a print of the steps on the paper. 


\section{Drawixgs}

1. Imago, dorsal view, wings in place. $\times 10$.

2. Left side, showing stigmata; wings having been removed and preserved for further study. $\times 10$.

3. Front view of head, with antennæ (lens). $\times 15$.

4. Posterior view of first pair of legs. $\times 15$.

5. Dorsal view of wing and balancer of the right side. $\times 15$.

6. Abdomen, ventral aspect. $\times 10$.

7. (Optional.) Egg of fly. $\times 10$.

8. (Optionul.) Larva, side view. $\times 7$.

\section{Questions on External Axatomy}

1. How many body-segments has the fly behind the head?

2. How many segments in the antenna?

3. How many segments in the leg? (Compare with grasshopper.)

4. Can you detect any difference between different individuals of the same species in respect to form of the head and eyes?

\section{Observations on the Living Animal}

Each student should be provided with the following: (1) a belljar (or any broad glass vessel) containing a fly and covered with a card; (2) a soup-plate; (3) vials of various colored, pungent, sweet, and neutral substances, such as white sugar, vinegar, butter (preferably rancid), ground gypsum, white sugar reddened with carmine, $\frac{1}{2} \%$ acetic acid, molasses.

1. Place on the soup-plate at a little distance apart some sugar, a drop of vinegar, grains of sugar, and a drop of water. Invert the bell-jar containing a fly, over the soup-plate, and carefully move the bell-jar until it covers all of the substances. Note all the movements of the fly for five minntes - these are the instinctire movements of the fly in the given situation; note especially its movements with reference to the substances.

2. Try the same fly with other combinations such as vinegar, molasses, water.

3. Try a second fly with one of the same combinations of substances. 


\section{QUESTIONS}

By what substances are the flies most attracted? What is the particular quality which seems to attract? What sense (sight, smell, or other) seems to have most influence?

\section{Toplcs For Further Stury}

1. The habitat and food of the fly. 2. Development. 3. Respiration. 4. The parasites of the fly. 5. Other Iiptera: Glossina (tsetse-fly), bot-flies, Syrphus, horse-fly, black-fly, crane-flies, gall gnats, gnats, mosquitoes, sheep-ticks or lice-flies, fleas, and jiggers. 6. The economic importance of Diptera as parasites on animals and plants, as gall producers, as destroyers of grain, as distributers of disease, and as scavengers.

\section{LITHOBILS}

This myriapod may be obtained under woodpiles, or damp leaves in woods, even in late autumn or during mild days in winter.

1. Dorsal view. $\times 5$.

DrawiNgs

2. Head, under side, naming principal parts, e.g. antennæ, jaws, first trunk appendages, etc. $\times 15$.

3. Head, upper side. $\times 15$.

4. Two consecutive segments seen from left side, showing legs and stigma. $\times 10$.

\section{Questions on External Anatomy}

1. How many segments in the body? Is the number constant? (Examine two or three individuals.) Are nẹw segments formed throughout life? Compare with earthworm.

2. How many segments in the antenna? Is this number constant?

3. How many segnients in the leg?

\section{Observations on the Living Animal}

Each student should be provided with the following: (1) a glass rod as in No. VI. or toothpicks; ( 2 ) vial of cologne; (3) vial of $2 \%$ acetic acid; (4) a soup-plate; (5) a pane of glass large enough to cover the plate; (6) forceps to hold Lithobius. 
1. Study the movement of a single leg and draw three of its phases. The Lithobius is held in the covered plate. ${ }^{1}$

2. Make a diagram exhibiting the coördination of leg movement.

3. Touch the antenna with a needle. Response?

4. Bring a clean glass rod near to an antenna; then the rod dipped in cologne; then cleaned and dipped in acetic acid. Record results and conclusions.

5. Does Lithobius tend to move from or toward the source of light?

6. Place on a piece of filter paper, one-half wet and one-half dry, and note reaction at edge of wet part.

\section{TOPICS FOR Furtiner STUdy}

1. Habitat and food of chilopods in general. 2. Distribution of Lithobius. 3. Allies of Lithobius : Scutigera, Scolopendra, Geophilus, Polydesmus, Julus; their habitats.

\section{SPIDER (Argiope and Theridium)}

The large black and yellow garden spider (Argiope) should be obtained in the fall and preserved in alcohol. The house cobweb spider (Theridiums) can be obtained alive throughout the year in unswept corners, especially in cellars. Despite its small size it will serve for the studies on activities. It may be kept in a 4-inch battery jar where it will spin its web. Feed upon flies, plant-lice, and other insects. Other spiders may be substituted for these.

\section{Drawivgs (of Argiope)}

1. Ventral view showing appendages, opening to air sacs, and spinning glands. $\times 5$.

2. Side view (left). $\times 5$.

3. Front dorsal view of head, showing eyes and jaws (hand lens). $\times 10$.

\section{Observations on the Living Animal}

Each student should be provided with the following: (1) a glass rod about $10 \mathrm{~cm}$. long and $2 \mathrm{~mm}$. in diameter, or toothpicks; (2) a

1 The movements of the animal may be reduced by adding a little ether, or by holding the body with a forceps. 
vial of essence of heliotrope ; (3) a vial of cologne; (4) a vial of dilute ammonia; (5) a glass-covered box about 8 inches cube.

1. Offer to the spider the end of the glass rod, first clean, then dipped in essence of heliotrope ; cleaned and dipped in colog'ne; in ammonia. Note and record movements.

2. Place the spider in the box and note for ten minutes its instinctive movements.

3. Leave the spider in the box for a day or two and draw the web; in successive stages of formation if possible.

\section{Topics for Furtiler Study}

1. Habitat and food of Argiope and Theridium. 2. Distribution of these spiders. 3. Spinning habits of spiders in general: forms of webs and nests of the different classes of spiders; economic importance of spiders' webs. 4. Biting and poisonous spiders.

\section{CRAYFISH (Cambarus)}

Crayfish can be obtained from small streams in most parts of the United States, except New England. They are also for sale in the markets of large cities, and are easily transported and kept alive for days in damp moss. They may eventually be transferred to an aquarium containing water not more than an inch deep. Feed upon earthworms or pieces of meat. The crayfish may be replaced by the lobster.

\section{DraWINGS}

1. View from left side, taking care to preserve accurately the proportions. $\times 1.5$.

2. Ventral view. (Omitting legs.) $\times$ 1.5.

3. Draw the posterior aspect of the following appendages of the right side of animal, without removal from body. $\times 2$.
(a) small antenna.
(g) 4th thoracic appendage.
(b) large antenna.
(h) 5th thoracic appendage.
(c) mandible.
(i) Sth (last) thoracic appendage.
(d) 1st maxilla.
(k) 4th abrominal appendage
(e) $2 \mathrm{~d}$ maxilliped. (swimmeret).
(f) $3 \mathrm{~d}$ maxilliped.
(l) last abdominal appendage. 
4. Draw right side of thorax (carapace previously removed) to show the number and position of gills. $\times 2$.

5. Draw dorsal aspect of eye-stalk. $\times 4$ 。

\section{Questions on Exterixal Axatomy}

1. How many segments in the last thoracic appendage? Number the segments upon your drawing, beginning at the proximal (attached) end. Number as far as you can the homologous segments upon the other thoracic appendages drawn.

2. How can you honologize ${ }^{1}$ with one another the swimmerets, the legs, and the mouth parts? Give evidence for each step and indicate results on the drawings already made.

3. Which is the least differentiated of the series of appendages? ${ }^{2}$

4. What is the gill formula of the animal in hand?

\section{Observations on the Living Aximal}

Each student should be provided with the following: (1) soupplate; (2) needle; (3) vial of dilute ammonia; (4) vial of $5 \%$ acetic acid; (5) vial of carmine.

1. Hold a living crayfish in a soup-plate of water so that the free edge of its carapace is near the surface. Put a few drops of the carmine into the water in front of the thorax; behind the thorax; between the legs. Draw a diagram showing the currents. What is the use of these currents, and by what mechanism are they produced?

2. Hold the living crayfish so that its head and anterior half only of thorax are submerged; observe what takes place at hinder edge of carapace. Hold the crayfish so that abdomen and posterior half only of carapace are submerged; what takes place at anterior edge of carapace? Interpretation?

3. Determine the function of each pair of legs used in locomotion and the correlation in their movements.

1 The idea of homology should be made clear. The pupil should indicate the protopodite $(p)$, exopodite $(e x)$, and endopodite $(e n)$ upon all the drawings of appendages.

2 The teacher should make use of the crayfish to explain the principle that different organs have a different degree of specialization or "differentiation." This will lead to the topic of Division of Labor, as indicated below. 
4. To the tip of one of the large antenma and to the small antennæ apply (a) the point of a needle; (b) the vapor of ammonia; (c) a drop of water; (d) a drop of $5 \%$ acetic acid. Tests (a) aud (b) should be performed npon the antenna of one side and $(a),(c)$, and $(d)$ upon that of the other. Record the results. What inferences do you draw?

5. Wave the hand over the crayfish. Does it react? If possible flash a light at its head. Can the crayfish see? Cover the eye-stalks with wax. Does it still react to a movement of the liand?

\section{TOPICS FOR FURTIER STUIY}

1. The habitat and food of the crayfish. 2. The geographical distribution of crayfishes. 3. Other stalk-eyed Crustacea (long and short tailed); lobsters, shrimps, hermit-crabs, spider-crabs, edible crabs. 4. Economic importance of stalk-eyed Crustacea. 5. The breeding habits and general development of crayfish and lobster. 6. The capacity for regeneration in the higher Crustacea and the occurrence of monstrosities. 7. Division of labor in the appendages of the crayfish.

\section{DAPHNIA}

Daphnia may be obtained from pools at almost any time of the year except midwinter. They may be reared in large numbers in aquaria properly stocked with decaying plants, upon which they feed. Select for class work the largest individuals (females), which may attain a length of $2 \mathrm{~mm}$.

\section{DraWING}

Place a living animal on a slide under a cover-glass, and with the aid of the simple microscope draw a side view. $\times 20$.

\section{Observations on tile Living Animal}

Each student should be provided with the following: (1) Stender dish; (2) pipette; (3) watch-glass containing Daphnias; (4) three pieces of glass tubing $20 \mathrm{~cm}$. long and $4 \mathrm{~mm}$. bore, with two corks to fit.

1. Place a Daphnia in the straight glass tube (6) filled with clear water and corked at both ends. (Exclnde air-bubbles in corking.) Place parallel to the rays from the source of light (preferably lamp 
light) and cut off side lights. Observe and record movements or lack of movements.

2. Place a Daphnia in a tube containing a single wad of algæ; place another Daphnia in a tube containing a small pebble; observe and record behavior with reference to the foreign body.

3. (Optional.) Place an egg-bearing female in a Stender dish containing bits of decaying plant. After seven days count the number of individuals. Compare with the number in a similar dish kept (by the teacher) for seven days in a cool place ( $5^{\circ}$ to $10^{\circ} \mathrm{C}$.).

\section{Topics for furtiler Study}

1. The habitat and food of Daphnia. 2. Allies of Daphnia: Branchipus, Cyclops, Cypridopsis, barnacles, trilobites. 3. The pupil should learn to distinguish Daphnia, Cyclops, and the other Entomostraca in the aquarium by their locomotion.

\section{EARTHWORM (Allolobophora or Lumbricus)}

Various species may be used. During the winter time, when the ground is frozen, earthworms are best sought under compost heaps; or they may be kept in laboratory in flower-pots containing rich, moist vegetable mould and covered by a glass plate. They may be fed upon fallen leaves placed in the pots.

\section{DRAWINGS}

\section{(From alcoholic specimens)}

1. Whole animal, dorsal view. $\times 2$.

2. Head end, 6 or 8 segments, ventral view. $\times 5$.

3. Tail end, 6 or 8 segments, ventral view. $\times 5$.

4. Two adjacent middle segments, showing setæ. $\times 5$.

5. Cross-section, showing position of seta. $\times 5$.

\section{Questions on External Anatomy}

1. Count the number of segments of two or three individuals. Are they the same? Inference to be drawn from the result?

2. Where does growth in length take place? Evidence for your conclusion? 


\section{Observations on tile Living Animal.}

Each student should be provided with the following : (1) plate covered with moist filter paper; (*) hand lens; (3-5) vials containing sugar solution, acetic acid, and beef extract; (6) four new toothpicks; (7) pipette.

1. Touch with a toothpick, first the head end, then the tail end of the worm; to which contact does it react more strongly?

2. Place the earthworm near the window. Does it move toward or from the light?

3. With the breath blow upon the head end of the worm. Record results. Are results due to the warmth of the breath or to the current of air? To test, send a puff upon the head with a pipette.

4. Bring near to the head end in succession the ends of toothpicks dipped in water, in sugar solution, in acetic acid, and in beef extract. How does the worm react to each fluid?

5. Place the earthworm on a piece of filter paper two-thirds of which is wet. Reaction of worm at edge of wet part? How do these reactions of the earthworm accord with its ordinary movements ont of doors?

6. When the head end is being thrust out forward, in what phase (contraction or expansion) is the middle of the worm? The tail end? In what direction does the contraction wave pass?

\section{TOPICS FOR FURTIER STUDY}

1. Habitat and food of the earthworm. 2. Economic importance of earthworms. 3. Allies of the earthworm: Nais, Dero, Tubifex, the leeches, the Gephyrea, the Bryozoa.

\section{NEREIS}

Nereis can be obtained at the sea-shore by digging in mud flats between tide lines. It can be transported in damp sand or seaweed, and will remain alive for several days in a shallow vessel filled with sea-water and kept in a cool place.

\section{DRAWINGS}

\section{(From alcoholic specimens)}

1. Whole animal, dorsal view. Natural size. 
2. Head end, dorsal view. $\times 5$.

3. Tail end, dorsal view. $\times$.).

4. Two adjacent middle segments, dorsal view. $\times 5$.

5. Posterior aspect of a single middle segnent, showing parapodia. $\times 8$.

\section{Questions on External Anatomy}

1. Which segments are most specialized?

2. Does the number of segments increase during life? Compare several worms.

3. Which segments are last formed in the individual's development?

\section{Observations on the Living Animal}

(Two persons may work together upon a single Nereis.) Each student should be provided with the following: (1) hand lens; (2) needle; $(3,4)$ vials containing $5 \%$ sugar solution and $5 \%$ acetic acid; (5) pipette.

1. How is locomotion accomplished by Nereis? Analyze the movements involved in locomotion. Relation of phases of writhe to phases of stroke and recovery of fin. Form of fin at various phases of its movement. Indicate by diagrams the relations which you discover.

2. Touch the head with a needle; what movements? The tail; what movements? What faculty in Nereis is indicated by the changes of movement after contact?

3. Drop quietly, by means of a pipette, sea-water upon the head end and the middle of Nereis; repeat with acetic acid; with sugar solution. What difference in the movements? What faculty in Nereis is indicated by these differences in movement?

\section{Topics For Further Study}

1. Ilabitat and food of Nereis. 2. Its distribution. 3. Its allies: Autolytus, Lepidonotus, Amphitrite, Serpula, etc. 4. The round worms and flat worms.

\section{SLUG (Limax)}

Slugs may be found during the winter in greenhouses and during the spring and autumn in gardens and orchards, under boards and stones. They may be kept for considerable periods in a box whose 
bottom is covered with damp moss; they may be fed upon fresh apples, cabbage leaves, etc. Limax maximus is to be preferred on account of its large size.

\section{DraWiNgs \\ (From the living individual)}

1. Dorsal view, showing mantle, foot, respiratory opening, head and tentacles. $\times 1.5$ to 3 .

2. View of right side. $\times 1.5$ to 3 .

3. Front riew, showing tentacles, mouth, and lips of slime-gland. $\times 3$.

\section{Orservations on the Living Animal}

Each student should be provided with a pane of glass, 8 by 10 inches.

1. Place the slug on the glass and study its locomotion from the under side of the plate. Describe in the note-book what is seen.

2. Place the slug on the glass plate, hold the plate vertical and parallel to the window, the slug being horizontal and parallel to one edge of the pane; shield from lateral lights. Having made in the note-book an outline to represent the plate, indicate in this the position of the slug at the beginning of the experiment and at intervals of ten seconds for about a minute. Repeat. A piece of planed board is better than the glass plate, excepting that it cannot be kept so clean.

3. Place the plate horizontal near a window and let the shug be parallel to the window. Do not let direct sunlight fall upon it. Plot in the note-book, as before, the position of the axis of the slug at intervals of ten seconds. Repeat.

4. Note the reaction of the slug to contact on different parts of the body : tail, head, antennæ, edge of mantle.

5. Does the shug react to passes of the hand? To moisture?

\section{Topics FOR FURTHER STUdY}

1. The habitat, food, and methods of feeding of the slug. 2. Its distribution. 3. The economic importance of slugs. 4. The shell of the slug. 5. Allies of the slug: Helix, Pupa, Limnsea, Physa, Planorbis, Littorina, Fulgur, Fissurella, Eolis, Chiton, the Nautilus, and other cephalopods recent and fossil. 


\section{FRESH-IVATER CLAM (Anodonta or Unio)}

Venus may be substituted for these; and Mya is a favorable object for this study. Anodonta or Unio may be obtained from most streams and ponds at any time of the year except midwinter. This exercise will therefore be best taken in the spring or autumn. To prepare animals for the study of the soft parts, place them in hot water $\left(60^{\circ} \mathrm{C}\right.$.) for a few minutes; the valves will then open so that the muscles can be cut where they join the shell.

\section{DRAWINGS}

1. Exterior of left valve, showing lines of growth, beak, and margin. Natural size.

2. Interior of right valve; name some of the more important parts, such as margin, scar of mantle, scars of adductor muscles, and retractor of foot, hinge. Natural size.

3. Bit of fractured edge of burnt shell, to show layers. $\times 5$.

4. Remove the left valve from the killed animal and draw the external form of the soft parts from the left side. $\times 2$.

5. Laying back the mantle, draw in place gills (showing surface structure), body, foot, and labial palps; mark anterior, posterior, dorsal, and ventral surfaces of the body. $\times 2$.

6. Draw an imaginary cross-section made through the middle of the body.

\section{Questions to be Answered by INference from Structure}

1. How does the shell grow?

2. How does the animal close its shell; how open it?

3. How does the animal gain its food?

\section{Observations on the Living Aximal}

Every student should be provided with the following : (1) vial containing finely powdered carmine in water; (2) vial of carmine in $5 \%$ acetic acid; (3) carmine in $5 \%$ sulphuric acid; (4) carmine in sugar solution; (5) pipette; (6) 4-inch battery jar half full of water.

1. Notice in a living individual in the aquarium the movements of the mantle, especially at the posterior end. 
2. Hold the clam just below the surface of the water and by means of a pipette place some carmine suspended in water near the posterior end. Notice the results. How are they to be interpreted?

3. Offer carmine in sugar solution; in acetic acid; in sulphuric acid. Is there any difference in the results?

\section{Topics for further Study}

1. Habitat and food of Anodonta (or Unio). 2. Geographical distribution of fresh-water clams. 3. General development. 4. Allied animals from fresh water, such as the Unionidæ and Cycladidæ; and from the sea, such as the Myidæ, Veneridæ, Arcidæ, Aviculidæ, Pectinidæ, and Ostreidæ.

\section{STARFISH (Asterias vulgaris)}

Starfishes can be readily got at low tide in rock pools and on piles and walls at the sea-shore. They may be transported alive considerable distances, if packed in wet eel-grass or seaweed. The living animals may be placed for study in a soup-plate full of sea-water, or water containing about $2.5 \%$ sea salt. Dry preparations, for the study of the hard parts, may be made as follows: Leare a living starfish in a shallow dish of warm, fresh water until fully expanded. Next dip it into boiling water until hardened, and then dry it in the sun or in a slow oven.

\section{DRAWINGS}

(Nos. 1, 2, 4, and 5 from dried specimen, No. 3 from an alcoholic one.)

1. Aboral view. Natural size.

2. Oral surface of arm showing ambulacral groove. Natural size.

3. Cross-section of arm with ambulacral feet. $\times 4$.

4. Ambulacral ossicles, dissected out. $\times 2$.

5. Spines from aboral surface. $\times 10$.

\section{Observations on the Living Anmal}

Each student should be provided with a soup-plate full of salt water. 1. Observe the eyes, the ambulacral feet and their sucking disks, the gills upon the back. Has the starfish strict radial symmetry?

2. Note the method of locomotion by ambulacral feet. With the aid of a diagram show what takes place in a single foot. 
3. Invert the starfish; observe and record the changes undergone in reassuming the normal position.

\section{TOPICS FOR FURTHER STUDY}

1. Ilabitat of starfish. 2. Food and economic importance. 3. General history of development. 4. Allied forms; Solaster and other starfishes, brittle stars, sea-urchins, holothurians, crinoids.

\section{HYDRA}

This exercise requires the use of a lens.

To obtain Hydra it will be necessary to search carefully in freshwater pools. Lemna together with sticks and grass should be collected from the pools and put into an aquarium. The Hydras, which are attached to these objects, will then usually migrate in the course of a few days to the light side of the vessel, where they can be easily found. Hydras can be kept readily throughout the entire winter in a large glass jar containing Lemna and other plants, and Entomostraca for food. All the following exercises can be done on the living animal, and either the brown species (II. fusca) or the green species (H. viridis) may be employed.

\section{DRAWINGS \\ (From living individuals)}

1. Side view of a single Hydra, not budding. $\times 10$.

2. Side view of a Iydra with buds. $\times 10$.

(Optional, requires compound microscope.) Draw one of the tentacles of Hydra, showing discharged and undischarged nettling capsules. $\times 300$.

\section{Observations on the Living Animal}

Each student should be provided with the following: (1) 4-inch battery jar; (2) 2-inch Stender dish; (3) vial containing $5 \%$ sugar solution; (4) vial containing $5 \%$ acetic acid; (5) a few Daphnias in a watch-glass; (6) pipette; (7) needle; (8) watch-glass; (9) pasteboard box of a slightly larger size than the battery jar and with a vertical slit half an inch wide along one side.

Place a Iydra in a watch-glass full of water. 
1. Touch the tentacles of the Hydra with a needle. What movements?

2. Drop cautiously and at intervals of a few minutes upon the surface of the water over the tentacles of the Hydra a drop of water, of sugar solution, of acid. What differences in the movements?

3. Bring a Daphnia (previously stranded) on the end of a needle to the tentacles of the Iydra. Note the result. With another Hydra, use a bit of plant tissue.

4. (This and the following experiment must extend through several days.) Place a Ilydra in a watch-glass with a little water, and by means of the needle and a penknife cut it into two or three pieces. Let the pieces expand and draw them. By means of a clean pipette place the pieces in the small Stender dish, in clean water. Draw the pieces again after twenty-four hours, and after a longer period if necessary.

5. Place in a 4-inch battery jar full of water containing Lemna and Entomostraca two or three large, budding, green Hydras. Cover the jar with the box, placing the slit next to the window. Note at short intervals for two weeks the position and number of Hydras in the jar.

\section{TOPICS FOR FURTHER STUDY}

1. The habitat and food of Hydra. 2. Other fresh-water or brackish-water hydroids (Cordylophora, Limmocodium) and the origin of fresh-water Hydrozoa. 3. Marine hydroids (Obelia, Sertularia, etc.) and their jellyfishes. 4. Sea-anemones and corals. 5. Corals as island builders. 6. Budding and the formation of colonies among animals. 7. Division of labor in colonies. 8. Regeneration in polyps.

\section{PARAMECIUM}

This exercise requires the use of the compound microscope.

Two or three weeks before Paramecia are needed, put hay and decaying leaves in stagnant water and keep in a warn room. When the water has become foul, Paramecia have probably appeared. To prevent the Paramecia on the slide from moving too rapidly, it is advisable to put them in a $2.5 \%$ solution of gelatine in water. Study first with the low power, then with the high. To bring out the 
nuclei in the living animal, run a $5 \%$ or $10 \%$ aqueous solution of methyl green under the cover-glass by placing the solution at one edge of the cover-glass and drawing it under by filter paper placed at the opposite edge. To stain the plasma, a little iodine may be added; this will kill, with explosion of trichocysts.

\section{DrawiNg}

\section{(From observations on several individuals)}

Whole animal, showing shape of body, cilia, vestibule, foodglobules, non-contracting vacuoles, contracting vacuoles, nucleus, trichocysts. $\times$ about 200 .

\section{Observations on the Living Animal}

Each student should be provided with the following: (1) vial containing beef extract; (2) vial containing finely powdered carmine in water; (3) common salt; (4) pipette; (5) filter paper.

1. Is the protoplasm in the body of Paramecium quiet or moving?

2. Place Paranecium in a drop of the gelatine solution. Cover with cover-glass. Run carmine-water under the cover-glass; select a quiet individual and observe how the carmine graius pass by it. Indicate by arrows placed outside the periphery of the drawing the direction of movement of the carmine. What do you infer concerning the movement of the cilia? Do the grains whirl as much about a moving individual as about a quiet one? Can you explain? Why are not all the Paramecia carried off by the current when carmine is run under the cover-glass?

3. Place upon a clean glass slide a drop of water containing Paramecia. When they are uniformly distributed, put a few grains of common salt in the centre of the drop. After a few seconds observe and draw the distribution of the organisms. How is the result to be interpreted?

4. Place upon the glass slide a drop of water containing Paramecia; by means of a pipette (drawn to a fine point), add a drop of $\frac{1}{2} \%$ to $\frac{1}{10} \%$ acetic acid; after two or three minutes draw the distribution of the Paramecia. How do reactions to acids and to salts compare? ${ }^{1}$

1 See H. S. Jennings, American Journal of Physiology, May, 1899, and American Nuturalist, May, 1899. 
5. Under a moderate power observe the reactions of Paramecium when it comes to the salt or acid.

\section{Topics for Further Study}

1. How the Infusoria get into the aquarium. 2. The habitat and food of Paranecium. 3. Allies of Paramecium: Stentor, Vorticella, Carchesium, Euglena, the Suctoria, Amœba, the Gregarinidx. 4. Economic importance of Amoba and the Gregarinidæ. 5. Reproduction of Paramecium.

\section{SMELT (Osmerus mordax)}

Various other bony fishes may replace the snelt, e.g. brook trout (Salmo fontinalis), lake herring or white fish (Coregonus), perch (Perca).

\section{DraWINGS}

1. Whole animal, from left side, fins extended, showing number of fin rays, position of lateral line, mouth, tongue, teeth, nostrils, anus, urinary openings. $\times 1$ to 2 .

2. Side view of a few trunk segments as seen after removal of skin.

3. Ventral view of head, gill cover removed, mouth open, probes passing from mouth through each of the gill slits. Show teeth and slime-glands. $\times 2$ to 3.

4. Dorsal view of head, showing, when possible, form of brain seen through brain case. $\times 2$.

5. Cross-section (5 $\mathrm{mm}$. thick) of whole animal in front of anus and behind dorsal fin. Name organs as instructed by teacher.

6. Lateral view of vertebra, from the section mentioned in 4 , isolated by boiling.

\section{Questions on External Anatomy}

1. How many rows of scales are there above the lateral line; how many below?

2. How many segments behind the head? Is this number constant? (Compare with two other individuals.) 
3. What special fitness in the form of the body to the habits of the fish?

\section{Observations and Experinexts on the Living Aninal}

1. Rôle of fins in locomotion. By means of a cotton string wrapped around body, bind down the pectoral fins and replace in water; result? Bind ventrals similarly; result? Wrap string around tail and replace in water; result? Conclusions?

2. How do the movements of the caudal fin cause the fish to progress?

\section{TOPICS FOR FURTHER STUDY}

1. Habitat and food of the species. 2. Distribution and economic importance. 3. Allied species: salmon, trout, white fish. 4. Other groups of fresh-water bony fishes: the darters, perch, sunfish, sticklebacks, silversides, nimnows, pike, shad, suckers, catfish, eels. 5. Other kinds of fish: Amphioxus, lampreys, sturgeons, spoonbills, garpike, Ania. $\quad$ 6. The ontogeny of a bony fish. 7 . The migrations of fish. 8. Artificial breeding and fish-hatching stations.

\section{NEWT (Diemyctylus viridescens)}

For this species may be substituted the small spring or brook salamanders (Desmognathus and Spelerpes), Amblystoma, or even Necturus. The small size of the brook salamanders makes them especially useful for external study and preservation in alcohol.

\section{DraWixgs (of comenient size)}

1. Entire animal.

2. View of the left side of head, mouth open.

3. Left fore foot, dorsal surface.

4. I eft hind foot, palmar surface.

5. Form of frout lateral teeth. $\times 10$.

\section{Questions ox External Anatomy}

1. Which is the thumb side of hind foot?

2. Are the spots on the body arranged according to any law?

3. Are there two movable eyelids?

4. Where is the ear? 


\section{Observations on the Living Animal}

1. How are the movements of appendages and tail correlated in locomotion ( $a$ ) on land, $(b)$ in water? Diagrams.

2. Observe the instincts of the aninial when placed in a box of earth ( $\frac{1}{2}$ damp and $\frac{1}{2}$ dry) lighted on one side from the window and strewn with leaves and stones.

\section{Topics for furtiler Study}

1. Ilabitat and food of the species studied. 2. Distribution of Amphibia. 3. Allied organisms in the United States: Desmognathus, Plethodon, Amblystoma, Amphiuma, Necturus, Siren; their distribution and habitats. 4. Experiments upon changing Axolotl iuto Amblystoma. 5. Egg-laying of Urodela and general formchanges accompanying development.

\section{LIKARD (Anolis carolinensis)}

This may be replaced by any other species. Where live lizards cannot be easily obtained, substitute a snake or tortoise and make appropriate changes in the following outline.

\section{DraWTNGS}

1. Entire animal, dorsal view. $\times 1$ to 3 .

2. Dorsal view of head, showing scales, especially the parietal scale. $\times 3$.

3. Left side of head; mouth open, tongue exposed. $\quad \times 3$.

4. Left fore foot, dorsal aspect. $\times 3$.

5. Left hind foot, pahmar aspect. $\times 3$.

6. Outline of front lateral teeth. $\times 10$.

7. Outline of scales on ventral side at base of tail. $\times 10$.

S. Outline of scales on back. $\times 10$.

\section{Questions on External Axatomy}

1. Which is the thumb side of the fore foot? Why? Of the hind foot? Why?

2. What is the function of the structures on the pads of the toes? 
3. Where is the ear-drum?

4. (This may best be studied on the living animal.) Is there a nictitating membrane, as in birds?

\section{Observations on the Living Animal}

Each student should be provided with a set of Bradley's color cards.

1. Which eyelid is more used in winking, the upper or the lower?

2. Locomotion : Order of movement of legs; correlation of leg and tail movement.

3. Change of color: Effect of colored backgrounds (Bradley's colors ${ }^{1}$ ), of warming by holding in the hand, of stroking the back.

\section{TOPICS FOR FURTHER STUdY}

1. Habitat, food, and distribution of Anolis. 2. Common lizards of the region, if any. 3. Other interesting lizards, such as the chameleon, the blindworm (Anguis), the Gila monster (Heloderma), lizards of Europe (Lacerta), fossil Reptilia.

\section{XIX. "ENGLISH” SPARROW (Passer domesticus)}

This introduced bird can be obtained in most large cities in sufficient numbers. Recently killed birds are the most favorable for laboratory work. Subjection to fumes of carbon disulphide is a useful precaution against bird lice.

\section{Drawings}

1. Side view (left). Name parts. Natural size.

2. Head and bill, side view, mouth open, showing tongue. $\times 2$.

3. Foot (left), dorsal surface. $\times 2$.

4. Foot (left), palmar surface. $\times 2$.

5. Contour feather (from tail). $\times 2$.

6. Plumage feather. $\times 3$.

7. The egg. $\times 2$.

\section{Questions ox External Axatomy}

1. Color of: $(a)$ eye ; $(b)$ bill ; (c) feet; $(d)$ throat; (e) breast; $(f)$ belly; $(g)$ crest; $(h)$ side of head; ( $i)$ back ; $(k)$ wing ; $(l)$ rump; ( $m$ ) tail feathers?

1 Milton Bradley Company, Springfield, Mass. 
2. Number of tail feathers?

3. Number of primaries?

4. How many segments in the leg; in the wing?

\section{Topics for further Study}

1. The introduction of the "English" sparrow into America and similar instances of introduction and spread of exotic species. 2. The food and habits of the "English" sparrow in America. 3. The native sparrows. 4. Other groups of birds: thrushes, bluebirds, titmice, nuthatches, creepers, wrens, warblers, tanagers, swallows, waxwings, vireos, shrikes, larks, orioles, crows, flycatchers; parrots and cockatoos; toucans and cuckoos, kingfishers ; woodpeckers, hummingbirds, swifts, goatsuckers; pigeons; grouse and fowl; ostriches; waders; swimmers, and divers. 5. The migrations of birds; migration data. 6. Flight of birds. 7. The food and economic importance of birds. 8. The preservation of birds. 9. Fossil birds.

\section{MOUSE (Mus mustelus)}

Tame mice may be obtained from bird fanciers in most of our large cities. ${ }^{1}$ They can be kept in the laboratory indefinitely. Galvanized wire cages with doors and galvanized iron bottoms are serviceable. Supply with cotton, hay, or excelsior for a nest. Keep at an equable, moderate temperature, and pay great attention to cleanliness. Feed on oats and bread, with occasional fruit, carrot, and cooked meat.

\section{Drawings}

1. Side view (left). Name parts. Natural size.

2. Head, dorsal view. $\times 1.5$.

3. Fore foot (left), dorsal surface. $\times 2$.

4. Fore foot (left), palmar surface. $\times 2$.

5 . Hind foot (left), dorsal surface. $\times 2$.

6. Side view of skull. $\times 3$.

7. Upper surface of lower jaw showing teeth. $\times 3$.

8. Incisor tooth (free). $\times 10$.

$1 \mathrm{Mr}$. H. C. Ostendorf, 420 N. Eutaw St., Baltimore, has been found reliable by the writer, and keeps a stock on hand. 


\section{Observations on the Livixg Animal}

Each student, or set of students, should be provided with the following: (1) a cage of wire netting about 8 inches cube, with a door on top; (2) a tin box or small cigar box, closed except for a $\frac{3}{4}$-inch hole and small enough to be put into the cage.

1. Enumerate the kinds of activities of the mouse in the cage.

2. Bring a piece of toasted cheese to one side of cage. Note any change of movements.

3. Place the small box in the cage. Note the actions of the mouse. Does he go directly to the hole or does he find it by accident, or otherwise?

\section{Topics For Further StunY}

1. The distribution of mice and rats. 2. The habits of rats and mice. 3. The food of mice. 4. The races of tame mice. 5. Other rodents. 6. Other mammals: the monotremes, marsupials, edentates, Cetacea, Lngulata, Insectivora. Carnivora, Cheiroptera, and Primates. 7. The ciescent of man.

\section{DEVELOPMENT OF THE FROG'S EGG}

The eggs of toads and even of Urodela may be substituted, although this outline accords closely with Anura only. Frog-spawn may be obtained in April in ponds and marshes as jelly-like masses containing the eggs. Toad-spawn occurs as threads intertwining with the grass at the margins of shallow pools. Eggs may he obtained from animals in captivity by placing breeding males and females in a large glass aquarium in the laboratory. The eggs should be studied shortly after being laid and at various later periods.

\section{DraWiNGS}

(While it is desirable that these be marle from the living eggs, they may be made from eggs killed in hot wuter at $S 0^{\circ}$ C.)

1. A bit of spawu with a few eggs in place. $\times 2$.

2. Isolate eggs, watch and draw various stages till hatching. The series should include as many of the following stages as possible: cleavage, morula, blastopore formation, medullary folds, gill covers, 
gills, newly hatched tadpole, tadpole several days after hatching. (Optional, a series of tadpoles showing metamorphosis.) $\times 15$ to 20 . (Keep a record of the time - day, hour, minute - when each stage was draw11.)

\section{ExPERIMEXTS}

1. Keep some of the same spawn in a refrigerator for ten days, then draw and compare with the eggs kept at normal temperatures for the same length of time.

2. At the time of formation of neiral folds, free an embryo from the albumen, and add carmine grains to the (shallow) water. Note the direction of currents and motion of cilia.

3. Amputate the tail of a newly latched larva and observe the result after a week or two.

4. Find the (approximate) specific gravity of a tadpole by placing one or two in each of the following solutions of gum arabic in water:

$$
\begin{array}{lllllll}
\text { Per cent by weight, } 33 & 16.5 & 11 & 8.2 & 3.3 & 1.65 \\
\text { Specific gravity, } & 1.11+ & 1.06 & 1.037 & 1.028 & 1.011 & 1.006
\end{array}
$$

The solution in which they tend, when motionless, neither to rise nor fall is of their specific gravity. Repeat with tadpoles just hatched and with those one week, two weeks, three weeks, and four weeks old. ${ }^{1}$

\section{Topics For further Study}

1. Effect of heat and light upon development. 2. Capacity of organisms for healing and regeneration. 3. Postembryonic development of the frog, Amblystoma, and Necturns. 4. General laws of development. 5. Development of the chick. (This should be illustrated by opening several eggs at various stages of development.)

It may interest teachers to have reproduced here the examination requirements of two universities which are exactly covered by the preceding outline :-

${ }^{1}$ See S. R. Williams in the American Naturalist, February, 1900, p. 98. 


\section{METHOD OF EXAMINATION IN ZOOLOGY FOR ADMISSION TO THE LAWRENCE SCIENTIFIC SCHOOL, HARVARD UNIVERSITY.}

The candidate is required to pass both a written and a laboratory examination. The written examination will test the range and thoroughness of his knowlerge of the subject. The laboratory examination will test his skill in observation and experinentation, and his ability to apply names properly to the parts of the organisms studied.

At the time of the written examination the candidate nust present the original note-book containing (with dates) the notes and drawings he has made in the course of his laboratory work, and bearing the endorsement of his teacher, certifying that the book is a true record of the pupil's own observations and experiments. An index of subjects should be appended.

\section{METHOD OF EXAMINATION IN GENERAL BIOLOGY (ZOOLOGY AND BOTANY) FOR ADMISSION TO THE JUNIOR COLLEGES, THE UNIVERSITY OF CHICAGO.}

The candidate applying for admission credit in General Biology will be required: (a) To submit to the examiner a note-book consisting of drawings and descriptions of the animals and plants studied. It is recommended that studies of at least fifteen principal forms be undertaken, that these studies be largely such as do not demand the use of a compound microscope, and that attention be given chiefly to those organisms that can be studied in a living condition; (l) to demonstrate, in the college laboratory, under the supervision of college officers, that he possesses some power to observe accurately and intelligently. More stress will be laid on correct observation and on the careful record thereof, than upon technical terms; $(c)$ to answer in writing a few general questions about familiar animals and plants, such as the perch, crayfish, grasshopper, moss, fern, sone common type of flowering plant, etc. 


\section{APPENDIX II}

\section{A LIST OF BOOKS DEALING CHIEFLY WITH ECOLOGICAL AND SISTEMATIC ZOOLOGY OF AMERICAN ANIMALS.}

\section{A. GENERAL SYNOPTIC WORKS}

Leunis, J. - Synopsis der 'Thierkunde. Dritte Auflage von H. Ludwig. 2 Bande. Hannover. 1883-86.

This is the nearest approach to a systematic manual, taking the place in Zoology which Gray's and Coulter's Manuals do in Botany. It deals chiefly with European species; and has not been translated.

Thomson, J. A. - Outlines of Zoology. 3d edition, with 332 illustrations. New York: D. Appleton \& Co. 1899. 819 pp.

An excellent condensed compendium; in which, however, the structural side predominates.

Riverside [formerly Standard] Natural History, edited by .J. S. Kingsley. 6 vols. large $\delta^{\circ}$. Boston and New York: Houghton, Miftlin \& Co. Price $\$ 30$.

The most important large compendium written by American authors, somewhat after the plan of Brehm's Thierleben.

Cambridge Natural History, edited by S. F. Harmer and A. E. Shipley. New York: 'The Macmillan Company. 1894.

An English work of surpassing merit; five volumes have appeared but the work is still far from complete.

Klassen und Ordnungen des Thierreiches, edited (originally) by Bronn. Leipzig u. Heidelberg: C. F. Winter.

An extensive and thorongh work. Although the whole work is not yet completed, some of the volumes are out of date. The most recent and important are the volumes on Protozoa, Porifera, Corlenterata, Vermes, Echinodermata, Crustacea, Mollusea, Reptilia, and Birds. 
Das Tierreich. Eine Zusammenstellung und Kennzeichnung der rezenten Tierformen. General redacteur: F. E. Schulze. Berlin: R. Friedländer und Solnn. 1896-

A systematic account of every known species, with keys for their determination. An ambitions enterprise which will hardly be finished during one generation.

\section{B. WORKS RELATING TO ANIMALS OF A PAR'TICULAR HABITA'T}

Verrill, A. E. (and S. I. Smith).-- Report upon the Invertebrate Animals of Vineyard Sound and the adjacent waters, in Report (of U. S. Fish Conmission) on the Condition of the Sea Fisheries of the South Coast of New England in 1571 and 157.2. (1573.) 1p. $295-778$.

An indispensable accompaniment of the zoologist at the sea-shore; separate copies can be purchased of dealers in scientific books.

Emerton, J. E. - Life on the Seashore. [For sale by Bradlee Whidden, Boston.]

\section{GENERAL WORKS ON IIABITS, ECOLOGY, AND DISTRIBLTION}

Verworn, M. - General Physiology. An outline of the science of Life. New York: The Macmillan Company. 1899. 615 pl. Price $\$ 4.00$.

Morgan, C. L.-Animal Life and Intelligence. New York: Edward Arnold. 1891. $503 \mathrm{pp}$.

Morgan, C. L. - Habit and Instinct. New York: Edward Arnold. 1896. $851 \mathrm{pl}$.

The two best books on the topies considered.

Lubbock, J.-On the Senses, Instinct, and Intelligence of Animals, with special reference to Insects. International Sci. Ser., Vol. LXIV. New York: D. Appleton \& Co. 1888.

Marey, E. J.-Movement. International Sci. Ser., JXXIII. New York: D. Appleton \& Co. 1895.

Poulton, E. B. - The Colors of Animals. 'The International Scientific Series, Vol. LXVII. New York: D. Appleton \& Co. 1890. 
Semper, K. - Animal Life as affected by the Natural Conditions of existence. International Scientific Series, XXX. New York: D. Appleton \& Co. 1881.

Even to-day the best book on Animal Ecology.

Wallace, A. R. - Tropical Nature. London and New York: Macnillan \& Co. 1895.

Wallace, A. R. - Geographical Distribution of Animals. 2 vols. London: Macmillan \& Co. 1879.

Beddard, F. E. - Text-book of Zoogeography. Cambridge (Eng.) Scientific Series. 1895.

\section{WORKS DEALING CHIEFLY WITH ANATOMY AND EMBRYOLOGY}

Parker, T. J., and W. A. Haswell. - Text-book of Zoology. 2 vols. Many illustrations. New York: The Macnillan Co. 1897.

Parker, T. J., and W. A. Haswell. - Manual of Zoology. Adapted for use of American Schools and Colleges. 563 pp. 327 figs. New York: The Macmillan Co. 1900.

Rolleston, G., and W. H. Jackson. - Forms of Animal Life. 1888.

Lang, A. - Text-book of Comparative Anatomy. Translated by Bernard. 2 vols. New York: The Macnillan Co. 1896.

Brooks, W. K. - Handbook of Invertebrate Zoology. For laboratories and seaside work. Boston: S. E. Cassino. 1882. [May be purchased of Bradlee Whidden, Boston.]

Korschelt, E., and K. Heider. - Text-book of the Embryology of Invertebrates. 3 vols. New York: The Macmillan Co. 1899.

Balfour, F. M. - A Treatise on Comparative Embryology. In 2 vols. London: Macmillan \& Co. 1880-81.

Although decidedly out of date, yet gives the best general discussion of the subject.

Hertwig, 0. - Text-book of the Embryology of Man and Mammals. Translated by E. L. Mark. New York: Macnillan \& Co. 1892. Wilson, E. B. - The Cell in Development and Inheritance. New York : The Macmillan Co. 1896. 


\section{E. PERIODICALS}

Besides "Science" and "Nature," both published by The Macmillan Co., New York, there will be found of especial interest to the zoology student:-

The American Naturalist. A Monthly Journal devoted to the Natural Sciences in their widest sense. Published monthly by Ginn \& Co., Boston. Price $\$ 4.00$ per year.

This journal is publishing keys for the determination of North American Invertebrates.

\section{F. WORKS ON SPECIAL GROUPS}

\section{INSECTS IN GENERAL}

The Cambridge Natural History. Vols. V and VI. - Peripatus, by A. Sedgwick: Myriapods, by F. G. Sinclair; Insects, Parts I. and II., by David Sharp. Macmillan \& Co., London and New York. 1895 and 1899.

Deals especially with Ecology.

Comstock, J. H. and A. B.-A Manual for the Study of Insects. Ithaca, N. Y.: Comstock Publishing Co. 1895. Price \$3.75.

The best systematic treatise (with special reference to economic entomology) on Insects of the United States, with keys to families.

Comstock, J. H. - An Introduction to Entomology. Ithaca: Comstock Publishing Co. 1888.

Unfinished, but more detailed than the Manual. Treats of Thysanura, Pseudoneuroptera, Orthoptera, Physopoda, Hemiptera, and Neuroptera only.

Comstock, J. H. - Insect Life. An Introduction to Nature Study and a guide for teachers, students, and others interesterl in out-ofdoor life. D. Appleton \& Co. New York, 1897. 349 pp. Price $\$ 2.25$.

Packard, A. S. - Entomology for Beginners. Henry Ilolt \& Co., New York. 18s8. Price $\$ 1.40$.

Packard, A. S. - Half Iours with Insects. Boston : C. E. Lauriat. 1881. 
Smith, J. B. - Economic Entomology. Philadelphia: J. B. Lippincott \& Co. 1896. Price \$2.50.

Packard, A. S. - Fifth Report of the United States Entomological Commission [U. S. Department of Agriculture], being a revised and enlarged edition of Bulletin No. 7 on Insects Injurious to Forest and shade Trees. Washington: Gov't Printing Office. 1890. $928 \mathrm{pp} .306$ text figures and 40 plates.

A valuable and inexpensive treatise ; can usually be obtained of dealers in second-hand books.

Miall, L. C. - The Natural History of Aquatic Insects. London and New York: Macmillan \& Co. 1895. Price \$1.75.

Lubbock, John. - On the Origin and Metamorphoses of Insects. Nature Series. London and New York: Macmillan \& Co. 1895.

McCook, H. C. - Tenants of an Old Farm. Leaves from the Notebook of a Naturalist. New York: Fords, Howard \& Hulbert. 1885.

Riley, C. V. - An Enumeration of the published synopses, catalogues, and lists of North American Insects. U. S. Dept. of Agriculture, Division of Entomology, Bull. No. 19. 1888. 77 pp.

A very valuable bibliography.

Riley, C. V.-Directions for Collecting and Preserving Insects. Smithsonian Institution, Washington, D. C., 1892. Price 25 cents.

\section{ORTHOPTERA, NEUROPTERA, HEMIPTERA, ETC.}

Scudder, S. H. - Guide to the Genera and Classification of the North American Orthoptera found north of Nexico. Cambridge: E. W. Wheeler. $1897.89 \mathrm{pp}$.

Scudder, S. H. - Revision of the Orthopteran group Melanopli (Acridiidæ), with special reference to North American forms. Proceedings U. S. National MIuseun, XX. pp. 1-421. Plates $1-26 . \quad 1897$.

Calvert, P. P. - Catalogue of the Odonata (Dragon-flies) of the vicinity of Plhiladelphia, with an introduction to the study of this group of insects. Trans. American Entomological Society, Philadelphia. Price $\$ 1.00$. 
Hagen, H. - Synopsis of the Neuroptera of North America, with a list of South American species. Smithsonian Miscellaneous Collections. Washington, D. C. 1861.

Banks, N. - A Synopsis, Catalogue, and Bibliography of the Neuropteroid Insects of Temperate North America. Trans. American Entomological Society, Philadelphia. [Sec'y Amer. Entom. Soc. Price $\$ 1.00$.

Osborn, H. - Classification of Hemiptera. Entomologica Americana. Vol. I., pp. 21-27. 1885.

\section{LEPIDOPTERA AND HYMENOPTERA}

Scudder, S. H. - Brief Guide to the Commoner Butterflies of the Northern United States and Canada. Henry Holt \& Co., New York. 1893. Price $\$ 1.25$.

French, G. H. - The Butterflies of the Fastern United States. For the use of classes in Zoology and private students. Philadelphia: Lippincott \& Co. 1886.

Scudder, S. H. - The Butterflies of the Eastern United States and Canada, with special reference to New England. 3 vols. Cambridge, Mass. Published by the author. 1889.

Edwards, w. H. - The Butterflies of North America. Boston : Houghton, Mifflin \& Co.

Holland, W. J. - The Butterfly Book. A popular guide to a knowledge of the butterflies of North America, with 48 plates in color photography. New York: Doubleday \& McClure Co. 1898.

Knobel, E. - The Day Butterflies and Dusk Flies of New England; how to find and know them (1895); also The Night Moths of New England; how to determine them readily (1895). Boston: Bradlee Whidden.

Cresson, E. T. - Synopsis of the Families and Genera of the Hymenoptera, North of Mexico, together with a catalogue of the described species and bibliography. Trans. Amer. Entom. Soc., Suppl. vol., Pt. I., 1887. [Sec'y Amer. Entomological Society, Philadelphia. Price \$3.00.]

Lubbock, J. - Ants, Bees, and Wasps. Internat. Sci. Series, Vol. XLII. New York: D. Appleton \& Co. 1882. 


\section{COLEOP'TERA}

LeConte, J. L., and G. H. Horn. - Classification of the Coleoptera of North America. [Can be purchased of the Secretary of the American Entomological Society, Philadelphia. Price \$2.50.]

Hoffmann, E. - The Youug Beetle Collector's Handbook. New York: The Macmillan Company. 1897. 178 pp., 20 color plates.

This book deals with European species; but many are closely related to ours.

Knobel, E. - Beetles of New England and their kind. A guide to know them readily. Boston: Bradlee Whidden. 1895.

\section{DIPTERA}

Williston, S. W. - Manual of North American Diptera. Second Edition, 1896. Jas. T. Hathaway, New Haven, Conn. Price \$.2.25.

Knobel, E. - The Mosquitoes, Gnats, Crane-flies, Midges, and Flies of the Northern States. Boston : Bradlee Whidden. 1897.

\section{MYRIAPODA}

Bollman, C. H. - The Myriapoda of North America. Bulletin U.S. National Museum, No. 46. 1893.

\section{ARACHNOIDEA}

Emerton, J. H. - The Structure and Habits of Spiders. Salem, Mass. 1878. Price $\$ 1.50$.

Emerton, J. H. - New England Spiders [of various Families]. In Transactions Connecticut Academy, New Haven.

Peckham, G. W. and E. G. - North American Spiders of the Family Attidæ. Transactions Wisconsin Academy of Science, Arts, and Letters, Madison, Wis. Vol. VII., 1S8s. 256 pp., 2 plates.

Peckham, G. W. and E. G. - Some Observations on the Mental Powers of Spiders. Journal of Morphology, Vol. I., Dec., 1887.

McCook, H. C. - American Spiders and their Spinning Work: a Natural History of the Orb-weaving Spiders of the United States, with Special Regard to their Industry and Habits, 3 vols. $4^{\circ}$, 
1889-93; $372+479+406$ pp.; $353+401$ wood cuts; 35 plates. Philadelphia: published by the author [Academy Nat. Science, Philadelphia].

Very valuable and readable treatise.

McCook, H. C. - The Natural History of the Agricultural Ant of Texas. Philadelphia, 1879.

Kraepelin, K. - Scorpiones and Pedipalpi. Das Tierreich, 8. Lieferung. Berlin: R. Friedländer und solu. 1899.

Weed, C. M. - A Descriptive Catalogue of the Harvest Spiders (Phalangiide) of Ohio. Proc. U. S. National Museum, Vol. XVI., pp. 543-563, 3 plates. 1893.

\section{CRUSTACEA}

Stebbing, T. R. R. - A History of Crustacea, Recent Malacostraca. International Scientific Series, Vol. 71. New York: D. Appleton \& Co. 189:3.

Rathbun, R. - Natural Iistory of Economic Crustaceans. In Bulletin U. S. Fish Commission for 1889, pp. 763-830, plates $260-275$ and plate cxxi. 1893.

\section{MALACOSTRACA}

Huxley, T. H. - The Crayfish. An Introduction to the Study of Zoology. International Scientific Series, Vol. XXVIII. 1880.

Faxon, M. - A Revision of the Astacida. Part I.: The Genera Cambarus and Astacus. Mem. Mus. Comp. Zool., Vol. X. No.4. Cambridge, Mass. 1885. 111 pp., 11 plates.

Herrick, F. H. - The American Lobster: A Study of its Habits and Development. Bulletin U. S. Fish Commission, Vol. XV., for 1895. 25:2 p., 54 plates. 1896.

Kingsley, J. S. - Synopses of North American Invertebrates: III. The Caridea of North America; IV. Astacoid and Thalassinoid Crustacea. American Naturalist, Vol. XXXIII. Sept. and Oct., 1899.

Benedict, J. E., and Mary J. Rathbun. - The Genus Panopeus. Proceedings U. S. National Museum, Vol. XIY., pp. 355-385, 5 plates. 1891. 
Rathbun, Mary J. - Catalogue of the Crabs of the Family Periceridæ [Spider Crabs] in the U. S. National Museum. Proceedings U.S. National Museum, Vol. XY., pp. 231-277; 3 plates. $189 \cdot 2$.

Rathbun, Mary J.-Synopses, etc. VII. The Cyclometopous or Cancroid Crabs of North America. American Naturalist, Vol. XXXIV. Feb. 1900.

\section{ENTOMOSTRACA}

Herrick, C. L., and C.H. Turner.-Synopsis of the Entomostraca of Minnesota: Copepoda, Cladocera, and Ostracoda. Geological and Natural History Survey of Mimnesota. 1895.

Giesbrecht, W., and 0. Schmeil. Copepoda: I. Gymnoplea. Das Tierreich, 6. Lieferung. Berlin : R. Friedländer und Sohn. 1898.

Includes the free-swimming marine species.

\section{WORMS}

Cambridge Natural History. Vol. II. [Flatworms, Mesozoa, Nemertini ; threadworms, Sagitta, rotifers, polychæt worms, earthworms, leeches, Gephyrea, Phoronis, Bryozoa.] New York: The Macmillan Company. 1896.

\section{OLIGOCH.ETA AND LEECHES, GEPHYREA AND BRYOZOA}

Darwin, Charles. - The Fornution of Vegetable Mould through the action of Worms, with observations on their Habits. New York: D. Appleton \& Co.

Michaelsen, W. - Oligochrta. Das Tierreich, 10. Lieferung. Berlin : R. Friedländer und Sohn. 1900.

Davenport, C. B. - Synopses, etc. I. Fresh-water Bryozoa. American Naturalist, Vol. XXXIII, July, 1899.

\section{POLYCHETA AND LOWER WORMS}

Verrill, A. E. - New England Annelida. Part I., with Plates III.-XII. Trans. Connecticut Academy, Yol. IV., Pt. 2. 1881. 
Andrews, E. A. - Report upon the Annelida Polychreta of Beaufort, North Carolina. Proc. U. S. National Museum, Vol. XIV., pp. 277-302, 7 plates. 1891 .

Johnson, H. P. - A preliminary Account of the Marine Annelids of the Pacific Coast, with Descriptions of New Species. Proc. California Acad. of Sciences, Tol. I., No. 5. 1897.

Montgomery, T. H. - Synopses, etc. II. : Gordiacea (Hair-worms). American Naturalist, Vol. XXXIII. Aug., 1899.

Ward, H. B. - The Parasitic Worms of Man and the Domestic Animals, in Report for 1894 of Nebraska State Board of Agriculture. Lincoln, Neb. 1895.

\section{AND XII. MOLLUSCA}

The Cambridge Natural History : Vol. III. : Mollusca, by A. H. Cooke. New York: The Macmillan Company. 1896.

Tryon, G. W., Jr. - Structural and Systematic Conchology : an introduction to the Study of the Mollusca. 3 vols. 140 plates. Philadelphia: published by the author. [Price, $\$ 6.00$; for sale by S. R. Roberts, Glen Ridge, N. J.]

Gould, A. A. - Report on the Invertebrata of Massachusetts. 2d edition, by Binney. 1870. $52+$ pp. 528 figures.

Devoted to Mollusea and Tunicata.

Apgar, A. C. - Molluses of the Atlantic Coast of the United States, south to Cape Hatteras. [Copies bound in cloth, for sale by author, Trenton, N. J. Price, \$1.00.]

A very convenient book for the pocket.

Ingersoll, Ernest, and J. A. Ryder. - Natural History of Economic Molluses of the United States. Bulletin U. S. Fish Commission for 1889 , pp. 687-758, plates 25:3-259. 1893.

\section{RADIATES}

Agassiz, Elizabeth C., and A. Agassiz. - Seaside Studies in Natural History. Marine Animals of Massachusetts Bay. Radiates. Boston: Ticknor \& Fields. 1865.

Fewkes, J. W. - An Aid to a Collector of the Coelenterata and Echinodermata of New England, with cuts. Bull. Essex Institute, Vol. XXIII., pp. 1-2. [Sec'y Essex Institute, Salem.] 


\section{ECHINODERMATA}

Agassiz, A. - North American Starfishes. Memoirs Museum Comparative Zoology at Harvard College, Vol. V., No. 1. 1877. 137 pp. and 20 plates.

Agassiz, A. - Revision of the Echini. Illustrated Catalogue of the Museum of Comparative Zoology at Harvard College, No. VII., 2 Parts. $187 \cdot 2-1873$.

Lampert, K. - Die Seewalzen (IIolothuroidea). Eine Systematische Monographie mit Bestimmungs- und Verbreitungs- Tabellen. Weisbarlen : C. W. Kreidel. 1885. 4. 310 pp., 1 plate.

Brooks, W. K. - Iandbook of Invertebrate Zoology. Boston: Cassino. 188.2.

Has an excellent chapter on the development of Echinoderms.

\section{COELENTERATES}

Trembley, A. - Mémoires pour servir à l'histoire d'un genre de Polypes d'eau douce à bras en forme de cornes. Leyden. 1744. 4 . 323 pp., 13 plates.

A remarkable memoir on Hydra ; obtainable from European dealers in second-hand books.

Agassiz, L. - Contributions to the Natural IIistory of the United States of North America. Vols. III. and IV. Second Monograph, in five parts. - I. Acalephs in general. - II. Ctenophore. - III. Discophoræ. - IV. Hydroidæ. - V. Honologies of the Radiata. With 46 plates. Boston: Little, Brown \& Co. 1860, 1862.

Hincks, T. - A History of the British Hydroid Zoophytes. 2 vols. London : Van Voorst. 1868. Vol. I. text, - Vol. II. plates. Price $42 s$.

Allman, G. J. - A Monograph of the Gymnoblastic or Tubularian Iyydroids. London : Ray Society. 1871. 4. pp. 450, 23 plates. Darwin, Charles. - The Structure and Distribution of Coral Reefs. New York: I. Appleton \& Co. [First published, London, 1842.]

Agassiz, A. - A Visit to the Great Barrier Reef of Australia in the Steamer "Croydon," during April and May, 1896. Bull. Museum 
of Comparative Zoology at Harvard College, Vol. XXVIII. April, 1898.

Bowerbank, J. S. - A Monograph of the British Spongiadæ. 4 vols., numerous plates. London: Ray Society. 1861-1852.

Hyatt, A. - Guides for Science Teaching. III. Commercial and Other Sponges. Boston : Heath \& Co. 1893.

Potts, Edward. - Contributions toward a Synopsis of the American forms of Fresh-water Sponges, with descriptions of those named by other Authors and from all parts of the World, with 8 plates. Proc. Acad. Nat. Science, Philadelphia, 1587, pp. 158-279.

\section{PROTOZOA}

Bütschli, 0. - Protozoa, Bronn's Kilassen und Ordnungen des Thierreiches. Leipzig u. Heidelberg: C. F. Winter. 1859.

Kent, W. Saville. - A Manual of the Infusoria : including a description of all known flagellate, ciliate, and tentaculiferous Protozoa, British and foreign, and an account of the Organization and Affinities of the Sponges. 2 vols. and vol. of plates. London : D. Bogue. 1880-188:.

Leidy, J. - Fresh-water Rhizopods of North America. Washington : Government Printing Office. 1879.

\section{VERTEBRATES IN GENERAL}

Jordan, D. S. - Manual of the Vertebrates of the Northern United States. 5th Edition. Chicago: McClurg.

Systematic, with keys.

Kingsley, J. S. - Text-book of Vertebrate Zoology. New York: Holt \& Co. 1899.

About equally devoted to Morphology and Classification.

Darwin, C. - The Variation of Animals and Plants under Domestication. 2 vols., 2d edition. New York: D. Appleton \& Co. 1894.

Domestic races of various vertebrates.

Note. - In many States, the Geological Survey or Natural History Survey Reports contain lists of vertebrates found in the State. 


\section{PISCES}

Goode, G. B. - American Fishes. A popular treatise upon the Game and Food Fishes of North America, with especial reference to habits and methods of capture. New York : Standard Book Co. 1888.

Jordan, D. S., and B. W. Evermann. - The Fishes of North and Middle America. Bulletin U. S. National Museum, No. 47. 4 parts. Washington: Gov't Printing Office. 1898. 3136 pages and atlas.

An exceedingly valuable work, full of biological data; with keys to genera and species. Atlas not yet (1899) published.

\section{AMPHIBIA}

Gage, S. H. - Life IIistory of the Vermilion-Spotted Newt (Diemyctylus viridescens Raf.). American Naturalist, Dec., 1891.

Ritter, W. E. - Diemyctylus torosus Esch. The Life History and Habits of the Pacific Coast Newt. Proc. California Acad. of Sciences. 3d series. Zoology. Vol. I., pp. 7:3-11t. 1897.

Wilder, H. H. - Desmognathus fusca (Rafinesque) and Spelerpes bilineatus (Green). American Naturalist, Vol. XXXIII., pp. 231-246. March. 1899.

Kirkland, A. H. - The IIabits, Food, and Economic Value of the American Toad. Hatch Experiment Station, Amherst, Mass., Bull. No. 46. 1897.

Mivart, St. George. - The Common Frog. Nature Series. London : Macmillan \& Co. 1881.

Boulenger, G. A. - The Tailless Batrachians of Europe. London : Ray Society. 1897-1898.

Jordan, E. 0. The IIabits and Development of the Newt. Jour. of Morphology, Vol. VIII., No. 2. 1893.

Sherwood, w. L. - The Frogs and Toads found in the Vicinity of New York. Proceed. Linu. Soc. of New York, No. 10. 1898.

\section{REPTILIA}

Agassiz, L. - Contributions to the Natural IIistory of the United States of America. First Monograph. II. North America Testudi- 
nata ; III. Embryology of the Turtle. Vol. 2. Boston: Little, Brown \& Co. 18.57.

To be obtained from dealers in second-hand books.

Taylor, W. E. - The Box-Tortoises of North America. Proc. U. S. National Museum, Vol. XYII., pp. 573-583. 1895.

\section{BIRDS}

Newton, Alfred, and Hans Gadow. - A Dictionary of Birds. London : Adam \& Charles Black. 1593-1s96.

Coues, Elliott.-- Key to North American Birds. Boston: Estes \& Lanriat. $1896.906 \mathrm{pp}$.

Ridgeway, R. - A Manual of North American Birds. 2d Ed. Philadelphia: J. B. Lippincott Co. 1896.

Chapman, F. M. - Bird Life. A Guide to the Study of our Common Birds. New York: D. Appleton \& Co. 1897.

Parkhurst, H. E.- How to Name the Birds. New York: Charles Scribner's Sons.

Wright, Mabel 0., and E. Coues. - Citizen Bird. With 111 illustrations by L. A. Fuertes. New York: The Macnillan Co. 1598.

Besides these are a score or more good books on American birds, and guides to their study. The foregoing are representative.

\section{MAMMALLA}

Flower, W. H., and Lydekker, R. - An Introduction to the Study of Manmals, living and extinct. London: Adam and Charles Black. 1891.

Lydekker, R. - A Geographical IIistory of Mammals. Cambridge Geographical Series. Cambridge (Eng.), at the University Press. 18s6. [The Macmillan Co., New York. Price 10s. 6rl.]

Mivart, St. George. - The Cat. An Introduction to the Study of Backboned Animals. New York: Scribner's. 1851.

\section{DEVELOPMENT OF THE FROG}

Morgan, T. H. - The Development of the Frog's Egg: An Introduction to Experimental Embryology. New York: The Macmillan Co. 1897. 


\section{APPENDIX III}

\section{SYNOPSIS OF THE ANIMAL KINGDOM}

\section{GROUPS OF ANIMALS ARRANGED APPROXIMATELY IN AN ASCENDING SERIES; WITII REFERENCES TO EVERY FAMILY MENTIONED IN THE MAIN TEXT; AND WITH DEFINITIONS OF THE CLASSES AND ORDERS}

NotE. - Owing to the method employed in the text of proceeding from a type to the allied groups, the systematic relations of the organisms considered are often obscured. This synopsis is intended to make these relations clearer. It can also bo used as a systematic index of the book. Horeover, the student can use it in reviewing his knowledge of the text, and as a key for the determinution of the class in which a specimen falls. The teacher can employ it as a guide to collerting illustrative material; for every family mentioned should, as fur as possible, be illustruted by specimens or good figures.

In the synopsis group-names printed in full-face are phyla; in LARGE CAPITALS, classes; in Small Capitals, orders; in italics, families. Subphyla, subclasses, and suborders are indicated by bracketing. Thus [CIIIATA] is a subclass. Numbers in parentheses refer to pages of the text.

\section{PROTOZOA}

Animals composed of a single cell; or, if of several cells, these are of one kind.

RIIIZOPODA. Protozoa with retractile pseudopodia: A mœba (227).

SPOROZOA. Protozoa without appendages; internal parasites $(\cdot 27)$.

FLAGELLATA. Protozoa without cilia but with one or more flagella $(2 \cdot 25)$. 
INFUSORIA. Protozoa with cilia or sucking tentacles (22.2).

[CILIATA]. Locomotor, with cilia: Holotricha (Paramecium, 224); Heterotricia (224); Peritricha : Vorticella (225).

[SUC'TORIA]. Sessile, with sucking tentacles (225).

\section{COELENTERATA}

Animals of radial structure, whose digestive cavity is lined by the body-wall (205).

\section{[SPONGIARIA]}

Cœlenterata whose body-wall is perforated by incurrent pores (205).

\section{[CNIDARIA]}

Cœelenterata whose body-wall is not perforated by incurrent pores, and which have nettling organs of some sort (205).

HYDROZOA. Cnidaria whose body is composed of more than two rays and contains a simple cavity. IIrDrouedusx, attached Hydrozoa in hydroid stage; medusa simple: Hydroidce (208); Hydrocorallida (208); Tubularida (208); Campanularida (209); Trachomedusce (Zygodactyla, 21:). Siphoxophora, a free swimming colony of Hydrozoa (212).

SCYPIOZOA. Cnidaria with many radii, and with radial partitions in cavity of body (214).

CTENOPHORA. Cnidaria with only two radii, and rows of ciliaplates (219).

\section{SCOLECIDA}

Animals of worm-like form, with bilateral, unsegmented body.

PLATYHELMINTHES. Bilaterally symmetrical, soft-bodied animals, without true segmentation of the body ; flattened in a dorsoventral direction, and having body-cavity filled with a loose meshwork of cells. Turbellaria, free-living flatworms whose body is covered by cilia; alimentary tract with only one opening to the exterior: Planaria (15:3). Trematond, parasitic, without cilia in the adult; the mouth leads into a forked food-canal without anus: I)istomum (153). CestodA, elongated tape-like intestinal parasites, without mouth or food-canal: Tænia (156). Nenertivi, body more or less flattened; food-canal with mouth and anus; a separate protrusible proboscis (158). 
NEMATHELMINTHES. Bilateral, unsegmented, round-worms; usually with alimentary tract, mouth, and anus: Ascaris (151).

ROTIFERA. Small aquatic Scolecida, with ciliated band around mouth, and a special organ for attachment, the foot; wheel-animalcules.

BRYOZOA. Scolecida in which the ciliated band is carried out on a series of tentacles surrounding the mouth; form colonies by budding. Exdoproct A, Bryozoa with head and stalk, and crown of tentacles surrounding both mouth and anus (143). ЕсторкостA, with anus outside tentacular corona (143).

\section{MOLLUSCA 1}

Animals with unsegmented body and without jointed appendages. Usually with a shell and with a muscular organ of locomotion, the foot.

LAMELLIBRANCHIATA. Mollusca with nearly symmetrical body, leaf-like gills, and a shell composed of two valves. Lerlicla (187); Arcidce (184); Mytilida (184); Aviculida (185); Pectinida (186); Ostreidle (187); Unionidce (179); Cycladidce (180); Mactrida (18:); Venerida (18:3); Myidle (182); Solenidle (18:2); Pholadida (181); Teredida (181).

GASTROPODA. Mollusca with head, feelers, and eyes, an unpaired foot, and a shell that is univalve when present. Amphineura, with strict bilateral symmetry, no externally visible gills, and usually a shell composed of eight pieces: Chiton (171). ProsobranchiATA, with gills in front, shelled and operculate: Acmaidce (170); Patellida (170); Fissurellide (170); Naticidce (168); Calyptraida (Crepidula, 169); Littorinicle (167); Muricida (Urosalpinx, 169); Fasciolarïlce (Fulgur, 168). Opisthoвranchíta, with gills behind heart; if shelled, without operculum; Eolidiille (171). Pulmonata, breathing by means of lungs, no operculum : Auriculide (165) ; Limnaidce (166); Limacidce (161); Helicidle (164); Pupidce (165).

CEPHALOPODA. Mollusca with large head, mouth surrounded by a circle of arms, and fumnel-shaped foot. Argonautirle (17.2); Spirulidce (172); Loliginidee (172); Nautilidce (173).

1 This classification, unlike that of the text, follows Cooke in his "Mollusea." 


\section{ECHINODERMATA}

Animals of a prevailingly radial structure, with intestinal wall distinct from body-wall and with calcareous plates in the skin (192).

CRINOIDEA. Sessile Echinodermata, having a cup-shaped body (203).

ASTEROIDEA. Star-shaped Echinodermata, with a furrow along the under side of the arms (193).

OPHIUROIDEA. Star-shaped Echinodermata, with ungrooved arms (198).

ECHINOIDEA. With armless, globular, or cake-shaped body (199).

HOLOTHUROIDEA. Worm-like, with tentacles around mouth $(201)$.

\section{ANNELIDA}

Bilateral, segmented wornıs without jointed legs.

POLYCHETA. Annelida possessing parapodia on one or more segments, and with many bristles on parapodia. Erravtia, freeswimming Polychæta: Autolytus (147), Lepidonotus (147), Nereis (145), Euglycera (147). Sedextaria, Polychæta which live in tubes composed of mud, sand, or lime: Cirratulus (149), Amphitrite (150), Polycirrus (150), Cistenides (151), Clymenella (150), Serpula (151).

OLIGOCH.ETA. Annelida without parapodia and with few seta; living in fresh water or in the ground. Lnicols, aquatic: Nais (137); Dero (137); Tubifex (136). Terricol.E, earth-inhabiting: Allolobophora, Lumbricus (133).

GEPIIYREA. Annelida having sessile habits and consequently without external segmentation in the adult, setæ sometimes present. Phascolosoma (139), Echiurus (139).

HIRUDINEA. Annelida with short rings or none at all and with a ventral sucker; " bloodsuckers." Clepsine (141); Nephelis (140).

\section{ARTHROPODA}

Symmetrical, segmented animals, with jointed appendages.

CRLSTACEA. Typically, aquatic and gill-bearing Arthropoda. Two pairs of antennæ, except in Gigantostraca. 
[ENTOMOSTRACA]. Crustacea with varied number of pairs of appendages; usually of small size. Braxchiopoda, mandibles without palps, numerous legs (127). Trilobita, fossil (130). Clanocera, mandibles palpless, few legs (126). Ostracoda, palp on mandible, only two pairs of legs (127). CoPEPODA, elongated Crustacea, with only one pair of maxillæ; females with external ovisacs (127). CirripeniA, attached Crustacea (barnacles, 129).

[MALACOSTRACA]. Crustacea with nineteen pairs of appendages. Amphipoda (112). Isopoda (112). Cumacea (112). Stomatopoda (111). Podopthalmata: [Macrura], large-tailed Podopthalmata : Caridida (104); Astacida (97); Thalassinida (105); Paguride (105); Hippirle (107). [Bracirýra], crabs: Oxyrhyncha (107); Cyclometopa (108); Catometopa (110).

[GIGANTOSTRACA]. Crustacea with five pairs of appendages on cephalo-thorax, abdomen without feet; body ends in a long telson, Limulus (114).

ARACHNOIDEA. Air-breathing Arthropoda without antennæ. Acarina, mites (95). Prcnogonida, sea-spiders (95). Arenerna, spiders: Saltigrarla (90); Citigratre (89); Laterigradre (89); Tubitelarice (88); Retitelarice (87); Orbitelaria (86); Territelarice (85)). Phalangina, harvest-men (93). Artirogastra, scorpions (92).

TRACHEATA. Air-breathing Arthropoda, with one pair of antennæ.

[IIRIAPODA]. Tracheata with distinct head and abdomen, all the segments of the abdomen bearing appendages. C'mLOpod, centipedes: Scutigeridce (75); Litholiedce (75); Scolopentrida (76); Geophilide (76). DIPlOPODA, millipedes: Julida (76); Polyrlesmidre (77). Sympiyla : Scolopendrella (78), Pauropus (77).

[HEXAPODA]. Tracheata with only three pairs of legs, confined to thorax. Orthoptera, Hexapoda with two pairs of wings, masticating mouth-parts, incomplete metamorphosis: Forficulidce (9); Blattida (8); Mantida (8); Phasmidce (7) ; Acridida (2); Locustida (5); Grillidre (4). Neuroptera, Hexapoda with two pairs of netveined wings; biting month-parts, metamorphosis complete or incomplete: Odonata (9); Ephemerida (10); Termitidce (11); Sialidre. Corydalis (12). Hmmprera, Hexapoda with two pairs of wings or none, sucking and piercing mouth-parts, incomplete metamorphosis. [Heteroptera], upper wings leathery: Reduviidce (12). [Homop- 
TERA], wings alike: Cicada (14); [here, also, plant lice and animal lice]. Diptera : Hexapoda with (typically) one pair wings; piercing and sucking mouth-parts; complete metamorphosis. [APHANIPtera], fleas (71). [Pupipara] : Hippoboscidce (71). [Brachycera], true flies: MLuscidce (62); Estrida (65); Syrphidce (66); Asilida (66); Tabanidce (66); Simuliidce (67). [Nematocera], gnats: Cecidomyide (67); Culicidce (69); Tipulidee (70). Coleoptera, Hexapoda whose fore wings are modified into wing covers; hind wings folded when not in use: Coccinellide (55); Chrysomelidce (54); Cerambycidce (54); Curculionidce (53); Scolytidce (53); Tenebrionida (52); Lampyrida (51); Elaterida (51); Buprestidce (51); Lamellicornia (49); Lucanida (49); Dermestidce (49); Silphida (48); Staphylinida (47); Hydrophilidae (47); Gyrinidae (46); Dytiscidae (46); Carabide (45); Cicindelidce (45). Lepidoptera, Hexapoda with two pairs of scale-covered wings, sucking mouth-parts, complete metamorphosis: Tineidce (29); Tortricidae (29); Pyralida (29); Geometridce (28); Noctuidce $(19,28)$; Bombycidce (26); Arctiidce (24); Xylotropidee (23); Sphingidle (22); Papilionidae (21). Hymenoptera, Hexapoda with two pairs of membranous wings; biting and licking mouthparts; complete inetamorphosis: [РнуторнAGA], plant-eating (38). [Entomophaga] insect parasites (38). [Aculeata] stinging: Formicidae (34); Fossoria (34); Vespidae (33); A pidae (31).

\section{CHORDATA}

Animals which possess, at some time of life, throat slits and a dorsal supporting rod or chorla.

\section{[HEMICHORDA]}

Animals of worm-like form, showing gill-slits like fishes. Balanoglossus (2.51).

\section{[TUNICATA]}

Chordata which are either attached or form colonies or both (251).

\section{[VERTEBRATA-ACRANIA]}

Free-living fish-like Chordata, but without skull, paired fins, or heart, and with colorless blood. Amphioxus (251). 


\section{[VERTEBRATA-CRANIATA]}

Free-living Chordata, with skull and complex brain, and red blood.

CYCLOSTOMI. Eel-like vertebrates without lower jaw, and living a parasitic life (245).

PISCES. Aquatic vertebrates with gills, without lungs, and with paired fins instead of legs. SELACHII, skeleton cartilaginous, no operculum, spiral valve (246). GAxorder, skeleton either cartilaginous or bony, spiral valve and operculum present: sturgeons (247); spoon-bill (247); garpike (248); bowfin (248). Teleostei, skeleton bony, no spiral valve. [ACANTHOPTERI], dorsal, anal, and ventral fins with spines, pharyngeal bones distinct : perches (235); darters (234); sunfishes (235); toadfishes (236); sculpins (236); silversides (296); sticklebacks (238). [Pharyngognathi] fins with spines, pharyngeal bones united. [ANACANTHINI], fins without spines, ventral fins far forward: codfishes (239); flatfishes (240). [PнYsostomi], fins without spines, ventral fin placed far backward: smelts (230); trouts (233); whitefishes (234); catfishes (239); suckers (241); minnows (242); pikes (242); shads (243); eels (244). [Рlectogsatur], intermaxillaries and maxillaries united. [LOPновRANсHII], body covered with bony plates: pipefishes (244).

AMIPHIBIA (= Batrachia). Vertebrata having no lateral fins (but instead, legs); functional external gills during a part of their life. Urodela. Amphibia which retain the tail permanently: Sirenidce (255); Proteidce (257); Amphiumidce (257); Cryptobranchidae (257); Amblystomidce (257); Plethodontidce (259); Desmognathidce (259). Pleurodelide (254). Axura, Amphibia which lose the tail in the adult stage: Pipidae (263); Hylidae (263); Bufonidce (265); Ranidce (265). Grmnophrova, Amphibia which have no limbs nor tails; body worm-like.

REPTILIA. Vertebrata which breathe exclusively by lungs and whose skin contains lorny epidermal scales or bony plates. Ch ELonia, trunk enclosed in a bony case: Chelonidce (274); Trionychida (274); Testudinidoe (275). SAURIA, shoulder-girdle and sternum present, usually with eyelids : Chamceleonidce (272); Iguanida (268); Varanidce (269); Lacertida (270); Helodermidae (270); Anguida (271). OpHIDIA, footless scaled reptiles with no shoulder-girdle, sternum, nor 
movable eyelids: Colulrida (276); Elapida (277); Crotalida (277). Crocodilina, large reptiles, with longitudinal vent (279).

AVES. Feathered Vertebrates. Cursones, Aves with keelless sternum (307). Natatores, swimming birds (305). Grallatores, wading birds (305). Gallinacer, large ground birds with strong. perching feet and flat nails (304). Columbix.s, short cloven feet and compressed nails (303). ScAxsores, birds with powerful beak and feet adapted for climbing (299). CYPselomopinz, cereless birds, with scaleless metatarsus (301). Passeres, birds whose metatarsus is covered with laminæ or scales, usually with singing apparatus: Tyrannirla (295); Alaudida (295); Corvila (294); Icteride (293) ; Fringitlidce (284); Tanagrida (292); Hirudimida (292); Ampelida (291); Laniidce (289); Vireonida (285); Mniotilide (287); Troglodytida (287); Certhiidce (286); Parida (286); Sylevida (285): Turdidre (285). RAptores, birds with cere, hooked bill, and strong, hooked claws (29S). Psittaci, birds with cere, high, hooked beak, and fleshy tongue (parrots, 297).

MAMMALIA. Vertebrates which nourish the young by means of milk, and are usually covered with hair. Mosotremata, oviparous nammals (321). Marsvidat provided with a marsupium (322). EnextatA, teeth either absent, rudimentary, or without enamel (:32:3). Certacea, marine hairless mammals, hind limbs absent (324). InguLATA, hoofed mammals: even-toed ungulates (326); odd-toed ungulates (327); elephants (327). Ronfxtia, canines absent, incisors grow continuously through life (320). CArsivora, canines large (328). Ixsectivora, small, terrestrial, carnivorous mammals, with small canines (327). CHerroptera, mammals with flying membrane between elongated digits (329). Primates, with hands (329). 


\section{GLOSSARY}

abdomen, in Arthropoda, the hindermost of the three divisions of the body, 59.

aboral, the side of the body opposite to the mouth, 193.

alveolus, a depression, e.g. the socket of a tooth, 280 .

angulated, forming an angle or sharp corner; opposed to rounded, 249.

antenna, horn or feeler, one of the anterior tactile appendages of Arthropoda and Mollusea, 4, 46.

anterior, situated at the front end of the body.

anus, the posterior opening of the food canal.

corta, the main blood-vessel coming from the heart.

articular, relating to a joint; the hinge bone of the lower jaw of fishes, 232.

atripore, the external opening of the atrium, 249.

atrium, or vestibule, a chamber placed either in front of the mouth or, in Chordata, around the gill-slits.

auditory clubs, club-shaped sense organs on the margin of the bell of jelly-fishes, 221.

basihyal, a bone found in tishes, forming the base of the U-shaped arch which supports the tongue, 232 .

bifid, two-parted.

bivalve, having two valves or shells, $131,178$. blastula, a stage in the early development of the egg when it forms a hollow sphere, 193.

branchial, relating to the gills.

branchiate, bearing gills, 131.

branchiostegal rays, the bony rays supporting the membrane below the bones of the operculum in fishes, 232.

buccul, pertaining to the mouth cavity or cheeks, 59, 143.

byssus, a tuft of tough threads spun from the foot of bivalves and used for attachment to foreign bodies, 180 .

calcareous, consisting of a calcium or lime compound.

calcified, rendered calcareous by deposition of salts of lime.

callus, a soft substance secreted over

a harder bony material, 175.

calyx, cup.

cambered, concave on the under side, $4:$.

canine, or canine tootl, the pointed tooth situated immediately behind the front cutting teeth, 331 .

capsule, a little sac containing a fluid. carapace, the thick shell or skin covering the back of Crustacea or Chelonia, 103, 280.

cardinal, belonging to the hinge, as the teeth of lamellibranch shells, 188.

curnivorous, flesh-eating. 
cephalothorax, united head and thorax. cere, a waxy sheath at the base of the bill of certain birds, 315 .

chelicer $a$, the first pair of mouth appendages in the Arachnida, 80.

cilia, microscopic, vibratile processes of certain cells.

cirrus, a filamentous appendage of the

parapodia of Annelida, 159.

cleavage, the multiplication of cells at

the beginning of the development of the egg, 193, 336.

clitellum, a thickened glandular ring

sometimes found in the earthworm. $\operatorname{cox} a$, that joint of an Arthropod leg

which is nearest the trunk, 59 .

culmen, the upper ridge of a bird's bill. cuticula, the tough secreted "skin"

covering arthropods, hydroids, and other animals.

dentary, a bone of the lower jaw of fishes which carries the teeth.

dextral, right, applied to right-handed shells, 166.

diaphragm, a dividing membrane, 119 .

elytron, the horny upper wings of beetles, 59 .

enamel, the hard covering of teeth and some fish scales, 248.

encyst, the act of secreting a cyst or vesicle, 227 .

enteric, pertaining to the enteron or food canal.

epidermis, the outermost skin of vertebrates; also a superficial horny secretion over the shells of mollusks, 175.

epimeron, a lateral piece behind the episternum of insects, 59 .

epiotic, one of the bones surrounding the inner ear in the lower vertebrates, 232. episternum, a piece just lateral to the sternum in the thorax of insects, 59 . epistome, in beetles, a piece above the mouth, 59 .

facetted, composed of numerous small eyes, making up a compound eye, 78 . femur, thigh of insects, 59 .

fertilization, the union of two germcells, 335 .

flagellum, a microscopic, lash-like, vibrating thread of certain Infusoria, 226.

foliaceous, leaf-like.

frontal, applied to a bone of the skull lying between the orbits, 232 .

gastrolith, a calcareous nodule occurring in the stomach of the higher Crustacea, 103.

gastrula, a stage in development of the egg just after the digestive cavity has been formed, 193.

gastrulation, the process of forming the gastrula, 336 .

gonad, a germ-producing gland, 221. gonophore, a sexual zooid, generally reduced to an exclusively reproductive function, 212.

gula, the throat plate on under part of the head of insects, 59 .

hrmal, relating to the blood system.

hirsute, hairy, shaggy, 42.

hydranth, the "heads" or zooids of a hydroid stock, 210.

hyomandibular, a bone which, in fishes, conmects the lower jaw with the skull, 232.

imago, the adult of an insect.

intermaxillary, the same as premaxillary. 
interopercular, the posterio-inferior opercular bone of fishes, 232.

jugal, the cheek-bone, 232.

keel, a ridge on the breast-bone of birds for attachment of flying muscles, 314 .

labial, pertaining to the labium.

labium, the under lip of insects, 59 .

labrum, the upper lip of insects, 59 .

lamella, a leaf or plate, 58 .

lamina, a thin plate.

lancet cell, a lancet-shaped cell on the

hinder margin of the fore wing of Phytophaga, 43.

larva, an immature but active stage of development, 10.

ligula, the front edge of the labium, 59. liver area, in crabs, the anterio-lateral

area of the carapace in front of the gill region, 123.

lumen, the central space of a tube.

lunule, a crescentic or heart-shaped area in front of the beak of some bivalve shells, 190 .

madreporic plate, in echinoderms, a perforated plate admitting water to the system of water tubes, 204 .

mandible, in arthropods, the most anterior of mouth parts, 59 ; in vertebrates, the bone of the lower jaw.

mantle, the fold of the skin of a mol-

lusk, or cirriped, which secretes the shell, 160 .

manubrium, in jelly-fishes, the mouth stalk, corresponding in position to the clapper of a bell, 211 .

marsupium, a pouch, in Marsupalia, on the ventral side of the body, 331 . maxilla, in Arthropoda, one of the mouth parts immediately following the mandible, 59 ; in vertebrates, a tooth-bearing bone of the upper jaw. maxillary, relating to the maxilla.

maxilliped, one of the foot-like mouth parts which in arthropods follow the maxillæ.

mentum, the front plate of the labium in insects, 59.

mesopterygoid, one of the bones forming the base of the skull in bony fishes, 232 .

mesothorax, the middle segment of the thorax, 59.

metamerism, the fundamental repetition of parts of the body along the longitudinal axis, as in earthworms 139.

metapleure, in Amphioxus, a lateroventral fin, 249.

metapterygoid, one of the bones forming the base of the skull in bony fishes and lying behind the mesopterygoid, 232.

metasternum, the ventral plate of the last thoracic segment of insects, 59 . metatarsus, in birds, the foot proper, 315.

metathorax, in insects, the third or last segment of the thorax, 59 . morula, an early stage of egg development when the germ consists of a nearly solid mass of cells, 336 .

moult, to change the skin, as in insects.

myocomma, the thin layer separating two muscle plates in vertebrates, 246 . myomere, a muscle plate, 246.

nasal, belonging to or forming the nose, as nasal bones.

neural, pertaining to the nervous system. 
neural groove, the groove which marks in the vertebrate embryo the developing central nervous system, 261. nodulous, covered with nodules or little lumps, 175.

notochord, the axial supporting rod of chordates, 249.

cesophayus, the gullet, the part of the food canal leading to the stomach.

operculum, in gastropods, the horny plate which closes the aperture; in fishes, the gill-cover, 232 .

oviduct, the duct which carries eggs from the body, 120 .

oviposit, to lay eggs, as in insects, 53.

palatine, of the palate or roof of the mouth; name of a pair of bones forming the palate, 232 .

pallial line, streak formed in a bivalve shell by the margin of the attached mantle.

pullial sinus, an incurving of the pal-

lial line to receive the siphon in certain lamellibranchs.

palp, a secondary sensory outgrowth of a mouth part of an insect, 59 .

puragloss , a pair of small appendages of the under lip of insects, 59 .

parapodia, the paddling feet of polychætes, 147.

parasitic, living on the nutritive juices elaborated by another organism.

parasphenoid, a bone occupying the base of the skull, 267 .

parietal, bones of the middle upper part of the brain case, 232 . pectinate, comb-like.

pectoral, of the chest; the chest limbs of fishes, 246.

pedicellarix, minute forceps-like organs found on some echinoderms, 194. pelvic fin, or ventral fin, the hinder paired appendages of fishes, 246. penultimate, next to the last.

percoid, like a perch.

perisarc, the outer tough skin of hydroids, 211.

pharyngeal, relating to the pharynx or throat, 252 .

polyp, the sessile form of cœlenterates. posterior, situated behind.

premaxilla, the most anterior toothbearing bone of the upper jaw of fishes, 232.

preopercular, the most anterior of the bones of the operculum of fishes, 232.

primuries, the large feathers on the distal joint of a bird's wing, 315 .

proboscis, in insects, a sucking tube connecting with the mouth, 61 .

prosternum, the most anterior of the ventral plates in the thorax of insects, 59.

prostomium, in worms, a lobe of the body projecting above and in front of the mouth.

prothorax, the most anterior of the segments of the thorax of insects, 59.

pseudobranch, in fishes, a rudimentary gill in front of the first throat slit, 231.

pseudopodia, retractile processes in Protozoa.

pterotic, one of the ear bones of fishes, 232.

pterygoid, a bone of the base of the cranium, 232.

pupa, a stage in insect development preceding the imago, 11.

quadrate, a bone lying between the skull and the hinge of the lower jaw in fishes, 232 . 
radii, lines proceeding from a common centre like the spokes of a wheel, 86.

ramus, a branch or projecting process, 131.

rictus, the corners of the mouth in birds, 315 .

rostrum, beak, the frontal process of crustaceans.

scunsorial, capable of climbing, 315 . scutellute, composed of plates, 31\%. scutellum, the third of the four pieces composing the upper part of a thoracic segment of an insect, 59 .

septc, the radial calcareous plates of a coral, 215 .

sinistral, left.

siphon, the drawn-out edges of the mantle folds of lamellibranchs, 18:3; the strand penetrating the chambers of the Nautilus shell, also called siphuncle, 173.

sputulute, shaped like a spatula, or a paddle.

sphenotic, one of the bones forming the ear capsule of fishes, 232.

spimnerets, the tubercles through openings in which the spider thread is spun, 84 .

spiracle, one of the openings to the air-tubes of insects, 59 .

spurious, not genuine.

squame, a scale in decapods attached to the antenna, 124 .

sternum, in vertebrates, the breastbone, 280 ; in insects, the ventral part of a somite, 59 .

stigmuta, spiracles. stock, colony, 207. stolon. a rumer from which zooids bud, 220 .

subopercular, the lowermost bone of the operculum in fishes, 2:32.

suborbital, a bone in fishes, lying below the eye, 232 .

supraethmeoid, a bone of the nose in fishes, 232.

supruoccipitul, a bone forming the upper part of the back of the head. suture, a seam or structural line, 70 . symplectic, a bone uniting the quadrate to the bones suspending the lower jaw, 232 .

tursus, the jointed foot of an arthropod leg, 59.

telsom, the tail-piece of a crustacean, 116.

tentacle, a projecting tactile organ.

thoracic, pertaining to the thorax or chest.

tibiu, the joint of an insect's leg next above the tarsus, 59 .

trachea, one of the respiratory tubes of insects, 64 .

tirchanter, a joint of the insect leg lying distal to the coxa, 59 .

umbilicus, a depression in the centre of the base of many spiral shells, 175.

umbones, a protuberance just above the hinge of a bivalve shell, 188.

velum, a circular membrane extending like a shelf from the margin of the jelly-fish bell, 211 .

viviparous, giving birth to well-developed progeny, 331 . 



\section{INDEX}

\begin{tabular}{|c|c|}
\hline 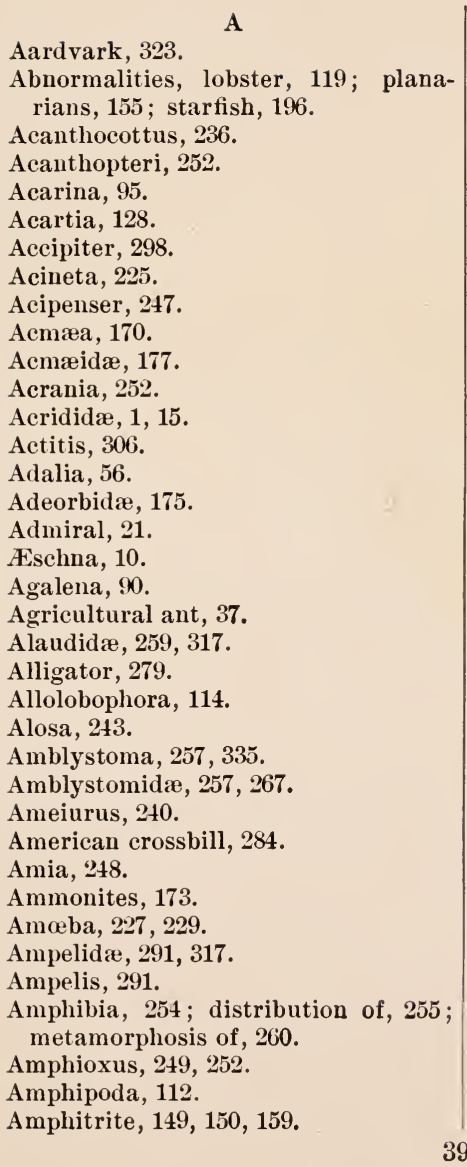 & 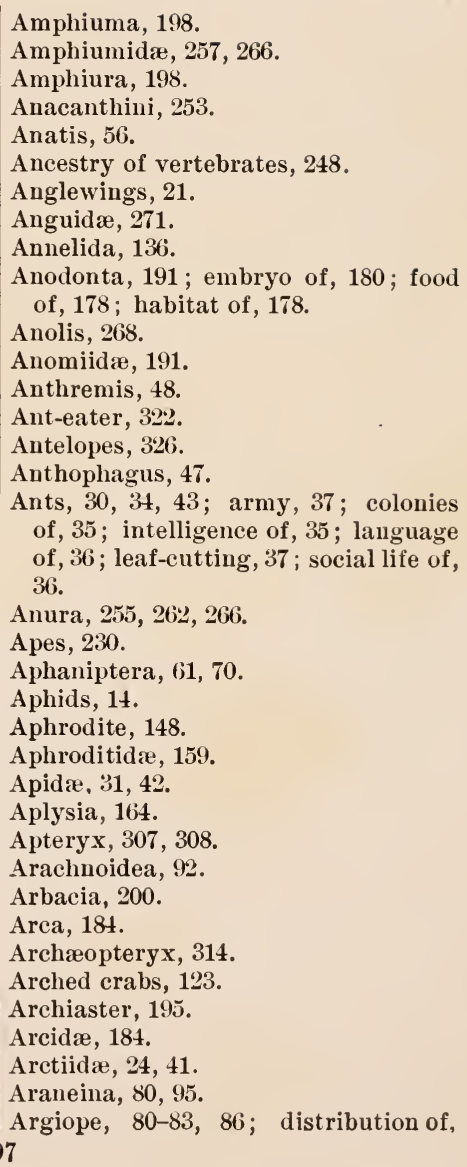 \\
\hline
\end{tabular}


83; food of, s2; spinning habits of, 8.2.

Argonauta, 172.

Arion, 162.

Ark shells, 162.

Armadillo, 32:3.

Army ants, 37.

A rmy worm, 28.

Arthrogaster, (12.

Ascaris, 151.

Asilidæ, 66 .

Asiphonata, 178 .

Asp, 277.

Asparagus beetle, 56 .

Assassin bug, 1‥

Astacidæ, 124.

Astacus, 97-99, 113.

Astartidæe, 190.

Asterias, 197 ; distribution of, 192, 197.

Asteriodea, 197, 203.

Astrangia, 216.

Atoll, 217.

Attus, 91.

Auriculidre, 161, 166, 176.

Autolytus, 147, $15 \%$.

Aviculidæe, 185 .

Axolotl, 258, 260.

\section{B}

Baboon, 330 .

Badger, 328.

Balaninus, 53.

Balanoglossus, 250, 251 .

Balanus, 129.

Bald eagle, 298.

Baltimore oriole, 293.

Banded horse-fly, 66 .

Bark-borer, 53.

Barnacles, 102; habits of, 129.

Barn-swallow, 292.

Barrier reef, 217.

Bat, 329; food of, 329.

Bat rachia, 254 .

Batrachus, 236 .

Bears, 328.

Beaver, 310 .

Beaver parasite, $5 t i$.

Bee-moth, 29.

Bees, $30,31,42$; swarming, 32.
Beetle, 44; development of, 44 ; economic importance of, 57 ; food of, 56 ; larval habits of, 45 ; number of species of, 45 .

Bell-hydroid, 209.

Belted kingfisher, 300 .

Birds, 281; economic importance of, 311 ; extinet, 313 ; flight of, 310 ; protection of, 312; migration of, 309; teeth of, 314.

Bird's-nest, edible, 303.

Bittern, 305.

Black-fly, 66.

Black lobster, 103.

Black moceasin, 279.

Black snake, 276 .

Blattidae, 8,14 .

Blister-beetle, 57. 61 .

Blow-fly, 61.

Blue, 22.

Bluebird, 285.

Bluejay, 29\%.

Boa, 276.

Bobolink, 294.

Boll-worm, 2ע.

Bombus, 31.

Bombycida, $24,42$.

Bombyx, 24.

Bonasa, 304.

Bony fishes, 252.

Bosminida, 1:31.

Bot-flies, 64, 72.

Botryllus, 250 .

Bougainvillea, 211.

Bowfin, 248.

Box tortoise, 275.

Brachiopoda, 127, 130.

Brachycera, 61, (j;).

Brachyura, 107.

Branchipus, 1:27, 130.

Brittle-stars, 198.

Brook sucker, 241 .

Brown creeper, 2888 .

Bruchida, 57.

Bryozoa, 141, 217.

Buccinidae, 175.

Buck-beetles, 54 .

Budding, 217.

Buffalo gnat, 6t;, 72. 
Bufo, 264.

Bufonidae, 265.

Bugula, 142.

Bull-frog, 266.

Bull-head, 2\$1.

Bullida, 174 .

Bumblebee, 31 .

Buprestidæ, 51, 60.

Buprestis, 51 .

Buthus, 93.

Butterflies, 41 ; broods of, 17 ; habits and food of, 16; mimicry of, 18-21; polymorphism of, 17 ; protective resemblance of, 18-21.

\section{C}

Cabbage butterfly, 18 .

Callianassa, 105.

Callinectes, 109.

Calosoma, 46.

Calyptraida, 177.

Cambaroides, 99.

Cambarus, 99, 100, $11:$.

Camels, 326.

Campanularian hydroids, 210.

Campanularidre, 209, 2:21.

Camponotus, 35.

Canada grouse, 304 .

Cancer, 114.

Carabidae, 45-46, 60.

Carchesium, 224; food of, 225.

Cardiidæe, 190.

Cardinal grosbeak, 285.

Caridida, 124, 180.

Carolina paroquet, 297 .

Carnivora, 328, 331.

Carpenter ant, 35.

Carrion-beetles, 48, 57, 60 .

Carrion-fly, 73.

Case-bearers, 29.

Cassowary, 307.

Catfishes, 239, 253; range of, 239-240.

Catocala, 19, 28.

Catometopa, 12:3.

Caudina, 201, 20:3.

Caviare, $2+7$.

Cecidomyidre, $66,68$.

Cedar-bird, 292.

Cedar waxwing, 291.
Centipedes, 74 .

Centrurus, 93.

Cephalopoda, 171.

Ceratodus, 249.

Cerambycida, 54, 56, 61 .

Cerebratulus, 158 .

Cerithia, 288.

Certhiidre, 286, 316 .

Cestoda, 386.

Cetacea, 324, 331.

Centhophilus, 6 .

Ceryle, 300.

Chameleo, 272.

Chameleon, 272 .

Cheetah, 328.

Cheiroptera, 329, 3:31.

Chelidon, 392.

Chelonia, 273, 280.

Chelonidre, 274 .

Chestuut-sided warbler, $28 \%$.

Chewink, 28.).

Chigger, 9.).

Chigoe, 71.

Chilopoda, 74 ; food of, 74 .

Chimuey-swift, 302 : nest of, 302.

Chimpanzee, 330.

Chipping-sparrow, 2.i5.

Chiton, 171.

Chlorops, 72.

Cholcepus, 324.

Chordata, 388.

Chrysomelidæ, 57, 61 .

Chrysops, 66.

Cicada, 13: pupal case of, 13 .

Cicindela, 45.

Cicindelidxe, 45.

Ciliata, 229.

Ciona, 250.

Cirratulidae, 159.

Cirratulus, 149, 159.

Cirripedia, 131.

Cistenides, tube of, 150 .

Citheronia, 25-26; larva of, 25.

Citigradre, 89,96 .

Civet-cats, 328.

Cladocera, 127, 131.

Clam, 178.

Claws, abnormal, of lobster, 120.

Clepsine, 140-141. 
Click-beetle, 61 .

Clisiocampa, 26, 27.

Clothes-moths, 29-30.

Clymenella, 150-159.

Clypeaster, 201.

Cnidaria, 205; fresh-water, 207.

Cobra, 277.

Cobweb spiders, 80 .

Coccinellidæ, 55, 61.

Cockatoos, 297.

Cockroaches, 8, 14.

Codfishes, 253; habitat of, 239.

Coelenterata, form of, 205.

Colaptes, 301 .

Coleoptera, key to families, 58-61; terminology, 59 .

Colonies, of ants, 35 ; formation of, in Cnidaria, 217-218.

Columba, 304.

Columbellidse, 176 .

Columbidæ, 303.

Columbinæ, 314 .

Columbridæe, 276.

Condor, 298, 299.

Congo suake, 256 ; liabitat of, 257 .

Conurus, 297.

Cooper's hawk, 299.

Copepoda, 127, 131.

Copperhead, 279.

Copris, 50 .

Coral cup of Manicina, 216.

Coral, polyps, 215-216 ; reefs, 216217.

Coregonus, 233.

Cordylophora, 207-208.

Corvidre, 294, 316.

Cotton-worm, 28.

Cow-bird, 293.

Crab's eyes, 104 .

Crab spider, 89, 90, 96.

Crane-flies, 68-69, 73.

Cranes, 305.

Craspedosomidæ, 79 .

Crassatellidæ, 190.

Cray fish, 97, 122; development of, 117 ; edible, 113; food of, 98; moulting of, 103, subfamilies of, 98-99.

Creepers, 286.

Crepidula, 169-170, 177.
Cribrella, 196-198.

Crickets, 4-5, 15 .

Cricket-grasshopper, 6 .

Crinoidea, 203.

Crocodile, 279.

Crocodilina, 279-280.

Crossbills, 285.

Crotalidæ, 277-278.

Croton bug, 8.

Crow, 294.

Crow-blackbird, 293.

Crustacea, 97, 104, 125.

Cryptobranchidæ, 257, 266.

Cryptobranchus, 258.

Ctenophora, 219-220.

Cuckoos, 299; laying habit of, 300 .

Culex, 68.

Culicidæ, 68.

Cumacea, 122.

Curculionidæ, 53, 61 .

Cursores, 306, 315 .

Cuttlefishes, 172.

Cyanocitta, 295.

Cycladidæ, 180, 191.

Cyclas, 191; habitat of, 180 ; distribution of, 180-181.

Cyclometopa, 123.

Cyclostomi, 252, liabits of, 245 ; parasitic on fishes, 245-246.

Cyclops, 127-128.

Cyllene, 54-55.

Cypselomorphæ, 301, 315.

Daddy-long-legs, 93.

Daphnia, 97, 125; food of, 126; effect of temperature on, 127.

Daplunidæ, 131.

Darcus, 49.

Darters, 234, 252 ; habitat of, 234.

Decapoda, economic importance of, 111 ; eyestalks of, 121.

Deer, 326.

Degenerate flies, $7 \phi$.

Dendroctonus, 53.

Dermestidæ, $48,49,61$.

Dero, 137, 144.

Desmognathidie, 259, 267. 
Desmognathus, color of, 259 ; habitat of, 260 .

Development, of beetle, 44 ; crayfish, 117 ; edentates, 333 ; effect of heat on, 333; effect of light on, 333 ; of egg, 115; frog's egg, 332 ; fly, 62 ; general laws of, 335 ; grasshopper, 3-4; lobster, 115-117 ; Spelerpes, 261262 ; starfish, 193-194; Urodela, 261.

Diapheromera, 7 .

Didelphys, 323 .

Diemyetylus, 267 ; food of, $25 t$; habitat of, 254 ; life history of, 254-255.

Digger wasp, 34, 43.

Diplocardia, 143.

Diplopoda, 74.

Dipnoi, 248, 252.

Diptera, 61, 63, 72; injurious to man, 71 ; scavengers, $7 \%$; short-horned, 63 ; source of disease, 71.

Discontinuous genera, 99-100.

Distomum, 155.

Divers, 60,306 .

Division of labor in Cnidaria, 219; physiological, 120.

Dodo, extermination of, 314 .

Dogs, 328.

Dogfish, 246.

Dolphins, 324 .

Doryphora, 55 .

Downy woodpecker, 301 .

Dragon-fly, 9-10.

Duckbill, 322.

Duck-bill eatfish, 247.

Dytiscidæ, $46,56,60$.

Dytiscus, 47, 138.

Eagles, 298.

\section{E}

Earwigs, 9.

Earthworm, 132-134; economics of. 135; food of, 134; habits of, 132 ; regeneration of, 134; relationships of, 132 ; resistance of, 134 .

Echidna, 322.

Echinarachnius, 201.

Echinoidea, 322.

Echinoids, 204.

Echiurus, 139.
Economic importance, of beetles, 57; birds, 311; decapods, 111; eartlworms, 135 ; parasitic worms, 158 ; protozoa, 228 ; slugs, 162 ; starfish, 193 ; smelt, 230.

Ectopistes, 304.

Ectoprocta, 143.

Edentata, 323, 331.

Edentates, discontinuity of, 323.

Edible, birds' nests, 303; Carididæ, 114; crabs, 108-109, 113; crayfish, 113 ; lobsters, 113.

Eels, 253; description, distribution, reproduction, 244.

Egg, fertilization, 336 ; masses of tent caterpillar, 26 ; nauplius, 115.

Egrets, extermination of, 305 .

Elapidæ, 277.

Elaps, 277.

Elateridæ, 51, 61.

Elephants, 327.

Endoprocta, 143.

Enemies of lobster, 102.

English sparrow, 281; food of, 282 ; spread of, in America, 281-282.

Engraver beetles, 61 .

Ensis, 182.

Entomophaga, 43.

Entomostraca, 97, 125 .

Eolis, 171.

Ephemeridæ, 10.

Epiera, 80 ; web, 87.

Erycinidæ, 190.

Euglena, 225-226, 229.

Euglycera, 146, 159 .

Eunicidæ, 159.

Eupagurus, 106.

Eupomatis, 235.

Eutænia, 276.

Even-toed ungulates, 326.

Exotic species, increase of, 283.

Extinet birds, 313 .

Eyestalks of decapods, 121.

Faleons, 298.

F

Fasciolariidæ, 175, 177.

Felis, 328.

Fiddler crabs, 110, 123. 
Fireflies, 51-52, 58, 60.

Fishes, 230.

Fissurella, 170.

Fissurellidæe, 177.

Flagellata, 225, 229.

I'latishes, 239-240, 253.

Flatworms, 153.

Fleas, 61, 70 .

Flicker, 301.

Flies, 61 ; degenerate, 70 ; development of, 62 ; food of, 62 ; plant-infesting, 72 ; mimiery in, 65 ; parasites of, 63 ; parasitic, 70 ; trachea of, 63 .

Flight of birds, 310-311.

Flycatchers, 295.

Food of, beetles, 56 ; butterflies, 16 ; crayfish, 98 ; earthworm, 134; fly, 62; hydra, 207; mouse, 319 ; English sparrow, 282; startish, 193; whale, 325.

Forficulidx, 9.

Formicidæ, 3t-35, 43.

Fossil, birds, 314; lizards, 272 ; man, 331.

Fossoria, 34, 43.

Fowls, origin of, 305 .

Fox-sparrow, 285.

Fresh-water clam, 178.

Fresh-water Cnidaria, 207.

Fresh-water jelly-fishes, 208.

Fringillida, 284, 317.

Fringing reefs, 217.

Fritillaries, 22.

Frog, development of, 333 ; postembryonic development of, 334 .

Frog's egg, development of, 332; healing of, 334 ; regeneration of, 334 ; size of, 332 .

Fulgur, 168, 169, 175.

Fundulus, 242.

Gadus, 239.

\section{G}

Ganoidei, 247-252.

Ganoids, 252.

Garpike, 248.

Garter snake, 276.

Gasterosteus, 237-238.

Gastropoda, 160, 161.
Gall-gnats, 66, 72.

Gall-tlies, 31 .

Gall-producing Hymenoptera, 43.

Gall-wasps, 31, 38-39.

Galls on plants, 67 .

Galley-worm, 76.

Gallinacei, 304, 314.

Gallus, 305.

Gebia, 105.

Geese, 306.

Gelasimus, 110-111.

Genera, discontinuous, 99-100.

General laws of development, 335.

Geometridæ, 28, 42.

Geomys, 320.

Geophilus, 76.

Geothlypis, 289.

Gephyrea, 138-139, 141.

Germ theory of Infusoria, 223.

Gibbons, 330.

Gila monster, 270-271.

Giraffes, 326.

Glossina, 65 .

Glow-worm, 271.

Glyceridæ, 159.

Gnats, 61.

Goat-suckers, 301, 303.

Golden-crowned kinglet, 287.

Gopher, 320.

Gorilla, 330.

Grallatores, 305, 314 .

Grapta, 21.

Grasshopper, 1-4 ; development of, 3-4.

Grass spiders, 90 .

Gray-veined white, 18.

Great horned owl, 299.

Great northern shrike, 290.

Green frog, 266 .

Grillidxe, 4-5, 15 .

Grillus, 5.

Ground-beetles, 45-46.

Grouse, 304 .

Gryllotalpa, 5.

Guinea fowl, 304 .

Gulls, 306.

Gymnophiona, 255, 266, 389.

Gypsy moth, 28.

Gyrinida, 46,60 . 
$\mathrm{H}$

Habitat, of Anodonta, 178; butterflies, 16 ; Daphnia, 126 ; earthworns, 132; Hydra, 205; slug, 161; Unio, 17s.

Habits, of Acrididae, 1; mouse, 319; rat, 319.

Hadrosaurus, 273.

Hair streaks, 22.

Hairy ant-eater, 323.

Hairy woodpecker, 301.

Halistemma, 213 .

Hard-shelled clams, 190.

Hares, 3:21.

Hawkbill-turtles, 274 .

Hawk-motlis, 22, 41 .

Hawks, 298.

Heating of frog's egg, 334 .

Heat, effect on development, 333.

Helicidae, 161.

Helix, 161-165; introduction of nemoralis, 164 ; variations in, 164 .

Hellbender, 257, 258.

Heloderma, 270, 271.

Hemiptera, 12, 67.

Hen clans, 189.

Hermit crabs, 10., 107, 123.

Herons, 30 ).

Hessian-fly, 67, 68, 82.

Hesperornis, 313.

Heterandria, 272.

Heteroptera, 12.

Heterotricha, 224, 229.

Hippa talpoides, 107.

Hippida, 107, 123.

Hippoboseidæ, 70 .

Hippopotamus, 326.

Hirudinida, 292, 316.

Holothurians, 201.

Holothuroidea, 204.

Holotrichia, 229.

Homarus, 100, 113.

Homoptera, 13-14.

Honey bees, 32-33.

Horn-pout, 241.

Horned corydalis, 12.

Horned thy, 72 .

Holned toad, 269.

Hornet, 34 .

Horses, 327 ; fossil, 327.
Horse-flies, 65, 72.

House-Hy, 61.

House wren, 288.

Humming-birds, 301 .

Hydra, 205, 335; deseription of, 205207 ; food of, 207 ; labitat of, 205 ; regeneration of, 219 .

Hydractinia, 209.

Hydrocorallida, 208, 220.

Hydroidae, 2:20.

Hydromedusa, 212, 220.

Hydrophilidæe, 60.

Hydrophilus, 47.

Hydrozoa, 220.

Hyenas, 328 .

Hygrotrechus, 12.

Hylida, 263.

Hymenoptera, 30, 72 ; gall-producing, 43 ; parasitic, 38,43 ; plant-eating, 43 .

Hypotricha, '29.

\section{I}

Ichmeumon flies, 30 .

Icteridæ, $293,317$.

Idylia, 219.

Iguanida, 268-269.

Importation of niouse, 318.

Increase of exotic species, 283.

Indigo bird, 285.

Infusoria, $222,229$.

Insectivora, 327,331 .

Intelligence of ants, 35 .

Iphiclides, 18.

Isopoda, 112.

Jay, 294.

\section{J}

Jelly-fishes, fresh-water, 208; life history of, 210 ; salt-water, 208.

Jigger, 71, 95.

Jingle shells, 191.

Julidae, 79.

Julus, 76, 77, 79 .

Jumping mice, 321.

Jumping spiders, 90, 91, 96, 321.

June-bugs, 50.

Kallima, 20.

K

Katydids, 6, 15 . 
Key to classes of Echinodermata, 203; principal families of Acrididæ, 2; Coleoptera, 58-61; Hymenoptera, 42-43; Lamellibranchiata, 188 ; Lepidoptera, 41-12; Myriapods, 78; Orthoptera, 14; Polychæta, 159; Pulmonates, 161 ; principal genera of Daphnidæ, 126 ; Lamellibranchiata, 191; to genus Lithobius, 79 ; to chief orders of Birds, 314-317; Entomostraca, 130 ; Gastropoda, 160 ; Malacostraca,122; species of Earthworm, 143; of Lithobius, 79.

Killer whale, 325.

Killifish, habits, food of, 242.

Kingbird, 296.

Kingfisher, 300 .

Kitchen-middens, 188.

\section{L}

Lacerta, 270.

Lacertidæ, 270 .

Lachnosterna, 50 .

Ladybird beetles, 55,61 .

Lamellibranchiata, key to families of, 188.

Lamellicornidæ, 58 .

Lamellicorn beetles, 49-50, 58 ; leafeating, 50 ; scavengers, 50 .

Lamprey, 245.

Lamprey eels, 252.

Lampyridæ, 51, 60 .

Land-locked fishes, 230.

Language of ants, 36 .

Laniidæ, 289, 316.

Lanius, 290.

Larks, 295.

Larval habits, of beetle, 45; grasshopper, 3-4; lobster, 116.

Laterigradæ, 89, 96.

Leaf beetles, 61 .

Leaf-cutting ants, $37-38$.

Leaf-eating lamellicorns, 50 .

Leaf-hopper, 44.

Leaf-miners, 42.

Leaf-rollers, 42.

Lecanium, 13.

Ledidæ, 187, 188, 191.
Leeches, 139-140.

Lemurs, 329.

Leopards, 328.

Leopard frog, 266 .

Lepidonotus, 147-148, 159.

Lepidosteus, 248.

Libinia, 108.

Life history, of mosquito, 68; Union. idæ, 179-180.

Light, effect of, on development, 333.

Limacidæ, 161.

Limacinidæ, 177.

Limax, 161-164.

Limnæa, habitat of, 166.

Limnæidæ, 161.

Limpets, 170, 177; economic importance of, 170 .

Limulus, 114.

Line-weavers, $87,96$.

Liobunum, 93-94.

Lions, 328.

Lithobiidæ, 78 .

Lithobius, $74,75,78,79$.

Littorina, $16 \overline{-}-168,175$; littoria, introduction, 167 ; range, 167 ; spread, 283.

Littorinidæ, 175 .

Liver-flukes, 153-154; life history of, 154-155; stages of, 156.

Lizards, 268 ; fossil, 272.

Llamas, 326.

Lobster, 100, 103, 113; abnormalities in, 119 ; development of, 115 ; embryos of, 116 ; enemies of, 102 ; moulting of, 103; protection of, 102.

Locust borer, 55 .

Locusts, 14, 15 ; of old world, 2.

Locustidæ, $1,15$.

Loligo, 172.

Long-horned beetles, 54 .

Long-horned grasshoppers, 15.

Long-horns, 61.

Lophobranchii, 244, 253.

Lost parts, regeneration of, 118.

Louse-fly, 70.

Loxia, 284.

Lucanidæ, 49, 58 .

Lucanus, 49.

Lucius, 243.

Lumbriculidæ, $1+4$. 
Lycænas, 22.

Lycosa, 91.

Lycosidæ, 92.

Lynceidæ, 131.

Lynx, 328.

\section{M}

Macaque, 330.

Macrodactylus, 50.

Macrolepidoptera, 22.

Mactra, 183.

Mactridæ, 182, 189.

Maggots, rat-tailed, 65 .

Malacostraca, 97, 111, 125.

Maldanidæ, 159.

Mammalia, 318, 331.

Manatee, 324.

Mandrills, 330 .

Mantidæ, 8, 14.

Margaritana, 191.

Marmosets, 324.

Marsupalia, 322, 331.

Martens, 328.

Maryland yellow-throat, 288, 289.

May beetles, 50 .

May-flies, 10.

Meadow grasshopper, 6 .

Meadow-lark, 293.

Meal-beetles, 61 .

Meal-worms, 52.

Mealy bug, 14 .

Measuring-worms, 42.

Medusa, 211.

Megascops, 298.

Melampus, 161, 176.

Melanoplus, 2.

Meloidæ, 61.

Melophagus, 70 .

Metacrinus, 202.

Metallic wood-borers, 51,60 .

Metamorphosis, of Amphibia, 260 ; Anodonta, 180; beetles, 44; crayfish, 117 ; dragon-flies, 9 ; fly, 63 ; frog, 335 ; Hemiptera, 12 ; Lepidoptera, 16 ; liver-fluke, 152 ; lobster, 116 ; Neuroptera, 11; Orthoptera, 1; starfish, 194.

Metridium, 214, 215.

Microhydra, 208.
Microlepidoptera, 22.

Midgets, 62 .

Migrations of birds, 309 .

Milk-suake, 276.

Mimicry, 18-21; flies, 65.

Minks, 328.

Minnows, 242, 253.

Minyas, 214.

Mniotilidæ, 287.

Mocking-bird, 287.

Modiola, 185.

Mole crabs, 123.

Mole cricket, 5 .

Mollusca, 160, 178.

Monarch, 22.

Mongoose, 328.

Monkeys, 330.

Monotremata, 321.

Morone, 234.

Morula, 336.

Mosquito, 68.

Motacillidæ, 317.

Moths, 22.

Moulting, 103.

Mourning cloak, 21.

Mouse, distribution of, 318 ; food of, 319 ;

habits of, 319 ; importation of, 318.

Mud-daubing wasp, 82.

Mud eel, 255, 256.

Mud fishes, 252 .

Mud puppy, 257.

Mud wasps, 34, 43.

Muricidæ, 169, 175.

Mus, 321.

Muscidæ, 61, 64, 72 .

Muskallunge, 242.

Muskrat, 321.

Musk turtle, 276 .

Mussels, 120, 190.

Mustelus, 246.

Mya, 182, 183.

Myidæ, 182, 189.

Myrmica, 37.

Mytilidæ, 184, 190.

\section{$\mathrm{N}$}

Naidæ, 144.

Nais, 137-138, 144.

Narcomedusæ, 221. 
Natatores, 305, 314 .

Natica, $168,175$.

Naticida, 175, 176.

Nautilus, 173.

Nebalia, 122.

Necturus, 257, 335.

Nemathelminthes, 386 .

Nematocera, $61,66$.

Nematus, eggs of, 40.

Nemertini, 158.

Nephelis, 140.

Nereidre, 159.

Nereis, 136, 138, 145, 146, 159; food and habitat of, 145 .

Nest, of barn-swallow, 292; of chimney-swift, 302 ; of pewee, 296 .

Neuroptera, 11-12.

Newts, 254, 362; how to capture, 255 .

Night-hawk, 303.

Nightingale, 285.

Nile varanus, 269.

Noctuidæ, 27-28, 41.

Norwegian lobster, 113.

Notodelphys, 263.

Notolophus, 28.

Nuculidæ, 191.

Nuthatches, 286.

Nymphs, 21.

\section{O}

Obelia, 210.

Odd-toed ungulates, 327 .

Odonata, 9.

Estridæe, 64.

Oligochæta, 132, 136, 139.

Oniseus, 112.

Operculum, of worms, 151; of fish, 233.

Ophidia, 280.

Ophion, 39.

Ophiuroidea, 198, 203.

Opisthobranchiata, 161.

Opisthobranchs, 164, 170-171; degeneration of shell of, 162 .

Opossum, 322-323.

Orang-utan, 330 .

Orbitelarix, $86,96$.

Orb-wea vers, 86, 96 .
Orbweb, diagram of, 86 ; of Epiera, 87 ; nomenclature of parts of, 86 .

Orbweb spiders, 80 .

Orca, 325.

Orchard oriole, 293.

Orehelium, 6.

Ornithorhynchus, 321.

Orthoptera, 1.

Orthosoma, 54 .

Osmerus, 230.

Ostracoda, 127, 131.

Ostrea, 187.

Ostreidæ, 190; economic importance of, 187.

Ostrich, 307; habits of, $307-308$.

Otter, 328.

Owlet moths, $2 \bar{i}-28,41$.

Owls, 298.

Oxen, 326.

Oxyrhyncha, 123.

Oyster drill, 169.

Oysters, 187-188, 190.

\section{$\mathrm{P}$}

Paddlefish, 247.

Paguridæ, 105, 123.

Painted turtle, 276 .

Palæmonetes, 104.

Palinurus, 101.

Pallene, 95.

Palm-crab, 107.

Pandoridæe, 189.

Pandorus, 23.

Panopeus, 109.

Papilionidæ, 41.

Papilio, 21.

Paramecium, 222, 229; food of, 224; fusion of, 229; habitat of, 224 ; rate of division, 229.

Parasites of $\mathrm{fly}, 63$.

Parasitic, flies, 70; Hymenoptera, 43; worms, 158.

Parida, 286, 316.

Parrots, 297.

Partridges, 304 .

Passenger pigeon, 303.

Passer, 281-282.

Passeres, 315. 
Patella, 170.

Pauropus, 77.

Pearl-bearers, 185; fishery, 185-186.

Peccaries, 326.

Pecten, 186.

Pectinatella, 143.

Pectinidæ, 190-191; locomotion of, 186.

Pedicellina, 141.

Pelicans, 306.

Perches, 235, 252.

Peritricha, 229.

Petrels, 306.

Petricolidæ, 189.

Petromyzon, 245.

Pewee, 296 ; nest of, 296.

Pheasants, 304 ; range of, 305.

Phalangina, 93.

Pharyngognathi, 93.

Phasmidx, 7, 15.

Phasmomantis, 8.

Philampelus, 23.

Philinidæ, 176.

Phoca, 328.

Pholadidæ, 181, 188.

Pholis, 237.

Photuris, 52.

Phrynosoma, 269.

Physa, 161, 167 ; food of, 166; habitat of, 166.

Physalia, 213.

Physiological division of labor, 120 .

Physostomi, 253.

Phytophaga, 43.

Pickerels, 242.

Pickerel frog, 266.

Pieris, 21; rapæ, increase and spread of, 283.

Pigeons, 304.

Pigs, 336.

Pike, 242.

Pimpla, 37.

Pinworm, 153.

Pine borers, 53.

Pinnotheres, 109-110.

Pipa, 262; with embryos, 263.

Pipe-fishes, 24t, 253.

Pipidæ, 263.

Piranga, 293.

Piroplasma, 228.
Pisidium, 191.

Pithecanthropus, 331.

Planarians, abnormalities of, 155 ; fresh-water, 153; regeneration of, 154.

Planorbis, 167; eggs and habitat of, 167.

Plant-eating hymenoptera, 43.

Plant galls, 67.

Plant lice, 14 .

Platyonichus, 110.

Platypsylla, 56.

Plectognathi, 253.

Plethodon, 259.

Plethodontidæ, 259, 267.

Pleurodelidæ, 267.

Pleurotomida, 176.

Plovers, habitat of, 305 .

Plumatella, 142.

Plume-moths, 42.

Podophora, food and habitat of, 225.

Podopthalmata, 122.

Poisonous spiders, 91-92.

Polistes, 33.

Polychæta, 136, 148.

Polyeirrus, 149-150.

Polydesmida, 79.

Polydesmus, 77, 79 .

Polymorphism in butterflies, 17.

Polyphemidæ, 131.

Polyxenidæ, 78.

Polyzoniidx, 79.

Pond snail, habitat of, 166.

Portuguese man-of-war, 213-214.

Postembryonic development of frog, 334.

Pouched gopher, 320 .

Prairie dog, 320.

Prawns, 104, 124.

Praying-mantis, 8, 14 .

Primates, 329, 331.

Prionus, 54.

Prosobranchiata, 160.

Protection, of birds, 312; of lobster, 102.

Protective resemblance, 18-21.

Proteida, 257, 266.

Protozoa, 222; relations to man, 228; reproductive capacity of, 228 . 
Psammobiidæ, 189.

Psittaci, 297, 315.

Psoroptes, 94.

Pterophoridæ, 42.

Pulex, 70.

Pulmonata, 160, 161, 164, 165; aquatic, 166.

Pumpkin-seed sunfish, 236.

Pupa, 16, 165.

Pupidæ, 385.

Pupipara, 61.

Purple grackle, 294.

Pyralidæ, 29, 42.

Pyramidellidæ, 174.

Quail, 304.

Q

Quadrate, 232.

Quiscalus, 294.

\section{$\mathbf{R}$}

Raccoons, 328.

Races of tame mice, 319-320.

Rails, 305.

Rana, 265.

Ranidæ, range of, 265.

Raptores, 298, 315.

Rat, habits of, 319 .

Rat-tailed maggots, 65 .

Rattlesnake, 278.

Rays, 252.

Razor clams, 188.

Razor shell, 182.

Red-eyed vireo, 289-290.

Red-headed woodpecker, 301 .

Reefs: barrier, coral, fringing, 217.

Redpoll warbler, 288.

Red-winged blackbird, 293.

Reduvius, 12.

Regal moth, 25.

Regulus, 287.

Regeneration, of earthworms, 134 ; flat worms, 153; frog's egg, 334; Hydra, 219 ; lost parts of lobster, 118 ; planarians, 154 .

Relationships of earthworms, 132.

Reproductive capacity of protozoa, 228 .

Reproduction, 332 .

Reptiles, 268.

Resistance of earthworms, 134.
Retitelariæ, 87, 96.

Rhea, 307.

Rhinoceroses, 327.

Rhizopoda, 229.

Rice bird, 294.

Rissoidre, 174.

Robber-flies, 65, 72,73 .

Robin, 285.

Rock-eel, 236, 237.

Rodentia, 320, 331 .

Rodents, 320 .

Rose-breasted grosbeak, 285.

Rose-bug, 50-51.

Round worms, 151.

Routes of bird migration, 309 .

Rove beetles, $47,57,58$.

Ruby-crowned kinglet, 285.

Ruby-throated humming-bird, 302.

Ruffed grouse, 304 .

Rumners, 60.

Running beetles, 45 .

Running spiders, 91, 96 ; habits of, 89 .

$\mathrm{S}$

Salmo, 233; skull of, 232.

Salmonidæ, 230, 231; distribution of, 231; spawning of, 231-233.

Salamander, 259.

Saltigradx, 90,96 .

Sand dollars, 200-201.

Sandpipers, 305.

Sauria, 268, 280.

Saw-fly, eggs of, 40 ; larvæ, 39.

Saxicavidæe, 189.

Saxicolidæ, 315.

Scalariidæ, 174 .

Scale bug, 14 .

Scale insect, 13 .

Scaled worm, 148.

Scallops, 190.

Scaly ant-eater, 323 .

Scansores, 299, 315.

Scaphandridæ, 176.

Scarlet tanager, 293.

Seavengers, Diptera, 72; Lamellicorns, 50.

Schizopod larva, 116.

Schizoneura, 14.

Scolopendra, 75, 76, 78 . 
Scolopendrella, 78.

Scolopendridæ, 78 .

Scolytidæ, 53, 61.

Screech owl, 298, 299.

Seulpin, 236, 252.

Scutigera, 75,78 .

Scutigeridæ, 78 .

Scyphozoa, 214, 220.

Sea-cows, 324.

Sea-crayfish, 113.

Sea-cucumbers, 204.

Sea-lilies, 203.

Sea-lions, 329.

Sea-mats, 218.

Sea-mouse, 148.

Sea-spiders, 107.

Sea-squirts, 218.

Sea-urehins, 204; food and habitat of, 199-200.

Sea-walnuts, 219.

Seal, $328,329$.

Searcher, 46.

Sedentary polychæta, 148.

Selachians, 246.

Selachii, 252.

Semelidæ, 189.

Serpent stars, 203; description and habitat of, 199.

Serpula, 151, 159; tube, 151.

Serpulidæ, 159.

Sertularia, 210.

Sexton beetles, 48 .

Sexual dimorphism of spiders, 92 .

Shad, 253; range, 243-244.

Sharks, 252.

Sharp-shinned hawk, 298.

Sheep, 326.

Sheep-tick, 70.

Sheep scab, 94.

Shipworms, 188.

Short-horned diptera, 64.

Short-horned grasshoppers, 51 .

Short-winged beetles, 47 .

Shrews, food of, 327.

Shrike, 289.

Shrimps, 104, 124; value of catch, 111.

Sididæ, 131.

Silk-worms, 42.
Silpha, 48.

Silphidæ, 48, 60.

Silversides, $2: 36,252$.

Simia, 330.

Simuliidæ, 67 .

Simulium, 67.

Siphonophora, 212-213, 220.

Siphonata, 178.

Siren, $255,256$.

Sirenia, 331.

Sirenidx, 255, 266.

Sitta, 287.

Sittidæ, 316.

Skunks, 328 .

Sloths, 323; two-toed, 324 .

Slugs, 132, 160, 162 ; apparent absence of shell in, 162 ; economies of, 162 ; food of, 161-162; habitat of, 161; species of, 162 .

Smelt, 230, 253; artificial propagation of, 231; economic importance of, 230 ; habitat of, 230 ; range of Atlantic form of, 230-231; value of Atlantic fishery, 231 .

Snapping beetles, 51 .

Snapping turtles, 275 .

Snipes, habitat of, 305 .

Snout beetles, 61 .

Snow-bird, 285.

Snowy owl, 299.

Social bees, 31 .

Social life of ants, 36.

Soft-shelled clams, 189.

Solaster, 197-198.

Solemyidæ, 189.

Solenidæe, 182, 188.

Song-sparrow, 285.

Song-thrush, 285.

Sow-bug, 112.

Spanish fly, 58.

Sparrow-hawk, 299.

Speckled tortoise, 276.

Spelerpes, color of, 259; development of, 261-262; habitat of, 260.

Sphex, 82.

Sphingidæ, 22, 41.

Sphinx moth, 23.

Spiders, 80, 92; ballooning habits of, 83-81; classification of, 85 ; food of, 
82; poisonous, 91-92; sexual di- Sylvicolidx, 317 .

morphism of, 92 ; spinning habits of, Sylviidæ, 285, 315, 316 .

83 ; wandering, 88.

Spider-crabs, 107, 123.

Spider webs, economic importance of, (10.

Spinning habits, in spiders, 83.

Spiny ant-eater, 322.

Spiny lobster, 101.

Spirulida, 174.

Spizella, 285.

Sponges, 205.

Spontaneous generation theory, 223.

Spoonbill, habitat of, 247.

Spore of Infusoria, 223.

Sporozoa, 227, 229.

Spotted sandpiper, 306 .

Spreading adder, '276.

Spring azures, 18, 2.2.

Square crabs, 123.

Squash bug, 13.

Squids, 171.

Squilla, 111.

Squirrel, 320.

Stable-tly, 61 .

Stag-beetles, 49, 58 .

Staphylinidx, 47, 58 .

Starfish, 192, 203; abnormalities of, 196; development of, 193-194; distribution and habitat of, 192 ; economic importance of, 193; food of, 193; larval stages of, 195; metamorphosis of, 195 ; systematic position of, 192.

Stentor, 229; habitat of, 224-225.

Sterna, 307 .

Sticklebacks, 238, 252.

Stomatopoda, 111, 122.

Storks, 305.

Strongylocentrotus, 199.

Sturgeons, 247 ; economic importance, habitat, food of, 247.

Suckers, 241, 25.3.

Suctoria, 225, 229.

Sunfish, 235, 252.

Swallows, 292.

Swarm of bees, 32 .

Swifts, 301, 302 .

Sycon, 206.

Syllidæ, 159.

Synapta, 202, 203.

Synotus, 329.

Syrphidre, 66, 73.

Syrpus, 64 .

Tabanidæ, 65.

Taballus, 65, 66.

Tænia, 157.

Talorchestia, 112.

Tanagers, 292.

Tanagridx, 292.

Tapeworm, 156; human, 157.

Tapirs, 327.

Tarantula, 92.

Teeth of fossil birds, 314 .

Teleostei, $25 \%$.

Tellinidre, 190.

Tenebrio, 52.

Tenebrionidae, 52, 61.

Tent caterpillars, 26; egg masses of, 26 ; nests of, 27.

Terebellidae, 159 .

Teredidæ, 181, 188.

Teredo, 181.

Termes, 11.

Termites, 11.

Terns, 306, 307.

Terrapene, 275 .

Territelaria, 85, 95.

Testudinidæe, 275.

Texas fever in cattle, 228.

Thalassinidæ, $105,124$.

Theclas, 22.

Theridium, 80, 82; food of, 82 .

Thomisus, 90.

Thrushes, 385.

Tineidæ, 29, 42.

Tigers, 328.

Tiger-beetles, 45.

Tiger-moths, 24, 41.

Tipulidæ, 68-69.

Titmice, 286.

Toadfishes, 252; habitat of, 236.

Tornatinidæ, 176.

Tortricida, 29, 42.

Toucans, 299. 
Trachea of fly, 63 .

Tracheata, 387.

Tiachina, 152, 153.

"rachomedusa, 2:1.

irap-door spiders, 86 .

Tree-hoppers, 14.

Trematoda, 385.

Trepangs, economic importance of, 202.

Tree-sparrow, 285.

Tree-toad, 265.

Triangular crabs, 123.

Triforidæ, 177.

Trilobites, 130.

Trionychida, 274.

Trionyx, 275.

Trochide, 175.

Trochilus, 302.

Troglodytida, 287, 316.

Troglodytes, 288.

Trouts, 233, 253.

True bugs, 12.

True wasps 83 .

Tsetse-fly, 64 .

Tube-forming worms, 102.

Tube-weavers, 8s, 96.

Tubifex, 136, 144.

Tubificidæe, $1+4$.

Tubitelarix, 88, 96.

Tubularia, 208.

Tubularian hydroid, 210.

Tubularide, $208,221$.

Tumble-bugs, 50,57 .

Tunicata, 218, 251.

Tumnel-weavers, 85, 95.

Turbellaria, 385.

Turdidx, 285, 315, 316.

Turdus, 286.

Turkey-buzzard, 299.

Turkeys, 304; wild, 305.

Turtles, 273 ; range of, 274 .

Tussock moth, 28 .

Twin-spotted sphinx, 23.

Tyrannidæ, 295, 315.

Tyrannus, 296.

Unau, 324.

\section{U}

Ungulata, 325, 331; even-toed, 326; odd-toed, 327.
Unio, 178, 191

Unionidse, 17!), 180, 191.

Urodela, 255, 2666; development of, 261.

Urosalpinx, 169, 175.

Varanide, 269.

\section{V}

Variations in Helix, 165.

Veneridre, 180, 183, 190.

Venus, 183.

Vermetids, $17 t$.

Vertebrates, ancestry of, 248 .

Vespa, 34, 35.

Vesper sparrow, 285.

Vesperidæe, 43.

Vespida, 33.

Vireo, 288, 290.

Vireonidæ, 288, 316, 317.

Volvox, 226, 227.

Von Baer's law, 3:36.

Vorticella, 225, 229.

Vultures, 298, 299.

\section{IV}

Walking-sticks, 7, 15.

Wall-eyed pike, 235 .

Walruses, 329.

Wandering spiders, 88 .

Warblers, 285.

Wasps, 30, 33, 43; social, 33.

Water-dog, 257.

Water moccasin, 279.

Water scavengers, 60 .

Water snakes, 271.

Water strider, 12.

Weasels, 328.

Weevils, 57 .

Whales, 324; feeding habits of, 325 .

Whippoorwill, 303.

Whirligig, 60.

White ants, 11

White-breasted nuthatch, 287.

Whitefishes, 2:34, 25:3.

White-lined horse-fly, 66 .

White-throated sparrow, 28.5.

Wingless birds, 307 .

Wingless cockroach, 8.

Wood-borers, 41. 
Woodchuck, 320 .

Wood frog, 266.

Woodpeckers, 301.

Wood-tortoise, 276.

Wood-thrush, 286.

Wood-warblers, 287.

Worms, tube-forming, 102.

Wrens, 287.

\section{X}

Xylotropidæ, 23, 41.

\begin{tabular}{|l}
\multicolumn{1}{|c}{ Y } \\
Yellow bird, 285. \\
Yellow warbler, 288. \\
Yoldia, 187, 188. \\
\\
Zebra, 327. \\
Zebra swallow-tail, 18. \\
Zygænidæ, 41. \\
Zygodactyla, 212.
\end{tabular}




\section{A TEXT-BOOK OF ZOÖLOGY}

BY

T. JEFFERY PARKER, D.Sc., F.R.S.

Professor of Biology in University of Otago, Dunedin, N.Z.

AND

WILLIAM A. HASWELL, M.A., D.Sc., F.R.S.

Professor of Biology in the University of Sydney, N.S.W.

In two volumes, containing many illustrations

Cloth. 8vo. 2 vols. \$9.00, net

"The book deserves a warm welcome, and . . . will be found an 'nvaluable aid not only to students of zoölogy, but also to a large numver of those whose main interest lies in other branches of scientific study. Written with a clearness, accuracy, and method of a practised teacher, it is admirably illustrated with a profusion of figures - there are nearly twelve hundred in all - of the highest excellence."

- Science.

"This work, the significance and usefulness of which must be unqualifiedly conceded, represents an enormous amount of labor upon the part of two experienced teachers. Nor would we underrate the admirable mechanical features of the work and the educational portent of the issue of so large and costly a text-book upon a single branch of natural history. The intent and method of the authors are clearly set forth in the preface. After a general introduction and a section upon 'General Structure and Physiology,' there are presented in turn the twelve phylums recognized, viz.: Protozoa, Porifera, Colenterata, Platyhelminths, Nemathelminths, Trochelminths, Molluscoida, Echinodermata, Annulata, Arthropoda, Mollusca, and (occupying the whole of the second volume) Chordata, corresponding nearly with Vertebrates. The discussion of each class is based upon a more or less letailed account of the anatomy and development of one or more forms, fairly representative and commonly available. The second olume also contains a discussion of the mutual relationships of the Chordata and of the twelve phyla. The last seventy pages are devoted to Geographic Distribution, the Philosophy and History of Zoölogy, and Modern Literature; seven of the sixty writers recommended being American." - The Nation.

\section{THE MACMILLAN COMPANY}




\section{EXPERIMENTAL MORPHOLOGY}

BY

CHARLES BENEDICT DAVENPORT, Ph.D.

Instructor in Zoölogy in Harvard University

PART I.

Effects of Chemical and Physical Agents upon the Protoplasm

Cloth. 8vo. $\$ 2.60$, net
PART II.

Effects of Chemical an' Physical Agents upos Growth

Cloth. 8vo. \$2.00, net

"The material which is discussed has been well digest: and is well arranged, and the style is on the whole clear a: concise. The book is a readable one, and the descriptions al: criticisms of the methods employed in experimentation, and $\mathrm{t}$ : bibliographical lists at the conclusion of each chapter, cc tribute materially to the value the book possesses for both t: morphologist and the physiologist." - Science.

"In this second instalment of his valuable treatise, $\mathrm{D}$ Davenport considers the effects of chemical and physical ager on growth. Plants lend themselves so readily to observati; respecting growth that they have received from Dr. Davenps a degree of attention in this work which compels the stude of plant physiology to accept his aid. On the whole, the ed torial work has been wonderfully well done, and the errors a, so few that they need not be mentioned here; they do $r$ appear likely to mislead seriously any students who make u: of the vast amount of material which has been gathei: patiently, and for the most part has been well arranged."

- American Journal of Scienc

\section{THE MACMILLAN COMPANY}









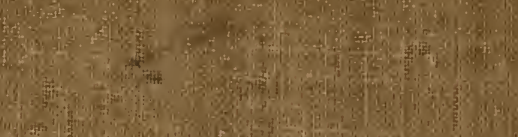

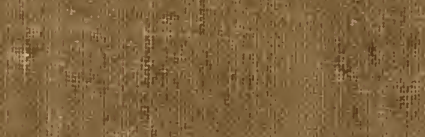
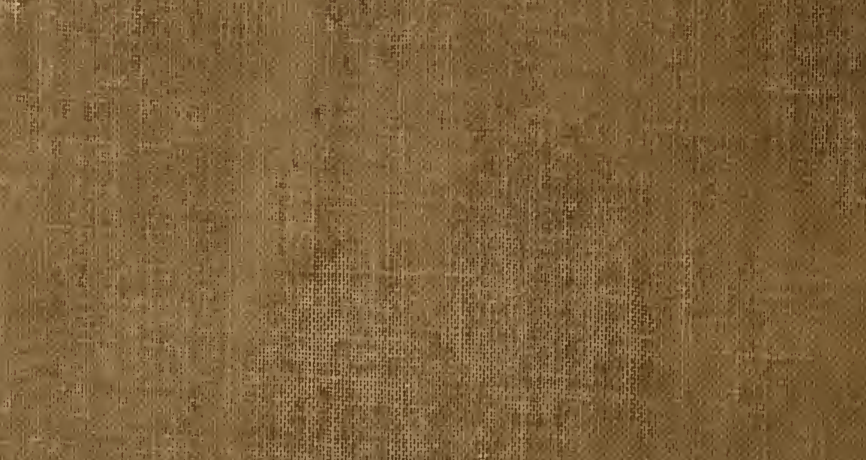

(3)
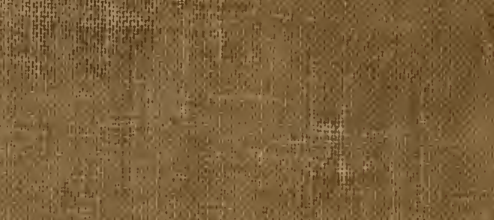

(1)

(2)

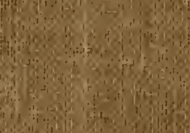

(3)

17. $\quad$ of

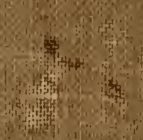

(t)

r. - 3

(1)

$\frac{1}{2}$

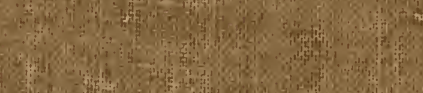

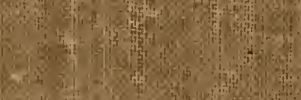

30 (3)

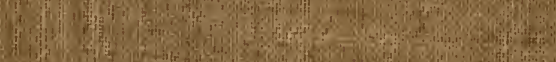

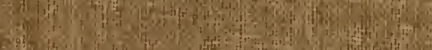

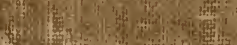

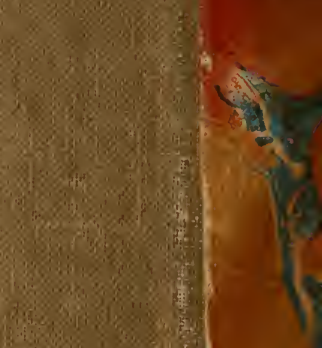
in
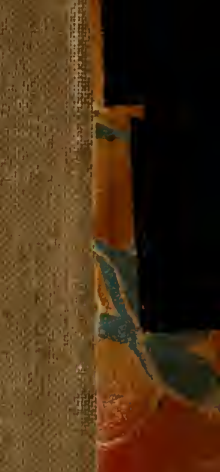